\title{
Jerzy Faryno
}

\section{Мифологизм и теологизм Цветаевой}

„Магдалина“ - „Царь-Девица“ - „Переулочни“

Verlag Otto Sagner München · Berlin - Washington D.C.

Digitalisiert im Rahmen der Kooperation mit dem DFG-Projekt „Digi20“

der Bayerischen Staatsbibliothek, München. OCR-Bearbeitung und Erstellung des eBooks durch den Verlag Otto Sagner:

http://verlag.kubon-sagner.de

( bei Verlag Otto Sagner. Eine Verwertung oder Weitergabe der Texte und Abbildungen, insbesondere durch Vervielfältigung, ist ohne vorherige schriftliche Genehmigung des Verlages unzulässig.

«Verlag Otto Sagner» ist ein Imprint der Kubon \& Sagner GmbH. 


\section{JERZY FARYNO}

\section{МИФОЛОГИЗМ И ТЕОЛОГИЗМ ЦВЕТАЕВОЙ}

(«Магдалина» - «Царь-Девица» - «Переулочни») 


\section{WIENER SLAWISTISCHER ALMANACH \\ SONDERBAND 18}

(LITERARISCHE REIHE, HERAUSGEGEBEN VON A, HANSEN-LÖVE) Wien 1985

Titelgraphik: "Figure mnémonique" aus: Ars Memorandi (um 1470

\section{DRUCK}

Offsetschnelldruck Anton Riegelnik

A-1080 Wien, Piaristengasse 19

$\mathrm{Zu}$ beziehen Uber: Wiener Slawistischer Almanach

Institut für Slawistik der Universität wien

A-1010 Wien, Liebiggasse 5

\section{Ba: crleche}

Staatsibliothek

Minchen.

\section{EIGENTUMER UND VERLEGER}

- Gesellschaft zur Forderung slawistischer studien Alle Rechte vorbehalten 
Предисловие

"МАГДалина"

I. "Меж нами десять заповедеи..." 10

II. "Масти, плоченные втрое..." 37

III. "О путях твоих пытать не буду..."

IV. 'Мироносица' 70

Примечания

"ЦАР Ь-ДЕВИЦА" 11

1. Персонаки 111

1.1. Царь 112

1.2. Мать царевича 146

1.3. Мать и Мачеха 152

1.4. Царевич 184

1.5. Царь-девица 215

2. Сюжеты 233

Прнмечания 239

"ПЕРЕУЛОЧКИ"

I. Предварительные замечания 257

II. Разбор 260

III. Заключение 351

Примечания

SOME ASPECTS OF CVETAEVA'S POETICS (Résumé) 393

References $\quad 409$ 


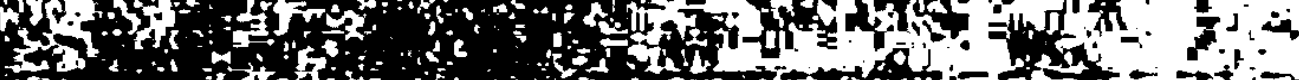

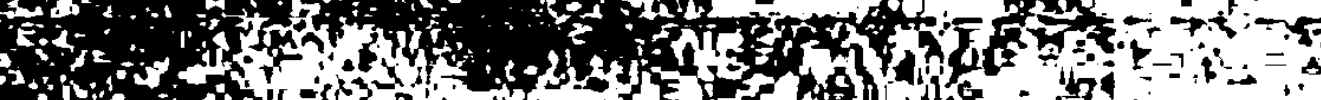

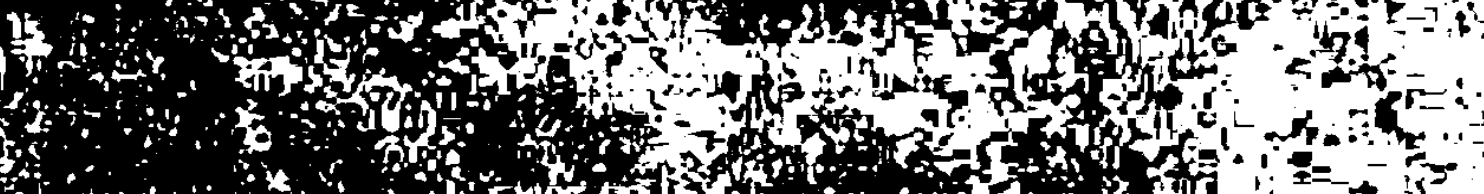

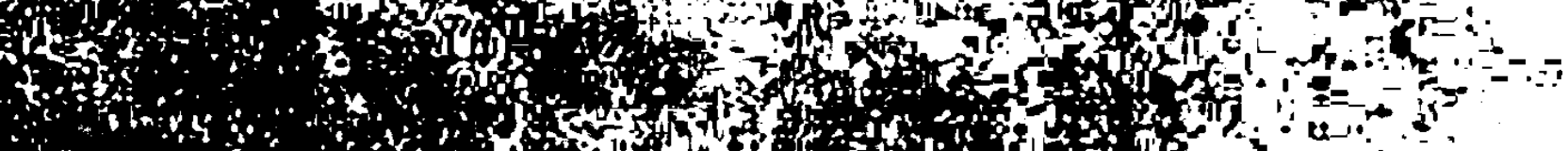

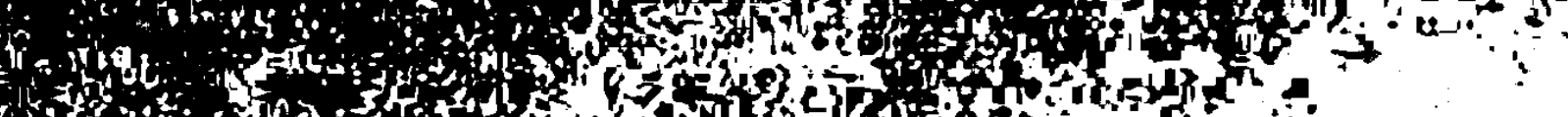

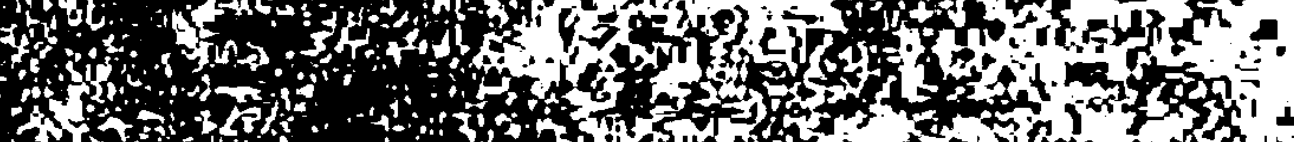

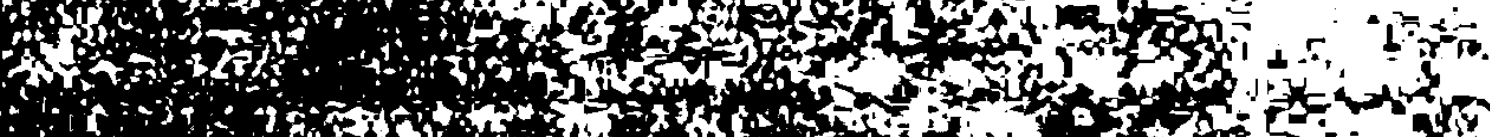

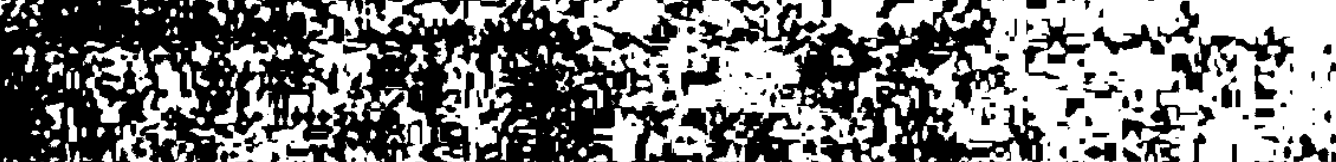

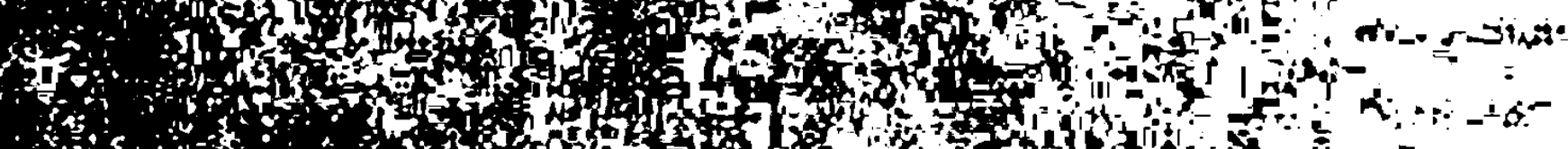

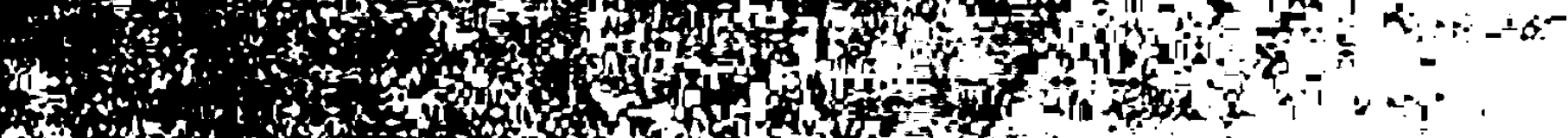

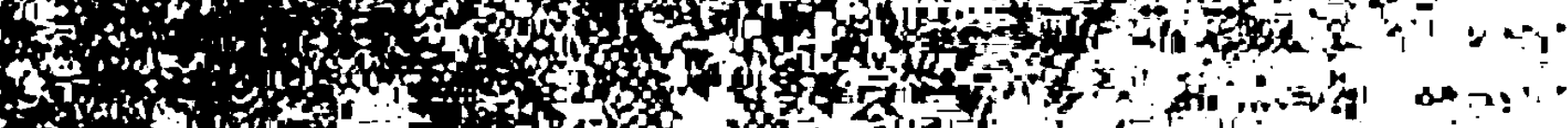

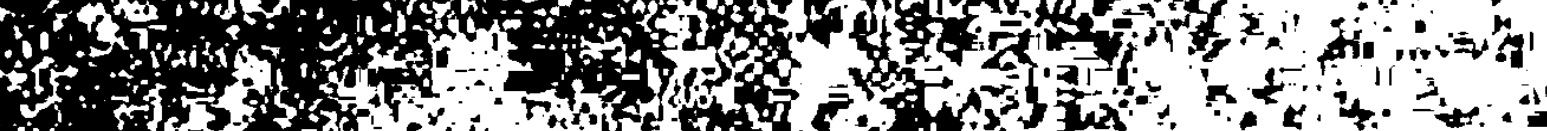

sos of

ond

150

2itition

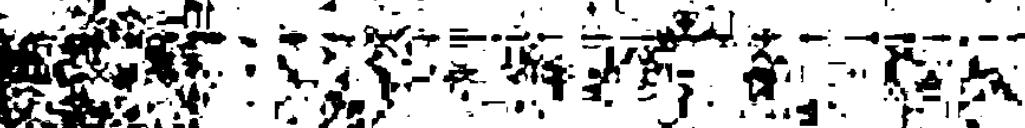

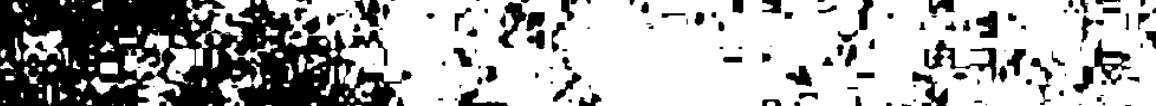

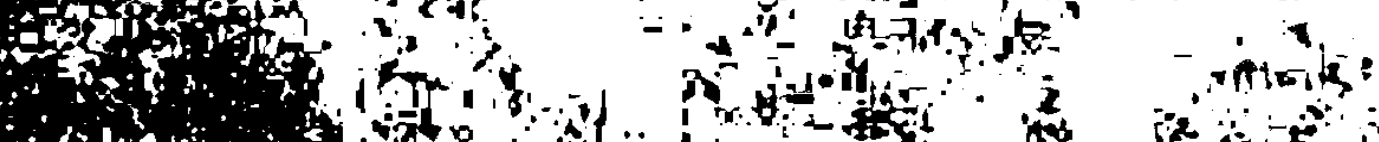

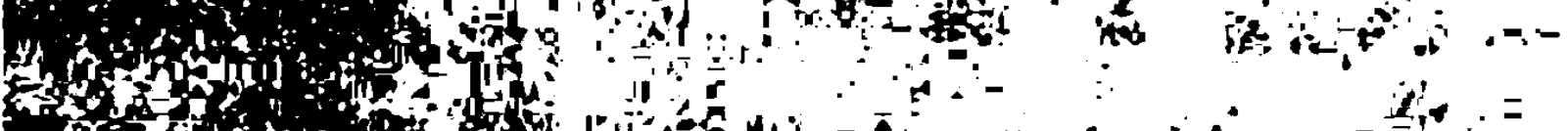

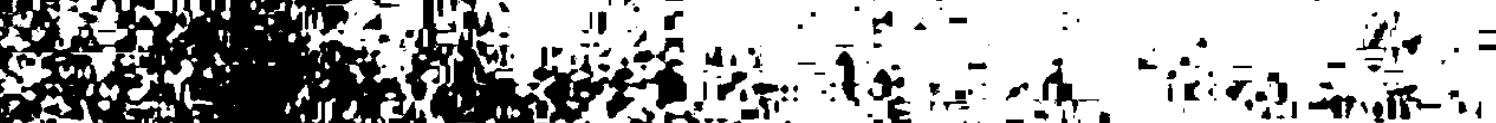

5.9.100

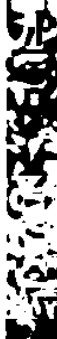

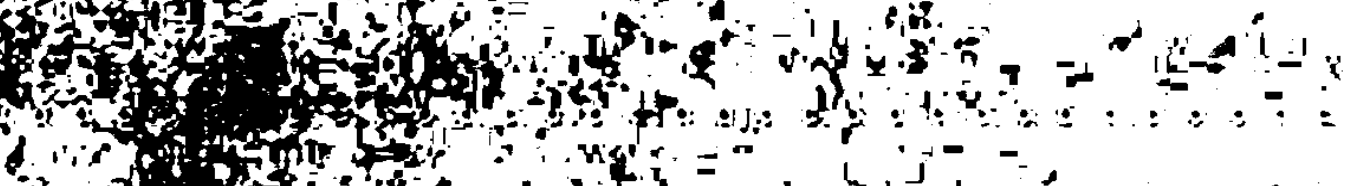

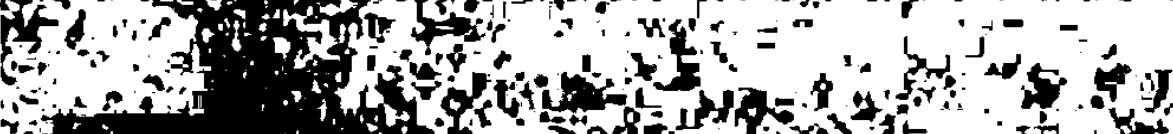

ond

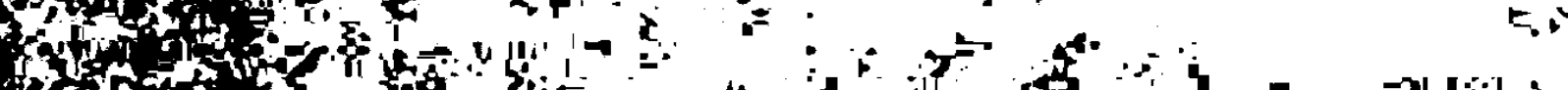

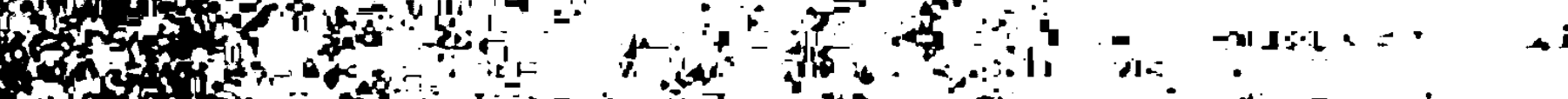

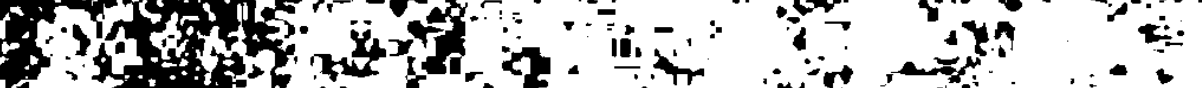

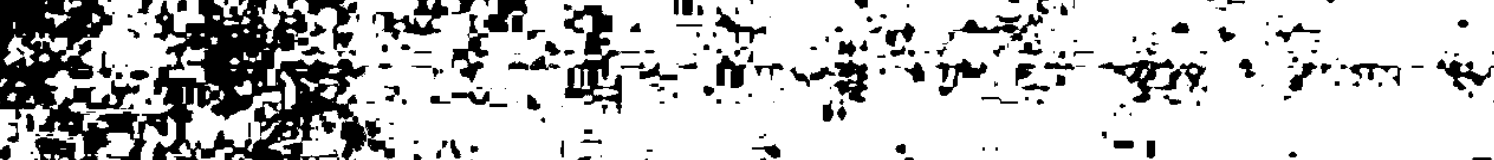

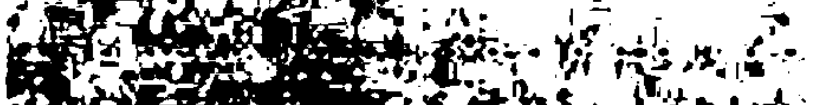

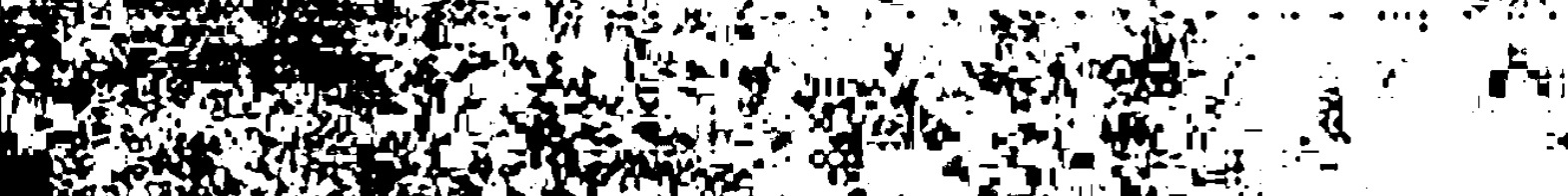

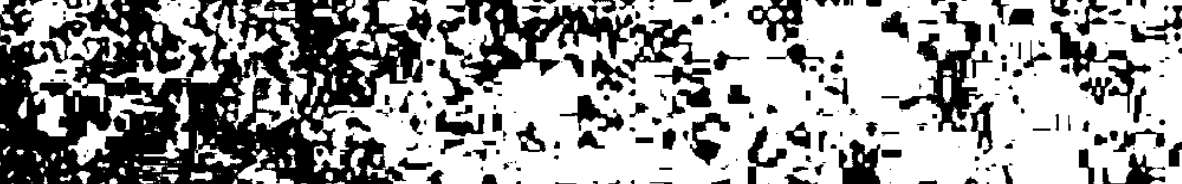

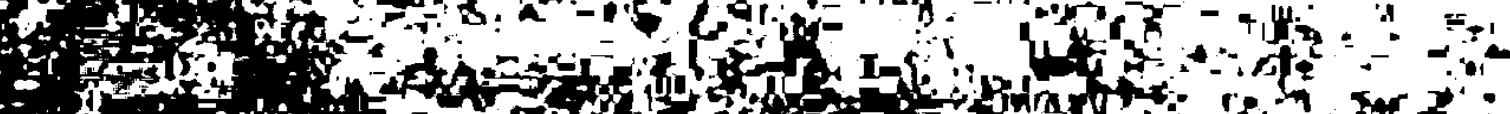

Hed

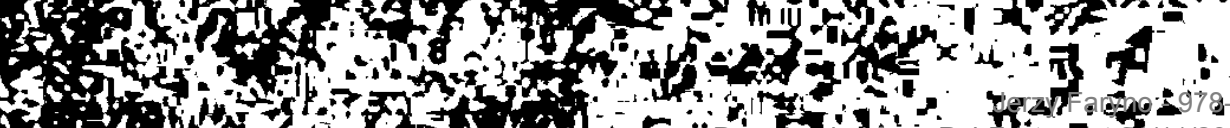

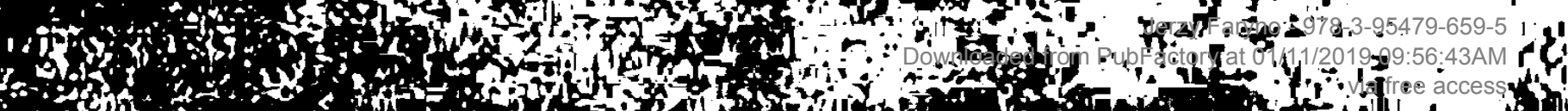


Как ханровое единство - как книга - предлохенные здесь три статьи и их композиция (ухе задним числом) отрахают не столько установку их автора, сколько свонственную и самов Цветаевон и поэзии вообще "циклизирующую" тенденцию. Эти статьи возникли как самостоятельные и независимые друг от друга предварительные разборы отдельных веще цветаевоя, цель которых, правда, еще далекая и теперь, одна и та же - расинфровка Цветаевской поэтической системы (главным образом, на уровне семантики). Поэтому, по мере возмохности, в них ограничены всякие выходы в более широкий внешния контекст. Привлекаемых же контекстов три: контекст предиествующих и совпадаюмих по времени написания собственншх Цветаевских произведения (с незначительньми забеганиями вперед) и явно подсказываемые разбираемым произведениями контексты библеиско-теологического характера и мифопоэтическод системы народнод культуры. Такая установка долхна была, по крайеи мере по замыслу, предохранить от сверхинтерпретация и хотя бы частично смягчить неизбехные искахения. По мере открывающеися картины искомого Цветаевского кода эти контексты постепенно включаются в текст изложения. Так если в случае анализа Магдалики они вынесены в примечания, то в случае Переулочков введены уже в сам разбор, всегда, конечно, сохраняя статус отступления.

Читатель заметит, что в случае Царо-Девииш и Переулочков не привлекается сам собо напрашнваюинся "фольклор" и что он уступил тут место "народнои культуре". Даннья факт объясняется не только терминологически. Под "Фольклором", особенно в ФилологическоЯ среде, подразумевается обычно устное народное словесное творчество. Это значит, что Цветаевскую связь с ним долхно бы рассматривать на уровне текстопостроения - жанра, речи, ритма, - тогда как моеи задачея был друго уровень: Цветаевския мир и семантика. Известно, однако, что "Фольклор", понимаемы как словесные тексты, - всего лишь часть проявления более крупного едннства, народного миропонимания и народноя годовои обрядности, и что они не выдают своен семантики в случае их изъятия из этого единства, т.е. в случае их приуроченности определенным событиям в космическом круговороте и в человеческоя жизни. Вот это миропонимание и обрядность и подра- 
зумеваются здесь под термнном "иародная культура", и с нер как раз и вскрывается Цветаевская связь.

Вынесенные в заглавие книги "мифологизм" и "теологизм" вместо окидаемвх "мифология" и "теология" продиктованы как простон осторохностью, так и сообрахениями более судественного порядка. Сказать "мифология" или "теология" - и прехдевременно и неответственно, ибо это обязывает кболее строгому и более широкому рассмотренио всеи Цветаевскоя системы, с одноң стороны, a, с другон, в Цветаевском решении они уке не явлется ни пошннно мифологиеи, ни подлинноя теологиен. Так Магдалина, персонах заведомо культовын, обнарухивает ряд свонств мифологического (вне- или дахе пред-евангельского) характера, а царь-девица, персонах сугубо народно-миФического склада, как раз наоборот, обладает рядом черт персонаха культового. Само по себе ни одно ни другое не долхно особо порахать, если учесть принятые у всех славян (и не топко славян) нарашые контаминации обеих традиция, т.е. своего исконного язычества и виятельного христианства. У Цветаевон, однако, дело обстоит гораздо слохнее: наблюдающиеся у нее "контаминация" - отнюдь не прямое заимствование иэ народных представления, и далеко не всегда контаминация. Если бы С этон точки зрения мохно было применить градацию по признаку 'цветаевския', то наиболее 'цветаевским' персонахем оказалась бы, несомненно, 'Ведунья' из Переулочков.

Остановиться хе только на "мифологизме" или только на "теологизме" означало бы иэменить денствительному полохению вемен: обе эти системы миропонимания не только налицо у цветаевон, но и вступают друг с другом в принципиальные диалектические отношения. И ради равновесия обеих аспектов в книгу и включен разбор Магдалики. на первое же место (вопреки хронологии разбираемых произведения) он выдвинут и потому, что бшл предпринят раныше остальньх, и также по некоторым другим соображениям.

Упомянутая в начале "циклиэируюмая" тенденция заключается в том, что некая серия произведения (стихотворения и др.) организуется по принципу "От - до" и создает некия единың сюжет или дахе фабулу. на своем семантическом уровне отдельные тексты такого цикла преврамаются в отдельные звенья этого сюжета. Поместив Магдалику после Переулочков мохно поэтому вызвать нехелательное впечатление их "продолхения" - Согласно же раскрытои логике цветаевскон скхетики у Переулочков продолхения ухе быть не может. Если в

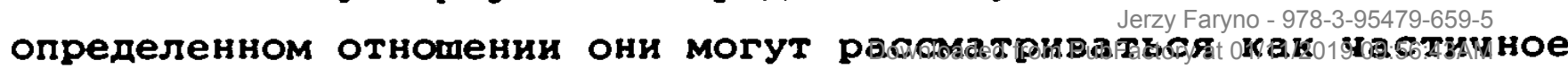


продолхение Царо-Девиии, то сами никакого постихимо вырахаемого продолхения ухе не предполагают. В рамках излохенного в книге понимания Џветаевскон сюхетики Переулоики скорее всего инвариант, которь может лишь сколько угодно вариироваться, сколько угодно переосмысляться и становиться "языком описания", т.е. нагрухаться моделирующе Функциен. Отсюда их законная замкаюмая позиция в этон книге. Помещение же Магдалики как варианта после них открьвало бы ухе совериенно иную перспективу: не поиск системы, а разработку ее моделируюиих возможностен.

Заключительная статья Some Aspects of Cvetaeva's Poetics (Heкоторие aсnекти поэтихи Lеетаевой) играет роль реэюме. Но это итог не только предлохенньх раэборов, а и других моих работ по цветаевон, уиитьвающи в какод-то мере такхе и опыт других исследователер ее творчества (что частично отрахено в References).

Без поощрения и помощи Christa и Aage Hansen-Lóve эта книга вряд ли была бы написана и опубликована в таком объеме и в таком темпе. Более того: предложив мне подключить еие "нечто" к анализу магдалики они помогли мне также и "кое-что" лучше понять в поэзия цветаевоя. Для этого я выражаю им свою глубочаяную благодарность.

кафедра Сельскоя Культуры

Сельскохозяяственно-Педагогическия Институт

г. Седльце, 14 января 1985

(Zakład Kultury Wsi

Wyzsza Szkoła Rolniczo-Pedagogiczna

w Siedlcach)

Jerzy Faryno 
or

(1)

iti

(4)

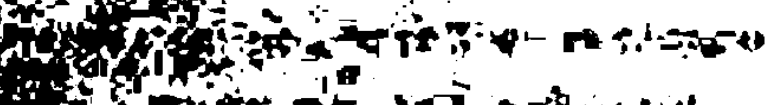

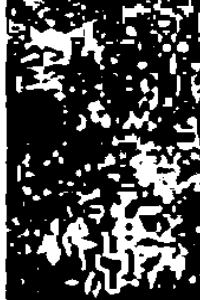

4.

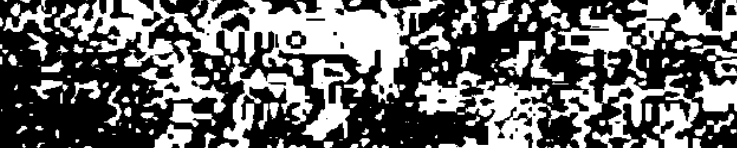

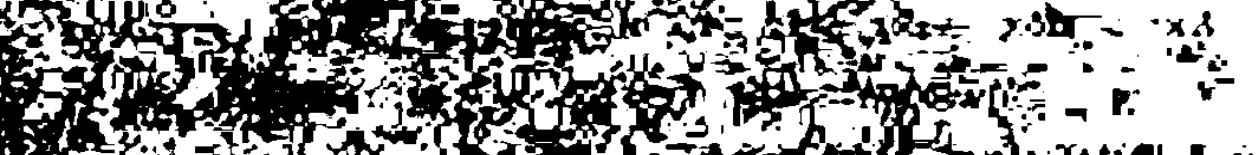

It]

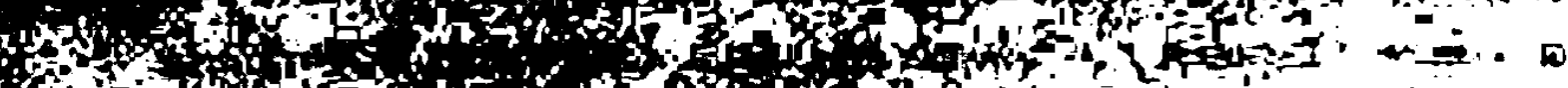

Fot

$37 f_{0}$

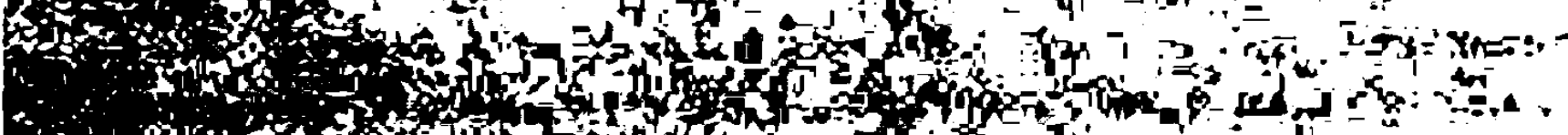

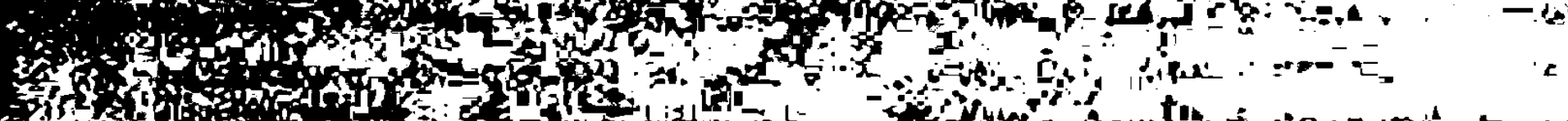

Af

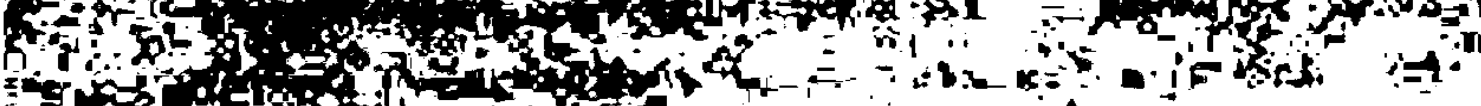

Ninis

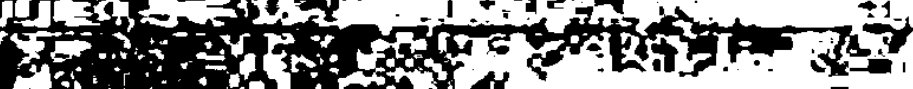

ros

(2)

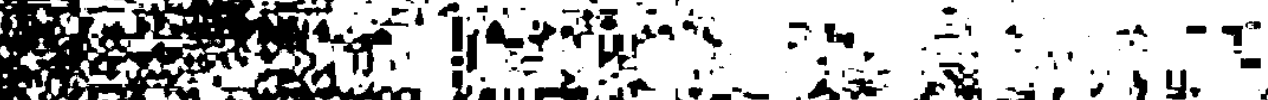

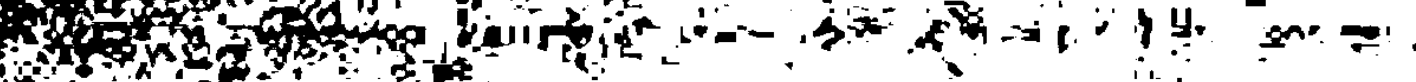

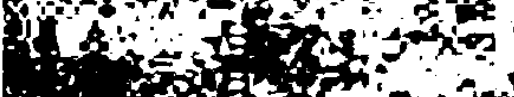

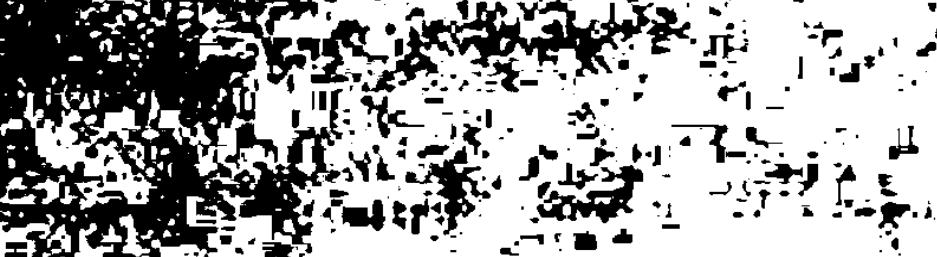

a $P$ P

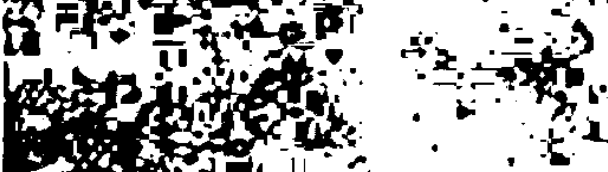

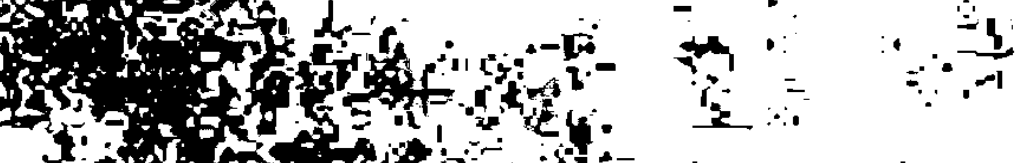

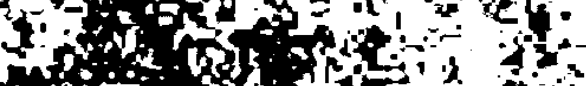

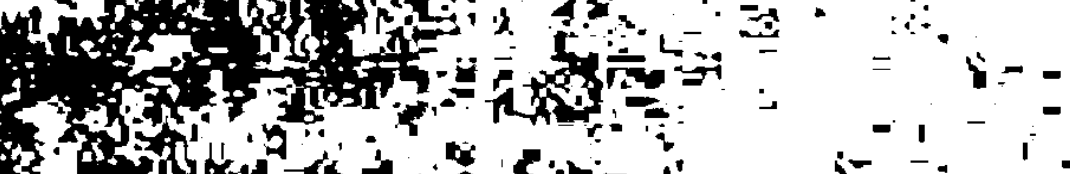

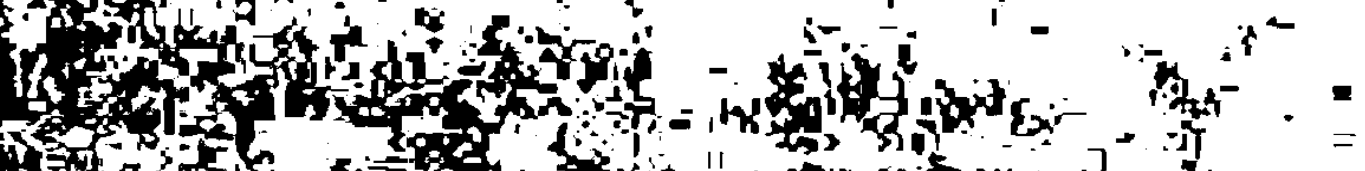

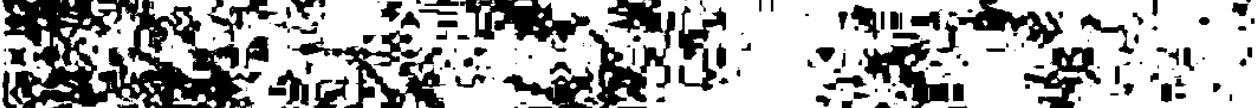

(1)

dof

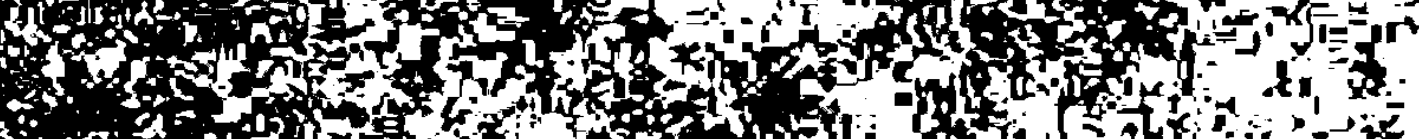

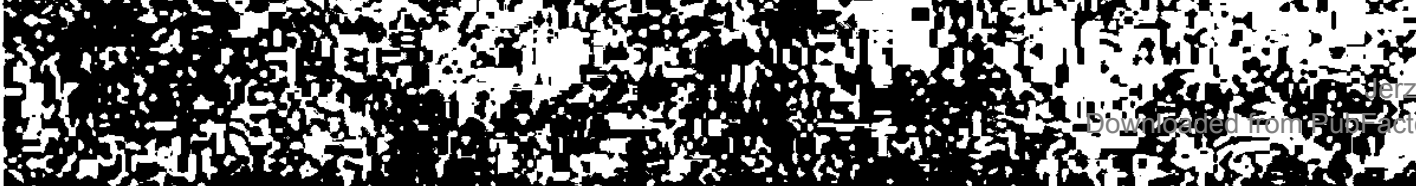


"М А Г Д А Л И Н А"

И заглавие и событияны уровень триптиха Магдалина свидетельствуют ○ том, что основу сюжета здесь образует история евангельского персонаха - Марии из магдалы, или иначе Мария Магдалины. Поэтому анализ произведения проме всего было бы начать именно с изложения данноя история. Однако, само собоя разумеется, что таков подход мог бы привести к нежелательным последствиям, хотя бы в виде непронзвольного вчитывания в текст заданного внешнего кода. Поэтому автор івыбрал более сложныя и долги путь. Правда, апокрифическия и евангельския контексты привлекаются здес, по мере возможности, в Функции дополнительных, a не определяюмих моментовь но все-таки - в силу необходимости - не так уж и редко. Создавияеся проблемы пришлось поэтому решать при помоми обильных примечания, отсылающих к другим поэмам и стихотворениям Цветаевоя, и при помощи особого характера этих примечания: их цель - уравновесить возможные "сверхосмысления", с одноя стороны, а с цругоя дать некоторые предварительные, пусть и далеко несистематизированные, представления о своеобразия чисто "цветаевскоя" поэтическов системе. 1 


\begin{tabular}{|c|c|c|}
\hline \multirow[b]{2}{*}{1.0} & \multicolumn{2}{|r|}{ I. } \\
\hline & $\begin{array}{l}1 \\
2 \\
3 \\
4\end{array}$ & $\begin{array}{l}\text { Меж нами - десять заповедея: } \\
\text { Жар десяти костров. } \\
\text { Родная кровь отшатывает, } \\
\text { Ты мне - чужая кровь. }\end{array}$ \\
\hline & $\begin{array}{l}5 \\
6 \\
7 \\
8\end{array}$ & $\begin{array}{l}\text { Во времена евангельские } \\
\text { Бшла б однои из тех... } \\
\text { (Чужая кровь - желанненшая } \\
\text { и чуждеяшая из всех!) }\end{array}$ \\
\hline & $\begin{array}{r}9 \\
10 \\
11 \\
12\end{array}$ & $\begin{array}{l}\text { К тебе б со всемн немонамн } \\
\text { Влеклась, стлалась - светла } \\
\text { Масть! - очесамн демонскимн } \\
\text { Таясь, лила б масла }\end{array}$ \\
\hline & $\begin{array}{l}13 \\
14 \\
15 \\
16\end{array}$ & $\begin{array}{l}\text { и на ноги бы, и под ноги бы, } \\
\text { и вовсе бы так, в пески... } \\
\text { Страсть по купцам распроданная, } \\
\text { Расплеванная - теки! }\end{array}$ \\
\hline & $\begin{array}{l}17 \\
18 \\
19 \\
20\end{array}$ & $\begin{array}{l}\text { Пеною уст и накипямн } \\
\text { Очес и по̀том всех } \\
\text { Нег... В волоса заматываю } \\
\text { Ноги твон, как в мех. }\end{array}$ \\
\hline & $\begin{array}{l}21 \\
22 \\
23 \\
24\end{array}$ & $\begin{array}{l}\text { Некою тканью под ноги } \\
\text { Стелюсь... Ве тот ли (та!) } \\
\text { Твари с кудрями огненньми } \\
\text { Молвившня: встань, сестра! }\end{array}$ \\
\hline
\end{tabular}

1.1. Стихстворение открывается строфои, напоминающей традиционную эпическую экспозицию: в неи наэваны деиствующие лица (мы = Ты и я) и намечены реляция между нимн. От обычнои экспозиции она отличается лишь особьм коммуникационным статусом. Открываюцие текст местоимения [мех] мами и Ти мие эксклюэивны, т.е. объемлют только говорящего и адресата и исключают кого-либо третьего, а речь я обращена только к ТЫ и не имеет характера предназначенности для постороннего слушателя или читателя ${ }^{2}$. Поэтому информационная роль данноя речи-экспозицин весьма сомнительна: сомнительно, сообщается ли здесь что-либо этому ТЫ, так как в не нет ничего такого, чего ты мог бы не знать. Скорее всего, здесь имеет место нечто иное: ре-артикуляция известного, уяснение субъектом (я) се- 
бе и партнеру своего вэаимоположения ${ }^{3}$.

1.1.1. на самом общем, так сказать, Фабульном уровне и в самом общем - инвариантном - виде это исходное положение есть ' же - попытка более детальнои категоризации разъединялде их черты.

В первом стихе она определена вырахением десято заповедей, которое однозначно отсылает к библеяским заповедям вообще и к Моисееву Десятисловию в частности ${ }^{4}$ и означает 'установленное свьше, данное от Бога, изначальное' .

Но это не простая констатащия ситуации и не простое упоминание Дехалога. Оно введено сюда уже интертетнрованно, т.е.с отределенноя смылловоя нагрузкоя. Предварялдая интонационная пауза (графически выраженная знаком тире) и его финальная позиция в стихе возводят его в ранг категорического предиката, акцентирукщего непрекословность, непреложность и неотвратимость заповедеи, а этим самым и роковую непреодолимость разъеднненности. и тем не менее все это относится главным образом к рангу данноя ситуащия, а не к раскрьтию ее содержания.

Последнее анонсируется знаком двоеточия, проставленным после выражения десято заповедей. Согласно правилам пунктуации естественно ожидать, что вслед за ним последует либо изложение (например, перечисление) заповедея, либо же раскрытие их смысла, т.е. семантическия их эквивалент. Так оно и есть, с тем однако, что место ожидаемого эквивалента десяти заповедей занимает Жар десяти костров. Из заповеде эксплицируется смысл 'сверхмотного жара': количественное совпадение заповедеи (десять) и костров (десяти) однозначно связывает понятие 'заповеди' с понятием 'костра', костер оказывается имплицитным сводством заповеди. Более того. Числительное десято [костров] в сочетании Жар десяти костров теряет сво количественны аспект и играет роль интенсификатора хара (его, так сказать, удесятирения), а его повторность к [десяти] заповедям влияет и на это вьражение - оттесняет в нем на задния план идентифицируюиия его аспект С Декалогом, а на первое место выдвигает строгость заповедея, их безаппеляционны характер.

и это все, что можно извлечь из первых двух стихов. Очередной шаг уже невозможен без выхода за пределы текста, т.е. требуется знание по крайеи мере соответствучщих мест из Bетхозя 3аяета 
(ввиду явньх отсылок в тексте стихотворения).

1.1.2. Текст Bетхого завета допускает два близких, но не тождественных толкования упомннаемого у Цветаевод сверхмоцного хара косmpos.

Первое связано с обстоятельствами провозглатения Десятислоөия: Господь объявляет нарсду (через монсея) заповеди на горе, пылакще огнем, из среды пламени, дьма и мрака 5 , причем это огонь такоя силы, что никто не смеет приблизиться к горе, ибо он повергает и истребляет всякую плоть, внушая еи этим трепет пред своим могуществом и боязнь перед несоблюдением заповедей ${ }^{6}$, почему приближақпиеся к нему обязаны освятить себя, а сама пылалшая гора должна быть очерчена освященноя чертоя ${ }^{7}$.

Второе - с наказанием за ослушание, за нарушение заповедея, т.е. С истреблением огнем воспламенившегося гнева Господня ${ }^{8}$ или с его более бытовым вариантом: сожжением провинившегося на огне 9 .

В этом контексте Цветаевская экспликашия заповеди: Жар десяіии жостров становится совершенно естественнои и самоочевидноя ${ }^{10}$. $3 а-$ то ее истолкование все еще остается неопределенньм.

В случае первого варианта в ты надлежало бы усматривать соответствие Господа, источањщего жар и пребывающего в недоступном сакральном огненном локусе. А Я должно бы, соответственно, нахопиться в профаническом локусе (и испытывать трепет и боязнь).

Во втором случае Я и Ты должны бы быть одноранговы, а разъединянци их хар получить смысл предостережения и предупреждения о немннуемом наказании (гневе Господнем) за своеволие.

1.2. Следуюшие два стиха первоначально производят впечатление, будто они вовсе не связаны с предыдущими. Однако при более внимательном их рассмотрении отчетливо проступает целья ряд признаков, призванных обеспечить обратное - как раз очень высоку связность всен этон строфы.

1.2.1. На уровне Фонетическон организации текста она выражена в виде демонстративнон рифмы костров (2-он стих) - крово (4-ын стих). Ее демонстративны характер подиерживается и тем, что вторая рифма заповедей - отиативает кранне бедна и (по временам написания цикла) еле ощутима: она сведена всего лишь к одному отодвинутому вглубь ударному гласному, тогда как разбираемая пара звуково повтор всего слога: КостРОВ - КРОВЬ, локализованного к таму же в финале стиха; тем, что по звуковому составу оба рифмун- 
щнеся слова могут восприниматься как своеобразные, полныя и редуцированның, варианты одного и того же: КостРОВ - К-РОВБ.

За этим поэтическим ходом позволительно подразумевать интенцию смыслового сближения обоих слов, а то и вовсе родство упомнаемых явления ${ }^{11}$.

1.2.2. На синтактико-интонационном уровне - в виде графического (и интонационного) параллелизма стихов 1 и 4:

меж нами - десять эаповеден:

[...]

Ты мне - чужая кровь.

такое обрамление строфы спаивает ее окончательно и превращает в замкнутое отдельное целое, вряд ли предполагающее продолжение.

Таким образом, на этих уровнях ярко манифестируется тенденщия К уплотненно когерентности стихов $4-1$ и $4-2$ (в формальном отношения третия стих пока отодвинут на задния план; содержательно же и он вкличен в сплошную когерентность - см. 1.2.3.) и их Основных терминов - "заповеден: костров" (см. 1.1.1.) и "крови", вследствие чего "кровь" как бы должна присутствовать уже в заповедях-кострах, хотя и в неявном виде (имплицитно) .

1.2.3. На семантическом уровне такое стремление к уплотнени: когерентности еще очевиднее: Мех ками и десято заповедей: Жар десяти костров - раэъединенность Я и ТЫ предписана иэвне, свьше; Ти мке - чухая крово - такая же разъединенность, но на этот раз углубленная и имманентная: вытекающая из свонств Я и Ты (разобщение по крови).

Единственны же смысл объединения, возможнын в выражении Родкая крово, провокационно аннулирован - и ему предпослано свонство отшатывает, т.е. опять-таки 'разъединять', причем во избежание каких-либо нежелательньх толкования намеренно динамизированное (единственны во всеи строфе глагол) и, кроме того, родственное сводству только что упомянутого хара [...] костров (допускавего поначалу приблизиться к себе, а затем почти внезапно вынужда:mего попятиться).

Короче говоря, вся эта строфа сплошь пронизана семантикон 'разъединенности'. И если бы здесь не был вклкчен еще один механизм, она могла бы считаться вполне самостоятельным и исчерпанным текстом (ср. 1.2.1.). Дело, однако, в том, что последние два стиха построены по принципу антиметаболы, а это вводнт 9 в- 
разъединенность суцественную дифФеренцированность.

1.2.4. В плане вырахения крово дифференцируется по банальному прнзнаку на родкуо и чухую, но в неожиданном пля бытовых представления повороте: родкая вопреки своему названию разъединяет (отшативает), призванная же разъединять чухая поставлена в позициі противовеса родкой, и если не объединяет, то во всяком случае более приемлема для Я (может быть, как менее препятствуспая соединенил Я и ты - она по краннея мере не отшатавает; а если строго отстанвать наличие антитезиса, то можно было бы даже сказать, что наоборот - привлекает, притягивает).

В плане содержания родкая крово тесно примыкает к Жару [...] костров, а этим самым и к заповедям (см. 1.2.3.). Поэтому его расшифровку следует искать во все том же внешнем контексте.

Кроме лаконичного Десятисловия Господь объявляет народу через моисея целы ряд более детальных заповедея ${ }^{12}$, среди которьх больmое место отводится запретам эротических отношения между родственникамы по плоти и наказаниям за их нарушение (в виде истребления и сожжения на огне).

Этот контекст отшатыванщея родкой крови наконец проливает некия свет на отношения "я - ты": они мыслятся здесь в категориях противопоказаннон любви. Но поскольку заповеди: Жар [...] костров объемиют всю исходную ситуашніо и поскольку ты пля Я не родкая крово, а чухая, то все еме остается невыясненным, в чем суть (причина) запрета и в чем своеволие (провинение) Я или Ты.

Ответ на этот вопрос заставляет обратиться к внешнему контексту и, в первую очередь, относительно слова костер, поскольку крово (иухая). как уже говорилось в 1.2.1.и 1.2.2.. формально перекликается, рнфмуется, именно С ним.

И на этот раз нужның контекст подсказывается (хотя и не столь явно, как в случае ветхозаветного) самод лексикои строфы. Дело в том, что костер и крово отсутствуйт в пределах словаря заповедеи, и что они - Цветаевские эквиваленты библеяских слов "огонь" и "плоть". И это, надо полагать, не случаяно.

Денствительно, уже при самом беглом обзоре их употребления в других произведениях Цветаево обнаруживается, что им свояственен некоторы постоянны дополнительның и, несомненно, предпочитаеми поэтом смегл.

1.2.5. Так, "костру" сопутствует у цветаевон особыя йвесьма 
устончивы смысл 'рокового и желательного предела губительнон неистовод страсти. ${ }^{13}$. Самосожкение - кульмннационны момент страстнор хизни, окончательное и целостное выбывание из мира сего (а не, например, акт отчаяния). При этом гибель в костре противопоставляется бытовоя смерти как наивысшая Форма ухода из жизни и быта, а сожжение - бытовому захоронению в гробу и в могиле (это, по Цветаевоя, - место коснои плоти, гниения) ${ }^{14}$.

и тем не менее в разбираемоя строфе этот смысл не возникает стихияно. В пределах первых двух стихов костер воспринимается всего лишь как форма наказания (проявления гнева Господня), хотя уже само это словоупотребление создает возмохность его модификации в сторону цветаевских предпочтения. Активизация нужного смалового оттенка - результат дополнительного усилия: сопряжения жостров при помоци рифмы со словом жрово.

Упоминаняя "крови" бесполезно искать у Цветаевон там, где речь идет о бытовом уровне мира. Этот мир у нее, так сказать, бескровен. Они возможны в случае уровнея иного ранга - внебытовых, а точнее - под-бытовых, где осудествляются высшие, более глубокие формы Цветаевского бытия. "Кровь" в этих случаях - сублимированная стихия жизни, стихия стиха, стихия ночи, стихия страсти, т.е., стихия духовного и чувственного 15 , средоточне жизни страстея, говоря иначе, истоки ее, а в обратном направления - ее предел ${ }^{16}$.

1.2.6. В этом контексте видно, что рифма "костров - крово" семантическая Цветаевская рифма (см. причем. 11): оба ее члена объединяются общим признаком 'неистовоя предельноя страсти'. Но, как всякая рифма, и эта - не полныя семантическия повтор, он оттеняется противопоставлением по другому признаку: 'отшатываюия привлекаищия' (о6 этом см. 1.2.7.).

Теперь ясно, что в разбираемом стихотворении переименование библеяских "огня" и "плоти" в костер и крово - продуманныя "ход" поэта.

В Цветаевском костре явно присутствует признак предначертанности, неизбежности, С одноя стороны, и, С другоя, - признак финала-предела (результата, следствия) неистово страсти. Из коннотация библеяского "огня" сохраняются, таким образом, те, которые не противоречат смысловым предпочтениям Цветаевского кода, т.е.

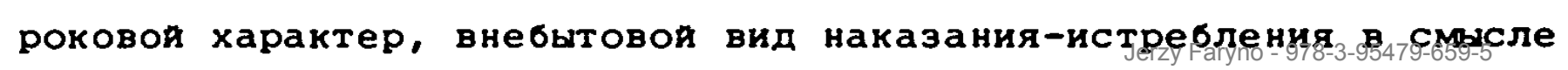


полного уничтожения, абсолютнон - без всякого остатка - вычеркнутости из мира сего. Но одновременно дает возможность обогащения своим смыслом - неистовон страсти.

Аналогично и в случае крови. Смсл 'плоти' сохраняется (крово как признак 'родства-чухдости'), но и открывает возможность для Цветаевскон высшен страсти.

Из общего названия десято заповедей в первых двух стихах никак не следует, что именно противопоказано и наказуемо в отношениях Я и ты. Зная же цветаевскую семантику костра и крови, теперь уже с большен определенностью можно сказать, что тут подразумевается любовная страсть и соответственно заповеди 1,2, 3 и $7: 1$. да не будет у тебя других богов пред лицем Моим. 2. Не делая себе кумнра и никакого изображения (...). 3. Не преклонянся им и не слухи им $(\ldots)$. 7. не прелюбоденствун ${ }^{17}$.

И тем не менее приращенные цветаевские смыслы не очевидны, они присутствукт тут всего лишь потенциально. Но как раз это и может открыть возможность для продолжения текста (так как в других отношениях он производит впечатление исчерпанного - см. $1.2 .2 .-1.2 .3 .1$.

1.2.7. Более явственна эта открытость на других уровнях организации данноя строфш: ритмическом,интонационном, Фразовом и жанровом:

$$
\begin{aligned}
\text { (A): } & -=-11=-111----111 \\
& =\| 11--=11--111 \\
& -=-1=11-=---111 \\
& =-11-=-1= \\
\text { (B) }: & -=-11=-=---111=11--=11-=111 \\
& -=-1=11-=---111=-11-=-1=
\end{aligned}
$$

Акцентная схема строфы исключительно регулярна и поэтому сама по себе информационно нентральна ${ }^{18}$. Ее ритмнческое разнообразие, а этим самым и информационность ритма возникалт здесь за счет других свонств речи: длины слов (от 1 слога до 5), выразительности и плительности словоразделов (диктуемои то знакамн препинания - тире, то затрудненно сочетаемостью звуков на стыках слов - десяТЬЗАповедеЯ, жаРДЕсяти, кровьОТшатывает) и их распределения.

Разительная плина слова заповедей и еще более удлиненного отшативает с гипердактилическон клаузулор станй 
риализованного увеличения цистанции между Я и Ты, а замыкаюеее строФу односложное слово крово в этом контексте способно принять на себя смыл сокрапения такои дистанция. При этом заметна одна закономерность: в первоя паре рифм "заповедей - отшативает" дистанция возрастает, а во второя - падает, редуцируется: "костров кPOQ0".

Иначе дерствет длительность словоразделов. В первых двух стихах они отделякт каждое слово, повышая их вьразительность и придавая им декламационның авторитарның характер. Во вторых двух преобладает тендениня к сплошному потоку речи, и на первын план выдвигаются разговорные интонацин.

Это же явление наблидается и на жанрово-синтаксическом уровне Обоих двустиши.

Первое тяготеет к категорическому утверждениі. По двум причинам. Одна из них - синтаксис. Втород стих - не продолжение, а переложение, вариант, экспликация смысла первого. другая - распеделение ударения в словах: в первом стихе подударны начальные слоги, во втором же - финальные, что как бы окончательно замыкает извлеченныр смдсл и не предполагает никакого его развития (расширения). Остальные два стиха построены иначе. Это два вполне самостоятельных предложения, связанных друг с другом отношением противопоставления. Содержание первого члена, правда, не опровергается, но оно показано как нечто безотносительное к Я и ты, как нечто такое, чего нет необходимости учитывать, принимать во внимание, ибо Я и Ты подлежат иному закону. И тут как раз возникает возможность лазеики, обхода заповедей. Если к таму жє учесть еше Факт, что эти стихи насыпены риторически (явнын парадокс третьего стиха, скрьты - последнего и антиметаболическая конструкция обоих), и что они тяготеют к сплошному говорному высказыванио (преобладают срединные ударения в словах), то позволительно сказать, что тут имеет место стремление убедить, "совратить" партнера (или оправдать се6я).

И последнее замечание. В чисто Формальном отношении первья и последния стихи - пунктуационно-графическия параллелизм (равно как и семантическия: Мех мами, разделяющне заповеди и Ти мне ч $у x$ a ж жрово), заключающи всю строфу в замкнутые рамки (см. 1.2.2. - 1.2.3.). Но он вводнтся с целью подчеркнуть различия, $а$ тождественная формальная схема оборачивается своея противополож- 
ностью: есть, оказывается, возможность обоити заповеди.

1.3. Как текстовое образование вторая строфа неоднородна, она состоит из двух субтекстов, отъединенных друг от друга пунктуационно-графически - при помощи многоточия и скобок.

Первы субтекст, т.е. стихи 5-6, являет собон продолжение предыдущего речевого потока, обращенного к ТЫ, но на этот раз формулирует не Ты, а самое Я. Иначе говоря, здесь имеет место переход с речи о Ты и для Ты на речь о Я, но с неопределеннои преднаэначенностью: Тут С одинаковьм вероятием можно усматривать и предназначенность для Ты и безотносительность К присутствию ТЫ, нечто вроде явного произнесения уже не адресованного, не диалогического высказывания. Условно эту Фразу можно назвать полумонологом или, точнее, - полувнутреннею речью. Кстати, на графическом уровне она обрывается знаком многоточия и перебивается другим типом речи.

Второи субтекст (стихи 7-8) отъединен допюлнительно - он заключен в скобки и может поэтому читатьля уже как речь "про себя", не вслух, как внутренния монолог, не предназначенны для слушателя.

Заданная языковоя письменно-произносительноя линеиностью последовательность этих субтекстов не обязательно должна отражать. такую, именно последовательность: оба этих субтекста могут протекать и единовременно, но на разных уровнях - произносимом и мыслимом.

При таком взгляде заметнее становится другая особенность этод строфы. Если первая ее часть имеет в виу самое Я, то вторая имеет

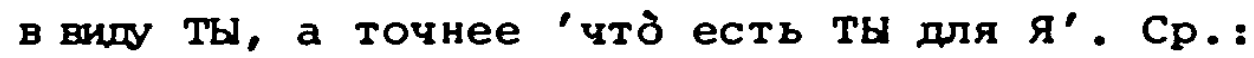

ты мне - чужая кровь.

и

(Чужая кровь - желаннеяшая

и чуждеишая из всех!),

где сначала была "экспликащия" Ты для Я в общих терминах 'чужая кровь', а потом очередная "экспликация" уже понятия 'чужоя крови' для $Я$, но теперь уже окончательная - абсолютизирующие формы $x e-$ ланяейшая и чухдейшая и эксклюзив из өсех, усиленныя к тому категорическим восклицательньм знаком (из өсех!). Синхронность обонх потоков указывала бы на то, что оба персонажа (я и ТЫ) мыслятся здесь субъектом Я единовременно, неразрывно, как одно целое (думая о себе, я думает в то же время о TH). 
Но Я и ТЫ - еще не единство. Как и в предыдуден строфе, и тут их разделяет некая грань. Она состоит в неодноранговости Я и Ты: если я - одна из многих (Била би одкой из тех...), то ты - некто искл.чительныя, единственныя (категорическия эксклозив из өсех!). неодноранговость же, как видно, проистекает из категории 'численности. 19.

Но это уже вплотную подводит к семантике строфы.

1.3.1. Стихи 5-6 непосредственно связаны со стихами 1-2 через общность в обеих этих парах отсылок не только к одному и тому же контексту, к Сөященному Писанио (десято заповедей и өремена

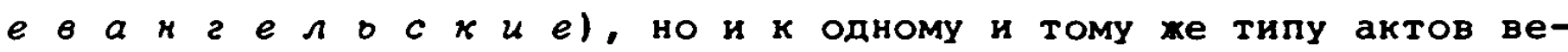
щания: ср. "заповедь" и смысл слова "евангелие" (от греческого

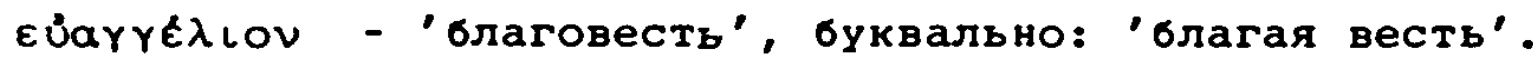

Казалось бы, что в данном случае состоялось противопоставление разъединяопих заповедей и единящих времек евакгелоских в пользу последних. Такоя вывод, однако, вряд ли доказуем. Дело в том, что обе сопоставляемые пары стихов базирултся на однои и тои же категории 'численности' (десято, десяти; өремена, одкой из mеx...) и продолжајот сохранять одннаковую неопределенность. Неопределенность возникает за счет возможности читать хар костров двояко - как отшатывающия и как притягивањщия (ср. 1.2.5.-1.2.6.) - и так же двояко читать одку из теx: так - 'была 6 такоя же, как и остальные, многие'; и так - 'была 6 тон однои-единоя из многих', 'избранноя' (интонационно стих 6 допускает оба прочтения при одинаковод интерпретации многоточия - то как оборваннои Фразы, то как эмоционального знака, соответствующего восклицательному в стихе 8; кроме того,ритмнческие поэиции слов одкой и тех уравновешены в акцентном отношении, и только прозаическая трактовка стиха могла бы его нарушить в пользу одного или другого).

1.3.2. Раньше (в 1.2.7.) была отмечена риторическая насьденность стихов 3-4 и ее, так сказать, 'совратительныя, увещеваония' характер. Если теперь стихи 5-6 рассматривать как продолжение тех, то и здесь бы он сохранялся, а их смысл мог бы читаться так: 'Во времена евангельские и меня - как и тех других - ты бы не отверг' или 'Мне - как и тем другим - было бы позволено приобщиться к Тебе (невзирая на "десять заповеден")'.

но в этом случае второя субтекст (стихи 7-8) был бы чистым текстом "про себя", "таяным умыслом я", а первыя - лишь обманчи- 
вым соблазняюшим приемом, уловкон.

1.3.3. Стихи 7-8 - открытая отсылка к стихам 3-4, получившая вид усиленного лексического повтора чухая крово и чухдейшая. Hо это - не буквальныя повтор. Если раньше чухая крово имела главным обраэом смысл 'родства', хотя и не исключала смысла 'чувственнои плоти' (см. 1.2.6.), то теперь имеется в виду прежде всего 'кровь-плоть' в чувственном аспекте (притягательная, вызыванщая страсть: хеланкейшая), а чухая, сохраняя смысл 'не-родственнон', явно эволюционирует в сторону 'удивительноя', 'чудесноя' (иухдейmas) 20 .

1.3.4. Но так или иначе обе эти строфы сохраняют высокух степень неопределенности и предполагалт двоякое прочтение. Правда, в конце перво и во второи устанавливается однозначное полохительное влечение я к ТЫ, но тем не менее природа этого влечения еще не определяется. Оно мохет быть равным обраэом как 'чувственно' и даже 'порочно', так и чисто 'духовно', 'мистически непорочно', т.е. как эротом, так и агапе.

1.3.5. Разбираемая строфа позволяет наконец минимально приблизитьск определению "деяствуюши лиц" текста. Форма глагола Била $\sigma$ свидетельствует о том, что Я, говоряпия субъект, - женщина. Ты в прямо форме здесь вовсе не упомннается, но наличие сочетания өремена евангелоские, а в его контексте упомннание крови с абсолютиэнругшим хеланнейшая и иухдейшая (с воэможностьі смысла 'удивительнеяшая') почти однозначно связует Ты с Христом' . И это пока все. Можно еще только отметить настоячивую "анонимность" обоих персонаже - Я пока что только одка из тех, а ты дан в виде его инобытия - крови, и то не в однозначном толковании. По всея вероятности это не случанно, однако смысл данного приема еще никак не раскрывается 22.

1.3.6. Мехду разбираемыми двумя строфамн наблідается заметнын временнон сдвиг: время второи строфы (өремека еөангелоские) не совпадает по краинеи мере со временем акта речи. Время же акта речи на основании данного отрывка неустановимо. Это может быть, например, условное современное время начала 20-х годов (т.е. время написания-публикации-чтения данного текста). Но может быть такхе и временем говорящего субъекта - Я. Если согласиться с первьм вариантом, то можно было бы предполагать, что:

а. Некая любовная ситуация моделируется тут по образиу биб- 
леиско-евангельскоя. А смисл такого моделирования должен раскрыться позднее.

6. Вообще здесь имеет место мнстическая, а еде точнее - теологическая медитация и коммуникачия с Богом-Христом. Это опять-таки должно выясниться по ходу развития текста.

Если же принять во внимание второ вариант, то тут неопределенность возрастает, но становится более приемлемоя:

в. Условное Я (фиктивная героння) современно Цветаево и поставлено в ситуаци:о а. или б. Причем во всех этих случаях форма сослагательного наклонения Била $\sigma$ давала бы расслоение времени на настоящее (современное) пля героини и историческое прошедшее время евангельских события.

Г. Условное Я (фиктивная героиня) локализовано в ветхозаветном времени (во всяком случае между временем установления Декалога и временем евангельских события). Форма Бала $\sigma$ тогда была бы обрамена в будущее. Вследствие этого Я обладал бы неким даром провидения, или хотя бы неосознанного интуитивного опознавания в ты христа (Бога), хотя бы по образцу блудницы Раав 23.

1.4. Стихи 9-14 выражены формоя сослагательного наклонения, поэтому целесообразно разбирать их как одно целое. Дополнительно это оправдывается и синтактико-пунктуационным членением данного текста: все шесть стихов являют собои сплошно речево поток, пунктуашионно объединенны в одно предложение; гранишы мехду стихами и между строфамн сильно размыты переносами; конец отрывка помечен многоточием (аналогично к концу первого - см. стихи 1-6).

По свое модальности эта часть тесно примыкает к предыдушеи строфе, а особенно к стихам 5-6, в которьх впервые введена Форма сослагательного наклонения, и является как бы ее естественньм продолжением. По композишия, однако, это едннство (связь) если и вовсе не расторгнуто, то, по кранне мере, решнтельно ослаблено как обрывом-многоточнем в конце стиха 6, так и промехуточным монологом "про себя", взятым к тому еще в скобки (стихи 7-8). Такая последовательность текста создает определенның модальның сдвиг.

В первом случае (стихи 5-6) сослагательное наклонение выражает условно-утвердительную модальность: 'если бы я жнла тогда-то, я была бы такая-то, т.е. одной из тех, но нначе я не та, а другая'.

Во втором случае условие в определенно мере сохраняется, но 
ввиду его текстово удаленности начинает преобладать описательның (повествовательның, изъявительның) аспект возможноя тогдашнеи Я, с однор стороны, a c другоя - возможность отождествления обоих вариантов Я. На это указывает все возрасталдая "увлеченность" Я воображаемьм: синтаксическая непрерывность речевого потока, интенсификация предполагаемых дейтвй вплоть до персеверацин ( коги $\sigma u, u$ под коги $\sigma a$ ) и обрыва речи (многоточяе в конце). $Я$ тут как бы "заговаривается", захлебывается своея речью и отождествляется $c$ ее содержанием переходя на перформатив: вряд ли случанно в очередных стихах (особенно в 12) появится повелительное наклонение настоящего времени теки! (но об этом ниже).

На сдвиг в модальности может указывать также и последовательная смена частицы $\sigma$ (она употреблена трижды) на частицу би (тоже употребленнуі три раза). Некоторые из смыслов этого противопоставления будут учтены поэже, но некоторые целесообразно отметить уже теперь. Первая ( $\sigma$ ) претерпевает заметную эволицию: сначала она относится к самому я (Бала б), затем, все еще относясь к 9 , уже предпосылается Ты ( $K$ тебе 6 ; лила $\sigma)$, переход же на $\sigma$ и совпадает с перенесением всего воображаемого денствия на ТЫ. Частица 6u получает, таким образом, адресованность к ТА, становится риторическим приемом уговаривания (можно бы сказать в свете сделанных уже наблюдения - "обольщения", "соблазна"; ср. 1.2.7.), интенсификашия которого может, в свою очередь, свидетельствовать о постепенном отождествления Я $\mathrm{C}$ воображаемъм. 24

1.4.1. Лексическия и поведенческия уровни данного Фрагмента отсылахт к евангельскому контексту и воспринималтся как некин сооирательныя образ евангельских женщин, встречавшихся Христу: страданщих от недугов и ищуших у него помощи (со всеми м $е$ м о u а м и влекласо) 25 , одержнмих бесамя (очесами демонскими таясо) ${ }^{26}$, воздақиих ему надлежащие почести, в том числе и грешниц и блудниц (лила 6 маслі) ${ }^{27}$. и именно по этому собирательному обраэу строит Я свое воображаемое поведение (кстати, согласно словам в стихе 6: Eила 6 одной из $m e x$ ).

Нетрудно заметить, что предполагаемое Я поведение весьма двусмысленно, и что оно излагается в определенноя последовательности.

В стихе 9 речь идет о кемощах, поэтому интенцию Я можно читать как желание исцеления. Но в стихе 10 появляютяя слова Влек- 
лась, сmлалась, которые не так уж и однозначны. Влекласо может обозначать не только 'передвигаясь с трудом', но и любовное эротическое 'влечение'. Cmлаласо же, в свою очередь, повторяя смысл слова влехлась, усиливает динамику влечения, интенсифицирует его, что резко противоречит прямому его смыслу 'передвигаться с трудом'. Более того: оно обнарухнвает в Я некую предрасположенность к метаморфозе, а этим самьм придает ему своеобразную окраску 'колдовского, демонического' 28

Cөеmла Macmo! поставлена в позицию мехдометного восклицания (безразлично, "про себя" ли, или же адресованного), смьсл которого известен только произносящему. Он может расшифровываться по-раз ному :

а. Как захваливакщия рекламның базарнын выкрик;

6. Как иносказание, перенменование немощей с акцентом на скрытоһ связи с 'плотью'; ср. кемОЩАМи - МАСТь;

в. Как игра слов масто в смысле 'бальзамическое снадобье' и масто в смысле 'окраска шерсти (животного)'. 29

Ни один из этих смыслов пока отчетливо не прорисовывается, тут мохет поддерживаться лишь двусмысленность междометного Свеmла Maсmo! из-за его позиция вводного слова. Зато его риторическия ореол (захваливание, иносказание, игра слов) здесь значительно явственнее, чем в стихах 3-4 и 7-8 (см. 1.2.7. и 1.3.2.), что отражено в смене скобок на тире, ослабляющих вычленимость даннон фразы как отдельного субтекста, и в приеме межстихового переноса. на поверхность же текста он будет выведен в стихах 13-14 и к их финалу вообще вытеснит собоя основно текст.

Вторая часть 11 стиха очесами демонскими Таясо эксплиширует то, что интуитивно чувствовалось в подтексте: демоническия соблазняюияя характер поведения Я, подделанны под естественныя обряд воздаяния почестен и якобы желание исцелиться (Таясо).

Стих 12 опять возвращается к ложнон поверхности: Таясо $\Omega$ и $\wedge$ a $\sigma$ м a $c \wedge \grave{a}$. Но текст построен так, что слово масла тут уже нагружено всемн предваряљщими смыслами, особенно благодаря звуковоЯ организации этоЯ строфы (ср. влекЛАсь - СтЛАЛАСь - СветЛА МАСть - ЛИЛА 6 - МАСЛА; ср. также б. и в.).

В последних двух стихах (13-14) демонския умысел, казалось бы, осушествляется. Но на деле это не совсем так.

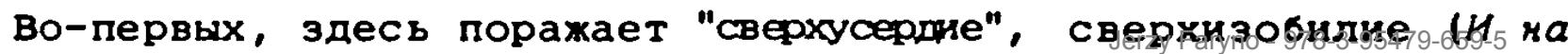


ноги [...], и под ноги [...]), переходящее в 'бескорыстие, бесцельность' (H вовсе [...] так) и даже некия десператизм (в песжи.... где многоточие указывает не сталько на какое-то возможное, но недосказанное продолжение, сколько на осознание бесполезности данного деяствия и отказ от негоl.

Во-вторых, тронное скопление частишы $\sigma$ вместо предваряюдего варианта 6 открывает теперь и другие свои смыслы (кроме отмеченного в 1.4. перехода к отождествлению Я с евангельским образцом).

Если Форма 6 способна вызвать впечатление бо́льшей энергичности, категоричности, решительности, то форма би говорит скорее о желательном, чем о возможном, и обнаруживает некут неуверенность.

кроме того существенна и внутренняя дифференциация самих этих бш. Если первых два попадают в сильную синтактико-метрическую позицию (конец синтагм, конец полустиха и стиха) с усилением длительности благодаря предваряіиим $u(u-A-a-u-b u-0-a-$ $u$ - b) и с заметным огублением $u$ - $b$ из-за промежуточного 6 , то третье би упрятано: $u-0-e-u-A$ - - - ... . Четвертое же, охидаемое по инерции в последнем полустиши, уже вовсе не появляется: здесь как бы совершается полнын отказ от сослагательного неклонения .

Более того. Сильное огубление, ниэкотональность $(2, \sigma, x$, $u-u)$, ДиФФузность $(u-u)$ легко ассоциируотся с мимнческим и звуковьм ореолом плача-рыдания. В контексте стихов 11-12 (очесами демокскими таясо) этот "рыдательнын" ореот может восприниматься как соответствие "бесовского воя", которын к концу однако ослабевает. В контексте же явных отсылок к евангельским грешницам этот ореол позволительно читать также и как признак деиствительного "рыдания" со смыслом 'покаяния'. Отмеченная эволюция частид ба позвотет здесь усматривать оба этих признака с постепенньм сдвигом в сторону "рыдания".

Если согласиться с таким толкованием, то предел расточительства ( $ө$ пески...) раскрывал бы и еще один свод смысл. Теперь его позволительно читать как своеобразное желание "провалиться сквозь землю" от испьтываемого-осознаваемого стыда (вряд ли случаяна тут парадигма ка ноги $\rightarrow$ под коги $\rightarrow$ пески, ведущая вниз вглубь). такое прочтение, кстати, намечается значительно раньше, в словах очесами демокскими $T$ a $A$ 0 (стихи 11-12), где упрятанность глаз может быть не только признаком элого умысла, но и симптомом стыда 
(а во всяком случае осознания внновности).

1.5. Очередная часть (стихи 15 до начала 19) вичленяется по тому же приншипу - от многоточия до многоточия:

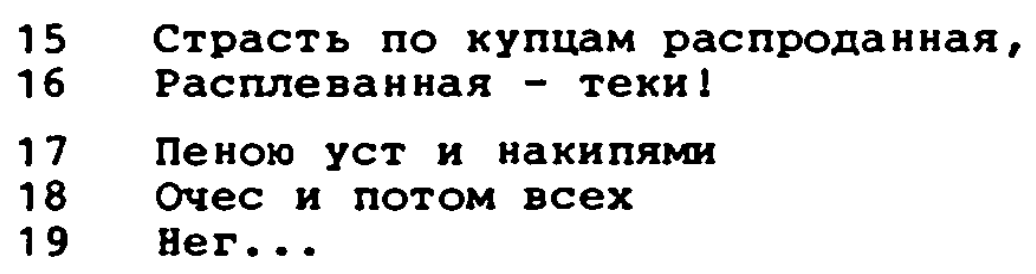

В свете предыдуших талкования ее смысл представляется весьма очевидным: здесь имеет место отказ от бесовского начала, от соблазна, от греховности плоти.

1.5.1. Cтрасто имеет здесь один смысл - чувственнон страсти и блудодеяния: по купиам распродаккая. Но существенно не только это. Гораздо существеннее,как кажется, установить, на каком хновании вообще появляется здесь слово страсто. Возвращаясь к предэаря.инм партиям текста, легко обнаружить следуюпее.

В более или менее явном виде 'страсть' присутствовала в таких словах как: Жар десяти костров; чухая крово; Чухая крово - хелакмейшая $И$ чухдейшая из өсех; $K$ тебе $\sigma$ со всеми кемочами Влекласо, cmnanaco.

Менее очевидно было ее наличие в масти и маслах. Теперь же картина принцинально меняется: масти и масла̀ - лишь эквивалент страсти. По следукщим соображениям:

а. Императив Страсто [...] теки! следует сразу же после поливания ног маслами. Тут, во-первых, страсти и масла́ объединяљтся общим признаком 'текучести' (лила би масла̀ и Страсто [...] теки!). А во-вторьх, страсто есть переименование предыдущего масла (ср. рифму лила б масла [...] в песжи - тежи!).

6. Слово Cmpacmo занимает в свое строфе такое же место, что и Macmo в своеи (в первых двух строфах это место занимает соответственно Родкая крово и Чухая крово), к тому хе они из-за своен однослохности явно рифмованны. Более того: страсто определена здесь как по купиам распродаккая, т.е. как товар. Аналогичны "коммерческия" признак улавливается и в выкрике сөетла масть! (cM. 1.4.1.a.) .

1.5.2. Слова распродаккая, Расплеваккая вводят смысл бессмысленнои растраты, 'несохранения' 'обесцененности' ' поругания' и 'ненужности'. Но он не совсем нов. Он - продолжение и следствие бесцельнои сверхрасточительности в стихах 13-14, а с другоя точки 
эрения - просто экспликация одного из смыслов слова маслd.

1.5.3. Теки! в контексте слов лила 6 масла̀ [...] H өовсе 64 так, ө пески... получает смысл полного отказа от предыдудего образа жизни, от себя прежнея как чего-то уже ненужного.

1.5.4. Внутри же разбираемого фрагмента происходит следуюпее: Cmрасто [...] техи! Пенор уст и нахипями очес и потом өсех Нег...

теперь страсто получает вид не мастей, а телесных удаления. их природа опять-таки раскрывается при помощи предыдущего контекста. Все они перекликаются с упомянутьми в стихе 9 немощами (ср. дополнительно: $c 0$ e $c$ e $u$ мемочами и $\theta$ c $e x$ Нег): страсть тут вырахена критическим состоянием организма - пена уст и махипи очес, читаеме как "воспаленные глаза", пот, читаемы как симптом болезненного жара.

Раньше в немочах домннировал признак 'недугов' и стремление я к нсцелению (ср. 1.4.1.). Этот признак, как видно, не устранен и элесь. Дахе наоборот: создается ожидание такого исцеления (ввиду отказа от блудодеяния в императиве техи!). Криэнсное воспаленное состояние Я является, несомненно, картиноя такого исцеления, овобождения от недугов. И так оно и есть. Указание к прочтениі этон картины содержится в слове Очес, которое в данном тексте употреблено уже во второн раз. Первы раз оно появилось в стихах 11-12: очесами демонскими таясо.

Страсть в ее превратном бесовском варнанте была тогда сокрыта (Таясо) и имела обманчивы вид немочей и масти (ср. 1.4.1.6. н, кроме того, рифму нЕмочами - дЕмонскими). Теперь же она выведена наружу в своея собственноя разновндности (махипями Очес).

Если смотреть на этот текст так, то не менее очевидно и другое: пена усm, махипи очес, пот Не2 песечнслены в одном ряду как однородные явления, как взанмоэквиваленты. Вывод, таким обраэом, возникает сам по себе: перед нами картина исцеления от недугов, но особьх - от недугов-немощей одерхимости бесами. иначе говоря, это - картина извержения бесовского начала.

Поскольку весь текст постоянно удерживается в контексте евангельских события, то дополнительно можно привлечь и этот контекст. По поводу женщин, сопутствующих Христу, там говорится: "и некоторые женщины, которых он исцелил от злых духов и болезнеи: Мария, называемая Магдалиною, из котороя вьшли семь бесов" 30 . А вот как описывается одержимы бесом: "Его схватывает дух, и он 
внезапно вскрикивает, и терзает его, так что он испускает пену: и насилу отступает от него измучив его" 31.

1.5.5. Даннья Фрагмент примечателен и еде в одном отношенин. Здесь наблюдается очередная смена глагольного наклонения и отчасти времени. Эта эволишия такова: изьявительное наклонение и неопрепеленне настоящее время (стихи 1-4и, может быть, 7-8), сослагательное наклонение и предположнтельное евангельское время (стихи 5-6 и 9-14) и, наконец, повелительное наклонение и форма настоящего времени (стихи 15 до половины 19), которое все-таки неопределенно: то ли это время евангельского варианта Я, то ли время реальноя $Я$, то ли вообще комментария $Я$ к своеи евангельскон ипостаси. Зато эволюция на уровне наклонения налицо: от некоен настояшея ситуашии через воображаемую до императива.

1.6. Четвертая часть текста начинается с середины 19 стиха и кончается (все тем же делимытатором - многоточнем) на середине 22-ro:

$\begin{array}{ll}19 & \text { [...] В волоса заматываю } \\ 20 & \text { Ноги твои, как в мех. } \\ 21 & \text { Некою тканью под ноги } \\ 22 & \text { Стелюсь... }\end{array}$

От всех предыдуиих частер -тот отрывок отличается определенностью глагольного настоящего времени и однозначным сослагательным наклоненнем. Такую же классическуя однозначность получает и ситуация Я - Ты: Я окутывает ноги Ты. Но это ситуация особая. Здесь почти буквально воспронзводится евангельская ситуашия омовения и вытирания ног Хрнсту - омовение слезами, натирание нардовым миром н осушение волосамн свонмн 32 .

в этом случае существенны следукине Факторы.

1.6.1. Осушение ног есть продолжение предыдущего поливания маслами (лила $\sigma$ маслӓ $H$ на ноги би, и под ноги би) 33 . Но поливанне масламн было дано в плане воображаемон реальности, тогда как вытирание-окутывание - в плане реальнои деиствительяости. Это значит, что здесь произошло отождествление Я с Я воображаемоя. Произошло оно, однако, не сразу, а через неопределеннух ситуацик в стихах 9-14.

1.6.2. Поливание ног масламн имело двусмысленныя характер: деяствительного обожания н симулирования его, эротическия и непорочның (может быть, дахе сакральның). Окутыванию же ног в

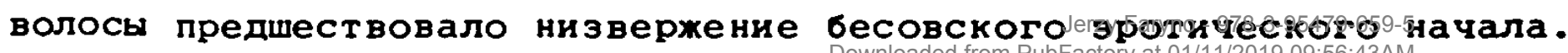


Поэтому картину осушения естественно интерпретированть как лишенную соблазнительно-эротического аспекта. 33

1.6.3. Таким образом, здесь происходит отождествление я не с какоя-либо из сопутствукщих Христу евангельских женщин, не с любоя из тех (см. стих 6), а с более конкретноя - освободившеяся от бесовского наваждения и уверовавше в него. и заглавие цикла и весь строя первого стихотворения говорят о том, что здесь речь идет о Мария Магдалине. Но поскольку она здесь еще не названа, целесообразнее этого уточнялщего шага еще не делать.

1.6.4. На смену масти и масел появлянтся волоса и мех, вследствие чего волоса становятся своеобразным эквивалентом прежнен масти, а этим самым и прежнея страсти (см. 1.4.1.а.и 1.5.1.а.). Существенно, однако, что этим эквивалентом стали именно волоси. Пока смысл волос раскрывается еще слабо и по данному Фрагменту можно установить всего лишь следуопее: волоса - нечто иное чем мех; это не 'звериное', а 'человеческое', или иначе: 'человеческое' вместо 'звериного' 34 Последнее тем более значимо, что признак 'звериного' потенциально присутствовал уже раньше: в слове масто, способном означать и 'благовонные масла' и 'окраску шерсти животного' (см. 1.4.1.в.), и в слове [очесами] демомскими. Переход на волоси, таким образом, свидетельствует о преодолении 'зверино-демонского' начала. Кстати, это следует также и из других Фактов.

а. С 'волос-масти' снимается 'звериныя' признак путем двояного его снятия с меха. Во-первых, мех получил тут вид предмета домашнего обихода, предмета 'уюта' 35 это, так сказать, уже не зверь, а нечто освоенное, домашнее, хотя связь со 'зверем' окончательно не устраняется. ображо выражаясь, можно сказать, что это 'зверь побежденның' - Во-вторых, мех упомянут тут на уровне языка описания, в сравнении (как в мех), введение которого позволительно понимать так: 'освободившись от звериного неопасно употребить его на правах сравнения' (тем более, что это сравнение принадлежит Я - это Я сравнивает самое себя, свои волосы, с мехом).

6. Перевод 'звериного' на уровень языка описания на этом не заканчивается. Он имеет свое продолжение и свол эволюциі в словах Hекох ткакох под ноги Стелісо...

Данные слова отсылают к стихам 9-10 (K meбе 6 [...] влекласо, c $m \wedge$ a $\Omega$ a ol, где, как уже говорилось в 1.4.1., я обнаружнвает свою предрасполохенность к колдовскоя, јрвериня-беяядякоя ме- 
таморфозе. Теперь же и 'звериное' и метаморфоза претерпевалт знаменательную эволюцию: звериное 'Сваивается', сначала получая вид предмета домашнего обихода, своеобразного трофея от побежденного зверя, а затем вообще 'не-телесного', 'растительного' (мех -

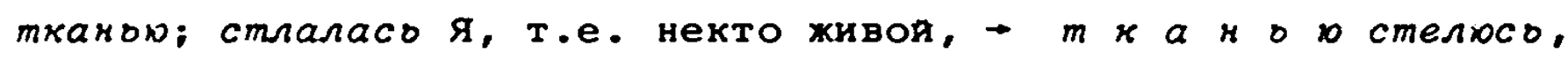
т.е. не-живым, не плотью в виде кемощей, ср. 1.4.1.6.l, а метаморфоза Некок ткакор [...] Стелюсо расшатывается как таковая (она одновременно и не метаморфоза, а сравнение, так как следует тут же после сравнения как в мех, и все-таки метаморфоза, поскольку открывает новуз строфу и новое предложение, но, по всен вероятности, уже совсем иного ранга). 36

И, наконец, небезынтересна и эволюция скрытая в выражениях $\kappa$ meбe $\sigma \rightarrow$ Ноги mвои - под коги с промежуточным $И$ на коги би, $u$ под коги $6 x$. Во всеи этон эволюции без труда опознается символическая картина побежденноя бестии, укрощения нрава, а также эволюция в сторону 'смиреннон рабыни' 37 .

1.7. Последняя часть - стихи 22-24:

\section{2 [...] не тот ли (та!)}

23 Твари с кудрямн огненными

24 Молвившия: встань, сестра!

являет собоя окончательное опознание-идентификащию.

Благодаря соседству вопросно-опознавательнон формулы Hе mоm ли следующее тут же за нея та! c вослицатељым знаком также читается как идентифицирующия возглас-жест. Обособленность при помощи скобок переводит его в ранг немого внутреннего возгласа, одновременного с произносимои речью, и этим самым указывает на глубинныя, сущностның характер идентификации. Неожнданность - разрыв речи, осооенно в графическом варианте, в самом ее начале, ударная позиция в конце стиха и, наконец, восклицательныя знак говорят о внезапности внутреннего озарения, О внезапном опознании той (сp. стих 6: Бала 6 одной из $m e x$ ).

В стихах 7-8 скобки заключали речь "про себя", Формулируюаую сущность ты для Я (см. 1.3.), теперь же при помощи аналогичного приема формулируется сущность я для Я и ты. иначе говоря, возглас (та!) следует читать как "я есть та! или точнее - та тогдашняя". В контексте стихов 5-6 расшифровывается и местонмение "та": Была б одной из $т$ е $x$ и "я есть та тогдашняя". Я, как видно, наконец полностью идентифицируется, а точнее - окончательно опознает в себе одну из тех, т.е. одну из евангельских жентин, 97из, 
но, не какую-либо из них, а четко определенную.

Если согласиться, что оба субтекста второя строфы протека.т синхронно, единовременно (см. 1.3.), то такую же единовременность позволительно видеть и здесь, тем более, что оба местоимения (субтексты) оказались не только в одном и том же стихе, но и рядом друг с другом: Не mот ли (та!). Эту синхронность мохно записать так:

\section{Не тот ли \\ (Ta!)}

А это означало бы, что тот и та мыслятся здесь как одно единство, или - по Цветаевскому коду - как семантическая рифма, как нерасторжимая изначально предназначенная друг другу пара (см. примечание 11$)$.

Далее: если тот узнан в ТЫ, а та в Я, то такоя же глубиннои семантическор рифмоя, таким же Глубинным единством становятся здесь и Ты-Я. Тем самым окончательно снималось бы здесь первоначальное их разобщение (см. стих 1: Мех ками... и сплошноя смысл 'разъединенности' во всея первон строфе; см. 1.1.1.и след.).

Теперь остается лишь установить, кто же таков топ и кто такая ma, что и позволит определить уровень, на котором осуществляется объединение $Я$ и ты.

В стихе 23 упомннается төаро с кудрями огкенмими. И Төаро и кудри огкенкие - несомненные признаки бесовского ${ }^{38}$. Здесь, как видно, возобновляется характеристика одноя из тех евангельских женщин, которо била $\sigma$ Я (см. В стихе 11 выражение очесамн демонскими; извержение бесовского в стихах 17-19; а также теперь уже очевидны подспудны смысл слов сөетла масто! в стихах 10-11 как обозначение светлого - золотистого? - цвета волос, а точнее масти животного, нынче получивтего эксплицированное выражение в слове meapu).

На этом смысл кудрей огкекких не исчерпывается. Огненныя медныя - цвет волос традиционно воспринимается как признак чувственного, эротического, сексуальноя невоэдержанности ${ }^{39}$ (см. примечание 38). Это обстоятельство подсказывает, что тут имеется в виду не какая-либо из тех евангельских женщин, а как раз грешница, блудница. и наконец, упомннание волос, но в варианте кудри, которыя, сохраняя греховныя их характер подчеркивает и их обилие, недвусмысленно отсылает к Мария из Магдалы, т.е. Мария Магдалине.

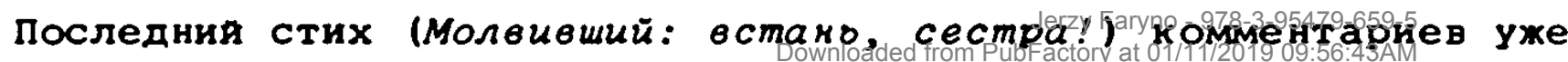


не требует - он устанавливает тождество между тот и Христос. Цветаевское "рифмующееся" единство, получает теперь, таким образом, определенны конкретныя вид:

$$
\text { 'Хрнстос/Магдалина' = Ты/я }
$$

Не менее значим здесь и факт, что ни Христос ни Магдалина в тексте не называются, что они $О$ п $о$ н а ю ципиентом стихотворения). И дело не только в прямоя иллістраџии теологического положения, согласно которому узнавание-вера есть пробны каменз веры-уверования. Дело го́раэдо сложнее.

После момента оэарения-опонания в ТЫ mого, а в ceбe moй (He mот ли (ma!j) следуют формы явно их различа.жне. Тваро с кудрями огненними ставится здесь в положение отличного от Я существа (объекта речи) и этим самы как бы водворяется на свое историческое место и в свое евангельское время (за этим отчуждением Твари стонт, несомненно, и отчуждение Я от прежнеи 'греховноя' своеи ипостаси - ср. стилистическую окраску всер этоя Фразы: она носит явны оценочны характер и, что существенно, произносится ведь все тем же я). Аналогичньм образом и деепричастие Молвиөший восстанавливает прошедшее совершенное и свершённое евангельское время (ср. его однократность). Но в данном случае это деепричастие не отодвигает того (ТЫ:ТОТ) в прошлое, а лишь подчеркивает его темпоральное присутствие и тогда и теперь, т.е. его вневременность. В прошлое отодвигается лишь акт прощения ("благовестия") по отношению к конкретнор женщине - блуднице Магдалине.

ты, таким образом, оказывается нензменен, он - все тот же и лишь постепенно опознается Я как ТОT (Христос). Зато Я меняется: перевоплощается в некую блудницу, в которо опознает самое себя нынешнюю, а затем как $\Pi$ р 0 щ $е$ н н у ю. или могущую надеяться на прощение по образцу Магдалины. Магдалина для Я всего лишь модель, объяснялиая Я ее самое.

Случанно ли, что несмотря на отождествление я с тоя (ma!) после следует тваро с кудрями огкенмими как некто посторонния? 3а этим ходом стоит различение я и ТОЯ, но различение особое. ТА дана здесь в своем демоническом обличье, а не в новом инобытии после извержения бесов (См. Стихи 11-19 и 1.5.4.). В такои разобщенности и объективации можно видеть отказ от бесовского начала, идентификацию только с Магдалиноя покаявшеяся, а не с ее ипостасью блудницы. 
Заключительные слова встано, сестра! имеот особыя статус. В одном смысле они - цитата некогда произнесенного Христом, и в этом плане воспроизводятся как адресованные к ТОИ (Магдалине). Но их же можно читать и как обращенные непосредственно и к Я. По следуіинм сообрахениям.

Глагол встано оправдывается здесь всен сериея предпосланных Я позиция-поэ, общия признак которых - 'неустоячивость, приземленность, горизонтальность' и т.Л.: отшативает (стих 3), со всеми кемочами Влекласо, стлаласо (стихн 9-10), Таясо (стих 12), В волоса заматхваю Ноги твои, как в мех (стихи 19-20), ткакољ под коги Стельсо (стихи 21-22).

обращение же сестра вносит смысл равенства, также и в социальном (ср. позу "рабыни" в стихах 19-20) и в позиционапьном ("стоячем") отношениях. Но оно читается как обращение к я не только поэтому. Имея свонм основным смыслом смысл 'родства (по плоти, крови)', оно непосредственно отсылает к открываіщим весь текст убеждениям Я (см. стихн 3-4: Родкая крово отшативает, $T$ и мяе - иухая крово.), которые теперь опровергаются. Но и понятие 'родства' уже принципиально иэменено.

төаро, названная сестрой, снимает с сестра признак родства по крови (плоти) и вводит признак абстрактного 'духовного' родства-равенства. И тем не менее, несмотря на очевидность наличия такого смысла в словоупотребления сестра, остальными комлонентами текста он почти вовсе не подтверждается. Только с большон натяжкоя он может усматриваться в Масти как "целебном снадобье" и в акте заматывания ног, которые могли бы здесь ассоцияроваться с выражением "сестра милосердия", а этим самым и с понятием 'духовного'. Поэтому чрезвычаяно интересно, что остальные сводства текста, ообенно его фонемнческого уровня, акцентирует в слове cестра нечто иное и более сложное. Ср. сплошную перекличку в словах: $2 A P$ - жОСТPов - төAPо - КРово - КудРЯми - МАСТЬ - СТРАСТЬ PACпродакная - РАСплеванмая и финальное СеСТРA.

Я, как видно, вправе отнести обращение сестра также и к себе, а не только как цитату, поскольку звуковоя состав этого обращения концентрирует в себе все относившееся прежде к былым состояниям Я: тут налицо и связь с блудодеянием и с наказанием. Причем наказание вкличается перекличкон с коСтрамн, которая споспобна, в свол очередь, подкл.чить блудодеяние к смыслу наказания (фигуральго 
выражаясь, жострх есть наказание за блуд, а блуд оказывается "костром" наказания; ср. дополнительно повторение этого же эвукоряда в словах PACпроданкая и РАСплеванмая - см. 1.5.2.). С этои точки эрения смысл слова сестра расшифровывается как 'страдагдая грешница' (кстати, в менее заметном виде он присутствует и в Төари в связи С тем, что она охарактернзована кудрями $о 2 \mu e *-$ * $а$, $u$, указывающнмн на ее сопрнчастность кострам-огно) .

Поставленны в конце восклицательның знак тоже может чнтаться трояко:

а. Как принадлежащия только цитате.

6. Как знак духовного озарения-восклицания Я, аналогичның восклицательному знаку в случае внутрекнего возгласа та!, т.е. как знак изумления-догадки.

в. И, наконец, как знак изумления-откровения-радости при вопроизведении евангельских слов Христа и опознания в них адресованности к самои себе (т.е.к я).

и последнее замечание. ТЫ во всем тексте почти отсутствует, во всяком случае никак не проявляет себя никаким поведением. Ты, так сказать, пребывает в своеобразном бездеятельном состоянии. Даже заключительное встако, сестра! - не прямая речь ТЫ, а воспроизводимая Я цитата. Зато Я - деятельно. Это значнт, что тут преображение (возрожление) Я происходит самопроизвольно, без внешнего вмешательства, исключительно путем опознания в себе некоя грешницы, а в Ты - Христа (или вообще Бога, недаром ведь текст открывается упомннанием ветхозаветных десяти заповедей).

1.8. Теперь, после прочтения всего текста, проясняется его croxet .

Сначала дана некая не совсем ясная отвлеченная ситуашия с двумя персонажамя: Я и Ты, где они оба могут читаться как пара возлюбленных, обреченных на разъединенность. При этом Ты может прочитываться как в обычном, так и в божественном планах. Во всяком случае препятствием является божественның закон (Декалог), на возможность преодоления (обхода) которого указывает 9.

далее следует предположительныя вариант этоя же ситуации, но во өремека евангелоские. Я мылит здесь себя по образцу евангельских женщин, сопутствуюиих ты (т.е. подразумеваемому Христу). Ее модель поведения амбивалентна: на первом (обманчивом) плане выво-

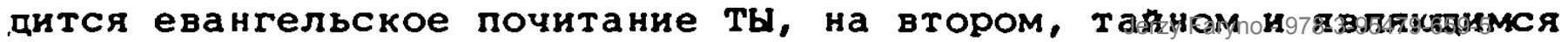


деиствительноһ целью поведения Я, - эротическое обольщение, совращение ТЫ.

Однако по мере идентификашия Я с евангельскоя грешницеи начинает брать верх первы план почитания, а коварны совратительны подлехит искоренению, вплоть до акта экзориизма - изверхения эротико-бесовского начала.

После изверхения возобновляется некая реальная (в настоящем времени) ситуащия почитания возлюбленного. Эрос приобретает черты агапе и боготворения ты.

И, наконец, В финале в Ты опознается Высши Возлюбленныя, а Я опознает в себе очищенную, пропенную блудницу (Магдалину). Раздединякщая в начале преграда между Я и Ты снимается: их объединяет равенство и 'кровная' связь (в мистическом плане).

Короче говоря, сожет строится на постепенном прозревании я и приобщении к Богу (Христу).

1.9. Более глубокое осмысление этого скхета осуществляется на композиционном уровне текста. Графически в данном тексте на первы план вьдвигается традиционная разбивка на строфы-четверостишия. И это отнюдь не случаяно: привычная композиционная схема работает здесь как Фон для иноя, более скрытои сегментация текста и сожета. Несовпадение между обеими сегментациямы и обеспечивает второ - менее броскои - высокую смысловую нагрузку.

"Скрытая" сегментация "упрятана", конечно, весьма условно - она тоже оформлена явным, заметным образом, что предотвращает произвольность членения текста читателем. Делимитатором этой сегментация является знак многоточия, которын разбивает весь текст на пять частеи-эпизодов 40 .

Первых два раздела, межпу первымя тремя эпизодамн, приходятся на середину строф (2-ои и 4-ои), Т.е. на конец их вторых стихов. Этим самым они как бы сильно замаскированы, имеют, так сказать, "естественны" вид. Такая "незаметность" или "естественность" знаменует плавность, незаметность перехода Я в иные его состояния: от настоящего к предположнтельному и от излияния обольстительных страстея к излиянию-избавлению от них.

Последние два раздела-между 3-им и 4-ым и между 4-ым и 5-ым эпизодами - Формально более заметны из-за их ббльшей неожиданности - они приходятся на середину внутренних стихов (19 и 22) и совпадают С концом предложения. НО, С другоя стороны, они предваряются 
межстиховымы переносами, а это ведет к тому, что конец предыдущего эпизода вплотну: соприкасается с началом очередного, т.е. объединяются в некую иную еднницу иного членения (на стихи). Плавность и незаметность переходов от эпизода к эпизоду здесь, таким образом, менее резка чем раньше, но одновременно подчеркнута гораздо более демонстративно, что долхно повьшать как внимание читателя, так и значимость данного приема.

Делимитационное многоточие в стихе 19 появилось в конце следумдего эпизода: Страсто [...] техи! Пеною уст и кахипями очес и потом өсех Нег.... основноя смысл которого - эволющня от потока страсти к ее иссяканию: пена $\rightarrow$ какипи $\rightarrow$ nоm с переходом в Неги. Страсто и неги оказались на противопольжных полисах. И то в двонном смысле. По сегменташии на эпизоды и по синтаксическому члененню неги - самы слабн варнант страстей, но все-таки еше страсmей. По сегментащии на стихи и по локализация делимитатора внутри стиха (19) кеги уже тесно примыкают к очередному эпизоду и даже входят в его состав и теряют связь со страстями. Если они все еще и разновидность страстей, то теперь уже совершенно иного плана: они не только конечная точка иссякамщего потока страстей, но и начало очереднон градации (см. стихи 19-22) в очередном эпизоде. Перевод кег на иноя уровень и их включение в очередноя эпизод однозначно манифестируется также и при помощи звуковон организации текста: Не2 $\rightarrow$ Hоги $\rightarrow$ меx $\rightarrow$ Hеко:о (mкако口)

Нечто подобное пронсходит также и с волосами: открывая новое состояние Я, они все-таки - из-за локализации в одном и том же стихе с мегами - сопричастны предваряющему и поэтому отнюдь не лишены признака 'эротического, страстного'. В результате делимитационное многоточне играет здесь роль знака,указывахиего на смену качества или статуса: 'это то же самое, но в ином качестве и с иним статусом', Т.е. 'страсть, но облагороженная' (ср. появление признака 'нежның', 'мягки', 'заботливыя' в сравнения как $в$ мех, рифмуюшемся с всех Нег, в выражения В волоса замативаю Ноги твои и в mканои nоd rozи Cmerioco...).

Нетождественность одного и то же, его переход в иное качество (от нег к'нежности'), передается здесь иначе - при помощи дискретности или преломления как раз в месте многоточия других признаков называемых тут элементов.

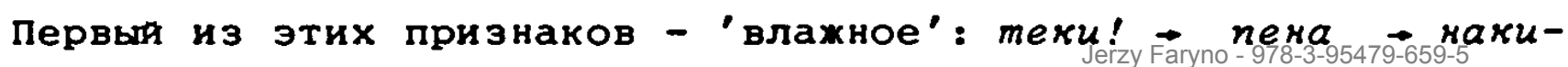


nи - nоm (Нег), при этом, если учесть, что данная серия предварялась маслами (стих 12 и след.), то 'влажное' имеет тут и еще одну особенность, оно - 'липкое'. Но самое интересное то, что в очередном эпизоде оба этих признака получнли вид своен противоположности - 'сухого' (еолоса, мех, ткако), 'укутывақиего' (заматавар, ткакор стелюсо под коги) и, возможно, даже 'впитывающего'. 4

Второи из признаков значим еще более, но он заметен уже после многоточия - благодаря удвоенному предлогу $\theta$ ( $B$ өолоса; как $\theta$ мех) со значением 'вовнутрь' Предыдущия эпизод, оказывается, строился на направлении 'изнутри вовне' и на смысле удаления-выделения с уменьшажщенся интенсивностью, и этим самьм как бы с ок-

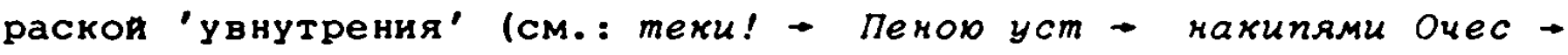
пӧтом өсех Нег...). Новын же эпизод строится на направлении 'извне вовнутрь' и на смысле 'завладевания, усваивания, поглодения'

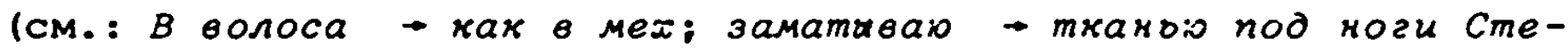
лico...) С возрастанием интенсияности (ср. өолоса̀ как внешния атрибут я и ткако как метаморфоза всен Я; коги как часть ты и под коги подразумевающее всего ты).

и именно теперь, после удаления страстеи и перерождения их в 'нежность', после извержения бесовского и перехода на возможность поглодения-впитывания ТЫ, внезапно раэражается озарение-постижение Не mот ли (та!). Роль многоточия здесь уже несколько иная, чем в стихе 19. Находясь внутри стиха оно на этот раз даннын стих деяствительно "разрывает" надвое, что особо видно на уровне семантики, уже не предполагапиея, как это было раньше, постепенноя градации ${ }^{42}$. Только на фонетиеском уровне наблідается нарастание частотности звука $m$ (төои, ткакою, стелюсо $\rightarrow$ Тот ли, Та, Теари и в финале өстано, сестра), которая может расцениваться как признак возбужденноя прерывистон речи от взволнованности, вызваннов озарением-опознанием Ты и некоторого единства с ним $Я$ (ср. наличие $m$ не только в тот, но и в словах, относящихся к я; см. также 1.7.).

Опознание Ты и объедннение с ним происходит, таким образом, через приятие его в себя, а осторожнее говоря - "на себя", поскольку завершается текст все-таки локализашнея я внизу (под моги Cmersco...).

и еще одно. Примечательно, что ты представлен в тексте не только 'бездеятельно' (см. 1.7.), но и без "образа": относящееся к Ты абстрактное жрово и упомннание ког только подчеркивают его 
невидимость, а точнее - невидимое его присутствне. Его, оказывается, нельзя "узнать", его можно лишь опознать внутренне, а не при помони обычных чувств. Тем временем Я представлена некими внешним физическимн деталямн lочеса, уста, өолоса, пот и мемощи, предполагакшие плоть). Существенно, однако, что Я обладает не устоЯчивым внешним обликом, а изменчивым. Изменения же выстраиваится в строгую эволюцнонирующую последовательность: телесные кемочи-страсти $\rightarrow$ их извержение из себя (очищение от них) $\rightarrow$ их качественное перевоплощение в 'нежность' $\rightarrow$ истончение плоти до волос и ткани со свояством 'впитывания'. Иначе говоря, и Я теряет своя внешния облик и в этом отношения уподобляется в финале поглоцаемому ТЫ. Тем не менее некая дифференцированность между ними все-таки сохраняется: за ты сохранена деталь ноги, а за я - өоло$c \dot{a}$. Но пока смысл этой дифференциации не раскрывается 43.

$$
\text { I. }
$$

2.0. 25 Масти, плоченные втрое

26 Стоимости, страсти пот,

27 Слезы, волосы, - сплошное

28 Исструение, а тот

29 В красну: сухую глину

30 Благостнын вперяя зрак:

31 - Магдалина! Магдалина!

32 Не издариваяся так! 44

В отличие от предыдущего стихотворения это не делится на части, оно являет собои одно сплошное целое. Его целостность, несомненно, сознательныи прием, и, по всеи вероятности, - призвана нести некия смысл. Как и раньше, она манифестируется как при помощи несовпадения формального членения на строфы (тут их ьсего две) и синтаксического построения - синтаксически весь этот текст есть одно сложно-сочиненное предложение с противительноя союзнои связью (союз а), так и при помоци межстрофического переноса.

далее бросается в глаза то, что здесь принципиально изменена точка эрения, так сказать, изобразительная перспектива, или ракурс. Теперь это не внутренняя перспектива Я, за которую реципиент буквально вытолкнут (см. 1.1.), а внешняя, которая свободно включает и позицию реципиента (зрителя, читателя). Но с одноя либопьтнов особенностью. Субъект речи (повествуичия, изображающия) из этого текста предельно устранен: он не обнарухивает себя ни в определениях, так как они даются тут на правах объективных, ис-

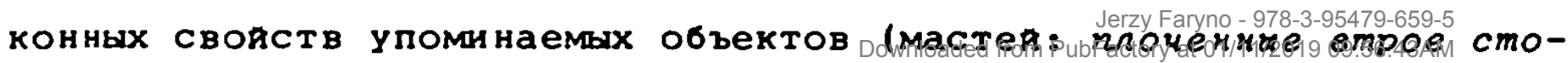


имости; глины: краская сухая; взгляда-лика: благостний [...] зрак), ни в естественном в таком случае глаголе говорения - такого глагола здесь просто нет (B [...] глику [...] өперяя зрак: магдалияа! Магдалика!). При этом отсутствие глагольных Форм, назывноя строи всего перечня всех упоминаемых явлени и цитатность слов Христа, которая с единственного глагола Не издариөайся снимает его "глагольность" и переводит в ранг объекта, - все это вдвигает данную сцену в измерение непреходящего, вечного настоящего. В результате возникает эфФект непосредственного предстояния читателя-зрителя перед подлинно евангельскоя ситуациея. Иначе говоря, здесь осуществляется принци иконного изображения-видѐ${ }_{\text {ния }}{ }^{45}$. Если согласиться с таким толкованием статуса данного текста, то незначительное наличие говорящего субъекта в словах сплошное Нсструение, a mот объясняется само собоя: это метатеклт к иконе, устанавливамиия связность и вербализирующия опознаваемую (а не привносимую извне) реляцию между персонажами иконы.

В чем же суть этоя иконы и что происходит между ее участникамн? По ходу текста на первое место выдвинута магдалина (теперь она уже названа). Поэтому раэбор текста начнем именно с нее.

2.1. В основном образ Магдалины составлен здесь из тех же атрибутов, что и в предыдудем стихотворения, но, естественно ожидать, что это не простое повторение, а повторение модифицированное и призванное оттенить именно разницу.

2.1.1. МАСТИ вызыва.от в памяти прежние масто и масла́ (стихи 11-12), но они им не тохдественны.

а. Множественное грамматическое число исключает возможность прочтения их как 'цвета волос-шерсти' (см. 1.4.1. 6-в) и этим самвм отсекает ассоциацик со 'зверино-бесовским', сохраняется только смил 'благовонного бальзамнческого снадобья', что тремя стихамн позже обнаружнтся в Нсструении, подразумеваюием также и распространяемое (струящееся) благовоние.

6. Здесь налицо и расподобление с предыдущим страсто (стих 15). Вместо него масти перекликаются с Формон страсти (уже в пределах данного текста - в очередном стихе). Совпадение формы страсти с формоя именительного падежа множественного чнсла можно читать как указание на подспудның смал 'страдание, муки'. Тогда со страсти снимался бы ореол 'плотского, чувственно-греховного, в пользу ореола 'жертвенного страдания' - и тогда же откровенная 
внутренняя рифмовка мАСТИ - стрАСТИ (с единственньм в обонх стихах ударным а в противовес остальным четырем ударным 0 (и на этот раз упраздняла бы ассоциацні мастей с 'телесно-чувственньм' (ср. а) и вписывала бы в них именно признак 'страдания, жертвоприношения' Так, кстати, мйсти постоянно и топкуются Христом во всех Евангелиях: как безотчетное преклонение и как предзнаменование близящеяся смерти и погребения 46.

в. Мастям здесь предпослана дополнительная характеристика: плочемкие өтрое Стоимости. А это уже совсем однозначно подчеркивает их повышенны жертвенны характер: өтрое, и свидетельство бескорыстия Магдалины (ср. раньше в стихе 11: очесами демомсхими Таясо, лила $\sigma \alpha$ масла̀ и дальше обольстительную сверхрасточительность), и свидетельство ее обманутости, обиженности.

Аналогичную роль играет также и демонстративны звуково повтор МАСТН - СТоимОСТИ, способныр вписать в масти цену-жертву, а в акт покупки - предвосхищение предсмертного помазания (см. 6). Дальше, этот звукоряд с полноя закономерностью распространится на слово СТрАСТИ, чтобы суммноваться потом в финальном НССТРуении (CM. a).

Г. Не менее интересно и значимо здесь и слово плочемкие. По Своему звуковому составу, ввиду ударного слога пло- и и, сменившего $m$ (плочеккий - "платить"), оно способно вызвать ассоциацию с "плотью", а этим самым и с телесноя страстью. Такая ассоциация усиливается дополнительно наличием сочетания страсти пот с ударным звуковым комплексом ПОТ (ср. ПлОЧекмае).

'Торговыя' мотив прозвучал уже в первом стихотворении (стих 15) и был тесно связан со словамн масто, масла́ и страсто, а в итоге - с торгованием плотьк, С блудодеянием Я. Но там он был повернут аспектом 'продажи', тогда как здесь речь идет о покупке или - точнее - о 'плате'. Далее: там 'продажа-доход' оборачивалась полноя растратоя, измельчанием (Страсто по купиам распроданмая, Расплевакмая), здесь же 'плата-расход' оборачивается, правда, грабительским, но все-таки обменом на эквивалент масти, и не измельчанием, а наоборот - сохранением или даже повьтением собственного достоннства (плочекние өтрое Стоимости).

Более того: там масто через смысл 'цвета волос' и созвучие с "распроданнои страстьк" носила оттенок причастного к телесности я. Теперь же масти, будучи покупкои, - нечто внемнее нең 
ное плоти Магдалины. Их причастность К Магдалине переведена на духовны уровень (признак упорства в покупке мастеи с сильно завьтенно стоимостью) .

В свете сделанных набл.лдения, думается, более полно раскрывается смысл стоящия за отмеченным уже сближением "платить" с "плотъю" и потом при помощи неправильного, просторечного плоченние вместо нормативного"плаченные".

Это уподобление вводится с целью расподобления. Во-первых, затем, чтобы на первын план выдвинуть именно противоположное - духовное (см. выше в пункте а сопоставление масти и Нсструекие). А во-вторых, чтобы и с жертвенности ("плата" как жертва) также снять оттенок телесноя жертвы (плсченные - "плоть") и перевести ее в ранг духовного дара.

у разбираемоя платы-жертвы эа масти есть и еще однн существенның аспект. Масти приобретаются здесь не для себя, а с предназначением для Христа, и становятся знаком воздаяния должного, совершения надлежащего обряда почитания. Имея признак жертвоприношения они есть просто дар (ср. финальное: Не издариөайся max!). 47

2.1.2. СТРАСТИ ПОТ. И страсто и пот упомннались и ранъше (стихи 15 и 18) - в криэиснын момент экзорцизма, извержения бесовского, и были там выстроены по шкале от наиболее обильного потока (Cmpacmo [...] теки!) до его иссекновения и перехода в противоположное качество - в нежность (потом всех нег...). На этом Фоне сочетание страсти пот - явнын оксюморон, если за страстои сохранить ее прежния смыл. Несмотря на инверсию, и там и тут в сильную акцентную позищию поставлены Не2 и страсти и этим как бы уравниваются друг с другом, становятся своеобразнымя эквивалентами. Если к тому учесть еще и порядок следования, то в страсти позволительно усматривать если и не очередную ступень шкалы, то по краянеи мере именно смысл Нег, 'нежности', а, может быть, и 'умяления'. Это тем более вероятно, что тут наблидается как бы возврат к началу тон шкалы, но на очередном - высшем - уровне.

Форма страсти, как уже говорилось, благодаря созвучию с Формов множественного грамматического числа Масти (см. 2.1.1.а.), приращивает к этому слову смысл 'страдания, муки'. Тогда пот в этом сочетании звучит уже бесконфликтно: как симптом сильного горя, страданяя. 
06е возможности не гротиворечат друг другу: нежность, умиление и страдание, мука свободно могут объединяться чувством со-страдания. Это тем более вероятно, что находясь в одном однородном перечне с мастями, которые приобретены не для себя, а ради Христа, страсти пот тоже не признак страдания самои себя от чего-то, а страдания ради Христа, а точнее - эа него: горестноя озабоченности о нем, боли за него (ср. кульминашионное стечение звукового повтора СТ именно здесь: мАСТи - Плоченные - вТРое - СТОиМАСТИ - СТРАСТИ ПОТ).

2.1.3. СЛЕЗЫ. В первом стихотворения "слез" нет. Некая их возмохность наблюдается в стихах 11-12 - очесами демокскими Таясо, лила 6 масла, - но там ассошиация лито маслd и "лить слезы" не актуализируется (а если бы даке, то в аспекте притворных, обольщающих слез). Определенная возмохность появляется и в стиxax 17-18, в выражения кахипями очес, но с них снят ореол горя и вписан ореол извержения демонического, греховного начала. Естественно поэтому предположить, что на этот раз иментся в виду совершенно иные слезы.

Их ино статус подсказывается, между прочим, одно малозаметноя деталью: прежде, если бы слезы и подсказывались, то в первом случае им предписывалась позиция межиу мастою и страстох (т.e. перед cmpacmox), а во втором - в одном ряду и в одном и том же стихе с Пеною уст и перед потом [...] Нег... (т.е. в более бурном месте потока страсти, а не в его иссяканщем конце, куда поставлен nom [...] Не2...]. Теперь же слези следуит после страсти пота, a $к$ тому - в иом, очередном стихе. Более того: перечислительная конструкция строфы заставляет рассматривать все перечисляемое как однородное (конечно, не обязательно как одноранговое). А это значит, что слези поставлены в этот ряд как выражение горя, страдания и со-страдания (см. 2.1.1. и 2.1.2.).

отсутствие слова "слезы" в первом стихотворении (т.е. до опознания Христа) и появление слез здесь (т.е. после опознания и в присутствии Христа) придает им статус проявления просветления, обоготворе ния .

Возвращаясь к стихам 17-19, теперь можно отметить и инуы градация - постепенное очищение от скверны в последовательности от внутреннего до внешнего: $y \mathrm{~cm} \rightarrow$ очес $\rightarrow$ "тела" (nom), после чего

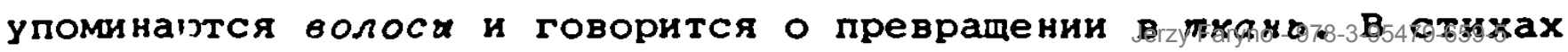


25-27 обратнын порядок следования: масти $\rightarrow$ nот ("тело") - слеза ("глаза") и затем өолоси. Слези, таким образом, по отношению к плоти занимант позицию более внутреннюю. Но это не всё.

В первом стихотворении слези не упомнались, зато двахды упомннались очеса (стихи 11 и 18), здесь же речь как раз о слезах, тогда как глаза (или очи) вовсе не упомннуты. Как видно, и на этом уровне налицо та же интенши: вместо внешнего - овнешнение внутреннего. В результате чего слези получант статус скорее духовных, чем физических ${ }^{48}$. вряд ли поэтому случанно, что в данның текст попал вариант плочеккие, а не нормативны "плаченные", которын независимо от намерения автора в близком соседстве со слезами выэывал бы, видимо, нежелательнын образ натуралистического плача вместо 'плача душ'.

Перевод слез на духовның уровень, их, так сказать, дематериализашия в плач души, в явном виде обнаруживается в финальном Нсструении. Согласно обиходному речевому фразеологизму, слезы, конечно, "струятся", но дело в том, что тут Нсструение - общия знаменатель и для заведомо не струящегося, или, вернее, пля струятегося иначе - невидимон воздушно струен (Масти). Так или иначе, в финале строфы слеза уравнены с мастями по признаку 'струения', и даже если вопреки всем другим своиствам текста видеть в них все-таки фиэические слезы, то и тогда здесь налицо уравнение материального и нематериального (в сторону последнего).

Горесть же, плач наличествуют в это строфе в виде идеи, в виде модальности образа, а не его отдельнон самостоятельнои, вычленимои, детали. Весь этот образ, вся эта "икона" есть сплошнон плач. Это вытекает из фактуры "изобразительных" средств: вся строфа сплошь охвачена огубленным, диФФузным низкотональньм произносительным жестом-эвуком:

$$
\begin{aligned}
& a-0-0 \\
& 0-a-0 \\
& 0-0-0 \\
& \text { и }- \text { - } 0
\end{aligned}
$$

в сочетания с обилием напряженных и длительных $c$, $r, \Omega$, то и дело прерываемых смычным $m$, вэрывным $n$, и с предельноя приглушенность:Ј консонантов (что особо заметно и значимо в контексте звонкости следулше строфы ${ }^{49}$ ).

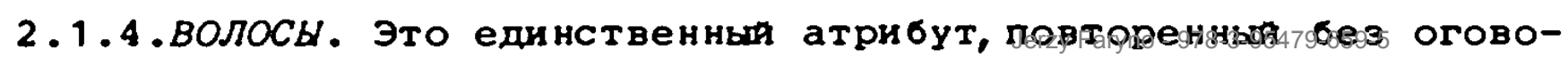


рок и в такоя же конечноя позиции в ряду (ср. стих 19), только в более правильноя нормативно форме волоси (a не волоса).

Видоизменение формы направляет внимание на стилистику лексики в обоих случаях и на ее смысловую нагрузку. В стихах 17-20 просторечие өолоса̀ резко противостоит высокопарному стилю предваря-

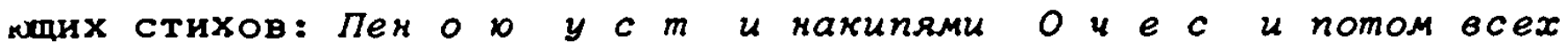

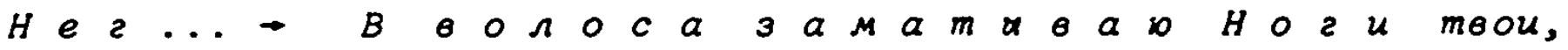
как $\theta$ м $e x$. Одновременно обе эти части строфы противостоят друг другу как очищение от скверны и как обретение естественного человеческого вида. Стилистическое огрубление өолоса́, замативаж и затем сравнение с бытовои деталью как ө мех открывалт обычның земноя, а то и приземленныя, облик Я (так сказать, "отфальшнвленның"; ср. еще раньше, в стихах 11-12 очесами демомскими Таясо, лила $\sigma$ масла̀).

Нечто аналогичное наблюдается и в стихах 25-27, но опять-таки в инверсии и в ином регистре: от обиходного сниженного масти (в отличие от высокого масла), грубоватого плочеккие по неитральное слези и волоса. Прежнее бытовое становится эдесь не конечнои точкоя, а исходноя, и подвергается повьшению в ранге. Волоси из стиха 27, таким образом, по краннея мере на один ранг выше өолос из стиха 19, а также на некую ступень выпе и мастей из стиха 25, чем и снимается с них статус бытовоя детали (во всяком случае, они облагораживахтся).

Волоса завершали эволюциі от 'изнутри-телесного' и от влажно-липкого до 'внешне-телесного' и 'сухого-мягкого, нежного' (Cmpacmo [...] техи! - Пекою усm u $\rightarrow$ макипями очес $u \rightarrow$ потом всех Нег... - В өолоса замативаю Ноги төои), знаменуя истончение плоти и переход во внетелесное (Нехор ткакор под коги Стеת $000 . .$.$) .$

\section{Волоса тем временем увенчивают иную эволюцию: Масти -} (страсти) nоm $\rightarrow$ Cлези - волоси. Во-первых, от внетелесного в сторону внутрителесного (Масти - Слези), и если быть последовательньм, то өолоси надлежало бы зачислить в наиболее внутреннее.

Во-вторых, эволиция к полюсу возрастающего признака 'влаги, жидкости', 'текучести', по ходу которои теряются признаки 'Густого-липкого'. Как видно, и в этом случае волоса эанима.от не согласуюдуюся С бытовымн представлениямы позицию нанболее 'влажного, текучего'. 
и еще одно наблкдение. Волоса следуіт после слез, слеза же бесконфликтно читаются как овнешнение внутреннего, т.е. как проявление духовного (см. 1.2.3.). Поэтому, если здесь деиствительно имеет место некая шкала, то волоса были бы очереднои ступенью более высокоя степенью овнешнения еде более внутреннего и еще более духовного.

Последнее толкование косвенно подтверждается итоговым сплошное Нсструекие, но тем не менее вопрос "как понимать самуі внутреннюю и самую текучую позицию волос и как согласовать оба этих признака со смыслом духовного?" пока остается открытым (возможно, что искомы ответ покоится в дальнеишем контексте, но не исклочено также, что и вовсе вне текста магдалики).

2.1.5. СПЛОШНОЕ НССТРУЕНИЕ. Синтаксически это выражение поставлено в позицих подытожнваюего обцего знаменателя всех упомянутьх раньше явления-атрибутов, и уже на данном абстрактном уровне вводит между ними знак однородности, взаимоэквивалентности, а еще точнее - их дифференциальные признаки отодвигает на задния план, делает несущественными, и этим самым создает категориально индиФферентное единство. Деяствительно: материальное и нематериальное, внешнее и внутреннее, твердое и жидкое, телесное и нетелесное - все уравнивается и теряет различительную роль. Но уравнивается по строго определенному критерню - критерик способности 'струиться'.

Ва поверхностном уровне эта способность свободно угадывается во всех перечисленных явлениях (дополнительно она подсказывается речевьмы Фразеологизмамн) : мастях, которые могут струиться благовонием: nоте, слезах и волосах, которые могут свободно ниспадая переливаться блеском, и т.п. И тем не менее не этот или не только этот уровень здесь имеется ввиду. Другои и более глубокия подсказывается как словом сплоикое, так и приставкои ис- со значением финальности, эксгаустивности, в слове Нсструекие.

В стихах 15-22 истончение плоти остановилось на уподоблении Я ткани (Некол ткакор под моги Стелюсо...), после чего наступает озарение-опознание Христа. Но ткако предваряется иньм сравнением - өолос с мехом (в волоса замативар ноги твои, как $\theta$ мех). С одноя стороны, это признаки обретения Я естественного (бытового) человеческого облика. С другон же - перевоплоцение в нетелесное: өолоса в Функции предмета домашнего обихода 
ности ("полотенца"), но все еще с призвуком 'звериного, плотского' (жак ө мех), и, наконец, в такой же Функции вся Я и уже с признаком предельнои истонченности и бестелесного, 'растительного' (mкаяох [...] Cmenivo

на этом перевоплодение не останавливается. Второе стихотворение начинается как раз с мастей, в которьх теперь заметнее становится именно их 'растительное' происхождение, и включает обратное движение к проявлениям 'телесного' (страсти пот, Слези, волоси), но, несомненно, на ином уровне. Плоть теперь уже не предыдущая 'плотская плоть', а выводимое наружу, овнешненное 'содержание плоти" (образно говоря - "душа плоти"), получажщее вид сплошного пневмо-акватического потока (Нсструения). Примечательно, что в первом стихотворении хотя внешнего "портретного" образа я и нет, тем не менее ввиду наличия Я упомннаемые там отдельные детали воспринималтся как элементы телесности Я. Во втором же стихотворения хотя образ Магдалины и строится С внешнея переспективы, почему естественно было бы ожндать появления деталея портретного (телесного) характера, ничего подобного не происходит. Магдалина здесь - набор самостоятельных (отчуждаемых и отчужденных от телесного облика) признаков-атрибутов, к тому же атрибутов в их первичноЯ, СущностноЯ, Функция, в Функции овнешнения содерхания персонажа, позволякщен безошибочно его опознавать-идентифичировать 50

В конце стихотворения Исструение переименовано Христом в Нздарияание.

Перевоплощение Я в Магдалину и в пневмо-акватическую струю происходит с момента приятия Ты в себя (см. 1.9.) и откровения-опознания в ТЫ Христа, где "открыть-опознать" означает проявить истинную веру, самопроизвольно уверовать, а пробным камнем веры есть в свою очередь стихияное опознание 51 . Таким образом, здесь осуществляется идея со-страдания С Христом и со-участия в Христе. Пневмо-акватическая струя - не обычное обоготворение, а именно со-участие. Такои смысл вводится заключительным переводом Исструекия в категорин дара (Не издаривайся так!) 52 .

на Фонетическом уровне выражение сплошное Нсструение вклічается в два контекста: собственноя строфы и предыдущего стихотворения.

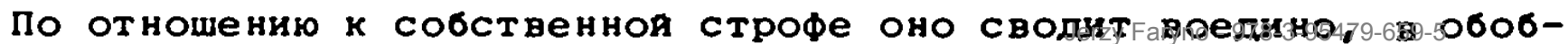


щающи звуковон, Фонемно-семантическия, комплекс все предидущие относительно разрозненные смысы: C-ПЛО-II-H-OE ИCСТРуЕНИе - -

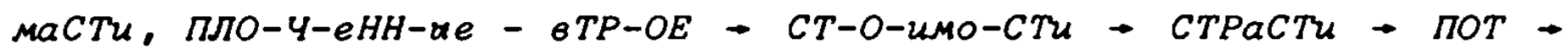
Слези $\rightarrow$ волоСи, где сплошкое играет также и роль плеонастического метакомментария, а Исструение своен семантикон подводит под них объединякин универсальның признак 'струения' .

По отношению к предыдущему стихотворению оно перекликается $C$ отсутствуюиими здесь, и тем самым не переосмысленнымы и поэтому деяственными, словами вСТаНо CE-CTPa!

Встано было противопоставлено предшествуюнему ткакок [...] $C m$ e $\Omega$ o 0 , а сестра - подразумеваемоя раньше рабыне, уподобленной домашней утвари-веши (B өолоса замапхвал Ноги төои, как $\theta$ нех: тхакою под ноги Стелісо...), т.е. инертному, бесцельному, бездвижному, не-живому (ср. обезжизненность з мехе), и этим самым выдвигало на первыя план именно 'движение $K$ ', 'целеустремленность' 'живое', 'деятельное' и равенство с ты.

При таком взгляде насьщенность образа Магдалины в стихах 25-28 темн же эвуковымя комплексами воспринимается как реализация воззвания Христова. Нсструение - окончательное обретение движения в новом (не механическом) качестве целеустремленного (ср. Финальное издаривайся) живого деятельного движения.

идея живого внутреннего движения может усматриваться и в контрастности речевого безглагольного образа Магдалины с внутреннея динамикоя (семантическоя) упомннаемых атрибутов, где даже предельно процессуальное, усиленное эксгаустивнои приставкоя ис- Нсструение дано в форме существительного, субстантивность которого усилена в свою очередь предпосланным ему определением сплошкое с оттенком субстанщиальности ('непрерывность', 'плотность", а кроме того намек на причастность к "плоти-плате", но в инои ипостаси - из-за переклички ПЛОч - ПЛОш).

2.2.1. Начало "второя части" стихотворения приходится на последния стих первоя. Оно представлено одним единственным словом mom (если не считать "метаиконного" противительного солза a - см. 2.0.). идея тако сегментации текста ясна: Христос и Магдалина объединяются во взаимосвязанное единство (а не рассматривантся как безразличные и безотносительные друг к другу персонажи; ср., кстати, в стихе 1 слова Мех мами). Поэтому тем более кажется не-

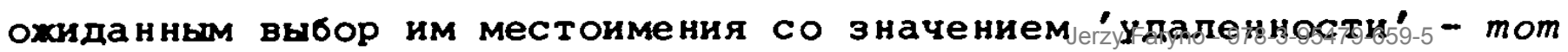


(а не, скахем, более неятрального в повествуюшея речи "он"). Объясняется этот Факт, по всея вероятности, следуюпим образом.

а. для смотрящего на икону Магдалина занимает так называемы первың план, может быть, совпада:оия с позициеи смотряпего-моляцегося (тогда имело бы место своеоразне отождествление Магдалины С молящимя и включение вместе с нен в обращенность к Христу).

Втород же план, куда обращена магдалина, представляет Христа, которы этим самым обрацен своим ликом к Магдалине (и в сторону молящихся). А это обеспечивает нентральность удаленности: это бы была талько Формальная, условно-иконописная удаленность, имекая своен цельк как раз обратное - сохранение тесноя связи с Христом.

6. Tom момет также читаться и как материальная удаленность-отсутствие, как принадлежность к иному миру, к иному измереник53, и как своеобразның библеизм (повыпаюиия ранг персонажа, в отличие от нентрального или даже снижаюего "он") - в Еөангелиях Иисус неоднократно на вопрос "кто Ты?" отвечает формами местоммения "тот"54. В этом случае местоимение mот было бы единичным опознавательным индексом Христа.

в. Данное тот можно рассматривать также и как своеобразное подтверждение (ответ) изумления-догадки (с признаком вопроса) я в стихе 22: He mom ли [...] !

2.2.2. КРАСНАЯ СУХАЯ ГЛННА. В Лексическом Отношении стих 29 построен из совершенно новьх, до сих пор не употреблявшихя в рассматриваемых текстах, слов. И тем не менее небезынтересно будет проследить некоторое, пусть самое приблизительноє, их родство с предыдупея лексикои.

а. Красная - самое яркое цветное пятно во всем этом почти бескрасочиом тексте. "Почти" потому, что, как оказывается при более внимательном взгляде, все-таки не едннственное. в явном виде цвет

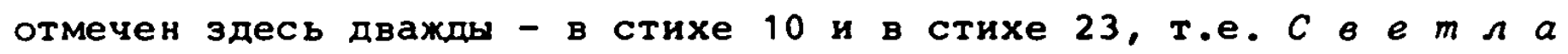

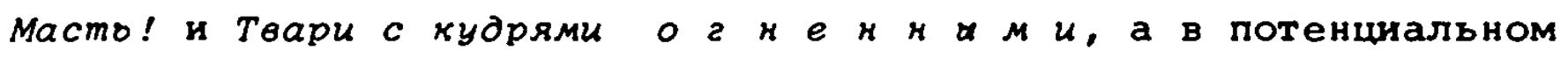
присутствует также в Жар десяти костров и в трижды употребленном слове крово (см. стихи 2-4 и 7). Легко заметить, что во всех случаях денствительные и возможные цветовые признаки сопряхены с носителями смыслов 'огненное', 'греховное', 'плотское'. Причем все эти смыслы взаямосвязаны, если и вовсе не эквивалентны, через наказукщи хар 'костров-заповедея', демоническия характер кудрей именно огненнах, перекличку костров с кровор-плотин- 
смыссленное и обольщанщее сөетла Maсmо! 55

В этом свете намечается и иное осмысление противительного $a$ и 'удаленности' в mот: здесь как бы сызнова активизируется смысл 'разъединенности', открыванцеи весь этот триптих (см. стих 1 Мех нами - десято заповедей и 1.1.-1.2.3.).

6. Сухая ассоциируется в свою очередь с Жар [...] костров по признаку 'иссушапщего жара', с песками - в стихе 14 - по признаку 'сухости, безводности' и с макипями Очес по признаку 'иссушения, иссякания'.

в. Глина имеет свое соответствие только в песках. Их может объединять признак 'бесплоднои почвы' и 'земного праха', т.е. 'бренного'.

Г. В собственном контексте по причине противительного а в выражении краская сухая глика проступакт признаки 'бездвижного', 'безжизненного', 'безводного', 'отвердевтего'. но ввиду наличия определения и яркого цветового признака и предыдущего отсутствия определения и предыдущеи без-цветности (а скорее всего - прозрачности) интенсивно пневмо-акватическои струи (Нсструекие) характеристики краская сухая предельно интенсифицируются, вводят оттенок напряжения, сильно страдательности, жажды (дополнительно подсказываемы повышенным огублением почти непрерывного дифФузного низкотонального " ${ }^{\prime \prime}$ : в крАснују сУхУју глНнУ, родственного такому же "о" в предыдущеи строфе, ср.2.1.3.).

д. В итоге получилась следующая картина: глика оказывается воплотением 'греховно-плотского' (см. а, в), 'безжизненного' и ' бесплодного' (см. 6, В, г) начала, но страждущего и жаждуцего (см. Г.). И именно она вводнт некую "отдаленность" между Магдалиноя и Христом (см. а.).

2.2.3. БЛАГОСТНЫЯ ВЛЕРЯЯ ЗРАК. Контекстуально слово зрак употреблено здесь в смылле 'взгляд'. Но благодаря архаическои славянскоя Форме 'взгляд' возводится в высшия ранг - в ранг неземного, божественного зрения-ви́дения. Лексическое же его значение иное: "лицо, вндъ, обраэъ, ликъ, обликъ; // изображение, картина" 56 . Контекстуальнын смысл, естественно, доминирует хотя бы из-за редкого употребления слова "зракъ" в лексическом его значении, но он последним сильно модифицируется, и, как несложно заметить, трансформащия идет в сторону перевоплощения образа Христа

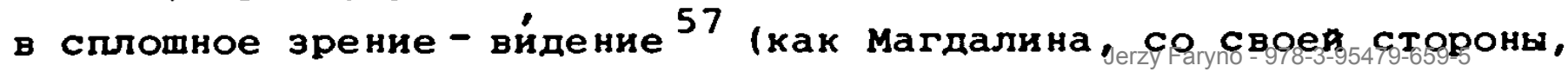


стала сплошкам Нсструекием).

Деепричастие өперяя придает этому зрению признак оязаемости, оцутимости, с одноя стороны, а с другоя - признак испьтулщего взгляда.

Определение Благосткий более сложно. В нем заметно звучит 'умиротворенность, просветленность'. Она исходит, по всеи вероятности, от, так сказать, состояния глика: испьтующия взгляд отмечает там нечто удовлетворяюдее, некую благую весть.

По своему звуковому составу Благосткий ввиду такой высокон насьщенности всего текста сочетанием $\mathrm{cm}$ перекликается по краннен мере с предыдушея строфоя (масти - стоимости - страсти - исCTруекие) и выдает причастность к их смыслу 'страстея-страдания-платы-жертвы' и 'излияния' .

По контексту первого стихотворения Благостний незаметным образом связывается со словом евакгелоские (стих 5), которое буквально значит 'благая весть; благовествование' (см. 1.3.1.).

Поведение Я и потом Магдалины (стихи 19-22 и 25-28) уже не во внутреннем контексте, а в контексте Евангелия, есть предвестие крестноя мукн, страстеи, смерти. В стихах 25-28 оно уже слито воедино с образом Магдалины в виде со-страдания и разрешается в Форме Нсструения. Христос же воспринимает эту 'весть-струо' благостио (и это епе однн смасл противительного а). По Евангелих как подтверждение и исполнение своея искупительноя миссии на земre.

Но в данном случае Благосткай [...] зрак Хрнста обращен не к магдалине, а к глине. Таким образом, источник благостного состояния Христа есть глияа, некая весть оттуда. Если так взглянуть на глику, то аналогом интенсивноя струи-магдалины тут будет интенсивность 'красноты и сухости' имеюиен также смысл страдательности и, кроме того, жажды (см. 2.2.2.r.).

2.2.4. Как уже отмечалось, глика имеет свое соответствие в песках (см. 2.2.2.в.). Теперь вернемся к нему еще раз, так как оба слова выступают в одинаковои синтаксическоя конструкции: лила $\sigma$ масла் $H$ ка коги $\sigma u$, $u$ под ноги $\sigma u, H$ вовсе $\sigma x$ max, $\theta$ nески' (стихи 12-14) и $B$ [...] глину Благостний вперяя зрак (стихи 29-30). Завершалиее тот эпизод $H$ өовсе би так, ө пески... читалось как знак сверхрасточительности с оттенком бескорыстия, но и

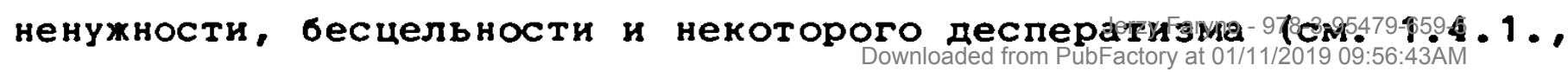


1.6.2., 1.8. и 1.9.), здесь же интеншиональное, волевое вперяя ставит глику в положение цели, предмета зрака.

2.2.5. После слова зрах стоит двоеточие, за которым следует прямая речь - обрапение к магдалине. Один аспект Факта, что глагола говорения, вводящего прямую речь, здесь нет, уже обсуждался (см. 2.0.). Теперь отметим инои его аспект. Дело в том, что зрак как раз и стонт в том месте, где обьгно полагается глагол говорения. Результат таков, что зрак способен принять на себя смысл акта произнесения и стать 'эраком-гласом', в привычных термннах "звучащим, говорящим взглядом". Но поскольку слова Христа обращены все-таки к Магдалине, а не к глике, в которую он смотрит, а зрах в свою очередь направлен не на магдалину, к которов он говорит, а $B[\ldots]$ глику, то от признака 'говорения' в зраке сохраняется только указующия жест, и указующи Магдалине именно на глину.

2.2.6. Если согласиться с таким толкованием, то в данном обращении и жесте свободно просматривается смысл определения миссии магдалине. А слова Не издаривайся тах!, кроме всех уже раньше отмеченных смыслов, читабтся как 'сохрани силы для глины'.

2.2.7. Глина, оказывается, является в этом образе центральным понятием. Основные ее смыслы, выводимые из разбираемого текста (см. 2.2.3. и 2.2.2.г.и д.), вплотную подводят к понятию 'бренного мира сего', 'обреченного рода человеческого'. Но в более эксплицитном виде его не раскрывают. Он раскрывается при помоци иного контекста, предусмотренного в данном случае, - при помощи контекста Еөангелия. В крестном пути на Голгофу сопровождалт Христа толпы народа, в том числе и Магдалина. У Луки этот момент передается так:

"И шло за ним великое множество народа и женщин, которые плакали и рыдали о Нем. Иисус же, обратившись к ним, сказал: дпери Иерусалимские! Не плачьте обо мне, но плачьте о себе и о детях ваших; ибо приходят дни, в которые скажут: 'блаженны неплодные, и утробы неродивше, и сосцы непитавше!' Тогда начнут говорить горам: 'падите на нас!' и холмам: 'покроите нас!' ибо, если с зеленеспим деревом это делагт, то с сухим что будет?" 58 .

2.2.8. Магдалина и глина категорически противостоят друг другу уже по одному тому, что магдалияа тут - некин имматериальныя акватическия поток, тогда как глима - осязаемая вещественность (в

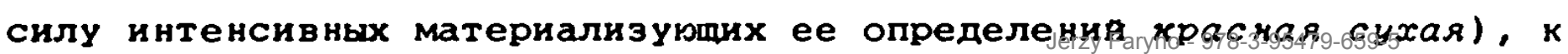


тому 'иссушенная', лишенная какои-либо влахности (акватического начала). Тем более поразителен факт, что глика и магдалина объединялтся рифмоя, предполагағщея, как всякая рифма, не только различия, но и некоторое сходство (последнее усиливается и звуковьм повтором в этих словах: Г-ЛИНу $\rightarrow$ маГда-ЛиНа). Чрезвычанно интересно и то, что оба этих слова, а особенно имя магдалияа, появлястся здесь вообще впервые, что даже вопреки интенции автора долхно повысить внимание $\mathrm{K}$ данноя рифме-перекличке.

С Магдалиноя мохет роднить глику ее краснота как признак 'греховного', 'бесовского' (см. 2.2.1.), и ее сухость. Последняя требует более расширенного комментария.

В образе Я-Магдалины признак 'сухого' появился поле экзор-

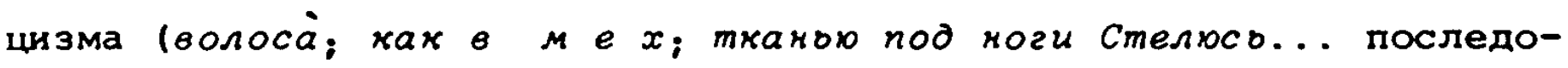
вавшие после удаления из себя влаги-страсти). Но это - не обычное сухое, лишенное влаги, а сухое 'впитывахнее' (волоса; мех; ткано в роли "осуителея" после омовения ног, в роли "полотенца" - см. 1.6.1., 1.6.4., 1.9.). Магдалина-акватическин поток в стихах 25-28 - новын, высшия этап сущности Я-Магдалины.

Краскук сухую глику позволительно также читать и как некое страждущее и жаждущее состояние "мира сего" (см. 2.2.2.г-д.), а в контексте общности с Магдалиноя по признаку 'сухости' - как состояние готовности 'впитывать влагу'. Глика, таким образом, могла бы теперь интерпретироваться как аналог прежнего состояния Магдалины: уже лишенно бесовского начала, но еще весьма аморфнон (ср. неопределенность метаморфозы-сравнения Некол ткакох под коги Cтелюс⿰... и 1.6.4.6.) и уже способнои приять-впитать в себя ты-Христа (ср. 1.9.), иначе - уверовать. Для я это еще означало 'обрести свою сущность', получить отчетливую Форму, оформиться в личность - случанно ли, что по имени она названа лишь теперь, т.е. лишь после перевоплощения в сущностның пневмо-акватическия поток?

Если читать так, если глика есть "неоформившаяся Магдалина", но уже обладағлая соответствующея готовностью, то смысл Благостного [...] зрака направленного именно $B$ глику очевиден (см. 2.2.2. - 2.2.7.): оттуда поступает знак готовности уверовать (благая весть) и туда же должна быть направлена искупа:мая жертва, а в случае магдалины - ее со-страданне, ее акватическия по-

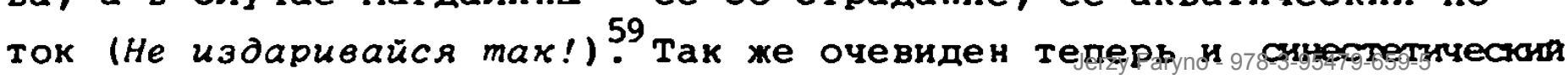


характер 'зрака-гласа' (см. 2.2.5.) как всеобъемлюдего - обращенного и к магдалике и к глике, т.е. к пребывағпему еше в аморфном со стояния "миру сему" (См. 2.2.7.).

\section{III.}

\begin{tabular}{|c|c|c|}
\hline 3.0. & $\begin{array}{l}33 \\
34 \\
35 \\
36 \\
37\end{array}$ & $\begin{array}{l}\text { О путях твоих пьтать не буду, } \\
\text { Милая! - ведь все сбылось. } \\
\text { я был бос, а ты меня обула } \\
\text { Ливнямя волос - } \\
\text { и - слез. }\end{array}$ \\
\hline & $\begin{array}{l}38 \\
39 \\
40 \\
41 \\
42\end{array}$ & $\begin{array}{l}\text { Не спрошу тебя, какой ценою } \\
\text { Эти куплены масла. } \\
\text { я был наг, а ты меня волною } \\
\text { тела - как стеною } \\
\text { обнесла. }\end{array}$ \\
\hline & $\begin{array}{l}43 \\
44 \\
45 \\
46\end{array}$ & $\begin{array}{l}\text { Наготу твою перстамн трону } \\
\text { Тише вод и ниже трав. } \\
\text { я был прям, а ты меня наклону } \\
\text { Нежности наставила, припав. }\end{array}$ \\
\hline & $\begin{array}{l}47 \\
48 \\
49 \\
50 \\
51\end{array}$ & $\begin{array}{l}\text { В волосах свонх мне яму выроя, } \\
\text { Спеленая меня без льна. } \\
\text { - Мнроносица! К чему мне миро? } \\
\text { Ты меня омыла } \\
\text { Как волна. }\end{array}$ \\
\hline
\end{tabular}

И опять смена перспективы (ракурса) - с внешнея, изобразительноя, на внутреннюю. Аналогичнул перспективе в первом стихотворении, но исходящую на этог раз не от Я-магдалины, а от ты-Христа. Персоиажи, таким образом, как бы меняются местамн, но и здесь являют собо взаимосвязанное интимное единство, которое в данном случае тем теснее, что реципиент текста осведомлен, кто и к кому обрадается с речью, почему также и здесь поставлен в положение 'отсутствуюего третьего' (типичная в случае лирического текста возможность идентификации реципиента с "я" или "ты" текста здесь на предполагается и делается невозможноя).

Краяне интересна здесь и принципиальная смена временниго ракурса. Во всем стихотворении с абсолітным постоянством употреблены две глагольных временных формы: форма будущего и форма прошедmeго совершенного (перфектного). Лишь в последнен строфе эту регулярность нарушит форма волеизъявительного наклонения (сказать "повелительного" было бы слишком много). При этом если прошедшее из-за перфектности глагольных форм замкнуто само по себе и как бы отстранено от подразумеваемого настоянего (т.е. времени акта ре-

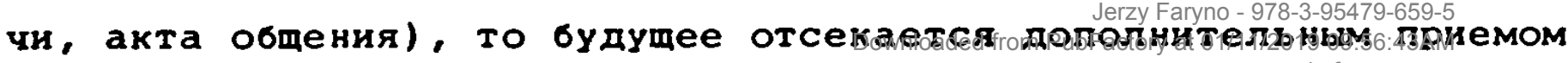


- отрицанием ме и глаголом совершенного вида (nаmamо ме буду, [...] ведо все cбuлoco; He cпрошу). Этим самым создается эФфект неизменного настоящего, выключенного из временного потока.

но весь парадокс заключается в том именно, что предметом высказывания в обоих случаях является именно время, и именно прошлое. Оно распадается на два потока: прошлое магдалины безотносительное к Христу, и прошлое магдалины в связи с Христом. Первое при помощи Форм будущего времени с отрицанием полностьк перечеркивается и предается забвению, 'не существованию' 10 путях твоих

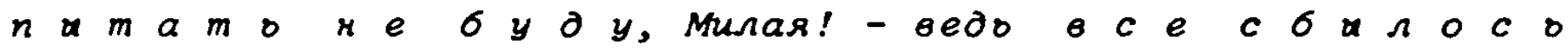

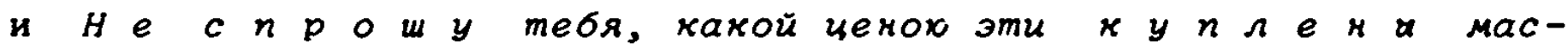
ла). Второе, хотя тоже сбылось (свериилось), повествуется, и этим самым как бы сохраняется в памяти и какбы излагается заново. Идея перерассказывания и памяти здесь очевидна, так как Магдалина не может не знать рассказываемого - она сльшит ея известное, только в ином освещения, в ином ракурсе. Вот этот инои ракурс и есть основное содержание данного стихотворения. Деиствительно, даже при беглом ознакомления с текстом возникает впечатление, что во многом оно - просто заново переписанньх первых два.

3.1.1. Стихи 33-34, несомненно, имелт ввиду судьбу (пути) Магдалины (ТЫ) вплоть до момента извержения бесовского начала (т.е. стихи 5-19). Слова өсе cбилосо, однако, не столь однозначны. Первың их смысл - 'кануло в небытие', 'предано забвенио' (см. 3.0.). Второя - 'исполнилось', 'осуществилось'. Он относится к пожелательному бала $\sigma$ одной из тех... и т.д. Слово же милая!, заменившее прежние сестра! и Магдалина!, - знак полного преодоления прежнеи разъединенности ТЫ и Я и некоторои разъединенности между Магдалинои и Христом во втором стихотворении. Оно уже не только знак равенства, но и знак любви (теперь, естественно, в смысле агапе). Сбылось, таким образом, и танное желание Я, содер-

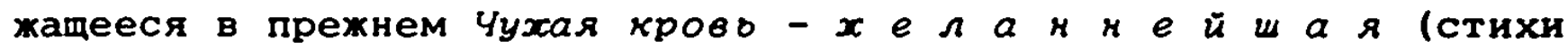
7-8).

3.1.2. Стихи 35-37 соотносятся, со своен стороны, С очередным эпизодом омовения-вытирания ног волосамя (стихи 19-22), но сквозь призму второго стихотворения, так как в обула присутствует 'дар' из Не издаривайся так! (стих 32), а өолоса названы ливмями, т.е. теперь уже эксплицитно тем смыслом, которы имипниияво5 содержался 
в их позиции в перечисляемом ряду атрибутов Магдалины (стихи $25-28 ; c p .2 \cdot 1 \cdot 4$.$) .$

3.1.3. Стихи 38-39 отсылают как будто к стихам 25-26 второго стихотворения, но переименованием прежних мастей в масла переотсылают к еще более раннему эпизоду обольщения (стихи 9-16). Как и раньше (3.1.1.), эта сторона прежнего "жития" Магдалины предается забвенн, погружается в небьтие (Не спрошу, какой иемок [...] куплеми). Но местонмение эти, так сказать, сохраняет масла в современности акта речи. Такои ход объясняется, по всеи вероятности, следугчим образом.

а. С "мастея-масла" снимается их 'цена' или 'плата' (ср. в стихе 25 масти, плочекмие, где в форме плочекние подспудно присутствует признак 'платы-плотью', и масла̀ в стихах 11-14, где им присущ признак 'соблазна'), они подвергаются своеобразному 'очищению от греховного начала' и повышению в ранге. Формула Не спрошу в этом свете не только формула прощения, но и соответствие эпиклесиса, т.е. воззвания не только освящающего, но и приобщажиего к Богу ${ }^{60}$. Об этом мохет дополнительно свидетельствовать как переименование в масла் в противовес мастям, Фонетическая структура которых сильно связывалась со страстями в обоих смыслах (гораздо раньше - в стихах 11-12 - имела место такая же последовательность: масла́ сменили масть, но тоже не как вещество, а в стилистическом плане; ср. обольстительную риторнческую окраску всего этого эпизода, призванную возвышать низменное; см. 1.4.1.), так и Финальное (в стихе 49) окончательное переименование в откровенно сакральное миро.

6. Масла̀ - ввиду более однозначноһ соотнесенности С чувственноя любовью (стихи 11-14) чем позже вытеснившее масти, соотнесеннее в большей степени С жертвенностью и чисто духовным (превращение в пневматическую струю в стихах 25-28), теперь после отторжения от "цены" (см. а.) - в состояния объединить в себе и одно и другое в "правильном равновесии": и плоть и духовное, и эротику и агапе. Кстати, забегая вперед, отметим, что в этом направлении и развивается дальнеяшия смысл текста (ср. хотя бы появление каготи и тела уже в стихах 40-43).

3.1.4. Стихи 40-42 по своему строению аналогичны стихам 35-37. Поэтому если искать для них такого же соответствия в предыдущем тексте (ср. 3.1.2.), то оно обнаружнвается, хотя уже и не 
столь эксплицитно, в стихах 25-28, где Магдалина - сплошкое Иеструение. С той разницея, что теперь струя перенменована в өолку тела. Слово обкесла употреблено здесь в той же функции, что и слово обула (стих 35), т.е. подменяет охидаемое "одела" и этим самым - подобно слову обула - восходит к понятию 'дара' в Не издаривайся так! (стих 32). И это пока, пожалун, все.

3.2. Остальноя текст (стихи 43-51) с гораздо меньшея откровенностью "перечитывает" предыдушее. Поэтому здесь позволительно остановиться и вернуться к более детальному рассмотренил стихов $35-37$ и 40-42.

3.2.1. Отсылк, так сказать, Фабульного порядка повторянт последоватсльность эпизодов-события предыдуиих текстов (см. 3.1 .1$. и 3.1.3.), зато отсылки сюжетного порядка идут вспять, создавая противодвижение (арабские цифры означахт номер стиха):

Tekct I

19 заматываю

20 как в мех

19 в волоса
Teкст II

28 Исструение

27 валосы

27 слезы

19-18 потом всех ног 26 страсти пот

21 тканью

21 стелюсь (под ноги)
(25 масти)

Особенно заметно это явление в сопоставлении с Те:стом I. Событияны уровень - аналог обувания-одевания - развивается в нем в сторону линеяного развертывания высказывания $(19 \rightarrow 21)$, так же, как и в тексте III $(35 \rightarrow 42,43)$. Текст II собитияного уровня лишен. Направления же сюжетноя эволюции противостоят друг другу: 36 - 41 (42) как бы возвращается от 28 к 26 (25) в случае текста II и от 20 к 18 в случае текста I.

Таким образом, если эволюция $19 \rightarrow 21$ и затем $25 \rightarrow 28$ шла в сторону истончения материально-телесного вплоть до перевоплощения в пневмоакватическую струю (Нсструение), то эволюция 35 - 43 исходит как раз из пневмо-акватическон струи (ливнями) и устремляется к телесно-материальному (өолкою тела - как стекор обкесла), т.е. К обретению-возобновлению плоти.

3.2.2. О том, что здесь имеет место "обратное перечтение" 
предыдущего текста (особенно второго), свидетельствует еще и прием пересегментации на стихи: волкок (40) тела (41) и страсти nоm
Лиекями өолос
(36) и слез
(37) и Ксструение
(28), cresa, волоса (27). Дробление стихов - своеобразное затрудненное чтение вспять.

На этом пересегментация не останавливается. Она есть одновременно и категориальная переакцентовка. Ни один из предыдущих атрибутов не сохраняется в своем объектном статусе. Синтаксически все они поставлены в позищиь определительного дополнения, а место определяемого занимают только ливми и волка.

В лексическом составе предыдушего контекста ливни и волка отСутствулт, но в семантическом отношения они - варианты окончательного перевоплодения Ты-Магдалины в сплошкое Нсструекие (и 'издаривание', поскольку в лиөкях четко проступает смысл 'сверхиэобилия' ; кстати, также в результате переклички со сверхизобилием в стихах 12-14 и наличного там слова лила б). В итоге, как ни парадоксально, окаэывается, что стихи 35-37 и 40-42 - не движение вспять, а последовательное продолжение предыдутей эволющии. Впечатление обратного движения $\mathrm{K}$ телесно-материальному облику возникает за счет "яэыка описания" (определительных дополнения и сравнения как стекор обнесла).

Естественно, "язык описания" здесь небезобиден. Благодаря ему ливни и волна сохраняют общность с телесностью, становятся ее инобытиямн.

Но, С другоя стороны, ливки и воляа не неятральны по отношению к свонм определителям. В сочетаниях Ливмями волос - Н - слез и волмою Тела они (ливми и волма) занимакт место сущности волос, слез и тела. Эту суцность можно было бы определить как 'акватическое начало', если бы не наличие слез, которье уже самн по себе 'акватичны'. Поэтому по краинеи мере в ливкях содержится еще и признак 'интенсивноя эмоциональности'. В результате телесность по ее сущности окаэывается здесь 'эмоционально-акватическим' бытием, a 'духовно-акватическое', со своея стороны, эмоционально-телесным. Иначе говоря, здесь вновь обретается телесность и чувственность, но на ином уровне бьтия.

Более того: эта духовная (пневмо-акватическая) телесность не абстракция. Она сохраняет свою конкретность, так как является инобьтием Магдалины как таковод. Последнее өөово отуетдњя 
в сравнении как стенор.

По внутритекстовьм связям стека лишь отдаленно подводит $k$ своему смшслу 'Магдалина': лила 6 масла́ [...] ө пески (стихи 12-1) и далее глика рифмующаяся с магдаликой (стихи 29 и 31 ). кроме того см. сравнение-метаморфозу Некою тканою под коги Стелісб... (стихи 21-22), особенно ввиду наличия в как стенор обнесла смысла 'одела' (см. 3.1.4.), а также ввиду фонетическон перекЛички СТЕЛисо и СТЕною.

Внетекстовые связи отсылают к этимооти именн Магдалика, которое образовано от топонима и означает уроженку города мигдаль-Эль. А Мигдаль-Эль восходит, в свою очередь, к евреяскому migdāl и араменскому magdalā, что означает "башня" 61 . Стека в стихах 41-42, как нетрудно заметить, "башнеобразна" (стекох $о 6$ н $e$ $\Omega$ a). В результате стека оказывается вторым, сущностным, именем Магдалины, а точнее - наиболее истинньм и наиболее сущностным (исторически "Магдалина" было идентифицирующим приложением к имени Мария: Мария Магдалина = Мария из Магдалы или Мигдаль-Эль, которое впоследствин стало восприниматься как самостоятельное имя собственное) .

Так обретается мечтавшаяся некогда Ты возможность стать одкой из тех (стих 6). А точнее - осуществляется обретение ею подлинноя своея сущности.

но в данном тексте Магдалина - не стена, а как стека. По тексту она - волма. И по тексту же өолка - сущность магдалины. из этого возникает чрезвьчанно интересная тавтология: Магдалина описывается при помощн магдалины же, она и предмет описания и язык описания, ее сущность описывается ее же сущностью. Этим самым образ магдалины как бы исчерпан, замкнут в самом себе.

Аналогичное явление наблюдалось уже в первом сравнения (как cmeкоN - лишь второп сравнительнын оборот в разбираемом триптихе) : как в мех (стих 20). Оба они объединяются общим признаком 'поглощения вовнутрь'. Поскольку, однако, ни мех ни стена не являнтся тут объектами, а всего лишь языком описания, это 'поглодение вовнутрь' не имеет буквального ризического характера. Оно метафорично, а точнее - метафизично.

Еще одно. В случае сравнения как в мех сущность высшего порядка (обретенныя Я человеческия облик после экзоршизма, описывается при помощи категории низшего порядка, уже я несвонственноя 
(1.6.4. а.-6.). Становясь языком описания, эта категория теряет свою денственность, абстрагируется от Я и указывает на прннадлежность Я к иному порядку, на ее иное бьтие. Этот же механизм вклочен и в случае сравнения как стеною. Магдалина-стена (Магдалина-башня) оторвана от магдалины и переведена на уровень кажямости (языка описания - не стена, а как стена). На уровне деиствительности осталась только Магдалина-волна, т.е. ее более глубокая сущность. Сохраняя некое сходство с самои собоя прежнея, она уже совершенно другая. Но сказать, что это предел эволюция образа магдалины, еще нельзя, так как текст до конца еще не дочитан.

3.2.3. Вернемся теперь к последовательности обула - обнесла, читаемую также и как "обула - одела". Эти деяствия повторяют в тон же последовательн - денствия ты в стихах 19-22 (в еолоса замативар Ноги mеои [...] Некол mканок под коги Стелюсо.... но не в тон же реализации: совиадаот первые денствия ("заматывание-обувание"), вторые же принципиально расходятся.

В случае Текста I имеет место движение вниз и вширь: $B$ волоса замативар Ноги твои $\rightarrow$ под коги стелюсо (однн его смьсл рассматривался в 2.1.5.). В случае текста III наблюдается усложненная картина: движение вниз и спиралью вверх (обула Ливкями волос - слез - волнор тела - как стенор обнесла). Здесь как бы дважды повторяется тот же жест "заматывания", но теперь направленнын вверх и как бы осуществлякдия призыв встако, сестра! (стих 24 ).

В семантике этого Фрагмента одутимо удерживается смғл 'одела' по аналогии к обула. Однако этот смысл получил тут выражение обнесла. И это отнюдь не случаяно. обнесла бллее однозначно вводит спиралевидное движение вверх, с одноя стороны, а с другоя смысл поглощения Христа вовнутрь себя (на что слово "одела" в такои степени уже не указывало бы хотя бы из-за свободнон отчуждаемости одежды), причем погломение окончательное, не предполаганщее выхода (стена подразумевает массивное, сплошное; обнесла - со всех сторон, "отгородила"). Это - погломенье-заточенве, но со смыслом' охранительности, защиты, безопасности. 63 .

и еще одно наблюдение. В контексте слов $\mathcal{A}$ бил наг слово "одела" ввело бы нежелательную физическую наготу, ликвидация котороя при помощи слова "одела" исключала бы из текста наличие какон-ли6 наготы вообще. обнесла же переводит наготу в 'беззапитность', 'одинокость', т.е. в иноя план, и одновременно сохраняет некия 
признак телесного начала (плоти).

Последнее обстоятельство тем существеннее, что до сих пор образ ты-Христа был почти бесплотен. Сначала он был представлен только одноя детальо-атрибутом - могами (стихи 13, 20-21). Потом в виде нерукотворного зрака-лика (стих 30). Здесь же коги не упомннаются, вместо них употреблено слово бос (стих 35), и поэтому казалось бы, что телесность этод детали вовсе не предполагается. но "вещественное" обула (стих 35) придает признаку бос смысл ало щенности, но не в физическом, а в высшем смысле (так как обула Ливнями волос - $И$ - слез). В стихе 40 появляется слово наг, где нагота предполагает некую телеснссть. Естественно, что и здесь это не физическое тело, но тем не менее образ Христа приобретает в своем высшем плане облик существа во плоти. И, наконец, последняя деталь - персти (стих 43) - жак бы окончательно оформляет образ Христа в человеческом виде.

кроме того "обутость" Ливкями волос - H - слез и "обнесенность" волною тела создают идею обретения христом плоти. Самое интересное, однако, что это плоть, так сказать, чужая, ему 'дарованная-пожертвованная' ( mа меня [...] обкесла). Как раньше ты, так же и христос здесь принципиально бездеятелен. Не он облекается плотью, а его облекаNт. Так строится идея приятия Христа в себя, облечения его своен плотьн, дарования ему жилища в себе. Тут отметим еще один из неучитываемых до сих пор возможных смыслов слова стека. Оно может толковаться и как метонимяя 'дома' - храма, дома божья, и как метафора человека, т.е. его тела-души, как обиталища Бога-Христа.

Эта метонимяя-метафора не совсем неожиданна. Подспудно она вырастает из стихов 4,7 с подчеркнутым там смыслом 'чуждости' (Чухая крово): 14 из возможноя там ассоинации песков с 'пустынея', способнои означать 'бездомность', а также - согласно словоупотреблению слова "пустыня" в Ветхом Завете и в Евангелиях - как место интимно встречи С Богом-Христом, так и место искушения; 15-16 из их общего ореола 'базарного локуса' (Cтрасть по $x$ у $n-$ и $а$ м $p a c n p \circ \partial а н к а k)$ и этим самым 'бездомности'; 19-21 из их ореола 'гостеприимства' противостоящего прежнеи 'чуждости' и ореола 'домашнего уюта' (см. 1.6.4.а.-6.), со своеи стороны противостоящего прежнен 'пустыне'64. Стека эту эволюцию $\mathrm{k}$

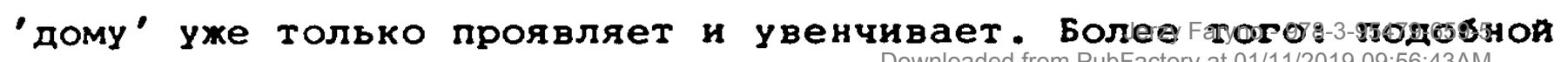


эвол.оции подвергается и сам этот "дом": пустынның ("песочнын") вариант со смыслом бесовского обиталища (ср. очесами $а$ е м о $⿻$ с-

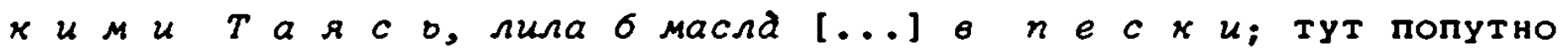
отметим, что грамматическое множественное число слова пески недвусмысленно подсказывает смғл 'пустыня') - домашния, представленның атрибутами уюта (мех, ткаяо), ухаживанием за гостем, со смиллом человеческого жилья и 'семеиственности, родства' под его кровом (встако, $c e c m p a !) \rightarrow$ внутричеловеческин сущностның локус (ср. рифму глику - Магдалику и палее сравнение Магдалины со стеной) лишенны физического выражения и получивши вид волка с общим смыслом обители Бога-христа, "храма на воде" 65.

3.3 Стихи 43-46 по своен схеме тесно примыкахт к стихам 33-42, но Формально являют собой как бы новую часть текста - послєдния стих этон строфы (46) дан сплошь, а не разбит, как во всех остальных случаях, на два. Этим данные стихи как бы противостоят предыпущим, подчеркивают свов некую обособленность. На самом общем семантическом уровне она выражена отсутствием отрицания (ср. ке будy $\rightarrow$ He cпрошу $\rightarrow$ троку), что особенно заметно ввиду уже выработавшеися инершии ожидания первыми двумя строфами и ввиду сохранения этои инерции в стихах 45-46.

3.3.1. Стих 43 созвучен с начальными стихамн предыдущих строф (33 и 38) по употреблению формы будущего времени. но если там она была употреблена с отрицанием, то здесь это форма утвердительная. Место отрицания тут занимает уменьштельность в стихе 44, но это лишь первое впечатление, поскольку семантически она призвана как раз интенсифицировать содержание прикосновения (трону).

Стих тише өод и кихе трав (44) опирается на фразеологизм "Тише воды, ниже травы", но не тождественен ему. Разница закличается в следуюдем: Фразеологизм относится к поведению, способу держать себя, и значит "вести себя скромно, робко, незаметно". К тому он не сочетается с переходными глаголамн деиствия. Здесь же он сильно модифицирован: он употреблен с глаголом троку, кроме того, в нем изменена форма сушествительных на Форму множественного числа и введен союз $u$. Такая перестронка выпвигает в нем на первын план смысл буквальныя, хотя легкая опознаваемость исходного варианта сохраняет и смысл переносның.

'Робость', скромность, незаметность' прикосновения локализуются, таким образом, на общен шкале с материальностьки означа- 
Nт еще низшую ее степень. Если акватическия уровень мира данного текста был уровнем наименее материальным (ср. волнол Тела), то прикосновение еще менее материально.

Нихе трав откровенно отсылает к стихам 21-22, где ткакои под ноги Стелюсо определяло самы низки уравень вертикальнои оси мира текста (после него начинается движение вверх - өстако, сестра!). ткано же, со своея стороны, вводила смысл 'растительного мнра', а точнее - изделия из 'растительности'. Появление трав в этом контексте не неожиданность, особенно ввиду принципа "обратного чтения", на котором зиждется данное стихотворение. Трави - это вновь "оживақдая ткань", наинизшия уровень пробуждения к жизни. И если Тиме вод читать как пред-материальное состояняе мнра, то кихе трав означало бы пред-витальное, пред-жизненное. 66

В сочетанин с глаголом троку слова тише вод и кихе трав есть обстоятельсгво способа деяствия. В свете же изложенного значения стиха 44 это деиствие пребығает на нижаишем уровне, почти на нулевом уровне деиствия и на нулевом уровне бытия, в итоге - на уровне без плана выражения, так как признак деяствия (троку) все-таки не аннулируется. Речь, таким образом, идет о деиствия пред-бытияном, О неощущаемон физическимн чувствами энергин.

Фразеологическая родословная стиха 44 заставляет усматривать такую же родословную и в стихе 43: перстами троку - "и пальцем не трону", что значит 'не обижу'. Смысл 'обиды, поругания' уже присутствовал в первых двух стихотворениях. В стихах 15-16

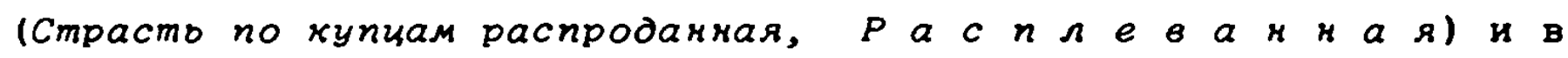

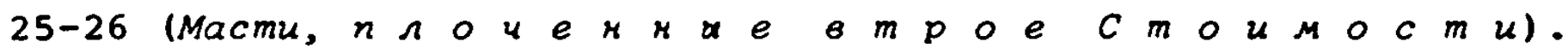
Качественная градация тут налицо: явное поругание и обида, $\rightarrow$ смягченная, скрытая обида-обман - нежное, неопутимое прикосновение (а в контексте стихов 45-46 также и знак-жест благодарности, своеобразное 'воздаяние должного' в отличне от грубоя 'продажи-платы-жертвы') . 67

3.3.2. Аналогичным образом должна, по всея вероятности, читаться и Нагота Магдалины (стих 43). В определенном смысле кагота здесь совершенно неожиданна, так как она следует после перевоплощения Магдалины в сплошнод акватическия поток. Упомннание наготи подчеркивает в Магдалине, таким образом, ее материальную исчерпанность. Согласно стиху 32 и стихам 35-37 и 40-42 она оконча-

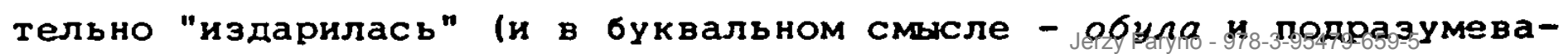


емое "одела"; и в метафизическом смысле облачения Христа своен же сущностью - Ливмями волос c me r o to oбrecral.

Но, С другоя стороны, упомннание нагота восстанавливает в Магдалине и некую телесность, но уже трансформированнуі. Из стихов 35-37 и 40-42 следует, что Христос локализован теперь внутри Магдалины. А это значит, что нагота имела бы здесь смысл не внешнеи 'наготы-обнаженности', а наготи внутреннея, а точнее - 'изнутреннен', маготи как суцности, поскольку магота оказалась здесь внутренним сводством. В этом плане она была бы эквивалентом ливмей и волки, которые тоже занимали место сущности атрибутов Магдалины (волос, слез, тела) и содержали в себе признак эмоцнонального (см 3.2.2.). Нагота, появляопаяся на продолженин акватическои парадигматики, сбнаружнвает и сходство с ней и различне. С одноя стороны она конкретизирует 'эмощнональное', придает ему оттенок 'чувственно-телесного'. С другоя же - вводит еде один уровень, так сказать, 'под-водның', поскольку это магота не только 'изнутренняя', но также и кагота волка, акватическон сущности магдалины, а короче говоря - сущность сущности.

3.3.3. Выбор славянизма персти вместо "пальцев" (тем более оцутимя, что под этим стихом угадывается Фразеологизм "и пальцем не трону" - см. 3.3.1.) дематериализирует пальш, возводит их в высши ранг. во троку заключает в себе некую реальность деяствия, которое немыслимо по отношению к абстракцин и нематериальному. Поэтому в троку позволительно чнтать не только как "коснусь", но и каг. душевную растроганность (умиление). Это знач:лло бы, что троку включает в себя и смысл 'возбуднть', 'передать и вызвать некие чувства'. А тогда персти означали бы орган передачи некоеи энергия, жизненноя силы, сообщения-излучения благодати (особенно в случае прочтения троку как благодарственного жеста - см. 3.3.1.). Короче говоря, теперь в этом жесте отчетливо просматривается эрото-агапическия смысл.

3.3.4. Слово прям, в силу деиствия одноя и тоя же синтаксическоя схемы, попадает в парадигму бос - каг как ее продолжение, как ее очередноя элемент, а этим самым как элемент, несуию аналогичнуз омсловуо натрузку. Этот смыл прост - 'прямота' становится разновидностыи некоего убожества, несовершенства, может быть, даже

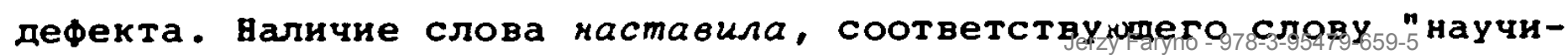


ла", говорит и о прямоте как 'простоватости', грубости. Прямота и маклон имеөт и еще один смысл.

В предыдущих текстах она прочитывается дважшы: в словах встано, сестра! и в словах вперяя зрах (стихи 24 и 30). В первьх она означала равенство: по иерархия-родству, вводя одноранговость между Я и Ты; по "ровности" позиции-позы, вводя идею социального равенства. Но все эти смыслы пока лишь я и ты делагт равноправными партнерами, но не единят их в некое одно-единое целое. Вторые, ввиду взгляда-зрака, уже объемлют магдалину, но все еще косвенно, даже как будто "мимо" нее (ср. употребление местоимения тот со смыслом отдаленности, а также домннацию вертикальноя оси взгляда над гориэонтальнои подразумеваемого во взгляде "гласа").

оба эти типа разъеднненности снимантся здесь при помощи наклона. Первы - гри помощи смысла 'наклоненности $K$ ', 'участия в другом', 'внимания к другому' (маклояу Нехяости). Второи - при помощи смены направления луча взгляда не вертикально вниз, а по наклонно линин (наклоку Нехности наставила, припав). Присутствие слова припав локализует Магдалину внизу, а это значит, что наклон есть наклом сверху вниз к Магдалине, и это значит, в свою очередь, что маклон Христа объемлет собой теперь и Магдалину, включает ее в себя. И злесь именно оба персонажа впервые создают одно целое (на языке живописи или скульптуры можно было бы сказать, что они создают одну общую фигуру). Но это еце не все, это, так сказать, лишь внешняя общность.

Во всех трех текстах Магдалина постоянно "показана" в обнимаюце-заключаюием жесте-поэе (өлекласо; стлаласо; $H$ на ноги $6 u, u$ под коги би; $B$ волоса заматхвах Ноги твои; тканох под моги стелюсо; струяшаяся волнообразная линия в волоси, слези, Нсструение; наконец - обула; обнесла; припав; каклоку наставила). Даже стека, суцность Магдалины, здесь не прямая - она вертикальная, но 'огибағдая', 'обнима!ищая' (как стенох обнесла).

И лишь в этом контексте становится очевидноһ "цель" эволюшия образа Хрнста: Ты-Хрнстос обретает согласованность с контурноя линиея Я-Магдалины, что на языке поэтики Цветаевои можно определить как рифмовку по "контуру" или точнее - по контуру внутреннего напряжения, внутренних "силовых" линин" 68 .

Припав вызывает в памяти открываюдее текст слово отшатшвает

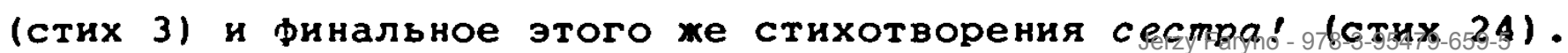


Промежуточное сестра смягчает первоначальную разъединенность и отчужденность между Я и ТВ: для Я - Ты уже не чухая крово, а 'родственная', родная же крово, в свою очередь, уже не отшативает и даже способна объединять (см. 1.7.-1.9.). Но объединение в одно целое там еще не состоялось. То был лишь первын существенның шаг к такому едннству. Единство я-Магдалины и Ты-Христа осуществляется лишь теперь, после соответствуюиих трансформаци обоих персонажея.

Прикосновение (трону) со стороны Христа - окончательное преодоление прехнея разъединенности и окончательное слияние обоих сущностея. И последнее замечание. В этом контексте стих 44 (Tише вод и яихе трав) - не что нное, как варнант глубокого 'сущностного' какломс, чуткости к другому, вслушивания в него (ср. двовнои смесл слова muше) 69.

3.4. Сущностное совпадение и слияние обоих персонажея получает свое выражение в финальноя строфе триптиха, в стихах 47-51, и со всеи последовательностью носит характер полнои взаиморастворимостн .

3.4.1. Растворимость христа в магдалине показано тут по образцу евангельского обряда погребения (яма, спелекай, миро, омила). Но одновременно этот же образец разрушен сплошными отрицаниямн, и погребение становится в то же время не-погребением, и даже его противоположносты: закличительное омила Как волна подсказывает смысл 'очищения' и этим самым 'перерождения в нечто новое" (кстати, употребленные тут "погребальные" термнны с одннаковон вероятностьо :яогут относиться и к обряду кредения, т.е. рождения) .

но чтобы понять это растворение Христа, необходимо разобраться в Магдалине, В том, В каком состояния она пребывает в данноя cтpoфe.

3.4.2. Из всех признаков-атрнбутов Магдалины здесь сохраняются талько волоси и еще, может быть, ее новое наименование мирокоcuua.

Ее прехние инобытия поочередно аннулируются. Первое - ткако переформулировано теперь в без лона. От него сохраняется только деяствие Спеленай. В переводе на бытово язык это могло бы выглядеть так: 'спеленая в себя без себя'. 70

Второе - миро - восходит к прехним мастям и маяядім 
нование их в миро есть одновременно возвышение в ранге и перевод на нефизическия уровень бытия. Но и этот уровень, и это небытие, отстраняется: $K$ чему мне миро?

Последнее инобытие Магдалины в триптихе - өолна. Она была одновременно самой глубокон сущностью Магдалины. Но Магдалина как өолка переведена тут уже в прошлое (омила как глагол прошедшего совершенного времени), С одно стороны. А С другон - слово волка поставлено здесь на уровень языка описания, попало в сравнительның оборот Как өолка, демонстративно подчеркнуты его перебросом в отдельны и последнин стих (51). Аналогично предыдущим двум сравнениям и это локализует өолку на более низком уровне, чем описываемы объект (здесь ты=магдалина), которья более деиствителен, нежели язык описания (ср. 3.2.2.).

Результат таков, что в конечно стани этои своеобрознои апофазы $\infty-$ тается некое ТЫ без какого-либо плана выражения (сущность сущности:

ТЫ-Магдалина все-таки имеет здесь свое наяменвание:Мирокосиал. Отказ от мира не полностью десемантизирует его. С этого имени снимается лишь связь с баль амическим снадобьем. Остается зато созвучие с омонимом "мироносица" со значением 'носительница мира-света' и 'носнтельница покоя'. Иньмн словамн: Мирокосииа может означать 'удерживающая мир, правящая мнром' и поэтому свободно объединять в себе смерть-рождение (ср. двояственныя характер обряднои лексики в этои строфе, одинаково применимоя к погребенио и к крещению: см. 3.4.1.1.71

В начале этого параграфа мы сказали, что из всех атрибутпв магдалины не отрицаются тут только өолоси. Так оно и есть. Вадо только отметить, что это уже не прежние өолоси. Если прежде они были внешним атрибутом Магдалины претерпевакдим эволющию в сторону ее акватическоя сущности и певратается в ливки, то теперь они носят характер локуса, некоего вместилища. И если раньше им сводственно было движение в направления сверху вниз, то теперь как локус они предполагают направление вниз вглубь (в волосах своих мке $я$ м $y$ e a $p$ о йl. Оставаясь сущностью Магдалины, они,наконец проясняіт ее окончательның смысл как м и т е $\boldsymbol{\pi}$ ь н и ц

3.4.3. Слово яма выэывает в памяти слово глину из второго

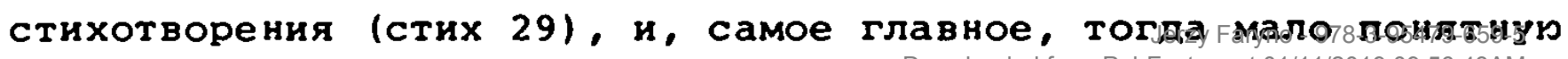


рифму ГЛИНу - маГдалННа. Теперь, когда Магдалина оказалась 'ямод-мировместилищем', смысл того созвучия уже не требует разъяснения. Мохно только досказать, что зрак направленныя в глияу не мннует магдалину, а лишь смотрит в ее более глубокую сущность не останавливаясь на глубоких, но все-таки еще относительно поверхностньх уровнях ее бьтия. Дистанция мехду Магдалиноя и Хрнстом, наблидавшаяся в местоимении mom и противительном $a$, носила не пространственны характер, а характер несовпадения сущностных уровнея. Согласование сущностен, сошествие магдалины и христа на общия, окончательныя, уровень устранило все дистанции. Но устранило и разницу между персонажами. Вряд ли случанно в третьем стихотворении произошла симметрическая перестановка личных местонмения Я и Ты. Персонажи триптиха помснялись не только "местамн", но н сводствами. Эти местонмения уже не дифФеренцируют, а объединялт (ср. насьденность строфы местонмениями: своих, мне, мекя, мне, меня, Tи; 'пеленаіиим, обөивающим' движением: спеленай, омила: и смыслом' вовнутрь, вглубь': В волосах своих мяе яму вирой).

В данном стихотворении яма замыкает следующую последовательность: $Л и$ в к и волос $\rightarrow$ волмој тела $\rightarrow$ в волосах $\rightarrow$ яму вирой. Упоминаемая во втором стихотворении глияа завершает иную последовательность: Масти - nоm $\rightarrow$ cлези - волоси $\rightarrow 3$ краскую сухую глику. Несмотря на их разницу,позиция глияи и ямх в обоих случаях одинакова - после волос. Разница же состоит в том, что там өолоси завершали овнешнякпияся акватическия поток и подразумевали смысл более интенсивноя 'водноя стихии' (см. 2.1.4.), тогда как тут өолоси уже есть акватическая стихия (Ливни) и все-таки эта стихия в финале опять именуется волосами (стих 47), а ее 'акватическая сущность'переводится на уровень языка описания и этим делается сущностью низшего ранга по отношению к описываемому. Все это означало бы, что теперь өолоси понимаітся как явление (сущность) наивысшего ранга, и что на тот же уровень поднята также и прежняя глияа, ставшая теперь ямой. При этом яма как очередной этап глика предполагает некую 'сухость', которая в силу контекста долхна теперь быть свояственна и өолосам (так как она была им сводственна на их первом этапе - в стихах 19-21).

Без выхода во внешния контекст эту "непоследовательность" смъслово структуры өолос в данном триптихе объяснить уже нельзя. Блихаяшия и подразумеваемы всем триптихом внешния коконтекст - 
Евангелия. Символика волос, правда, там не раскрывается, зато однозначно раскрыта символика цветаевского эквивалента волос - воды. Наиболее прямое соотнесение Цветаевского текста и Евангельского - стих 38 из 7 главы От Ноаняа: "Кто верует в Меня, у того, как сказано в Писании, из чрева потекут реки воды живон". Эти слова как нельзя лучше дополняют и расшряют смысл Џветаевскон последовательности в стихах 22-28: Магдалина превращается в сплошное Нсструекие именно после опознания ТЫ, т.е. после опознания-уверования. Теперь весь последовавши за этим акватическия поток можно читать как поток "воды живоя", в отличие, например, от предыдущих потоков масел (пророчествуищих погребение) и разорязинх страстей (стихи 11-19).

Однако, как мы уже заметили, ораз воды у Цветаева раздваивается. Акватическия поток Нсструекия во втором стихотворении всего лишь предварительның этап к появлению вода более сущностнон. Такое раздвоение наблюдается и в тексте у иоанна (глава 4, стих 14): "А кто будет пить воду, которую Я дам ему, тот не будет жаждать вовек; но вода, которую Я дам ему, сделается в нем источником воды, текущев в жизнь вечную".

И этот смысл, как видно, свободно прилагается к цветаевскому тексту: прияв в себя Христа, Магдалина становится источником, акватическим началом. Это значило бы, что внутренние воды Магдалины есть воды дарованные ен (или вызванные в нея) ты-Христом. Воззвание к Магдалине при одновременном устремлении $B$ красную сухую глику, в котороя обнаруживался признак 'жажды', есть своеобразное перенаправление "воды живон". Не случанно также, видимо, в стихе 36 акватическия поток именуется Лиөкями, предполаганцими направление сверху (с небес) вниз Но это указывало бы, что теперь Магдалина стала самостоятельным источником өоди, а Христос его только вызвал к денственности.

Все это объясняет глубинны смал акватическо темы в триптихе, но еде не позволяет связать ее с темоя волос. Некое указание на возможность такоя связи позволительно усматривать в еще одном Фрагменте Ееангелия от Ноанна (глава 3, стихи 4-5):

"Никодим говорит Ему: как может человек родиться, будучи стар? неужели может он в другоя раз вонти в утробу матери своен и родиться?

Иисус отвечал: Истинно, истинно говорю тебе: еслия кто не ро- 
дится от воды и Духа, не может вонти в царствие Божие:

Рожденное от плоти есть плоть, а рохденное от Духа есть дух".

Если перевоплодение Магдалины в акватический поток рассматривать как ее перерождение или даже 'новое рождение', то естественно ожидать наличия в ее образе и 'воздушного' потока, пневматическоro.

из всех ее атрибутов причастность к 'пневматическому' обнаруживают масти (см. 2.1.1.), слези (см. 2.1.3.и 3.2.2.) и, по всен вероятности, именно волоси, поскольку именно они наименее 'акватичны' в бьтовом представления, а также и в предыдуших эпизодах триптиха (см. стихи 19-20, где өолоса даны в Функции 'осушающего', 'впитываюего'; кстати лишь теперь окончательно проясняется смысл 'впитывания' - это получение "воды живоя" от Христа). 72

Итак, м вплотнуг подошли к неэксплицируемому у Цветаевоя смыслу волос как 'духовного начала'. По всен вероятности этот смысл өолос для Цветаевон очевидность, и может восходить как к бытовым представлениям о волосах как вместилище души, так и $к$ тако именно символике во многих мифологических системах. Согласно последним, волосы символизируют духовнуњ силу, положнтельное извечное космогоническое начало, и - более того - в акватических системах связываются с представлением о Мировом (верхнем) Океаne ${ }^{73}$.

Так наконец, объясняется странная на первыя взгляд эволюция в последнем стихотворении от Лиөкей $к$ волосам. теперь она принципиально логична: в финале өолоса стали пневмо-акватическим мировместилищем. Понятно теперь и пожелательное погружение Христа: именно в таком средоточии и возможно евангельское "второе рождение" (ср. цитированнуг выше беседу с Никодимом).

3.4.4. Яма и Спелекай мекя без лока - погребальнье термнны. Веобычность же яма (ө волосах) и необычность "пелены" без "пелены" (лока) переводят это погребение в мистическия план, а яма становится наименованнем преисподнен, бездны. Одновременно, однако, здесь наблюдается и нечто противоположное (см. 3.4.1.): мягкое отстранение погребальных атрибутов - лока (савана), мира. Создается, таким образом, впечатление "погребения без погребения", которое в последних стихах (50-51), а особенно в слове омила, подразумевает возрождение. При этом Функцию мира выполняет тут сама

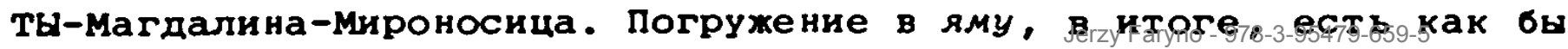


погрухение в Ты-магдалину, в пневмо-акватическое чрево - для второго рождения. С точки зрения православноя теологии, это - почти идеальная картина крещения - "вечнон купели" и анагенесиса, т.е. полного возврата человека к истокам, где его плазма получает истинныя образ по подобию Божью. Более того: реальныя обряд крещения совершается через троекратное погружение крещеного в воду, знаменующее также и сошествие в пренсподнюю ${ }^{74}$. (ср. троекратность в разбнраемом стихотворения: обула ливнями - өолкох Тела [...] обнесла - Ти меня омила Как өолна).

Теперь, кажется, становится объяснимоя одна странность в Финальном образе магдалины: слова В өолосах сөоих мке яму вирой вывываіт ассоциацию со 'звериным', хотя предыдущне признаки 'звериного' и 'бесовского' были уже "побеждены". Их возврат поэтому можно читать как указание на слияние в Магдалине 'хтонического' и 'космического' начал, на ее первичныя, предвечның амбивалентның характер как перестраивающея энергия, как поглощаяея и одновременно порождаюцен стихин. 75

В поэтическом коде Цветаевоя такая энергия или такая стихия чаще всего воплощается в любви. Не лишен любовно-эротического плана и данны триптих. Но здесь Цветаевская эротика, так сказать, теологизирована явственнее, чемв других ее произведениях. Возможно потому, что это одно из весьма немногих ее стихотворения, где встреча Я и ТЫ получает желательныя - воссоединяющия воедино - исход. И тем не менее здесь поражает именно точность совпадения с теологическими положениямн.

так, например, весь триптих (а особенно второе и третье стихотворения) совєршенно свободно читается в терминах эпектасиса, которы означает устремленность, краянюю напряженность, и синтетизирует два аспекта единого акта: экстаза - выхода и энстаза входа. Душа рвется от себя самоя к Иному, а этот Инов находит обитель в пуше и становится более внутренним по отношению к душе, чем сам человек 76 .

Как любовная лирнка этот триптих также свободно читается в термннах Григория нисского "эрот" и "агапе". Нисския их не противопоставляет, а наоборот - утверждает, что эрот развивается в агапе и в любовь к ближнему. Евдокимов разянвает эту мыль следияим фиазом: обе формы любви дополняют друг друга, эрот под возденствием Святого Духа устремляется навстречу божественнод агапе. В этом 
смысле Фундаментальное значение получает эпиклесис мнстического слияния, поскольку человек уже только потому, что стал пневматоФорическим, становится христофорическим 77.

Само собо разумеется, что ни сознательное, ни случанное совпадение с теологическми положениями ещё никак не свидетельствуют О поэтическон системе Цветаевон. И одно и другое должно рассматриваться именно с точки зрения последнен, так как от ее свояств эависит и выбор объекта высказывания (тут Магдалина и Христос), и его артикулячия (кстати, лексика триптиха гораздо менее теологична, чем рохдаюшнеся в нем системы смыслов).

IV.

4.0. Получившияся у нас образ Магдалины в высшеи степени теологичен. Но, как ни странно, он не совпадает ни с ее образом в Еөангелиях, ни с апокрифнческим. В Евангелиях он эпизодичен. О прошлом Магдалины упомннается там только вскользь - как о последовавие за Христом и сделавшеися как б его собственносты вместе с другим женщинами; из нее некогда было изгнано семь бесов ${ }^{78}$. В настоящем же она - одна из мнроносиц, к таму же первая, котороя явился воскресши Иисус: "Воскресши рано в первын день недели, Иисус явился сперва мария Магдалине, из котороя изгнал семь бесов" ${ }^{2}$. Ни сцены изгнания бесов,ни сцены покаяния и возлияния мастея и омовения ног там нет. Это происходит С инымн участникамн и участницамн евангельских события. Поздненшим осмыслениям Евангелий, правда, своиственно отохдествлять иных грешниц и ухаживаюши за Христом женшин именно с Мариер Магдалинои, но существуют одновременно и другие версии отрицаюине такоя контаминации. В апокрифах же основное внимание уделяется позднеишен, проповедническои, деятельности св. Магдалины 80 . Цветаевская Магдалияа поэтому - своеобразныя очередноң "апокриф", частично соответствуюши закрепившимся конвеншональны "знаниям" О Магдалине, но в большем и существеннеишем - обнаруживаюиия черты, сводственные утраченному Евангелистами и ее первооб$\operatorname{pas} y^{81}$

4.1. И в плане выражения и в плане содержания финальная стадия образа Магдалины отличается от всех привычных представлениях об этом персонаже. В плане выражения образ вариативен. магдалина - акватичес кое облачение (точнее: подразумеваемая "обувь" и"одежда"), волна-

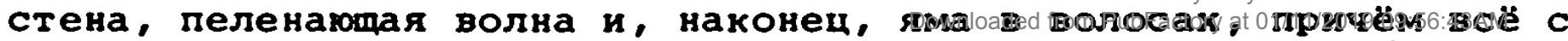


инвариантно кинемограммон вовлекающея вовнутрь бесплотноя суцности. В плане содержания - она защнта, храм, небо-преисподняя 82 и, наконец, могила-кольбель с инвариантньм смилом 'чрево, лоно', где захороняются, но и возрождаются ${ }^{83}$. В итоге от магдалины, от ее евангельских и апокрифических образов, сохраняется - или вернее: сызнова вводится в финале - то, что сохраниться не долхно бы (также и по ходу текста): смысл 'поглощаюыего лона', т.е. некия отголосок 'блуда'. Скахем иначе: блудница превратилась здесь в некую идеальную сущность женского начала, в 'Утробу', в 'Лоно' С явственными хтоническимя признакамя (яма в волосах).

Это в некотороя степени сблихает ее с мариен Богородицея ${ }^{84}$, но еше теснее С Богинеи-Матерь:, которая "соотносится с землея и - более широко - с женским творческим началом в природе" 85 , и, кроме того, "в большинстве мифология соотнесена с умираюиим $и$ воскресаюиим богом (Исида и Осирис, Кибела и Аттис, Иштар и Таммуз и Т.д.), мухем или возлюбленньм Богини-Матери" 86 , сохраняя свою еще более древнюю связь с гороя, водоя, со звериным, т.е. с предкосмическим хаосом, с косным состоянием мира ${ }^{87}$, а этим самм и глубокую внутреннюю противоречивость: В иньх вариантах она и разрушительница, завоевательница (например, Гея), и созидательница, как например, ставшне покровительницами городов (космоса) Иштар и Кибела (они "часто изображаются с короноя в виде зубчатов городсков стены") 88.

Все эти корни, безусловно, выявляко в ярком свете природу Цветаевского Я вообще, и особенно его вариативность в плане вырахения $^{89}$. И тем не менее трансформация блудницы в космогоническое Лоно, особенно в далеко не кощунственном решения евангельскоя темы, остается пока загадкоя.

4.2. Яма - не единственная характеристика Магдалины у Цветаевоя. Она всего лишь завершает следу ощую "пространственну10" эволюшию: подразумеваемая пустьня (стих 14: пески), базарнын локус (стих 15: упоминание купиов), домашния локус (19-20: В волоса замативаю Ноги твои, как $\theta$ мех), ткако как метонимия пространСтвеннов протяжённости (21-22: Нехою ткакою под коги Стелюсо..), рифменная связь с глимой (28-31), подразумеваемая "обувь" (35-37), стена (41) и яма (47). Критерия эволюшии очевиден: утрачнвается разобщённость между Я и пространством и нарастает отождествление 
Я С пространством. Я, строго говоря, замещает собоя всякое пространство, С одно стороны, с другон же - возрастает признак объемности Я-пространства и его углубление. Более того: оно начинается С явно безводного, безжизненного пустынного (пески) и бездушного базарного локусов 90 и кончается одухотворенно-акватическим образом лона-мировместилипа (яма в волосах, өолка), символизирующего смерть-жизнь (амбивалентность последнеи строфы) .

С мифологическон точки зрения такая трансформашия и такое отождествление с пространством - закономерность. По словам Фреяденберг, "[...] мировоззрение земледельческого периода создало образ земли в виде родящея женщины, в виде матери, дающеи жизнь и людям, и животным, и растительности. Первоначально это божество земли представлялось и божеством местности, так как обоготворялся и тот участок земли, на котором проживала данная общественная группа, занимавшаяся его обработкон. Бохество местности позднее становится божеством всякого поселения, в частности с развитием производства, и бохеством города; поэтому в древних языках, в том числе и евреиском и греческом, город - женского рода. Это женское божество плодородия, мать-земля, имеет своего супруга, бога небесного, которы оплодотворяет ее светом и влагоя. Боги неба и земли ехегодно справляют своя свяшенның брак; временны холод, засуха или неурожая представляются древним земледельцам временным расхождением мехду женоя и мужем, землёя и небом, но С наступлением тепла и посева супруги мирятся, справляют снова свон брак и производят новое потомство людея, животньх и растения. Этот бог неба, позднее перешедшия в яхве, у пророка исаии говорит Сиону, что она не будет больше называться Покинутоя, но Возлюбленноя, а ее (Сиона) земля - 'замухнен', потому что господь любит ее и она сочетается браком; как жених радуется о невесте, так бог будет радоваться о нея, о Сионе" 91 .

На этоя основе строятся ритуалы торжественных въездов в город (божеств, затем царен, властителея и т.п.), где совершается свяшенны половоя акт С ожидающен там невестоя-божеством данного города 92 . Причём и въезд и бракосочетание рассматриваются в категориях спасения: "[...] на языке земледельческоя обраэности спасителем представлялся конкретны спаситель от смерти, податель жизни, новых рохдения - другимн словамн, оплодотворитель. 
Баудиссин давно уже показал, что культ богов-спаснтелея принадлежал к культам плодородия и что самы акт рождения, подачи жизнея, избавления от смерти, самы акт жизни передавался на религиозном языке термином 'спасения'. В свою очередь, и я пришта в другои своен работе К тому, что образ спасения неразрывно связан с образом плодородия, в особенности производительного акта; спасители боги брачные и земледельческиен 93 .

Согласно расследованию и доказательствам Фреяденберг, эти же смыслы сохранились и в евангельских описаниях въезда Иисуса в иерусалим, и, более того, - даже в средневековых христианских эит ургиях, ФФормлявшихся, конечно, пародияно, С воспроизведением сцены бракосочетания включительно, обычно обозначаемого въездом в церковь блуднищы на осле:" [...] здесь, в христианском обряде, эта женщина долкна быть блудницея, потому что в этом и заключается [...] культовая идея 'спасения' как плодородия. И потому литургия заканчивается повальньм распутством, то есть позднейей формоя, В которую вылился акт обрядного соединения полов" 94.

Вернемся теперь к пространственньм характеристикам магдалика в начале этого параграфа. Полномерным пространством-вместилищем Я становится после приятия ТЫ "на себя", то есть после перевоплощения в некую ткань, которое, в свою очередь, предваряется признаками пустынного и домашнего локусов. Иначе говоря, эти локусы могут чтаться как соответствия евангельского пути Христа до въезда в Иерусалим:искушения в пустыне, миропомазания в Вифании и самого въезда 95 , в описании которого говорится также и об одеждах расстилаемых перед ним: "Привели ослицу и молодого осла и положили на них одежды свои, и Он сел поверх их. Множество же народа постилали свои одехды по дороге, а другие резали ветви с дерев и постилали по дороге" 96.

Цветаевская метаморфоза я в ткано может иметь, таким образом, два смюла: с отсылкон к евангельскому тексту и с "подкожноя" отсылкой к мифологическому въезду в город, оплодотворяющему въездуспасению 97 . Причём спасение следует тут понимать как спасение мира, как восстановление его возродхаюших сил, а не как спасение кого-нибудь из персонажен 98 .

И именно этот мнфологическин контекст, вероятнее всего ощущаемы Цветаево интуитивно, и объясняет как эротическия план 
евангельскоя истории Магдалика, так и токируютую на первых порах эволюшию блуднищы в космогоническое мировместилище (см. 4.1.).

4.3. В свете привлекаемого тут мифологического сккета эначительно четче прорисовываются и сущности обоих персонахея Магдалики.

В стихе 23 подразумеваемая Магдалина именуется Тварох с кудрями огмекмими. Эта характеристика весьма естественно читается как указание на греховную эротику, с одноя стороны, и на связь с демоническим началом, С другоя, особенно если эпитет ог кеккие рассматривать как обозначение цвета волос (популярно "рыкего") и учитывать его распространенную символику (что мы и делали в первом толкования - см. 1.7. и примечание 39).

Однако ни закрепившаяся за "рькимн" волосами символика не первична, ни выбор Цветаевоя варианта огмемкие вместо более цветоопределяюших не так уж и однозначен, тем более, что ему

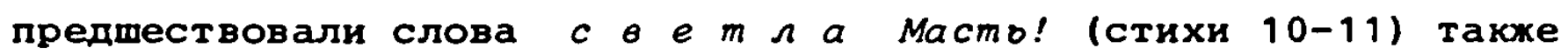
не исключакщие цветообозначения. Этот ход цветаевоя открыто акцентирует связв со светом и огнем.

Аналогичным образом выражается связь с огнем и в случае неназванного Ты (стихи 1-2), причём ветхозаветның контекст позволяет видеть Ты как некую сущность, пребывающую в сакральном огненном локусе (см. 1.1.2.).

По признаку связи с огненньм началом Я и ТЫ представляются поэтому скорее равно- чем разносущностны. По этому признаку Ты и Я были бы всего лишь мухским и женским соответствиямя одного и того же (тогда отнядь не случаяно текст открывается объединяюшим местоимением Мех н $а$ м $u$ ) со взаимноя предназначенностью друг для друга (ср. смжл Цветаевскоя "рифмы" как Фундамента всего сущего - см. примечание 11).

Вскрывая наиболее древние пласты ритуального въезда на оле в город Фреяденберг привлекает мехду прочим и египетския культ Тифона: "[...] в нём [в Тифоне - Е.Ф.] олицетворялись самые темные и разрушительные силы природы, и этот Тифон представлялся губителем и зльм врагом своего брата Озириса, бога светлого и благостного. Этот Тифон имел свое культовое соответствие в осле; [...] осел - то бохество темных и разрушаюих сил, которое у египтян носило имя Тифона" 99 . Несколько ниже исследовательница, ссылаясь на Плутарха, говорит: "[...] в 
культе Тифона люди и животные с огненным цветом волос (то есть рькие, по-нашему) уподоблялись и ослу, и этому богу; огненны цвет считался цветом Тифона. Мы знаем и из других культов, у других народов, что рьхия, или огненның, цвет волос почитался в связи С огненньми божествами (каковы Арес, Гефест, Марс и т.д.) и что стихия огня, разрушительная стихия, явилась стаднальньм эквивалентом солнечного пламени, солнца в его зените, одинаково светящего и губящего. Таков у греков Арес, грозное световое бокество вояны, но позднее и бог плодородия. [...] и у осла в том же Египте сохранена его солнечная природа [...]"100

Впоследствия это божество и его вариант божество-осёл становлтся "из божества солнца-неба божеством производительньх сил"101 и теснеишм образом связываются С оплодотворением-спасением, С акватическон стихиен, С утробон и, наконец, со священньм ритуальньм блудодеянием 102.

У Цветаевоя, в частности в Магдалияе промехуточные звенья, естественно, отсутствуют - сохраняется лишь единение двух огненных сущностен, равных друг другу, но с противоположными знаками, и сохраняются условия такого единения и их смысловая нагрузка (ср. примечания 97 и 98). Тем не менее именно знание промехуточньх звеньев проливает свет на закономерность эволюции блудницы в сторону лона-мировместилища. Явственнее проступает теперь также и семантика, казалось бы - необъяснимои и "сочиненноя", эволюция в триптихе от истребительнон "всепоядағен" огненнои стихия (Кар десяти костров; кудри огкеккие) до перевоплопения в возрождающую стихию акватическую (Жар десяти костров; кудри огкенкие - финальное омила Как волна).

Более того: именно теперь открывается некая возможность "расшифровать" глубинның сюкет Магдалики, которы не только не упраздняет более поверхностного евангелького и не только не противоречит ему, а наоборот - составляет его первооснову.

4.4. Этот сюкет - брачное соединение-спасение двух равносущностньх огненньх божеств (персонажен), но с противополохнымн знаками 'небесного' и 'земного', 'созидательного' и 'разрушительного', 'бессмертного' и 'смертного'. Разъединенные, они - только 'бессмертие', 'жизнь' и только 'смерть', 'небытие'. Объединенные же создают бесконечную цепь 'умирания-воскресания', становятся нерасторжимым 'жизнепорождающим началом', полноценным Мировым 
Лоном.

С обеих сторон, однако, требуется жертва. С однои - приятие смерти, приобщение к земному. Таков здесь ты: постепенно облекаюпияся в земно образ, в акватическое тело я. Так объясняется

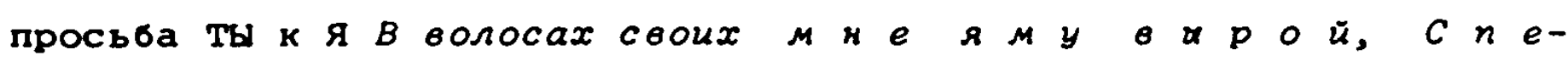
$\Lambda e x$ а й мекя без лока (47-48), а ранее - ЕГо Благостний [...] зрак-лик (30) ${ }^{103}$. С другоя, от магдалины или Я, осуществляется иная жертва: мена сущности. Я сначала подвержена 'размену', 'растрате', греховному блуду (см. примечание 90), затем претерпевает полноценную мену сущности, преврашается в жертву-дар (ср. одинаковую эксгаустивность Нсструекия и Нздаривания (стихи 28 и 32) ${ }^{104}$, становится нетелеснон пневмо-акватическои струея и вместилищем для ТЫ, обретая способность производить хизнь - поглощая сохдать-воскресатв 105 .

Открывающие гекст эаповеди: Жар десяти костров читаются теперь не столько как нечто тотально разъединяющее, сколько как указание на изначальную предназначенность я и ТЫ друг для друга и как условие выполнения их взаямнои миссия, то есть как требование ж $е$ р в ы: воссоединение возможно лишь после ее осушествления, В ином инобытия Я и ТЫ. Недаром ТЫ локалиэуется в библеиском локусе грозного всепседающего огня (см. 1.2.4.), а я наделяется чертами поглощаюея сущности. В первом случае проглядывает требование жертвы огня от Я, во втором - требование жертвы земля от Ты. Жертва огня обеспечивает бессмертие, идеальное бытие. Жертва земли, в свою очередь, ведет в смерть, небытие 106. Взаимная жертва образует единство В Форме воскресения, потенции жизни. Само собо разумеется, что дейтвенность этой взанмнон жертвы не возможна без эротического акта-спасения в его высшем священном смысле.

Данное сюкетное ядро позволяет продвинуться и по отношению к еще не до конца расшифрованному парадоксу в стихах 3-4:

Родная кровь отшатывает,

ты мне - чухая кровь.,

которы теперь звучит ешё удивительнееввиду р а в н $о$ с у щн $О$ С $\mathbf{x}$ и

Родкая хрово в отношениях мехду Я и Ты внесла бы признак родства типа "сестра - брат" или "отец - дочь". Оба варианта ис- 
ключают возможность эротического акта (см. 1.2.4. и примечание 12), а этим самым идеи спасения и идеи воскресения, а в иных терминах - идеи плодородия (см. примечание 87). Жертва огня, естественно, возмохна и в данном случае. Но она ведет к совершенно иному сюкету: самосожскения и этим самым обохествления 107 , то есть переходу в идеальное бессмертное бытие, а в иньх вариантах - воссоединению с Богом 108 .

Чухая крово, наоборот, создает неродственные отнотения и этим самым открывает возмохность эротического акта-спасения. Но тогда требует жертвы земли от партнера: я для него губительно в одном плане и спасительно-воскресаюие - в другом. 109

"мечта" Я о времеках евангельских (стих 5) оказывается меч-

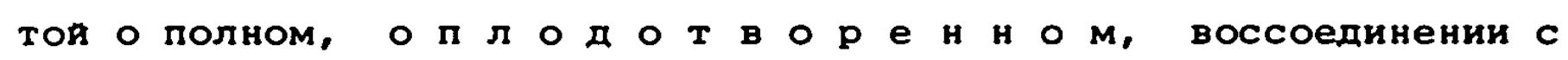
ТЫ: евангельская "Благая Весть" и есть Божественное Оплодотворение. Но от Бога оно требует жертвы крови: воплощения в земном облике и смерти.

Теперь, думается, нашли свои места и некоторые лругие "темнье" детали Магдалияи: настончивое упомннание крови вместо ветхозаветноя плоти (см. 1.2.4.), чухдости, рифма костров крово с признаком редуцированности дистанции мех Я и Ты (см. 1. 2.5. и примечания 15 и 16), а также - исходная ситуашия я-Ты: нет сомнения, что здесь ма имеем дело с разновидностью мистическоя медитации (см. 1.3.6., в частности пункт 6), а далее - мистического перевоплощения и обожествления, Божественной Оплодотворенности. И это с одинаковьм успехом может толковаться как в теологических терминах (см. 3.4.4. и примечание 76), так и в термннах язнческои мифологин.

Само собои разумеется, что отмеченные совпадения с теологическими положениями или с мифологическими представлениямн еще никак не характеризуют поэтическую систему цветаевоя. Кроме одного: того, что эта система в высшеи степени родственна этим представлениям. Это значит, что одно и другое должно рассматриваться именно с точки зрения поэтическоя системы Цветаевоя, так как именно от нее, от ее свонств, зависит и выбор объекта высказывания (тут магдалина и Христос), и артикуляция этого объекта (кстати, лексика триптиха гораздо менее теологична или мнфологична, чем возникаюшие в нем системы смылов). Конечно, соблаз- 
нительно было бы увидеть Магдалияу в полном освещения ухе теперь, но это невозможно без более упорядченно, чем в настояших примечаниях, картины Цветаевского кода. Желательную картину мы попытаемся наметить в другоя работе и тогда еде раз вернемся к некоторым сушественньм свояствам данного триптиха.

Вартава, июнь 1982- январь 1983.

Эта статья является основательно переработанным вариантом локлада, которы должен был быть прочитан на "COLLOQUE MARINA TSVETAEVA. LAUSANNE 30.VI. - 3.VII.1982".

1. Три стихотворения, объединеннье общим заглавием Магдалима, возникли почти одновременно (первое Мех ками... написано 26-го августа 1923 года, а остальньх два - масти, плочекмие втрое... и О путяx mвоих питато ке буду... - всего лишь через несколько днея: они помечены датон 31-го августа) и как бы на одном дыхании - если не в тохдественном, то во всяком случае в краяне узком лексическом диапазоне. Иначе говоря, все эти Факты - и творческая настроенность, и артикуляционная установка, и, наконец, внешнее композиционное оформление - свидетельство тому, что это одно нечленимое е д и н С т в О. И тем не менее каждая иэ частея этого триптиха обладает высокои степенью законченности и может считаться (особенно с внешнен читательскоя - точки зрения) полностью самостоятельным проиэведением. Однако, если закпнченность последнего стихотворения O путяx mвоиx пumamo ке будy... из-за его финальнон позиции в цикле самоочевндна, то по отношению $к$ первому и ко второму возникает справедливое сомнение. Деиствительно, может ли считаться удовлетворительноя его законченность, если Цветаева буквально через пять днеи находит нужным, так сказать, дописать продолхение?

Без предварительного разбора всего триптиха ответить на этот вопрос нельзя, но уже теперь позволительно выдвинуть предположение, что оставаясь единичньм текстамн они, т.е. мех нами... и масти, плочеккие втрое..., не удовлетворяли бы каким-то серьезньм требованиям поэтики Цветаевон.

Текст Магдалики цит. по изданию: Марина цВетАЕвА, После Poсcuи. 1922-1925. [Парих 1928] YMCA-PRESS, Paris 1976, c.112114. В дальнеишем ссыли на это издание даются сокрашенно: ПР С указанием страницы. Сокращение же иП отсылает к: Марина ЦВЕТАЕВА, Нзбраккие произведекия. Москва-Ленинград 1965.

2. В случае перевода этих местонмения в третье лицо (например: меж ними, он ея) воэник бы эФфект некотороя общности говорящего субъекта с читателем, а речь получила бы обрапенность и преднаэначенность для читателя. 
3. Кроме того выключенность из внешне аудитории повышает для этон аудитории и степень неопределенности текста: по тексту данной строфы никак нельзя, например, определить, ни кто таков я, ни кто таков его партнер - ты.

4. Ср. Исход, гл. 20; Второзакокие, гл. 5; Левит, гл. 18 и 20.

5. Нсход, гл. 19: 20-21; гл. 20: 18-19; Второзаконие, гл. 4: 11-12 и $36 ;$; г. 5: 4-5 и 22-26; гл. $9: 15 ;$ г г. $10: 4$.

6. Нсход, гл. 19: 21-24; Второзакокие, гл. 5: 25-26.

7. Нсxод, гл. 19: 21-24.

8. Второзакокие, гл. 6: 15; гл. 7:4; гл. 9: 3.

9. Левит, гл. 20: 14; гл. 21: 9 .

10. Попутно небеэннтереско отметить одну особеннссть употребленного здесь двоеточия. Согласно последоватепьности речи оно эаставляет видеть костер как имплицитне свояство заповеди (см.1.1.1.). С исследовательскоя же точки зрения ясно, что цветаева мыслит заповедо значительно шире, чем только формулу запрета, - включительно с наказанием, предполагаемвм эаповедью в случае ее нарушения, т.е. все целиком - и причину и следствие как неразъемлемое единство, как своеобразнын перформатив. Ср. также на блюдения в статье: О.Г. РЕВзинА, "Знаки препинания в поэтическом языке: двоеточие в поэзии М. Цветаевон". - Marina Cvetaeva. Studien und Materialien. "Wiener Slawistischer Almanach", Sonderband 3, wien 1981, S. 67-85.

11. Тут по всеи вероятности имеет место глубинная "цветаевская рифма", подразумевающая взаимную согласованность и исконную предназначенность друг другу явления мира. Ср. в стихотворении Eсто рифма в мире сем...(30-го июня 1924) из цикла Двое: Eсто рифмх в мире сем: // Разәедикишо - и дрогкет; Да, хаосу вразрез // Построен ка созвучоях // мир, и, разәединек, // Mстит (на согласоях строен!); Eсто рифма - в мире том // Подобраяние. Рухнет // Сей - разведешо. (Пр, 128). А в данном тексте такоя рифмоя является пара "Елена - Ахиллес".

12. См. Левит, гл. 18 и 20.

13. Ср. хотя бы следуюшие ближаяшне по времени контексты. Сестра (11 мая 1923; ПР, 89) :

Мало ада и мало рая:

За тебя уже умирают.

вслед за братом, увы, в костер -

Раэве принято? Не сестер

Это место, а страсти рдяноя!

Разве принято под курганом...

С братом?...

- "Был мов и есть! Пусть сгнил!"

- Это местничество могил ! ! !

Браm (13 июля 1923; ПР, 101):

Брат без других сестер:

на-прочь присвоенның!

По гробово к костёр -

Брат, но с условием: 
Вместе и в рая и в ад!

Раноя - как розаном

Соупиваться!

Ахилл на өалу (13 сентября 1923; ПР, 118):

Отлило - обдало - накатило -

- Вавзничь! - Умру.

так Поликсена, узрев Ахилла

там, на валу -

В красном - кровавая башня в плёсе

тел, что простер.

так Поликсена, всплеснувши: "Кто̀ сея?"

(знала - костер!)

Соединенное чародеяство

Страха, любви.

14. Ср. хотя бы Но тесна өдвоем... (8-го августа 1922; ПР, 29):

Берегись могил

Голоднеम блудниц!

Мертвын был и сгнил:

Берегись гробниц!

[...]

Дахе самы прах

Подари ветрам!

Любль - но мука ещё хива... (24-го октября 1923; ПР, 127):

Дождь в крьшу бьет: чтобы мне на лоб,

Ва гроб стекал, [...]

[...] Сквоэь скважины, говорят,

Вода просачивается. В ряд

Лежат, не жалуются, а ждут

Незнаемого. (Меня - сожгут).

Финальные строки Сестра (цит. В примечании 13); написанныя в в начале 1935 года цикл Надаробие и др.

Противопоставление "сожжение - бытовое захороненне" лишь вариант более универсальноя цветаевскоя оппозиции "целостның, нечленимд - частичның, членимы" .

По отнотению к человеку первоя означает единство духовного и материального (чувственного) начал. Уити из бытового состояния мира, "из мира сего" - уити без остатка (ср. в Прокрастося... - 14 мая 1923; ПР, 90: ке оставито слеda; не оставито тени: Распастося, не оставив праха // На урну... и попасть в мир "тот", адекватның целостнои личности, т.е. такке нечленимын и "не лоскутны", где все взаимосвязано, созвучно друг другу, изначально "рифмовано" (в отличие от механических сходств, "тирахноя" штампованнои безликости; ср. прнмечание 11). Ср. кроме того стихотворение напрасно глазом - как гвоздем... (5-7 января 1935; иП, 311) и его анализ в: Юрия М. ЛОТмАВ, Акализ позтического текста. Cтруктура стиха. Ленинград 1972 , с. 235-247.

Второе - характеризует у цветаево косное, категорическн отвергаемое и презираемое состояние мира или его же ложное и неприемлемое для Цветаевон понимание, видение (частнын вариант - раскол на "прах" и "душу"). 
Более того. Первому члену этоя оппозиции соответствует полная растворимость, рассеянность в мировом потоке, с сохранением особоя творческоя, не механическоя динамики (мехду прочим, способности к метаморфозам и воскресаниям; отсюда полёm, ветер, волна и т.п.). Второму же соответствует обездвиженное состояние (между прочим, модгробие, памятник, труп и т.д.), механическое распадение, измельчание вплоть до "ничто", разложение (м. пр. гниение, прах, мелочи и т.п.). Ср. выше Дахе самий прах // Подари ветрам; стихотворение Минута (12 августа 1923; Пр, 109-110) или Кто создан из глина... (1920; иП, 162) и его разбор в моен статье: "Из заметок по поэтике цветаевон. - Marina Cvetaeva. Studien und Materialien. "Wiener Slawistischer Almanach", Sonderband 3, Wien 1981 , S. 29-47.

15. А вот некоторые, наиболее эксплицитные, контексты: Голос сираx и малих... (26-го сентября 1922; ПР, 41):

Крик, что кровью окрашен:

там, где пюбят и бъют...

орфей (1 декабря 1921; иП, 187):

Не лира ль истекает кровью?

Вскрила хила: неостановимо... (6 января 1934; иП, 342):

Вскрыла жилы: неостановимо,

невосстановимо хлещет жизнь.

$[\ldots]$

Невозвратно, неостановимо,

Невосстановимо хлещет стих.

Ночо (12 мая 1923; ПР, 89):

час обнахаюихся верховия,

Час когда в души глядишь - как в очи.

Это - разверзтые шлюзы крови!

Это - разверзтые шлюзы ночи!

Лютая юдоль... (12-го июня 1922; ПР, 8):

Лютая юдоль,

Дольняя любовь.

Руки: свет и соль.

Губы: смоль и кровь.

Не чернокнихнииа! В белой книге... Из цикла Проводи (25-го марта 1923; ПР, 69):

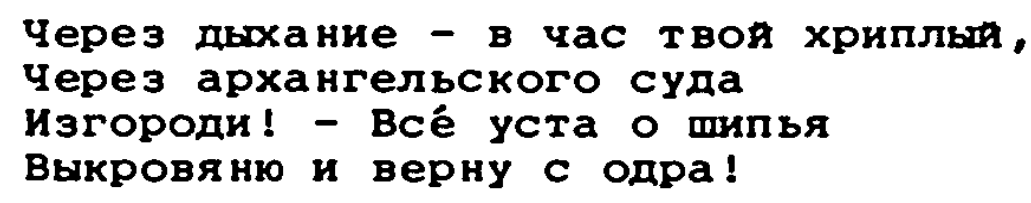

Сдаяся! Ведь это совсем не сказка!

- Сдаяся! - Стрела, описавшн круг...

- Сдаяся! - Emе ни один не спасся

От настигающего без рук:

через дыхание... (Перси взмии,

Веки не видят, вкруг уст - слюда...)

Ахилл ма өалу (13-го сентября 1923: ПР, 118): см. выдержку в примечании 13 и ее продолкение 
Так Поликсена, узрев ахеяца

Ахнула - и -

Знаете этот олив атлантския

Крови от mек?

Неодолиман - прострнсь, пространство! -

Крови толчек.

16. Ср., например: Сиөилла - младениу (17-го мая 1922; ПР, 26-27):

Плачь, маленькия, и впредь, и вновь:

Рохдение - паденье в кровь,

и в прах,

и в час...

[...]

Плачь, маленькия: рожденье в счет,

и в кровь,

И В пот...

Но встанешь! То, что в мире смертьо

Названо - паденье в твердь.

Бо2 (1-го октября 1922; ПР, 45-46):

Лицо без обличня.

Строгость. - Прелесть.

[...]

Победа над ржавчннон -

Кровью - сталью.

Все́ навзничь лехавшие

В тебе встали.

Нет, правди ке оспаривай... (8-го февраля 1923; Пр, 50-51):

Девичия и мальчишеския:

на самом рубеже.

Единственны из тысячи -

и сорваннын уже.

В самбм истоке съуженныя:

Растворены вотще

Сто и одна жемчужина

В голосовом луче.

Я в голосах мальчишеских

Знаток... - и в прах и в кровь

Снопом лучея рассыпавшись

О гробовоя покров.

Люткя (14 февраля 1923; ПР,56):

Горе! Как рыбарь какоя стою

Перед пустон жемчужницею.

Это же оловом соловью

Глотку залить... да хуже еше:

[....]

Это - но хуже, чем в кровь и в прах:

Это - сорваться с голоса!

Поэма застава (23-го апреля 1923; ПР, 75): 
День без числа.

Bepóa sачахла.

Жизнь без чехла:

Кровью запахло!

Последмий моряк (15-го сентября 1923; ПР, 119):

Ломала руки, а рядом драк

Удары и клятв канаты.

(Спал разонравившияся моряк

и капала кровь на мя-

ту ио наволоку...)

А потом, вверх дном

Стакан, хрусталем и кровью

Смеясь... - и путала кровь с вином,

и путала смерть с любовью.

Как видно по всем этим выдерхкам (такхе в примечании 15), крово употребляется у Цветаевоя в довотьн отичаншхся друг от друта значениях, и подвести к ним некия общи знаменатель вряд ли возмохно. Так, одно из значения, несомненно, созвучно библеяскому толкованию крови как носителя души: "душа тела в крови", "душа всякого тела есть кровь его" (Леөит, гл. 17: 11 и 14). но оно ослохнено признакамн 'неоформленного, свободного' состояния души и 'Оформленного, связанного', поэтому кров ч часто у Цветаевон "амбивалентна", играет роль черты мехду земньм и внеземным бытием. Кровонзлияния (типа "разверстые шлюзы крови", "Вскрыла жилы" и т.П.) открывакот выход-вход в "мир тот", в сплотноя мировон поток душ, гарантирует полное с ним единство вплоть до растворимости в нем. И наоборот, переход душі в мир "сен" (ср. Сиөилла - младекиу) есть "паденье в кровь" т.е. обретенье обособленного бытия и всех следствия, вытекающих из такон обособленности (прах, час, вес, cyem, пот), принципиально неприемлемьх в аксиологическо системе Цветаево (ср. примечание 14 и 11). Учитывая это значение, в стихах 3-4 и 7-8 позволительно усматривать оба аспекта крови: и аспект роковоя обособленности, и аспект роковоя необходнмости раствориться без остатка, что еще прочнее связывает крово с кострами (ср. 1.2.6).

Крово Цветаевоя ослохнена и другой еще двонственностью, на этот раз созвучнои античному (Аристотелевскому) толкованию со всеми его позднеишими переосмыслениями. Как говорит Мурьянов, "по Аристотелю, в крови рождается семя, несушее в себе плотское желание и дух - субстанцию, аналогичную веществу звезд. На основе выработанного греками смыслового ряда

$$
\text { Кровь - семя (=жизненная сила) - душа - огонь }
$$

могли строиться разнообразные сцепления художественных иден; осознание художниками логических связея и историн понятия было, конечно, необязательным" М. Ф. МУРьянов, Вопроса интерпретация антологическоя лирики (Стихотворение Пушкина "В крови горит огонь желанья"). - Амализ литературкого произведения. Ленинград 1976, с. 197; здесь же и ссылки на следующие работы:

L.DEWAR, "The biblical use of the term "blood". - Journal of Theological Studies, vol. 4, Oxford 1953. pp. 203-208;

F.RUSCHE, Blut, Leben und Seele, Paderborn 1930; J.H. WASZ- 
INK, "Blut". - Reallexikon für Antike und Christentum, 2. Band Stuttgart 1954, S. 459-473.

17. Нсход, гл. 20: 3-5 и 14; Второзакокие, гл. 5: 7-9 и 18 .

18. Длительность словоразделов помечена здесь количеством вертикальных черт мехду обозначениями слогов: наименьшая - одна черта, наиболее долгая - три черты. Запись (В) приводится с целью показать акцентную регулярность, которую мохно толковать как указание на стабильность, "незыблемость" излагаемьх в этон строфе исходньх положения, а дальнеишне отклонения от данноя регулярности - как признак нарастаюея "эластичности".

19. Желание стать одкой из тех, т.е. такой же, как и другие, не согласуется с цветаевскоя семантикои - цветаевскому Я свояственноя стремиться быть исключительным, единственным, что в случае наличия партнера означает быть единственным соответствием ему (другим словамн - "рифмоваться" с ним). Ср. в стихотворения Ваш кехний pот - сплошкое иелованое... из цикла Комедоякт (конец ноября 1918; иП, 137):

Ваш нежны рот - сплошное целованье...

- И это всё, и я совсем как нищия.

Кто я теперь? - Единая? - нет, тьпа!

Завоеватель? - Нет, завоеванье!

где сходство с другими сопровождается не только пренебрехительньм просторечнем тища, но и переводом Я из статуса субъекта (Завоеватело?) в статус пассивного объекта (Неm, завоеөакье!). Поэтому во фразе Била 6 одкой из тех... позволительно видеть и иную, подспудную, интенцию: 'таким путем "завоевала 6" Тебя, став не любои, а тои однои-единственноя иэ тех'. Эта же оппозиция распространяется у Цветаево и на ее предметныя мир. Ср., например, Писомо (11-го августа 1923; nP, 108):

Так писем не жиут,

так ждут - письма.

Ввиду данных и многих других аналогичных случаев в общую категорию 'численности' целесообразно ввести более тонкую дифФеренциачию. Рассмотренные примеры подсказывают оппозицию не столько 'численның - единичның', сколько 'тиражның - единичны', или еще точнее 'один из, любоя - четко определенныя' или же 'инклюзивны - эксклюзивны'. Другие примеры (мехпу прочим Микута - 12 августа 1923; Пр 109-110) покоятся на оппозиции 'исчислимы, измеримы - неисчислимы, беэмерның' с разновидностью 'дробяшия, разрушительныя, дробимы, разрушаюшия - целостны, животворяпи '. Не менее редко численность играет роль такке и интенсификатора, но тогда он дополнительно помечен указаниямн полохительного или отрицательного характера. Так, дважды употребленное десято в стихах 1-2, несомненно, интенсификатор, но его легкая исчислимость активизирует скорее отрицательнын ореол заповедей и костров, чем полохнтельнын, и усугубляет разъединенность Я и ТЫ.

20. Ср. объяснения Даля: "чухоЯ, не своЯ, стороннія, собъ дру- 
гаго; незнаемя, незнакомы; не родня, не нашен семъи, не изъ нашего дома; не нашеи земли, иноземнын. [...] Чухій или чухдай, чухой. [...] я его не энаю, или онъ не родня мнь. [...] Чему чуждаются или дивятся, странныя, непонятныя, удивительны" . Владимир ДАЛЬ, Толковий словаро хивого великорусского язика, том IV. Москва 1980, С. 613 (статья "чужон").

21. Это, конечно, подсказывается как общим заглавием триптиха магдалияа, так и библеиским и теологическим контекстом, где Христос часто именуется Возлюбленньм, Мнстическо Плотью и Кровъю. Ср.: "и когда они ели, Иисус взял хлеб и благославив преломил и, раздавая ученикам, сказал: приимите, ядите: сие есть тело мое.

И, взяв чашу и благодарив, подал им и сказал: пеите из нее все;

Ибо сие есть Кровь Моя нового эавета, эа многих изливаемая во оставление грехов". Матфей, гл. 26: 26-28; ср. также Ноккк, гл. 15: 9 и след.

22. Значительно позднее, уже во втором стихогворения, Я будет названо по имени ("Магдалина"), но имя Ты абсолютно последовательно не эксплицируется до конца всего триптиха. Оно может тут только угадываться, опознаваться (кстати, не исключено, что во втором стихотворении оно также и эаанаграммнровано). "Безьмянность" ТЫ - дополнительное указание, что здесь имеется ввиду именно Христос. Дело в том, что, как правило, Цветаева демонстративно именует (называет именами) своих лирических героев, включительно с лирическим субъектом (Я), а в случаях

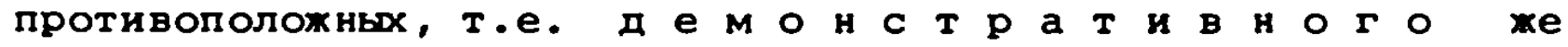
н е н а $з$ в а н и я, подразумевается Бог или уравнение С Богом. Так стронтся, например, шнкл Стихи к Блоку и, в частности открывающее его Имя төое - птииа в руке... (15 апреля 1916; иП, 92-93), героем которого есть некое нерасшифрованное имя (ср. намеренное воздержание от произнесения этого имени в стихе Нмя твое - ax, мелозя! -). Но вскоре после этого воэникшия инкл Ахматовой выводит имя поэтессы на первыр план уже в открывающем его стихотворения 10 муза плача, прехраснейшая из муз!... - 19 июня 1916; иП, 103). Заметим, однако, что если Блок изображается в сакральных христианских термннах, то Ахматова - в терминах музических (она возводится "всего лишь" в ранг Музы).

Табуирование имени несет у цветаевой более весомую нагрузку, чем элементарная сакрализашия персонаха: с одноя стороны, оно вводит уровень непостижимого, с другоЯ же - ввиду явности иньх компонентов текста и легкои угадываемости по ним сокрьтого имени - приобщает к Я читателя: как и артикулируюши субъект, так же и читатель уже не "читает", а "артикулирует" опознает, постигает. И триптих Магдалика - один из нанболее ярких примеров такого эФфекта. Более того: с даннои точки эрения Магдалика скорее икона, чем текст.

23. Нисус Навия, гл. 2: 1-11.

24. Другими словами, можно сказать, что тут имеет место "заборматывание", одно из исконных своһств Цветаевского Я. Ср. в стихотворенин Лктая рдоло... (12-го июня 1922; ПР, 8) :

Бог с замысламы! Бог с вымыслами!

Вот: жаворонком, вот : жимолост ью, Jerzy Faryno-978-3-95479-659-5 
Вот : пригоршнямн вся выплеснута

С монмн дикостямн - и тихостямн,

С монмя радугамн заплаканными,

С подкрадываньямн, забарматываньямн...

25. Лука, гл. 4: 38-39; гл. 8: 43-56; гл. 4: 40; гл. 6: 17-19; гл. 7: 3; и др.

26. Лука, гл. 4: 35; гл. 8: 27 и след.; гл. 9: 38 и след.; а также гл. 8: 2: "и некоторые женщины, которых он исцелил от зльх духов и болезнея: Мария, называемая Магдалиною, из которои выпли семь бесов, и Иоанна, [...], и Сусанна,и многие другие, которые слукили Ему имением своим" .

27. Иоанн, Гл. 12: 3 (Мария из Вифания, сестра Лазаря); Матфей, гл. 26: 7-11, Марк, гл. 14: 3 (некая безьмянная женшнна, никак не охарактерияованная); Лука, гл. 7: 37-50 (безьмянная грешница). В христианскоя литературе (особенно в апокрифическоя) сбразы этих женщин часто контаминируются и отождествляются С Марие Магдалиноя. См., например: С. С. АВЕРинцЕВ, "Мария Магдалина" (В:) Мифа мародов мира. Экииклопедия. Том 2. Москвa 1982, C. 117-118; T. J. MESCHLER, Zywot Pana Naszego Jezusa Chrystusa w rozmysianiach. Tom I. Krakbw 1913, s. 307;

[Don Paolo CRIVELLARO], Ewangelia Jezusa. Paris 1980, s. 137 [I Vangelo di Gesü. Vicenza 1977]; Apokryfy Nowego Testamentu. Pod redakcja ks. Marka Starowieyskiego. [Tom I: Ewangelie apokryficane] TN KUL Lublin 1980, s. 84-85, 135, 280,469, 170-172.

28. К метаморфозам, к смене облика, Цветаевское Я прибегает чаmе всего с целью беэраэдельно эавладеть партнером ("ты"). Ср. , например, Даба та мекя ке видел... (25-го июня 1922; ПР, 1516):

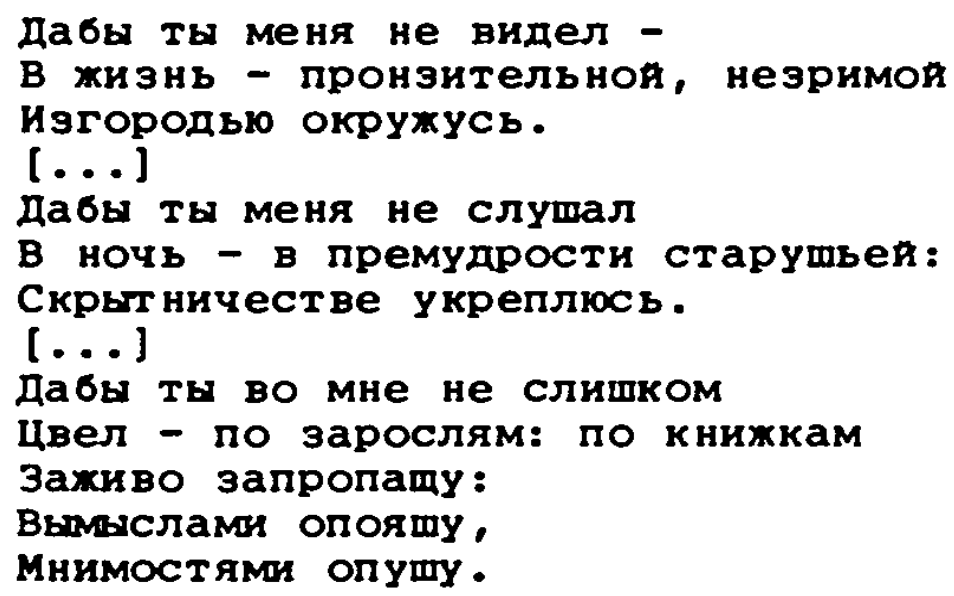

Здравствуй! Не стрела, ке камеко... (25-го июня 1922; ПР, 15):

Я сегодня в новоя пкуре:

Вызалоченноя, седьмон!

- MOA! -

Не черкоккихкииа! В белой кмиге... (25-го марта 1923; Пр 69-70)

- Сдаяся! - Eme ни один не спасся

От настигающего без рук:

[...] 
Есмь я и буду я и добуду

душу - как губы добудет уст -

Типологическая родственность слов Влекласо, стлаласо лексике процитированных метаморфоз не вызывает сомнения, а этим самым присутствие в них сокрытого умысла эавладеть ты делает еще более очевидным.

29. Ср., например, Вкрадиивостор волос... (17-го ияля 1922; Пр 21), где все три компонента однозначно соотнесены друг с другом волосы, их ивет и нечеловеческия ореол (Сияо полунощнур, масто Ворокову) и признак "мастея, масел" (B гладо и ө лоск):

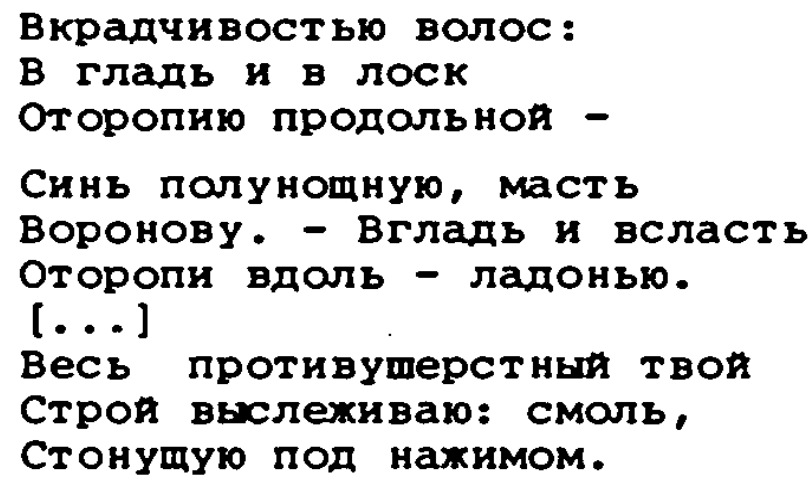

30. Лука, гл. 8: 2 .

31. Лука, гл. 9: 39; ср. еше: Марк, гл. 9: 18-27. Само собои разумеется, что перекличка с евангельским образом бесноватого здесь вторична, она надстраивается над самостоятельньм и типичньм для Цветаево образом одержимости Я неистовон страстью. Ср.. например, в Не чернокнихнииа! B белой кмиге... (25-го марта 1923; IIP, 70):

\section{- Сдаяся! - Еще ни один не спасся \\ От настигаюиего без рук:}

Через дыхание... (Перси взмыли,

Веки не видят, вкруг уст - слюда...)

Как прозорливица - Самуила

Выморочу - и вернусь одна:

Без отсылок к библенскому контексту (стихи 1, 12-14, 5-6; заглавие Магдалияа) эта картина читалась бы только как отказ (изживание) от исступленноя плотскоя страсти и - ввиду наличия в стихе 11 очесами демонскими - от бесовскон метаморфозь, а ее интенсивность - как предельнын десператизм.

32. См.: Матфей, гл. 26: 7 и Марк, гл. 14: 3 - в Вифании, в доме Симона некая женшина возливает миро иисусу на голову; Лука, гл. 7: 37-38 - некая грешница "ставши позади у ног Его и плача, начала обливать ноги Его слезами и отирать волосамн галовы своеи, и целовала ноги Его, и мазала миром."; Ноан,, гл. 12: 3 - сестра Лазаря, Мария, "взявши Фунт нардового чистого драгоценного мира, помазала ноги Иисуса и отерла волосамн своимн ноги Его; и дом наполнился благовонием от мира."

Для понимания Цветаевского текста не столь существенно отыскать наиболее адекватное место в Евакгелиях (тогда имелась бы в виду только сцена из Ноамка, а мария Магдалина отождеств- 
лялась бы с собирательноя евангельскоя ситуащнея. В этом случае может быть значимо как расторжение единого акта на два отдельньх (поливание ног масламн - стихи 12-14 - и окутывание ног лишь в стихах 19-20; такхе неодинаковая модальность этих двух актов), так и "пропуски" - упомннание только ног, отсутствие упомннания головы ты и отсутствие упомннани о слезах $Я$. Но об этом позже (см. 1.6.1., 1.6.2., примечания $41,48,59,72)$.

33. В Евакгелиях поливание Иисуса масламн объясняется Им же как приготовление Его к погребению (См. Матфей, гл. 26: 12; Марк, гл. 14: 8; Ноакк, гл. 12: 7). В случае прочтения стихов 11-14 как превратного соблазнительного акта Я евангельския смысл не аннулируется, но модифицируется и совпадает с устоячивым Цветаевским смыслом завладевания Цветаевским Я партнером как захоронения в себе, в Я, уподобленном растворяюшея стихии (а иногда и смерти, конечно, в особом цветаевском варианте). См. некоторые выдержки в примечаниях $24,28,31$ или хотя бы следуюшие строки из стихотворения Расщелика 117-го ионя 1923; ПР 94-95):

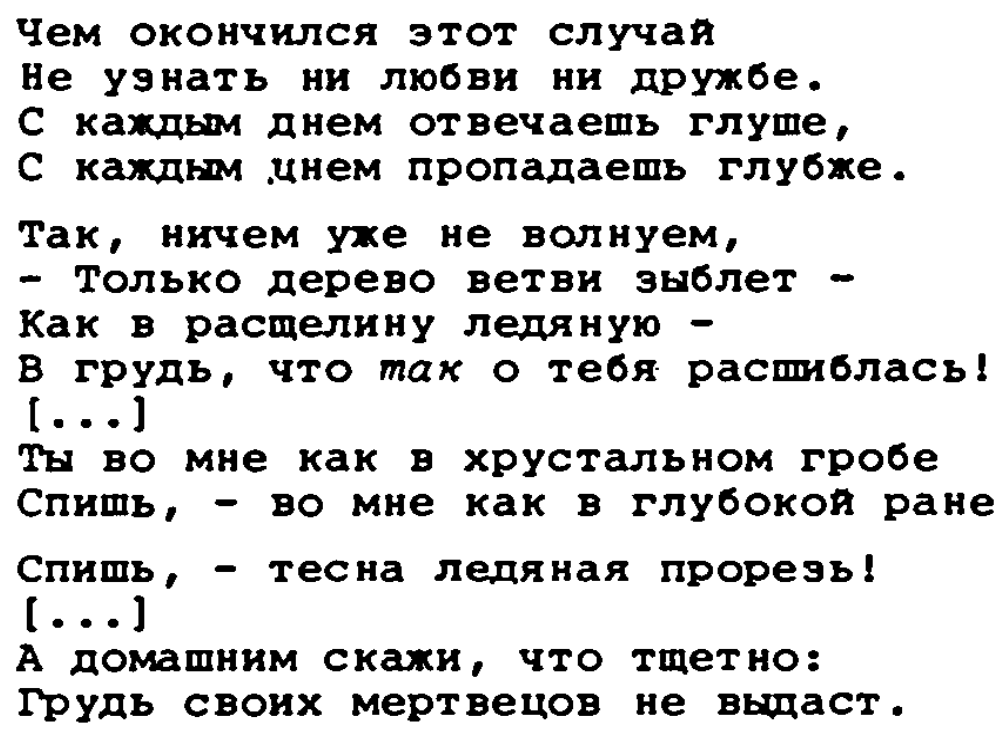

34. Взаимосвязанность волос и меха и даже их эквивалентность, но С внутреннея градациея 'человеческое - звериное', эксплицитно вырахена, например, в Сегодкя кочор $я$ одна в кочи́... (1 августа 1916; иП, 89) из цикла Бессонкииа:

$$
\begin{aligned}
& \text { Вздьмаются не волосы - а мех, } \\
& \text { и душныя ветер прямо в душу дует. }
\end{aligned}
$$

Тут мех - не последняя ступень градации и эволюции я: дальше слепует раковика и финальное растворение в мировом потоке. Об этом см. мою статью: "'Бессонница' Марины цветаевоя (Опыт аналиэа цикла)" - Зборкик за Славистику. т. 15, Нови Сад 1978, с. 131 и след. Казалось бы, что в Магдалике Я эволюционирует в обратном направлении, но это не совсем так: как выяснится позже, со 'звериного' здесь снимается только причастность $к$ 'бесовскому' (см. 4.1. - 4.4.).

35. Ср. аналогичное осмысление меха в По загарам - monор и плуг... (24 июня 1922; ПР, 14) : 


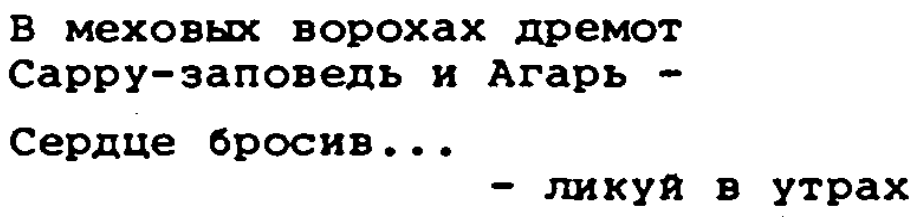

Вечнов мужественности взмах!

36. Смысловая нагрузка ткаки здесь,по всея вероятности, значительно сложнее. Во-первьх, это едва ли не первая деталь (если пренебречь песками в стихе 14. которые могут ассоциироваться С Пустынея - библеяским лоскутом интимно встречи С БоГом и испытания или искушения,.как в случае сорокодневного пребывания в пустыне Христа; см.: Лука, гл. 4: 1-14; Матфей, гл. 4: 1-11; марк, гл. 1: 12-14) вводящая признак пространственности. Из этого вытекает, что в это метаморфозе угадывается стремление $я$ подменить собон все пространство или стать пространством, "всместилищем" для ТЫ. Это тем более вероятно, что Цветаева относительно часто обоначает пространство "техстильньмн" терминамн. Ср. хотя бы в Броху - не дом хе плотничато... (16 октября 1923; ПР, 126):

Брожу - не дом же плотничать,

Расположась на росстани!

так, вопреки полотнищам

Пространств, треклятьм простыням

Разлук [...]

Причем и само Я не редко становится тканью. Ср. в Занавесе (23 июня 1923; ПР, 97-98):

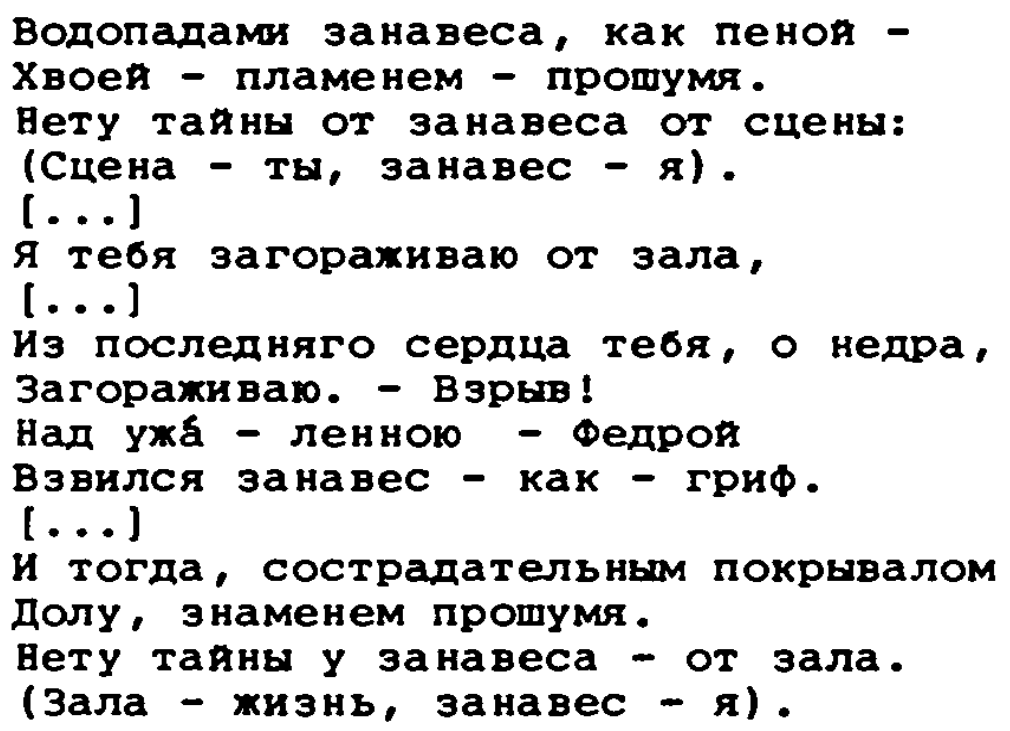

Физическое пространство и расстояние расцениваются в системе Цветаево как помехи. Поэтому если ткано и вводит пространственның аспект, то, несомненно, в нематериальном, в непротяхенном плане.

Во-вторых, контекст только что процитированного Занавеса делает более ощутимым 'оградительныя, защитның' смысл акта тканою под ноги Стелюсо (см. прияечание 37 ).

В-третьих, нельзя исключить и присутствия здесь, так сказать "иконописного" смысла ткаки. Клубяшиеся одежды и развевающиеся велумы на иконах были призваны передавать ветер, "которыя в средневековоя поэтике Фигурировал как знак прибликения 
божества, как зримое воплощение духа бохьего". И.Е. ДАниЛОВА, "О византияскон иконе XVI века "Благовемение" из ГМиИ им. А.С. Пушкнна. (Опьт интерпретация)" - Античносто - Средкие века - Новое время. Проблема искусства. Москва 1977, с. 42. Кстати, аналогичны смысл есть и у Цветаевон в стихотворении Бито малочиком твоим светлоголовим... из цикла Учекик (15 апреля 1921; иП, 169), но в характерном для нее повороте "улавливания в себя" :

Быть мальчиком твонм светлоголовым -

0 , через все века! -

За пыльны пурпуром твонм брести в суровом

плаще ученика.

Улапливать сквоэь всю людскую гущу

Твоя вздох животворящ -

душоя, дьханием твонм живутея,

Как дуновеньем - плащ.

[...]

От всех обид, от всея земноя обиды

Слукить тебе плащом.

Бьть мехду спяшими учениками

Тем, кто во сне - не спит.

При первом чернью занесенном камне

уже не плаш - а шит!

37. По обычаям Иудеи евангельских времен омовение ног входило в обязанности рабов. Поэтому исполнение этого церемониала блудницея (Лука, гл. 7: 36-50) рассматривается в теологическоя литературе как акт глубокого покаяния и смнрения. Кстати, аналогично поступает и Иисус пред Последнея Вечерея, давая этим пример своим ученикам смирения и любви к ближнему (см. Ноамк, гл. 13: 4-17). С случае блудницы глубнна покаяния подчеркивается дополнительно вытиранием ног волосами: покаэываться женшне на людях с распущеннымя волосами считалось у Иудеев наивысшия позором и унижением (сM. T.J.MESCHLER, Op. c1t., p. 305).

Смысл обряда омовения ног перед трапезоя раскрыт у Иоанна (гл. 13: 8-10): "Петр говорит Ему: не умоешь ног моих вовек. иисус отвечал ему: если не умою тебя, не имеешь части со Мною. Симон Петр Говорит Ему: Господи! не только ноги мои, но и руки и голову. Иисус Говорит ему: омытому нужно только ноги умыть, потому что чист весь". На высшем уровне это значит приобщение к Христу. На более элементарном - очищение от праха земного. У Цветаевон, несомненно, присутствуют оба значения, но пока более эксплиинтно второе: в словах Некою ткакою под моги Стельсо... прочитывается стремление защитить, оградить от "нечистого", от грешного праха земного (такова, кстати, Функция ковров в древних храмах).

Приведенные слова из Ноанка проливают свет и на Факт, что ты представлен в разбираемом стихотворения однои только деталью - ногами: он "чист весь", и только ноги отягчены соприкосновением с "нечистьм" . Я же, представленная волосами, должна рассматриваться в этом контексте как охваченная грехом вся целиком и как вся и целиком раскаивающаяся (Тут существенную роль играет символика волос, но об этом позже, так как 
пока она еще не раскрывается; см. 3.4.4. и 4.3.).

38. Слово төаро не однозначно. Его можно читать как ругательство, как соответствие презрительному "скотина", "безобраэина" . тогда на первыя план (особенно в сочетании с кудрями 02 $r e r k$ a $\mu$ ) выдвинется аспект 'звериного' и 'бесовкого' . Если его читать как неитральное, со значением "творенья Божья", то тогда возможны два иньх смысла: в сочетании С кудрями возникает возможность смысла 'дерзкой гордыни' ' 'дерзкого своеволия" (ср. в Кто создан из камкя, кто создак из глика... - 23 мая 1920; иП, 162: Мекя - өидишо кудри беспуmмае эти? - Земкою ие сделаешо солою; и его разбор в моен статье Нз заметок по позтике Цветаевой, ук. соч.); а в сочетании с (кудрями) огкемками - смил демонического супества, некогда изгнанного дерзкого ангела и обреченного на вечное горение в огне (кстати, не этот смысл ли имеется ввиду в заповедях-костpax в стихах 1-2? и не этот ли аспект разъединяет Я и Ты? Последняя ассоциация была подсказана на семннаре проФ. Флакеpa 26.XI.82 в Загребском Университете после изложения основньх положения данноя статьи).

39. CM. J. E. CIRLOT, A Dictionary of Symbols. Second Edition. Translated from the Spanish by Jack Sage. Foreword by Herbert Read. New York 1981, x. 135 ("Hairs").

40. Если не считать субтекстовых образования в стихах 7-8, 10-11 и 22. Кстати, они здесь отражают двояственность речи Я, пвояственность смысловую, а не как это бывает в некоторьх других вепах Цветаево (например, в цитированном ухе Занаөесе - см. примечание 36), скоетную двонственность, а точнее - стереоскопичность скоета (свонственную, мехду прочим, и древним иконам и современному Цветаевоя кубизму в живописи).

41. Ввиду отсутствия "канонических" слез (см. Лука, гл. 7: 37-38) и "канонического" отирания от них признак 'впитывания' эдесь очень слаб, но если предполагается, то тогда означает впитывание влаги ты, а не собственнон влаги $Я$.

42. Резкость этого многоточия родственна резкости многоточия после стихов 6 и 14. Но его ситуированность внутри стиха (тогда как те ситуированы в конце) отражает, по-видимому, внутренния сдвиг в Я (в отличне от более овнешненных и фабуляризованных первьх двух).

43. См. примечание 37 .

44. Во избежание путаницы мы ввели сплошную нумерацию стихов для всех трех стихотворения магдалики.

45. Термин "икона" понимается здесь в соответствия с его пониманием в православноя теология - как видение Божественнои деяствительности и как деяствительное духовное восприятие этои деиствительности, а не как значимы материальның артефакт. Сущность иконы всесторонне изложена в: Павел ФЛОРЕнСКиЯ, "Иконостас". - Богословские Труди, сборник 9. Москва 1972 (издание Московскоя Патриархия) . Некоторое сходство Цветаевскон изобразительнон манеры со зрительноһ живописнои прослежены Ревэиноң, но в данном случае это явление не имеет места. См.: О.Г. РЕВЗинА, "Структура поэтического текста как доминирующи Фактор в раскрытии его семантики". - Marina Cvetaeva. Studien und 
Materialien. ("Wiener Slawistischer Almanach", Sonderband 3 , wien 1981, S. 56-61.

46. "и когда был Он в Вифании, В доме Симона прокахенного, и возлехал, - пришга женшнна с алавастровьм сосудом мира из нарда чистого, драгоценного, и, разбивши сосуд, возлила Ему на голову. Некоторые же вознегодовали и говорили между собою: $k$ чему сия трата мира? Ибо можно было бы продать его более, нежели за триста динариев, и раздать нищим. И роптали на нее. Но Иисус сказал: оставьте ее; что ее смушаете? она доброе дело сделала для Меня. ибо нищих всегда имеете с собою и, когда захотите, можете им благотворить; а Меня не всегда имеете. Она сделала, что могла: предварила помазать тело мое к погребению. Истинно говорю вам: Где ни будет проповедано Евангелие сие в целом мире, сказано будет, в память ее, и о том, что она сделала". Марк, гл. 14: 3-9.

47. Как дар, как проявление чистосердечноя преданности и глубокои веры-любви толкуется этот акт также и в Еөангелиях - см. хотя бы выдержку в примечании 46; эпизод с блудницен у Луки (гл. 7: 36-50), где посторонняя совершает надлежащи обряд гостепринмства вместо хозяина и где Христос, ксмментируя все событие, говорит: "прощаются грехи ее многие за то, что она возлюбила много; а кому мало прощается, тот мало любит"; а также упоминание $о$ женщинах, в том числе и о Марии Магдалине, которые последовали за Христом и "служили Ему имением свонм" (Лука, гл. 8:2) .

48. Tут намечается возможность объяснить отсутствие "канонических" слез в первом стихотворении и введение их в текст лишь теперь Форма "очеса" /стихи 11 и 18) вместо "глаз" переводит Я на сверхъестественны уровень и способна "сакрализовать" Я. То же самое происходит в стихотворения, с тем, что "сакрализация" получает прямо противоположнын знак: очесами $\partial e x$ 的 $\kappa и$ м $и$ T $a$ \& $c$ o. При этом "демонская" природа я сокрыта $(m a \& c$ o) пол поддельноя, обманчивоя поверхностью (мемощами) и занимает место глубокоя (Увнутреннои) истиннои сути Я. очеса, таким образом, мыслятся здесь традишионно - как внутреннее око, око душ (в этом случае пуха-демона). По той же традиция и слезы есть проявление душ (ср. слезы как кровь души у св. Августина) . Подмена очес слезами, оказывается, весьма закономерна, но она меняет природу $я$ - $c$ демоническоя на сакральную. Данная подмена, однако, не механична, не навязана извне, а представлена как эволючия самоя Я. Обманчивая или точнее - амбивалентная поверхность Я (немочи, телесность) К концу первого стихотворения истончается и извергаются овладевавше ею плотские бесовские страсти - Я становится очищенно нагоя душои, или иначе - обретает душу. А слезы знак ее обретения. Более того: они появляются после опознания ТЫ (Христа), после опознания-уверования. Эта последовательность созвучна известнои последовательности обретения "слезного дара" как признака благоволенья Божья. Ср., например, историю купца Скотобоиникова у достоевского: Ф. М. ПоСТОЕВСКия, Полное собрание сочинекий в тридиати томах. Том 13 Подросток. Москва 1975, с. 321 и предипушие (Часть третья, Глава третья, IV). Некоторые замечания по этому поводу см. также в: P. Тименчик, "Храм Премудрости Бога: Стихотворение 
Анни Ахматово "широко распахнуты ворота..".- Slavica Hierosolymitana, vol. V-VI, Jerusalem 1981, p. 304

но наиболее поразителен в данном случае собственно Цветаевския контекст. Это следуюши эпизод из поэмы-скаэки Царо-Девииа (из встречи өторой): не сумев разбудить царевича любящая его Царь-девица приходит в отчаяние и начинает плакать (14 июля - 17 сентября 1920; иП, 392-394) -

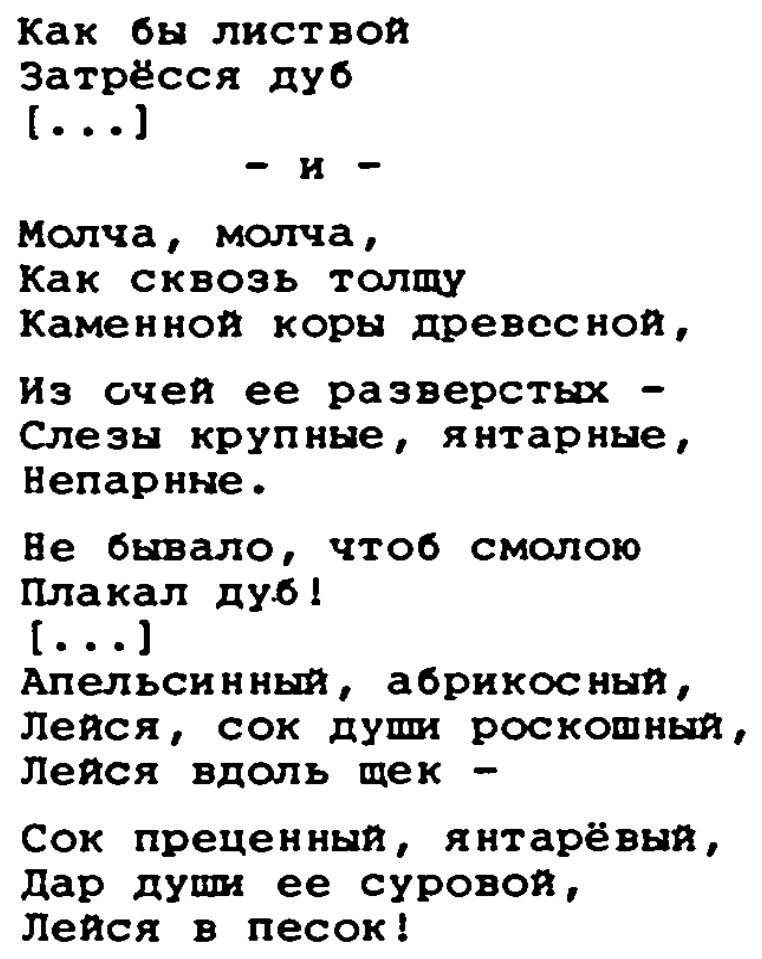

Ва кафтан его причастнын, Лик безгласның - кровью краснон Kana , cмora!

Кровью на немую льдину...

- Растопись слезоя, гордыня, Камень-скала!

Во-перяьх, здесь экспгишитно выведены все основные эквиваленты слез: сок души - дар души - крово - 'живица' (Сок ямтарёвий; смола) - 'жгучесть, жар' (растопись) - 'самое внутреннее', 'суть' (Как сквозо толиу Камекмой кори древесной) 'воскресакщее, оживляющее' (растописо).

Во-вторьх, так же эксплицитно выведен здесь и сакральның характер слез. И дело не в том, что плачет царь-девица, т.е. божество солярного цикла. А в том, что царь-Девица приравнена здесь $\partial$ у $\sigma y$, варианту наивысшего $O \Gamma$ н н н $0 \Gamma$ божества, и в том, что дерево вообще у Цветаевои связано с понятием Бога-огня (ср. хотя бы чикл Деревоя; примечания 105109 и параграф 4.4.l. Более того: именно это звено в состояния пролить свет на эволюцию g от ее 'огненноя' раэновидности (см. стих 23: Твари с кудрями $о г к е н$ и м и) до акватического потока.

В-третьих, упоминание апелосикного и абрикоского сока не только прием инфантилизации царевича, но и нечто гораздо большее. Это явная отсылка к апокрифическому мотиву. В ряде апокрифов, посвященных младенческим чудесам иисуса, имеется и такоя эпизод. Святое семенство скрывается от преследования 
ирода в пустыне. Страдает от голода и жажды. Встретившаяся пальма плодоносна, но слишком высока, а ее подножие безводно. Тогда маленькия Иисус повелевает пальме наклониться и поделиться свонмя плодами. За послушание она удостанвается чести предстоять в Саду Господнем, а в земном варианте поить жаждуших забившим из-под ее корнен источником. Воды же источника - сладки, как Фруктовын сок (по египетсков традиции: персиковые). См. хотя бы так называемое "Евангелие от Псевсдо- Матвея"(Гл. XX) в: Apokryfy Nowego Testamentu. Pod redakcja ks. Marka strowieyskiego. (Tom I: Ewangelie apokryficzne). TN KUL Lublin 1980, s 226.

Последнее Обстоятельство лишни раз говорит О том, что учитывание евангельского, апокрифического или мифологического контекстов по отношению К Цветаево н не совсем несостоятельно.

49.

$$
\begin{aligned}
& a-y-u \\
& a-a-a \\
& и--b \\
& a---a
\end{aligned}
$$

50. В живописи, например, Магдалине предпосылается сосуд с мастямн, череп - как знак бренного мнра сего, а на нем раскрытая книга, как знак дарованного еи откровения. Сама же она изображается в глубоко смиренноя позе, с жестом покаяния, в слезах и с обильным волосам, которые теперь могут читаться не только как признак ее грешного прошлого, но и как признак отпущения (согласно позднея христианской традиция длинные волосы - знак невинности). Ср. хотя бы икону тициана магдалима каючаяся в Ленинградском Эрмитаже. В сакральнои иконе ее персонах - не лицо (икона ведь - не портрет), а личность, лик, а еще точнее - определенная идея, духовная Божественная энергия. Иконны принцип лика Магдалины у Цветаевон более чем очевиден буквальны уровень изображения (атрибуты) сразу же поднят на уровень анагогическия (мистическия) объединяюпим сплотное Исструекие (это только линейость речи отъединяет все атрибуты от Нсструения: на самом деле они "струятся" с вряд ли случайно первого слова Масти) . О толкования иконы как воплощения Слова-Бога см. уже цитированную статью и.Е. Даниловон. О первичном статусе атрибутов в пластике и их пред-эпитетнои (предопределительноя) стадия в словесности (в эпосе) см.: Ольга м. ФРЕИДЕВБЕРГ, Миф и литература древкости. Москва 1978, с. 203 и след. (глава Метафора в исследовании Образ и помятие).

51. Ср. слова Христа к Фоме: "ты поверил, потому что увидел Меня: блаженны не видевше и уверовавшие". Ноаки, гл. 20: 29. Ср. стихотворение Наука Фоми (24 августа 1923; ПР, 111-112), написанное Цветаевой за два дня до Магдалика:

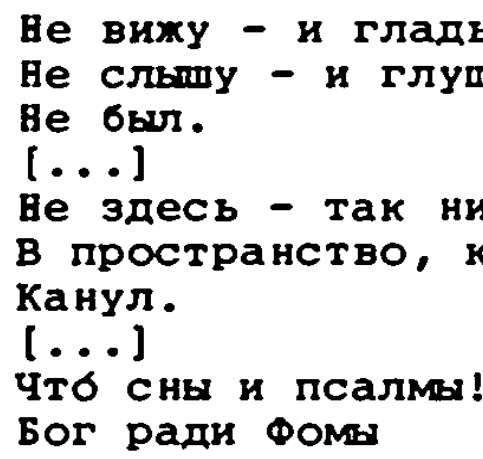




\section{B map cen}

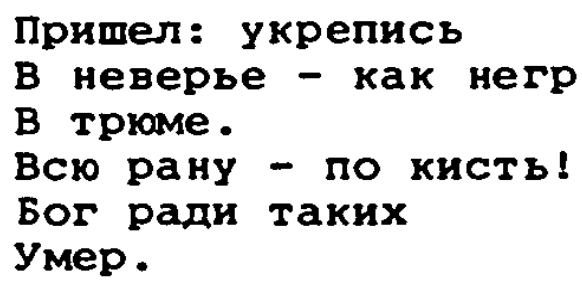

52. В свете Евангелия $H$ e издаривайся $m$ a $x$ ! позволительно как указание на земную миссию Магдалины, указание обратить свон дар на блихних. Ср. у Луки (гл. 23: 27-28): "и шло за Ним великое множество народа и женщин, которые плакали и рыдали о Вем. Иисус же, обратившись к ним, сказал: дщери Иерусалимские! не плачьте обо мне, но плачьте о себе и о детях ваших". Попутно напомним, что в Православии Мария Магдалина считается равноапостольной.

53. Так, в Евангелиях Иисус говорит о себе, что он из иного мира. Ср.: "Иисус сказал им в ответ: если Я и Сам о Себе свидетельствую, свидетельство Мое истинно, потому что Я знаю, откуда пришел и куда иду; а вы не знаете, откуда Я, и куда иду; Вы с夕дите по плоти, Я не сужу никого; [...] вы от нижних, Я от вьшних; вы от мира сего, Я не от сего мира; Потому Я и сказал вам, что вы умрете во грехах ваших: ибо если не уверуете, что это Я, то умрете во грехах ваших". Ноакк, гл. 8: 14-15, 23-24.

54. Ср.: "и пославшия Меня Отец Сам засвидетельствовал о Мне. [...] и вы не имеете слова Его пребываюмего в вас, потому что вы не веруете тому, Которого Он послал". Ноаки, гл.5: 37-38.

55. Сp. следуюшие наблюдения Ревзиноя по поводу стихотворения Та, что без видекия спала... (12-го октября 1922; нХ, 36-37) из цикла Деревоя: "Характерноя особенностью цветаевской 'Говорящен' живописи является то, что она 'пишется' яэыком линия, $а$ не красок. В словеснои картине стихотворения нет ни одного цветового эпитета. Краски играют второстепенную и даже искажающую роль в облике леса (ср. В другом стихотворении из цикла Деревоя: Не краскоЯ, не кистью! Свет - царство его, ибо сед. Ложь - красные листья: Здесь свет, попирающия цвет). Краски играют роль завесы, лишь прорвав которую можно обнажить суть явления (cp. Об осеннем лесе: Над тихою заводью днея Как будто завеса рванулась - и грозно за нея...)". О.Г. РЕВЗивА, "Структура поэтического текста как домннируюиня фактор в раскрытии его семантики". - Ук. сои., с. 59.

56. Владимяр ПАЛЬ, Толковий словаро живого великорусского язика, том I. Москва 1978, С. 694 (статья "зрьть").

57. Тут возможна ассоцнация с третьим - внутренним мистическим оком, встречаемьм во многих иконньх ликах и особенно в иконах Николая Чудотворца, а также - и это более согласуется со всеми идеямн Магдалина - С Оком Провидения. Попутно обратим внимание на откровенное противопоставление "очеса - зрак", тем более заметное, что оба слова взяты из одного и того же архаического запаса. Связь зрения с обликом, ликом объясняется следуюцея Евангельскоя формулон: "Светильник для тела есть око. Итак, если око твое будет чисто, то все тело твое будет светло: Если же око твое будет худо, то все тело твое будет темно". 
Mamфей, гл. 6:22-23 (ср.: Лyка, гл. 11: 34-36).

58. Лука, гл. 23: 27-31.

59. Ср. слова старицы в рассказе Марьи Лебядкинон в Бесах: "А тем временем и шепни мне, из церкви выходя, одна наша старица, на покаянии у нас жила эа пророчество: 'Богородица чтб есть, как мнишь?' - 'Великая мать, отвечаю, упование рода человеческого'. 'Так, говорит, богородица - великая мать сыра земля есть, и великая в том для человека эаключается радость. И всякая тоска земная и всякая слеза земная - радость нам есть; а гак напоншь слезамн свонми под собои землю на пол-аршнна в глубину, тотчас же о всем и воэрадуешься. И никакои, никакон, говорит, горести твоен больше не будет, таково, говорит, есть пророчест во' - Запало мне тогда это слово. Стала я с тех пор на молитве, творя земнон поклон, кахды раз землю целовать, сама целую и плачу. И вот я тебе скаху, шатушка: ничего-то нет в этих слезах дурного; и хотя бы и горя у тебя никакого не было, все равно слезы твои от одно радости побегут. Сами слезы бегут, это верно". Ф.М. ДОстОЕВСКиЯ, Полное собрание сочинекий $\theta$ тридиати томах. Том 10: Беси. Москва 1974, с. 116 (Частв первая, Глава четвертая: Хромонохка, Ү).

О каком-либо соотнесении С Достоевским здесь, видимо, речи быть не может. Но приведенная выдержка наталкивает на мсль, что рифменное сближение глики и магдалика, устанавливаяне между ними некую неформальную, более глубокую связь, может открывать путь к решению образа Магдалины на подобие "великон матери сыро земли", что отнюд не противоречило бы Цветаевско поэтическон системе.

60. Через эпиклесис елен (масла, миро) и вода подвеггаются очищению ото всякого дурного влияния и получают освятительную силу. Болеe того: в них пребывает Святон дух и через них денствует. CM.: Paul EVDOKIMOW, L'orthodoxie. Neuchatel 1959. Пользуюсь польским переводом: Paul EVDOKIMOV, Prawoslawie. Przezozyz k8. Jerzy Klinger. Warszawa 1964, s. 308.

61. С.С. АВЕРинцеВ, "Мария Магдалина". - Мифи кародов мира. Экииклопедия. Том 2. Москва 1982, с. 1982, с. 117; Н.А. ПЕТРОВСКИЯ, Словаро русских личних имен. Москва 1966, с. 146.

62. Весь этот механизм поразительно совпадает с описанньм в работе образ и пояятие (в главе Метафора) механизмом пред-метафорного иносказания. См.: ОЛЬга ФРЕДДЕнБЕРГ, Миф и литература древкосmu. Москва 1978, с. 180-205.

63. Ср. примечания 36 и 37. Кроме отчуждаемости "одежда" могла бы вносить нежелательның у Цветаевон признак 'отдельности'другого и в итоге - 'разъединенности'персонажея. В иных вещах Цветаевон он снимается либо метаморфозоя Я в одежду другого, либо обшим для обоих "покровом". Ср. эпиграф к Учекику (15 апреля 1921 иП, 169):

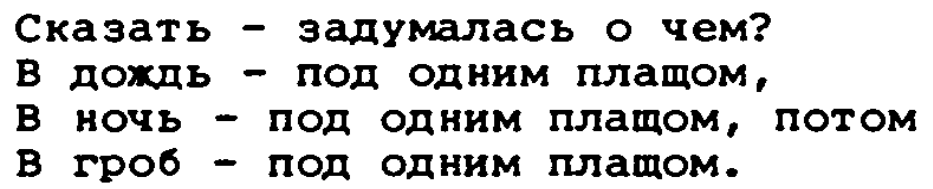

64. См. примечание 36 . 
65. Включить в этот ряд пески позволяет не только библеиския контекст, но и чисто Цветаевския. Ср.: Некоторим - ке закок... (25-го июня 1922; ПР, 15):

некоторым - не закон.

В час, когда условны сон

Праведен, почти-что свят,

Некоторые не спят:

Всматриваются - и в скры-

тнершем лепестке: не ты!

[...]

Впьтываются - и сти-

снутьм кулаком - в пески!

Caxapa (3-го июля 1923; Пр, 99-100):

Стихами - как странамн

Он въехал в меня:

Сухую, песчаную,

Без дна и без дня.

Стихами - как странами

Он канул в меня.

[...]

Адамова яблока

Взывакщи вздрог...

Взяла его наглухо,

Как страсть и как Бог.

[...]

Стиханье до кипени

Вскипающих волн. -

Пескамн засьпанныя,

Caxapa - тво холм.

Здесь интересно не только то, что Я идентифицируется с пескамя, С пустынея, но и то, что и в данном случае за песками

(пустынея) сохраняется своиство 'поглощения вовнутрь' и что в финале появляется упоминание Вскипающих волк как анти-эквивалента песков. Кстати, и өода является у Цветаево поглощаюея стихиея. Ср. Ноинае места (4-го октября 1923; Пр, 122-123):

[...] Платньх теснот

Ночных - блаже вода!

вода - глаже простынь!

Любить - блажь и беда!

Туда - в хладную синь!

когда 6 в веры века

Нам встать! Руки смежив!

(Река - телу легка,

и спать - лучше, чем жить!)

Любовь: зноб до кости!

Любовь: зноЯ до бела́!

Вода - любит концы.

Река - любит тела.

66. В других, близких по времени написания, текстах цветаевоя трава соотнесена с внебнтовым уровнем ее мнра, с потустороннеонеярическон сферон. Например: Когда хе, Господин... (22-го - 
23-го июня 1922; ПР, 12):

Как под упорством уст

Сон - слушала - траву...

(Здесь, на земле искусств,

Словесницеи слыву!)

Веска наводит сон. Уснем... (5-го апреля 1923; ПР, 72-73) из цикла Провода:

[...] 0 , печаль

Плачуших без плеча!

$[\ldots]$

О том, что тише ты и я

Травы, руды, беды, воды...

Мореплаватело (12-го июня 1923; ПР 93-94):

Закачая меня, звездныя челн!

Голова устала от волн:

[...]

Положите меня меж трав и хвоя,-

Голова устала от вонн...

Занавес (23-го июня 1923; ПР, 97):

Танна занавеса! Сновиденным лесом

Сонных снадобия, трав, зерн...

И стихотворение Прокрастося...(14-го мая 1923; ПР, 90):

А может, лучшая победа

Над временем и тяготеньем -

Прояти, чтоб не оставить следа,

Проити, чтоб не оставить тени

На стенах...

[...]

Распасться, не оставив праха

на урну...

может быть - обманом

Взять? Выписаться из широт?

Так: Временем как океаном

Прокрасться, не встревожив вод...

67. В свете приведенньх в примечания 66 контекстов для трава и $60-$ du любопытно отметить, что в этот же период творчества аналогич но толкуется у цветаевои и нехносто.: Рано еще не бито!... (19-го июня 1923; ПР, 95):

\footnotetext{
Рано еще - не быть!

Рано еще - не жечь!

Нежность! Жестокия бичь

Потусторонних встреч.

Как глубоко ни льни -

Небо - бездонныя чан!

О, для такои любви

Рано еmе - без ран!
}

Нехносто, как видно, родственна у Цветаевоя упокоению, умиротворенности, означающим в свою очередь состояние за пределами 
мира сего, состоянию (взаимо) растворенности в мировом потоке. В пределах же мира сего она имеет форму неистовои страсти, неутолимости и изнурительноя борьбы за партнера, за овладение им до конца. В этом контексте упоминание Не2 в стихе 19 долино, таким образом, читаться как знак выхода из земного воплощения, как переход в "потустороннее бытие" (кстати, вслед эа этим речь уже о өолосах и истончении плоти до ткаки, предваряюши эпизод - отрешение от себя бывшея).

По отношению к Магдалине небеэынтересно отметить и теологическое толкование нежности. Согласно ему нехность соотносится с материнским чревом и его более древним представлениями типа земньх недр. Это толкование проливает свет на весьма неожиданное упоминание ями в финальноя строфе триптиха. См. статью "нежность" ("neznost") B: Xavier LEON-DUFOUR, Rječnik biblijske teologije. Zagreb 1969, c.710; в русском варианте см. Стр. 559-560 и 66-67 (Словаро библейского богословия, Под ред. Ксавье ДюФура и цр., Брюссель 1974; статьи: "Благоутробие" и "Мнлосердие").

68. В терминах биомеханики и физиология движения их мохно определить как кинематические установки-програмы. Интересно, что у цветаевкого я они чаме всего не получают никакого внешнего виражения (не становятся Физическимя или механическимы движениямы) и указывают только на внутреннее предельно динамизированное, напряхенное состояние Я (они, так сказать, внутрителесны) . Таков, например, статус глаголов өлекласо, стлаласо (в стихах 9-11) или стелюсо (стих 21), где "локомоция" (передвижение) или "распростирание" вовсе не осуществляются. Такова и лексика метаморфоз в примерах, приведенных в примечания 28. Осушествляеме, "овнешненные" движения моделируют у Цветаевоһ, главным образом, инертның, косның, бескачественны уровень мнра. Ему предпосылаются и "локомоционнье" двикения и средства (что понятно, так как только этот уровень ее мнра обладает физическоя протяженностью, пространствами и расстояниями; см. примечание 36 ; как таковая пространственность и расстояния преололеваются у Цветаевоя при помощи подмены всего пространства самнм Я или при помоши его поглощения в себя).

Если Говорить о "языке линия" у цветаевоя (См.: О.Г. РЕВизинА, "Структура поэтического текста как домннируюпия Фактор в раскрытия его семантики",ук. соч.. с. 59 и след. а также примечание 27 на с. 65), то его удобнее называть "языком кинемограмм", в котором легко вычленяются по краинея мере три следуюших категории: кривое, прямолинеиное и "спиралевидное" . Кривым моделируется неприемлемы косның уровень мира. Ср. в Други! Братствеккий сокм!... (17-го сентября 1922; ПР, 33) из цикла Деревоя.

древа вещая весть!

Лес, вещаюти: Есть

здесь, над сбродом кривизн -

Совершенная жизнь:

Где ни рабств, ни уродств, там, где все во весь рост, Там, где правда виднеи:

По ту сторону днен... 
Прямолинеиньм, что видно и по данному Фрагменту, - сакральның уровень Цветаевского мира. Спиралевидньм - постулируемая форма бьтия, Со всемя инобытиямн-метаморфозами самого Я включительно. Ср. хотя бы в первом стихотворении из цикла Поэти (8-го апреля 1923; ПР, 77-78):

Поэт - издалека заводит речь.

Поэта - далеко эаводит речь.

Планетамн, приметамя, окольньх

Причт рьтвинами... Между да и нет

Он даже размахнувшись с колокольни

Крюк вьморочит... Ибо путь комет -

Поэтов Путь. Развеянные звенья

Причинности - вот связь его! [...]

[...]

Он тот, кто смешнвает карты,

обманывает вес и счет,

[...]

- нбо путь комет

Поэтов путь: жкя, а не согревая,

Рвя, а не взрашивая - вэрыв и взлом -

Твоя стезя, гривастая кривая,

не предугапана календарем!

Здесь, кстати, примечательно, что в иньх случаях отрицаемы признак кривая в этом дополнительно помечен цветаевскои поло-

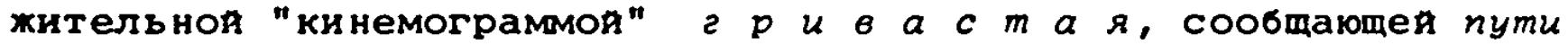
позта характер своевольнод волны (ср. хотя бы в Магдалине

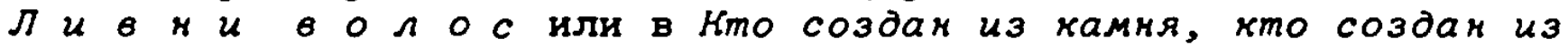
глини... параллель $Я$ - бренкая пена морская - кудри беспутные)

Такая дифференциация (намеченная здесь всего лишь схематически) имеет глубокие основания в остальньх свояствах поэтическоя системы Цветаево . Кривое соотносится с дискретностью, членимостью (ср. примечания 14 н 19): прямолинеиное - со сплош ньм, нечленимьм, егиньм; спиралевидное или волнообразное - $С$ деятельным, живым, способньм к метаморфозам и воскресаниям. С точки эрения визуальньх искусств, кривое толкуется как нанболее трудная и "искусственная" "сверъестественная" линия, волнистое - как наиболее "естественное". Более того: изогнутая линия передает усилие, напряжение или умиротворение. Такова, кстати, дифференциашия изогнутых "кинемограмм" у Цветаевон: восходящих, знаменуюших усилие, внутреннюю энергию, что часто отражается обильными у нее приставками "вз-"; н нисходяших, которые означают упокоение, умиротворение и обнгно ведут в запредельные онеярические локусы. Вряд ли поэтому ее внутрисловесные "рисунки" родственны экспрессионистско граФике. Если искать такие соответствия, то они ближе всего к модерну (Secessionstil).

и еще одно замечание. Выбор прямолинеиного движения для сакрального мира н не-прямолинеяного для остальных Форм бытия согласуется с древнея теологическои мылью, по которои прямолиненное движение было присуше Божественному началу (Божественному свету), а круговое - для креатур. С этои точки зрения диФференциашия Я и ТЫ в первьх двух стихотворениях по приэнаку 'круговьх' и 'горизонтальных' двикения (стихи 10 и 19-21) и 'прямолинеяного' и 'вертикального' (стихи 24 и 30: өстано,

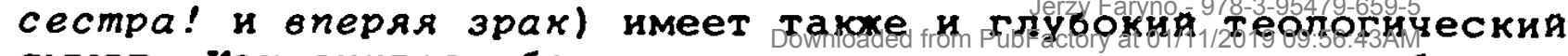
смысл. Как синтез обоих признаков, как примнреняе ессобъедине- 
ние обоих начал (Божественного и креатурного) может читаться тогда переход Я-Магдалины на спиралевидное движение (стихи 41-42 и 50-51). См. М. Ф. МУРьянОВ, ук. соч., c. 177; Rudolf ARNHEIM, Art and Visual Perception. A Psychologiy of the Creative Eye. The New Version. Universit of California Press, Berkley and Los Angeles 1074, pp 162-217 (IV: Growth).

69. Ср. возникшее за месяц до Магдалины стихотворение Наклок (28го июля 1923; ПР, 105), Где каклок интерпретируется, в частности, как тяготенье к родственному или соположенному:

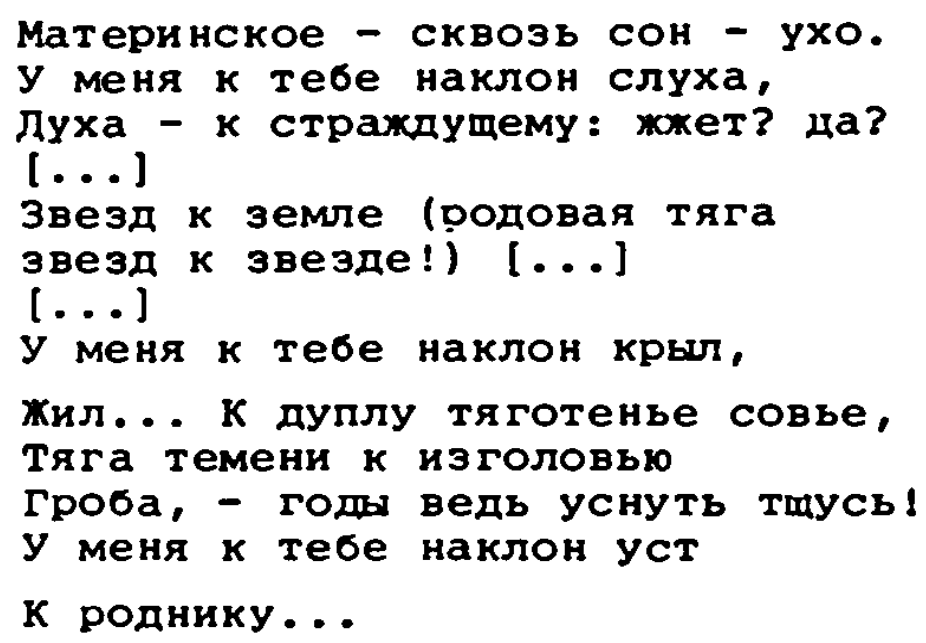

४ свете же наблюдения, изложенньх в примечании 68 , каклок Христа можно понимать и как переход с прямолинеяного на спиральное и совпадение с "кинемограммоя" Магдалины: а также как склонность раствориться в нея (см. толкование кехности в примечания 67).

70. Заметим, что после стиха 21 ткако нигде больше не упоминается, а подразумеваемая в стихах 40-42 получила вид волящ тела. Эквиваленция "вода - одеяние" имеет свое основание в библенском контексте. См. Притчи Соломоновы, гл. 30: 4: "кто завязал воду в одежду?". А в чисто цветаевском - см. Так. захиво раздав... (7-го октября 1922) и ПР, 48) из цикла БОг:

Пагом Семирамиды,
Спускающеяся в пруд
Лестницея трав несмятьх,
и знающея, что ждут
Ризы - прекраснея снятьх

По выходе из вод...

Поэтому без лока позволительно читать как "без какои-либо материальности". Тогда от Магдалины сохранялась бы только "пеленаюцая, овладевающая' сущность.

71. Будучи пневмо-акватическоя сущностью, состоящея из мастей и еода заключив в себя ты-Христа (стихи 35-42) она сама стала христофорнчноЯ, т.е. миром (см. примечание 60). Отсюда отказ К чему мке миро? относится, вероятнее всего, к матернальному атрибуту, отчуждаемому от Магдалины. Кроме того имя Миромосииа созвучно с Цветаевскоя умиротворяющея уст-Упокоителониией (в финале стихотворения Не черкокнихнииа! В белой книге... - см. выдержку в примечания 28). Переименование Малдалины- сиақала на 
миую, а затем на Мироносицу (см.стихи 31,34 и 49) и этим самом установление непосредственнои связи С миром приводит на память аналогичның прием в Песке Пескей, где имя ТЫ (по имени не неазванного) толкуется как миро: "От благовония мастея твонх имя твое, как разлитое вин миро; поэтому девишы любят тебя. [...] мирровы пучек - возлюбленныя моу у меня; у грудећ моих пребывает". Пески Пескей Соломока, гл. 1: 2,12. Как Говорит М.Ф. МуРЬЯнОВ (Ук. соч., С.195), "Сравнение имени С 'иэлиянньм мором' по русски не звучит, оно имело смасл в древнеевреиском подлиннике, где художественныя эфФект достигался созвучием:

$\begin{array}{lll}\text { Sămăn } & \text { Semäka } & \text { shelomo } \\ \text { моро } & \text { имя твое } & \text { Соломон } \\ & & \text { ("умсротво- } \\ & \text { ряншин") }\end{array}$

shelomo

("умеротво-

рямани") shulammit

Суламифь

("Yмaротво-

ренная")".

Этот контекст, думается, весьма значим для эротического плана триптиха магдалина.

72. Такоя генезис слез учитывается у цветаевод в стихотворении Балкон (30-го июня 1922; ПР, 16):

Стиснутое в руке комочком -

Чтб: сердце или рвань

Батистовая? Сим примочкам

Есть имя : - Нордань.

и лишь теперь палностью проясняется смысл пропуска слез в первом Стихотворении - они появляются после получения "воды живоя" От ТЫ и, видимо, этон "водоя живон" и понимаются У Цветаево (См. примечания $32,41,48$ и 59).

73. J.E. CIRLOT, A Dictionary of Symbols. Second Edition. Op.cit., p. 134 ("Hair (Body-Hair)"). Связь волос с сущностью (глубинньм внутренним светом), с душоя (волосы как вместилище души), с созидательноя энергиея (как вместилище жизни), благоприятСтвованием возрастанию (в духовном и даже физическом смыслах) и, что в данны момент для нас существенно, - с листвоя, сол-

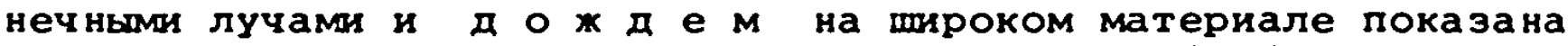
в статье HAIR в энииклопеднческом словаре Dictionary of Mythology, Folklore and Symbols by Gertrude JOBES, The Scarecrow Press Inc.. New York 1961, pp. 709-711.

74. Paul EVDOKIMOV, PrawosEawie. Op. cit., s. 307.

75. Если яму рассматривать в контексте предыдушнх песков и глика, то от них сохраняется в ней признак 'поглощаюен утробы' (см. примечание 105; а также 2.2.2.-2.2.8.) и признак эротичского начала. Последния хорошо прослеживается по следующему контексту глики у Цветаевоя: Неподрахаемо лхет хизко... (8-го июля 1922; ПР, 18):

В белую книгу твонх тишнзн,

В дикую глину твоих "да" -

Тихо склоняю облом лба:

ибо лапонь - жнзнь.

Удостоверишося - повремеки!... (12-го июля 1922; ПР, 20): 
Нет, руки за́ голову заломив,

- Глоткою соловьннон! -

не о сокровищнице - Суламнфь:

Горсточке красноЯ глины!

Но теска вдвоем ... (8-го августа 1922; ПР, 27):

До начальньх глин

Потупляя слух -

над источником,

Слушая-слушая, Адам,

чт6 проточные

жилы рек - берегам:

Так - через связь с гликой - лодготовлен в яме смысл первоначала и любви. Яма, естественно, у Цветаево амбивалентна. Это и "могила" и "чистилище", способное возрождать. Первые варианты нам уже знакомы, теперь приведем несколько выдержек на втоpoе: Eсто кекий час - как сброшемная клаха... (15 апреля 1921; ип, 170) из цикла учекик:

и калос взрос, и час веселын пробил,

и жерновов возжаждало зерно.

Закон! Закон! Еще в земноя утробе

Мно вожделенное ярмо.

Под шалор (8-го ноября 1924; 132):

Женшина, яму какую вырыла

и заложила дерном?

[...]

Женщина, чтб у тебя под шалью?

- Будущее!

Сивилла (5-го августа 1922; ПР,24-25):

Сивилла: вьюокена, сивилла: ствол.

Bсе птицы вьмерли, но бог вошел.

[...]

И вдруг, отчаявшись искать извне:

Сердцем и голосом упав: во мне!

Сивилла: вещая! Сивилла: свод!

Так Благовещенье свершилось в тот

Час не стареюшия, так в седость трав

Бренная девственность, пещерой став

Дивному голосу...

- так в звездныл вихрь

Сивилла: выбывшая из живых.

Cp. еmе примечание 59.

76. Paul EVDOKIMOV, Prawoszawie. Op. cit., s. 136.

Cp. аналогичную мысль у Флоренского: "София - это истинная

Тварь или тварь во Истине - является $\pi$ р д д а р и те $\pi$ вн О как н а и е $к$ на преображенның, одухотворенныя мир, как незримое пля других явление горнего в дольнем. Это откровение совершается в личноя, искреннеи любви лвух - в дружбе, когда любящему дается $\Pi$ р е д в а в и $\Gamma$ a нарушение самотождества, снятие гранея я, выхожде- 
ние из себя и обретение своего я в $я$ другого - Друга. Д 6 , как таннственное рохдение ты, есть та среда, в котороя начинается откровение Истины". Свящ. Павел ФЛОРЕнСКй, Столи $u$ утверхдение Истика. Москва 1914, с. 391-392 (цитируо за: Р. Ти МЕНЧИК, УК. СОч., С. 317).

77. Paul EVDOKIMOV, Prawoszawie. Op. cit., s. 127.

78. матфей, гл. 27: 55-56; Лука, гл. 8: 2; Марк, гл. 16: 9.

79. Марк, гл. 16:9.

80. См. примечания $26,27,32$.

81. Вряд ли случанно ен отведено такое почетное место в финалах Евангелий: Марк, гл. 16: 1-10; Ноакк, гл. 20: 1-18: Матфей, гл. 28: 1-10; ср. также: Лужа, гл. 24: 9-10. Не случанно, видимо, у Ноанка (гл. 20: 15) она не сразу узнает воскресшего Христа и принимает его поначалу за с а д $О$ в н и ка. и вряд ли случаяно так сильно распространились и привелись ее отождествления с другимн Мариямн, в особенности с сестрои Лазаря .

82. По тексту она и ливни и яма, т.е. и верх и низ, а кроме того еще и ограхление-стена, что и в разнвх мифологиях и у самод Цветаево истолковывается эквивалентно границе мнра - горизонту. Ср. в Раковике (31-го июля 1923; Пр, 106-107):

Спи! Застилая моря и земли

Раковиною тебя объемлю:

Справа и слева и лбом и дном -

Раковинны калыбельнын дом.

[...]

жемчугом вындешь из бездны сен.

$[\ldots]$

Матери каждая пытка в пору,

В меру... Лишь ты бы, расторгнув плен,

целое море хлебнул взамен!

или более эксплицитно, но в более позднем цикле Стихи сироте (21-24 августа 1936; иП, 318-319):

Об нимаю тебя кругозором

Гор, гранитноя короною скал.

[...] ]

Феодального замка бокамн,

меховьмя рукамн плюща -

[...]

... И рекоя, разотедшеяся на две -

Чтобы остров создать - н обнять.

Всер Саводе и всем Пиемонтом,

и - немножко хребет надломя -

Об нимаю тебя горизонтом

Голубым - и рукамн двумя!

83. Эти смыслы совпадают с наиболее архаичнымя пониманиями жизни, смерти и земли. Ср.: Ольга М. ФРЕЯПЕнБеРГ, Миф и литература древкости.Москва 1978, с. 72 и след. (работа: Вөедекие в теорих античного фолоклора. Лежиии. - Лекиия XII н след.). 
84. Ср.: С.С. АВЕРИнцЕВ, "Мария" - Мифи народов мира. Экииклопедия. Том 2. Москва 1982, с. 114:"[...] Мария - как бы невинная Ева, пришедшая исправить дело 'падшея' Евы; в неи снимается проклятие, постигшее за вину человека мир природы ('землю' - Битие, $3,17-18)$, а потому с ней соотнесено вовлечение природноң жизни и космнческих циклов в сферу христианскоя святости (православное песнопение 'всех стихия земньх и небесньх освящение', 'всех времен года благославление'). Неортодоксальное заострение этого ортодоксального мотива в художественноя литературе - слова персонажа достоевского 'богородица - великая мать сыра земля есть'". Cp. также примечание 59. Кроме того следующее замечание денберг (ук. соч., с. 528 в примечании 81): "Евангельская блудница Мария - остаток было культовод роли Марии-Матери". Там же отсылка к литературе оговариваюе семантическое тождество "Двух метафор 'блудницы' и 'матери'": И.Г. ФРАНК-КАМЕНЕЦКИЯ, "Вода и огонь в библеяскоя поээни". - Яфетический сборкик. Том 3. Ленинград 1926, с. 152; О.Г. ФРЕЯДЕНБЕРГ, "Ми Ф Об Иосифе Прекрасном". - Язик и литература. Том 8. Ленинград 1932, с. 147.

85. Е.Г. РАБИнович, "Богиня-Мать". - Мифи кародов мира. Экииклопедия. Том I. Москва 1980 , с. 178.

86. Там хе, с. 179. Ср. замечание Фреиденберг, что "сын богиниматери был всегда и ее возлюбленным, как Таммуз для Иштари, Адонис для АФродиты и т.д." ОЛьга М. ФРЕЯДЕнБЕРГ. Миф и литература древкости, ук. соч., с. 528, примечание 81 к статье "Въезд в иерусалим на осле (Из евангельскои мифологии).

87. Ср. в ук. Соч. Френденберг Веедекие в теорих античного фолоклора, в Лекиии XIII: "[...] образ 'матери'возникает неподалеку от 'отца', от охотника-тотема. Ее, 'мать', так и приходится помещать при самом возникновения родового общества, в начале земледельческон эпохи. [...] Этим, может быть, объясняется и то, что все 'охотнищы' типа Дианы счнтаются 'сестрамя' и 'девами', то есть лишены и родовых и плодородящих черт; 'влальчицы', напротив, уже 'матери' в земледельческом смиле. [...] Уже 'смерть' не еднноборствует с 'жизнью', небо-тотем - c преисподнеи-тотемом: 'смерть' есть 'рождение' в смысле произрастания, и 'небо' заглушается 'землен', доминируюшим теперь образом. Земля, растения, все, что рождает земля, умирает-произрастает. 'Дети' это не светила новые, а цветы, злаки, плоды, юные животные. Они умирают в земле и рождаются землея, женским лоном. Смерть и рождение как отвлеченные понятия отсутствуют; их заменяет образ 'преисподнең' (земли) - 'матки'. Женшина 'умирает' значнт, 'рождает' и 'рождается'" (с.78).

88. Е.Г. РАБИНОВИЧ, уж. Соч., С. $179-180$.

89. Кроме отмечавшихся в данноя и других работах здесь хотелось бы обратить еще внимание на то, что цветаевске я бывает также и воинственно и обладателем города. Ср., например, $\mathcal{A}$ тебя отвори у всех земело, у есех небес... (15 августа 1916; иП, 108):

я тебя отвоюю у всех земель, у всех небес, Оттого что лес - моя колыбель, и могила - лес, Оттого что я на эемле стою - лишь одноң ногоЯ, Оттого что я о тебе спою - как никто другоя. 
или цикл Стихи о москве, знаменательная уже самым своим заглавием поэма Царо-Девииа и многие другие. Аналогично моделируются у Иветаево и многие ее герои - персонажи или персонификация, но тогда, как правило, они - двояники Я, хотя и не всегда Я с нимя идентифицируется.

90. В случае 'базарного локуса' наименее существенна ассоциация С изгнанием из храма Иисусом торговцев (ср. Матфей, гл. 21: 12-14). Существеннее нечто другое: откровенная враждебность Цветаевон к этому локусу. Ср. хотя бы знаменитое

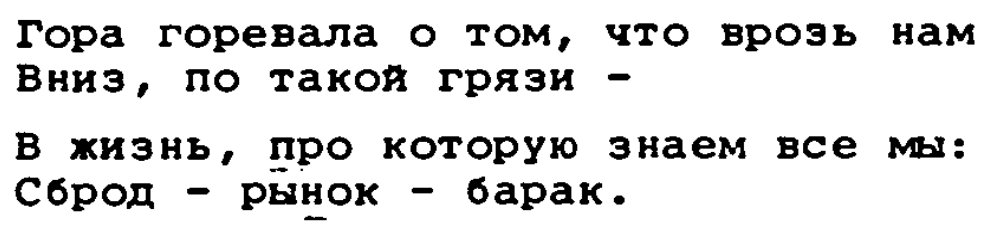

из Поэми Гори (1-января - 1 февраля 1924; иП, 447). В рамках Цветаевсков системы 'базарное' соотноснтся С 'цроблением' и 'измельчанием', с растратон 'целостного' (см. примечания 14 и 19). А за этим стоит более древнее и еще более глубокое осмысление 'торговли' как 'обмена' или 'потери' сущности, давmеe потом образ мены неба и преисподнер в весах (см.: Ольга ФРЕИДЕНБЕРГ, "Введение в теорию античного фольклора", $y$ к. сои. с. 68-70, Лекиия XII). В случае магдалима отказ от 'базарного локуса' и есть тот переломның момент, С которого Я меняет свою сущность, а точнее - обретает ее вновь. Очищению, так сказать, "сакрализации" подлежит теперь и блуд Магдалины: он уже не 'растрата сущности' (не 'торговля'), а проявление 'животворящея сущности'. Ср. показательную в этом плане оппозицию "лавочники- распутные" в 9 и 10 частях Поэми Гори (там хе, с. 448-449):

Пока можешь еще - греши! -

Будут лавочники на отдыхе

Пережевывать барьши,

[....]

Дочь, ребенка расти внебрачного!

Сын, цыганкам себя страви!

91. ОЛъга М. ОРЕИндЕнБЕРГ, "Въезд в Иерусалим на осле", ук. соч. C. 494-495.

92. Там хе, с. 495 и след.

93. Там $x е$, с. 496.

94. Там $x е$, с. 521.

95. Ср.: Матфей, гл. 4: 1-12, гл 26: 6-13; Ноаня, гл. 12: 2-3

96. Матфей, гл. 21: 7-8. Ср. также: Марк, гл. 11: 7-8; Лука, гл. 19: 35-36; Ноаня, гл. 12: 12-15.

97. Ср. почти буквальное воспроиэведение этод схемы у Цветаевод: Нз рук моих...(31 марта 1916; иП, 79) из цикла Стихи о Москве:

из рук моих - нерукотворнын град

Примн, моя странның, мон прекрасның брат.

[...]

И встанешь шы, исполнен дивньх сил...

- ты не раскаешься, что ты меня любнл. 
Терпеливо, как щебеко бомт... (27 марта 1923; Пр, 72) из цикла Провода:

\author{
Буду ждать тебя (пальшы в жгут - \\ Так Монархини ждет наложник) \\ [....] \\ Скрип полозьев, ответның скрип \\ Двери: рокот ветров таежньх. \\ Ввсочаһши пришел рескрипт: \\ - Смена царств и въезд вельможе. \\ И домон: \\ В неземно - \\ да мон.
}

Дополнительно ср. еще стихотворение $\mathcal{A}$ - страница төовму перу... (10 июля 1918; иП, 130) :
Я - страница твоему перу.
Все приму. Я белая страница.
Я - хранитель твоему добру:
Возращу и возвращу сторицен.
Я - деревня, черная земля.
Ты мне - луч и дождевая влага.
ты - Господь и Господин, а я -
Чернозем - и белая бумага!

Частичны разбор этого стихотворения см. в: Е.Г. ЭТкинд, "Опыт - местонмении в системе поэтическор речи". - Поэтика и стилистика русской литература. Ленинград 1971, с. 406-407. Cp. еще цитированное в прнмечания 82 обкимаю тебя кругозором...

Как видно, и во внешнем, мифологическом, контексте, и в собственно цветаевском превращение Я в ткаяо и затем сравнение Я С пространственной протяженностью, а уже - с землей или местностью (городом, деревкей), понимаемой в категориях плодородия-творчества и взрашивания-воскрешения в последнем примере.

98. Знаменательны в этом отношения заключительные слова данного эпизода (стих 24): өcm a к 0 , сестра! Теперь өстако может читаться как возобновление равносущности Я по отношению к ТЫ (ср. примечание 90). Об эквивалентности понятия "встать" и "исцелиться" и "воскреснуть" см. в ук. соч. Фреиденберг (С.527, в примечания 621.

99. ОЛЬГа М. ФРЕДДЕНБЕРГ, ук. соч., С. 499.

100. Там $x e$, с. 499.

101. Там $x e$, с. 502-503.

102. Там $x e$, с. 514-522.

103. Теперь, в этом контексте, определение краская по отнотению $к$ глине, куда устремлен зрак ты (стихи 29-30) может читаться как знак "воскресения", а не только "зноя" или "жажды". Просьба же ты имеет и еще одно обоснование: в древних мифологиях мужское божество, мужское начало, как правило пассивно, а активность предпосылается его женскому соответствию, женскому началу. "Мы не знаем мифов об умирающих и воскресаюих женшинах, а только о мужчинах. У женшнн 'воскресение'заменено мета- 
Фороя 'родов' и 'рохдения'. Рождая, женшина рсждается. Ее лоно - земля, могила, сосуд, яма. Я обращаю на это внимание. 'Роды' и 'рождение' - более древние метафоры чем метафора 'воскресения', хотя означают то же, что и та". Ольга М. ФРЕЯДЕВБЕРГ, ук. соч., с 78 ("Введение в теорию античного фольклора. Лекция XIII).

104. "Дар, дарение" - еще одна и, так сказать, прямая противоположность "торговли" у цветаевои. (см. примечание 90). Обе восходят к общему признаку 'мены сущностен', с тем, что "дар" предполагает полную ее отдачу, тогда как "торговля" - измельчание, растрату и окончательную потерю сущности, сопричастность смертинебьтию. "Дар, отдача" - один из путен в идеальное Цветаевское инобьтие, часто, как это имеет место и в магдалиме, - в рассеянное или растворенное в мировом потоке состояние. Ср. В Но теска вдвоем... (8-го августа 1922; Пр, 29) :

\section{Даке самын. прах}

Подари ветрам!

105. Здесь необходимо сделать одно серьезное уточнение. Связь с 'землеи-могилои'цветаевского Я очевидна и повсеместна, и это мы отмечалы уже не раз. Һадо, однако, подчеркнуть, что эта 'земля-могила' особая, только внешне сходная с 'могилоя-гробом'. Перво своЯственно в ческих умирания-воскрес ния. Вторая же безжизненна и знаменует небьтие, ничто, косную безжизненную и смертоносную материальность. Поэтому Цветаевское Я никогда не становится 'могилоигробом', хотя поверхностно может ен и уподобляться (ср. хотя бы цитированные в примечаниях 33 и 65 Чем ококчился этот случай... и (ахара).

106. О различиях мехду жертвон огня и жертвон земли ср. В ук. соч. Фреяденберг ("введение в теорию античного фольклора. - Лекция XVI), с. 90-91: "Жертва- это огонь, световое животное. Но жертва-огонь имела свою параллель в жертве-земле. В этом, втором образе, однако, другая смысловая основа. Это, Говоря понастоящему, уже не 'жертва': тут нет ни 'жнзни', ни 'жранья', ни 'жгучести' (огня), а потому нет и 'жертвы'. [...] Тут надо вспомнить, что мы имеем дело с сознанием, которое повторяет образы и воспроизводит их в деиствии: 'сожигание' и 'еда' разные метафоры 'жизни', а 'земля' и 'зарывание' передают 'смерть'. [...] Итак, жертва (жизнь) огня - сожжение, жертва земли - зарывание". Так, кстати, может обосновываться устоячивая Цветаевская оппозищия "сожжение - бытовое захоронение" (н ее вариант "костер - могила"), отмеченная намн в 1.2.5. и в примечаниях 13 и 14. Так по всея вероятности, объясняется и "противоречивость" Цветаевского Я, когда в одних текстах оно сильнее уподобляется 'могиле-гробу', а в других 'огню (тоже истребительному)' или инвм "растворякшим" стихиям. Имея характер 'родящего' начала это $\&$ по необходимости вынуждено и 'нести смерть'. И если читать Цветаеву еднничными стихотворениями, а не как единын текст, то тогда именно и может возникнуть впечатление "противоречивости" ее Я. Могила-гроб, зарывание в эемлю имеют место у Цветаевон в приниипиально отвергаемом ею косном мире, но тогда они получают статус отчужденньх От Я Объектов.

ОГонь н Бог неоднократно отождествляются у Цветаево экс-

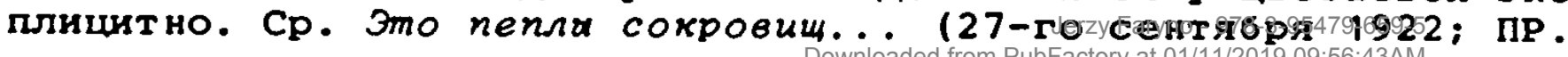


42):

Значит Бог в мон двери -

Раз дом сroper!

не удушенны в хламе,

Снам и дням господин,

Как отвесное пламя

Дух - из ранних седин!

Более того: по образцу божества-огня моделируется и само Я. Ср.: Похираюиий огоко - мой коко... (14 августа 1918; иП, 132):

Пожираюши огонь - мон конь.

Он копьтамн не бьет, не ржет.

Где мон конь дохнял - родник не бъет,

Где мои конь махнул - трава не растет.

OX, огонь-мон конь - несьты едок!

Ох, огонь - на нем - несытыя ездок!

С краснои гривою свились волоса...

Огневая полоса - в небеса!

И это Я-божество-огонь, как и мифологическое божество-огонь, нуждается в жертве огня - ср. Что́ другим ке кухно - несите мне!... (2 сентября 1918; ип, 135):

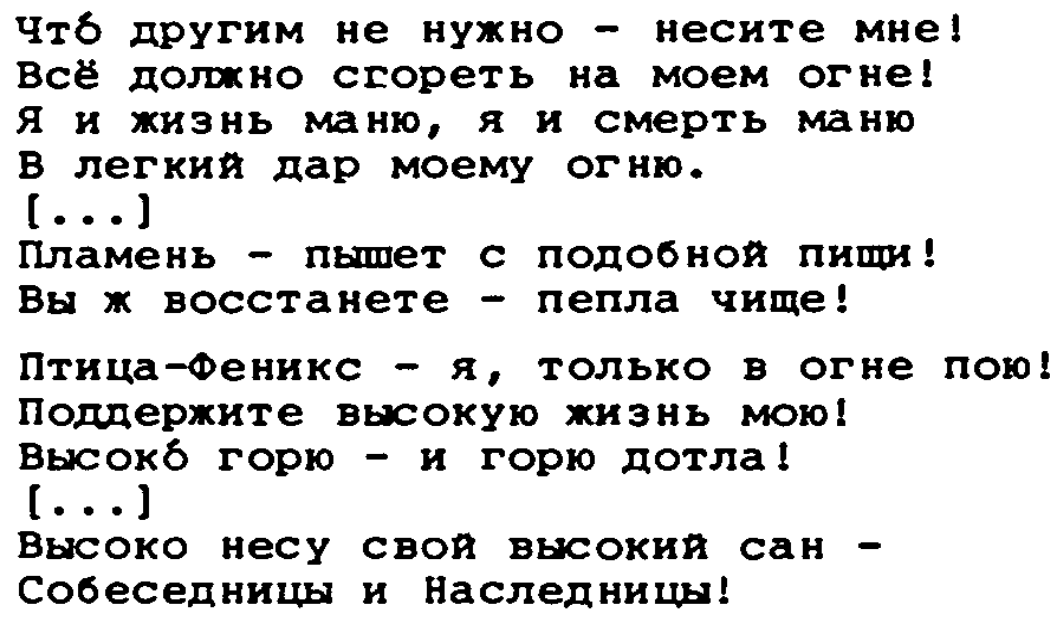

107. Ср. хотя бы цитированное в примечании 106 Что́ другим не кухно несите мке!..., где самосожжение обеспечивает Я внеземную високую хизяо и равносущность божеству (ср. заключительные слова Собеседнииа и Наследкииа, данные с прописно буквы; кроме того здесь явственно звучит мотив совместноя пипи как тотемистического единения) .

108. Ср. хотя бы Бато малочиком твоим светлоголовим...(15 апреля $1921 ;$ иП , 169) из цикла Ученик:

Быть мальчиком твонм светлоголовым, -

O, через все века! -

За пыльным пурпуром твокм брести в суровом

Плаще ученика.

$[\ldots]$

...И - дерзновенно улыбнувшнсь - первым

Взоити на твон костер.

109. Как показывают приводимые примеры, губителен и огненны вариант Цветаевских персонажея. Но он "губителен" иначе - не облекает 
в бренную и смертную плоть, а истребляет ее, переводя в бессмертное рассеяное состояние, приобщает к высшея жизни, к непреходящей форме бытия. Огонь "поедает", а не "вовлекает" для нового рождения. Он лишен признаков "порождения", зато в нем сильно выражен признак "единения", "родства" . Зная это свонство огня, легко теперь понять, почему тут Родная крово отшативает: она предполагает только сожкение и не дает возможности Я реализовать своеи "порождающей сущности, лишает ее - говоря словам Фредденберг - "родовьх и плодородяших черт" (см. выдержку в примечании 87). И это - закономерность у Цветаевод. Там, где речь о высшей форме бытия, о бессмертии, о идеальноя гармонии, - там речь и об огне во всяких его Формах и, самое важное, о равенстве, равносущности в различньх вариантах: братьях, сестрах, братствах, ученичестве, друхбе, обожествления. См., в частности, в Други! Братственний сонм!... (17-го сентября 1922; ПР, 33) из иикла Деревоя:

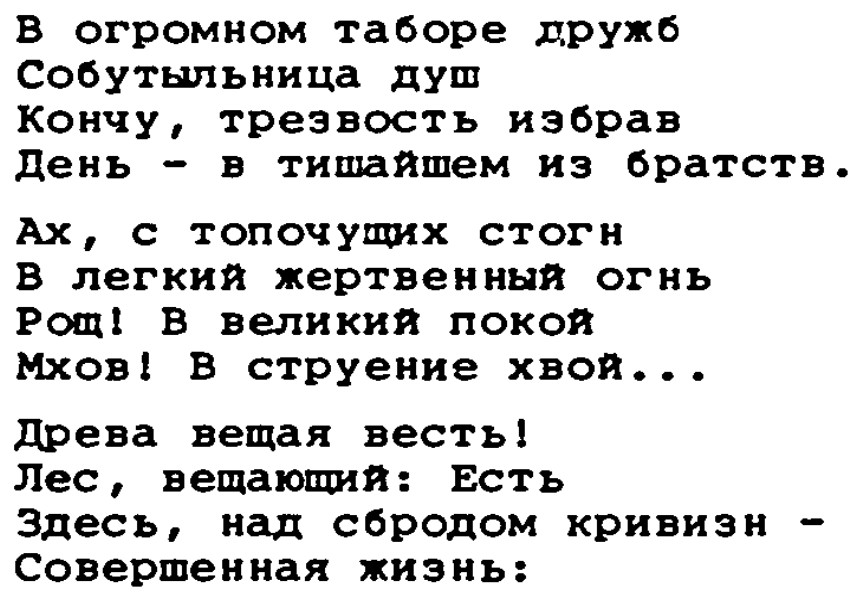

а такое примеры в примечаниях 13, 14, 97, 106, 108. С этов точки зрения первое стихотворение Магдалияи принципиально не может считаться законченньм из-за появления в финале слова cестра! (См. примечание 1). 
Вряд ли будет преувеличением сказать, что самы глубокия, исходны пласт цветаевскоя поэтическон системы наиболее эксплицитно вырахен в поэме-сказке царо-девииа. 1 с предельнон четкостью он раскрывается как на уровне ее сюжета и состава персонажен, так и на уровне семантики. Эта четкость, однако, проистекает не от какойлибо метапоэтическои установки в поэме (данное явление здесь вообще не имеет места), а оттого, что тут выведена та народная (или шире - мифологическая) глубинная основа, на котороп поконтся вся Цветаева.

По своен структуре поэма очень проста, как всякая сказка, но ее мифологическия заряд, как и сказки, требует соответствуютих разъяснения. Поэтому, думается, проме всего будет начать с разбора не сюхета, а персонахен.

1. ПЕРСОНАХИ.

мир поэмы не перенаселен, но и не так ух пустынен. Есть здесь Царевич, его отец - подземны царь, вторая хена царя - Мачеха царевича, их воинство. Есть здесь царь-девнца и ее вонска со своеи генералицен. Есть, кроме того, персонифицированнья Ветер, есть море и есть еме воздушные и морские обитатели. Все они так или иначе соотнесены в первую очередь с царевичем, и с ним именно связана вся их "сюхетная" активность. Поэтому вопреки заглавию поэмы ее центральньм персонахем является скорее именно он, чем царь-Девица.

Царевич - персонаж самын странны. В отличие от остальньх єму чухда какая-либо активность и какое-либо влечение. На протякении всех событин поэмы он пребьвает в бездеятельном, сонном состоянии. Полная отрешенность от "мира сего" дополнительно углубляется его пристрастием играть на гуслях (ср. 354) и к прогулкам по морским зыбям на парусноя лодке (ср. 386; 414). Разгадка его странностея кроется, несомненно, в его происхождении, в генетике, а точнее в родителях: царе и перво его хене, т.е. матери царевича. 


\section{1. ЦLAP B}

В сохетном отноиения Царь - персонах по краинеи мере второстепенның: С ним не связано ни одно из события поэмы. Дахе соверпаемы им обряд бракосочетания сына, Царевича, со своеи второя женои, Мачехо царевича, - не столько событие с его участием, сколько еме одна характеристика его самого. Зато в семантическом строе поэмы он занимает едва ли не главное место: в нем в первую очередь кроется ключ к пониманию мира поэмы вообме и образа царевича в частности.

Это отнюдь не значит, что он семантически сложен. Наоборот он прост, и дахе моносемантичен. Дело только в том, что это не привьчны моносемантизм, а ми - моносемантизм, и другое - мифологизм, ярко вьрахены в оформления его образа, и уже с первого с ним "знакомства" (Ночо өторая, $371-374):$

Сидит Царь в нутре земном, ус мокры щипет, Озирается кругом - чего бы вытить?

Уж питб-пито́, - полцарства прбпито!

А всё как быдто чегои-то не дбпито.

Как боярышни пред грозным пред отиом,

вкруг него все́ чарочки кольцом.

Тут и турецкие, тут и немецкие,

Архиереяские да венецеиские...

"Быстрее глоточки моея,

Eн-ен, вы сохнете!

Пью не напьюсь, лей не жалея,

А все пустёхоньки!" (371)

1.1.1. По своен локализация ("в нутре земном") он - Царь подземны, властелин подземного цирства, или, согласно мифологичес-

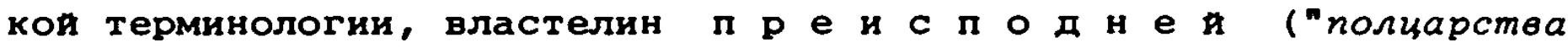
прбпито!"). Последнее станет очевидностью в свете других его сво-ств, а пока существенно то, что он локализован в глуби-вннзу и в замкнутом пространстве ("в нутре").

1.1.2. И по локализации ("в нутре земном") и по своему внеш-

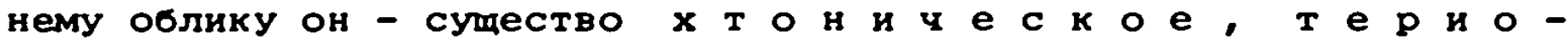
м ○ $\$$ н $О$ е. В приведенном Фрагменте об этом свидетельствуют "ус мокрың" и глагол "щипет", а позже - настоичивое упоминание в связи С ним красного цвета и разнкх животных и насекомых.

а. Из насекомых непосредственно и косвенно упоминаются в поэме клоп, комар, паук, муха и пчелы.

Пчель в этом ряду занимают особое место ёу ғх удоминдание при- 
звано указьвать на мистификаторство подземного мира и на мир ему противостояшин: то, что сљшит Царевкч принкмая за гуд пчел, оказывается, исходит от "слюнки" (поцелуя мачехи):

Не морскои, не гусельны:

Пчелиньम - гуд.

$[\ldots]$

Нет, не пчелки розанам

Ведут дозор.

то с печатью грозною

у слюнки - спор. (410)

К Царю, правда, эта сиена прямого отношения не имеет. Но косвенно соотнесена и С ним - через причастность к аналогичнои ему мачехе и к подземному локусу вообме, с однон стороны, а с другон - через явную связь мнимых пчел со "ллюнкон", т.е. с 'мокротой'

Значительно больше связен с образом Царя в случае упомннания о пауке. Прехде всего он - одна из личии "шептуна" или "дядъки" стерегущего Царевича, притом наиболее вредоносная: он "крестовик", "теремноя" и "мушиная кровь" (415). В этом случае с Царем его роднит как принадлехность к замкнутому локусу (царь пребывает в "нутре" и к тому еме в "шатре", а этот - "теремнон"), так и 'кровохадность' (этот - "мушнная кровь", Царь хе сравнивается с клопом: "Лик - wap сургучовьн, краскее клопа": 400).

В другом месте "дядька"-паук однозначно связан с 'мокротон':

Размахнулся всею силоя рук:

Ан улк нету старика - паук!

Как притопнет, поглядев вострб:

Ан уг нету паука - мокро! 428

Интереснее всего, однако, то, что и этот паук подключен к сквозноя к $о$ м а $\mathrm{p}$ и н $о$ теме подземного царства:

и тоненько так, комарье струноя:

"не простон я паучок, - теремноя!"

В основном тексте поэмы комариная тема в образе царя почти незаметна - она замаскирована упоминанием Камаринскои:

- Эн, холопы, гусляра за бока!

чтоб Камаринскую мне, трепака! (398)

Маскировка эта, однако, прозрачна. Дело в том, что о Камаринскои была ухе речь во время обхода покоев царицы и что там была речь также и о комарах:

Что за звон такоя комарин,

Что за звон такон претонкия?

То чесальщишы Камарин-

скую шпарят на гребенках! (376) 
В финале же поэмы, В Конце, царь назван комаром эксплицитно: Нет, - ты не царь, скажи: Комарь .

Кровосос ты, ишь раздулся С наше кровушки! Где крестьянские все наши телочки-коровуики?

$[\ldots]$

Чтоб спознался Царь крестьянския с нашнм горемМы Царю-то Комару-то - брюхо вспорем! (433)

итак: все упомянутые в поэме насекомые хтоничны, все они связаны с кровью и мокротон, а по своея сути восходят к комариному началу, т.е. $к$ самому Комару или царю.

и еме одна деталь: комариное явно связано здесь с в $о л 0$ С а м и ("чесальниш", "гребенки") и со С к ты, [...] Где [...] телочки-коровупки?").

б. Соотнесенные с Царем животные и птищы также подобраны по принципу их хтоническоЯ, потустороннея природы: индюк-кохинхин, петух, кориуны, слон, лев, дракон, пес.

Включить в этот ряд индюка, слона и льва позволяет Цветаево их подчеркнуты экзотизм. Но это далеко не достаточны критерия - поэма есть схазка, и ухе этим самым на всех свонх уровнях ее мир долкен быть необычен. Отсюда чрезвычанно показательны дополнительные приемы, при помощи которых Цветаева переводит их в ряд суместв мертвого царства.

Лев здесь естественен в том смысле, что по распространенным представлениям он - царь зверея, символ царско власти вообие. Но, по тем хе представлениям, он одновременно и суяество солярное, воплощение жизненно силы. Подземны Царь есть Царь, и лев, так сказать, ему полагается. Он же, однако, Царь п о д з е м н ы А, а в этом случае лев ему не полохен. Цветаева поступает со свокм львом очень просто - перекранвает его: "Сын ли С батюикои, аль с львом красньм - лань?" (399).

Иншок - амбивалентен. Но и амбивалентность, согласно Цветаевскому замыслу, подземному царству и его царю не присута. Она упраздняется погашением прнчастности $\mathrm{K}$ нехелательному в данном случае другому полюсу - $к$ полюсу оплодотворяюмего, солярного: "Разгасился - что индок-кохинхин" (373), где "раз Г а с и л с я" намеренно противостонт охидаемому по языковон инерция "раз $\Gamma$ -

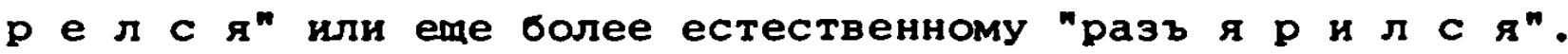


Пес - сумество лунарного цикла, поэтому значительно блике подземному царству. Авторского вмешательства эдесь нет. Зато есть сюжетное вмешательство царя:

Подымаятесь, воры-кориуны-мятехники! для костра свово я сам припас валехнику. Двери - настехь - все́! В клети эаперт пес! Частоколы сам по кольику разнес!

Рухая-рухая, наше царство развалённое! красны грянь, петух, над цами несолеными! Красны гряиь, петух: - Царь-кумашның нос Всё, как есть, свое именьице растрёс! (398)

Пес nonaл здесь в один ряд с дверьми и частоколом по признаку 'эащиты' от расхимения, а шире - по приэнаку соблюдения миропорядка. 2 интересно, однако, что царь не до конца властен иад псом: в отличие от распахивающихя по его признаку дверея (так, видимо, мохно считать "Двери - настехь - все!") и от самолично разрушенноя ограды пес только "заперт", а не, скахем, иэгнан или убит. Это бы означало, что пес является носителем некоего противостояmего Царю самостоятельного начала.

Упоминание пса и его обособленность сильнее подчеркивают родственность "воров-кориунов-мятехников" и "петуха" . И кориуны и петух окаэьваются вариантамн одноя и тон же разруштельнон (расхитительноя) стихии. ${ }^{3}$ в буквальном смысле эта стихия есть о Г о н в: упомннается "костер" и взывается : "Красныя [..] петух", обозначающи именно огонь, пожар.

На первы взгляд связь коршунов С огнем по краянея мере необычна: они ведь наэваны "ворами", а воры, как известно, орудуют охотнее всего в темноте. На более глубоком, мифологическом, уровне эта связь, однако, закономерна: там в о $\mathrm{p}$ является похитителем огня и света, с вет о ( о г не) уносите л е м. не противоречит мифу о похимении огня также и второе имя кориунов - "мятехники", т.е. взбунтовавшиеся, восставшие против васти, установленного порядка и угрожающие ему падением. С этои точки зрения аппелятив царя к коршунам может читаться не только как прк-

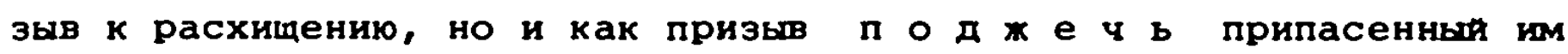
валежник для костра. Сам Царь, как следовало из формы "раз г а -

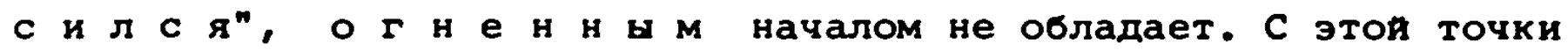
зрения более понятен также и "заперты пес": теперь позволительно в нем видеть также и устранение $\pi$ у н н $~ г$ o начала и этим самым потенциального лунного $\mathrm{C}$ в $\mathrm{e}$. 


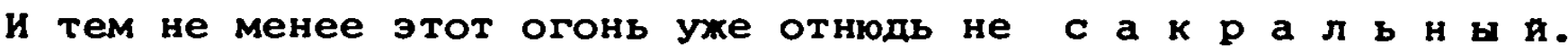
Он - только "красны петух", т.е. сохранил только свою истребительную, разрушительную силу, и потерял созидательную силу "всепоедаюмего" свяменного огня. На это указывает как костер из в а $\pi$ е жи и ка, так и "щи не с о $л$ е н ы е". одно и другое проявления мертвого царства. 5

Во всех мифологиях преисподняя, мертвое царство - не хаос, а упорядоченны, строго организованның мир. ${ }^{6}$ Как ни парадоксально, но мертвые здесь х и в у т, естественно, по особьм законам этого мира. Распахнутые двери вовне, устранение границ (тут - "частоколов") мохет обозначать конец мертвого царства, выход в царство жизни. Но двери и ограды амбивалентны, их знает также и жизнь. Тут они раскрываются или временно разрушаются в двух случаях: при появления в хизнь, т.е. при рождениях, и при уходе из жизни, т.е. при смерти. В случаях долгои и мучительнои смерти, дабы облегчить дуие уход в сво мир, часто распахиваются не только двери или окна, но разрушается пымоход, раскрывается потолок, снимаются заборы. 7 в разбираемом Фрагменте цветаевоя нет места ни для одного, ни для другого: здесь подземнш мир раскрывается для полнеңшего

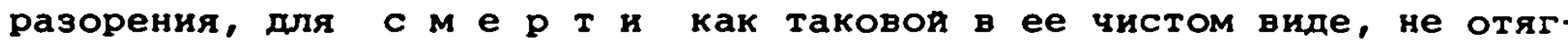
ченном каким бы то ни было бытием ("В клети заперт пес!" свидетельствует об этом ярче всего), для кромешного хаоса, тем более поразительно, что он построен на идее саморазрушения.

В сиене, когда на пытавшегос встать царя обваливается его шатер, есть и такие строки:

Как черт - красньм машет,

шатер царски пляшет.

Аль, мохет, в нем слон какоя?

Аль, мохет, дракон какон?

Аль, мохет, все сон какон?

чтоб в умишке нам самим не порешиться,

мы проидем пока на половиночку к царице. (374)

Если упоминание "дракона" в контексте только что упомянутого "черта" не удивляет, то упоминание "слона" в этом обществе заставляет задуматься: ведь дахе не в индияских, а в европеиских символических интерпретациях он никак не соприкасается с демоническими коннотациями. 8 ответ, думается, содеркится в синтаксических особенностях этоһ строфы. Сравнение с чертом вьрахено изъявительньм наклонением и повествовательньм предложением. Дракон же и слон

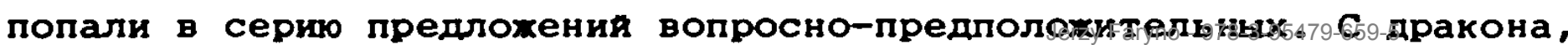


таким образом, снимается связь с чертом. Это усиливается еме демонстративноя анафороя альтернативного "Аль" ('или же'). В результате за слоном и драконом сохраняются лишь признаки 'необынного', 'непонятного', 'днковинного', ("дракон" - такой хе ориентализм, как и "слон") и 'н е в выдвигается на первын план благодаря завершающему вск серио "сну" . но кроме этого "сон" вводит и более существенның смысл: навахдения, неопознаваемости, призрачности. Содержнмое шатра, оказывается, - ни одно ("дракон") и не другое ("слон"), а только некая видимость.

Не менее значям в данном случае и отказ от дальнеңшего опознавания, которое иначе грозило бы умопоменательством (см. последних два стиха). Пляска шатра с неопознаваемым содержимым и умогомешательство вплотную подводят к смыслу 'пляшушеम смерти'. В римскон традиции, например, оба этих аспекта - смерть и помешательство-пляска - объединяли в себе ларвы, которыми впоследствия стали наэьваться и маски, ставшие атрибутом ритуальнор пляски смерти. 10

Царь, таким образом, получает здесь вид аморфноя сущности, С м е $\mathrm{P}$ т как таковои (случаяно ли, что даже "черт" употреблен эдесь в качестве сравнения? - судя по всему, он - некое более глубокое начало, чем черт) 11

В. И сам царь и его ближаяшее окружение постоянно атрибутируются в поэме к $\mathrm{p}$ а с н ы м цветом: шатер его - "кумач" (373) и "красныр" (374); вызываемын петух - "краснья" (398); лев, с которым он сравнивается, - "краснын" (399); он сам - "кумачовьд нос" (397), "Царь-кумашнын нос" (398), "Лик - шар сургучевын, краснее клопа" (400), "гора кумачовая" (400), а в финальном Кокие получает наименования "Кумач" (434) и "Царь-Кумач" (435).

В красном-кумачовом цвете повторяются все основные сводства царя: его царския сан; натура пропонцы - согласно сюжету больше всего он занят погломением спиртного, вина, и отсюда его "кумачовын нос"; кровохадность - он пропивает и разоряет свое царство, отсюда изобрахен "краснее клопа" и именуется "Комаром" (см.: 1.1.2.a.) .

Кумач, кроме того, сохраняя цветовую характеристику Царя, прочно эакрепляет за ним признак 'купца'. Кстати, слово "купец" не раз употребляется в описания Царя - ср.: 
и В Финале:

Выручая меня хоть ты, двор Гостиныл!

Аль в Груди, как на лотке, - одна Гниль?

- От купцов твоих, Кумач, - одна быль! (434)

В первом случае имеет место картина соблазнительнои пляски смерти (подробнее об этом нихе). Но пока в неи на первое место выдвинуто блудодеяство, торговля собственным телом или собственноя дупоя, если учитывать спиртное содержание "бутылочек".

Во втором сумность 'торговли-купечества'раскрывается шире и более определенно.

традиционно за торговлен закрепился ореол недостоиного, позорного занятия и воровства-грабежа. Он, в свою очередь, возник на основе древнеңшего генезиса эбмена-торговли как обмена судностями: "купить" означало "победить", "приобрести сущность противника". Традиционно же торговля перепоручалась иноземцам: разрешалось торговать свокм на ч у ж 0 земле, а на своеи - у у ж и М. Аналогична и судьба "гостя". "Гость" - это некто ч у ж О в, врахдебньн. Он становился С в О и м после обмена с хозяином суцностями - подарками, едой и Т.П. Это отразилось и на речевоя практике многих языков, когда словом "гость" называются и вор-грабитель, и купец, и визитер из загробного мира. Характер торговли как контакта с потусторонним миром, с преисподнеи, отчетливо проступает и в предпосланности ее чухим и чужо территории, рассматривавшеяся именно как преисподняя. 12

В этом свете призываемы на помощь царем "двор $\Gamma$ ○ с т и н ы " обнарухивает свою сущность $n \mathrm{p}$ е и $\mathrm{n}$ о д н $е$ н: он локус купцов-грабителеи, купцов-гостея, локус чужих, т.е. представителея "того мира". Попутно еме отметим явную вариантность этого аппелятива и ухе рассмотренного (в пункте б.): "Подымантесь, ворыкоршуны-мятехники! [...] Красның грянь, петух, над щами несолеHБMи! "

Архаическая же идея 'торговля = обмен сущностями' гольм глазом видна в стихе "Аль в груди, как на лотке, - одна гниль?", В подразумеваемом тождестве 'товара'и 'души' (того, что "на лотке", и того, что "в груди"). Здесь, правда, "гниль" соотнесена только с содерхимым "лотка" и поэтому сильнее акцентуирует "грабительсаи, воровскоя' характер торговли, но ретроспективно она вскрывает сущность царя. 
Легко эаметить, что в цветовоя характеристике царя преобладает словарь производның от кумача. Кумач - это не только цвет, но и ткань, Т о в а р. инауе говоря, на первое место вы двинута тут 'Т О в а р н а я' супность царя, его 'кумачовость'. И лишь теперь становится понятным, почему он назван "гороя кумачовон" (400), "холм-герон" (401), и почему его шатер "бахромчаты" (372), и почему "Был кумач тот не сменен - с коих пор!" (373; имеется ввиду ткань шатра, которыя обваливается на царя, когда тот пытается встать): царския товар-кумач - Гн и л, истрепан ("бах-

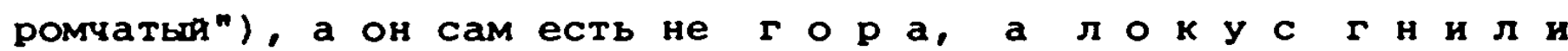
("гора кумачовая"; "холм-гора" как м г и $л$ а).

итак: кумач являет собо смертоносную 'купеческую', суцность Царя. Но это еме не все - с кумачевьм цветом чередуется в поэме еце и к $\mathrm{p}$ а н н . Что он значит?

Обвалившияся на царя шатер "Как черт - красньм машет" (374), что однозначно связввает красның цвет с дьявольским миром. В другом месте царь уподобляется льву, но красному (см. пункт б.). В этом случае лев не только приводится в соответствне со свокм эквивалентом, подземньм царем, но и выдает ино смысл красного - как эквивалента $3 \circ \pi \circ \mathrm{T}$ a: будучи солярным символом царя льву подобает быть именно золотым. Одновременно золото как металл и как вопломение богатства (сокровища, клада) в разных мнфологиях принадлехит подэемному миру и связано с хтоническими силами. 13 Более того: в тех хе мнфологиях и в народнон обрядности эаменителями золотого цвета выступают желты или красны, причем красны употребляется нередко как траурны цвет, как цвет смерти. 14 Поэтому цветаевския "красмий лев" вполне закономерен: в нем отсекается признак солярности и сохраняется признак 'богатства' с одновременньм включением его в семантическое поле 'смерти, преисподнея'. Известная нам уже 'купеческая' сумность царя и 'богатство' не противоречат друг другу. В связи с это темо есть у цветаево и еме две сумественные детали в "портрете" царя.

Спившияся царь причитает:

$$
\begin{aligned}
& \text { Кому я нухен - старья } \\
& \text { Пятиалтынныя - пара (373), }
\end{aligned}
$$

где появляется родственныя 'богатству' мотив 'деньги́', "пятиалтыннод" монеты. В буквальном смысле здесь речь о смерти и об обычае класть умершему медные монеты на глаза, в рот, или просто в 
гроб. Но слово "пара" переводит здесь монету в репрезентанта смерти, с одноя стороны, а с другон - в соответствие самого царя. "Пятиалтынны" оказывается двоиником Царя. И именно этот смысл и стоит за распространенным обрядом: первоначально сопровохдахиая мертвеца монета и была его дубликатом, его двонником. 15

Вторая деталь - уподобление царя сургучовому шару, когда тот упал в обморок, а царевич пытается его "охивить":

хлопочет вокруг тон горы кумачовон:

Лик - map сургучовья, краснее клопа.

"Ox, батюuки, - так и ушел без попа!" (400)

Слово "Лик" здесь не случаино - оно называет истинную суцность, так сказать, царского "тотема", потустороннего двонника. Сургуч, в свою очередь, - смолистое вемество, употребляемое для изготовления печатеи и при запечатывании. "Шар сургучовын" поэтому содержит в себе два признака - 'печати' и 'запечатывания' (признак ' смолисты" и эксплицитное "краснее клопа" очевидны) .

Признак 'запечатывания' соотносится со сквозным признаком 'закрытости' подземного царства, а этим самым связан со смыслом 'смерть' (детальнее об этом ниже).

Признак 'печати' же восходит к архаическои практике дублирования явлени мира, целью котород было отождествление этого явления (вещи, человека) с его тотемом и засвидетельствование присутствия этого тотема. С другоя стороны, такая печать - знак принадлежности $к$ тотему, $к$ потустороннему миру. 16

Сургучовы эквивалентен красному-кумачовому, а этот золотому, т.е. 'купеческому'. Так замыкается весь этот круг редитыкани.

г. Ус - всего лишь деталь 'волосатого'облика царя. В другом месте он показан в более полном виде:

- Веселитесь, наши верные народы!

Белогривын я ваш Царь, белобородың. (397)

Сама по себе такая 'волосатость' мокет быть как признаком 'сакрального', особенно в сочетании со старческим возрастом, на что здесь указывает дважды отмеченная 'белизна', так и признаком 'звериного, колдовского, загробного' (тогда 'белизна' с подраэумеваемым смыслом 'старости' вырахали бы причастность к 'смерти') . Характер 'волосатости' Царя указан тут эксплицитно: он - "белог р и в ы и $^{\prime}$ этим самым обнаруживает свою причастность к 'звериному' и родство с 'шерстью', 'мохнатостью' или 'волосатостью'. Ср. хотя бы перекличку по признаку именно 'мохнатости' (и 'старости') 


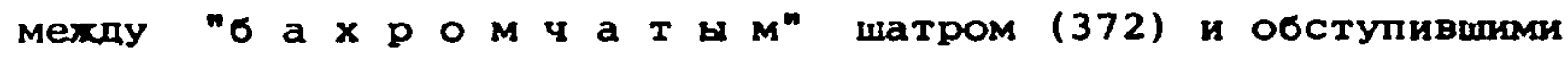
царя бутылками:

Лета́ми-плесенью седо захватаны,

Как леши, царь леснон, - гляди - мохнатые. (372),

А такхе уломинание "чесальниц" при обходе покоев царищы (376), В котором связь с шерстью очевидна. Кстати, в случае Царишы ее волосы вообще оказываются змеямн:

то не черных две косы, слуланки кроткие:

Две расхлестанных змеи - да с косоплетками! (401)

А в расшифровке сна царевича имеет место и связь волос со смертью, гибелью:

На хенском волосике

не один уж повис! (397)

Ус царя, таким образом, - показатель и хтонического и смертоносного начала. Тем более, что он еме и "м о к $\mathbf{p}$ и 17

д. В поэме мокрота непосредственно соотнесена с хтоническим и явно вредоносным - со "слюнкон" Мачехи и с "пауком" (см. пункт а.). Она же и разновидность подземноя воды и подземного вина, явных носителеи гибели, смерти. Ср. в монологе царя:

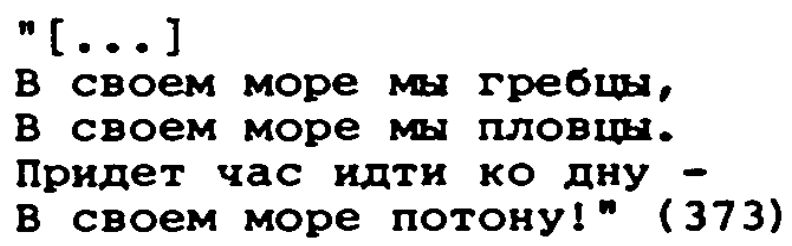

и несколько нихе - в описания сцены с рухнувшт на Царя шатром:

$$
\begin{aligned}
& \text { патер царя душит, } \\
& \text { Вино царя топит, } \\
& \text { уж не луки - а реки, } \\
& \text { Ух не реки - потоки... (374) }
\end{aligned}
$$

В таком контексте "Ус мокры" - не что иное как сама смерть, а точнее - смерть умеривляюмая. Этот смысл отчетливее всего виден

в следующих словах царя $к$ царице в сцене венчания:

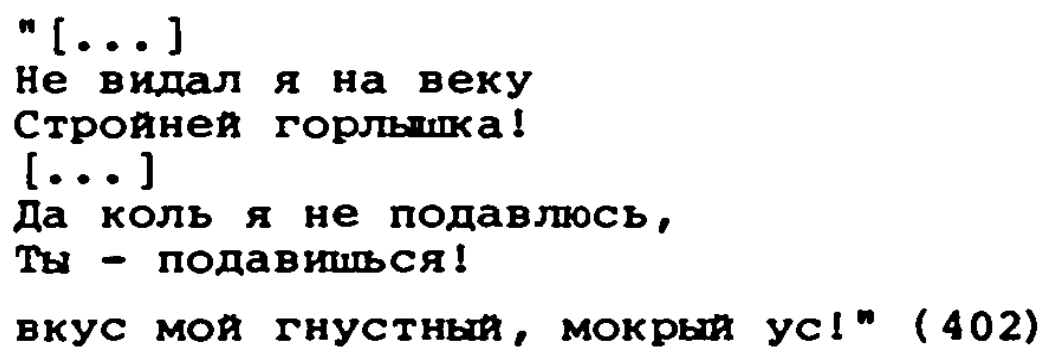

Смал 'умерщвляюпей смерти' станет понятнее, если учесть миФологическую основу разбираемого образа. Согласно мифологии (и сосласно логике поэмы) ус есть вариант волос вообще и поэтому мохет свободно читаться как эквивалент 'душ'. Мокрота же душе противо- 
показана: "стать водон есть смерть для души" "Ус мокрын", таким образом, получает смысл 'умершен душ' или 'мертвон души', которая мохет проявить себя, будучи ухе 'раствором', 'мокротоя', только в 'растворяюмен' или 'умеривляюен' деятельности или активности. е. В бытовом варианте жест "пощипывания усов" носит персеверативны характер, указывает на внешнюю бездеятельность, отклоченность от окрухения и сосредоточенность на себе. Этого значения не теряет он и здесь, но кроме него позволительно тут видеть также и эначение мифологическое. Жест "ципать ус" есть покручивание кончика усов в пальцах или подергивание пальцами, похожее на вырывание. Оба этих варианта семантически родственны. Покручивание волос-шерсти аналогично замбканяю-запиранию или завязыванию и знаменует прекрамение жизни, приостановку какого-нибудь процесса и задержание его в застигнутоя Фазе, в результате чего он становится вечно длящимся персеверативным рядом. 19 Подергивание-вырывание волос-шерсти - чаще всего эквивалент смерти, знак приобщения к царству мертвых.

1.1.3 Не менее "мнфологична" и поза царя - вряд ли случанно образ Царя открывается в поэме словом "Сидит [Царь в нутре земном]", кстати, демонстративно противопоставленном слову "Спит" (341), которое вводит образ царевича и, кроме того, вообме открывает нарративную часть поэмы-сказки.

"Спит" по отношенио к Царевичу, а потом "Сидит" по отношению К Царю, занимают место традиционного сказочного зачина "хил-был" . Интенция такоя подмены очевидна. С одноя стороны, она устраняет нехелательны смысл 'жить' и сохраняет только абстрактның 'иметь место, быть'. С другон же, благодаря экзистенциальному харктеру позиции зачина, вписьвает в "спит" и "сидит" неотъемлимы от персонахея способ их сунествования. Поразительна с даннон точки зрения последовательность Цветаевоя: дахе на событинном уровне поэмы ее Царевич никода по-настоянему не просыпется, а царь - не меняет сидячего полохения, хотя и бодрствует, т.е. все время развлекается.

Правда, раз царь пытается встать. Но эта попытка обернулась Tak:

Хочет на́ ноги - ан нет, тянет вниз!

$[\cdots]$

Разгасился - что индок-Кохинхин!

Д'как вцепился тут в шатер-балдахин! 
Был кумач тот не сменен - с коих пор!

царю на голову и рухнул шатер! (373)

[... ]

Как пошла тут дребедень стеклянно пылью!

Как тут чокаться пошти бутыль с бутылью! (374)

Сюжетно падение и невозмохность встать мотивируется опянением Царя. Но и сюхет и опьянение - не холостые приемы, а план вырахения глубинноя семантики произведения. Согласно этоя семантике, "сидеть" - единственная поза царя, всякая другая принципиально исключается. Смена позиции царя угрожает как ему самому, так и его окрухению, тем более, что они и его окрухение - изоморфны друг другу. Ср. хотя бы:

Ровно милочки - плясать перед купцом -

Вкруг него бутылочки кольцом.

Ух и горластые, цветные, красные,

Ух и бокастые, и ярыькастые!

Летами-плесенью седоя захватаны,

Как лешнд, царь лесноя, - гляди - мохнатые. (372),

где "горластые" перекликается с "глоточкоя", и "глоткои-гортанью" царя (371, 399) и "горльпком" Царишы (402): "красные" - с насыменностью красным-кумачовым как облика самого Царя, так и его шатра (см. 1.1.2.в.); "ярлыкастые" - с определением царя "шар сургучовы" по признаку 'печати', 'мечености' (См. 1.1.2.в.); и наконец слова "Лета́миллесенью седон", "мохнатые" - с 'волосатостью" и 'старостью' царя и его татра (см. 1.1.2.г.).

Само собо разумеется, что смена позы царем лишала бы смысла и его окрухение. Поэтому оно так агрессивно по отношению $К$ царю, когда тот пытается встать, и поэтому так активно восстанавливает его обьчную позицию:

Хочет на ноги - ан нет, тянет вниз!

- Эн, дорогу, мелкота, сторонись!

Попытался было с левоя ноги -

Снова навзнич повалили враги!

[... ]

Шатер царя дунит,

Вино царя топит, (373-374),

где "мелкота" и "враги" - не что иное, как окрухавшие царя бутылки, а семантически - бесовская свита его.

О неизменности сидячея позиции Царя ярче всего говорит эпизод его встречи с сыном: чтобы рассмотреть незнакомца (сына), Царь велит тому наклониться: "Нагнись-ка, друхок!" (399); а оч-

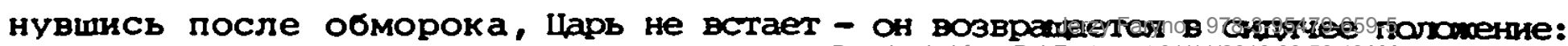


Смотрит: холм-гора-то кверху пошла!

А как пальчики пустил во всю прыть, Видит: Царь сидит, да ручкою: пить! (401)

Вставание царя ("хотм-гора-то кверху пошла!) - оборачивается всего-навсего сидением; гора - только "холмом"; верх же - все тем же низом (или точнее - имитациея верха: "кверху пошла!" - "сидит ${ }^{n}$ ).

Не менее показателен и Факт, что трн входе царевича царь продолхает сидеть. Дело в том, что Царь не узнает сына и принимает его за нездеинего: "Принц заморскин либо беглья монах" (399).

Вставание при встрече гостя, семантически связанного с преисподнен, было знаком его воскресения. Сидение ше - знаком преисподнеи. 21 Пренебрехительное оозначение "Принц заморския" свободно могло бы означать прибываюмего из потустороннего, загробного мира. Но мир Царя и есть тот загробны мир, преисподняя. Поэтому Царь не только не меняет свое позы (предподожительно сидячеи) при встрече царевича, но дахе наоборот - велит ему наклониться, т.е. приобщиться к царству смерти, в которое тот попал. 22

1.1.4. Подобно сидячеи позе и жесту помитывания усов приписанны Царю жест оглядки - "Озирается кругом" - также имеет 'смертельные' коннотации в мифологических представлениях. Этот мотив использован дахе в Евангелии от Луки (гл 17: 31-32): "и кто будет на поле, также не обраманся наэад: Вспоминаяте жену Лотову".

В случае Цветаевского царя дело обстоит гораздо слохнее. Его 'оглядка' весьма естественна и, в силу его 'смертоноснод' сумности, равнс как и 'смертоносности' всего подэемного локуса, где он пребьвает, казалось бы, ничем ему не угрохает. Тем не менее у цветаевои он все-таки "озирается", а 'смертельная' коннотация этого озирания никак не устранена, и этим самым не устранен и смысл 'опасности'.Отгадка данного парадокса выводится в тексте несколько позхе. Поэтому, не оперехая Фактов, укажем только, что она кроется в вине, такхе оэначаюмем 'смерть' (см. 1.1.2.д.), и что эдесь мы имеем образ смерти озирающеяся за смертью же.

Наречие "кругом", с однон стороны, дублирует смысл глагола "Оэирается", только обогомая его, быть мохет, ассоциациеи с мифологическим блухданием по царству смерти. 23

С другоя стороны, оно вводит новын признак - признак 3 а м К н У $\mathrm{I}$ О С Т и, которы несколькими строфами дальше получает свое развитие в описания бликаршего окружения Царя, Мегко-9аметить, что 
Царь "сидит" внутри нескольких концентрических кругов:

Как боярьшни пред грозньм пред отцом,

Вкруг него все́ чарочки кольцом. (371)

[... $]$

Ровно милочки - плясать перед купцом -

Вкург него бутылочки кольцом.

[...]

Как мальчоночки пред старьм пред бонцом -

Вкруг него бочоночки кольцом.

Каким кольцом?

Сплошнои стеноя!

Какон стенон, -

Bонна воннон!

$[\ldots]$

Прояех винных рек, бочоночных гор

Свон бахромуать раскинул шатер. (372)

Причем круги эти выстраиваются Цветаевон в определеннон последовательности: чем дальше от царя, тем эксплицитнее их сущность, и чем блихе к царю, тем эта суцность менее очевидна, но зато тем более yxacarona.

В направлении от Царя следуют: 'семеяның' круг - 'базарнокупеческия' - 'воинския', или - по иному критерио - 'порождаюиия' ("отец") - 'бесплодны" ("купец" и 'пляска блудниц') - 'убиваюция', 'смертоносның' ("боец").

В направления же к Царю, если учесть, что фактическое содержимое всех 'кругов' одинаковое, (вино), принцип упорядочанноси мохно определить как возрастание 'самонстребления': от внешних военных денствин до погломения собственного потомства ("чарочки" как "боярышни"-дочери перед 'выпиваюиим' их "отцом").

третия, 'воинския' круг тут же переводится в термины 'осады-тюрьмы' и 'вояны', т.е. активноя, разрушительноя смерти. В этом отношения чрезвычаино любопьтен тавтологизм "Воина воинои!", означающия и самое суть "вояны", и ее бесиельность: это вонна как таковая, ради самоя себя.

Дальше идет общая, "панорамская" картина локализации царя. идея 'круга', 'заточенья', как видно, повторена и здесь. "Промех винных рек" - некое подобие изолированного острова; "Промех [...] бочоночных гор" - такое же подобие изолированного острова ("горы" ведь состоят из наполненньх вином бочонков), но с признаком локализации глубоко внизу. 'Замкнутость' Царя усиливается к таму же "шатром" - дублирует 'замкнутость' по сторонам и еме вводит 'замкнутость" сверху • Шатер - "бахромчатьн" 
"бутылок", что "Как лешид, царь лесноя, - гляди - мохнатые" (372). кроме того своеи формон и цветом (он - кумачовын, красның) шатер перекликается и с содерхимым бутылок:

\section{Узнать-то надобно, что в них скрывается,}

Что цветом-радуго переливается! (372)

Царь, таким образом, здесь полностью изаморен своему окрухению. Поэтому он не только пребьшает в 'заточенье', но и сам есть 'заточенье'. Кстати, соотнесенность подземного царства с 'заточеньем, тюрьмоя, неволең' выведена эксплицитно в эпизоде обвалившегося шатра:

Взошел бы кто с воли,
Всяк диву б дался!
Шатер царския воет
На все голоса. (374),

а сам царь сравнивается с шаром наполненным кровью жертв ("Лик map сургучовыя, краснее клопа"; 400).

Но самое вахное то, что 'замкнутость' - неустранимое свояство подземного мира. Это лупше всего видно в случае вина.

Во-первых, оно здесь пребывает в замкнутом состоянии и лишь меняет 'сосуды': "бочоночки" - "бутылочки" — "чарочки" - "гло́точка" Царя (дахе горы эдесь "бочоночные", а винное море имеет "дно"; 373).

Во-вторых, оно само обладает свонством 'замыкать', 'окружать': концентрические круги сосудов с вином вокруг Царя, изолируюмин характер "винньх рек" и "бочоночных гор".

В-третьих, данному вину не свонственно свободное состояние вне эамыкающего его сосуда оно не возмохно и его нельэя вылить:

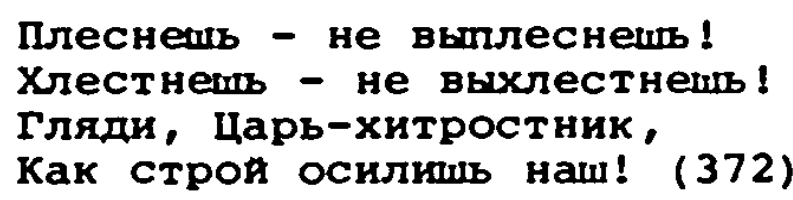

Это вино мохно талько перелить в инои сосуд или выпить, т.е. перелить в себя. И это абсолютно логично: если вино знаменует собо смерть и если 'замкнутость' тохе является смертью, то это и не мохет быть вино вы п л е си в а ю м е с я, т.е. пребываюmее в свободном состояния. Будучи 'смертью', оно долхно обладать 'замкнутостью'.

Не выплескиваюееся вино отчасти объясняет также, почему здесь Царь не мохет не пить. Но это только одна сторона его пьянства, другая, более сумественная, раскрывается в ином своястве царя. 
1.1.5. При описаня подземного царства, речь идет только о питье или о равносильном ему высасьвании (ср. упомннание насекомых, питаюмихся кровью - 1.1.2.а.; Мачеха, которая впиваясь в Царевича "Из сердца весь сок вытягивает" - С. 407) и вовсе не упоминается еда, дахе в случае свадебного веселья. Не едят, правда, такхе и в мире противополохном, т.е. В мире царь-девицы, но некие признаки еды все-таки там встречаются:

Ту песенку прослушала -
Как яблочка откушала.
Звон Струнны вобрала -
Как брагоя запила. (389)

Такая односторонность 'консумация' в подземном царстве покоится, несомненно, на мифалогическом противопоставлении "ешы" и "питья" как актов приобщения, соответственно, к 'небесному царству' и к'царству смерти'. 24 цагство смерти во многих случаях имеет акватически характер: его воды стремятся растворить в себе умершего, окончательно линить его каких бы то ни было признаков жизни; умерия же страдает от неугасимон жахпы и поэтому тохе стремтся утолить ее, т.е. тохе раствориться без остатка. 25

Цветаева не порывает с этод мифологическод семантикои питья, но, естественно, решает ее иначе. Главны образом - в случае признака 'неудовлетворенности', 'жақшы' 'неудовлетворенность' не имеет здесь какого-либо определенного вида и не является причиноя каких-либо страдания Царя:

Ух питб-пито́, - полцарства прбпито!

А все как будто чегойто не до́пито. (371)

Она почти иррациональна, а основная ее Функция - препятствовать прекрамению акта питья. 'Жахда', в свою очередь, вырахена признаком 'высыхания', но опять-таки не причиняющего никакого страдания, а только подстрекаюиего $к$ питью:

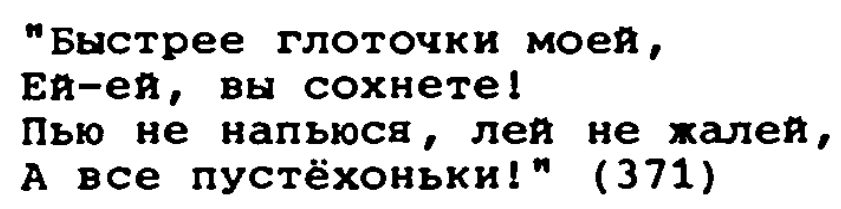

Более того: признак 'жажшы' тут очень ослаблен из-за демонстративноя эквивалентности 'горла' ("глоточки"), Царя и "чарочек" (к ним именно обращена речь Царя) ,.а несколькими стихами нихе такхе и "бутылочек" (они ведь тохе "горластые" - с. 372). На первое же место выдвинут признак 'высыхания' ("А все пустёхоньки!"). В результате 'пить' и 'лить, наливать' - эквивалентны, а их противо-

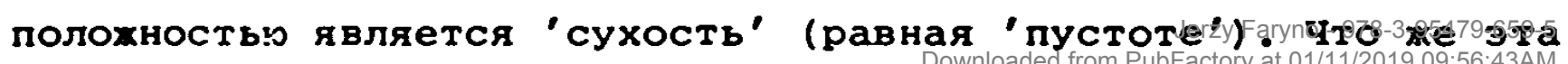


'сухость' значит?

В эпизоде встречи Царя с сыном есть следующие строки:

Сын ли с батюшкоя, аль с львом красным - лань?

Вся-то глотка-пересохла-гортань! (399),

а дальше - описание глубокого обморока ("смерти") царя, наступившего после вести о том, что он был женат и что у него есть сын. В обморочном состоянии царь становится "бревном-бревно" (400), и дахе вино в него ухе не вливается:

$$
\begin{aligned}
& \text { Льет в рот вино, назад - вино, } \\
& \text { К грудн припал, - бревном-бревно. (400) }
\end{aligned}
$$

После, приведенны сыном в себя, царь возврамается в прежнюю свою поэу и к прехнему своему занятию: "сидит, да ручкою: пить!"; "Пъет царь, подставляет" (401).

Показательно, что сравнение Царя со свирепьм львом не влечет за собон никаких лексем связанных С раэрыванием или пожнранием жертвы ("лани") : и в этом случае враждебные эмоция царя цветаева передает "пересохиен" "глоткои-гортанью". Аналогично построена и "гибель" Царя: он не "разливается", как можно было бы ожидать, а опять-таки становится вопломением 'сухости', как в эмоциональном, так и в физическом планах - бесчувственньм "бревном", куском сухого дерева. Вьвод напрашивается сам собон: 'сухость' знаменует 'гибель' царя. 'не пить' означает для него 'погибнуть', а 'пить' - 'поддеркивать свое сумествование'. Но в семантическоя системе поэмы вино эквивалентно 'смерти', и 'смерти' же эквивалентен царь. 'Не пить' означало бы в этом случае 'перестать быть смертью', 'потерять свою сущность', a 'сухость' надо бы понимать как 'смерть смерти', т.е. 'гибель' или 'отрицание' смерти. Так объясняется парадокс образа царя озирающегося на вино, смерти, оглядваюиеися на смерть же (см. 1.1.4.). При этом оглядка не теряет своен 'чреватости смертью' - она, как и сиденье или вино и питье, лиш способствует поддерхке сущности Царя. Так объясняется н решение Цветаевоя 'Гибели' Царя при помоми 'обездвихенности' и, предполохитепьно, выпряленноя 'лежачея позиция' ("бревном-бревно"), а такхе 'не вливающегося' или 'не проглатываемого' вина ("назад - вино"), т.е. при помощи неспособности оглядываться, сидеть и пить. но тем не менее не совсем еме ясно, почему 'гибель' царя выражена здесь "бревном", и почему в этом случае вино бездеяственно, не восстанавливает прехнея кондиции царя.

С точки зрения подземного царства гибелью может считаться Jerzy Faryno - 978-3-95479-659-5 
либо возвращение в царство хизни либо окончательное исчезновение. Подземное царство поэмы - мир полностью самостоятельның, а не, скахем, пронзводнья от царства жизни, существуюин за счет отмираюмего хивого. Во всяком случае эдесь нет никаких персонахен или хотя бы признаков сюда попавших умераих, выбывших из царства хивьх. Поэтому то, что с внешнея точки зрения, есть смерть, с точки зрения самого подземного царства есть своеобразная "хиэнь", имеюцая такхе и свою "смерть", или 'гибель'. Восстановление из 'гибели' рассматривалось бы тогда как "воскрешение". Будучи смертью, вино "воскрешать" не мохет. И так, по всеи вероятности, объясняется факт, что оно идет "назад".

'Гибель' Царя и воскрешение его царевичем мохно рассматривать как разновидность перехода или инициация. Но переход-инициация имеют смысл только тогда, когда состояние объекта или лица до лерехода разнится от состояния после перехода. 27 царь же нискоњко не меняется: по-прехнему "сидит" и по-прехнему имет "пить". Это эначит, что в данном подземном царстве никакие перемены-изменения не возмохны, что оно не знает альтернативньх решения. Оно мохет только либо существовать либо не существовать. Выхода в "хизнь" отсюда нет. Сравнение Царя с "бревном", думается, имеет именно этот смысл.

По отношению к Царю в поэме упоминается "валехник" (398) и - косвенно - лес, в сравнения мохнатости бутылок с "лейм, "царем лесньм" (372). По отношению к царь-девице - "дуб": она сравнивается с дубом, плачудим "сквозь толшу Каменноя коры древесноя" (393). Дуб здесь - древо хизни, древо солярного цикла. 28 г̃го наличие в поэме заставляет взглянуть на "лес" как локус 'смерти', а на "валехник" как на мертвое дерево, как на вопломение 'безжизненности', неспособности к порождению хизни. Более того: слова царя "для костра свово я сам припас валехнику. [...] Краснья грянь петух" (398) говорят о том, что "валехник" - последния этап разорения, истребления царства ("Рухая-рухая, наше царство развалённое!" - с. 398). "Бревно", без сомнения, родственно "валехнику". А это значит, что "обморок-смерть" Царя ведет не к древу хизни, а к мертвому дереву и в ничто (как бы на собственны его "костер").

1.1.6. Во время встречи Царевича с царем обнарукивается, что царь начисто забыл как о своем первом супрукестве, о том, что ца-

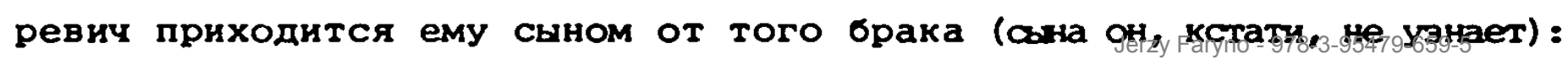




\section{"Времь, молочная лапша! каланча! \\ Прынц заморския либо беглы монах, - \\ Ни в каких я не повинен сынах!"; 399),}

так и о своем актуальном - втором - супрухестве. Напоминание об этих Фактах сыном и "убивает" царя:

" $[\cdots]$

Да иная нам тут малость вахна:

Коли сын, так твоя мать мне - жена?!"

и как взвоет - инда стекла дрожат:

"ох пропал-пропал, пропал-пропал, - женат!

Коль женат, так значит дочь, значит - зять?

Где х убивца моя, - твоя мать?!"

В земле пальчиком гусляр: "Вечнын дом! -

Ты в супрухестве живеш во втором".

Разом хмель пропал от этого сказу,

Растарапился, что сом пучеглазы,

Вздоху нету, - гляди лопнет шарб́м.

"Так в супрухестве живем во втором!.."

Дрохит сын, шепочет,

Вином Виски мочит,

Хлопочет вокруг тон горы кумачовон:

Лик - шар сургучовы, краснее клопа.

"Ox, батюшки, - так и ушел без попа!"

Льет в рот вино, назад - внно,

К груди припал, - бревном-бревно.

[... ]

"Коли вино не хочет в рот, -

Сам в руки гусельки берет, -

Бить мохет, Царь-отец моЯ,

мое - помохет средство!"

[…]

А как пальчики пустил во всю прыть,

Видит: Царь сидит, да ручкою: пить!

Отцу сынок налил

Пьет Царь, подставляет,

За кахдою чаркон

Сынка похваляет:

"И кудри-то - шапкон!

Стан - рюмки строннея!

Вот чтб бы без баб-то -

Рохать сыновен!

Зачем - жена?

На-коя - жена?

ты не жена,

Скахи, - ворна!

$[\ldots]$ 
Ох ты, Царь дурак, хенатия холостлк!

Приведи-ка мне, сыночек, жену:

Бить не стану, а разок - толкану!" (400-401)

После, так сказать, реанимация, Царь ведет себя по-прехнему. Кроме одноң детали: изменилось его отношение к сыну - "похваляет" его и даже называет "сыночком". Похвала эта, однако, особая: отмечает 'волосатость' ("И кудри-то - шапкон!") и сходство с 'сосудом для вина", С рюмкои ("Стан - ромки строянен!"). Не трудно увидетв, что это собственные признаки царя и его окружения: "Белогривын я ваш царь, белобороды" (397), "Как боярышни пред грозным пред отцом, Вкруг него все чарочки кольцом" (371). и это не только пьяны комплимент или бред, а деиствительное совмемение черт Царевича с отцом и его локусом: в нарративнои строфе именно Царевич наливает вино ("Отцу сынок налил", где деминутив "сынок" вводит оттенок пеиоративного уравнения обоих), и этим самым становится составнои частью подземного мира. Примирение с сыном, таким образом, есть результат обнаружения некоторон тождественности $\mathrm{C}$ нм. ЭтоЯ тождественностью или причастностью к подземному царству объясняется и мечта "Рожать сыновен!" (ср. третье кольцо из бочонКов, что обступают Царя, "Как мальчоночки пред старьм пред бонцом" - 372; см. 1.1.4.). Вывод прост: не сын "убивает" Царя.

Подлинно убияственное для Царя начало указано в условия, при котором царь не только мирится с сумествованием сына, но даже изъявляет готовность вообе "Рохать сыновен!": "Вот чтб бы без баб-то". Рождающая женщина-жена - вот что убивает Царя и вот с чем он принципиально не мохет примириться. А это вплотную подводит к пониманию самон глубоко супности царя.

В определенном смыле царь - сумество идеальное. Прежде всего он - царь, что может читаться как соответствие некоего бохества. Далее он изоморфен своему локусу. Потом и он и его локус имеют характер круга: он сам сравнивается с шаром (400), "круговым подносом" (397); локус расходится вокруг него концентрическими кругами-кольцами (371-372); шатер, в котором он пребывает, знаменует собон весь его мир в целом - его 'вселенную'. С другон, однако, стороны он одновременно и существо ушербное. Как царь - "Вином лишенның сану" (373); как изоморф локуса - не совсем самостоятелен (ср. эпизод с попытков встать - с. 373-374); круги-кольца являются также и ограничителями его свободы (ср. их сравнение

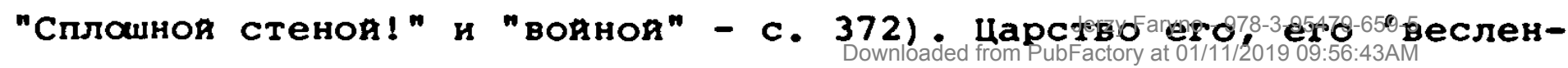


ная', и 'обветиалое'и к тому еме 'половинчатое': вторую половину занимает царица (374); он скован в свонх позах - ему принципиально нельэя вставать (373); он не властен над своим сыном: "Над тобою наш не властен приказ!" (398); и - самое главное - он не в состояния производить потомства ("сыновеи") без "баб" (401), т.е. без иного начала, без второи половины. Иначе говоря, его идеальность оборачивается его же ущербностью и слабостью. 29

идеал Царя - автодубликация, исключаямая какие-либо отличия от него самого. С однон стороны, это выражено требованием 'однополости', с другои - требованием 'сходства'. Венчая сына со своей хенон он категорически заявляет: "Да чтоб тот внучонок $C$ мекя бил скятой!" (406). 'Однополость' же понимается им исключительно как мухская, женския пол принципиально отвергается. Напомним в связи с этим еме раз: речь о "внученке", а не о внучке; похелание "Рожать симовей!", а не дочерен; паника на весть о жене и еме более паническия вывод "дочь", а не сын ("Коль жена, так значит - дочь, значит - эять?" - С. 400); винопитие как 'чадопогломение', но опять-таки оформленное в терминах 'женского пола' ("чарочки" как "барьшни"-дочки, а "бутылочки" как "милочки"-прелюбодеики - $c$. 371-372; ср. кроме того: "Чем крысиныр хвост, да великия пост Лучше с чарочкой-сударочкой взасос!" - с. 398). Как видно, 'женское' не только отрицается, но и и с т р е 6 я я е т с я Царем. и еме существенно, что оно понимается им как 'враждебное' и для него 'смертоносное' (ср. смысл цитат выше: из двух смертей или гибелея, т.е. идуиих от 'святого' и от 'женского', лупше последняя, т.е. от "чарочки-сударочки") .

Жена для него - "вояна!". Вонна же - как мы уже отметили в 1.1.4. - имеет смысл разрушения, смерти. Но вино-"воина", имея характер 'мужского' и иэоморфного царю начала, акцептируется царем. В этом случае он сам есть 'вояна', воплопение разрушительного. Эта "вонна" является его конституантоя. "Вояна"-жена зато разруштельна для него самого, убияственна для него. Легко догадаться, что она долкна лишать его свонства идеальности и способности разрушать, умермвлять. Вот почему он взвыл "Ох пропал-пропал, пропал-пропал, - женат!" (400), уэнав, что женат, и вот почему мать Царевича он называет своен "убивицея". 30

Итак, сущность Царя теперь очевидна. Он - Смерть-Разрушение, забвение, а в самом обмем плане - Небытие. Бытие же, Память, 
Жизн-Роқденне (сын, первая жена) - его прямые антогонисты перечеркивающие его суть. Этим объясняется мечта царя "без баб-то Рожать сыновеи!", т.е. дублировать самого себя, быть вечным Небытием. Этим же объясняется и его спешка поскорее избавиться от нынешнеи жены и от сына, похенив их друг с другом.

1.1.7. Сам обряд бракосочетания выполнен по всем правилам наоборотного подземного мира - вместо налоя бочонок, "В персты по бутылке Сует вместо свеч", "Две чарки - в венцы!", вместо ковров - "Вину велю течь!" и поливание брачубнхся двояньм фонтаном вина (406). Но все это, так сказать, наглядная достоверность подземного мира. Нам же интереснее вскрыть его достоверность посуместву. и на этом уровне цветаева оказывается исключительно последовательноп .

Царь ревностно следит, чтобы венчаемве непременно поцеловались в уста:

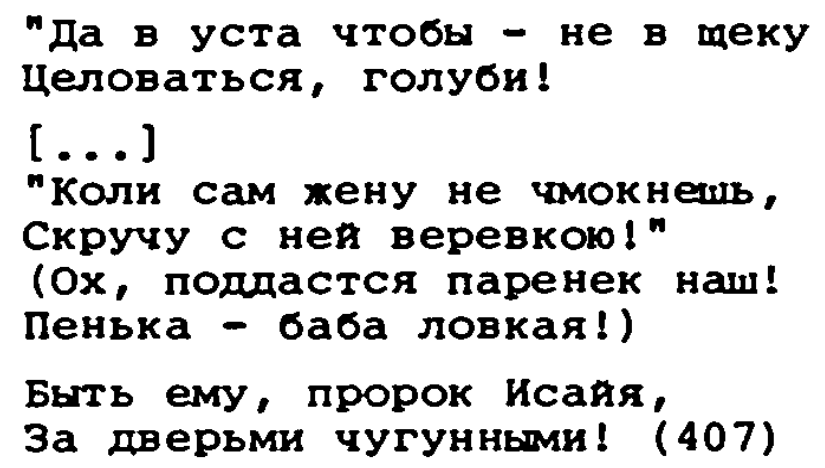

Целование в уста - 'поение-питье', чреватое смертью (см. позхе: почелуи Мачехи оказнается "слюнкон"-'мокротон' см. 1.1. 2.а. и д.). Этот же смасл стонт за угрозои "Скручу с неи веревкою!" и авторским уравнением "Пенька - баба ловкая!", где эквивалентнось "Связвает = умерщвлять" и "целоваться" выведена эксплицитно и еме раз повторена в образе 'заточенья-смерти' ("Быть ему [...] $3 а$ дверьми чугунньми! ").

Царь, как видно, энает, что делает, венчая сына со своеи женоЯ: Он не только избавляется от них, но и предает смерти-небытию сына. Этот свон акт он называет 'наградои':

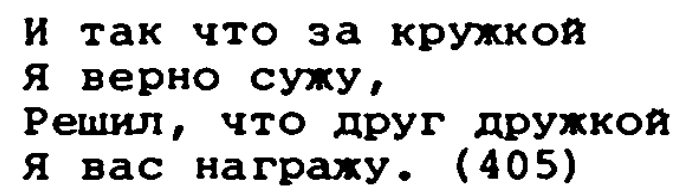

Правильное прочтение данных слов подготовлено как наоборотноя логикоя подземного мира, так и предваряюфими авторскими словами: 


\section{Глядит Царь на сына, \\ Глядит на жену. \\ Верней самострела \\ Глаз пьяных - прицел. (405)}

В их свете 'награждать'-значит 'наказывать', а 'судить' - 'выносить судебное заключение', а не просто 'приходить к выводу, полагать'. 'Награда браком' оборачивается 'наказанием браком'. Но это далеко не простое переиначивание обычно логики в потустороннем мире. Переиначивание, конечно, здесь есть, - только чего? Естественно: не брака, а наказания. Наказаняе браком - одна их арханческих Форм наказания преступника вплоть до убияцы. Выдача убияцы женшине и принухдение к производительному акту с неи воспринималось как выдача его преисподнеи, как предание смерти. После такого брака наказаннын (а вернее: 'умерщвленны') считался вновь рожденньм, очищенньм, и наступало примирение С ним, включение в свою семью. Эта основа брака-наказания полностью сохранена у цветаевод, с однои только разницея: 'возрождение' Царевича не предполагается; этот брак долхен закончиться полньм включением Царевича в мир Царя, Т.е. в царство смерти. И именно поэтому наказание - согласно наоборотнои логике преисподнеи - переименовано в "награду" (скажи Царь не "я вас маграху, а "я вас накаху", смысл брака поменял бы свов знак и стал бы равен смыслу древнего наказания браком, т.е. 'очищенио', 'спасенио') . 31

И тем не менее возрохдаюмия смысл мифологического брака-смерти сохранен и здесь. Это вырахено в требовании царя к брачующимся:

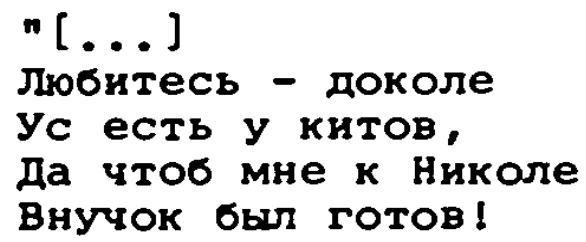

Однако это, как не трудно заметить, требование редупликация самого царя, а в конечном счете - редупликация подземного царства (см. 1.1.6.). Его же значение раскроется после определения "даты" события в поэме.

1.1.8. Датировка события в сказке не такой уж парадокс, как это могло бы показаться на первын взгляд. Естественно, здесь не мохет быть и речи о календарно историческо дате. Зато вполне закономерен вопрос об их соотнесенности с определенньм периодом

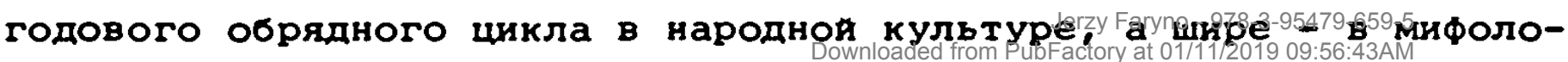


гическои модели мира. 32

Кпоч к расшифровке временноЯ приуроченности события поэмы наиболее однозначно указан в пожелания Царя "чтоб мне к Николе Внучок был готов!" (405). В русскоя народнои обрядности "Никола" празднуется два раза: "вешния" - 9 мая, а по новому стило 22 мая, и "зимния", так называеме "Николины святки", - 4, 5 и 6 декабря, т.е. 17,18 и 19 декабря по новому стилю. В связи с этим свадебны обряд, совершаемы Царем, происходит либо в августе либо в марте. О том, что дело происходит в марте и что "Внучок" охидается к "николиньм святкам", т.е. к декабрю, свидетельствует цепт ряд, казалось бы второстепенньх и чисто орнаментальных, Фактов. Самы показательныя из них - упоминания поста и Великого поcra:

\author{
Чем крысиның хвост, да великия пост - \\ Лучше с чарочкон-сударочкон взасос! (398) \\ "Видно, воду пьешь да постное ешь? \\ Что тебя-то не видел я допрехь?" (399)
}

При этом - в контексте упоминания костра и жокения лучины:

Для костра свово я сам припас валехнику. Двери - настехь - все! В клетки заперт пес!

[...]

Рухая̆-рухая, наше царство разваленное!

Краснья грянь, петух, над мами несоленьми!

Взял лучину Царь: "Нагнись-ка друкок!"

(Чуть-что всея ему копны не подкег!) (399)

Великия пост - пердпасхальның период, начннающияся за сорок шесть дне до первого воскресения (дня Пасхи) после первого весеннего полнолуния, т.е. не раньше 3 (16 Ст. Ст.) февраля, а кончаюмияся не позже 25 апреля (8 мая по ст. Ст.). Жкение лучины, в свою очередь, уже запремалось 25 марта по великорусским обьчаям, т.е. С наступлением весеннего равноденствия. Отсюда не трудно заключить что в поэме имеется в виду вем сревпостья или дни так называемой Смертельноя недели. В принипе это четвертая неделя Великого поста, но в разных регионах наблюдаются некоторые отклонения-сдвиги, приурочиваюцие соответствующие обряды к дням непосредственно предваряющим весеннее равноденствие. У восточных славян эти обряды известны под названием Костромы или Кострубоньки.

Николины святки и Смертельная Неделя, по народным представлениям, - кризисные моменты в поединке двух космических сил: Темноты и Света, Смерти и Жизни, Дьявола и Бога, и т.П. Это периоды 
особо активности первых - темноты, Смерти, Дьявола, хтонических суместв, загробного мира, ххаоса. К этому времени мохет разорваться последнее звено цепи, которо прикован подземнын Дьявол и которую круглы год он расковывает. С победо сил Света, Жизни, Бога или Неба вообме подэемная цепь восстанавливается, срастается снова. Этот Факт опознается как по перевесу дня над ночью, так и по первому небесному грому. Данны уровень мифа в Царо-Девиие не выводится, и тем не менее есть в поэме два факта, покоямиеся именно на нем.

Первь - в эпизоде любовного свидания Мачехи с дьяволом:

Стоит полоняночка

на башенноя вышечке.

Связалась, беляночка,

С тем самым с мальчишечкоя,

кто цепь нашу грубую

Раныше всех расклепал,

кто прехне супруга нам

шенны плат растрепал. (378-379)

Второи - в песенке царевича:

" [...]

Краснья круг заря прожгла мне,

Круг, пилающия вверху.

Есть мокм палатам - камни,

Есть невеста - жениху!" (389)

Первья гром знаменует не только срамение дьявольскоя цепи, но и вскрытие земного лона, а этим самъм активизацию плодоносямих потенция земли, в иных термннах - воскрешение жизни. Этот аспект мифа в песенке Царевича однозначно вырахен упоминанием "невесты" и "жениха", "камнея" и "палат" со смыслом 'построяки дома', прохиенного вверху круга как 'открытости' (в отличие от 'замкнутости-смерти'; ср. хотя бы обилие слов со смыслом 'плен', 'связанность' и финальное "Шеяны плат растрепал" со значением 'убияства', а также указание на 'смертоносность' "супруга" в эпизоде свидания Мачехи) и 'выхода из-(под) земли', а также смыслом 'наңденности' невесты и обоюдного их соответствия ("Есть невеста жениху!" в отличие от свидания 'не с тем' в случае мачехи: "Да нухен-то, нужен-то ЕЯ мальчонок другои!" - с. 378).

на уровне космических сил, на уровне их борьбы. Смертельная неделя - последние дни Смерти, а точнее - умирание Смерти. на уровне обрядности она ознаменована ритуалами изгнания Смерти, ее умерщвления. Для этого делается специальная кукла, которую тор-

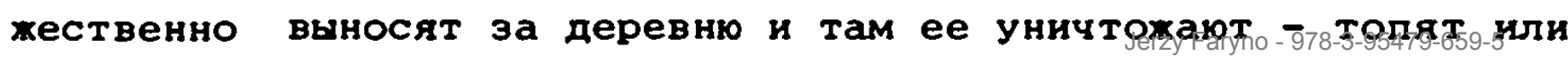


хгут, а взамен приносят куклу жизни (обычно особъм образом украшенное дерево). У цветаево все события происходят на самом абстрактном уровне. Поэтому здесь наблюдается только процесс самоистребления Смерти и одновременно ее самоподдерхки. Дабы продлить свое сучествование царь-Смерть не мохет не сидеть, не может не огляшываться и не мохет не пить. Но в то хе время он уничтохает и все свое царство, а этим самвм и самого себя. Так, видимо, должен читаться "костер" из припасенного Царем "валехника". Нет сомнения, что этот "костер" - вариант Костромы. С тем различием, что Царь может таким обраэом сжечь самого себя. С этон точки зрения и загадочное сравнение Царя с "бревном" (См. 1.1.5.) мохно рассматривать как соответствие чучелу Костромы (кстати, слово "кострома" восходит к "костер", означающему жестокую шершавую кору растения). 33

но в обрядах Кострома амбивалентна: она уничтожается затем, чтобы могла возродиться жизнь. Цветаевския Царь - моносемантичен. И тем не менее его гибель кончается там, где,по мифу,начинается хизнь:

\section{Веселитесь, наши руки даровые! \\ Все хлеба ваши я прб́пил яровые \\ Коли хлеба нет, будем есть овес: \\ Напитаемся - и личиком в навоз! (397)}

Примечательно, однако, что Цветаева демонстративно устраняет в этом месте возмохность ассоциагия гибели царя с началом нового вегетативного цикла: дальше идет речь о костре, потом эпизод встречи с сыном, обернувшеися обмороком царя, а затем эпизод венчания сына с мачехоя. Примечательно и то, что мачеху (свою хену) царь встречает наоборотными земледельческимн наяменованиями:

\footnotetext{
"Виноградинка в соку, Здравствун, зернътио!

не видал я на веку

Стронне горльшка!

Вся от пяточек до бус -

Bб как - нравншися!

Да коль я не подавльсь,

Ты - подавишвя!
}

Оттого что вкус мод гнустны, мокры ус!" (402)

"Виноградинка в соку" и "горльшко" перекликаются С вином и "горластымы" бутылками (372), а "зернышко" с "бусами", которые в подземном царстве знаменуют 'связанность-смерть'. Так с "виноградинки" и "зерньшка" снимается всякая связь с какон-либо плодонос- 
ностью. Продление своего существования Царь видит иначе: не как метаморфозу, а как редуппикацию. Такоя смхсл имеет заказ "внучонка" ,идентичного ему самому (406), и к определенному сроку - к николе. 34

Зимния Никола или Николины святки - самы опасның период в годовом природном цикле: Темнота, ночь заметно преобладают над Светом, днем, а их неравная борьба отчетливо наблюдается по пляске солнца, которое то останавливается, то наступает, то пятится, окончательно побехдая лиш к 6 января (по новому стилю). 35 В этом контексте приуроченность внука к николиньм святкам - не что иное как "подмога" стороне Царя-Смерти (ср. милитарное, военное осмысление Царя и окрухаюиих его бочонков-мальчиков с. 372 ; см. также 1.1.4. и 1.1.6.).

Смертельная неделя как эпизод годовон народноя обрядности всего лиш слабьи и второстепенны фон события Царо-Девица. Дело в том, что цветаева пишет поэму не о земноя реплике космическон драмы, а о само этоя драме, фигурно вырахаясь - о подлиннике. Поэтому и "даты" события поэмы определены значительно строхе, чем приблизительное время Смертельноя Недели. "Датоуказатели" же выведены ЦветаевоЯ эксплицитно: как при помомн выбора главных героев произведения, так и при помоми его "календарноя" композиции. Царевич - если не персонификация, то по кранне мере соответствие Л у н ы. Царь-Девица же - если и не само Солнце, то во всяком случае соответствие С $о$ л н ц а. Сюжетные отношения мехду

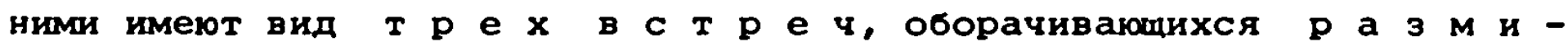
н О В ваниях глав-эпизодов Встреча перөая, Встреча өторая, Встреча третоя и последмяя. События, происходящие в подземном царстве, имеют место н О ч ь ю. А их композиционное отражение - счет главэпизодов именно по н О ч а м: Ночо перөая, Ночо өторая, Ночо mpemоя и мочо последняя.

В трех встречах-раэмнновениях Солнца и Луны и в трех ночах без труда опознается реальное астрономическое явление неомения, т.е. н $О$ в $о$ у н и я. Для пернода новолуния характерны два свояства. Это, во-первых, период наибольшего сблихения Луны и Солнца (у греков, например, он так и назьвается: бúvобоб, что буквањњо.оначает "сбликение", "схохдение"). од, когда Луна полностьо исчезает на три дня (ночи), после чего 
узкия серп молодоя Луны (кстати, у славян и у других народов эти три дня-ночи часто носят название "пустьх" или "порожних" днеяночея). 37

Четвертая неделя поста, а в народноя обрядности Смертельная неделя, долкна, таким образом, совпадать с первьм новолунием перед Пасхон. Ни Смертельная неделя ни Пасха в семантику поэмы не включены. Их некие признаки играют здесь роль только "датоуказателе" последнего зимнего новолуния, чаме всего приходямегося на начало марта. А это значит, что три ночи подземного царства совпадают с тремя "пустьми" ночами в жизни космоса, с продотхаюменся три ночи смертью Старо Луны, котороя в поэме соответствует подземны царь.

Но это не все. Неомении случаются двенадцать до тринадиати раз г году. Цветаева выбрала мартовскую. и, нет сомнения, что изза ее специальноя отмеченности или особой значимости.

Как и у многих народов, так же и у славян времянсчисление велось по лунному календарю, а годово вегетативны цикл кончался и начннался в период соответствующи началу современного марта. Многие исследователи дахе говорят, что древние славяне начинали год первого марта. Первомартовския новын год сохранился на Руси до 1492 года, т.е. в течение нескольких веков после перехода на лунно-солнечны календарь и дахе после приятия христианства $\mathrm{B}$ веке. Небезинтересно отметить, что в христианско системе начало года 1-го марта объяснялось тем, что именно 1-ое марта, к тому же пятница, было вообще первьм днем от сотворения миря. 38 иначе говоря, послепнее зимнее новолуние знаменует собо конец одчого годового цикла и начало очередного, конец или смерть мира и его вторичное возрождение. И это, думается, основная причина выбора Цветаево мартовского новолуния для события подземного мира поэм. но тогда следовало ы чтать царя не только как эквивалент Староя Луны, но и как эквивалент уходямего Старого Года; а этим самым и как эквивалент Творца-властелина Старого мира и дахе самого того мира. А это уже вплотную подводит к сатурническои природе царя. Николины святки, будучи периодом напряженнои борьбы между Темнотои и Светом, непосредственно предваряют начало нового солярного цикла, солярного Нового Года, которы многие народы праздновали 25 декабря (у римлян, например, это день рождения непобедимого солнца - Dies Natalis Solis Invicti) и которь хрнстианская церковь адаптировала впоследствия (с 354 годаn| 
дество христово. 39

Не надо быть особо проницательньм, чтобы заметить следуюмую любопьтную черту поэмы. Ее подземның мир имеет в основном языческин демоническия характер, но одновременно его демониэм обнаруживает и христианские влияния: наоборотныя церковның обряд венчания (406-407), наоборотны знак креста (412: "Слева - да направо, Снизу - да наверх..."), комунственные обрамения к церковным святым (406: "Исаия, ликуम!"; "Эх, Исаяя ты, Исаия, С небес свесь-ка голову!"), преэрительное отношение царя к служителям христианского культа (398: "крысины хвост" - о попах; 399: "Прынц заморския либо беглы монах" - о неопознанном сыне). Благодаря этим приемам подземнын мир получает статус не только демонического, но и дьявольского и антисакрального.

Аналогично строит Цветаева и небесны мир поэмы. Он тохе по своен природе языческин, но с положительньм знаком, придающим ему ореол мира сакрального. Сакральность же создается при помощи того же христианского репертуара: крещение Царь-Девицен спящего царевича (366), упоминание церковньх богослужения (352), обрамения к пророку моисею (344), Иисусу (380), царю Саломону (396), к ангельским чннам (423: "Силы - власти - престолы - славы"), 40 упоминание Иосифа Прекрасного (397) и - самое главное - присутствие в оружени Царь-Девицы таких персонахея как Егория $(350,416)$, Михаил Архистратиг (356) и по имени не названны,, но свободно опознаваемы пророк илья (425: "Гонит пророк конея. Гривами хлябь поwra. Пуще взметнулся бич В длани пророковоя").

мир поэмы распадается, таким образом, на две антагонистических системы: лунарную н солярную, дьявольскую и сакральную. В этом свете заказ внука к Николе обнаруживает еще один супественның смысл. Это не только "подмога" для борьбы с силами Света или Солнца, но и для борьбы с иньм временем (с солнечньм Новьм Годом, с солнечным календарем) и с сакральньми небесными силами. и не исключено также, что здесь непроизвольно обнарухил себя конфликт мехду древнеиним миропониманием и более новым, только отчасти адаптированными, напластованиями солярно-христианскоя модели мира.

1.1.9. Полохительное упоминание Николы Царем (в отличие от комунственнкх упомннанин других имен христианского культа) и заказ внука как ооственноя катия или двояника именно к Николе открывает еще одну перспективу для понимания мифологии поэмы: позволяют опоз- 
нать в образе Цветаевского Царя образ самого св. Николы, но не только - такхе и передавшего Николе многие свои качества более древнего славянского мифологического бохества велеса-волоса.

Эквивалентность мехду Николон и Велесом-Волосом в славянских традициях и особенно в русскоя разработана ухе вполне детально. Поэтому здесь мы остановимся на совпадениях Цветаевского Царя ухе с велесом-николор. 41

а. "Нарухность" Царя перекликается с "нарухностью" Велеса и николы по нескольким признакам.

Прехде всего это - 'волосатость' Царя (см. 1.1.2.г.). Волосатость Велеса и николы, конечно, бесспорны, но дело не в этом, а в том, что и Велеса и Николу даннья признак прочно связывает С дьявольским миром вообще и с леинм в частности. 42 Более того: по ряду свидетельств борода играла роль своеобразного "пропуска" на тот свет - она требовалась для отчета перед св. Николон, часто понимаемого как водитель душ в загробном мире. С этон точки зрения не кахется случаянон царская похвала царевича "и кудри- то - шапкоя!" (401) в момент их примирения и особенно ее первоочередность по отношению К, казалось бы - наивахнершему для царя, сходству царевича с "рюмкоя" ("Стан - рюмки строянер!"- с. 401).43

Отмеченная раньше навязчивость 'красного-кумачового' цвета в облике Царя указывает на связь Царя с подземньм богатством-золотом, с чертом, а в итоге - со смертью (см. 1.1.2.в.). Аналогичны и связи Велеса и николы: оба связаны со смертью, оба связаны С золотом или богатством-прибылю, и, наконец, оба они связываются с красным лешим, а многие европенские соответствия николы наряхаются в обрядных хохдениях чаме всего именно в красное. 44

В сидячем образе жизни Царя, В его невозмохности встать и в насильственном опрокидывания ("тянет вниз!"; "Снова навзничь повалили враги!" - с. 372; см. 1.1.3.) позволительно видеть вариант мифологическон $\mathrm{x}$ р м $о \mathrm{~T}$ хтонических существ. Тогда и этот признак Царя перекликался бы с хромотон Велеса и николы. В славянском фольклоре хромота приписьшается николе не так ух и редко, 45 но особенно показателен для наших наблодения случая отпиливания ног у иконы николы с целью предотвратить ее уход. 46

С Велесом-Николои роднит Царя такхе и его связь с 'печатью' ("Лик - шар сургучовыя, краснее клопа" - с.400; см.1.1.2.8.). у николы желтая (золотая) метка на лбу появляется несомненно 
вследствие победы над ним Егория и знаменует его приобщение $к$ царству мертвьх, к царству велеса. 47 то, что царв изобрахен у Цветаево не с меткои, а как "шар сургучовын", т.е. не с отпечатком, а в вице самон п е ч а т и, еме показательнее: он здесь не столько вариант Велеса, сколько сам велес. Метка (отпечаток) как таковая появляется в поэме на ином ее персонаже - царевиче, которың, правда, пркчастен к мертвому царству и к Царю как его сын, но С ним не тохдественен. И эта метка Царевича чрезвычаино показательна:

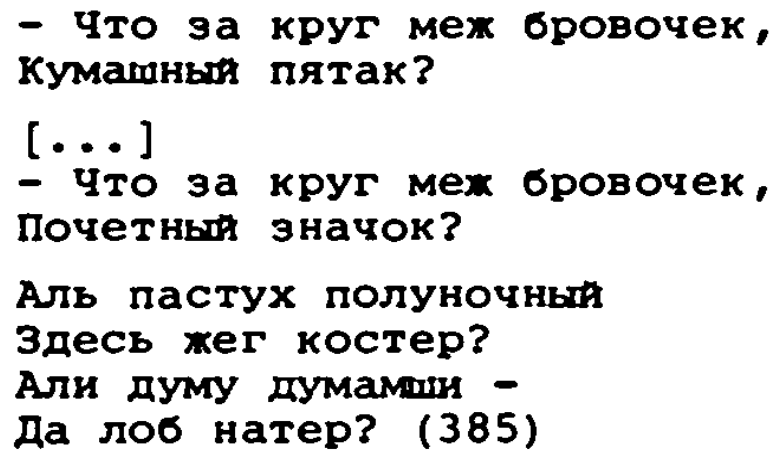

Во-первьх, она получена в результате объятия, борьбы с Мачехоя, женским соответствием Царя. Во-вторых, она "кумашная", т.е. присущая царю и его локусу (см. 1.1.2.в.). В-третьих, В неи налицо как связь с золотом-деньгами, так и со смертью ("пятак"; ср. смысл "пятиалтынного" - двонника Царя, оговаривавшияся в 1.1.2.в.). И в-четвертых, наконец, она эксплицитно связывается с понятиями

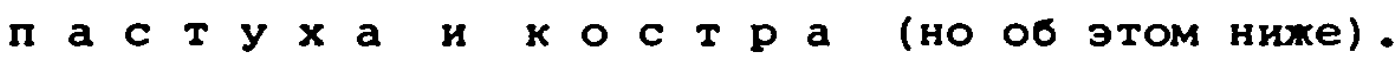

б. Связь Царя с насекомвми мы ухе обсухдали (См. 1.1.2.а.). Теперь отметим, что в поэме они эквивалентны иным помомникам Царя или его второи жены (Мачехи) - змеям. Ср., например, вырахение "стары змен-паук" (364) о дядьке Царевича, призванного стеречь юношу и никуда его не отпускать. С этон точки зрения интересно, что С насекомыми связан также и Велес, в частности - С комарами, 48 и что со змеями бывает связан еме и никола. 49

в. Как и Царь, Велес и никола ведают потусторонним, загробньм миром, царством мертвых. Причем в этом случае характерно, что никола является антиподом св. Михаила, ведающего, в свою очередь, раем, миром небесным. 50

Обладая такими же, как и Велес, хтоническими своиствами, Никола естественным образом свяэывается в народных представлениях С земньми и подземньми водами, а также с огнем. В случае огня никола выступает как его противник, как 'огнетушитель' (ср. о царе в 
поэме "Разгасился" с. 373), но опять-таки как огня небесного. 51 Отношение же его к земному огно, равно как и к водам (кроме очевидноя причастности к ним) еще, однако, не ясно. Зато Велесу свояственно стяхение и замыкание вод (что, несомненно имеет свод отзвук в безостановочноя 'выпивке' Царя ), а такке обладание собственным сожигаюмим (истребительным) огнем (ср. упомннание в поэме "костра свово" в случае царя и "пастуха полуночного" в случае царевича как варианта иссушамего губительного жара-сухости - $c$. $398 ; 385 ; 414) .52$

г. Цветаевския Царь обнарукивает целья ряд сходств с Велесомниколоя и по своям Функциям.

Как ухе говорилось (см. а.), велес и никола связаны с богатством и накоплением. Отсюда их покровительство торговле и купцам. 'Купеческая' же суцность царя в поэме вырахена эксплицитно (см. 1.1.2. B.).

Как акватические существа Велес и Никола покровительствуют также мореплавателям. 54 Ср. мотив 'мореходства', 'гребли' в монологе царя:

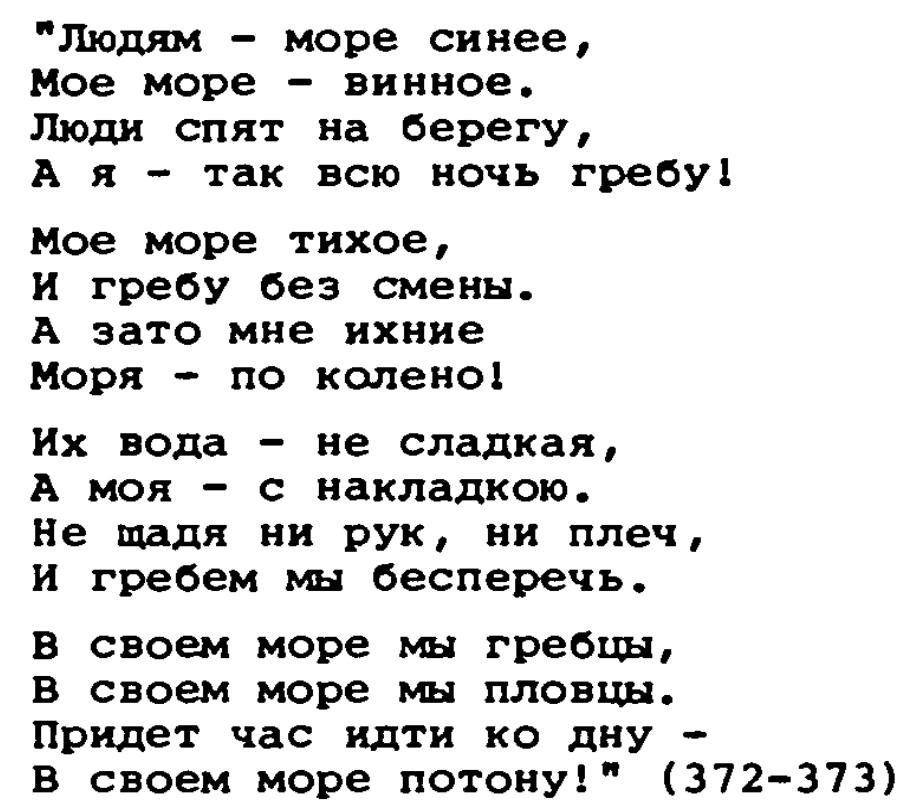

Характерно при этом, что 'гребля' Царя изобрахается как вечное скитание, как плавание без цели, что преврапает его в некия архетип моряка, в чистую идею мореплавания и как бы уравнивает с самим покровителем (Велесом, николод).

Совпадая со св. Михаилом и даже вытесняя его, Никола наследует от Михаила Функцию покровителя ратного дела. 55 Эта функция, естественно, сохраняется за ним и в случае контаминации с Велесом, на этот раз, однако, С противоположным знаком:Јеакупризаниямотив- 
ника Громовержца или - в его христианском варианте - пророка ильи либо Георгия. И эта черта, т.е. связь с вояноЯ, своиственна иветаевскому царью (См. 1.1.4.).

д. Велес - скотия бог. Никола, аналогично Велесу, - также покровитель скота. С ним связана м и К Л ь и и н а, жертвоприношения скота как на зимнего, так и на вешнего николу, а также в случаях падеха. 56 одновременно он связан и с земледелием. В этом случае в его честь вертеля "Миколину бороду" - оставляемы в поле в конце жатвы куст хлебов. 57 и велес и никола часто выстулают также в роли пастуха. 58 Все эти функция налицо и у Цветаевского царя. Появившаяся мех бровеи метка у царевича (см. вьдержку вьше в а.) рассматривается, мехду прочкм, как след "костра", которы мог жечь "пастух полуночны". Всеми свокми признаками эта метка отсылает К Царю. Поэтому С ним мохно соотнести также и наименование "пастух полуночның", тем более, что эпитет "полуночнын" недвусмысленно вводит представление о демоническом существе. 59

Eme явственнее признаки скотьего бога у царя в другом месте поэмы - в эпизоде разорительного пириества:

- Веселитесь, наин верные нарошы!

Белогривыя я ваш царь, белобородыя.

[...]

Веселитесь, наши руки даровые!

все́ хлеба ваия я прбпил яровые!

Коли хлеба нет, будем есть овес:

Напитаемся - и личиком в навоз!

Выпиваяте, брови черные, до донышка!

Всех-то телок ваших прбпил я, буренынек!

А коль тоино вам от ребячьих слез, -

Помолитесь, чтоб их черт скорея унес! (397) 60

Упоминание "хлебов" соотносит царя с земледелием, "телок" со скотоводством, "овса" - с коневодством; 'веселье-выпивка' - С соответствуомимн обрядами и жертвоприношениями, 'моление' - c обрядноя "разрешительноя" молитвоя (адресованноя лешему, бохеству или соответствующему святому): 'крестьянская' лексика - с народньм, "мухицким" заступником; 61 "вернье народы" - с богом "всея руси"; 62 упомннание "костра" и затем требование "Камаринскоя" и "трепака" (в очередных двух строфах; см. с. 398) - со специальным обрядньм шумом, которьм обычно сопровохдаются торжества вешнего николы, и с древнериим обрядом "коровьен смерти". 63 в определенном смысле "скотьим богом" или дахе "коровьея смертью" является также и царевнч: 
Трех быков на вертеле

сгублю, не мадя! (385)

Последнее тем более вероятно, что именно у него заказывает Царь свон, так сказать, обрядның шум - "Камаринскую" - для "костра СвОВо".

И все-таки, несмотря на параллели и переклички царя с Велесом и николоя, Царь у цветаевод - самобытны персонах и в некотором отношении дахе "архаичнее" Велеса-николы.

В приведенном фрагменте особо показательны с этон точки зрения следуомие "тонкости".

и "хлеба́", и "хлеб", и "телки", и подразумеваемы под "овсом" 'конь' подобраны по солярному принципу. Иначе говоря, Царем уничтохается все, что соотносится с Солнием, а этим самьм с небесньм миром. Небезынтересно отметить также, ч е $r$ ○ в этом перечне нет. Если из хлебов названы только "яровые" (а не озиме), то в слугае скота нет о в е и, тогда как жертвоприношения Велесу предполагали овиу, барана, лошадь и корову. 64 Причина, видимо, в том, что озиме родственны царю как 'мертвые', а овщы - как обладатели ш е р с т и (тохе 'волохатые' и сопричастны миру преисподнен). Кроме того,заметим, что все "хертвоприношения" здесь не пое-

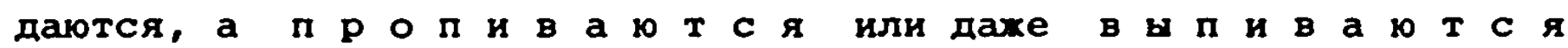
("Выпиваяте, брови черные, до донышка!"). Ср. дополнительно в Кониe поэмы:

Кровосос ты, ишь раздулся с нашен кровушки!

Где крестьянские все наши телочки-коровушки? (433)

Одно и другое означает 'предавать смерти', 'губить' (см.1.1.2.в.., так как в "пропивать" присутствует некин признак 'обмена-торговли', и 1.1.5.; ср. еме в случае царевича: "трех быков на вертеле Сгублю, не мадя!", а не, например, более естественное "съем").

Очевидное равенство "пропивать=выпивать=высасывать" и "телки=слезы=кровь" - нечто большее, чем поэтическия ход или стилизация под фольклор. Оно восходит к стареишему равенству "скот = вода" по признаку 'хизнепорождающее начало', которое у цветаевоя получило вид "телок", т.е. способного к чадородию хенского начала (ср. совсем не случайое упоминание "ребячоих слез, а такхе 1.1.4. и 1.1.6.). Вьше (в пункте в.) ма отметили, что царя и Велеса объединяет их роль стяхителе и запирателен вод, а в итоге - поглотителеи жизни. Теперь добавим, что в случае Велеса и особенно его ведияского соответствия Вритры, запирание или ложыещие зош9-зосDownloaded from PubFactory at 01/11/2019 09:56:43AM ходят к балее раннему затиранио в подземнам Царстве скота, и что сазиеялена 
Вритры и велеса восходят к словам означающим как "скот" и "шерсть" так и "воду" и "волну". 65

е. Народное представление о николе прочно присванвает ему многие свонства велеса-волоса. Не думается однако, что цветаевския Царь построен на образе николы. Он, несомненно, непосредственно выводится из бытуюмего в народнои культуре образа велеса (не обязательно выступаюего под этим именем). Но связь Николы с Велесом позволяет Цветаево и и его подключить к образу царя, хотя бы при помощи упоминания этого имени в лексическом поле Царя или подземного мира вообме, и этим самьм расширить его семантику.

В первую очередь это вводит в поэму мифологическиғ Фон борьбы мехду двумя космніескими циклами - солярньм и лунарньм (см. 1.1.8.). Далее: данны фон свободно трансформируется или хотя бы осмысляется как борьба мехду двумя системами миропонимания и времяисчисления. И, наконец, ореол Велеса-волоса в народном Николе позволяет соотнести сказочного подземного царя С конкретньм историческим лицом (царем Николаем II), а мифологическия конфликт с конкретным мироперестранвающи событием-свержением царя и револоциеи в Россия. Поэтому С данноя точки зреняя "навязанның", на первы взгляд, поэме-сказке Кокеи объясняется совершенно логически и естественно. 66

1.2. МАТЬ ШАРЕВИЧА.

В строгом смысле слова Мать Царевича - не персонах: в поэме она нигде не появляется как дейтвуомее лицо, а упомннания о ней и слипком малочисленны (всего два раза) и слишком беглы, хотя нет сомнения, что ее место в системе поэмы не менее сумественно, чем место Царя. О суцности Матери царевича приходится поэтому судить не столько по непосредственньм данньм, сколько по косвенньм "уликам". В первую очередь - по реляциям к царю, царевичу и к Мачехе. 1.2.1. Вот первое о нея упомннание:

n [...]

Где х убивица моя, - твоя мать?!"

В земпю пальчиком гусляр: "Вечны дом! -

Ты в супрухестве живеш во втором". (400)

Здесь отмечены следуюине факты: Мать царевича была женои царя; от этого брака произвела на свет сына - Царевича; потом, как видно, умерла; умершая пребывает в земле, в "вечном доме", 
предполагающем ее окончательное, безвозвратное исчезновение; 67 она сама и дахе напоминание о нея для царя губительны - "Где ж убивииа моя, - твоя мать?!"

Если Царь, согласно нашему прочтению, деяствительно являет собоя смертоносное разрушительне начало, то 'убивақмая' его первая супруга не мохет быть сущностью смертоноснои: она может быть губительна для Царя только как его противополохность, как хизненное, созидательное начало. Это подтверхдается хотя бы тем, что ея было сводственно 'чадородие', тогда как царь такоя способности лишен, а точнее - всячески от нее воздерживается (ср. 'морганатическия' характер второго его брака), мечтая "без баб-то - Рохать сыновея!" (401). Скахем иначе: его способность к чадородию выте-. кает из его односторонности, из отсутствия женского начала. В результате возникает неразрешимая антиномия: женское начало губительно для Царя, а Царь - для женского начала.

Если с масль о сыне царь в конце концов прнмирился, то мсть о жене ввергает его в паническия ухас (400: "Ох пропал-пропал, пропал-пропал, - женат!"). При этом характерно, что вызванные "женоя" катастрофические заключения царя усматривают опасность не в возможности родить "Сына", а в возможности родить "дочь" и этим самвм иметь "зятя":

$$
\text { n... }
$$

Коль жена, так значит - дочь, значит - эять? Где х убивица моя, - твоя мать?!" (400)

Все члены построенного цветаевор потока ассоциация царя "жена - дочь - зять - убивица-мать" в определенном смғсле эквивалентны, так как объединены общим признаком 'убияства-гибели'. В случае "жены-дочери-матери" наличие данного признака уже понятно им присуще губительное для Царя женское начало. Включение же сюда "зятя" вызывает на первых порах справедливое недоумение: "зять" ведь - начало мухское, не противоречащее ни 'сыновнему' ни 'отцовскому', почему весьма свободно мог бы быть включен в благоприятное для Царя его 'милитарно-винное' окружение (подобно сыну см. 1.1.4. и 1.1.6.). Недоумение возрастает и при более внимательном взгляде на эту ассоциативную цепь, а точнее на ее поочереднъе этапы: "жена - дочь", "дочь зять" и "зять - убияство"п. "Зять", оказывается, непосредственно свяэан с 'убияством', так же, как и "мать" ("убивица моя, - твоя мать"). С однор разницея: "жена-мать" поставлены тут на место первопричины, приводяме 
убияственную последовательность, "зять" же - на место 'финализатора' этои последовательности, т.е. исполнителя убияства или его орудия (по оразцу ноха в ритуале буффонии). 68

В семантическо системе подземного царства "зять", ввиду его мухского начала, правда, с некотород натяхкон, но все-таки мохет быть подключен к смыслу 'вонны' или вообще 'ратного дела'. К смыслу 'вонны' подключена также и "жена" ("Ты не жена, Скаки, - водна!" - c. 401). Но, как мы уже отметили, это две далеко не тохдественных 'вояны' : первая смертоносная, и, кроме того, входит в соСтав суиности царя, вторая же для Царя губнтельна, она прямо противополохна сущности Царя (См. 1.1.6.). Ассоциативная цепь Царя недвусмысленно вдвигает "зятя" во второя тип 'вояны'. Чтс же такое "зять" и чем Он опасен Царю?

Зять, несомненно, - некто 'чукоя', некто из иного, противополохного міра. Обьчно чужоя соотнесен в мифологическом мъллении с преисподнея, с царством мертвых. В случае же царя 'чукоя' долхен обозначать педставителя небесного мира, для Царя деяствительно 'потустороннего', т.е. находямегося за пределами его подземного царства, за окружаюиими царя реками или за морем (372-373; ср. такхе слова Царя о неопознанном и непризнаваемом сыне: "Прынц заморский либо беглын моках" - с. 399). Само собоя разумеется, что приобретение "зятя" вело бы к разомкнутости подземного царства, а этим самым как бы и к его гибели. Но это не самая главная опасность, таящаяся в "зяте".

Зять - муж дочери. Выдача дочери замуж носит характер 'купли-продахи', 'торгового акта', 'товарообмена'. Сумность хе такого обмена состоит в 'мене сумностея' и в 'потере' предыдуден своен сущности. При этом 'обменивающия-покупающия' имеет характер 'победителя'. Выдать дочь замуж значит поэтому для царя 'быть побехденным', 'потерять свою сущность' (ср. 1.1.2.в.).69

Купля-продаха имеет в своен основе поединок двух противоборствуюмих сторон. Народны свадебныр обряд - всего лишь трансформация этого поединка. По отношенио к невесте жених играет роль прибывахего из потустороннего мира похитителя-погубителя умыкаюмего ее в свои владения, обьчно понимаемого как царство смерти. Но если невеста пребывает в царстве смерти, то жених становится тогда ее спасителем. Кульмннационны момент спасительного акта имеет в свою очередь вид поединка на жизнь и на смерть с временньм 
обладателем невесты - отцом, подземным чудовитем и Т.几. сумествами. Поединок хе, как известно, заканчивается победоя жениха и крушением-гибелью подземного царства и его властелина. 70 и это и есть смертельная опасность "зятя" для царя. Она тем более реальна, что цветаевскому Царю отнюдь не чухшы черты подземного 'похитителя': он, как ухе говорилось, - грабитель-купец (1.1.2.в.); похититель скота, а точнее - вымогатель жертвоприношения (1.1.9.д.); чадо- и женопожиратель (1.1.4.), причем дети-дочери и "милочки", выливаеме Царем под видом "чарочек" и "бутылочек", кроме ухе обсуидавшихся имеют признак 'заморских', 'иноземных' и поэтому, несомненно, 'похименньх' :

Как боярьпни пред грозным пред отдом, вкруг него все чарочки кольдом.

Тут и турецкие, тут и немецкие, Архиерайкие да венецеиские...

$[\ldots]$

Ровно милочки - плясать перед купцом -

Вкруг него бутылочки кольцом.

Уж и горластые, цветные, красные,

Уж и бокастые, и ярлыкастые! (371-372)

итак, таянугоя в женском начале вообще и в жене в частности опасность для Царя и его царства мохно сформулировать следующим образом. Это, во-первьх, неизбехность прихода 'чухого', 'победителя' со всеми вытекающими отсюда последствиями вплоть до крушения царства. В этом свете ассоциация царя "жены" с "зятем" и называние "жены" "убивицея" и "воиноя" очень далеки от праздноя риторики. Они буквальны: жена деяствительно есть первопричина убинственно для царя вонны. Во-вторых, это неизбехность 'распахнутости' подземного царства с последующея катастрофоя, так как 'разомкнутость' означает конец 'замкнутости', т.е. 'смерти' или 'преисподнея', и торжество 'жизни'. Жена, таким образом, мыслится здесь как первопричина жизни или путь к жизни. В-третьих, термнны "дочь" и "зять" предполагают понятие 'семеиства' 'рода'. А это значит, что "жена" мыслится здесь как 'родоначальница', как инициатор 'древа жизни' (в отличие от бесплодного 'мертвого дерева" или "бревна" царя). 71

и последнее замечание. Царь был уже когда-то женат, т.е. долюен был когда-то $ж$ е н и т в сущностью хтоническон он мог ее только $\mathrm{n}$ ○ $\mathrm{x}$ и т и т ь. Для Ма-

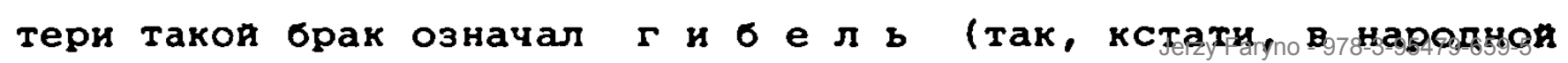


культуре рассматривается вьход замуж девушки ее сторонниками, тогда как для сторонников жениха это скорее 'спасение' невесты .72 В поэме это отрахено лаконическими словами Царевича "Вечның дом!" (400). Но для нас супественее другое: то, что Мать царевича долона била происходить из иного, не $\mathrm{n}$ о д з е м н о г о мира. Вероятнее всего - не 6 е с н $\mathrm{c}$, н, но пока об этом ничего не свидетельствует, кроме сликом косвенного факта (в разбираемом эпизоде) - ошиочного определения царем своего сына "Прынцем за м о р ски м" и "бегльм мона хо м" (399). 73

1.2.2. Второе упоминание Матери - в песенке царевича - епе более лаконично:

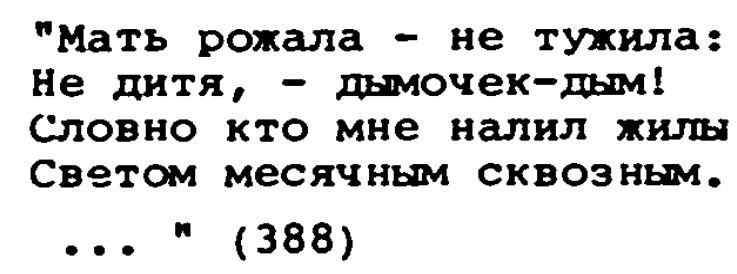

На его основания мохно заключить, похалуя, только одно:

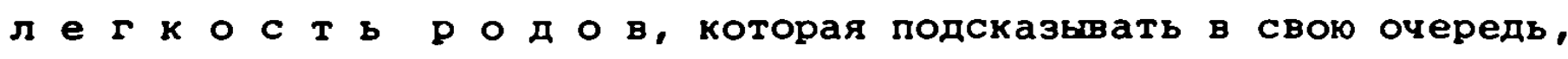

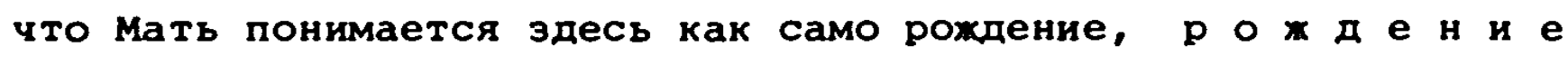

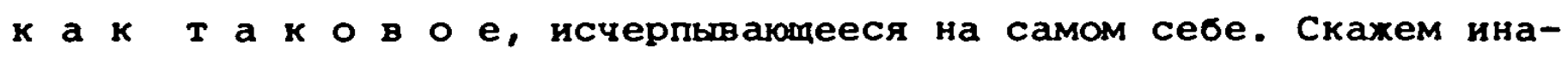
че: Мать осупествляется и исчерпьвается в своем рождающем акте. так, по-видимому, следует понимать ее исчезновение в "Вечныр дом!" (см. 1.2.1.) и ее отсутствие в мире поэмы. 74

1.2.3. Когда,навязывая свою пюбовь царевичу мачеха причитает "Ox, зачем тебя не я родила?" (343), Царевич отвечает ен так: - Мне не надо твоего - ничего! - (343)

Ответ знаменателен. Из него следует, что "родить" означает здесь как "нечто дать" или "передать" рождаемому из себя. А отсюда следует и другое: то, что царевич долхен содерхать в себе нечто от матери (и от Царя) и быть ее, по краянея мере частичньм, двоиникOM.

В картине рождения Царевича он назван "дљмочком-дљмом" (см. 1.2.2.). Если учесть, что дым - следствие горения, с одно口 стороны, и что, с другоя, слово "дым" восходит к санскритному dhuma, означаюмему 'двимутеея курево' 'Фимиам', и благодаря этому родственно греческому Эuน⿰冫, которое означает 'душу и движение страсти', то эта картина рохдения есть одновременно и картинои смерти Матери царевича: Мать сгорает преврамаясь в душу-сына. А это значит, что Мать неким образом долхна быть связана с о $r$ н $\mathrm{e}$. 
В тоя же картине рохдения царевич определен не просто "дымам", но "дымом"- "Светом месячньм сквозным", т.е. "дымом светящимся и прозрачным'. Как и дым, так и свет - производные от огня. "Месячны" же указынает на не $\sigma$ е $с$ н у ю локализацио огня. На этом основания позволительно заключить, что Мать Царевича связана

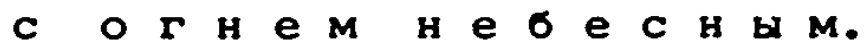

Но одновременно Царевич и сын подземного Царя. Зная же смертоносную судность царя, мохно теперь сказать следуюмее. "Свет месячныя сквозноя" - дефсрмированны под влиянием Царя-Смерти небесны материнския огонь. А удвоение "дымочек-дым" - отрахение как дьма-души Матери ("дымочек"), так и пьма-суцности отца-царя ("дым"). По этим признакам Царевит занимал бы срединное полохение между Матерью и царем. 76

Дьм и его варианты встречаются в образе царевича несколько раз: в словах Мачехи (351) -

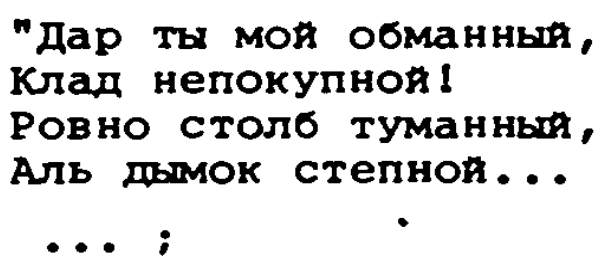

в словах царь-Девишы (365) -

$$
\begin{aligned}
& \text { А ну как зорче поглядим - } \\
& \text { И вовсе все обман один. } \\
& \text { и вовсе над туманом - дым, } \\
& \text { над херувимом - серафим?: }
\end{aligned}
$$

eч⿱八 раз в словах царь-девицы (368) -

$$
\begin{aligned}
& \text { "Синих очея твоих аль дохдусь я?" } \\
& \text { но - словно дым - } \\
& \text { Изнизу - вдоль впалых щек - } \\
& \text { облак - мброк - обморок.: }
\end{aligned}
$$

в словах морских обитателея, наблюдающих издалека за лодкоя царевича (390) -

\footnotetext{
"да нет, старина!

Ровно мо́рок какои-то.

Гляди - не волна ух:

Гривастая троика!"
}

Срединность суиности Царевича здесь повсеместна. В равнои степени он может быть отнесен к низу и к верху ("столб туманны" - "дьмок степноя"; "туман" - "серафим"; "облак" - "обморок"; "волна" - "Гривастая троика"), к земле и к небу, к смерти и к хизни ("обморок"), к материальному и к нематериальному ("дым", "туман",

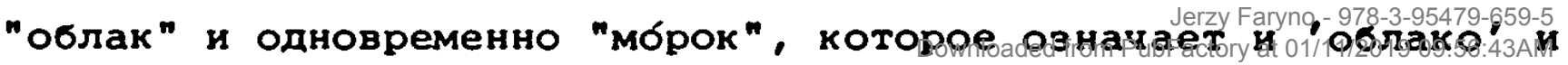


'призрак'), к реальному и османивому (кроме эксплицитного "обмана" ср. двонственность слова "мо́рок" = 'облако' и 'вводянин в заблухдение; заставляющи видеть то, чего нет'). 77 Будучи и тем и другим, он в результате - и ни одно, и ни другое: "мо́рок" (обманчнвьр призрак), "обморок" (т.е., ни смерть ни хизнь), а в обмен системе поэмы - "сон". Нет сомнения, что такое его полохение и состояние образовано уравновешенностью в нем признаков, унаследованньх от Матери и отиа-царя.

Дьм и туман во многих отношениях эквивалентны. Но есть между ними и существенная разница: дљм - производное от огня, туман же - от влаги, воды. Связь Царевича с водов однозначно отмечена в поэме при первом с ним знакомстве:

"[...]

Видно, месяц, плакамши,

Слезо обронил". (350)

но примечательно, что нигде позже вода в ее, так сказать, естественном состоянии в образе царевича не упомннается, хотя и не полностью исчезает - трансформируется в промехуточное состояние "тумана", "облака" и "мброка" = призрака и "обморока" = сна, уравниваясь с аналогичнов трансформациеи огня в "пом".

Царевич, таким образом, - порохдение огня и вошы, но под влиянием свонств отца-царя он не является ни огнем и ни водон. Он - их 'испарения', а точнее - смесь их промехуточных состояния.

"Свет месяикий" указывал на небесное происхохдение огненного начала Царевича. Такое же происхохдение наблюдается и в случае его акватического начала: "месяц, плаками, Слезой обронил" (350). Отсюда позволительно заклочить, что Мать царевича долхна была быть небесньм огненно-акватическим сумеством.

1.3. MATb И MAYEXA.

В принципе в поэме соблодается дискретность на уровне ее персонахен: дахе обладая некоторьми обмими признаками и чертами, они отчетливо отграничены друг от друга и совершенно свободно подиаются идентификации. Но есть здесь и небольшое отклонение от этого правила. Оно наблюдается в случае заметной размытости или пониженнов дискретности наяменования и обраменин в отношениях мехду Царевичем и Мачехоя. Особенно ярко вьражено это явление в употребления Царевичем и Мачехон слов "мать" и "сын". Факт этот тем более значим, что в случае другон, казалось бы аналогичноя, пары персонахеи

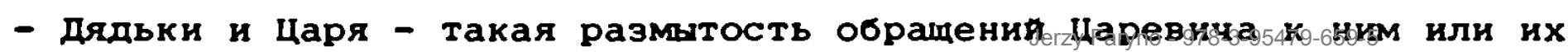


К Царевичу вовсе не наблюдается. 78 Поэтому же кахется неуместньм спросить, не являются ли Мать и Мачеха неким одним, пусть дахе удвоенньм, персонахем, и более пристально присмотреться к Мачехе и царевичу с данно точки зрения.

1.3.1. С одноң стороны Мачеха и Царевич прекрасно осознают свое взаимополохение в системе родственных связея. Ср.:

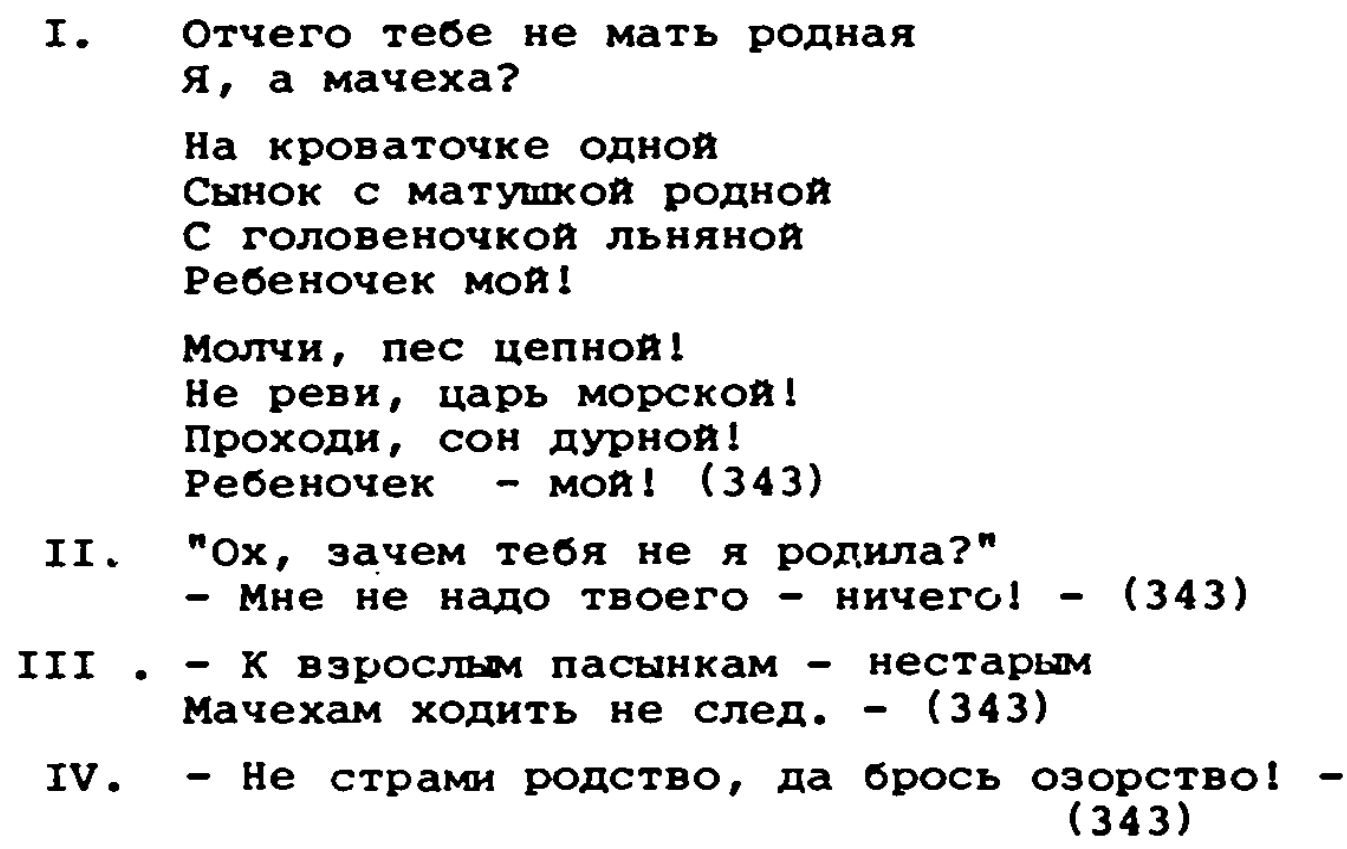

С дугоя, однако, дахе в этом препирательстве эаметны сдвиги в сторону реляции 'мать - сын' вместо исходноң 'мачеха - пасынок': в речи Мачехи дважш повторяется вырахение 'ребеночек мои' (пример I: "Ребеночек мои!" и "Ребеночек - мои!"), а в речи Царевича появляется слово "родство" (пример IV).

В эпиэоде встречи Мачехи и Царевича на башне этот сдвиг еме явственнее:

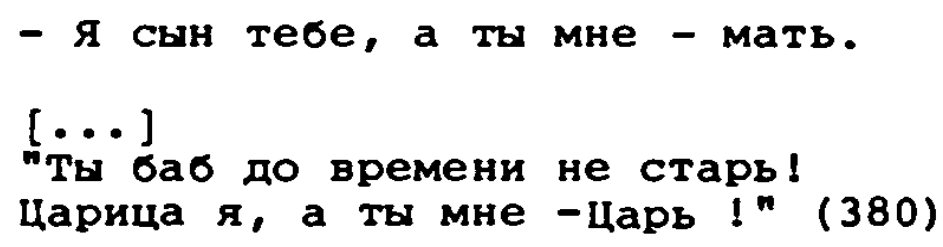

на уровне героев во всем чередовани то одих, то других аптелнтивов домннрует, несомненно, риторика "настаивания на своем": Мачеха пытается всячески соблаэнить Царевича, а Царевич - остудить ее пыткость. Таким объяснением, конечно, можно было бы вполне удовлетвориться, если бы не Факт, что подобное чередование сводственно также и нарративньм (авторским) партиям текста. Ср.:

Стоит смиренник юнын, Пошитывает струны.

Нет слов у мачехи-красы, Покусывает Хвост коCы. ( 379jerzy Faryno-978-3-95479-659-5 
буквально тут же, через десять стихов, говорится:

Как зверь нечеловечия -

Хвать! - сына за заплечье! (380)

Само собоя разумеется, что эквивалентность наименования 'сын' 'мать' и 'мачеха': первые в любом случае отсылают $к$ одному и тому же персонаху, к Царевичу, вторые же объединяют в одно два разньх - Мать царевича и его Мачеху.

1.3.2. Искпючая актуальныр облик и актуальное поведение Мачехи, попадающиеся в поэме обрывочные сведения о нея предельно скупы, но тем не менее их несравненно больше, чем в случае Матери. И именно благодаця им восстановима ее предыстория.

Похоже на то, что Мачеха не исконная обитательница подземного мира, что она попала туда не по своея воле. $\mathrm{Cp}$. :

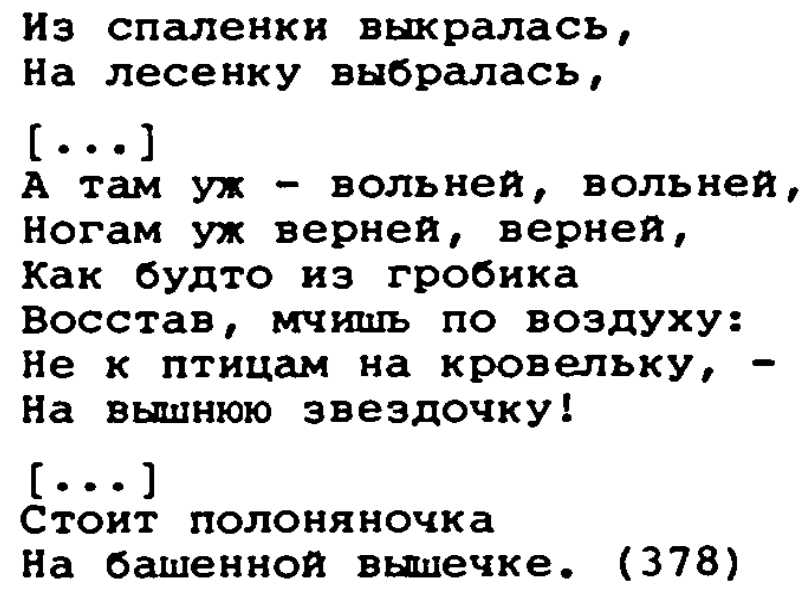

и в финале поэмы:

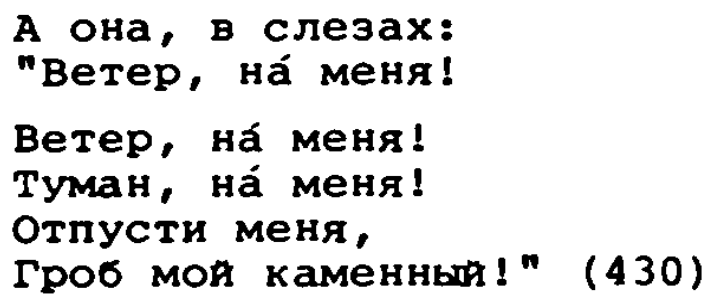

Раныше (см. 1.1.8.) имя "полоняночка" мы читали с точки зрения наличного в нем признака 'связанности' как константного свонства царства смерти, преисподнен. Этот признак сохраняется и теперь, с тем, однако, что по отношенир к Мачехе он явно навязан ея извне, подземным царством, а не исходнт от нее самоя. В предломенном контексте "полоняночка" отчетливо звучит как 'схваченная в плен', 'насильно ввергнутая в подземное царство' .

Небезынтересно также и упоминание в данном случае гроба. Оно показательно в двух отношениях. 
Во-первьх, в том, что оно вписывает в образ Мачехи не столько смысл 'смерти', сколько смысл 'у м е р ш е и'. А это позволяет взглянуть на мачеху как на попавшую в преисподнюю душу какои-то ино захваченноя в плен и погибшеи женщнны.

Во-вторых, в том, что гроб здесь однозначно эквивалентизирован со спальнея: "Из спаленки [...], Как будто из гробика Восстав". Но это не все. Деминутивы "спаленка", "гробик" откровенно перекликаются с "кроваточкоя" Царевича, которая, в свою очередь, тохе является гробом, на этот раз - его Матери:

на кроваточке одноя Сынок с матушко родноя. С головеночко льняно Ребеночек мон! (342).

из чего следовало бы, что и царевич долхен быть причислен к умерuим. 79

Есть в тексте поэмы и косвенные указания на то, каким образом попала мачеха в царство смерти:

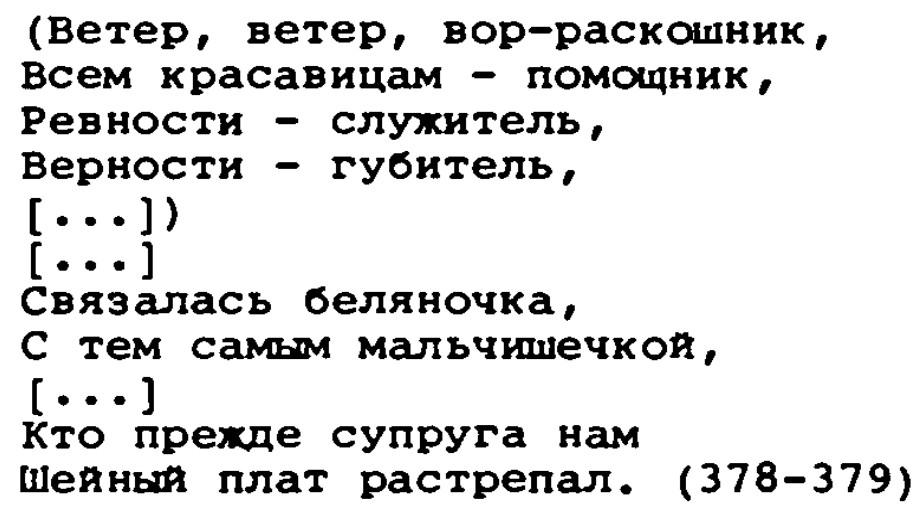

Из характеристики Ветра явствует смысл 'обольщения', а из связи С чертом ("мальчинечкои") - смысл 'самоубияства', отдағмего во власть нечисто силе (если так читать стих "山ерны плат растрепал"). Такое прочтение этои сцены подтверждается и еще раз - в описании вынужденного поцелуя с оборотнем-филином:

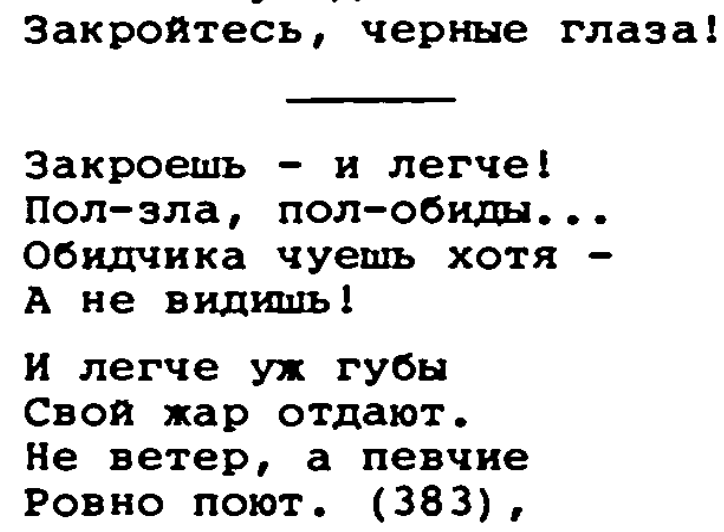


и 'смерти' (ложное восприятие реальности: вместо "ветра" - "певчие", а дальше вместо "Филина" - "лебедь младон!") •

Еме блихе к расшифровке истории Мачехи подводит следуюмая картина (все в том же эпизоде столкновения Мачехи и Царевича на бamн) :

Над бездноя окиянскон

Стоит, качает стан сво .

Покачивает, раскачивает,

Как будто днтя укачивает,

Больше глаза незрячие

К мучителю оборачивает.

[…] ]

Качӓется, качается, Шелх вкруг колен курчавится.

Как есть - дитя-проказница

Страх нагоняет, дразнится.

мачеха - ведьма, и 'качаюмаяся' требовательная поза для нее естественна. В данном раскачивании мохно также видеть и признак соблазняющего кокетства. Но ни первыя и ни второй смыслы не требуют для своего вырахения уподобления с укачиванием ребенка. Это уподобление привнесено извне, и, несомненно, с определеннои целью.

В данном моменте Мачеха и шантахирует царевича и деяствительно готова броситься с башни в "бездну окиянскую". Царевич не выдерхивает и предотврамает самоубияство мачехи, перехватив ее "На всем лету" (382). Вся эта сцена, думается, рассекречивается так: мачеха в беспамятстве повторяет прежнее свое самоубияство (ср. наличие этого смала в ее образе выше), к тому же-самоубияство с ре бенком. Не исключено, что здесь переигрывается сцена гибели Матери Царевича и что этой Матерью была некогда сама Мачеха.

значительно раныше, в первом эпизоде обольщения Мачехо Царевича, она, мехду прочим, говорит:

" [...]

Все, что знала, позыбыла нынче за ночь я:

Я крестьяночка, твоеи дуии слуканочка!" (343)

Забвение - вообще устойивая черта подземного царства. Сохраняется она и у Цветаевон, усиленная к тому еще и неузнаванием, т.е. забвением такхе и на зрительном уровне. Так, царь не только начисто забыл О сумествования сына или о первон жене, но и вовсе не узнает своего сына (399-400). Не было бы поэтому удивительным, если бы Мачеха оказалась давнишнея Матерью Царевича, которая, попав в подземное царство, забыла как свое прошлое, так и о сыне,

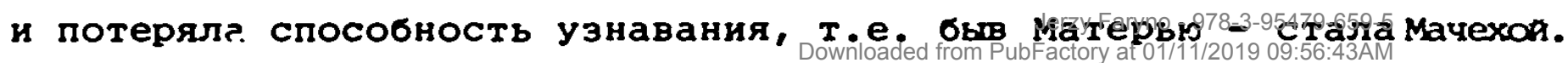


Преврамение в ведьму и в Мачеху так хе эакономерно для подземного царства, как и забвение, особенно в том случае, если Фактически имело место похимение и самоубинство. Тохдество Мачехи с давне Матерью тем более правдоподобно, что данная "мачеха" не совсем типична: она не преследует и не синвает пасынка, как это наблюдается в народноя мифология, и опасна для него только своен неестественноя чудовитноя любовью-страстью. Иначе говоря, у Цветаево имела бы место следуюмая трансформация: Мать $\rightarrow$ Мачеха-ведьма; материнская лобовь - губительная извраменная страсть; чадоро дное начало - бесплоднь эротизм.

В последне наше выдерхке Мачеха именует себя "крестьяночкоя". Стоямие за этим имением смыслы ясны, но требуот привлечения образа Царя, в котором крестьянская тема вырахена более экстинтио.

В Кояие поэмы Царь непосредственно назван "крестьянским":

Чтоб спознался Царь крестьянския с наним горем Мы царю-то Комару-то - брюхо вспорем! (433).

а воставшие его подданные - "мамкон":

Твоя мамка мы, кормилка никудытная,

Русь кулашная - калашная - кумашная!

В этом контексте дополнительную значимость получает оговорка Мачехи, что она - "служаночка" дуии Царевича: этим снимается С нее статус Царищы "крестьянскоя" и устанавливается статус "подданно". Более того: здесь возникает возмохность усматривать в нея соответствие принадлехамего царю царства (ср. "Твоя мамка мы, [...], Русь кулашная - калашная - кумашная!"). Впрочем, данное отохдествление уже прозвучало в поэме в эпизоде пляски обвалившегося на царя шатра:

Чтоб в умипке нам самим не порешиться, Мы проядем на половиночку к царице.

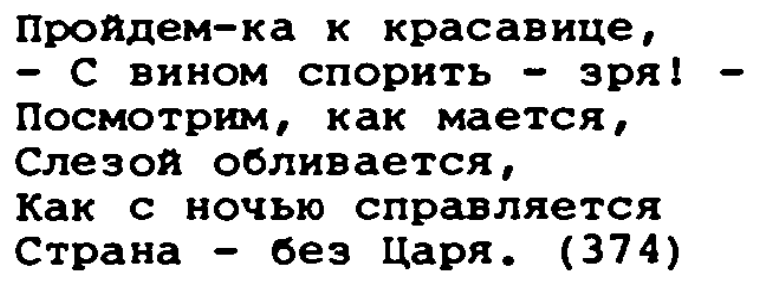

Итак, Мачеха - и "крестьяночка" и "Страна". При этом и в одном и в другом варианте она - узница. Вход К Царице или в Страну заперт на "засов" ("Прехде чем засов раздвинем, Ты скахи, дупа, [...]"), заперта также и сама царица (т.е. Мачеха):

Стены все́ в сетях-тенетах,

Колокольчиках-звоночках

чест тены - Царю Jerzy Faryno - 978-3-95479-659-5 
Уже сама по себе 'запертость' знаменует 'смерть, гроб'. Но не лишним будет еме раз напомнить, что посемение "покоев" Царишы, иначе - "Страны", завершается седьмы покоем-спальнен, которая тут же перенменована в поэме в "гроб": "Из спаленки вькралась, ... . Как будто из гробика Восстав" (378). и напомним еме, что на вопрос Царя "Где ж убивица моя, - твоя мать?!" Царевич показывает "В землю пальчиком" и отвечает "Вечның дом!" (400). Так замыкается, поначалу разрозненная и не совсем ясная, цепь эквивалентностен: Царица-Мачеха-Страна $=$ гроб $=$ эемля-Вечның дом = Мать Царевича и "спаленка" Мачехи = "кроваточка" Царевича С Матерью. Из всех этих перенменования самое супественное пля нас в настоямй момент накменование "Страна" и "земля", так как оно вплотную подводит к смыслу реляция "Мать - мачеха".

О Матери, как о первои жене царя, мы говорили в 1.2.1., что она долхна была быть похипена царем (что следует из подразумеваемор его первод 'женитьбы' как сумества хтонического). Из слинком скупых сведения о Матери в поэме смысл похимения, конечно, не вытекал, но он явно присутствует в ряде намеков на предысторию мачехи (О чем ухе говорилось) и в ее статусе "крестьяночки" (ср. хотя бы: пожирание Царем крестьянских жертвоприношения - с. 397 ; следуюине стихи в Кокие: "Кровосос ты, иш раздулся с нашей кровушки! Где крестьянские все наши телочки-коровуики?" - с. 433; соотнесение царя со свирепьм "львом красньм", а царевича с "ланью" c. 399).

Кроме того, в случае Матери царевича мы установили ее небесное происхохдение (см. 1.2.3.). В случае мачехи же налицо если не небесное, то по краинеи мере ее вне-подземное (крестьянское) происхохдение и связь с з $е л \pi$ е (она - "Страна"). И по отношению К Царю и по отношенио к Царевичу Мачеха замемает собор - функцнонально - Мать и в этом смысле является ее двоиником или эквивалентом. Отсюда вывод: либо Мачеха является подземньм перевоплоцением загубленно Матери Царевича, либо же она - тоже загубленное перевопломение 3 е м н г о соответствия Матери. В последнем случае возникает тогда парадоксальная ситуащия двояного материнства Царевича, говоря иначе - у него тогда должны бы быть д в $е$ матери, а он сам - двахшы рохденным.

1.3.3. И, деиствительно, в тексте поэмы упоминаются д в а разных рохдения Царевича. Одно из них дано в монологе Царевича: 
Видно, в полночь, в пятницу

На свет родился. (350)

Второе - в диалоге морских обитателея, комментируюиих лодочную погулку царевича:

- В сочельник крешенския,

Что ль, парень, рожден? (390)

Указания на то, что тут имеются в виду две разных даты, т.е. Фактических два рохдения, здесь нет. С равньм успехом это может быть одна и та же календарная дата, скахем, 18 января ст. Ст. в пятницу накануне христианского праздника кремения. Дело в другом: Царевич проявляет такие свонства, которые характерны рожденным в особо значимое время: В $П$ я Т н и ц у и одновременно В К $\mathrm{p}$ e-

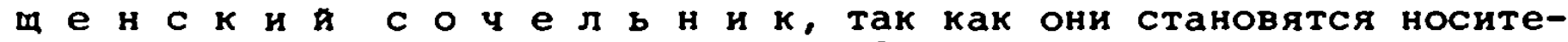
лями свонств этого особого времени. 80

Пятница связывает Царевича с народным мифологическим персонахем Мокошью-Пятницея. А пятничнын же кременския сочельник - со св. Параскевои-Пятницеम-БогородицеА. В результате у Царевича деиствительно была удвоенная мать, сочетаюмая в себе и Мокошь-Пяницу и Пятницу-Богородицу, 81 но в зависимости от обстоятельств проявляюцая то одни то другие свои свонства.

Мать Царевича соотносится, несомненно, С Пятницеи-Богородицея, О чем свидетельствует ее небесная огненно-акватическая природа (см. 1.2.3.), а также следующая мольба мачехи:

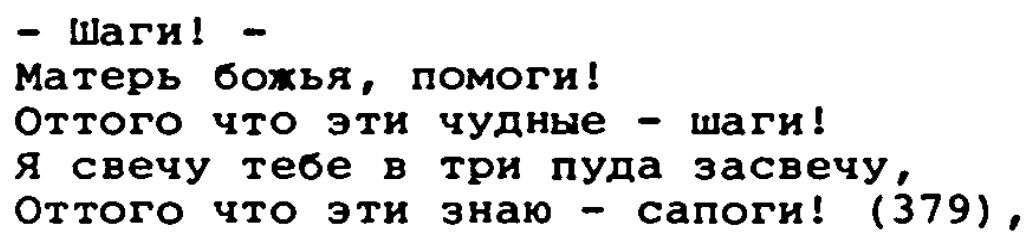

где Матерь Божья истолковывается как сущность обладаюмая особым влиянием на Царевича.

Мачеха же, соответственно, долхна бы соотноситься с Пятницеи-Мокошью. В данном случае отсылок к образу Пятнишы-Мокоши в поэме значительно больше:

а. Отчетливая связь с водоя - ср. хотя бы брачную пляску Мачехи (с. 402-405) и особенно уподобление воде:

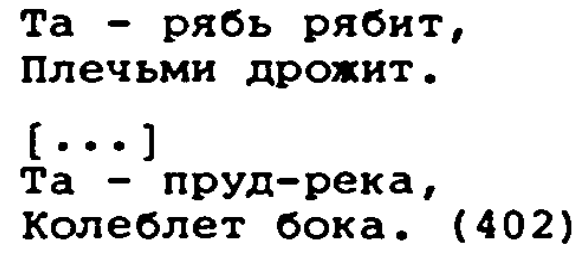

6. Буиные волосы, в частности, их распускание во время пияск: 


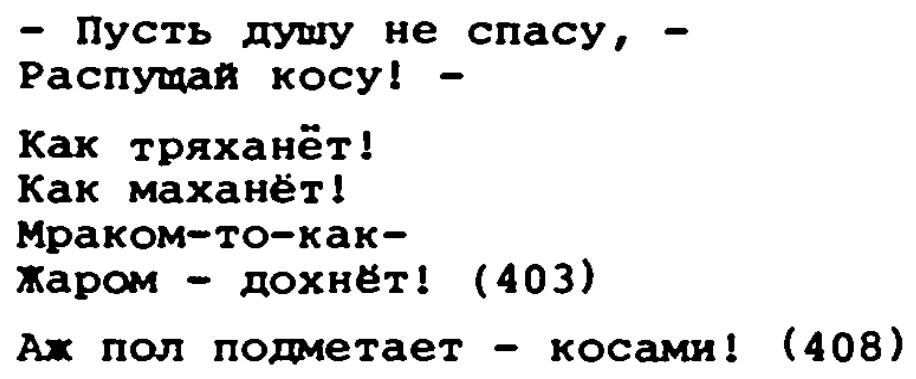

в. Булавки и иглы, которыми колется сама или направляет в свою жертву. Ср. в эпизоде венчания с сыном:

на полуномных-то разве

На летуньях - женятся?

Как поддет чудить в кровати

Булавками-иглами! (406)

или в эпизоде сговора с дядькои-Филином:

Красе на ухо шепочет, прильнув:

"За булавочкон к тебе я втород!"

[... ]

Двахны в грудь свою - булавку отправь!

Двахды филину - уста предоставь!" (383)

г. Полная власть над глазами: физическая и мимическая. Cp.

в эпизоде обольщения Царевича:

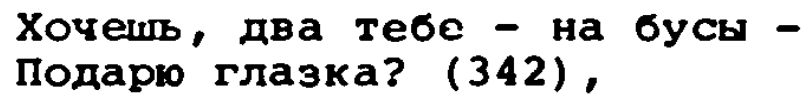

в эпизоде столкновения с llаревичем на башне:

Больше глаза незрячие

К мучитепо оборачивает.

[... ]

Из бахромы курчавод

Глазок глядит лукаво. (381-382)

и в эпизоде венчания:

Ииь, сокрыла черноглазье!

Хорона, смиренница!

[...]

Как радуга - запрокинулась!

Белки-то уже - под дёснами! $(406,408)$

д. Настончивое упоминание в ее образе ткани:

А ветер - шелка горячие

Как парусом разворачивает.

$[\ldots]$

Качается, качается,

шелк вкруг колен курчавится. (381)

Не змеиның шип - шелков рваньх скрип,

то не плетка-хлыст - шелков рваных свист,

То на всем плясу - шелка́ ручьями вниз! (404),

а также "атласа" (402), "Бель плат [...] нагрудның" (403), "рубахн" 
и "ткани" (404). Более того: уже "голая" (406) - уподобляется ткани же:

\author{
$n[\ldots]$ \\ не рябая, не косая, \\ Глахе шелку - платьице!" (407) \\ е. И, наконец, - связь с пряхея, пенькоя и обматыванием:
}

(Ox, поддастся паренек наш!

Пенька - баба ловкая!)

$[\ldots]$

обхватьвает, обматывает,

В грудь скудную - когти вкапњвает,

Вокруг обвилась, как жимолость,

Как радуга - запрокинулась!

Белки-то уже - под дёснами!

Ax пол подметает - космами! (407-408),

а раньше - упоминание "чесальщи" при прохождении покоев царищы (376), где "чесальмицы" с равньм вероятием соотносятся и с парикмахерским делом и с обработкоя шерсти или кудели, т.е. с пряхен и ткацким делом.

Рассматриваемые по отдельности, эти черты Мачехи могли бы считаться лишь случаяньм совпадением с чертами Пятниц-Мокоши, но их совокупность создает почти классическин состав свонств последнеи. 82 кроме них Мачеху с Пятницеи-Мокошю роднит и еще нечто.

3. Разительное сходство Мачехи с царем. И в образе царя и в образе Мачехи настоячиво повторяется их связь С 'тканью': Царь "кумашнын", "кумачовын" (см. 1.1.2.в.), мачеха - вся в шелках (см. вьше д.). Царь - 'волохатын': усаты, "белогривьд", "белобороды"; дахе его шатер - "бахромчатың" (см. 1.1.2.г.). Мачеха охарактеризована буиньми волосами и признаком "курчавости": "из бахромх курчавой Глазок глядит лукаво"; "курчавость" хе характерна и ее "шелкам": "Шелк вкруг колен курчавится" (см. выше г. и д.). Царь - "хитростник" (372), Мачеха - "глядит лукаво" (382). И у Царя и у Мачехи исполняется "Камаринская" (398 и 376; см. такхе 1.1.2.a.), а это и мачеху роднит с комаром; ср. дополнительно с высасываюмем поцелуем Мачехи "Из сердиа весь сок вытягивает, В глубиннуг глубь затягивает" (407) и эпитет "кровосос" по отномению к Царю (433). Царь локализован "в нутре земном" (371), Мачеха же пребывает в своем подземном "покое седьмом" (378), и так же, как царь кольцами из "чарочек", "бутылочек", "бочонков" " "рек" и "бочоночных гор" (см. 1.1.4.), она ограқдена предваряющими накрепко запертыми покоями, которые соответственно атрибутированы па- 
губными женскими превратностями. 83 При этом примечательно, что последния покон предваряют "кухня женского обману" и кузница, где кто-то "Из стекла кует союзы, Из свинца кует разлуки", откровенно перекликаямимися с окрухающими царя кольцом "бутылочек" прелюбодеек и кольцом "бочоночков"-"вояны". Более того: ретроспективно предваряюине шесть покоев именуются "реками" (377), подобно тому, как панорамирующи взгляд на царя обнаруживает его сидяпим "Промех винных рех, бочоночных гор" (372). Далее: Царя и Мачеху роднят их связь с темнотои и связь с мокротоя: дабы рассмотреть неузнанного сына Царь "взял лучину" (399), а седъмоя покои Мачехи - "ночноя" и в нем "Линь лампадочки в углах димят" (378); царь "ус мохрий мипет" (371; см. также 1.1.2.д.), а Мачеха вообе сумество акватическое (см. вьпе а.). и, наконец, их обоих сбликает обмая поза: Царь "Сидит", а основноя или исходни локус Мачехи - "спаленка" (т.е. все тот же седьмои "покой ночнои": см. 1.1 .3$. и 1.3.2.). В заключение этого, далеко не полного, сопоставления царя и Мачехи отметим епе их сходное соотнесение с огнем. Ни Царю ни мачехе огненное начало не присуше. Правда, в случае Царя, непосредственно и косвенно огонь упомннается двахды (398-399), но всякия раэ в смысле истребительноя стихия (СМ. 1.1.2.6. и 1.1.8.). В случае же царишы-Мачехи огонь подменен истребительньм жаром и адским чадом-дымом. Ср. хотя бы:

то не черны чад над жаркою жаровнею -

То из уст ее - шыханьице неровное. (401)

мраком-то-как-

Маром - дохнет! (403)

Этот хар - из груди

долтен в грудь перебечь,

Аль всю суть нашу схечь. (408)

Закрутилась дымовьм столбом! (404)

Лишь лампадочки в углах пьмят. (378)

Объчно жар и цым предполагают наличие огня. Здесь же подразумевание огня всяки раз исклочается: у этого "дыма" и "жара" совершенно иная природа. Он исходит из недр царишы-Страны, из подземноя "кухни", где стряпают "обман", и из подземной кузницы, где "Кто-то, молот взявин в руки" кует лохные "союзы" ("из стекла") и прочные "разлуки" ("из свинца" - СМ. 376), и уже по одному этому раэруинтелен. Кроме того недра царицы-Страны - "С семью смертньми грехами целых семь укладок бабьих" (376), где "укладка" = "гроб" ("грудь-то япик!" - 375), и стихия подземиыз 4 бад 5 (покои 
как "реки", уста как "устье" - 377; да и вся она - "пруд-река" с "паточным устьем" - 402, 407). Если поэтому и предполагать некия 'огонь' в образе царищы-Мачехи, то это был бы парадоксальнын а К в а Т и ч е С к и огонь, или точнее - сохнгакая (истребляющая) вода. Ключ $к$ решению этого парадокса кроется в "свечах", которые брачащимся подает царь:

\section{В персты по бутылке \\ Сует вместо свеч. (406)}

Нет сомнения, что поданные "свечи" - нечто большее, чем только колоритная деталь "наоборотного" подземного мира. Это - дейстительно "свечи", горящие особым подземным огнем. В связи с ними не будет лишним укаэать, что при первом упоминания окружающие Царя "бутылочки" были охарактеризованы так:

\section{Узнать-то надобно, что в них скрывается,} Что цветом-радугоя переливается! (372)

и что Царица-Мачеха, целуя Царевича, тохе "Как радуга - запрокинулась!" (408). Инымя словами, есть все основания в необъино "пламени" "бутылок"-"свеч" видеть вариант "цвета-радуги", а в итоге - подземного жара без огня. 84

По большннству отмеченных выше признаков Царица-Мачеха дворник Царя, а точнее - его женское соответствие. Но пока нам интересно не это. Дело в том, что в Царе и Царице воспроизведены основные черты волоса-велеса (см. 1.1.9.). Естественно поэтому сказать, что Царица-Мачеха во внетекстово мифологии имеет свое соответствие под видом женского эквивалента волоса-велеса, т.е. М ○ к ш и. Цветаевския Царь, однако, - не только Велес, но Велес-Никола. Отсюда и Царица-мачеха - не просто Мокошь, но МокоиьПятница. Далее. Ни Никола ни Пятница отнюдь не простые персонахи. В народноя мифология они опять-таки удвоены: Никола распадается на христианского св. Николу и на вариант, присвоивин себе многие черты языческого Велеса. То же самое случилось и с Пятницеи: она выступает и как христианская св. Параскева-Пятница, и как Пятница, присвоившая себе многие черты язьческоя мокоши.

По этоЯ причине сходство Царишы-Мачехи с Царем может считаться дополнительным указанием на Фактическую соотнесенность ЦаришыМачехи с самоЯ Пятницей-Мокошью, т.е. женским соответствием Николы-Велеса.

При таком толкования более понятным становятся и некоторые другие детали образа Мачехи: то, что она называет анебя--9щреблья- 
ночкон", отсылает как к крестьянскому покровительству Николы, так и к крестьянскому занятио Пятнищы, т.е. прядильно-ткацкому делу: то, что она уподоблена "радуге" как содержимому "бутылочек", а ее уста - "паточкому устью", роднит ее со 'спиртньм напитком' ("вином") и с алкоголизмом царя, и тем самым - с николов как покровителем пивоваренного дела (см. 1.1.9.); с николов же перекликается и ее соотнесенность с корабельным делом (см. 1.1.9. и ср. ее слова о царевиче: "'Ох, височки, волосочки мои!' - Корабелокие досочки мои!" - с. 343 и аналогичның рефрен на с. 351, 390 и 412): 85 и наконец более понятен теперь Факт, что именно у нее и Царевича заказан Царем внук именно "к николе" (405).

х. Прочтение Царищ-Мачехи в соотнесении с Пятницеи-Мокошњю и Николои-Велесом проясняет также и ее соотнесение с Матерьо Царевича.

Пятница-Мокошь - народно-языческин вариант Параскевы-Пятницы, а Никола-велес - такоя же вариант Николы. Далее: в народно-христианском восприятии Параскева-Пятница просто связывается С Богородицен и едва ли с нея не идентифицируется; Никола же, в свою очередь, связывается или вовсе отождествляется с самим Господом Богом. 86 Естественно поэтому спросить, не соотнесена ли в поэме Мать Царевича с ПараскевоЯ-Пятницеи-Богородицея?

Если у Царевича денствительно дводная мать, а один из ее вариантов - Пятница-Мокошь, то о другом варианте можно судить по свояствам варианта наличного в тексте поэмы, т.е. по царице-мачехе.

В семантическои системе поэмы у Мачехи-царицы есть свод противо-эквивалент. И это - Богородица:

Семь небес у Девы чистои,

у царицы - семь покоев. (375).

где нмена "Дева Чистая" и "царица" и названия 'зон владения" ("небеса" и "покои") раэводят Богородицу и царицу по противополохньм полюсам миропорядка, а 'количество зон' и Функции 'правительниц' ставят мехду ними знак эквивалентности.

На аналогично противо-эквивалентности покоится и сравнение це луюее Царевича Мачехи с "радугон":

из сердиа весь сок вытягивает,

В глубинную грудь затягивает.

$[\cdots]$

Вокруг обвилась, как жимолость,

Как радуга - запрокинулась! (407-408)

В народньх представлениях радуга чаmе всего связывается с Бо-

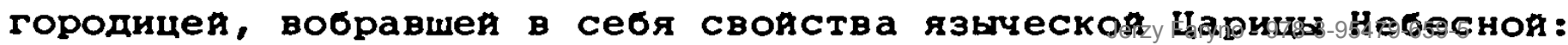


это - "божье кольцо": мост между небом и землен; престол Богородишы; коромасло, на котором Богородица носит земную воду дабы произвесть оплодотворяюми дождь: труба, при помоми которои Богородица поднимает на небеса воду из земного колодца и потом орошает земпо; и т.П. иногда, однако, радуга понимается как змей или пиявка, выпиваюине земную воду, но и в этом случае преобладает полохительная дохдепроизводительная функция. 87 По форме ("обвилась", а в другом месте обемание "свернусь в трубочку" - с. 343) и по Функции ("сок вытягивает") Мачеха - классическая радуга-Богородица, но с противополохньм знаком: она - радуга перевернутая ("запрокикуласо! [...] Aк пол подметает - космами!"). мрак и жар, исходящие из недр-груди царищ-мачехи (см. выие 3.), также позволительно рассматривать как признаки противо-эквивалентности мачехи Богородице.

В народно-язычеєких представлениях Богородица воспринямается как повелительница и укротительница небесного огня и часто именуется Марией Огненноя, занимая место более древнея богини-громовницы, которон, в частности, считается и мокошь как супруга громовержца Перуна. 88 В связи с этим свонством Богородицы-Мария Огненнои небезынтересно отметить еме факт, что наряду с нер и в такои же Функции иногда выступает и св. Мария Магдалина, 89 вплоть до отождествления с Богородицея. Нельзя поэтому исклочить такоя возможности, что в сжигаюцем греховном соблазне Мачехи предполагаются также и связи с прелюбоденством двонника Марии Огненноя, т.е. Марин Магдалины. Ср.:

и - взыграв как целын град Содом -
Закрутилась шымовым столбом! (404)

и тут же следуюине строфы о греховности и неверности хенщин воobme (404-405:.

В апокрифическоя литературе большое внимание уделяется рохдению Христа и целомудрию Богоматери. В этих эпизодах нам интересны два момента: засвидетельствование повивалками целомудрия и их рассказы об увиденном при входе в пемеру к разрешившеяся Богоматери. В первом случае отмечается $\Pi$ а $л$ н н * a $\mathrm{p}$ в лоне Богоматери (так, например, в Протоевакгелии от Иакова изображен случаи с Саломеен, продевшеи руку в лоно родившея и тут же выдернувшен ее от сверхъестественного ожога). 90 во втором же описывается поразительнын С $\mathrm{B}$ - $\mathrm{s}$ пемере и постепенное

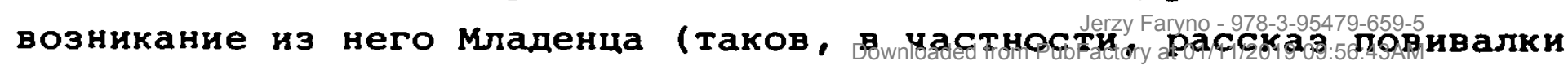


в Евакгелии от Псевдо-матфея). 91

Прямх отсылок к апокрифам в поэме, конечно, нет. Но параллель к чудесному рохденио и возникновению из огня-света очевидна в описания рождения царевича:

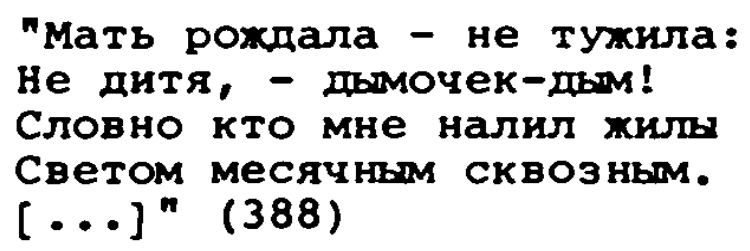

Помня, что Царевнч родился во временно $\Gamma \mathrm{P}$ н и ч н момент ("в полночо, в пятницу" и к тому же "В сочелокик крещенския" - см. 1.3.3.), в данноя картине не рискованно видеть картину рохдения от двоякоя матери - Параскевы-Мокошт или Матери-Мачехн, От которых наследуется их свєтоносное начало ("Свет месячныя") и дымовое ("дыночек-пьм") .

Возмохно, что это одна из причин частичного лишь узнавания в Царевиче сына Мачехоя (СМ. 1.3.1.), н полного неузнавания в нем сына царем. Царь, кстати, вообще видит в нем 'нездешнего':

$$
\begin{aligned}
& \text { - Птица в небе - выше нас родилась! } \\
& \text { над тобою наш не властен приказ! (398) - }
\end{aligned}
$$

говорит Царь к вызванному Царевичу-Гусляру и соткавшемуся из "дыма-тумана", на что Царевич в свою очередь отвечает:

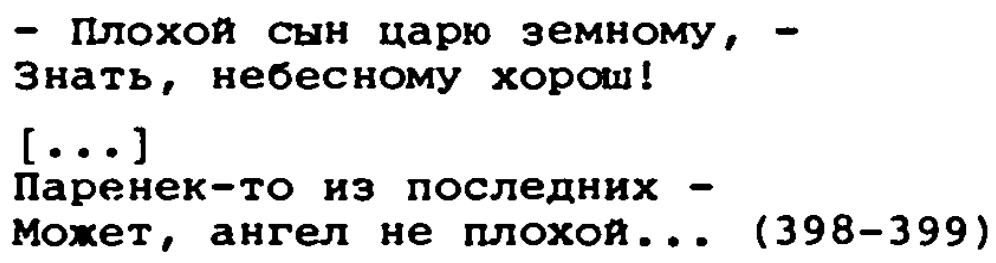

Попутно отметим и в этор ситуации некоторое совпадение с известным апокрифическим ответом Христа солдату на вопрос о его родителях (в Ормянском Еваягелии): "Нет у меня отиа на земле, а матери - в небесах" и "Едины у меня Отец, но нет с ним матери: единая у меня мать, но нет с неи отца". 92 дело, конечно, не в том, чтобы проводить необоснованные параллели между царевичем и Христом, а в том, чтобы раскрыть мифологическую логику его пронсхождения: имея мать, он ее не имеет, вместо матери - у него мачеха, т.е. мать, ставшая мачехон; имея отца, он не имеет и отца - этот его не знает и не признает; роднвшись он одновременно как бы и самороден (ср. мечту царя "без баб-то - Рожать сыновеи!" - с. 401). Обратим еще внимание на употребление слова "сын" в даннов выдерхке: оно имеет в виду не столько родственную связь, сколько статус или функиию Царевича (точно так же Функниянияуетяя-вдесь и 
слово "царь", дахе если и подразумевает толкование 'отец') . Отскда возмохность быть сыном 'плохим' и 'хорошт' одновременно (равно как и быть неодинаковьм 'царем', Т.е. "земным" и "небесньм"). Более того: "сын" в разбираемом фрагменте чередуется с формон "Паренек", которая с одинаковьм вероятием означает как 'юного неженатого мужчину', так и 'Сына'. Особо значимо это чередование в другом месте:

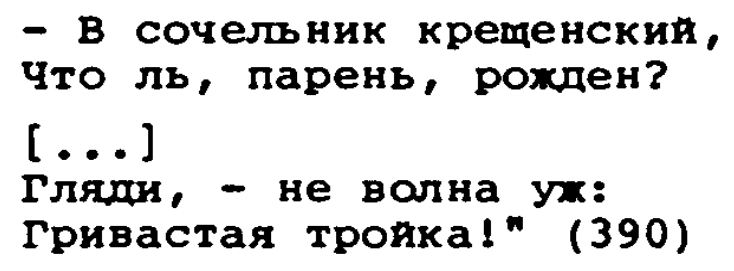

"Парень" - словоупотребление естественное: оно употреблено неким морским существом, которому сводственно видеть царевича с земной или подземнои точки зрения и причислять его к сфере "сочельника", т.е. еще не сакральноя (не с после-'полночноя' стороны праздника кремения Господня). Одновременно однако оно содерхит в себе и смысл 'Сын' в абсолютизированном варианте 'Сын'. Последния же выдвигается на первы план после комментария на тему поднявшеися волны и уподобления ее трехконно колеснице: "не волна ух: Гривастая трояка!" дело вот в чем. Христианския праздник Кремения есть праздник Б $О$ Г О я В $Л$ е и и я и эпифании воды. По распространенньм представлениям, акт Богоявления проявляется в полночь в виде непроиэвольно всколыхнувшедся воды. 93 взбурлившее море ("пучина Пошаливать стала!" - 390) под ладьеи Царевича и упоминание "сочельника крещенского" однозначно отсылают к бохественной природе царевича как "парня"-Сына. Те же коннотация получает теперь и "Гривастая троика": в ней легко читается намек на колесницу богагромоверхца.

так, косвенньм путем мы установили подспудное родство Матери царевича с Параскевод-Пятницеи и Богородицеи, а Мачехи - с Пятницеи-Мокошью. В заключение напомним еще один факт. В балканских легендах Параскева-Пятница, а точнее - Параська, попадает в турецкия или татарския полон и пребьвает в гареме, откуда с помочью ангела-хранителя бехит и спасается от погони, превратившись в чистую криницу. 94 В царо-Девице этого сюхета нет, но нельзя исключить, что его отзвук или самостоятельны вариант содержится в мотиве Мачехи "полоняночки" (см. 1.2.1.и 1.3.2.) и двоехенстве Царя и его увеселительном круге из "бутылочек", которые пляшут

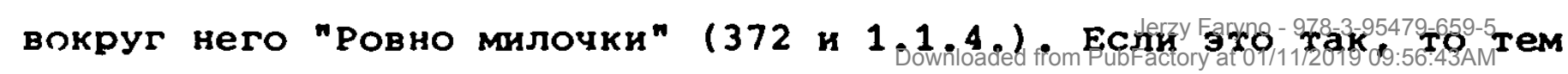


показательнее должна быть редукция всего сюжета только до ситуация плена и гарема и перенесение ее С Матери (Параскевы-Пятнишы) на Мачеху (Параскеву-Мокошь): тогда становитгя совершенно очевидньм, что свою Мачеху Цветаева мылит в тесноя связи с ПараскевояПятницея, т.е. как другую сторону Матери царевича.

1.3.4. В плане вырахения образ Мачехи несравненно разнообразнее и разветвленнее образа Матери Царевнча. В плане же содерхания оба этих образа одинаково просты и, в принципе, - тохдественны. Суть Матери - огненно-акватическая стихия небесного происхохдения (см. 1.2.2.). Суть мачехи - тохе огненно-акватическая, с тоя только разницеи, что она земного или подземного происхождения. Первая созидательна, утсрая - губительна. Первая - жизнь или рохдение. Вторая - смерть, погломение, небытие.

источаем Мачехон "хар" - некое паляпее пыхание без огня и света: "черныр чад" (401), "дымовоя столб" (404), "мрак" (403), "хлад" (403), жгучия "мороз" (403) и "жаркия воздушок, [...] инбирь-шафран-корица-корешок" (404). 95 Все это однозначно связывает ее с традиционньмя свояствами подземного мира, с преисподнеи. Тут мохно только добавить, что упоминание "чада" и 'пряностеи' вносит еме смасл 'отравляюмего' и 'галтоциногенного', которы перекликается со снотворными "настонками" и "маком" (348), которьми поят Царевича, с одноћ стороны, и опьяняющим внном, которое непрерывно пьет Царь, с другоя. В результате огненное начало Мачехи сильно удалено от огня как такового и резко приблккается к ее 'акватическому' началу.

На первын взгляд Мачеха - сплош 'акватнчна'. Ее тело - "пуддрека" (402), ее шелка́ - "ручьям вниз!" (404), ее уста - "устье" (407), ее покои - "реки" (377), а она сама - "В глубияную глубо затягивает" (407). Но это далеко не все. Мачеха-'вода' - отнюдь не обьчная вода.

Одно иэ ее проявления - 'вода-Гидра'. Ср.:

то не черных две косы, слуханки кроткие:

Две расхлестанньх змеи - да с косоплетками! (401)

вырывала тут из кос косоплетки,

Отползала змея к самоя середке, (402)

не змеины шип - шелков рваных скрип,

То не плетка-хлыст - шелков рваньх свист,

То на всем плясу - шелка́ ручьми вниз! (404)

другое - 'вода-вино'. Ее уста - "паточное устье" (407); она

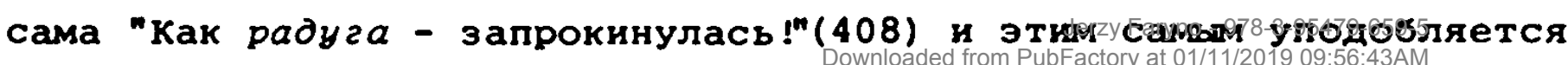


содерхимому окрухаюмих царя "бутылочек" 372); ее и Царевича Царь сталкивает друг с другом как 'чарки': "Царь их лбами чоккул" (407). При чем все это предваряется авторским отступлением, в котором женщина явно уподобляется "чарочке" и опьяняомему напитку:

Поделитесь чарочкоя -

и все с концом!

$[\ldots]$

Поделись по-бохески -

и кахшиम пьян. (405),

с завершающим образом виселицы и смерти:

Столбам с перекладкою

Никто не плох!

Хватан мертво хваткою,

A там - как бог! (405)

Более того: тема опьянения возобновляется после эпизода поцелуя мачехоя царевича:

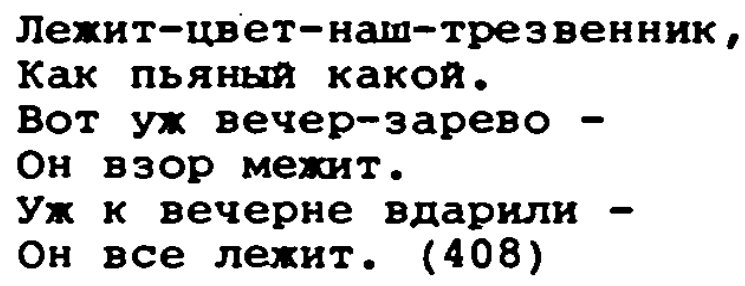

Иначе говоря, Мачеха есть смертоносная 'вода-вино' . Но и это не все. Она - то же самое вино, которьм постоянно упивается царь (см. 1.1.2.д. и 1.1.5.). Ср. обрамение царя К Мачехе "Виноградинка в соку" (402); наяменование Мачехи "Льни, тонкоствольная лоза!" (383) в эпизоде эротического акта с дядькои-филином; замечание царя о неисчерпаемости винных запасов в его погребах:

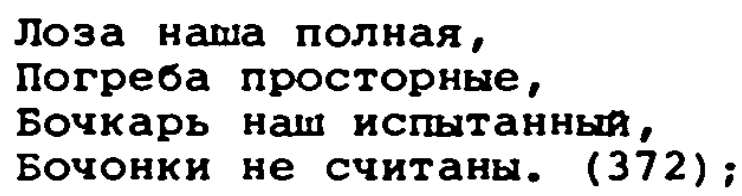

возобновление 'бочоночноя' темы в эпизоде пляски Мачехи: "Духом винным-тут-бочоночньм румянилась" (402); перекличку "вина" с "лозон", а венчального обливания вином с наказанием прутьям:

всего тела вдоль - винищем

В кровь исполосована. (406)

и, наконец, перекличку обступающих царя концентрическими кругами "чарочек", "бутылочек", "бочоночков" и построенного на 'обвивающер кинемограмме' финала брачноя пляски: "обхватывает, обматывает, [...] Вокруг обвилась, как жимолость" (408; с дополнительнов перекличкон "лоза" - "жнмолость").

В результате 'жар' и 'вода', составляющне суть мачехия ока- 
зываются эквивалентны: "чад" - "дъм" - "пряның" "жаркия воздушок"

- "дух винныр-тут-бочоночның" - "лоза" - "жкмолость" - "пенька"

- "радуга" 'бутылка' - "чарочка" - "змея" - "мертвая хватка" 'виселишы' и "химолости" - 'опьянение-смерть'.

Вся эта цепь эквивалентностея завершается оразом "крови" Мачехи: и змеиная природа Мачехи и ее 'винно-акватическое' начало оказываются Мачехинои кровью. Ср.:

\section{Кровь, что воет волком,}

Кровь - свирепы дракон, (408)

Само собоя разумеется, что такая кровь - убйственна. Именно ею мачеха несколько раз повергает царевича в 'сон-смерть'. Ср.:

- Вынь из бликнего, из нашенного

Из платочка совово - булавочку.

Ты упрись ею в грудь вьсокую,

напои ее кровью досыта.

$[\ldots]$

Вынимает из тела грешного

Пурпуровую - всю - булавочку:

"Всю до капли кровь

За его любовъ!

Всю из жилок прочь

За одну за ночь!"

[... ]

и вколи ему зменку в шиворот,

पтобы вся их любовь - навыворот!

От булавки тоя - будет крепко спать,

Она звать его, а он путе спать...

Ляхет парень смирнея травиночки

ОТ кровиночкя-булавиночки. (347)

и в другом эпизоде:

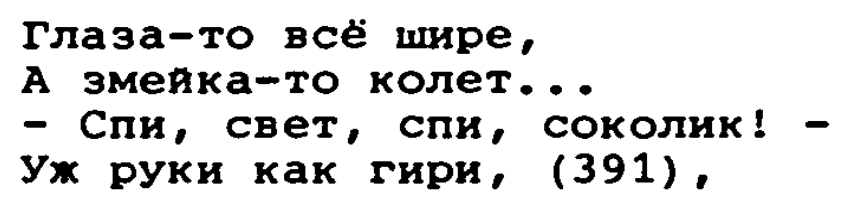

которы замыкается ощуиением-видением пожара:

$$
\begin{aligned}
& \text { "Дядыка, пожар!" } \\
& \text { Закрылся глазок. } \\
& \text { [...] } \\
& \text { - дядыка, пожар! - } \\
& \text { Закрылся другоя. }
\end{aligned}
$$

Так и спит с последним криком,

С ротиком полуоткрытым. (391)

А окончательно смысл "пожара" вызываемого кровью-булавками-змеиками Мачехи,раскрывается дальше: 


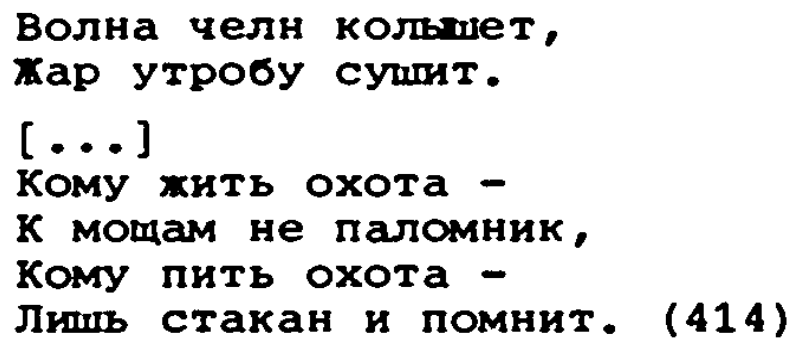

Этот "пожар", как видно, не имеет огненноң природы. Он - внутрен-

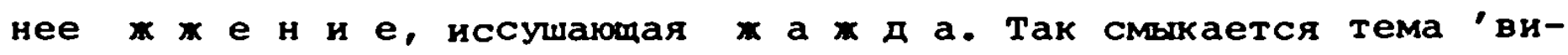
но-акватическоя' прирошы Мачехи и царя-'пропоицы' (см. 1.1.5.), т.е. неутолимо жахшы в подземном смертельном мире. По отношенио К Царевичу это значит следуюмее: вызвать у него жажду - вызвать у него 'любовь' $к$ 'вину'-мачехе, совратить на путь пьякства и разврата, а в итоге - окончательно 'погубить', приобщить к 'смерти'.96 но на уровне сюжета поэмы этого не пронсходт: царевич утоляет мучаюмую его жахду другон водоя - морскоя. С данноя точки зрения последния Фрагмент поэмы особо показателен. Во-первых потому, что, благодаря паралеллизму, "жить" и "пить" окаэались эквивалентны друг другу. Во-вторых потому, что прехние "рюмка" или "чарочки" подменены здесь "стаканом" или - иньмн терминами - 'женское начало' подменено 'мужским' (ср. выше эквивалентность: "чарочка" = "женщина" = Мачеха-"вино"-"смерть"). А сама эта смена в семантических реляциях объясняется тем, что в данном случае царевич пребывает на море и что именно море предлагает ему свою воду для утоления опасноя жахпы.

Естественно, обнаруживающаяся систематика не упраэдняет огненно-акватического начала Мачехи, но вводит в это начало момент спецификация. Оно не столько 'огонь-вода', сколько 'жар-вино', подземная смертоносная влага, мнфологическая вода забвения. Ср. - булавках, которыми Мачеха разит царевича:

$$
\begin{aligned}
& \text { Сталь из вброта - } \\
& \text { Память в лоб. (426) }
\end{aligned}
$$

1.3.5. Раскрытая выле суиность Мачехн заставляет теперь обратить внимание на некоторые другие ее свонства, пересмотреть образ царя и учесть ряд еще не рассматривавшихся свонств царевича. Мачеха - "Страна", но одновременно и "вино". Одно и другое взаимоэквиваленты: "Страна" есть "гробик" (см.1.3.2.), "вино" же смертоносно (1.3.4.). На этом, однако, данная эквиваленция не обрывается. Будучи "вином" Мачеха явлется одыовременоо и содеркмым и содержащим: вином и "чаркоя" ("Да как заталком чоккется С заслон-

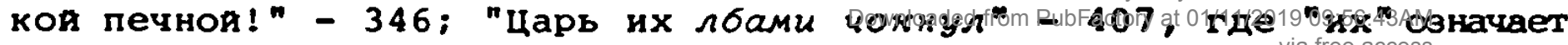


Царевича и Мачеху); вином и 'бутылкон' (ср. упомннание в ее образе и в описания окрухающих царя "бутылочек": "радуги" - с. 372 и 408; "горльпика" - с. 372 и 402); вином и "бочонком" (ср. "бочоночки" вокруг царя - 372; и в образе пляска Мачехи: "Духом викким-тут-бочокочким румянилась" - 402): вином и "лозоя" ("Лоза наша полная" в случае описания локуса царя - 372; "тонкоствольная лоза" - 383, "Виноградинка в соку" - 402 по отношению к Мачехе): вином и "реками" (Царь сидит "Промех викких рек", а его винные "погреба" "просторные" - 372; покои мачехи - "реки" - 377, ее уста - "паточное устье" - 407, она сама - "В глубиянуи глубо затягивает" - 407). Инњми словами, вся эта "Страна" есть некин 'винны локус'.

Если теперь вернуться к локализация царя "Промех викмих рек, бочокочких гор" и к окружаюмим его концентрическим кольцам из "чарочек", "бутылочек" и "бочоночков" (371-372; см. также 1.1.4.), то придется скаэать, что царь пребывает внутри царицы-мачехи. А если вспомнить, что "Сидит Царь в кутре земком" (371), то следовало бы сказать, что Царица-мачеха есть з е м л я (ср. 1.3.2.), а осторохнее вырахаясь - земля-преисподняя.

По нашпм подсчетам события поэмы приурочены к периоду последнего зимнего новолуния, предваряюмего первое весеннее полнолуние и тем сампм древнин славянскин новын год (См. 1.1.8.). При таком взгляде царь легко соотносится как со старои Пуноя, так и с умираямим старьм годом. Царевич - с молодои лунон и с рождаюмимся новьм годом. Царица-Мачеха хе, в таком случае, - с землеи-преисподнер как локусом умирания и рождения.

Локализация царя внутри царищы-Страны восходила бы тогда к народньм представлениям о Старон Луне, согласно которьм во время "пустых днен" (когда луна исчезает полностью) Старая Луна возврамается в лоно свое матери и там снова возрахдается, но уже как новая, Молодая Луна. 97 Возмохно, что так именно долкно толковать преклонны возраст Царя, его упомннание о "пятиалтынном" как своем двоннике, лишенность царского "сану", пьянство, разорение своего царства, обветшавши его "шатер" и заказ у Мачехи с Царевичем "внучка"-'копия" (373, 398, 405-406), а также столкновение с сыном-Царевичем именно В момент полнеишего разорения "именьица" (398). Но это далеко не достаточно: отсюда никак нельзя переити к сменяющему Царя Царевичу, равно как и ко миогим сво сстам царицыMayexи. 
Такои переход станет возмохным при учете, что царь - и старая Луна и Стары Год, т.е. при учете годового народного цикла. тогда царь соотносится с велесом-Николон, а царица - с Мокошю и ПятницеИ, Фунционально соответствующе Николе. Но Никола - отнюдь не однородны и не однозначның мифологическия персонах: необходнмо различать два его варианта. Ннкалу смнего, родственного Велесу, вешнего - додственного Егорию (опять-таки весеннему) и св. Михаилу. То же и в случае Пятницы: энмнюю, родственную Мокоши, и весенние, родственные Богородице. 98 Внук заказан царем к зимнему николе. Будучи копиея царя, он долкен будет замкнуть годовон цикл. Сын же - Царевич - хотя и имеет некоторое сходство с царем, тем не менее не является его дублем. Он соотносим С в е ш н и м Николоя, и его Функция - открыть нсвья годово цикл. Вот поэтому он не по сердиу Царю, и поэтому мачеха так к нему ревностна. В цанның момент от Царевича зависит как судьба Цаяя, так и судьба Царицы-мачехи .

на уровне литературного сюжета все они - вполне обособленные и самостоятельные персонахи. На уровне смысла и дахе на уровне миФа они - всего лишь определенные состояния мира на годовом витке этого мира, отдельные Фазы жи и н и м и р а. Поэтому они могут то расходиться, то взаимодополняться, то дублировать друг друга, то взаимно отождествляться. Так, например, Мачеха может быть и женои Царя и женои Царевича, она же может быть мачехоһ Царевича, но и его матерью; Царь же может быть и мужем царичы-Мачехи и пребывать в ее лоне как вернувшнся возродиться сын; у царевича мо-

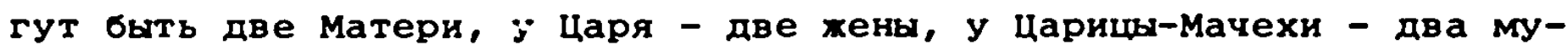
жа. Правда, нет у них д в у $x$ сыновея, царевич - один. Но и это не совсем так: Царевич у д в о н, а то и у че т в е так, на смотринах царь-девица видит в нем мальчика и девочку, С одноя стороны, а с другоһ - и двух мальчиков, и двух девочек (365).

Вернемся еңе раз к датировке событин поэмы. В начале поэмы, в главе Bстреча переая, говориться:

Не трубили зо́рю

С крепостнов стены.

B небеcax Eгория

не разжег водны.

Спит кузнец над горном,

Спит косарь в копне. (350)

В конце же, в главе Встреча третоя и последкяя, ухе иная картина: 
Гонит пророк конея, Гривами хлябь пошла. Пуме вэметнулся бич

В плани пророковон. (425),

а царь-девица

Молние поднялась,

Грудь-разломнла-сталь.

Если первы образ мохно было сначала понимать только как описание предрассветного часа, то в контексте второго он ухе читается как обозначение предвесеннего, п р е д г р 3 О в 0 г периода в хизни мира: не объявивши водны Егория означает, что еме не наступило время весенних гроз, борьбы со Змеем,завладевиим миром на время зим; спяние "кузнец" и "косарь" - спямую, погруженную в зимния сон-смерть земпо. Этим, конечно, понятие 'ночи' С первого образа не снимается. Тут денствительно имеется в виду ночь, но ночь как иное намменование 3 и м н $Г$ о периода, как время 'сна' мира.

Когда Мачеха Говорит Царевичу "Все, что знала, позабыла нынче за кочо я: Я крестоякочка, твоея дуии слуканочка!" (343), то не трудно опознать в этих словах указание на ночь-з и м у и на

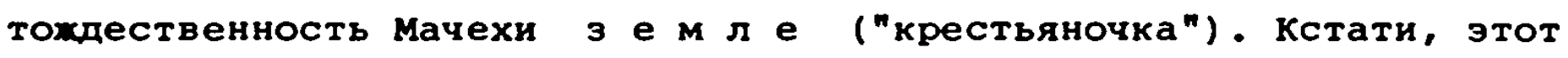
смысл возобновляется еме раз (в Ночи второй):

"три года завтрашне зареи,

Как я на персик восковоя,

Как ничия на базаре, -

На нехны лик твод зарюсь!

Три года эту ночь ждала!" (380)

Правда, тут речь о "трех годах", но по условностям сказки они означают не что иное, как т р и ме с я ц $а$, притом три 3 и м н и $\mathbf{x}$ месяца. "Завтрашнея зарен" должна наступить весна, новая Фаза в жизни мира. Дахе в сюхете поэмы в следуюмую ночь наступает "конец" подэемного царства, а на заре разыгрывается картина весеннен грозы (см. зыдерхку выле).

Итак, мачеха - з е $л$ л в Дополнительно об этом может свидетельствовать упоминание с н $е$ г а в ее образе, а в образе подземного мира - в р $\mathrm{\rho}$ в: "нашнх босых ног - Не белен снехок" (403):"ан мороз тебя охег?" (403) - царь к царевичу после того, как мачеха в своеи пляске скинула "босовички"; "До ковровой до земли склонилась истово" (402). Теперь, думается, понятнее также, почему она названа "по-

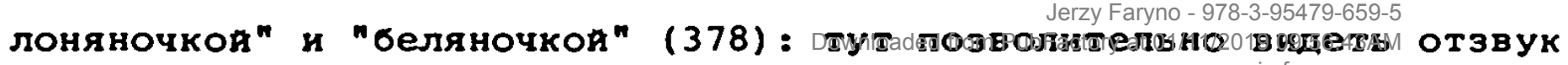


распространенного представления о эимнен земле как о пребываюеи в плену хенмине (сp. 1.3.2.).

Если видеть в Мачехе зимнюю земюю, то нельзя не обратить внимания на некоторые любопытные особенности ее брачноя пляски.

Мы ухе не раз отмечали, что прежде всего в этом эпизоде обнарухивается акватическая суцность мачехи. Но дело не только в этом. Дело в том, что она постепенно освобохдается от своих одехд н в конце предстает "босая, Того хухе - $20 л a я ! "$ (406), что ткани на нея сами рвутся и ниспадают с нее "ручьями вниз!" (404), что царь, венчая их, говорит:

\section{Берет царь бочонок: \\ "нало вам святон! \\ В ковры-вам-подстилки \\ Вину велю течь!" (406),}

поливает "двонным Фонтаном" из "бутылок" и "чарок" и притваривает:

"Чтоб в играх-затеяствах

Плодились птенцы,

Вот вам венеценских

Две чарки - в веншы!" (406),

и что в финале пляски Мачеха уподобляется "радуге" и "Ах пол подметает - косами!" (408). Напомним еме, что до этого момента вино в подземном царстве пребывало в замкнутом состояния, что ему не свояственно было 'вылеснуться' (См. 1.1.4.), теперь же оно свободно выливается Царем на новобрачных. Короче говоря, здесь налицо $\mathbf{p}$ a в e p 3 a н и e земных замкнутых зимних вод. Еще, правда, не дождь, но уже раскрепомение эемли и ритуальное вызывание или провоцирование оплодотворяюиего дождя небесного. 0 том, что цветаева подразумевает именно такое толкование, свидетельствуют два факта. Сама мачеха уподобляется цветуден яблоне:

Белы плат-то свон нагрудны распахнет!..

$$
\begin{aligned}
& \text { Плоть ли бабья - ая } \\
& \text { Просто яблонь-ман? } \\
& \text { Бабья пазуха - } \\
& \text { Али божия ран? (403-404) }
\end{aligned}
$$

Игра Царевича уподобляется в свою очередь оплодотворяюиему дождогрозе:

Заиграл сперва гусляр так-бт легонечко, Ровно капельки шумят по подоконничку. 
Та - пруд-река,

колеблет бока.

[…]

Отпустил гусляр своих конеи стренохенных -

Покатилась дрожь волнои до быстрых ноженек. (402-403)

Расточаемы Царицен-Мачехой соблазн, ее эротическая невоздержанность при толковании этого образа как пробуждающеися земли вполне закономерны. Закономерна также ее любовь к сыну-пасынку, двоемужество, характер прелюбодеики: дабы вояти в новую фаэу, она требует обсеменения. Этим, конечно, ни ее хтоническая природа, ни ее смертоносное начало не аннулируются: чтобы пронзвести жизнь, она вынуждена предать смерти мужское начало. С другоя стороны, вполне закономерна такхе и полная эротическая воздержанность царевича в поэме: пока эемля замкнута, она считается неприкосновенной. Этот подтекст проэрачно прогляшывает в песенке царевича, которую он поет после подземного венчания и, что особенно вахно, достигнув 'полнолуния' (в "двухнедельном" возрасте - с. 414):

"Сорнуло траву дурнуко

Не коси, косарь, с плеча!

не паma, не боронуя,

молодость моя прошла:

$[\ldots]$

только знал, что на перине

Струнным звоном ворожил.

Кто страшы земнор не принял -

тот земли не заслуиял.

$[\ldots]$

Ну, а этим ух именьем

Пуйе хлеба дорожил...

Кто К земньм плодам надменен -

Тот земли не заслукил!" (419-420)

Ни на сюжетном уровне, ни на уровне семантическом новая стадия мира - 'весенная' - в поэме не разрабатывается. Всё обрывается в момент крупения подземного царства, в момент его распадения, а в ином истолкования - С концом зимы или точнее: зимнего состояния мира. На сюжетном уровне это вырахено уходом и 'продажей' Царевича, отлетом на Ветре Мачехи, после того, как она узнала, что "челнок" Царевича "Пришел к побережью Без парня" (429), и - уже в Кокие - свержением царя восставшим людом ("мамкон", "кормилкои" Царя, "Русью" - 434). К вопросу такого решения сюжета цветаевоп нам придется еме вернуться, а пока остановимся только на том его аспекте, которы непосредственно относится к образу Lарин-мачехн. 99 
1.3.6. Судьбу мачехи Цветаева заканчивает так. Не сумев задерхать царевича и узнав, что тот уплыл с царь-девицен (так, во всяком случае, сообмил ен ветер - 430), она в отчаянии взывает:

$$
\text { " [...] }
$$

Ветер, на́ меня!

Туман, на́ меня!

Отпусти меня,

Гроб мон каменның!" (430)

Ветер предлагает ен свои услуги и уносит ее на себе не в погоно за беглецом, не на море, а в сторону материка. По пути они ссорятся и Ветер коварно сбрасывает мачеху, выявляя еи правду о царевиче, т.е. что тот попал не "под пятку" царь-девице, а "так и гает промех двух ее груден!" (431). мачеха падает вниз и превращается в змея:

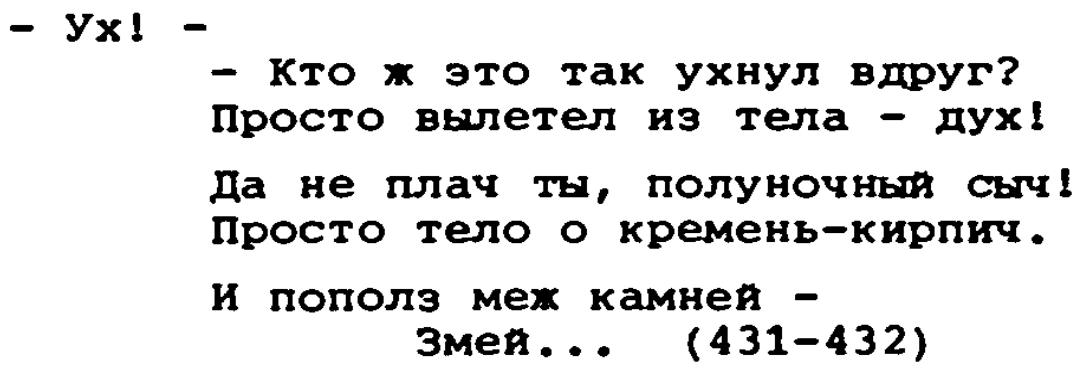

Царо-Девииа - не пересказанная сказка, а сказка п о э т и ч С С к а я, созданная П О э Т О М, что значит, что словесная ткань такои "сказки" так же же С тка, Т.е. з на ч и ма, как и любого другого литературного проиэведения, реализующего некин иноя жанр. Поэтому Финальное слово "Змен..." - не декоративиэм под фольклор и не обмолвка цветаевоя, тем более, что восемью стихами раньше мачеха три раза сряду была названа "змеея": "- Не сумела усидеть, змея, - так рухая! Знан, змея из змей" (431), равно как и во всем предыдущем тексте поэмы (ср. хотя бы в брачнои пляске: "Отползала змея" - 402; "То не черных две косы, [...] Две расхлестанных змеи" - 401; а также последовательность в называния "булавок" Мачехи "змеиками" или формами от суиествительного "змея́", а не "змен").

Из ссоры с Ветром следует, что мачеха - не $n$ e $p$ в а я из уносимых ветром: "чан, ке перөой в своен верности клянусь!" (430), "Не таких еще косил через всю Русь!" (431), хотя в самоя поэме о других подобньх случаях не говорится. С одноя стороны, это значит, конечно, просто коварство Ветра. С другои, однако, указывает на повторяемость изображенных в поэме события, на их цикличность:

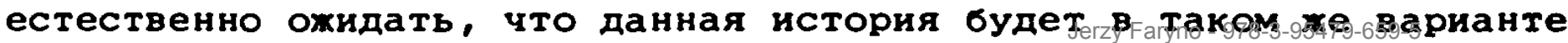


возобновляться и впредь. Мачеха в данном эпнзоде названа именем "молодая": "Мчится, мчится вместе с Ветром - молодая!" (430), подменяоцим здесь иные наяменования и благодаря этому эксплицируюмим нсконную 'молодость' Мачехн. Это в свою очередь подразумевает, что мачеха не подвластна возрастнои эволюции, что она и з в ч н а. такое ее своиство еме заметнее, если учесть, что царь в поэме - "старын" (373), а царевич - все 'взрослеет' (ср. в его песенке: "Молодосто моя прошла" - 419). Изменения, претерпеваемые мачехо в поэме, носят характер только перевопломения, метаморфоз, не затрагивакщих однако ни ее статуса ни ее сущности. Более того: убиваясь, она ке убивается, а всего лиш меняет своя внешния вид - становится Змеем. Змея и Змеи - вопломения вечности, непрерывноң цепи пернодических воскресания и условных умирания, получаюих вид смены кохи (тела; ср. рвушнеся "шелка" на Мачехе, которые ниспадают с нее "ручьми вниз", после чего - уже "голая" - она и далее остается в "платьице", что "глаке шелку" - 404-407) или временных переселения в иноя локус - при 'умирании'в подземы, потусторонния, при 'воскресания' в земоя. Таков именно характер имеет перелет Мачехи из подземного мира (ср. ее слова в финале: "Omпусти меня, Гроб мой каменның!" - 430) на материк, на землю, кудато "через всю Русь", В некое "царство-нам-Китая" (431) и окончательная локализация "мех камнер" (432) в отличие от морского "побережья" (429), где ситуирован весь мир поэмы, ее 'вырия'. 100

"Гроб каменны" "отпускает" Мачеху, однако, лишь частично: ее тело ударяется "О кремень-кирпич" и, превратившись в Змея, ползет "мех камнея" (432). Похоже дахе на то, что мачеха вообие не высвобождается из своего "гроба": "кирпич" предполагает некую 'постронку' и в данном контексте провоцирует ассоциация с 'Гробницея', 'склепом'. Но это не едннственная возможность. "Кремень" подразумевает 'прочность', 'гранит', "кирпич" же - 'непрочность' и 'глину', а "кремень-кирпич" - 'несокрушимую бренность' или 'непреодолимость бренного'. Иначе говоря, здесь налицо ассоциация с библеиским мотивом сотворения человека из земли-глины и его изначальноң греховности и бренности. У Цветаевоһ, однако, "тело" Мачехи не рассыпается в прах, а преврамается в Змея, т.е. одаряется живучестью и некое самостоятельностью. Такон ход, думается, объясняется просто: тело преврамается в совратившего его и поселившегося в нем мифического Змея. "Гроб каменның", полонивия мачеху, - не что 


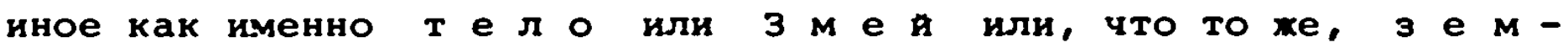
ля - г л н на. 101 Заметим, что освобождение Мачехи пвпется однвременно ее гибелью, распадением на два отдельных начала: тело и дух ("Просто вылетел из тела - дух!" - 431). Погибла Мачеха, но не погибло ее "тело", став Змеем, и, вероятнее всего, не погиб и "дух". Все вернулось к исходному моменту и продолхение этон история легко предвидеть: в соответствующи момент Змея снова завладеет чьим-то духом и снова станет такон же "Мачехон", такон же "эмеен", такоя ке 'преисподнен'.

"дух", надо полагать, соответствует не въведенному в поэме 'предсобытинному' состоянию Мачехи: не зря она в поэме ухе "полоняночка" и состоит в связи с "мальчишечкон"-дьяволом, "Кто прехсе cynруга нам шенны nлат pasmpenas" (378-379) и не зря, хотя и поначалу противится, но все-таки уступает дядьке-Филину и дахе повинуется ему (347, 383). Иным происхохдением ее "духа" объясняется, по-видимому, и ее параллелизм к Деве Чистон (375), ПараскевеПятнице (см. 1.3.3.), а также ее обрамение к Матери Божьея (379) и к крестному знамению (383), тут еме 'каноническому', с целью защититься от настончивости пакостного Филина.

Все это подводит нас к связи образа Мачехи с образом библенскоя Евы. Не думается, что Мачеха есть Ева. Она только некия очереднон вариант Евы на очередном витке мирового цикла ("не первая", по словам Ветра - 430), а точнее - прямая наследница Евы.

Наяболее однозначно к образу Евы отсылает вписанная в образ Мачехи "яблонь":

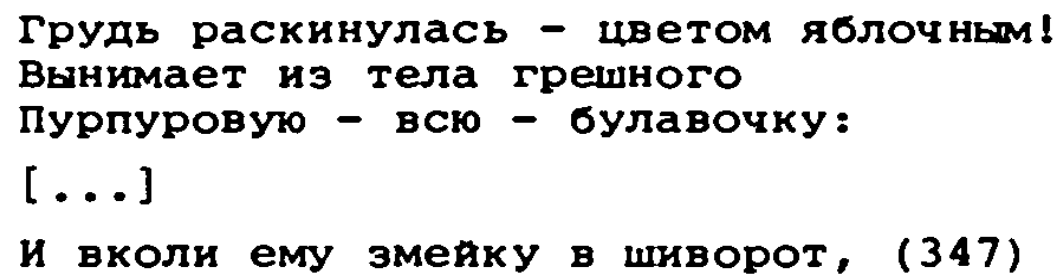

Белы плат-то сво нагрудны распахнет!..

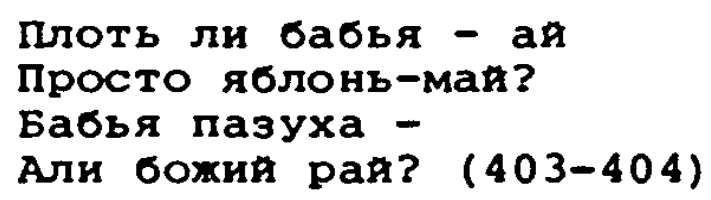

При этом примечательно, что в обоих случаях Мачеха уподобляется не соврапаемо Еве, а соврамаюмему древу-змею, а в итоге - прародительнице земле ("божия ран"). Первы Фрагмент мы взяли из эпизода первого по ходу событин в поэме сговора Мачехи с Дядькон. Эпизод этот начинается со 'святого' воэмущения Мачехи на нескромное пред- 
лохение Дядьки, когда она глубоко оскорбленная

Помертвела ровно столб соляноя,

Д'как сорвется, д'как взовьется струнон,

Как плевком ему да вызвездит лоб!..

"Хам! охальник! Худородны холоп!

Целовать тебя - повешусь допрежь!" (345),

но потом увлеклась ворожбор на "лампадном елее", в котором увидела близяцуюся встречу Царевича с царь-девицея (345-346):

Лево нохкоя топнула,

Да как охнет, взглянув!

Да как навзничь грохнетая,

Колен не согнув!

Да как затылком чокнется

С заслонко печноя! - (346)

Зная вегь текст поэмы и зная уже суть Мачехи, не слохно спознать здесь ее 'змеиные' потенция: "Помертвела" - "д'как сорвется, д'как взовьется струнон" = 'кинемограмма зменного прькка': уоиственњя "плевок" = "слонка" - мокрота" - "чокнется" = "чарка" 'вино' - "кровь"-"змеика", вынутая из "тела грешного", "яблочного". Но не это нам интересно, а эволюция Мачехи от "столба соляного" до "цвета яблочного".

Застывая "ровно столб соляноң", Мачеха уподобляется Лотовоя хене. Данное уподобление - свидетельство скрытоя в неи превратности, греховности и неверия-непослушания, а также признак 'наказанности Богом' (на психологическом уровне сюжета еце заметна здесь склонность к 'оглядке', т.е. потенциальная готовность сдаться Дядьке, пояти на сговор). Лотова хена - не первая библеяская ослиниа, еи прешшествовала Ева. Поэтому не кахется случаинои цве таевская последовательность в образе мачехи от 'столпа' к 'яблоне': она призвана вести вглубь мачехинои сущности, к истокам ее греховности, к содерхаменся в неи Еве.

В разбираемом эпизоде она всего лишь 'оглянувшаяся', Т.е. узница смерти (ср. "Помертвела" и 1.1.4.). 'Ева-яблонь' пробуждается в нея постепенно - в результате подстрекательств Дядьки и нарастаюме ревности. Здесь она еме жертва и орудие в чухих руках, податливая на грех почва. Зато в эпизоде брачноя пляски картина меняется. Там сначала речь идет о "яблони-мае" (403), потом о Содоме и в финале пляски - О взятия Царевича (404: "взыграв как целы град Содом - Закрутилась цымвьм столбом!"; 407: "Как жалом в него вонзается, Как в яблок в него вгрызается, Из сердца весь сок вытягивает, В глубинную глубь затягивает") На repвö 
активность. Это особенно заметно в смене сравнения с оглянувшеися Лотово жено на сам Содом, локус разврата, и "соляного" столба на "дьмовоя". Так Мачеха постепенно идентифицируется с соблазном и в конце сама становится его вопломением. В финале - Змеем. отметим еще, что с этого пути мачеха соити не мохет. Она долхна дояти до отохдествления со Змеем. "Помертвение" Мачехи и ее обморок аналогичны обмороку царя. Как ухе говорилось, смерть в царстве смерти долкна бы воскрешать, т.е. возврамать в состояние предшествуюеее попадению в царство смерти. Обратная эволюция царя останавливается на "бревне", сухом, мертвом дереве (см. 1.1.5.). Обратная эволючия Мачехи - на "столбе соляном" и 'чарке'. Мачеха, таким образом, - навеки 'оглянувшаяся' и навеки 'акватична'. Иначе - 'погибшая', чреватая смертью, ставшая землея. Не случаяно, обольмая царевича, она говорит:

Пля одно твоен леханки

Я на свет рождена. (342),

где "леханка" значит не только 'брачное ложе', но и 'гроб-земию' (напомним, что эти слова звучат после стихов: "На кроваточке однор Сынок с матушко роднон" - 342; см. 1.3.2.).

у Мачехи нет устончивого телесного образа. Она - сплошная кажимость ("виденьице" - 401), как и царь в эпизоде пляски обвалившегося шатра $(374 ; \mathrm{cm} .1 .1 .2 .0$.$) . Поэтому и появляюмияся в нея об-$ раз яблони - соблазнительнын обман. Мачехина яблоня - лишь частичная реплика запретного библеяского древа познания добра и зла. Та обольмала своями плодами, мачехина - цветом ("Грудь раскинулась - цеетом яблочньм!" - 347; "Плоть ли бабья - аи Просто яблонь-мая?" - 403). Данны цветаевския сдвиг вводит ряд существенных смыслов. 'неоплодотворенность' и 'жахду оплодотворения' - отсюда такая активность при совращении царевича. 'Oпасность' оплодотворительного акта с мачехоя - упомянутын "мая" ("яблонь-мая") отсылает к распространенньм народньм представлениям об опасности бракосочетания в мае и обычно свадеб в это время в народе избегали, 102 мачеха же 'кахет' свод маиския образ именно в брачной пляске. Кроме того мачеха - зима (см. 1.3.5.), а "яблонь-ман" следует тут же за упоминаниями зимних признаков Мачехи ("снехок", "мороз", "Белың плат-то сво нагрудны распахнет!.." - 403), где "мороз" определен как 'жаркия' ("ая мороз тебя охег?" - 403). Поэтому "яблонь-мая" позволительно читать как обольстительны, обманчивы

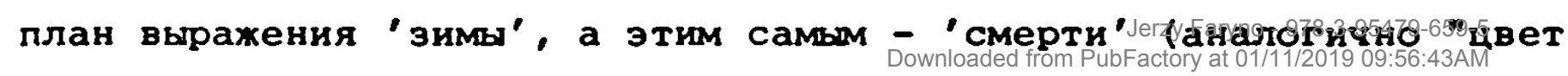


яблочнья" - как 'цветы мороза'; кстати, цветы вообще соотносятся В народноя обрядности с потусторонням миром и прочно связаны с помннальными ритуалами).

яблоко как плод упоминается в поэме несколько раз. Всегда, однако, в связи С Царевичем. В случае Мачехи речь идет исключительно о цветуме яблоне. При яблоке, если можно так сказать, Мачеха и Царевич сталкивахтся Цветаево дважды и всякия раз в реляции 'поедаюмая - поедаемы' . Ср.:

"Три года завтрашнеи зарен,

Как я на персик восковоя,

Как нития на базаре, -

на нехнын лик твон зарюсь!

три года эту ночь ждала!" (380)

и в финале брачнон пляски:

Как в яблок в него вгрызается,

Из сердца весь сок вытягивает,

В глубинную глубь затягивает. (407)

Если один из вариантов Мачехи - яблоня, то здесь на самом деле происходит картина поедания собственных же плодов: яблоня не рохдает яблоки, а поедает их. Если к тому учесть, что мачеха - мать царевича (пусть дате только функционально), а царевич - ее сын (хотя бы тохе функционально), то тогда мы имеем дело с картиной 'чадопоедания' (то же мы уже отметили и в случае царя - см. 1.1.4.. при этом и там и тут речь идет о выпивании-высасывании) .

итак, в основе образа Мачехи покоится мифологическия образ матери-эемли - рохдаюмей и обратно погломаюмен свон детима. и лишь теперь представляется возмохньм объяснить одну особенность финального полета Мачехи на Ветре: из восым строф в шести первых Ветер обраmaется к мачеху словами "мать моя" и "мать", потом переходит на местоммение 'ты' и "змею" (430-431). Конечно, "мать моя" и "мать" в устах Ветра получают окраску 'матерщины' и вписывают в эти обращения ореол 'блуда'. Но тем не менее такая частотность возводит эти обрамения в ранг имени собственного и ведет к понятию 'Мать'. Оба этих ореола не противоречат друг другу на мифологическом уровне поэмы: там 'Мать' и 'Блудница' - синонимичны, если вообще не тождественны. ${ }^{104}$ С тоя разницея, что на сюжетном уровне цветаева экспонирует только один аспект Мачехи - смертоносның, жизнепорсждаюан же, плодоносны остается за пределами поэмы, в ее контексте. 
1.3.7. Мачеха Цветаево более трагична, чем это может показаться на первья взгляд. Во-первьх, она - вторая и "чухая" жена: Отчего я не девица,

А чужая жена! (342)

Во-вторых, она - "не мать" Царевича, а "мачеха":

отчего тебе не мать родная

я, a mayexa?

[... ]

"Ox, зачем тебя не я родила?" (342-343)

и оба полохения, как видно, для нее нехелательны. Это ее, так сказать, предрешенные обязанности, ее природа. Освободиться ст них она мохег только через гибель (ср. ее намерение сброситься с башни в бездну).

У Царевича, строго говоря, О д н а мать, но в двух противоположных ипосталях: дающей хизнь и отнимахмей жищнь. Этот второи аспект Матери Царевича и представлен в поэме отдельным персонахем - Мачехон. Последнее с особой яркостью проступает в решения цветаево брачного акта Мачехи с царевичем: это не биологическое совокупление, а обратное затягивание царевича-плода вовнутрь, в родившее его некогда чрево ("В глубинную глубь затягивает" - 407). цветаевская Мачеха с ее необузданньм эротизмом, и с ее предрасположенностью К инцесту, с ее блудом и смертоносностью - персонах более древния и более естественны, чем обычные скаэочные мачехи.

Сохаление о том, что она "мачеха", а "не мать родная" Царевича, кроме обольщаюеи риторики, имеет инои епе смыл: это сохаление о том, что она - не рохдающая, а призвана умермвлять. Ее ревность к "родноң" матери - ревность смерти к жизни. Заметим: в поэме нет слова "зависть" - чувства Мачехи называет цветаева р е в н о с т ь ко стремиться разруштт жизнь, сколько хотела бы быть жизнью, но дабы жизнь произвести, сначала вынуждена ее умерщвлять.

Мачеха - не весь персонах, а только его часть, не весь годовои цикл, а только его один период, и не вся земля, а только одно из состояния земли. Поэтому безразлично, является ли Мачеха (генетически) изменившеися на время Матерью, или же кем-то другим. Так или иначе они обе входят в состав одного и того же целого, одного и того же мирового цикла. Тут существенно, что царевич родился в самы невральгическия момент: "в полночь в пятницу" (350) "В сочельник крещенския" ( 390) - на стыке двух состоянй мыра 65 (см. 
1.3.3.), тогда, когда оба аспекта родительнишы соприкасалась друг с другом, когда, фигураљьо выражаясь, Мать и мачеха имели возможность быть единством.

1. 4. ЦАРЕВИЧ.

К образу Царевича мы обрамались уже не раз, но в основном С мысыю раскрыть те или иные неэксплицитные свонства других персонажен поэмы. Теперь остановимся на нем ради него же, хотя и в этом случае придется возвраматься к уже раэобранным персонахам и, быть мохет, дахе вводить в сказанное некоторые уточнения. Естественно охидать, что царевич намного богаче остальных персонахер (что еме не значит, будто он слохнее тех), так как в нем долхны скремиваться и свонства обитателя подземного царства, и свонства,унаследованные от отца-царя, и свонства, унаследованные от Матери-мачехи, гричем -- вероятнее всего - в трансформированном виде. Если он, например, обнарухивает некоторые черты Царя-Велеса-николы, то, думается, это все-таки осове ипостася - скажем, юного Велеса, т.е. только возмохность стать Велесом, или - если николы, - то скорее его весеннего варианта, чем зимнего.

1.4.1. Царевич пребывает в том же мире, в котором пребывают такхе царь и мачеха, и которын условно мы называем царством смерти, подэемньм миром или преисподнеи. В отличие от царя и Мачехи он претерпевает в поэме возрастную эволюцню - сначала он "ребеночек", младенец, потом "малец" и совершеннолетния юнона, "богатирь" (342, 385,411 ). Поэтому он мохет рассматриваться как исконны персонах преисподнея, т.е. там родившияся и там же повзрослевшия, а часть его свонств - как свояства присущие ему изначально, а не только :звязанные локусом пребывания.

Подземны мир поэмы не совсем однороден, по краянең мере топографически, и его обитатели пребывают в разных участках этого мира. Царь - "в нутре земном" и "Промех винных рек, бочоночных гор" в своем обвепшалом "шатре" $(371,372)$, царица-мачеха - на своен "половиночке" в свокх "семи покоях" (374,375), Царевич хе - "на кроваточке" (342), без указания ее местонахохдения, но из хода событин и поведени персонахен явственно следует, что "кроваточка" Царевича находится в каком-то другом месте. на самом обмем семантическом уровне все этих три локуса эквивалентны по признаку 'локус смерти', однако нельзя пренебречь их различием на уровне плана вырахения. 
Так, семь Царишыных покоев подразумевают некое обштрное пространство, шатер Царя - пространство более суженное (не случаяно шатер обваливается при попытке встать - 373-374), "кроваточка", хотя и помемена где-то "за дверью" (348), - локус кранне редуцированныя, О нея в препирательстве Царевича с навязчивои Мачехо даже двахды говорится "узка" ("- Постеля узка! - Коль и впрямь она узка - свернусь в трубочку!" - 343). По этому же признаку дифФеренцированы также и позы-двихения данных персонахен: нанболее подвикна Мачеха, как внутренне, так и физически; двихения Царя строго регламентированы - он все время "сидит" и перемемение или хотя бы вставание ему противопоказаны (см. 1.1.3.); наяболее же скован царевич - он вынуллен 'лехать' и 'спать' (см. открывақия поэму стих "Cnит царевич, распросперся, Cпит, не слышит ничего" 341).

"кроваточка" царевича - ложе его Матери:

на кроваточке одно

Сынок С матушкон роднон. (342)

Мать его же пребывает в Вечном доме, в земле:

$n[\ldots]$

Где ж убивица моя, - твоя мать?!"

В земпю пальчиком гусляр: "Вечның дом! -

Ты в супружестве живеш во втором". (400)

Отсюда следует, что "кроваточка" Царевича - 'земля', и что он пребывает в земле. В этом отношения он там же, что и отец-царь - "в нутре земном", только на более 'глубоком'уровне. 106

Наиболее личное и интимное местопребывание царицы-Мачехи "покои седьмоя", "спаленка"-"гроб' с "пуховиком" (378). "Постеля" Царевича непосредственно не описана, но из песенки Царевича о его растраченно молодости следует, что это "пернна" и "солома" :

только знал, что на перине

Струнньм звоном ворожил.

[...]

на перине, на соломе, Середь моря без весла, -

ничего не чтил, окроме

Струнного рукомесла. (419-420)

"Перина" и "солома" здесь однозначно однородны и этим самъм - эквивалентны. Будучи планом выражения 'смерти', 'загробного', "солома" смысл 'смерти' вписывает и в "перину", которы дополнительно дублируется вырахением "без весла" как знаком 'бездеятельности' и 'бездвижности' (Царевнча). 107 "Середь моря" в 
сылает в свою очередь к локализации царя "Промех вннных рек" и к бесцельнор гребле царя (372-373; См. 1.1.9.г.).

Вывод напрашнвается сам собон: "кроваточка" Царевича обладает и свонствами локуса Матери, и свонствами локуса Царя, и свояствами локуса Мачехи. Она, иньми словами, - некия нсходның и центральны локус подземного царства, наиболее глубокия и наиболее узкия. Царь, как мы уже говорили, ситуирован внутри царицы-Мачехи как "Страны" и как винно-акватическод стихин (см. 1.3.5.), а Царевкч - внутри Царя-шатра: именно здесь он указывает на местопребывание свое Матери (а этим самвм и на свою "кроваточку").

Есть у Царевича и еще одни локус - лодка, на котород он несколько раз выплыает в море. Лодка эта во многом повторяег "кроваточку". Как правило, и в неи царевич л е ж и т в безденственном и сонном состоянии:

[...] Рученьки врозь.

Бусы в лево руке,

Гусли в правой руке. (346)

На дне - С гуслями в обнимку - гусляр! (362),

и она вылохена "подушками" (387). А на семантическом уровне она синоним "кроваточки" как локус смерти, как разновидность 'Гроба'. Последния смысл откровенно расшифровывается стихами:

$$
\begin{aligned}
& \text { "Ох, височки, волосочки мои!" } \\
& \text { - Корабельные досочки мои! - (343). }
\end{aligned}
$$

которые адресуются несговорчивому царевичу. Он еще откровеннее, если учесть, что корабль или лодка - популярная обрядная форма гроба у многих европенских народов, некогда распространенная также и на Руси. 108 В самои поэме этот смысл подтверждается как тем, что "доски" упоминаются то В связи С женским началом как носителем гибели ("- Мне что грудо - что доска! -" в ответе Царевича назоиливор Мачехе - с. 343), то непосредственно в связи с гробом (в песенке царевича о самом себе: "Для гробочка-домовики, Из досочек из шести - Из сосновых - ни единоя Я не выстрогал доски" - 419), так и противопоставлением корабля колыбели ("то - корабо тебе, то - люлока!" тут же "нет уж, - не до колибелокой!" - 361 ).

С другой стороны, смысл 'колыбели' с лодки однако не снимается. Наоборот, он несколько раз акцентируется в рефрене: 
Девицея (срахенны стрелами-змеиками Мачехи царевич в критическия момент засыпает) .

Лодка царевича, таким образом, - вариант "кроваточки" с возможностью смысла 'колыбели', 'хизни' или, иначе, 'гроб-кольбель'. Ввиду насильственного усьпления царевича в лодке, позволительно видеть в нея только 'кольбель', но оттенок 'локуса смерти' за нея сохраняется из-за того, что это все-таки 'купеческая лодка', лодка подземного царства (ср. Царевич на дне своея лодки как "мусорповар" - 362; Царь-Девица "крестит купецкую тварь", т.е. затопляет купеческие корабли - 359 см. такхе 1.1.2.Е.).

"Лодка" аналогична "кроваточке", но не тохдественна с нен. Между ними существует в поэме пространственны разрыв: "лодка" ситуирована на "море", на периферии подземного мира, а само "море" рассматривается как "дорога" к "воле", как "Окиянская дорога колыбельная!". Более того: "море" с "лодков" локализованы н и х $е$ локуса "кроваточки" - к ним спускается Царевич "С лестничек крутых" и "Вдоль перил витых" (350, а также 385 и 411). "Кроваточка", как видно, - не последния 'этах' подземного мира, а если смотреть на нее все-таки как на последния, то она - порог мехду 'смертью' и 'жизнью', мехду 'гробом' и 'колыбелью': за нея ухе "море" и "дорога" на "волю". Интересно, что обратны путь - 'вверх' - завершается в подземном царстве 'тупиком': 'лабиринт' семи покоев Царишы-Мачехи, завершаюияся "спаленкон"-'гробом' ("покон ночноя" - 378), кстати, прочно запертых на "засов" и оснаменных 'сигнальнор системон' $(374,375)$, а из "спагенки" ведет "лесенка" на "башенную вылечку" (378), которая недвусмњсленно подразумевает 'сторохевую вышку' (там перехватил Мачеху "мальчишечка" = 'дьявол-соблазнитель", там она пытается броситься "С башни вниз" в "бездну окиянскую" и там происходит ее роман с отвратительным дядькоя-филином - 378, 381, 382-383). И тут подземны мир обрывается: над ним открывается простор и путь в 'запредельное':

На лесенку выбралась, Ступень за ступенечкоя Лишь выти трудненечко!

[...]

А там уж - вольнея, вольнея, Ногам уж вернен, вернея, Как будто из гробика Восстав, мчишв по воздуху: Не к птицам на кровельку, На вьшнюю звездочку! (378) 
"Птицы" и "кровелька" в определенном отношении эквивалентны: первые - обитатели пограничнои сферы между небом и землеи, такоя же границея может считаться и "кровелька". Кроме того "птищы на кровельке" могут читаться, согласно народньм представлениям, как соответствие молния обитаюиих в тучах (это тем более вероятно, что в данно синтаксическоЯ конструкция подразумевается соответствие 'птищ - звездочки'). 109 Противопоставление "птицам на кровельке" "вышнер звездочки" отсылает еме выше - в небесния, заоблачның мир. Вероятнее всего - в мир ангелов-душ. 110

Путь вверх, "на звездочку", ведет через 'гроб' ("Как будто из гробика восстия, мчипь по воздуху"). Через 'гроб' же ведет и путь вниз, на "море" - кроме "кроваточки" как 'земли-гроба' см. eme уравнивание "лестничек крутых" с представлением о 'смерти': в первых двух царевич спускается по "лестничкам" с трудом:

Слабьми руками
Вдоль перил витьх,
Слабыми шажками
С лестничек крутьх.

причем во втором - значительно энергичнее:

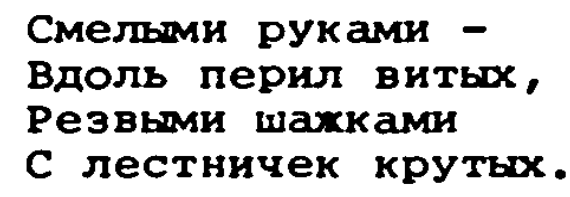

а в третьем - уже прькками:

Жаркими руками
Вдоль перил витых,
шальми скачкамя
С лестничек крутых.
какоя тут эаморьш!
Богатырь, еम̆-ен!
Одним махом - сорок
Спрыгнул ступенея.

где наконец вводится смысл 'смерти' в образе "С о p o k a c t yп е н е " (при этом прохождение "лестниц" имеет здесь вид 6 о р в 6 ы со смертью, присутствующея как в локусе 'лестница', так и в самом царевиче: сначала он "слаб", а потом - "Богатырь"). 111

но если путь вверх ведет к идеальноя, бесплотноң форме бытия, то путь вниз ведет к "мори", т.е. к беспредельноя 'пракольели', возврамает в предбытинное растворенное состояние со снятыми разделениям меку смертю и жизнью, между духовньм и телесньм. Таково во всяком случае "море" в поэме. Приведем несколько примеров. 
С точки зрения птиц, поючих Царевнчу об опасности моря и сна на море, оно представлено так:

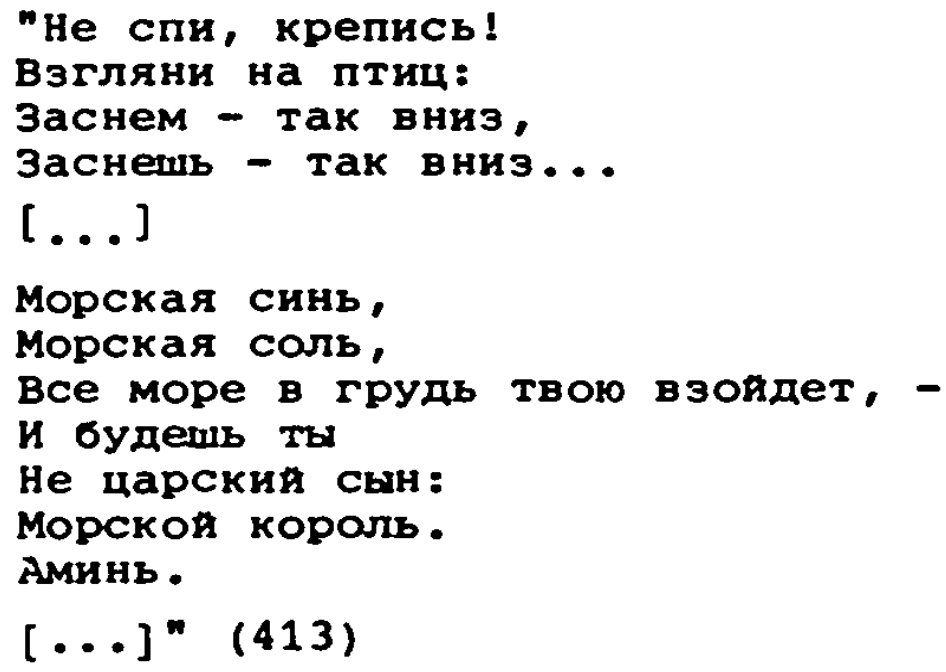

Тот же образ моря звучит и в словах самиго моря к царевичу, но в несколько иньх термннах:

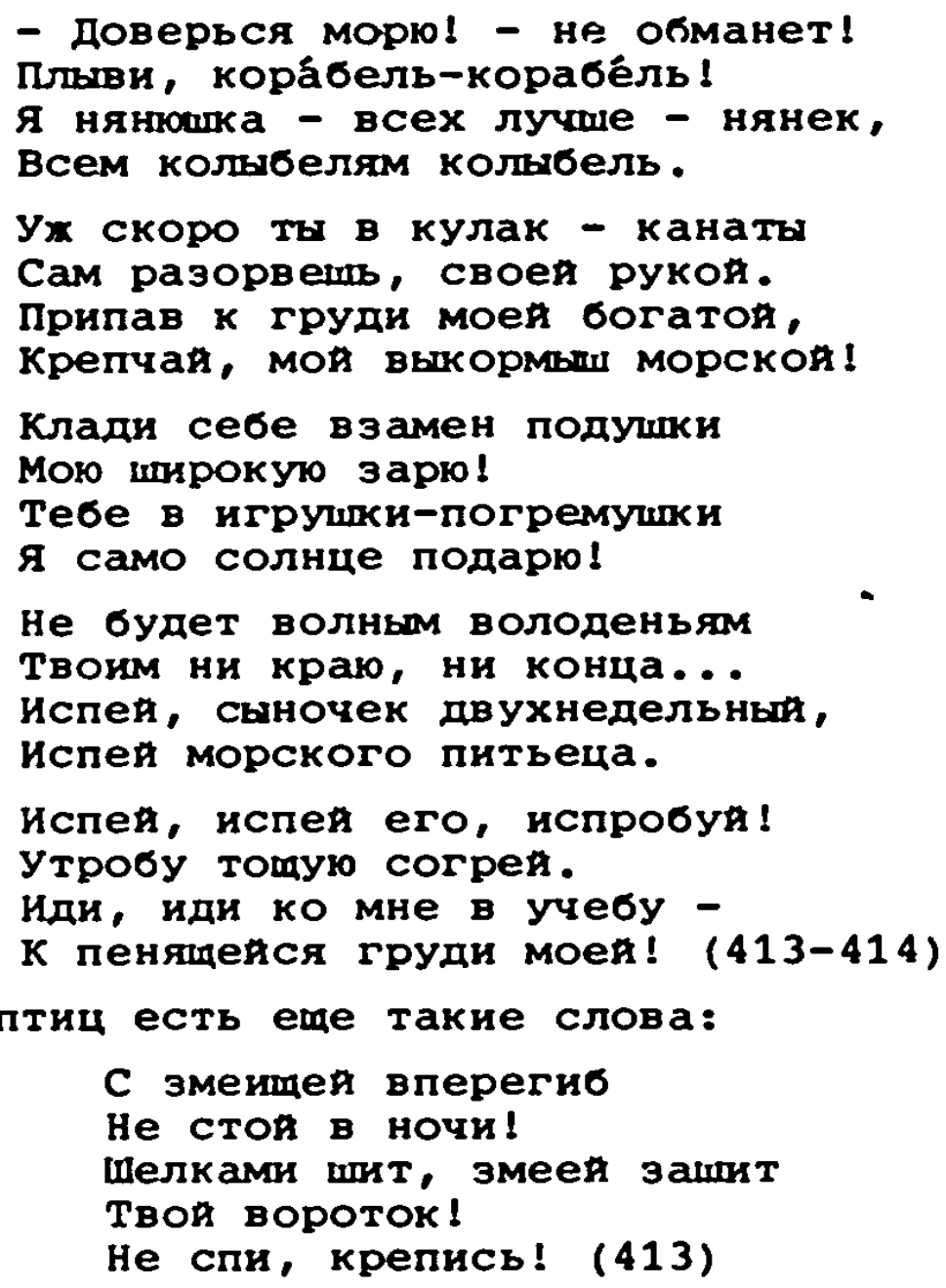

В песенке птиц есть еще такие слова:

Песенка и монолог моря следуют друг за другом. Поэтому "подушку" и "канаты" поэволительно понимать как перекменование предыдущих 'сна' и 'заиятости шелками', а "разорвешь" как перекменование птичьего предупреждения "не спи, крепись! Встряхнись!" 'Сон',

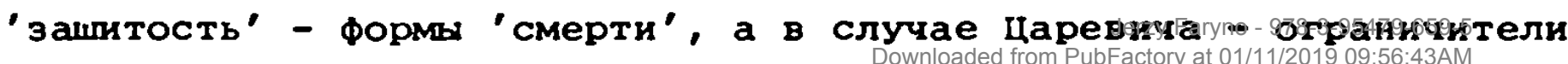


его жизненньх потенция. Не преодолеть их - значит погибнуть. Птишы настаивают на 'духовноя' Форме преодоления, на 'бодрствовании'. море же - на физическом. Оно предлагает смену "подушки" на "зарю", "корабля"-'колыбели' на свою, т.е. морскую, "кољыбель" (упоминание "игрушки-погремушки") и уговаривает освободиться от "канатов" (= 'зашитости') "своеи рукои". Более того: Царевич именуется Морем как "кора́бель-корабель" и этим самьм отохествляется с ним. Но Царевичев 'корабль' не только 'узилиме-гроб', но и 'колыбель', 'локус жиэни'. Поэтому 'разорвать канаты' и 'сменить подушку' означает и освобохдение от 'уз смерти' и от 'уз жизни', т.е. переход в недифференцированное и необособленное бытие, а в итоге - отохдествление с беспредельным мировьм океаном (ср.: "Тебе в игруики-погремушки $A$ само солкие подаро! Не будет вольньм володеньям Твокм ки краю, ки комиа..."). Но это еме не все: море в поэме имеет характер женского начала:

\section{Ведь все то $\pi$ тебя ждет \\ и у жен и у вод: \\ Грудь-волною встает, \\ Волна - грудњю встает. (386)}

Слияние с морем, таким образом, - возврат в материнское лоно, возврат к первоистокам жизни. С точки зрения жизни земноя это гибель, потеря обособленности. С точки эрения бытия - переход в универсальную предвечную форму существования. При этом заметная даже в данном случае взаимообратимость эквивалентности 'женина = вода' и 'вода = женщина' ("Грудь - волною встает, Волна - Грудью встает") снимает разницу мехду 'женщинойженои' и 'женщинойматерью' (См. море как "нянька" - 41.3). Отсюда: 'жениться' или 'иметь женмину' = 'погибнуть' = 'вернуться в материнское лоно' = 'раствориться в праокеане или праводах', а гибель в море - 'сладострастна' (и одновременно - 'спасительна'; см. 1.1.7.).

С этоя точки зрения вполне объясним сюжет поэмы, по краянеи мере то, что поиск невесты и встречи С невестон происходят на море. Объяснимо такие и направление выходов царевича вовне - из 'гроба'-"кроваточкя" вниз "С лестничек крутьх": это выходы к 'женцине -морю', в 'предрохденное' состояние. С точки зрения всего универсума - в запредельное измерение, с точки зрения земных Форм - в смерть, гибель, с точки эрения цветаевской поэтики - к'воскресению вспять', 'обретению своеи сущности и отождествлению с нер' (см. в песне моря, 413-414, совмещение царевича со всем 
универсумом: "Клади себе взамен подуики мою широкую зарю! Тебе в игрушки-погремуики Я само солнце подарю! Не будет вольным володеньям Твоим ни краю, ни конца..." и ср. понимание земнод смерти как 'рохдения вспять' в стихотворении Сивилла - младекиу - 17 мая 1923 - из цикла Сивилла: "то, что в мире - век Смехенье - рожденье в свет. Из днесь - В навек. Смерть, маленькй, не спать, а встать, Не спать, а вспять. Вплавь, маленькия! Уже ступень Оставлена... - Восстанье в день."). То хе самое происходит и в обратном направленин: тут он наталкивается на мачеху, тоже затягиваюиую вовнутрь акватическую стихию. Иначе говоря, Царевич локализован в поэме в "кроваточке"-'гробу' мехду двумя водами, с топ разницея, что вторая - подземная, Мачехина, предполагает 'дубликацию', 'ре-продукцию' царства смерти (см. 1.1.6.-1.1.7.), тогда как первая - морская - качественную трансформацию (подробнее эта сторона Цветаевскоя поэтики излагается в заключительноя части разбора Переулочков).

1.4.2. Соответственно своему рождению от двух матерен, а точнее - на стыке двух противостояних друг другу состояния мира (350: "в полночь, в пятницу На свет родился": 390: "- В сочельник кременския, Что ль, парень, рохден ?; См. 1.3.3. и 1.3.5.), Царевич долхен быть персонахем амбивалентным и идеальным в том смысле, что в нем долхны сочетаться прямо противоположные 'наследственные' свонства и долхно соблюдаться идеальное между ними равновесие. И это и есть весь его секрет.

Исконнын экзистенциальны статус царевича - 'быть сонным', 'спать' (ср. подмену сказочного зачнна 'Жил-бшл' на "Спит Царевич, распростерся, Спит не сльшит ничего" - 341 ; см. еме 1.1.3.) - это и есть состояние равновесия, пребьвания на границе между 'жизнью' и 'смертью'. На уровне позиция этому состоянию соответствуют две постоянные и регулярно чередующиеся в тексте позы царевича - лежачая, горизонтальная (341: "распростерся") и подвихная, вертикальная (341: "Как у мачехи у младенькоя - сикок $\theta$ пополок" и затем неоднократные 'вставания' Царевича). Позиции эти образуют две основных оси мироздания. Предпочтение какон-нибудь из них приведет, естественно, если не к крулению существующего миропорядка, то по краянея мере к его прининашноя перестроике. С данноя точки зрения царевич являет собоя центр мира и является очевидным эквивалентом Царя, локализованного в "шатре", в центральной точке концентрических кругово 
меду лежачен и стоячен) позиции (см. 1.1.3. и 1.1.4.). Иначе говоря, данныя мир держится на Царевиче - Царевич есть его основа, своеобразнь миропородитель и миродержец (ср. на стр. 422 предпосланное Царевичу наименование "Грудь Первопрестольная!") приходямин на смену одряхлевшему, разрушаюмему и разрушаюемуся, предшествующему миру - отцу-царю, еме не до конца себя изжившему.

Принцип уравновешенности противоречнвых свонств царевича с исключительно последовательностью выдержан цветаевон по всем привлекаемым признакам.

а. Согласно законам мифологического подземного царства, его обитатель долхен быть так или иначе 'ограничен' - 'связан', 'хром', 'слег', 'беспамятен' и т.д.

'Связанность' Царевича вырахается при помоци как особого набора предпосылаемых ему атрибутов, так и их однозначноя соотнесенности со сфероя вредоносного. Так, например, "бусы" держит царевич не в правон, а "в левой руке"112 (346); "перстни" и "охерелья" сопровождаются кокетством 'опасности' и 'смерти' - 390 : "Пльвет царь-моя-Лебедь В перстнях, в ожерельях. [...] (Живого такого напеть 6и дружка)", 387: "Расходился тут Царевич, - нет сил! охерельице в зубах закусил", где 'раскушенное' "охерелье" означало бы освобождение от зловемего Дядьки-филина и победу над ним, 363: "и кахшы пальчик-го Как царь закованның!", т.е. в перстнях и в инертном нетворческом состояния; 113 "кушак" $(385,415)$, "кафтан -шнуровка" (385, 391), 'зашитость' "шелками" (413), "серебрянын нагрудничек" (363) - все это 'теснит' (415: "Как ременньм кушаком сжата грудь") и исходит от демонических сил (413: "Шелками шит, змеей зашит твон вороток!"), стремяпихся повергнуть царевича в сонное состояние. Аналогичным образом передается в поэме и духовно-Физическая угнетенность царевича: "Все отдал бы, весь сан престольны, Кто бы мне дуиу распростал!" (348) и "Встал царевич сгорблеккий, кручинныя такои. Вкруг очей - что обручи, Набились круги. Чая, опять на ковричек - Да с левой ноги!" (349), которая дополнительно сочетается с представлением о хтоническоя 'слепоте' (ср. тут же: на стр. 350: "Где глаза лазурные? Дее черких дири".) 'хромотоя' (351: "А ступнет шахком - Вот сенчас обронит Нохку с сапожком") и с подземньми водами (350: "Киньте в воду - пробочкой Поверх всплыву!" или "Видно, месяц, плакамши, Слезоя обронил", где "пробочка" - а несколько раныше "обручи" - роднит это состояние 
Царевича с подземньм Царевьм и Мачехиным "вином", а 'слеза месяца' - все с тод же подземноп лунарно-акватическор стихиея).

С другор стороны, царевичевы "кольца" , "охерелья" " "серебряның нагрудничек" и "кушак" - атрибуты его царского сана, а тем самлм - показатели его бохественного и идеального статуса. Будучи ограничителями, они одновременно играют роль и 'охранителен', препятствующих нарушенио внутреннего равновесия. Так, "бусам" "в левои руке" (346) противополагаются "Гусли в правой руке" (346), при помоми которых в наиболее критическия момент создается 'защитныя круг': "От нее себя заставиЛ Изгородою струнною!" (407). но и сами "бусы" тохе амбивалентны: им присущ не только признак вошы, но и огня - 399: "Вспихкул пуще корольков-своих-бус: 'я вам, баткика, сынком довохусь!'n (ср. в случае царя демонстративное снятие связи с огнем при описании его гнева словом "Разгасился" - 373). У "шнуровки", в свою очередь, есть противовес под видом "кушака". Они противопоставлены друг другу по признаку цвета: "Белын стан с шнуровочкоп, Да красны кушак" (385). По блихаяшему контексту (См. в предваряомеи строфе - 385: "трех быков на вертеле Сгублю, не щадя!") не трудно установить, что "кушак" знаменует 'богатырство' Царевича и его связв с 'огнем'. Однако свод более полның смысл он раскроет в сопоставлении с иными атрибутами царевича.

\section{б. Царевич сплошь 'матерчат', 'текстилен'. И дело не только} в том, что в его образе на первое место выдвигаются детали его костома: "белое сукно" кафтана $(380,385,390,424,427,409)$, "wнртесьма" (385, 391, 424), красның "кушак" (385, 390, 415), застегнутын "ворот" (413, 415), а в том еме, что 'текстильная' лексика употребляется либо на правах именования царевича, либо на правах описываюего его языка: "Смотрит: не шелк-янтарь - мусор-товар: на дне - с гуслями в обнимку - гусляр!" (362), где царевич накменован "товаром"; "Сошлись на груди одноя, Одном сукне" (409), где отчетливо звучит эквивалентнсть 'Грудь-сукно'; "что шелка - щека, что шелка - рука!" (366), где с шелками сравнивается телесның облик царевича; "Матушка ты моя, тростинка, шелковиночка!" (364); "скатерть" в самосравнении царевича (350): "не заноза из тела вон - то из ткани булавка вострая" (369), где царевичево тело уравнивается С "тканью"; постоянное сравнивание и именование волос царевича льном: "С головеночкод льнянон" (342), "Лен - волосенк-то!" 
(364), "Спи, копна моя льняная" (366), "головка льняная" (398, 424) и "Ты расплетись,веревьице!" (364); предопределенность царевичевод руки "ковры расшивать" в отличие от руки Царь-девицы, которов только "дубы корчевать" (363).

и все-таки, несмотря на вст эту 'материальность', Царевич одновременно сплоиь 'бесплотен', 'аматериален'. Он - "дым", "свет", "обман один", "душа": "Мать рохала - не тухила: Не дитя, - димоиек-дхм! Словно кто мне налил жиы Светом месячным сквозким". (388) - "А ну как зорче поглядим - и вовсе все обман один, и вовсе над туманом - дым, Над херувимом - серафим?" (365) - "Ты скахи, душа, - отколе ты сама к нам: с мухскон ли Али с женскон половины?" При этом бесплотность дополнительно вырахается еще и половон недеФфиренцированностью царевича (см. в сцене омотрнн на стр. 364365: "- Гляху, гляху, и невдомек: Девица - где, и где дружок? Ты расплетись, веревьице! Где юноша? Где девица?"), и его 'монашеством', означақми лишенность чувственно-телесного начала (382: "Прочан, мон праведкик-моках!"; 399: "Врешь, молочная лапша! каланча! Прынц заморскин либо беглы моках"; 408: "Учись, учись, мокашек мон, Как в споре жить - да с мачеход!"), и намеками на его небесное происхохдение (365: "серафим?": 398: "- Плохон син иаро земному, - Знать, кебескому хораш!"; 399: "Хоть плохон я был наследник - Гуслярок зато лихоя! Паренек-то из последних - Мохет ангел не плсхон..."), и, наконец, внутреннея оппозициея 'ворот= =тело $\rightarrow$ лоб=масль" (426: "Сталь из ворота - Память в лоб".). 114

1.4.3. Противостоя духовному началу царевича его 'текстильның' образ, однако, не однороден. Преобладающие в нем мотивы "сукна". "шелка" и "льна" внутренне дифференцированы как по отношению друг $к$ другу, так и по отношению $\mathrm{k}$ самому царевичу. В последнем случае "сукно" соотносится с "кафтаном", Т.е. С нанболее внешним и отчухдаемым компонентом Царевнча - 'костюмом'; "шелк" - с 'телом', но редуцированном только до "руки", "пеки" и "воротка" (366: "что шелка - пека, Что шелка - рука!"; 413: "шелками шит, змееи зашит Твон вороток!"), т.е. до деятельного личностного начала; "лен" - исклочительно с 'головон' и 'волосами', которые знаменуют начало духовное. 115 Если взглянуть на эти 'ткани' иначе, со стороны наследственности Царевича, то в "сукне" позволительно видеть 'шерсть' и связь с Царем-'Велесом', В "шелках" - связь с Мачехон, во "льне" - с Матерью-'Параскевои-Пятницея', именуемоя в народе 
также Льняницея, 116 а "кушак", лишенның, правда, материальноя характеристики, но раз определенның как "ременнон" (415), выдает, по всеи вероятности, связь Царевича с противополохным Царю 'царем небесньм" (ср. на стр. 398: "- Плохо сын царю земному, - Знать, небесному хорош!" в песенке Царевича о самом себе). Но все это, так сказать, Формальная дифференциация, для расиифровки котороя требуются дополнительные данные.

Образ Царевича то и дело сопровохдается мотивом "снега". В первую очередь "снег" призван манифестировать принадлехность Царевича к мертвому царству: "Снеговее скатерти, Мертвец - весь сказ!" (350): "Не заноза из тела вон - То из ткани булавка вострая, То на личике снеговом Глаза синие, синеморские" (369), где "личико" снеговое" - результат наводящея 'сон-смерть' Мачехинои "булавки"; Белья стан с шнуровочкон, [...] Словно снег пуховочкои Пропелся вдоль щек". (385); "Ох, ресницы, две в снегу полуподковочки!" (398); "Белер снегу - сын, глаза в земпо впер". (404); "Белизнон лебякьен Всех ворон спугнул". (385). Не трудно, однако, заметить, что мотив снега здесь тесно сопрякен с мотивом ткани и главным образом с мотивом Царевичева белого кафтана из "сукна" . Иньми словами, под "кафтаном"-"сукном" мыслится в поэме волшебная зимняя науза земли - снег. 117 Этот смысл однозначно раскрывается в сцене плача Царь-девищы над спямим царевичем (393-394) и в сцене cпора Мачехнно слюнки с царь-девицыным ожогом (108-111).

Эпизод плача повторяет общензвестның сказочның мотив охивления или пробуждения поврежденного вредоносым силами героя в результате упавшея на него горючея слезы героини. В фольклористике он распифровывается как воскрешение природных сил живон водон, понимаемо как грозовая небесная вода. 118 у цветаевоя этот мотив дан не в занмствованном закамуфлированном виде, а почти эксплицитно, с мифологическо расшифровкоя. Так, плачущая царь-девица упоблена здесь "дубу", а ее "слезы" - "янтарю" и "смоле" (393-394: "Молча, молча, Как сквозь толщу Каменноя коры древесноЯ, Из очей ее разверстых - Слезы крупные, янтарные, Непарные. Не бывало, чтоб смолою Плакал дуб! [...] Апельсинныя, абрикосныя, Леяся, сок душн роскошны, [...] Сок преценныя, янтарёв , Дар души ее суровоя, Леяся в песок! На кафтан его приастын. Лик безгласның - кровью краснон Капая, смола!"), где "дуб" - не только древо хизни, но и дерево бо-

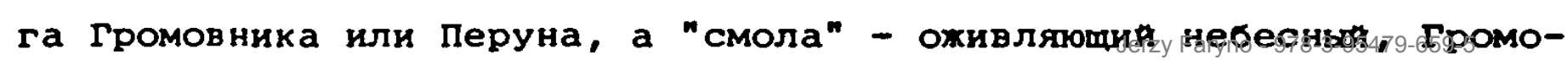


виков, дохдь 119 (см. еще одновременное переименование "янтаря" и "смоты" Фруктовьми соками, что "дубу" возврамает его мифологическин статус 'плодородного начала.120).

В этом контексте именование царевича "песком" (393-394: "Дар души ее суровоя, Ленся в песок! На кафтан его причастны,, Лик бесгласнь - кровью красноң Капая, смола!") - уже не метафора, а расшифровка сущности Царевича как соответствия 'земли'. Но Царевич еме не 'земля', а линь ее возмохность, так как он находится во власти подземных демонических сил. Пока что он скован зимнея волшебноя пазон: "Капая, смола! кровью на немую льдину... - Растопись слезоя, гордыня, Камень-скала!" (394). Для понимания образа царевича это значит, что по своен сущности он есть 'земля' ("лесок", "камень-скала"), но в данныр момент сн - 'земля в зимнем состояния' (скован бельм суконньм кафтаном = снегом; "немая льдина").

Эпизод спора по сути дела аналогичен: 'спорщики' уподоблены весенним подснехньм водам, а "кафтан" царевича - снехному покрову: "Словно ручеечка два Шумят сквозь снег... [...] Сошлись на груди одноя, Одном сукне. [...] По кафтану шитому шумят воянон" . (409). "Печать"-'поцелуя" царь-Девищы здесь уже однозначно соотносится с "грозоя" ("- С грозоя дружу!" - 409), а "слюнка"-'поцелуя" Мачехи - с хтоническим началом ("Тот - змеиньм шипом-то", "Из хвостазнать-кисточки!"), т.е. С противником Громивника.

По сравненио с "сукном" "кафтана", являющим собон навязанное царевичу состояние, "шелк" может считаться более органическим свонством царевича: "Паутинка ты моя, трслтинка, шелковиночка!" (364), "что шелка - мека, Что шелка - рука!" (366). Кроме того в противовес "сукну" в "шелк" вписывается признак 'истончения', 'нехности' и 'ценности'; ср. на стр. 362 противопоставление 'не шелк-янтарь" "мусор-товар" ", где сочетание "шелк-янтарь" роднит "шелк" с "янтарем" как 'соком дуия' и 'хивор водоя' (что эксплицитно выведено в элизоде плача царь-девицы), а сочетание "мусортовар" подразумевает 'гниль' вместо 'дуим' (см. разбор мотива 'купечества' в 1.1.2.в.). Не менее интересна в этом отношении и последовательность именования Царевича "паутинкоя" - "тростинкоя" -"шелковиночкон". Мотив "паука" однозначно связан в поэме со зловеще мокротон: "Как притопнет, поглядев востро: Ан уж нету наука - мокро!" (428; см. также 1.1.2.д.), мотив "шелка" - с водон: "То не плетка-хлыст - шелков рваных свист, то на всем плясу - шелка 
ручьями вниз!" (404). Мачехины 'шелка-ручьи' - результат ее перевоплощени во время пляски от зменн, ипостаси через ипостась соблазнительноя 'раяскоя яблоня' до 'шелков-ручьев' и 'дымового столба' (402-404). С одноя стороны, эти перевопломения являют собои истончение плоти и обнарухение наиболее глубокоя сущности Мачехи, с другоя, они читаются как постепенное разрушение волшебноя наузы, навязанно миру в его зимнем, подвластном демоническим силам, состояния (см. 1.3.5.-1.3.6.), тем более, что преврамение в акватическую стихию вызывается в этом эпизоде грозоподобнои игрои на гуслях (402-403: "Заиграл сперва гусляр так-от легонечко, Ровно капелькя шумят по подоконничку. Та - рябь рябит, плечьми дрохит. [...] Отпустил гусляр свонх конея стренохенных - Прокатилась дрохь волно до быстрых нохенек".). Послеловательность "Паутинка ты моя, тростинка, шелковиночка!" аналогична, как видно, последовательности мачехиньх перевопломения; что и позволяет видеть в кравнеи позиция "шелковиночки" последнюю, нанболее истонченную 'пред-акватическую" ипостась царевича. И если открываюмая данную последовательность "паутинка" откровенно хтонична, то замкаюмая ее "шелковиночка" уже сильно удалена от хтонического начала, хотя и не полностью от него освобождена. Она играет роль, так сказать, последнен, нанболее тонкоя волшебно науэы царевича. 121 Если теперь вернуться к наименованию "шелк-янтарь", то легко в нем заметить закономерную дводственность царевича - промехуточное состояние мех хтоническим и небесньм, связанньм и свободным, телом и душой.

В пределах поэмы "лен" соотнесен исключительно с царевичем "льном" многократно именуются его "волосы" и его "головка": "Лен - волосенки-то!" (364), "С головеночкоя льняноя" (342), "Спи, копна моя льняная" (366), "головка льняная" (398, 424), "куполокльняноһ-маковочка!" (398). В пределах Цветаевскои поэтическои системы "волосы" символизируют наивысшую одухотворенность, являют собоя средоточие личности, вместилиме божественного Вдуновения (духа). При освобохдении от земных связеи они легко трансформируются в пневмо-акватическия поток (часто христофорическия) и нередко 'озвучаются', становясь "струнами" или эквивалентом "голоса", за которыми - на еме более глубоком уровне - стоит представление - логосе, о творческом слове. 122 поэтому именование "волос" "льном" мохет в какоя-то мере снижать их ранг, скажем, отрахать 'скованность духа', но не мохет противоречить семантике "волос" (в таких 
случаях, как правило, вместо "волос" Цветаева употребляет другие названия, типа "кудри" - так, кстати, называет "волосы" Царевича Царь, См. 401, - или "косы" и "космы" - в случае описания Мачехи, см. 401, 408, хотя и тогда сохраняется за ними смысл 'овнешненноя сущности' персонаха, какова бы эта сущность ни была).

В эпизоде встречи царевича с царем есть и следующее описание Царевича: "Ох, ресницы, две в снегу полуподковочки! Розан-рот твой, куполок-льняноймаковочка!" (398). Там же на вопрос царевича "Какоя песнер услуху твоем Величеству?" Царь отвечает: "- Птица в небе - вьше нас родилась! Над тобою наш не властен приказ!" (398).

"Куполок" и "маковочка" вносят, естественно, представление о 'замкнутости', а "полуподковочки" - о 'неполноте' - Более того: если "куполок" отчетливо соотнеген с 'небом' и 'сакральньм' (см. тут же слова "Птица $\theta$ кебе" и тремя стихами дальше в песенке царевича "- плохов сын царю земному, - Знать, небескому хорош!" 398), то "маковочка" - $こ$ 'низом' и с 'колдовским' (см. на стр. 348-349 в гтвете Царевича на предлагаемое дядькон средство от бессоннин: "- Не испить тебе бы маку? - 'Не в настонке суть! В этих подлостях и так уж $\mathcal{A}$ уөяз по грудо. [...] отчего душа mеснится Грудо для вздоху мала?'") . Промежуточное положение морфемы "-льнянод-" в этом смысле вполне закономерно - выражает неполную реализованность сущности царевича, но еме ее не расшфровает.

В эпизоде смотрин царь-девица наклоняется над спящим младенцем-царевичем и приговаривает:

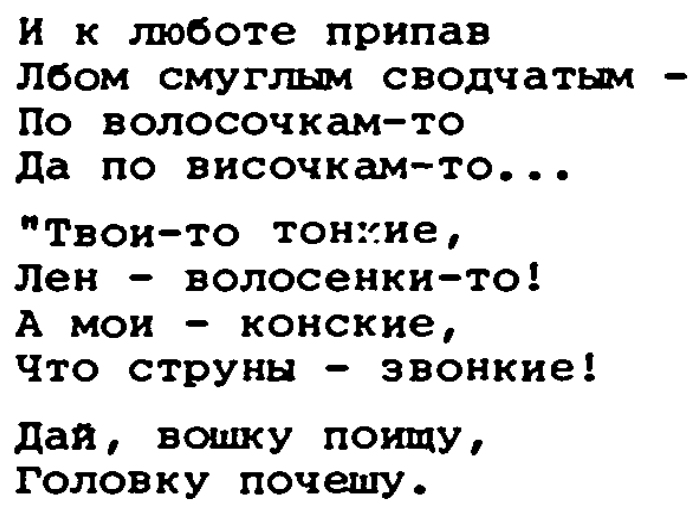

И к люботе припав

Лбом смугльм сводчатьм -

По волосочкам-то

Да по височкам-то...

"Твон-то тон:ие,

Лен - волосенки-то!

А мои - конские,

Что струны - звонкие!

Дая,, вошку поиму,

Головку почешу.

Ух такого из тебя детину вынянчу,

Паутинка ты моя, тростинка, шелковиночка!" (363-364)

После отплытия Царь-Девишы проснувшемуся царевичу Дядька излагает эту сцену так:

В кудрях тигрицея рыскала,

В лицо водицеи прыскала. 
Бушевала над тобон - как в день суднын!

да ух сон-то твон такон - непробудның! (370),

а сам Царевич рассказывает ее как сновидение:

"И сниться мне, - охает,
Руно гладя волос, -
Что с куполу С грохотом
Сто цепей сорвалось". (371)

'Искать в голове (вшен)' - вырахать ласку, любовь. Но кроме этого смысла, в народноя обрядности 'нскание', наряду с 'расчесыванием волос' имеет еме смысл денствия вызываюего дожиь, грозу, молнии, так как 'волосы' часто слухат метафоро громоносной и дожденоснов тучи. 123 Кстати, это эначение 'искания' и 'чесания' почти эксплицитно выводится Цветаевон в изложении Дядьки ("водицея прыскала", "Бушевала [...] как в день судның!") и в пересказе царевича, где "сорвавинеся" "сто цепея" отсылают к сказочному мотиву освобохдения взснов закованного зимнимя силами грома.

Определение Царв-Девишыных волос "конскими" и "звонкими" "что струны" (364) восходит к тому же фонду народнон символики 'гром = конь" (ср. хотя бы в пределах поэмы: "Вихорь-Конь к нен на крылечко Белов молние взлетает." - 355; "Конь с Девицею точно сросся; Не различишъ, коли вдали: Хвост конския, али семишёрстның Султан с девичьен головы! [...] Лишь где на том конце затихнет, Ух на другом конце гремит. [...] Гром-барабанщик обе ручки По локоток себе отбил". - 356 и еме заявление царь-девишна волоса: "- С грозо друку!" - 409). 124 Поэтому наличие 'конского' мотива в образе Царевича еще сильнее выявляет его 'громоносную сумность', хотя пока что не разбуженную (его "ресница" - всего липь "две $D$ снегу полуподковочки" - 398; "Гляди, - не волна уж: Гривастая трояка!" - 390; игра на гуслях передана словами: "отпустил гусляр свонх конен стренохенных" - 403 и уподоблена дохдю: "Ровно капельки шумят по подоконничку" - 402). На невысбожденность Царевичева громоносного начала указывает еме и Факт, что он еме не в состоянии 'расчесать' свонх волос - 349: "Гребешок потрагивал - Из рук пустил!", а рассказывая сон о с грохотом срываюшихся с купола цепях, только "гладит" свои волосы (371), но вахно, что он притрагивается $К$ ним именно в этом контексте.

При таком прочтении Царевича именование его "розаном", "птицея в небе" и "куполком-льнянои-маковочкон" (398) оказывается просто-напросто синонимическов сериеи с общнм инвариантным смыслом

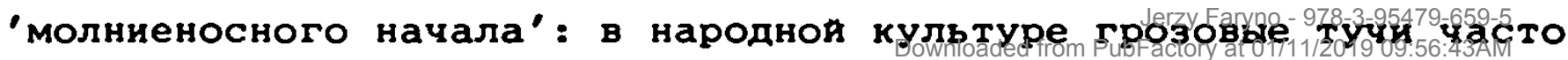


уподобляются пряхе, кудели (льну), а пронизывающне их молния цветам и птицам. 125 кроме того, эквивалентны также лен и мак - их семена наряду с семенами некоторых других растения принято сыпать в определенные водоемы во время весеннего обряда вызывания оплодотворительного дохдя и громов. 126 само собои разумеется, что смысл 'громоносного начала' мог быть вырахен только 'волосами'. Расширение серии на 'лен-кудель' и 'лен/мак-семена' ("куполокльняноя-маковочка") привносит некия иноя еще оттенок. Тот, которыя передается у Цветаево кинемограммоя 'льнуть' (ср. на стр. 386: "Песнопевец, в плену! Наша летопись: льну... Не Царевич $к$ челну - Лебедь к лебедо льнет. И опять ни к чему Тебе вольньр полет! никдму не уити Да из женских тенёт!"). Цветаевское 'льнуть' значит,'вникая в нечто, истончаться до полного иссекновения и исчезновения' (СР. в Тах вслушиваются... - 3 мая 1923; иП, 237: "Так внюхиваются в цветок: вглуеь - до потери чувства! [...] так влюбливаютя в любовь: Впадываются в пропасть. [...] Так вглатываются в глоток: Вглубь - до потери чувства! Так, в ткань врабатываясь, ткач Ткет своя последния пропад".). С этоя точки зрения, Царевичев "лен" - предельное истончене, самы кранния соблазн, за которьм открывается уже сфера 'не-сулего', 127 и он помимо всех остальных науз сдерживает царевича по эту сторону бытия, в материально оформленноя ипостаси.

"Кушак" во всю эту семантику царевича ничего нового ухе не вносит: Он играет роль своеобразного обобщения царевича как 'богатыря-Громовника'. В нагодно символическоя системе такои атрнбут (пояс) соптветствует разямеи молния, почему и знаменует Физическую момь и богатырство героя. Нередко он буквально подменяется орухием - отправляясь в опасны путь героя подпоясываются, например, дубинкон или мечом. Так, у самоя цветаевон ее царь-девица, собираясь завоевывать Царевича, подпоясывается саблея: " ' [...] Цельному ворску господином Была, - так справлюсь и с одним! одним свокм лучом единьм Мы светел месяц полоним'. Опоясалась тут саблея, Свиснула в кулак свод смуглья, и на зов ее кулашны Вихорь-Конь к нея на крылечко Белоя молние взлетает" . (355), а "кушак" Царевича упоминается лиш в тот момент, когда Царевич почувствовал себя "молодием" и готовится ко второму свиданию с царьДевицеп на море (384-385). Одновременно пояс знаменует собои и чувственное (жизнеродное) начало. Но это его своЯство в Цветаевско 
поэтическоп системе рассматривается ухе как узилише духа. В поэме это прекрасно видно в поведении царь-девицы: если в начале, поддавшись чувственному началу, она промается со своим духовньм двонником 'конем громом' (тут ее конь - "Вихорь-конь", она сама - "царь-Буря" - 355-356, а сцена процания на стр. 358) и опоясывается саблея, то в Финале, уже преодолевая этот чувственны соблазн, "Саблю-ломает-сталь" (425). Аналогичны смысл стоит и за царевичевьм "кушаком" - тогда, когда активизируются исходящне от Мачехи плотские силы соблазна, "кушак" уподобляется 'связываюему' началу: "Как ременньм кушаком сжата грудь" (415).

наблодаюмееся здесь определенное противоречие снимается на другом уровне Цветаевскон системы. Сам по себе 'дух' неуязвим. Уязвимо только 'тело' Но для 'духа' 'тело' есть его ограничитель, узилиме, тюрьма, псэтому он всячески стремиться преодолеть навязанную ему временную телесную форму бытия и вернуться в предтварное состояние. На границе мех 'тварным' и 'нетварным' ситуируется у цветаевон, в частности, поэтическое слово, Божественнын Логос и родственны ему Гром. Это, по цветаевоя, наиболее одухотворенное состояние мира физического, материального. По направленио вниз оно все более умербно и уязвимо (поэтому, кстати, Мачехины иглы-стрелы разят царевичевы 'матерчатые-телесные' наузы; см., например, 369: "не заноза из тела вон - Из ткани булавка вострая" или 426: "Сталь из ворота - Память в лоб".), по направлению вверх следуют уже бессловесные и все менее выразиые состояния 'чистого духа' и 'смысла'. 128 в ранге 'Громовнка' царевич - наиболее идеальное состояние материального, но никак не возможны предел на пути к чистому смыслу, это еме не выход в нетварное состояние, $а$ лишь самья краяния порог, которын требуется еме перешагнуть. Эта мысль как раз и вырахена в поэме 'теснямнм кушаком'. Активизация же креативных потенция 'Громовнка' или 'Грома-логоса' низведет его в отрицаемы цветаево мир 'веса и мер', мир механическон смерти, мир, где господствует не эволюция, а инертная ре-продукция, редубликация (см. 1.1.6.).

1.4.4. Пребывая в одном и том же локусе, герои поэмы все же разведены по разным его ипостасям: Царь, согласно главному его истребительному занятию-'питью', окружен 'винноя' стихиеи; Мачеха, соответственно с ее 'чувственноя' судностью занимает "семь покоев" "С семью смертньми грехами цельх семь укладок бабьих" (375- 
378); Царевич же - "на кроваточке" (342), "На перине, на соломе" в свое лодке (420) и иногда на лестнице $(350,385,398,411)$. Если к этому еме учесть, что Царевич неизменно обут в "сапохки" (349, 420), ступает то на "борток" лодки (420), то на "коврик" (349: "Чая, опять на ковричек - Да с левон ноги!"), то на "снег" (388: "Коли похде, иду без шапки, Коли скег, иду босой".), - то станет ясно, что он полностью изолирован от 'праха земного' (ср. в случае царь-девицы, когда она отправляется на смотрины - 358359: "Как по сходням взошла Стопудовоя пятон, Как прах с ког отрясла, Как махнула рукон".). 129 тем интереснее поэтому факт, что, С другоя стороны, он моделируется именно в терминах земли. и дело не только в том, что его "кафтан"-"сукно"-"науза" обнаруживает известное родство с зимнеи науэо земли "снегом"-"ковриком" (ср. замечание царь-Девицы о его руке - 363: "Твоя - ковра расшиөато, моя - дубы корчевать".).

Раз он однозначно соотнесен с 'полем, пастбинем': "- Чго за круг мех бровочек, Почетның значок? Аль пастух полуночныр Здесь жег костер?" (385; cp. eme 424: "Белого поля поперек [...] волос черның!"), а в другом эксплицитно назван "лужком": "Краса над ним" 'Где ж усики? Осьмнадцаты годок! Пора бы уж травиночке Пробиться на лугку! За первую пушиночку Весь сон тебе проиу!'" (367). Ни 'поле' ни "лужок", естественно, не выводят Царевича за пределы подземного царства и не меняют его родства с царем-'Велесом' (см. 1.1.2.г. и 1.1.9.а.), но "Осьмнадцатыи годок", "Пора бы уж травиночке Пробиться" и "первая пуиночка" ставят царевича в положение ю н О г о 'Велеса' и этим самвм николы в е ш н е $\Gamma$ о, отвечаюмего за возобновление очередного годового (космического) цикла, за возрождение жизни на земле. Поскольку, как уже говорилось в 1.1.8., события поэмы приходятся на Средьпостье, а шире - на период мехду последним зимним новолунием и первым весенним полнолу-

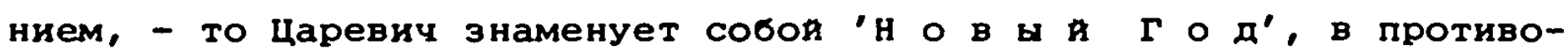
вес иссякающему ' $\mathrm{T}$ а $\mathrm{p}$ ○ м у $\Gamma$ о д $\mathrm{y}^{\prime}$-царю. Но мифологическое время, как известно, не сумествует само по себе, в отрыве от мира - оно есть С О С т О я н и е м и р а или, точнее, определенны ц и к $\pi$ состояния мира. Поэтому Царевич как раз есть и 'мир' (см. 1.4.2.) и 'время' или иначе: 'мир во времени', и поэтому будучи властителем мира он одновременно и сам этот мир. Но пока еще, так сказать, в свернутом, потенциальном виде, что выражено также и 
буквально при помоми его хтонического 'младенчества' - имея "Осьмнадцаты годок!" он все еме "в пеленки мочится! Пустыпечку еме сосет!" (362), - 'согнутости' (348, 349) и 'зашнурованности'. Само собоя разумеется, что судьбы мира (подземного) зависят от того, в каком направленин Царевич разовьется.

О том, что Царевич являет собод потенциальны очередноя годовон иикл (с точки зрения порохдающе грамматики вполне уместно было бы в нем видеть 'ядерное предлохение', т.е. исходную ядерную модель мира) красноречивее всего свидетельствуют применяемве в описания его образа 'вегетативные' мотивы.

Не говоря ухе обо "льне" и "маковочке" (см. 1.4.3.), Царевич то и дело именуется "тросточкоя" (364: "Паутинка ты моя, тростинка, шелковиночка!" , "Тонее тросточки!"), "стеблем", "стеркеньком" (388: "Не жених, а стебель шаткия! Кто прондет - дроху росоя"; 389: "Староя бабы беззапитнеи. Зеленее стерженька..."), "былинкоя" (394: "Водска в полон брала, - Былинкоя связана!"), "травиночкоя" (367: "Пора бы уж в травиночке Пробиться на лужку!"), "сосенкои" (364: "строинее сосенки!"), "одуванчиком" и "цветиком" (342: "Как на личико твое цветочное не зариться?": 366: "Спи, копна моя льняная, Одуванчик на стебле!"; 348: "тешат, нянчат, Ровно цветик я какои, Одуванчик!"; 395: "Синеи василечков, Синең конопли на заспанных щечках Глаза расцвели."; 424: "Кто спит - тот пьян, кто спит - тот сыт, Да, цветик благовонныр!"; 428: "Как цветочек! Смотреть-то жалость!": 429: "Жив белы твоЯ цветик, Да только не весел, светел."; 408: "Лехит цвет-наш-трезвенник, Как пьяның какоя") .

Сопутствующие этим именованиям 'хилость', 'шаткость', 'сонливость', 'жалость' и иные аналогичные признаки восходят, по всеи вероятности, $K$ древнедиим представлениям о цветах и растениях как - двоиниках покояников или как О возврамающихся в жизнь душах усопиях. $^{130}$ В случае царевича это мохет обозначать его выход из преисподнея, из царства мертвьх. С тем, однако, что этот выход не есть еме высвобождение из 'смертного' состояния. На этом уровне Царевич уже не 'мертв' (ср. 350: "Скеговее скатерти, - Мертвеи весь сказ!" и 429: "Жив белий төой иөетиж, Да только не весел, не светел"), но еме и не 'жив' (ср. 392: "А если уж жив он, - чего ж он летит-то? А если уж дьпит, - Чего ж он не сльият?" и 424: "Кто

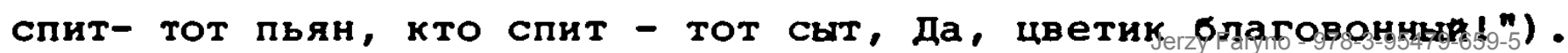


Кроме того, ему присуме изначальное 'смертное' начало - сравнение с "сосенкон" (364: "строннее сосенки!") выдает причастность к загробному миру, а точнее - к миру мертвецов (ср. в песенке царевича о самом себе на стр. 419 недвусмысленное соотнесение 'сосны' именяо С 'гробом': "Для гробочка-домовины, Из досочек из тести Из сосновьх - ни единоя Я не выстрогал доски".), а слова царь-Девицы "Вояска в полон брала, - Былинкон связана!" указывают на хтоническия, 'связывающия=мертвящия' характер царевича.

В контексте толкования посемения царевича царь-девицея в 'весенних' терминах (367: "То не тука молодая Лен кропит: То дружочка - дорогая Водоя племет, поливает, А он спит"; 370: "Уж долго я спал! Ровно дождь меня тонким Серебром поливал. Ровно жаворонок звонкия Вкруг меня ликовал"; 395-396: "Вот сон-то приспел! Как будто кукушку я взял на прицел! [...] - То не пташечка-кукушка куковала, То твоя подружка тосковала. Как под бурею ночнод стонут снасти"; 427: "Как дохдичком-бьет-серебром!") 'цветочно-стебельнор' аспект Царевича свободно читается как признак перехода 'Царевичамира' из потустороннего 'зимнего' состояния К 'жизненно-весеннему'. Факт хе, что царевич все еме не 'проснувшияся весенния мир', а только его возмохность, мотивируется, вероятнее всего, как календарноя приуроченностью события поэмы 'предвесеннему периоду' (350: еме "В небесах Егорин не разжег вонны", т.е. космические силы Света пока еме уравновешены силами мрака и епе не наступил роковои громовоя удар, расковываюмия похнменные животворяпие стихии земли), так и чисто цветаевскими предпочтениями (о чем несколько позже).

Самое примечательное в интересующем нас отношении, однако, то, что параллельно 'цветочно-весеннему' кодированию образа царевича осуществляется и кодирование 'Фруктово-осеннее'. Так, например, в одноя и тоя же речи Царь-девиуа говорит "Пора бы уж травиночке Пробиться на лукку!" (367) и называет царевича "Ох ты яблок моя, изюм-шептала!.. А достать тебя - Господь умудри." (368); шля Мачехи лицо царевича не только "цветочное" (342), но и "персик" (380: "Как я на персик восковоя, Как нимия на базаре, - На нежның лик твоя зарюсь!" и 382: "Моя персик абрикосик!"), а сам Царевич уподобляется "яблоку" (407: "Как в яблок в него вгрызается"); Дядька же именует его "колосом" (348: "Светль колос мон, опять клонишь лоб?"); и, ради полноты картины, напомним, что в поэме он именуется еще как "куполок-льнянод-маковочка" (398) с явньм акцентом 
на коробочке-плоде льна и мака, а не на их стебле или цветах. Конечно, во всея этон серии имен легко опознается общин инвариантны показатель 'плод=зерно=семя' , т.е. плодотворное и оплодотворяюмее начало, чем и мотивируется эротико-сладострастны ореол этих обрамения к Царевичу, особенно со стороны Мачехи (см. 1.3.6. -1.3.7.). на временно́ оси вегетативного года данныя смысл позволительно соотносить С весенним 'умермвлением' зерна, за которым долкна последовать Фаза ре-продукции. С другои стороны, однако, наличие мотивов 'снега' и 'цветов' с таким же успехом позволяет толковать 'плодовые' мотивы как конечную, осеннюю Фазу годового вегететивного цикла. Весь круг, таким образом, смыкастся и превращается в непрерывның замкнуты цикл. Одновременность же кодирования Царевича всеми тремя сериями мотивов ('снеговых', 'цветочных' и 'плодовых') преврамает его в миропорохдамее начало: он не столько мир как таковои, сколько п ра, требуюмая своен реализация по жестко определенным законам. Не исключено, что именно эта предопределенность эволюция 'Царевичамира' вырахена в поэме его 'скованностью', 'беэволием-пассивностью', 'сонностью', а также явнвми признаками 'смерти' и 'потусторонности' дахе в случае описывающих его 'цветочных' и 'плодовых' мотивов (ср. 428: "Как цветочек! Смотрето-то xaлосто!"; 429: "Лежит цвет-наш-трезвенник, Как пояний какоя"; 368: "изюм-шептала!..", где "шептала" - сушемие абрикосы; 380: "персик восковой"; 348 : "светлья колос мон, опято клонишо лоб?": 398: "куполок-льнянонмаковочка", где кроме 'замкнутости' дан еме признак 'снотворного' через отсылку к "маку" - см. 1.4.3.).

1.4.5. Как уже говорилось в 1.4.2., Царевич локализован на пересечения горизонтальноя и вертикальнои осен мироздания. Как модель годового цикла он соотносится, несомненно, С осью горизонтальноя, так сказать, синтаксическоя: отдельные состояния имеют здесь значение только как ч а С т и более крупного целого, они не могут репрезентировать собои всего этого целого. В частности, это и есть та семиотическая причина, по которой Цветаева моделирует своего Царевича со смслом 'годовои цикл' привлекая все три кода ('зимия', 'весенния' и 'осенния') одновременно. Вертикальная же ось - парадигматична или иерархична: тут разнье состояния всего лишь варианты одного инвариантного значения, а "Изменения в значении - это лишь степени углубления в одно значение не новые 
смыслы, а степени смысла в его прибликения к абсолюту" . 131 Помимо буквального вертикализма ('рост', 'вырямление', 'взросление') и скалярного (нарастание 'богатырства', интенсификация некоторьх иных свояств, особенно - 'синевы глаз'), Царевичу присуп вертикализм 'экзистенциальны', отчасти оговоренны в 1.4.3. под видом градация 'сукно - шелк - лен', т.е. истончения плоти, за которьм стоит семантика 'духовного раскрепощения'. Легко заметить, что продолжением это градация является иерархня 'небесная' .

На протякении поэмы Цветаева несколько раз привлекает образность теологическоя лестнищы чинов $(365,368,423$ и в модифицированном виде в финале - на стр. 432), при этом дважды соотносит ее непосредственно С Царевичем:
А ну как зорче поглядим -
и вовсе все обман однн,
И вовсе над туманом - дьм,
Над херувимом - серафим? (365)
'Синих очей аль дохдусь я?'
Но - словно пьм -
Изнизу - вдоль впалых тек -
облак - морок - обморок. (368)

Картина дополняетсљ еще заявлениями царевича "- Плохон сын царю земному, - Знать, небесному хорош! [...] Хошь плохо я был наследник - Гуслярок зато лихоя! Паренек-то из последних - Может, ангел не плохон... Хош и неуч $я$ в молебнах, Наверстаю - как помру!" (398-399) и сценоЯ кремения его Царь-девицея: "чтоб цельны полк поклал перстом, Чтоб первы гром пред ним ползком, Чтоб Деву-царь согнул кольцом - младенчика крещу!" и тут же: "То не тучка молодая Лен кропит: [...] На лице его из воску - Как серебряная россыпь, [...] По лицу его из воску - На все стороны - полоски Струики светлье - текут" (366-367).

Согласно православному толкованию, кремение есть "новое рождение": в отличие от "старого", Физического, подвластного смерти и "князк мира сего", это - јождение "духовное" в истинную жизнь, приобщение к Богу, а точнее - открытие пути к Богу, призыв к свободе, к усилию освободиться от уз диавола. 132 в случае Царь-Девишына "кремения" эти идеи выражены словами "Чтоб светльм встал, чтоб век не спал" (366) и пожеланием сверхмоми и власти над "громом" - "Чтоб цельны полк поклал перстом, Чтоб первын гром пред ним ползком" (366). Преобрахение же Царевича отмечено меноя "лица" со 'снегового' и 'цветочного' на 'восковое'=' сакральное' ("лицо из 
воску" значит еще 'лик', проступаючия сквозь умершее 'лицо телесное'). "Хошь и кеуч я в молебнах, Наверстаю - как помру!" (399) - восходит в свою очередь к полохению о непознаваемости Бога при помочи земных чувст и разума: они позволяют познавать только тварное, на этом уровне Бог мохет определяться только апофатическим путем, т.е. отказом от чувственного и интеллектуального. Познание Бога возмохно только в случае выхода в нетварное (ср. Царевичево: "наверстаю - как помру!"). 133

Первое после крещения приближағмее к Богу состояние - ангельское, за ним следуют все более адекватные уподобления Богу: архангелы, начала, власти, силы, господства, престолы, херувимы и, наиболее близкие но не тохдесгвенные Богу, серафим. 134

Цветаевская поэма - отнюдь не теологическия трактат, но теологическия контекст позволяет четче уяснить смысл вертикальноя структуры Царевича. Один ее полюс устремлен за пределт тварного, в сторону лишеннор всякого плана вырахения сущности: "все обман один, [...] над туманом - цым, Над херувимом - серафим?" (365). Другон - соприкасается с Физическон инертностью и смертью: "Изнизу - вдоль впалых мек - облак - морок - обморок" (368). Срединное полохение на этой шкале отведено "глазам", под которымя, неомненно, подразумевается 'душа' или 'духовное начало'. При этом существенно, что "глаза" Царевича, если они открываются, - неизменно "синие": "Синих очен аль дохдусь я?" (368), "не заноза из тела вон - То из ткани булавка вострая, То на личике снеговом Глаза синие, синеморские" (369), "Синеи василечков, Синеи конопли На заспаннъх щечках Глаза расцвели" (395), "чая, синие очи-то, Как по морю плыть!" (365), и связаны, как вндно, с 'синим морем' и 'морским путем'. Последнее раскрывается иначе - со стороны связея с царьДевицея: "Ты бренчи, Гусляр, задая нам пиру-звону! Синь-то водная - что синькои подсинёна! Исполать тебе, царь-Буря, будь здорова! Рот у мальчика - что розан пурпуровын!" (397) и в другом месте, где описывается спор мехду двумя поцелуями-водами - мачехи и царьдевицы: "Та из моря Че́рного, Акульих мест, Та из моря верного Жемчужны всплеск" (411). 'Синева', 'синь водная' явно соотнесены здесь с представлением о мифическом 'небесном, воздушном океане'= ='праведном пути душ" ("Та из моря верного - Жемчужны всплеск", где жемчуг символизирует облагорохенную душу).$^{135}$ в результате 'синие глаза' Царевича - соответствие его небебиого дузовноло на- 
чала, тор энергия, которая в случае ее освобохдения из усыпленнои телесности позволит ему подняться на нетварные уровни бытия (ср. на стр. 421: "То не ладан-пар От воды встает. То водскам гусляр Производит смотр. Не крестьянским полкам голодньм - Золотым облакам господним. [...] Возводи меня на царство, Рать ширококрылая! [...] То не два крыла - В золотоя костер, То царевич наш Две руки простер, Две руки свои разом поднял В золотую эарю господню!", где эпитет "золотая" не случаен - он канонически соотносится с нетварным бохественньм сиянием). 136

итак, Царевич - самая невралгическая гочка мира поэм. Правда, у него есть два пути развития, но оба эти пути ведут к одинакопому результату, хотя и по разньм причинам. Первыя, циклическия, требует как гибели царевича, так и катастрофы подземного царства: переход к весне для царевича означает поглощение его Мачехои-Землея, а для зимнего царева и Мачехина царства - его окончательное крушение (см. 1.3.5., 1.3.7.). Второ月, иерархическин, требует отказа от физического сумествования и чисто духовнои эволюция в запредельное. И для Царевича и для мира это означает физическуто смерть, но духовное воспарение, тогда как циклическия путь предполагает Физическую ре-продукцию, но зато смерть духовную (ср. упоминания о 'согнутон' душе Царевича на стр. 348: "Все отдал бы, весь сан престольның, Кто бы мне душу распростал!" и на стр. 349: "Встал Царевич сгорбленның, Кручинны такоя. Вкруг очея - что обручи, Набились круги." и, наоборот, пожелание Царь-девишы при кремения Царевича 'стать согнутои кольцом', т.е. обрести земную ипостать - 367: "чтоб Деву-царь согнул кольцом - младенчика креmy! ").

Царевич - не реализация мира, а всего лиш его возможность, Фигурно вьрахаясь, - 'зародыш мира'. Поэтому все потенции в нем предельно уравновешены. На сюхетном уровне это равновесие нарушается трикды - при всяком посемения царевича Царь-Девицея: ее ласки и поцелуи активизируют жизненные потенция Царевича, динамизируют его и способствуют эволюции. Но оно трихды же и восстанавливается противодеяствиями Мачехи - ее поцелуем и разяиими стрелами, причем всяки раз это уравновешивание получает все более драматические формы (ср. эпизод поединка мехду мачехиноя "слюнкон" и царь-Девицыньм 'ожогом' на стр. 408-411, где царевич едва не разрывается "на части две"). И все же между этими двумя соперничаю- 
цими силами есть некоторая разница. Царь-Девищыны 'ласки' денствуют на исконно Царевичевы свонства - он претерпевает эвотоцию в сторону богатыря-Громовника, способного преодолеть смерть (ср. градацию в трижды повторенноя сцене сбегания к морю по лестнице 350: "Слабьми руками Вдоль перил витых, Слабыми шахками С лестничек крутых." - 385: "Смелыми руками Вдоль перил витьх. Резвьми шахками С лестничек крутых." - 411: "Жаркимя руками Вдоль перил витых, Шальми скачками С лестничек крутых. Какой тут заморыш! Богатырь, ең-ен! Одним махом - сорок Спрыгиул ступенед." и 421: "То не меч с мечом, Не клинок с клинком - То пресветлы взор С заревьм лучом - [...] То водскам - гусляр Произвсдит смотр. Не крестьянским полкам голодньм - Золотьм облакам господним.- Выходи сам хан татарския - Поравнлюсь силою! Возводи меня на царство, Рать ширококрылая!") или по кранне мере вступить с неи в поединок, поскольку Цветаевское 'преодолеть смерть' означает 'физически погибнуть' и 'преобразиться в чистоте духовное начало'. Мачехины же стрелы имеют характер механической сковываюме внешнеи силы ее "стрелы" повергают Царевича в неодолимы сон, но не усиливают собственно сонности Царевича, вызываемы ими сон не становится его имманентным свонством (сp. 426: "Сталь из ворота - Память в лоб"), не затрагивает Царевичева духа (не случанно у цветаевои эти "стрелы" впиваются не в 'тело', а в 'матерчатую наузу' Царевича, т.е. в узилиме духа - см. 1.4.3.). Собственная сонность Царевича имеет совершенно иную природу.

С однон стороны, она - экзистенциальна, результат идеальнои уравновешенности обеих потенция (см. 1.4.2.). С другоя - наиболее универсальна: обеспечивает единство со всем мирозданием, причастность к божественному. Как уже говорилось выне, участие в божеСтве возмохно лишь в случае отключения земных чувств и земных Форм познания. 'Сонность' Царевича и есть именно такое 'отключение' (ср. хотя бы частое упоминание его 'монашества' и 'отрешенности' от всего земного). На ином уровне этот аспект 'сонности' Царевича выражен его "гуслями" (ср. разъяснение Дядьки: "Все гусельки! От них и сон глубок!" - 367).

1.4.6. Связь Царевнча с гуслями более органична, чем это может показаться на первын взгляд. Играя роль внешнего атрибута, они одновременно являют собо своеобразное овнешнение исконного свояства Царевича. С этон точки зрения частое именование в поэме 


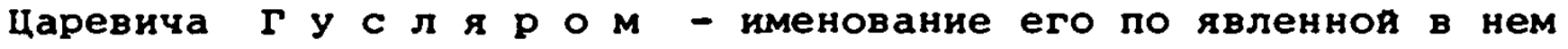
сумности.

Возврамаясь к 'анатомическому' строению Царевича, нельзя не эаметить, что, будучи полнокровньм персонахем, он все-таки бе сп Л О т е н, при этом в двояном смасле: он то "Дар [...] обманның, [...] Ровно столб туманны, Аль дымок степноЯ..." (351) или "обман один" и "серафим?" (365), то сплошь 'матерчат' (см. 1.4.3.). В случае 'матерчатости' небезынтересно отметить общи дия всех материалов, каким именуются наузы Царевича, признак 'волокнистости": "суконны кафтан" имеет свое соответствие в "wерстке"; "что шелка - челка, что шелка - рука!" (366) - в "шелковиночке" (364) "лен" - в "волосах" (364: "Лен - волосенки-то!"), а он сам уподобляется то "ягненочку" (361: "Как ягненочка на травку, Как купца валит к прилавку...Спит..."), то "веревьицу" (364: "Ты распгетись, веревьице! Где юноша? Где девица?"). Откровенная эквивалентность" "волосы" = "Струны"' (364: "Твон-то тонкие, Лен - волосенкито! А мон - конские, Что струны - звонкие!"; 371: "За волосиком волосик иэ руки роняет. [...] у морских цариц на лютнях, Чая, звонят, златые!"; 368: "Не видали вы такового руна! Каждын волос - золотая струна!") позволяет и всю эту 'волокнистость' Царевича рассматривать в соотнесения со 'струнностью'. Но самое существенное то, что "струны" непосредственно соотнесены с "жилами" и "светом месячнъм" :

Словно месяц в полнолунье -

Звон собоя все море занял. Струнки, струнки-говоруньи, Жилочки мои бараньи!

Лехит царския сын на спинке, Гусельки захал любовно, Ходят пальцы без запинки, Ходят славно, ходят ровно. (360)

Слушал, слушал гуслярок голоса, Просветлел, на локоток оперся.

Словно струнки под его пятернеи -

В теле хилочки пошли болтовнея. (387)

мать рожала - не тужила:

не дитя, - пьмочек-дьм!

Словно кто мне налил жилы

Светом месячным сквозным.

Кровь ли это в жилах,

Аль волна об челн,

Как та песнь слохнлась -

нам-то знать почем? (414) fry Faryno-978-3-95479-659-5 
В свете приведенных выдержек видно однозначно, что 'телесность' царевича оборачивается бесплотным 'гусельным звоном-светом' .

В рамках ухе рассмотреннах внутритекстовых соотнесения и в рамках их народно мифологическон основы такое решение "струнного рукомесла" (420) царевича понятно: оно в чистом виде вырахает его 'Громовникову' сущность. Напомним, что царевичева игра на гуслях недвусмысленно уподобляется в поэме дождо и грозе (в сцене пляски Мачехи - стр. 402-403) и изобрахается при помощи 'грозовьх' народньх мотивов "пчелиного гуда" и "коннон скачки": "Пробехался по струнам ветерком, Слинт: Кто-то ровно - мелк! - языком. Разжужжался, что шмелиха-пчела, Смотрит: холм-гора-то кверху пошла!" (400-401); "не морскои, не гусельнын: Пчелины - гуд. [...] Нет, не пчелки розанам ведут дозор. То с печалью грозною у слюнки спор." (410): "Отпустил гусляр свонх конен стреноженных - Прокатилась дрожь волноя до быстрых ноженек." (403). 137 напомним еме, что 'шерсть' и 'овш' соотносятся В народных представлениях С водоносньми и грозовьми облаками и с их похитителем-властителем Волосом-велесом (в поэме ср.: уподобление царевича "ягненочку" 361 и там же "купцу", а этим самым и Велесообразному отцу-царю; уподобление "ягнятам" утренних облаков - 367: "Ровно шерстка на ягнятах-баранах - Весь восход-то в завиточках румяных!"; и именованяе "струн" "барабанъми жночкам" - 360: "Струнки, струнки-говоруньи, Жилочки мои бараньи!". где и "говоруньи" могут рассматриваться как отсылка к народным представлениям о громе как 'говоре' или 'творческом, вемем, бохественном слове').

Гром грому, однако, не равен, он может быть как созидаютен, так и разрушительнон стихиен. В народных представлениях сумествуют, кроме того, по крайеи мере две разновидности громов: весенних и осенних. Если весенние разрушают зимнюю наузу земли и освобождают от сна-смерти жизнеродные потенция, то осенние, наоборот, - запирают земпю на зиму, погружают ее в сон. Соответственньм образом различается и эквивалентная громам волшебная музка: в первом случае она 'плясовая', разрушитльно-оживляюиая, во втором 'Фунеральная' , усыпляющая. 138 не слохно заметить, что царевичевы "гусли" объединяот в себе обе этих Функции, что на деле они являют собоя, так сказать, недифференцированны гром: заказанная у него царем "Камаринская" (398) амбивалентна, она воскрешает (царя - стр. 400-401) и разрушает волшебные науәы (Мачехи - Стр. 402-404), 
а кроме того ограхдает царевича от соблазна (407) и удерживает его в сонном (=вне-чувственном, бесстрастном) состоянии (367: "Все гусельки! От них и сон глубок!"; 419-420: "только знал, что на перине Струнньм звоном ворожил. [...] Ничего не чтил, окроме Струнного рукомесла. Ну, а этим уж именьем Пуме хлеба дорожил... Кто к земньм плодам надменен - Тот земли не заслужил!"). Если учесть, что Царевич, как ухе говорилось в 1.4.4. и 1.4.5., не реализация мира, а талько возмохность мира, то такая контаминация разныу разновндностен грома в однсм атрнбуте - "гуслях" - полная закономерность.

Аналогичная контамннация смылов "гуслея" наблюдается и на вертикальноя оси, а не только на циклическои (весенне-осеннея): они и 'подземная' музыка, и 'небесная', т.е. и "Камаринская" (398) и "имелиха-пчела" (401; ср. народное представление о пчеле как 0 "божьея пташке" и в поэме мотив 'воска', стр. 411: "Ему - капли воску две Из божьих сот"). Эта вертикальная шкала восходит, вероятнее всего, к символике арфы и лиры, которые знаменуют собоя гармоническия союз космических сил (на противополохном полюсе этого единства предполагается хаос, которы в свою очередь представляется в виде овечьего стада). Кроме того и лира и арфа осумествуяются во многих мифологиях как мистическия мост или мистическая лестница, соєдиняюеая землю с небом. 139 При таком взгляде "гусли" оказываются еме одним вариантом уже обсуждавшенся 'лестнишы чинов ангельских' (См. 1.4.5.). Но если последняя - некая серия все менее тварных состояния, то "гусли" - путь обретания этих состояния, путь в сторону нетварного. В пределах самоя поэмы эта их функция реализуется только частично - в виде 'отключения' Царевича от 'чувственного', в виде входов 'в море', т.е. к границе бытия, и в виде 'лебединого' мотива (ср. 386: "Пескопевеи, в плену! Наша летопись: льну... Не царевич к челну - Лебедо к лебедю локет." и 390: "Пывет Царо-мой-Лебедо В перстнях, в охерельях. Кафтан - нет белее, Кушах - кет алее... Сережка - подковой Висит из уика... (живого такого Напето би друхка!) [...] - В сочельник крещекский, что ль, парень, рохдек? [...] Гляди, - не волна ух: Гривастая тройка!", где лебеднность царевича тесно сопряжена c 'песнопением', 'громовниковостью', 'сакральностью' и 'потусторонностью'). 140 в пределах хе поэтики Цветаевоя вообще за ними стоит тот смбл, которы едва ли не наяболее эксплицитно высказан в Позме воздуха (1927; СиП IV, 284). 


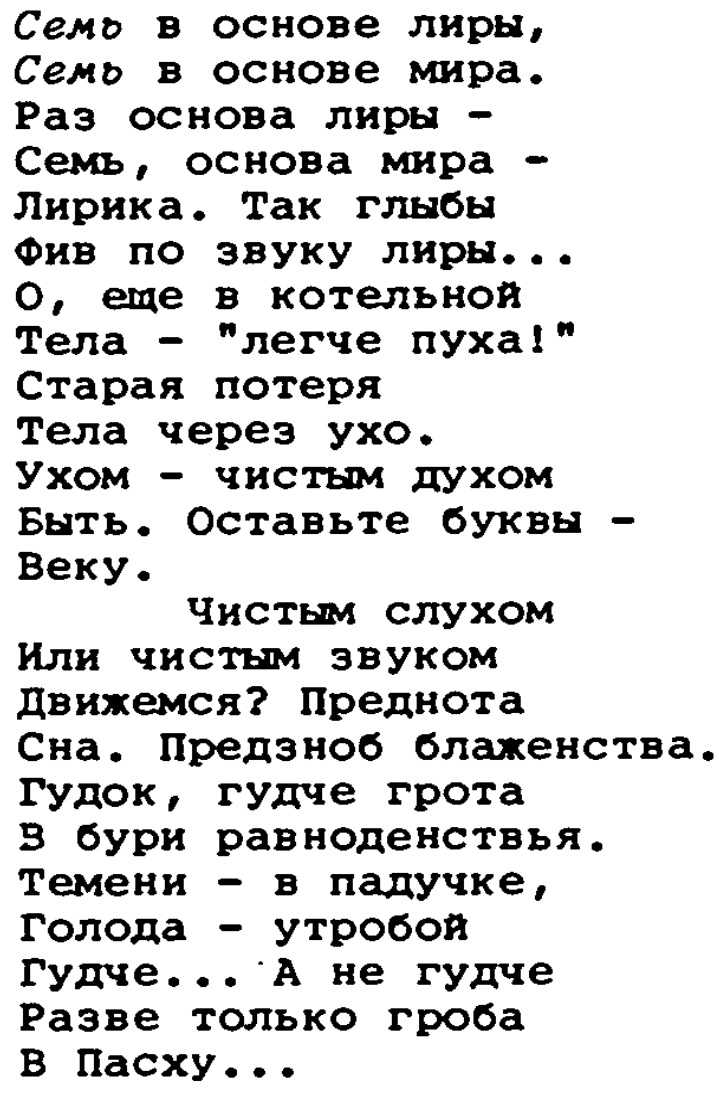

Сопоставление с Поэмой воздуха было бы, конечно, несвоевременньм, если бы Царевичевы "гусли" не были "самогуды" и не ставились бы в ранг "закона": "Гусли, гусли-самогуди мне - едикственний закон! Я до смертного до поту ке отстаку от струна!" (354). Правда, они - "закон" для Царевича, но, с другоя стороны, Царевич ведь и есть потенциальның мир, долхенствуюпия сменить рушацияся мир старың. 'Самогудность' же, как всегда у цветаевон, отнюдь не механическое закмствование из фольклора - в неА, несом-. ненно, видит Цветаева беспричинны, самовозникающи чисты звук. Царевичева игра на "гуслях" оказывается, таким образом, Формон самотождества и самоконституирования м!ра, или иначе - идеальнов Формоя сулествования мира.

Со смыслом 'мировод лестницы' "гусли" Царевича связаны и еще иначе: через именование их "струн" "бараньими жилочками" (360: "Струнки, струнки-говоруньи, жилочки мон бараньи!") и хотя бы через именование самого царевича "веревьицем" (364), которое предпологает не только переплетение в Царевиче разных начал (364: "Где юноша? Где девица?"), но и вертикальную, иерархическую, ось мира (365: "А ну как зорче поглядим - И вовсе все обман один, И вовсе над туманом - шым, над херувимом - серафим? Спим..."). Emе явственнее этот аспект "гуслея" проступает в случае сопоставления 'пения' и 'игры' Царевича с "яблоком" - 389: 
Ту песенку прослушала -

Как яблочка откушала.

Звон струнны вобрала -

Как брагоя запила.

Эквивалентность" "звон струннын" - "брага" - разновидность эквиваленции 'игра (на гуслях) - гроза (дождь)' (ср. 402: играл сперва гусляр так-от легонечко, Ровно капельки шумят по подоконничку"), а 'песенка - яблочко' - разновидность эквивалентность 'игра (на гуслях) - оплодотворяющия дохдь" (ср. 402: "Заработали тут струночки-прнслукницы, РОвно зернбики-посыпались-жемчукинки") . Эквивалент ность же "дохдь" - "брага"' восходит к народным мифологическим представлениям о грозе как варке пива и о грозовом дожде как о бессмертном напитке богов. 141 "яблочко" в этом контексте несет не только смысл 'соблазна', но и глубинного 'знания', Глубинноя 'мудрости' О хизни и смерти, О законах мира. На возможность такого прочтения "яблочка" позволяет наличие в поэме как именования царевича "раяским плодом" (395: "Все мы к рарскм плодам ревнивы"), так и именования игры на гуслях "ворожбои" (419: "Только знал, что на перине Струнньм звоном ворохил. Кто страды земнои не принял Тот земли не заслухил", где под "ворохбон" понимается "чистое знание', замкнутое на себе, ни к чему не прилагаемое и ото всего 'ограхдающее') . Естественно, "ворожба" предполагает некия таинственны, магическин ореол. В случае Царевича он не возникает. Но тем не менее именование его игры "ворожбон" не совсем неоправданно. Царевич, как ни как, - соответствие юного 'Велеса'. А Велес, как показывают современные мифологические исследования, обладает шаманско-поэтическо Функциеи (тут уместно напомнить, что царевич именуется в поэме такхе и "песнопевцем" - стр. 386, и что "струны6 а р а н в и жиы определяотся как "говоруньи" - стр. 360).142 Поэма не автотематична и лишена, как уже говорилось, метапоэтическои установки. Поэтому данные мотивы появляются в тои мере, в какоя они присущи самому миру, т.е. миру цветаевоһ, как его основа и предел, за которњм начинается сфера нетварного. Там, где сюжет стронтся на устремленности к Абсолоту, это - очевндность (ср. хотя бы такие вещи как Прохрастося..., Переулочки или Поэма воздуха). Здесь же сюхет построн на сохранения равновесия мира, почему акцент поставлен не на его границах, а на его основах. 


\section{5. ЦАР В-ДЕВИЦА}

Хотя в сюжетном отношения царь-Девица равносильна Мачехе, а в семантическом - Царевичу, заглавие поэмы - Царо-Девииа - именно ее выдвигает на первое мегто. Этот ход цветаевой мохет объясниться по-разному. С одноЯ стороны, особо ценностнои позициеи ЦарьДевицы в ЦветаевскоЯ модели мира - царь-девица, несомненно, локализована на полохительном полюсе вертикально оси мира поэмы. С другой, заглавное "Царь-Девица" может включать в себя также и царевича, так как он являет собои своеобразны вариант или дахе 'двоиника' Царь-Девишы (ср. симметрию их именования на стр. 354: "Как, к примеру, Дева-царь я, Так, выходит, - Царь-ты-Дева!" и симметрию 'родства-равенства' на стр. 389: "Сжалилась над братом тощим Моцная моя сестра.", где под "братом" понимается сам Царевич, а под "сестрон" - царь-девица), а кроме того и царевич и царь-девица в одинаковои степени 'андрогинны' - объединяют в себе и мужское и женское начала (ср. о Царевиче: "- Гляку, јляху, и невдомек: Девица - где, и где дружок? Ты расппетись, веревьице! Где юноша? Гле девица?" - 364, и о царь-Девице: "Тот муж светоносның в челнок белогрудн Нисходит - склоняется - сдернул покров... [...] Да что ж это? Аль обернулся бабьем? [...] Грудка-то - бабъя!" - 426-427). И третье возможное прочтение: все персонажи поэмы являют собой некин один - униерсапы , именуемы метафорически 'Царь-девицея', разбиты на четыре условных и самостоятельных ипостаси: Царь-Девицу, Царевича, Мачеху и царя, которые соответствовали бы отдельным состояниям в циклическом круговороте мира и отдельным Фундаментальным қосмическим стихиям (ср. в причитании царь-Девицы на стр. 422-424 всеобъемлющее перечисление: "- Бог на небе - и тот в аду, [..] Вихрь осенния и ветр полуденныя, [...] Силы - власти - престолы - славы - Стан пернатын и стан шершавыя, Ветер - воды - огонь - земля, Эта спяная кровь - моя! Царю не дам, Огню не дам, Воде не дам, земле не дам. [...] Есть страх - в раю, Не-наш - в аду, Земля - внизу, Судьба - вверху") •

1.5.1. В отличие от остальных персонажей поэмы царь-девица локализована за пределами подземного мира: "за морями царь-Девица живет" (349; в ответе Дядьки на вопрос царевича), "у окна свово, над взморьем, Царь-девица саблю чистит" (352; первое непосредственное введение царь-девицы в поэму) .

В Фольклоре "море" являет собои некое промежуточное прост- 
ранство мехду миром земньм и небесньм или подземньм, с одноЯ сто-

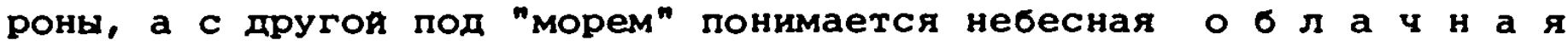
стихия. Точкоя отсчета в поэме является мир подземны, поэтому "за морями" значит в данном случае некия 'заоблачның' локус, 'не6о', но не атмосферическое, а мифологическое, понимаемое как локус приязненных космических сил или божеств. Ради удобства мохно его назвать 'сакральньм локусом', тем более, что и в самои поэме с ним именно связан цель ряд народно-христианских мотивов (344: "пророк Монсея!", "Ангел"; 356: "Сам Михаил-Архистратиг!"; 350: "В небесах Егория не разжег вояны"; 416: "То не свет-Егория Спор ведет с Советом"; 421: "Две руки свон разом поднял В золотую зарю господню" и "Производит смотр [...] Золотым облакам господним"; 425 : "Гонит пророк конея. Гривами хлябь пошла. Пуше взметнулся бич В длани пророковоя"; 426: "И видит гусляр: в облаках тех румяньх, В морях тех не напих - туманных - обманных - [...] в небесных морях [...] ТОт мулх светоноснын"; ср. еме именование неопознанного Царем-Царевича: "Прынц заморский либо беглын момах" - 399).

"Окно" в свою очередь имеет в народноя культуре смысл 'проема' в 'потусторонния мир' - В случае царь-Девнцы ее "окно" разграничивает чреваты опасностьо локус моря (352: "У, окна свово, над взморьем") и локус небесного огня-молния (352: "царь-девица саблю чнстит", где "сабля" - символ богатырства отправляюмегося в опасныя путь - ср. далыше, 355, "Опоясалась тут саблея" и 1.4.3., и эквивалент разящея небесноя молния). В случае царевича его "окно" таким же образом разграничивает небесны громоносның мир и внутренния мир смерти (349: "не слетались голуби К окну за крупоя Встал Царевич сгорбленны, Кручинны такоЯ. Вкруг очея - что обручи, Набились круги", где "голуби" - такой же как и "сабля" символ небесноя молния, а "крупа" - обрядово способ вызывания весеннея оплодотворяюще громоносноя стихии, грозы и дохдя). 143

1.5.2. Соответственно мифопоэтическому мшиению и аналогично другим персонахам поэмы (особенно - Царю) Царь-девица изоморфна своему небесно-гроэовому локусу. Все ее атрибуты - 'молниеносны', 'громоносны' или 'грозовые', таково же и ее окрухение. При этом показательно, что в больинстве случае цветаевские эквиваленты грозово стихии не только почерпнуты из метафорического фонда народноя культуры, но и, так сказать, расшифрованы, т.е. их связь с грозоя здесь более эксплицитна, чем это обычно бывает в 
По самоопределенню царь-девищы она "Вихрь-жар-град-гром была" (394) и это отражено на всех уровнях ее образа. Ее голос гром (356: "Гремит громоподобның глас. Рече - и, рассекая тучи, Промеж рядочков пронеслась"); ее пот - град (356: "Пот - градом); ее румянец - похар, естественно, грозовои (356: "Как вихрь промех рядочков вихрит, Пот - градом сквозь похар ланит. Лишь где на том конце затихет, Ух на другом конце гремит"); ее платок молния и гром (356: "И подает полкам Царь-Буря Тут знак малиновьм платком": 358: "На всем скаку рукон сердито Раздергивает харплаток. Рвет надвое платок-ширинку, И, голову пригнув к плечу: 'На, барабанщик, половинку! другая будет трубачу!'", где "барабанщик" - обессиливающия от усердия гром, а "тубач" - грозовая 'музыка', 356: "Уж никогда грознед да лучше трубач губасты не трубил. Гром-барабанщик обе ручки По локоток себе отбил"; ср. на 357 еме просьбу барабанщика: "Гром-барабанщик следом мчит. 'Как две руки мои отбиты, Даң хоть с мнзинца ноготок!" ", где "мизинец" и "ноготок" - распространенные народные метафоры молнии и грома) : 144 ее пояс - "змеи-самохлест" (346), т.е. опять-же вариант разямея молнии, такоя же, как и "сабля" $(352,355)$; ее волосы неотличимы от конско гривы (356: "Конь с девицею точно сросся; Не различишь, коли вдали: Хвост конския, али семишерсты Султан с девичьеи головы!"), а "конь" есть "вихорь" и "молния" (355: "и на зов ее кулашны Вихорь-Конь к неи на крылечко Белои молнией взлетает. [...] и с окошечка резного коню на спину с размаху Белон птицею махнула.", где перекличка эпитета "белын" оправдана народноһ эквивалентностьо 'птица - молния'); ее "чертог" - "краснын" (363), а "корабль" - "костер" (344, 361: "Жар-корабль", тогда как она сама - 352: "Жар-Девича!"; 346: "В синеморскую хлябь Выпльает корабь. [...] Посередке - костер, Пурпуровы шатер"; 359: "Что за костер это мчится в степях синих вод? [...] В хладноя пучине, чая, крестит купецкую тварь?"), где эквивален тность 'корабыь - костер' покоится на народном представлении грозового облака летучей огнедышаме ладьен) : 145 ее "вонска" - тоже все та же грозовая небесная стихня (356: "Как облачная рать в лазури - Полк за полком, полк за полком. И подает полкам Царь-Буря Тут знак малиновым платком", "Как из одноң груди тут громом: 'Сам Михаил-Архистратиг!'"; 355 : "Не колосочки овсяные до солнышка встают в ряды, - То ратнички ее стальные Равняются на площади", где "колосочки овсяные" в одина- 
ковон степени восходят $к$ солярным обрядам и к обрядам вызьвания грозы; ср. еме солярную мотивику в образе царь-девишы - 356 : "Грудь в светльх латах, лоб - обломом, С подсолнечником равен лик. Как из одноЯ груди тут громом: 'Сам Михаил-Архистратиг!'" ; 359: "с лицом-то как шар золотон, [...] А светлолиц, круглолиц, - Солнцу на ревность!"; 362: "То не солнце по златьм ступеням Сходит Дева-царь по красньм сходням"; 355 : "Одням свокм лучом единым Мы светел-месяц полоним"; 427: "Как новое солнце взошло во вселенноң! Как лев златогривын стоит над щенком..."); и, наконец, Царь-девица - 'великан', уравниваемыя со всем космосом (346: "Великановы рост, Пояс - змеи-самохлест, Головою до звезд, С головы конския хвост, Месяц в ухе серьгон..."). Если учесть ее определение своен руки "Моя - дубы корчевать" (363), то в изобрахении ее 'пеликаншея' легко просматривается народная метафора грозового неба. 146 нагляднее всего изоморфизм Царь-Девиш и ее мира вырахен в сцене отплытия в море в поисках царевича - уход царь-девицы является одновременно 'концом' мнра:

Полк замертво свалился пьяны.
Конь пенон изошел, скача.
Дух вылетел из барабана.
Грудь лопнула у трубача. (359)

Естественно, за этим стоит и более глубокия смшсл, но пока отметим лишь сходство с крушением подземного мира в сцене вставания царя (CM. 1.1.3.).

'Великания', космических масштабов рост Царь-Девицы не исчерпьвается обычным изоморфизмом. Заметим, что ее "султан" - "семишерстнья" (356). В самон поэме этот мотив не получает более эксплицитно, о решения, но контекст других вепея цветаево у убедает в его неслучаяности. "Семь" - это основа цветаевского мира (ср. 375: "Семь небес у Девы Чистоя, у царишы - семь покоев"; см. такхе 1.4.6.) и, в частности, шкала цветаевских трансФормация (мира, героев, лирического " $q$ "). "Семишерстнын" мохет поэтому означать 'семиликость' Царь-девицы, воэмохность семикратно трансформироваться. При этом следует помнить, что цветаевские трансформации отнюдь не пронзвольны, а строго последовательны и, как правило, выстраиваются в направления 'вглубь-ввысь', т.е. К наиболее истинной и наиболее ценно ипостаси, а одновременно наименее материальноя. "Султан" как атрибут коня (закономерно приписанны царь-девице, так как она не раз приравнивается к коню - 352: "осерчала нянька: 
'Полно Ржать-то, ровно кобылица! Как бы этим рханьем всех-то Женихов не распугала!" ; 358: промаясь с конем она целует его будто он "брат-еи-жених"; 364 : свои волосы она называет "конскимя") такхе и 'шерсть' переводит на свон уровень, а цветаевскин 'конь' уже 'духовен', ухе соотносится с небесным миром. Поэтому данная ' семишерстность' предполагает еме более идеализированные трансформации, уход в еме более высокие 'небеса' (ср., в частности, соотнесенность 'неба' и 'шерсти' - 367: Ровно шерстка на ягнятахбаранах - Весь восход-то в завиточках румяных!"). В этон семнчленно структуре мир не трудно опознать мифическую 'мировуго лестницу (ср. 1.4.5.-1.4.6.), хотя как таковая лестница в даннон поэме не упоминается (в отличие, например, от поэмы Переулочки). Но есть ее неэксплицитнын вариант - 352:

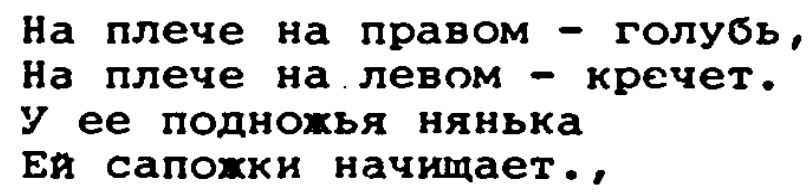

где "подножье" вводит и ассоциацию с 'горои' (имеюмен характер 'мирово горы' и 'мировоя лестнишы', скахем, в Переулоиках или в Поэме гора), и ассоциацио с 'деревом'. Тут домннирует смысл именно 'мирового дерева' из-за поселения на "плечах" 'птиц', обе из которых символизируют громоносную стихию, свет и духовность. И еме один вариант - "дуб" в эпизоде плача царь-девицы над непробудным царевичем (392-394 см. 1.4.3.), которы есть и так называемое Перуново дерево (ср. 392-393: "Как бы листвон Затресся дуб. Как пес цепнод Смех - с дерзких губ. 'Агу, агу, младенец!' Хохочет, подбоченясь. Все - как метлою замела! Все - как водою залила! Гляди: сенчас - грудь лопнет! Все корабли потонут!"), и древо жизни (393: именование дубовой 'смолы-слез' Фруктовьми соками: "Апельсинны, абрикосныя, Леяся, сок души роскошныя, Леися вдоль мек - Сок преценнья, янтаревын, Дар души ее суровоя, Леяся в песок!"), и мировое древо (393-394: "Все корабли потонут!", "Так, слезища за слезою, Золотые три дороги От истока глаз широких К устью губ", "Леися в песок! [...] - Растопись слезоя, гордыня, Камень-скала!", где явно подразумеваются три уровня мироздания: 'небесные моря" в "корабли потонут" - 'земноя уровень' в "три дороги" - 'подземның мир' в "немая льдина" и "камень-скала" означаюмих пребывание во власти зловещих хтонических сил). 147

1.5.3. Подобно остальньм персонахам поэмы царь-девица тохе 
персонах идеальны, замкнуты на самом себе. Так, 'генетически' в ней объединяются в одно целое два непримиримых космических начала - огонь и вода: "Огнь - стец мне, Вода - матерь, Ветер - брат мне, сестра - Буря" (352); 'биологически' - начала мужское и женское, что отрахено уже в самом имени "царь-девица" и частои его инверсии "Дева-царь" (362), которая призвана, в частности, уравновешивать их, в мене глаголов с грамматического женского рода на грамматическия мухско (например, в диалоге акулы с китом на стр. 359), в неразличении 'пола' в эпизодах,излагаюаих посторонюю точку зрения (356: "И вздох тут: 'Дева! дева!' и рокот: 'Царь наш! Царь наш! царь!'", а также см. стр. 359, 426-427): 'иерархически' - начала 'сакральное', 'рыцарское' и 'демоническое' (ср.: "Не то Ангел, не то Воин какоя. [...] не то в латы, не то в ризы одет!" - 344; "Что там за Воин - за Ангел - за Демон такон?" - 359): 'ољъемно' .. 'аеликанша' и 'луч' (346: "Великановыя ғост, Пояс змеи-самохлест, Головою до звезд, С головы конскин хвост, Месяц в ухе серьгон..."; 359: "Рогтом-то - башня, в плечах-то косая сажень! [...] - А поясочек-то! Перстень берет в пояски! [...] Кабы не плечики - вся 6 в перстенечек пропла!"); а по форме - 'круг' (356: "С подсолнечником равен лик"; 359 : "С лицом-то как шар золотоя, [...] А светлолиц, круголиц, - Солнцу на ревность!"). Подобно Царю и царевичу Царь-девица избегает 'супрухеских' связея (352: "Мне и любо без родин-то! Огнь - отец мне, Вода - матерь, [...] Мне другой родни не надо!"; 353: "Эка сладость - женихи-то! Мор жених - мор меч пресветлья, Меч мор сабельныр, веселья: Мне других друлков - не надо!") и целиком погломена одним - "бранньм" - занятием (353: "Трубны звон - моя забава! Мне иных забав - не надо! [...] Бранныр быт - моя забота! Мне иных забот - не надо!"). При этом чрезвычаяно показательно, что, откликаясь на услышанную от волн песню царевнча (353-354: "Не спьхал еме как бабы По ночам толкуют сны. [...] Я, мальчишка узкогрудыя, С бранным бытом незнаком. Гусли, гусли-самогуды Мне - единственның закон!"), царь-Де-

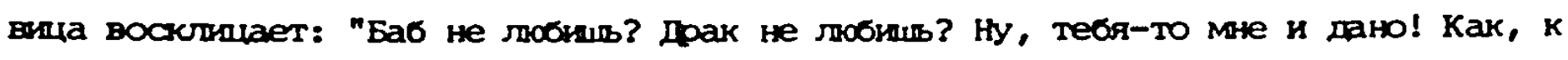
примеру, Дева-царь я, Так, выходит, - царь-ты-дева! Уж с такнм-то голосочком Мух за прялку не засадит!" (354). "Гусли" как громовая стихия и инверсия имени "царь-ты-Дева" ставят знак равенства между царевичем и царь-девицеи; "Баб не любишь?" - исключает возмохные 'семеиные узы' и позволяет царь-девице сохранить как свое 
'рыцарство', так и 'свободу'; "Муж за прялку не засадит!" оэначает не только 'свободу' от домашнего очага и бытовых дел, но и в мифологическом плане - 'свободу' от 'креативности' (если 'пряденье' читать как созидание 'телесного' или вообще вопломенного в материальную ипостась' - ср. смысл 'ткани' в образе царя, Мачехи и царевича: 1.1.2.в., 1.3.3.д.-е., 1.4.3.), а тем самым и от 'смертности': "Драк не любинь?" может отсылать как к "воһне" в подземном царстве, так и к 'смерти' вообме (см. 1.1.4. и 1.1.6.; не случайно царь-девица "крестит купецкую тварь" - 359, что значит 'топит корабли', или в сцене плача - 393 - от ее смеха='грома' "Гляди: сенчас - грудь лопнет! Все корабли потонут!"). Правда, царь-Девица 'воннственна' (353: "Бранны быт - моя забота! Мне иных забот - не надо!"), но ее "бранның быт" - не "драка" и не самоистребительная и разрушающая 'жизнь' "воина", а 'воина' как раз со 'смертью' (ср. 352: "Прискакав с ночнон атаки (на лбу пот росою крупоя), у окна свово над взморьем, царь-девица саблю чистит", где "ночная атака" значит борьбу с силами темноты ; ухе отмечавшееся 'затоплене' "купецкои твари", т.е. 'сущности царя-купца' и "кораблен" как соответствия 'гробов', см. 1.4.1.: попытки 'разбудить'='высвободить из смерти' царевича и освободить его от волпебноһ наузы - 366: кремение; 368: дарение своих - "конских" - "струнищ"-"волосим" ='небесного грома'; 394: прохигание царевнчевон наузы "горючеи слезон" и "поцелуем"-"печатью"-"ожогом"; 391, 424: расстегивание "кафтана" и разглахивание "шнуровки" - "весь кафтан-ему-шнуровку Расстегнула на груди. [...] Дьпит? - нет? Дьиит? - Да?"и "С великой нежностью ему Разглахивает шнуртесьму, Лик-наклоняет-солнце на белое суконце").

В Царевиче привлекают Царь-девицу главньм образом его "гусли": "Всколыхнлася лазурная рябь: К нам на гусельны на звон Жар-Корабь!" (344). С мифологическоя точки зрения это понятно: небесная грозовая стихия вызывается обрядным земньм 'шумом-музыкод', что явствует как из всего смыслового хода поэмы, так и из не сразу заметноя здесь ассоциации с 'водосвятием' (после "Всколыхнулася лазурная рябь" следуют сакрально-христианские мотивы: "Подивись со мноя, пророк Моисеи! Купины твоея прекрасноя - краснен! Посередке же, с простертои рукои - не то Ангел, не то Воин какои. Что за притча? Что за гость-за-сосед? не то в латы, не то в ризы одет!", ср. 390, где мотив 'водосвятия', на этот раз по отнонению 
к царевичу, уке вполне эксплицитныя: "Глянь, чтон-то пучина Пошалиеато стала!" - В сочелокик хрещенский, Что ль, парень рохден? [...] Гляди, - не волма ух: Гривастая тройха!"). Но, что вахнее, Царевичевы "гусли" есть его самая глубокая сущность, его, так сказать, 'духовность' (см. 1.4.6.), родственная 'грому' , но пребываютая во власти хтоняческих сил. Именно ее 'сльинт' Царь-Девица (она наделена исключительным слухом - 389: "тонок слух мон девичин", "Такоя уж слух мон воровскон, Что даке шум травы морскон О рыбия хвост чешунны, Не то что друга - чую!"; а "звон струнны" имеет характер "слов" и "песен" - 353: "что за Звон С воды всает за чудның? Чтон-2о под монм окошком Волны за слова лепечут?"; 389: "Ту гесенку прослушала - Как яблочка откушала. Звон струнны вобрала - Как брагон запила.") и именно ее стремится 'раскрепостить', вернуть ен подлинную 'теоцентрическую' свободу (что особенно видно в эпизоде крещения - 366: "чтоб светльм встал, чтоб век не спал, Одним моим речением, - Морским моим кремением - младенчика крему! Чтоб цельны полк поклал перстом. Чтоб первы гром пред ним ползком"; см. 1.4.5.). т.е. власть над инертньм физическим миром и динамическую волю воссоединения с Богом. На этом же уровне объясняется и особенность ее любви к царевичу. Эта любовь - не эрос (как в случае Мачехи), а божественная агапе. Она родственна даюпе хизнь любви материнскоя (ср. 366: "Будет грудь моя стальная Колыбелочкон тебе", помммо его гораздо раныше упомынавшеяся - 353-354 - "Осемнадцатои весны!" кремение как второе рохдение и 427: "и видит гусляр, как в волшебном стекле, [...] и светлую саблю с письмом рукописньм, и крест тот широкия - любви бескорыстнон, Которым нас матери крестят: - Живи!"; ср. также царевичевы 'видения' ее посеменин в категориях весеннего оплодотворительного и охивляющего природу дохдя - стр. 370: "Ровно дождь меня тонким Серебром поливал. Ровно жаворонок звонкия Вкруг меня ликовал."; 395-397: "ЭА, старья, послушька: Вот сон-то приспел! Как будто кукушку я взял на прицел. [...] и вику еме я, - Речет сам не свон, - что плачет смолою дубок молодон. Ветвями облапит Как грудку-мне-стан, и капит, и капит слезон на кафтан. [...]За перст безьмяннья Прикован - леху. АА к смерти? АА к свадъбе? Скахи, не мытарь!", где "жаворонок" и "кукушка" - народные вешие птищы, причем "жаворонок" дополнительно связан с Благовемением и חасхо) 148 
1.5.4. Именуемая "царем" (356: "Царь наш! Царь! Царь!" и имена "царь-девица" и "Дева-царь"), называемая царским символом - "львицен" (352: "Погляху на кудри гривои, Погляху на взор пожаром - Как не я тебя, а ловииа Ловияим молоком вскормила!" ; 427: "Как леө златогриөий стоит над щенком...", в отличие от "красного льва" в случае царя - см. 1.1.2.в.), имеюмая Форму "шара" (359: "с лицом-то как шар золотон") и располагаюмая 'царскои печатью' (410: "То с печатью грозною у слюнки - спор", где "П е ч а т ь (охог) - поцелу царь-девищы, с л ю н к а - поцелун мачехи"; 365: "Где царь не приложил печать, там надо надвое решать", где под "Печатью" понимается ритуал кремения, приобщения новсрожденного к Богу, попучения новорохденным вместо бесформеннои, неопределенной жизни ОФормленноЯ новоя и целеустремленноЯ, т.е. теоцентрическоя; 149 в отличие от Царя подземного, у которого "Лик - шар сургучевы, краснее клопа" - 400, содержамин явны смысл 'смерти' - см. 1.1.1.в.), Царь-Девица лишена в поэме таких атрибутов царского сана, как "кольца", "перстни" или "ожерелья" - ее рука, в отличие от царевичвоя, "бесперстневая!" (363), а "бусы" упоминаются лишь косвенно, лишь в виде их "следа": "Всеи крепостью нехенских уст Уста прикгла. (От шенных бус на латах - след двоннон.)", где "неженские уста" неитрализируют смыл 'соблазна-смерти' "бус". Зато неоднократно упоминается ее 'головнои убор', но не ожидаемая 'корона', а "каска" (367: "И, зардевшись путе каски своен, В лоб цєлует - промех ровных бровен"; 359: "Каску хвостатую ветр ему сшиб набекрень"; 427: "Да как ж это мохно, чтоб в каске хвостатон над дрянь-гусляришкон реветь в три ручья-то!"; 426: "И дивного мужа под красньм шатром Он видит - как золотом-писанның-краскои! и светлые латы под огненноя каскон, и красную каску на красных кудрях и властную руку, в небесных морях Простертую - через простор пургуровын - Через версты и версты к челну гуслярову") или "конския хвост" и "султан" (346: "С головы конския хвост"; 356 : "Хвост кснския, али семишерсты Султан с девичьер головы!" в отличие от полагаюменся, например, Царевичу "короны" - 353: "- Гусли, гусли-сомозвоны, Вся забавушка моя! Из зубчатоя из короны Ни зубца не стою $\boldsymbol{g}^{n}$ ).

Услышав первую песню царевича и опознав в нем 'равносумного' себе 'жениха', царь-Девица распоряжается о сборах в путь на смотрины. Обрадованная нянька торопится разгладить таяком еи пригото- 
вленны "наряд венчальның" . На это Царь-Девица отвечает:

как в раззолоченно попонке

Негоже бранному коню,

Ухель атласною тряпчонкон

Свою же славу заслоню?

цельному вонску господином

Была, - так справлюсь и с одннм!

Одним Свонм лучом единьм

мы светел-месяц полоним. (355)

Согласно коду свадебного обряда, роль жениха состоит в похимении невесты, освобождения ее иэ потустороннего мира (чего так бонтся Царь, см. 1.2.1.). Здесь эту роль берет на себя царь-девица, активизируя свое мухское начало (хотя "полоним" мохет пониматься и как намек на 'соблазн', кроющияя в хенском начале). Для невесты выход замух в этом обряде истолковьвается как 'гибель'. Переформулировка обряда в термннах 'завоеваиния', а не привычноя обрядности, воскрешает подспудны, уле почти неосознаваемы, смал свашбы. Но это свидетельствует о глубоком понимания народноя культуры самон цветаевон, а не царь-девицен, хотя в некотором смысле такое сознание приписывается и ен. Само бракосочетание, и, в частности, переодевание в "наряд венчальньд" - это символика временно смерти и перехода в иную хизнь. Отказ от "наряда венчального" - отклонение 'смерти'. В системе поэмы переименование свадебного платья в "атласную тряпчонку" данны смысл конкретизирует - сообмает ему статус волшебно наузы подземного царства, а еме глубже - телесного облика вообще (ср. народное представление о том, что атласом устлана дорога в ад; ${ }^{150} \mathrm{cp}$. также связь "атласа" с мачехиноя смертоносноя наузоя - 402-403: "Заходили тут и руки в странном плясе: коготочками гребет, что кот в атласе. [... ] Как тигр-лежебок Готовит прыкок. [.. ] Играючи да крадучись - Что кот с милом! [...] мраком-то-как-жаром - дохнет!"; кроме того небезынтересно отметить разницу мех "платком" Царь-девицы и "платочком" Мачехи: первыя - 'молниеносны', он не 'нашеиның', т.е. сковьваюии, но и его царь-девица разрывает и раздаривает: "На всем скаку рукон сердито Раэдергивает жар-платок. Рвет надвое платок-ширинку, И, голову пригнув к плечу: 'На, барабанщик, половинку! Другая будет трубачу'." - 358; второя, Мачехин, - "нашеннын" и 'смертоносның': "- Вынь иэ бликнего, из нашеяного Из платочка свово - булавочку. Ты упрись ею в грудь высокую, Напои ее кровью досвта. А плениш молодого сокола, Помяни и меня, красо- 
точка! - Дерганула рукою спешною: Грудь раскинулась - цветом яблочным! Вынимает из тела грешного Пурпуровую - всь - булавочку: [...] и вколи ему змеику в инворот, [...] От булавки тон - будет крепко спать" - 347; ср. еме разбиравшиеся в 1.5.3. слова Царьдевицы "Муж за прялку не засадит!" с их смыслом избегания 'креативности') .

Противопоставление "атласнои трятонке" "славы" - это противопоставление 'земнои красоте' 'небесноя красоты', 'бренному, смертному' - 'бессмертия', телесному' - 'бестелесного'. Ближағшия контекст "славы" - "луч" - указывает, что "слава" понимается здесь в теологическом коде, в котором она означает 'могущество' и 'блеск, сияние' и является атрибутом самого Бога, которы он дарует людям, царям, и которая может являться людям хак видимая бохественная реальность; "Среди природных явления гроза являет собой одно из самых ярких проявления славы". 151 далее: Слава Господня мохет являться в виде ослепительных Господних риз, всепоядающего огня в великих деяниях, в доблести. На прочтение царь-Девицынои "славы" в таком именно ключе поэволяет ее причитание, в котором она взывает именно к чинам ангельским, образующим нисходящую к людям Славу Господню: "Силы - власти - престолы - славы -" (423; см. 1.4.5. и примеч 134); кроме того см. упоминания облаков и зари как "золотых" и "ширококрыпых" (421: "золотым облакам господним"; "Возв वди меня на царство, Рать иирококрыльная!"; "Две руки разом поднял В эолотую зарю госпсдню!"), которые однозначно отсылают $\mathbf{k}$ каноническому золотому сиянию нетварного Бохественного мира (см. 1.4.5. и примеч. 136).

"Атласнои трятоне" противостоят в образе царь-девицы ее рыцарские доспехи - 'стальные латы', которые символизируют не топко доблесть или благодетели, 152 но и славу Господню: она "не то Антел, не то Воин какоя. [...] не то в латы, не то в ризы одет!" (344), а 'латы-ризы" - "светлы": "Грудь в светлых латах" (356). Окончательно этот мотив расияфровьвается в последних видениях Царевича 426-427: "Он видит - как золотом-писаннын-краскоһ! и светлые латы под огненноя каскоя, [...] в небесньх морях [...] через простор пурпуровия - [..] и вновь пурпуровыя Вскипающия вал промеж ними - и снова По грозному небу - как кистью златои - над Ангелом - Воин из стали литон". Видения эти выполены в манере видения иконописца и иконы: "золотом-писанны-краскои!" - каноническия цвето- 
свет икон; "как кистью златон" - каноническое представление о 'самопроявления, самописании иконы' 153 и о Боге как худохнике; 154 "над Ангелом - Воин" - каноническое представление о иерархичности иконного изобрахения-явления, предполагающего присутствие Невидимого за видимы, кроме того "Воин" отсылает, несомненно, к наивысшему - по церковно-библеискому канону - чину Архангела, а в рамках поэм имеется в виду "Сам Михаил-Архистратиг!" (так именует воннство Царь-Девнцу на смотре, С. 356). Соотнесенность С иконописью играет здесь двонную роль: в прямом смысле, выводит царьДевицу за пердеш предметного мира, сообщает ен ранг изобрахения, ранг ирреальнои сущности; в теологическом смысле, вводит естественное для правсславнои (а точнее - византияскоя) теслогия понимание мира как именно иконы, подобия Бога: не 'икона-холст', а мир пронизан Бохественно энергиея, проявляюиеяся в более или менее доступных человеческим ощумениям ипостасях. Ближаяшая $\mathrm{k}$ Богу ипостась, ухе почти совсем лишенная всякои воспринимаемо Формы, - Архангелы (по иноя градации чинов - Серафимы). Пространственно и иерархически здесь пролегает грань между сферои тварного и нетварного, грань, именуемая 'последним небом' или 'Твердью небеснои' Облачение царь-Девицы-'Архангела' в "сталь" - не что иное как именно облачение в 'Твердь небесную'. Здесь уместно напомнить, что насылаюиие 'сон-смерть' "иглы" Мачехи тохе - 'стальные'. В этом есть определенная логика: эти "иглы" - тоже 'молнии' (особенно в народных представлениях, но и в представлениях О связанноя С грозо воя стихнеи Пбраскевы-Пятнищ), однако это 'молнии' - 'запирающие' земпо на зиму (ср. двоекратное упоминание "первого грома" в поэме - стр. 366 и 425, грома, которын 'открывает землю весноя', второя же гром - осенни - ее замыкает, но в поэме он не упоминается), и этим самым связаны с понятием 'тверди земноя' (ср. именование Царевича Царь-Девицеи "Камень-скала!" - стр. 394).

Короче говоря, царь-девица решительно 'бестелесна' . Ее хе ' сверхматериальность' в поэме объясняется 'сверхматериальностью' бохественного и 'вечностью', 'нетварностью' 155

В первы раз царь-Девица вводится в поэму в сцене колдовского сеанса Дядьки в виде волшебного видения: "Всколыхнулася лазурная рябь: [...] Подивись со мноя, пророк Моисея! Купины твоея прекрасноя - краснең!" (344). В Финале поэмы мотив пророка Монсея оборачивается мотивом оставленного исчезнувшея царь-Девицея "писыа" 
Царевичу. За этим "Письмом" стоит несколько смыслов, родственных друг другу, но требуюмих объяснения. В первую счередь оно есть явленное Слово Господне, Логос: "Через все небо - вкось Красные письмена. Первы удар Грома далекого. Дева не крестит лба, Лат отломила бок, Сабельноя сталью в сталь Знаки-врезает-весть" (424425). Параллель 'гром, молния - Слово Божье' здесь очевидна. Параллель 'Моисен - архангел Михаил' тоже очевидна: однн и другои - посредники между Богом и родом человеческим, один и другой играют роль вожден народа Израиля. Выписывание-высекание "вести" на самоя cебе ("Сабельноя сталью в сталь Знаки-врезает-весть"; ср. еме именование царь-Девищы "жаворонком", т.е. птицея Благовецения, и "кукуикоя", птицен вещея, отсчитываюен срок жизни человеческон - 370, 395-396) в известнор мере ставит знак равенства между царь-Левицея и Логосом. Логос же - та граница в мироздании, откуда по направленио вниз, К земле начинается его созидательная и оформленная ипостась, по направлению же вверх, в 'небеса' он лишается всякоЯ воспринимаемоя формы, становится чистым духом-мыслью. "Письмо", оставленное Царевичу, как раз об этом и сообмает: "Он память-читает-письмо. [...] сразу прочел - по складам: - Нигде меня нету. В никуда я пропала. Никто не догонит. Ничто не вернет" (428), где название "письма" "памятью" сообщает ему исключительно ментальны статус, Логоса, еме допустимого дия мали, но сама царьДевица уже за пределами понимания.

Второя смњсл "письма" раскроется, если учесть народную контаминацию Архангела Михаила и св. Николы (ср. Связь Царя С Николоп в 1.1.9.). Один и другоя считаются привратниками рая, воднтелями душ в загробном царстве (Ср., в частности, именование царь-Девицы "Демоном" - 353: "я - Царь-Демон!" и 359: "Что там за Вонн - за Ангел - за Демон такоя?", где "Демон" называется на последнем в этон иерархии месте). В русскоя похороннои обрядности известен обычая класть "в руки покоянику 'письмо к св. Николаю'" , 156 считаюиееся своеобразньм 'пропуском' в рая. "Письмо" царевичу мохет поэтому считаться соответствием вручения ему 'ключея от неба' (ср. на стр. 425 уравнение 'писания "письма"' с "первьм ударом Грома далекого", т.е. с открыванием небом земли и победоя над смертью) 157

Третия смысл "письма" раскрывается, предположительно, в параллели 'царь-девица - пророк монсен', создаюме рамку этого об-

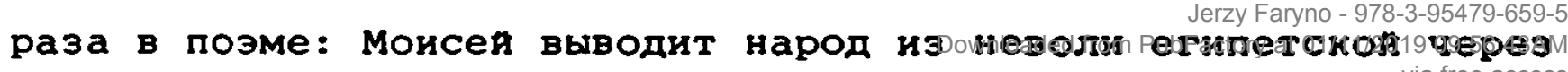


расступившееся море Чермное, т.е. побехдая 'смерть' (ср. на стр. 411: "Та из моря Чермного, Акульих мест, Та из моря верного Жемчухны всплеск", где "море Чермное" соотнесено со смертоносноң Мачехинов "слюнкон"). Для царевича это "письмо" должно быть указанием, как преодолеть свою 'смерть-сон' - именно через море, через собственную физическую смерть (надо думать, что как раз эти ассоциация имеются ввиду под окрашенностью "моря" "кровью" - 425: "Как кровяная - хлябь... Ветер замел круги" и под настончивьм повторением 'пурпурности' пути-расстояния мех Царь-девицеи и Царевичем в его последних видениях - 426-427: "Он видит [...] властную руку, в небесньх морях Простертую - через простор пурпуровы Чрез версты и версты к челну гуслярову", "и вновь пурпуровьи Вскипакоия вал промех ними") . И таков, собственно, и есть последния поступск Царевича: "Как притопнет, поглядев востро: Ан уж нету паука - мокро! Сам же в воду - добывать свое добро" (428), где уничтожение "паука"-Длдьки более чем однозначно - это символическое преодоление 'смерти' и 'материальности', причем сутественно, что совершается оно 'взглядом', 'силов воли' (до сих пор, кстати, Царевич был 'спям' и глаза его пребывали в пассивном состоянии, даже если и открывались), а прығок в воду - выход в 'тот мир = небесны' через собственную физическую смерть, через растворение в мировом акватическом потоке. Эпилог, т.е. Ночо последняя, досказывает, что встреча Царевича и царь-девицы, наконец, осупествилась (431: "Сахарок-твоя-клен Так и тает промех двух ее грудея!"). Теперь уместно вернуться к мотиву "каски". Установив соответствие мехду Царь-девицеи, Архангелом Михаилом и св. Николон, и зная, что оба последних играют в народньх представлениях роль водителен душ усопших в загробном царстве, легко увидеть в атрибутирования царь-Девицы "каскон", притом "хвостатоя", 'опереннон" (раз она ведь именуется "султаном" - 356) отошку к психопомпу Гермесу также носямему крылатыр илем (кстати, св. Никола иногда сблихается с Гермесом). 158 но Гермес не только водитель душ, не только посредник мехду миром смерти и жизни, но и иэобретатель лиры и покровитель искусств. Царевич ется как необыкновенное влечение к нему царь-девицы-'Гермеса', так и увод его за собоя в мир бессмертного чистого духа. В рамках поэтики Цветаевоя вообе атрибутирование Царь-девишы "каскоя-хвостатон", а царевича "головкон льнянон" получает иноя еме смысл, но в 
самон поэме, как кахется, этот смысл улавливается с трудом. 159 "кольца", "перстни", "охерелья", "бусы" - не только признак царского сана, но и 'связанности', 'несвободы', а в широком смысле - причастности к смертному земному бытию. Отсутствие этих атрибутов у царь-девицы не лишает ее 'царскости', вместо них она наделена 'латами-славоһ' , т.е. признаками 'нетварноя, небесноң царскости', а отсутствие всяких 'колец' означает 'свободу' от земного, от смертного. С этоһ точки зрения примечательно, что в ее 'родословноң'нет четвертои космогоническои стихии - 'земли': "Огнь отец мне, Вода - матерь, Ветер - брат мне, сестра - Буря. Мне другор родни не надо!" (352), где ожидаемая 'Земля' подменена "Буреи", т.е. видимым проявлением 'небесного' (сp. вьие библеиское понимание грозы как Славы; ср. также наличие "земли" в другом перечислении царь-Девице - 423: "Ветер - воды - огонь - земля", которое делает значимы первое ее отсутствие; кроме того значимы здесь также и различия начертательные - в первом случае все стихии даны с прописнои буквы, что сообщает им смысл судностер высшего ранга, во втором - с маленькои, что переводит их на бытовод, земно уровень). Вахно еме, что в свокх посемениях Царевича царь-девица нигде не соприкасается с землеи - встречи проясходят а "лодке", она всегда "в сапогах" и локализована вверху - то в виде "тучки", то в виде "жаворонка" и "кукушки", то "дуба", но дуба-'кроны" (392: "Как бы листвоһ Затресся дуб"), без указания 'корнея' - его контакт с землер осупествляется лиш при помоми 'капаюие смолы-слезсока' (393: "Сок преценньд, янтаревын, Дар дуия ее суровоя, Леяся в песок! ").

Показательно, что,собираясь на смотрины,Царь-девица расстается со своеи 'вольностью': "Перехожу в иную веру, Всю вольность отдаю за грош... Но следом моему примеру - Вы бабами не станьте тох!" (357), где "грош" перекликается с "Пятиалтынным" царя (373), т.е. с 'потусторонним' двояником (См. 1.1.2.в.; здесь же отметим точное понимание Цветаевон 'свадьбы' как 'продахы-обмена судностеи' - см. 1.2.1. - под видом 'перехода "в иную веру"' и потери самотождества: "бабами не станьте тох!"). Этот переход как раз и ознаменован 'подпоясыванием' : "Опоясалась тут саблея" (355). Пояс, как уже говорилось в 1.4.3., энаменует физическую мощь и богатырство (ср. ее 'естественныя' пояс в исходном варианте - 346 : "Пояс - эмеи-самохлест"), но несколько позже он переименовывается 
на "перстенечек", т.е. 'сковывающй' и 'земноя' , ограничиваюия свободу и момь Царь-Девищы. В частности, это отрахено в ее неохиданном 'истончения', означаюмем тут слабость: "Ух больно плеча высоки! - А поясочек-то! Перстень берет в пояски! Спорить-то нечего! Каб не свобода-душа: Кабы не плечики - вся б в перстенечек пропла!" (359) . Помня, что на "плечах" Царь-Девишы локализованы "голубв"='дух, свобода, пюбовь-агапе' и "кречет" = "сила, мопь, свобода" (352: "на плече правом - голубь, на плече левом - кречет") и что в теологическом истолкования 'плечи' вместе с 'локтямн' и 'руками' означакт "силу производить, деяствовать и совершать", 160 а в иных терминах - 'волю', легко заметить, что 'поясочек-перстень' разделяет ее надвое и, видимо, разграничивает наличное в нея 'огненное начало', связзнное с небесными силами, и 'акватическое', связанное с силами хтоническими (ср. дальше постоянное акцентирование 'огненности' ее "каски" и контактирования С царевичем-'землея' только в виде 'дохдя-слез', Т.е. охивляюмея и животворямен 'воды': "То не тучка молодая Лен кропит: То дружочка - дорогая Водоя племет, поливает. А он спит" - 367; "Ровно дожиь меня тонким Серебром поливал. Ровно жаворонок звонкия Вкруг меня ликовал" - 370 и 'вегетативно-цветочные' мотивы в образе царевича). Есть и еме одно переименование: "- Что: над конем не плакала, А над мальчишкоя - плачешь? Вихрь-жар-град-гром была, За все наказана! Вояска в полон брала, - Былинкоя связана!" (394). "Былинка" - символ бренного, пассивного бытия. Но она одновременно - в рамках внутритекстовых эквивален тностея - Царевич. Противопо ставление 'конь - былинка' дполне закономерно как вариантов 'грома': "конь" так хе громоносен, как и царевич-'былинка'. Но если первия - вариант могушественного Логоса, то второя - всего лишь его умербное земное подобие, деформированное вопломением. Раздаривание "хар-платка"-'молния-грома', процание с "конем", имеюмее вид привязывания-умерщвления (358: "Повязавши как шнурком поясньм, В нохки кланялась поклоном земным, Как покорно - что гаядукесаул - Бель конь в ответ колено согнул, Как пригнувшись, чтоб не сльлал никто, Сотворила ему речь на улко"), - это уход из сферы свободного Логоса, "в иную веру" (359), а точнее - оплощение Логоса (ср.: "Полк замертво свалился пьяның. Конь пеноя изошел, скача. дух вылетел из барабана. Груды лопнула у трубача" - 359), лишение его 'духа' и преврамение в 'хаос' (ср. соответствие между 
'струнами гуслен' и 'бараньими жилочками', которые знаменуют хаос бвтия - см. 1.4.6.. бытия бесцельного, без божественного плана; ср. также аналогичны бесцельны, самоистребительны хаос в сцене пьянки царя - см. 1.1.2., 1.1.4., 1.1.5). Поэтому царь-Девица бессильна разбудить Царевича и добиться встречи-воссоединения. Правда, ее опрыскивания водоя царевича, крецение и поцелуи-"печати" приносят жизнь, ОФормляют ее по бохественному плану - Царевич мухает, готов вступить в схватку с демоническими силами (421: " - выходи сам хан татарскин - Поравняюсь силою!") и простирает руки "В золотую зарю господню!" (421), но тем не менее он все еме уязвим смертью-сном, ибо воплощен, ибо материален (ср. тут же после его душевного подъема: "То не меч честнон мечу дерхиг речь, То булавка-сон Промех хилых плеч" - 422, где "хилые плечи", в противовес царь-девицыным, отнюдь не "свобода-душа", а 'матерчатын" "вороток") . На Фабульном уровне причина разминовения Царь-девицы и Царевича - Мачехины козни. На семантическом же - уязвимая смертью телесность. Истинная 'встреча' возмохна только вне телесности, на уровне свободного духа, но дия этого надо преодолеть телесность, победить смерть, принимая смерть физическую. Так, вероятнее всего, объясняется Факт, что ни Царь-Девица, ни Царевич не вступают в борьбу с Мачехоя непосредственно: вся борьба переносится вовнутрь Царевича (сцена спора-вояны мех "печатью" и "слюнкоя") и вовнутрь царь-Девицы (394: "А уж под сталью-латами Спор беспардонныр иачат"). При этом примечательно, что такого спора нет ни в случае царя, ни в случае мачехи. Он мохет быть только там, где сосудествуют два начала. Отсюда сплошная 'удвоенность' в поэме: удвоен мир, удвоены обитатели моря, удвоен или дахе 'учетверен' царевич, удвоена Царь-девица, удвоено рождение царевича, а у кахдого из них есть свон соответствия в противостоящем мире. На земном уровне бытия такая удвоенность означает внутреннюю диалектику, осмысленность бытия в его стремления воссоединиться с чистым Духом. На 'небесном' же - упразднение разъединяющих дифференииация, исходящих от материальности, от ущербности. 161 Так, 'жено-мухество' Царь-девишы вовсе не означает ее 'двуполости', а отсутствие 'пола' (половое начало проявляедся в неи лиш в 'этом мире'). Не 'двупол' и царевич - в его случае имеет место иное явление: 'хаотическая неоформленность', в этом смысле он скорее 'предрохденның', чем 'рохденнья' (отсюда акт крещения, оформляющин его как теоцентри- 
ческую сущность, и с этого момента в поэме мотив его пола не возобновляется). Весь мир поэмы покоится, таким образом, на глубоком теологизме (в его византияско-православном варианте). Недаром в Финальном видении царевича Царь-девица названа "новым солнцем": "Как новое солнце взошло над вселенно!" (427). "Новое солнце", несомненно, теологически идеал обновленного, приобщенного К Богу мира, мира, победившего свою бренность. Одновременно это и идеал Цветаевоя. Раныше образ царя мы соотносили главным образом с лунарньм годовьм циклом. Но не исключено, что его следует понимать как соответствие "солнца", но 'старого', Физического, которому подвластен мир материальның, так называемы 'подлунны'. Его 'царство' со всеми его персонахами к концу поэмы полностью распадается. Новое же открывается "В морях тех небесных - далечя-далече" (428), но ухе как трансцендентное.

1.5.5. Деталь "От шенных бус на латах - след двоһнон" не совсем ясна: то ли нмеются в виду "бусы" царевича, которого она в этот момент целует (напомним, что один раз в царевичевых "бусах" проскальзынает связь с 'огнем' - 399: Вспыхнул пуме корольковсвоих-бус", и что царевичевы 'объятия' 'огненно-хелезны' - См. В сиене ночного препирательства с мачехо - 382: "Ты на руках меня дерхал, К своея груди меня прихал... [...] Железом ты в меня впился, Как огневая полоса Под красньми фипцами - След твоих рук - на память!"), то ли "бусы" самои царь-Девишы, которые нигде больше не упоминаются, то ли одул и другое, что объясняло бы 'удвоенность их следа. Несомненно зато другое: наличие признака 'смертного, бренного" на "латах", некая их уязвимость. Зная, что Царь-Девица - соответствие Архангела михаила (См. 1.5.4.), не слохно понять, что и ен как творению Бохьему присума некая материальность, пусть самая незначительная, но все-таки тварность (если архангела рассматривать по библеиско-церковнон системе чинов, по системе же Псевдо-Дионисия архангељы занимают второе место снизу, сразу после ангелов и поэтому значительно сильнее материальны; но ход поэмы заставляет полагать, что Цветаева руководствуется более популярно первон системод). В этом смблле "латв" царь-Девишы тохе означали бы ее некуло несвободу.

Вторая деталь в образе царь-девицы - 'гордость': сон Царевича о плачудем дубе Дядька толкует, в частност, так: "- Нет, царь Лебединю, Не дуб, не смола: то спесь-ее-льдина слезон изошла" 
(396) : Ветер, пытаясь соблазнить царь-Девицу, комплиментирует ее словами: "- Нет во всеи вселенной Такоя дерзновеннон!" (418); a царь-девица укоряет себя за свою слабость так: "Сама винон, сама винод, - Гордын одолела!" (424). Комплиент Ветра нисколько не преувеличен: 'гордость' как 'дерзновение' - разновидность Славы, Дара Божъя, 'избранничества'; Дядька, сникая этот смысл 'гордости', все-таки близок правде: 'смола-слеза' это одновременно "Дар души ее суровоя" (393) и в этом смыле деяствительно 'гордость' (дарить мохет только получившия от Бога дар дарения), Слава нисходядая на земпю, К Царевичу; однако в 'спеси' присутствует признак самоуверенности, узурпирования прав не полагаюихся - и тут тохе Дянька по-своему прав; последнй оттенок выведен эксплицитно в самообвинения царз-Девицы в "гордыне". 162 'Гордыня' же ее проявляется в том, что она, будучи сама причастна материальному, тварному, возомнила себя в силах победить смерть, т.е. разбудить царевича. Поняв, что это невозмохно, и чтб является этому припятствием - прощается с ним и исчезает (424: "Видали вы такую стать, Чтоб вдруг ребеночку не спать? Да мне твои взор и спяни, Всех царств нёбесных - сламе! [...] Ты царь мон будешь - Сонның! [...] и вдруг будь счастлив паренек, что сон твон непритворньд! - Белого поля поперек - пропала! - волос черның!").

Разламывая в финале свою сабло, бивиую прехде 'перстнем-поясом' (см. 1.5.4.), взламьвая свою стальную грудь (425: "через коленку - враз - Саблю-ломает-сталь. В правои - чем грудь разить, В тоя - где рукон хватать. [...] Молниен поднялась, Грудь-разломиласталь. Правод рукон под грудь, Левою - сердие вон!"), преодолевает как свою 'слабость-силу', так и 'гордыню', а этим самым - всякую материальность, исчезая в 'нетварное' (428: "В никуда я пропала"). "След дөоймой", может, таким образом, означать и несовериенство материальное ("латы"), и несовершенство духовное ("гордыня"). Поэтому взламыаются не только материальные атрибуты, но и вырывается "сердце". Его место занимает 'дух' (426: "В грудь - сквозь сердечную дыру - ветр ворвался!").

\section{2. СШОКЕТЫ}

Отключиться от события при разборе семантики персонахен невозможно. Поэтому вопреки первичному замыслу сюжетика поэмы уже прочтена, хотя и в разбросанном виде. В связи с этим здесь предлагается 
только контурное ее обобщение с некоторыми корректурньми оговоркаMH.

2.1. Расхождения с послукившими Цветаевоя как образец сказками Царо-Деөииа 163 насцолько велики, что оговаривать их нет особого смысла, 164 тем более, что сказка - не закрепленныр каноническия текст, а цветаева тоже не задается целью создать еме одну 'сказку'. Сопоставление долхно идти в этом случае не на уровне персонахея, атрибутов и события, а на уровне 'семантики'. Семантика же волшебноя сказки - некая модель мира, или, в иных терминах, - некия 'основноя миф'. 'Миф', условно вырахаясь, лехащия в основе обих вариантов сказки Царо-Деөица, предельно прост: восстановление нарушенного космического равновесия, возобновление замкнутого космического цикла (в начале мир нарушается отмиранием 'старшей генерации' и переходом во власть 'неуполномоченных' а затем восстанавливается под видом торжества 'новоя генерация', 'истинных налледников'). Таков же, в принципе, и первь, нанболее поверхностны сюжет ЦветаевскоЯ Царо-Деөииа. В принципе. Но есть и серьезные отличия: восстановление не состоится. При этом важно, что возмохность восстановления систематически в поэме поддерживается: рушащияся мир прозрачно соотнесен С зимним состоянием, а грядущия - С весенним, а все события приурочены периоду наиболее драматическор борьбы космических сил - последнея зимнея неомении и первому весеннему полнолунию, Т.е. началу нового годового цикла. Хотя царевич как соответствие нового цикла и видит в свонх снах посещения Царь-девицы-' солнца' в терминах 'весенних' ("тучки", "дождя" и в финале - 'грозы', причем перво весеннея грозы, долженствуюмея раскрепостить мир земноЯ), Цветаева этот цикл демонстративно размыкает: Царевич не просыпается, а весь мир поэмы заканчивается в момент 'катаклиэма' - выход в аналогичныя очередныя цикл его не предполагается. Ясно - почему мир земных форм - неистинен, ущербен, подвластен смерти, но самое главное то, что он узилиме свободного и долхенствуюмего быть свободньм 'Духа' (в частности, царевич предельно духовен, он - Гусляр, он - чухд всяким земным соблазнам, но тем не менее в этом мире он - узник, его 'дух' от этого слаб, что выражено как в "хилости плеч", 'крошечности как б младенца', 'сгорбленности', так и буквально в его похелания "Все отдал бы, весь сан престольны, Кто бы мне душу распро-

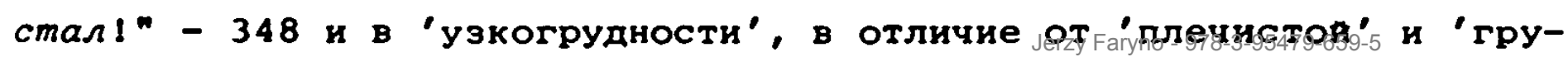

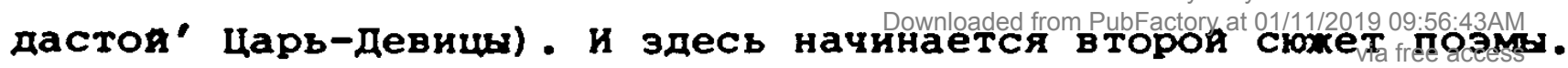


2.2. Миру земному или подземному противостоит мир небесның. Он небесны не только в Фольклорном аспекте, но и в теологическом. Царь-Девица однозначно соотнесена с Архангелом михаилом, а "облака", "заря" и "небеса" - с сияюмеи Славои Господнея. Как проявление этой Славы изобрахены в поэме и Финальная 'гроза' и финальные видения царевича.

На одном уровне Царевич "спяп" и 'незряч' - первые видения Царь-Девицы он воспринимает в ложных категориях земного бытия (весеннего пробуждения природы) . Однако - будучи постоянно ' спямнм' - он обретает 'умозрительное', 'духовное эрение': прежния "жаворонок" подменяется "дубом" (непонятая 'благая весть' обретает чертъ 'мирового дерева', но еие читаемого буквањьо, хотя просьыы растатыковать подсказываят, что речь идет о пробуждаюмемся опознавании сущности) и наконец обретает черты иконописного рынаря (тоже не совсем еме опознанного как Архангел Михаил). О том, что это зрение именно духовное, явственнее всего свидетельствуют два Факта: это всегда видения во сне или волшебные видения, подсовываемые несколько деформируючим их Дядькоя; Царевич обретает физическую момь, преврамается в 'богатыря', правда еме уязвиого, и поэтому тут же трансформируется в младенца.

Центральны эпизод для этого сюжета - крещение Царевича ЦарьДевицен: именно в этот момент он оформляется как личность и получает 'теоцентрическин' характер (ср. 421: вызов на поединок "самого хана татарского"). однако это все-еме путь земноя, не по этому пути обретается свобода. "Письмо" Царь-Девицы, ее связь С Моксеем и наличие "пурпурного вала" в последнем видения подсказывают, что истинны путь есть путь через 'море-смерть' (по образцу Исхода). "Письмо" Царевич 'прочел' в своен 'памяти' и бросился именно в море. Но это отнюдь не самоубияство, а 'поиск' Царь-Девиды.

такои же исход подразумевается и для всего мира (тем более, что Царевич и есть 'мир'), что эксплицитно звучит в сравнения Царь-Девицы С "новьм солнцем" "во вселенноя" (427). И тут оба сюжета соприкасаются снова, с тоя разницея, что "новое солнце" открывает не очередноя цикл, оно не дубликат педыниег, а беспредельное восхождение в обновленную духовно бесконечность.

2.3. Сквозь второи сюжет просматривается теологическая (византияско-греческая) основа. Особенно однозначно это вырахено в иконописном принципе последних видения царевича (с откровенными 
отсылками к 'Письму' 'знаками' и 'кистью' - 424: "Красные письмена"; 425: "Знаки-врезает-весть"; 428: "Память-читает-письмо" ; 426: "как золотом-писанны-краскон"; 427: "По грозному небу как кистью златон - Над Ангелом - Воин из стали литон" и "И видит гусляр [...] и светлую сабло с письмом рукописньм, И крест тот широкин - любви бескорыстнон, Которьм нас матери крестят: живи!" и к представлению О Благодати, Милости Божьея).

ЭллинскоЯ концепция вечноЯ повторяемости миров византияская теология противопоставляет иную, покоющуюся на понятии Логоса. Создавая мир во всеи его разнородности, Бог наделил частные его проявления благодатью, самостоятельнои волея, смыслом, Логосом. О.днако тварны мир автономен лишь относительно - он не мохет проявить своея благодати, не может быть подлинно 'добр', если его изначальные логосы (logoi) не сохранят своего единства с создавшим их Божественньм Логосом. Хотя logoi тварного мира и являют собо единство в едином Логосе, они не тождественны ни с сумностью Бога, ни со своен инцидентальноя, вещно ипостасью. Самотохдество отдельного создания ('твари') возможно лишь в случае, если это создание устремлено к своен подлинно цели (skopos) $к$ Богу, если выполняет задачу своего логоса, т.е. цели, ради котороя и было создано. Истинная цель отдельнои твари - не созерцание непостижимо и недостихимо Божественнои Сущности, а приобщение к двихению в Боге, К Божественно энергии, и трансфигурация, перевопломение, открытость для Бохественнои деятельности в мире. Nimp создан дабы участвовать в Боге, Боге, которы стал не только первопричиноя мирового двихения, но и есть окончательная цель и окончательны смысл ('логика') этого движения. В нынешнем упероном состояния тварның мир исполняет эту свою 'задачу' неадекватно, почему и стал царством и орудием демонических сил ('хаоса'). Демонизм мира идет от того, что он потерял свои первичные значения и направленность - вместо восхождения к Богу, он поддался своея материальности, телесньм страстям, соблазну, которье еме сильнее упрочивают власть смерти. Ослабить эту власть и возобновить исходную энергию logoi помогает тварному миру и человеку участие в священоденстви, в литургии, в освянении себя и мира (для чего слухит слохная система богослухения и благословения), в чем активно содеяствуют и силы небесные - вся иерархия бестелеснх ангелов, с возглавляюиям их Архангелом михаилом, которыя прирав- 
нивается дахе к Христу как единственному прямому посреднику меху Богом и родом человеческим. 165

2.4. Легко заметить, что большинство Цветаевских сохетов, как эпических, так и лирических, обнарухивает с излохеннон в 2.3. концепцие высокую степень родственности. Так, прочтение своего имени "Марина" в переводе с латинского marina как 'морская' и возведение акватическоя стихии в ранг космогоническоя может рассматриваться как выявление своего исконного ('Маринина', т.е. Цветаевского лирического ' $я$ ') 'логоса', а частное истончение плоти под видом серии метаморфоз цветаевского ' дествлению со свомм 'логосом' и гуть приобщения к мировому 'логосу' (См. хотя бы цикл Бессоккица; стихотворєние Наяда, где в частности,говорится: "Как вступюю в тебя, брак, Раз меж мною - и мною ж - Что? Да нос на тени" - 1 августа 1928; СиП III, 140-141; стихотворение из Волшебкого фокаря 1913 года Душа и имя - СиП I, где имя понимается как данная Богом "дупа": "но имя Бог мне иное дал: Морское оно, морское! [...] Но дулу Бог мне иную дал: Морская она, морская!"; ср. еме Краскою кистою... - 16 августа 1916; СиП I, 219 - из цикла Стихи о Москве, где свокм рохдением 'я' связывается с Иоанном Богословом).

Истинны контакт с миром, С другим сознанием воэмохен только на уровне logoi, в момент их слияния и включения в общую мировую устремленность к Бохественному Логосу. Отсюда, думается, идут такие Цветаевские сюжеты как 'трагическая' (С земноя точки зрения) любовь, завериаюмаяся бесстрастнои 'нежностью' по ту сторону бытия (тварного), любовь к равносунному, а на поверхностном уровне - неотличимому от 'я', захват партнера вовнутрь и 'умермвление' его, т.е. 'духовное взрамение' до проявления в нем его 'логоса'; 'вникание' в мир до самопотери и отождествление с его 'логосом' и т.п. (ср. хотя бы: Рано еще - не бито!... - 19 июня 1923; Сип III, 81-82; в Царо-Деөице любовь к Царевичу: она "Дева-Царь", а он - "Царь-ты-дева" - 354; Расщелина - 17 июня 1923; СиП III, 80-81 или Раховика - 31 июля 1923; СиП III, 89-90, где погломенни 'ты' претворяется через ' $g$ ' в "жемуг"='дин' =' логосово начало' ч чо ене явственнее звучит в $A$ - страяииа төоему перу... - 10 июля 1918; СиП II, 226, где 'я' отождествляется С "чернои землен" впитьваюен в себя Господню "дождевую влагу" и возврамаюеи ее уже в виде 'поэтического слова'; Так вслушиваются... - 3 мая 1923; 
СиП III, 72-73: "Так вглатываются в глоток: Вглубь - до потери чувства! Так в ткань врабатываясь, ткач ткет свон последния пропад. Так дети, вплакиваясь в плач, Вшептыватся в шепот" и т.П.). С этой точки зрения Царевич - чистыр 'логос' в его первичном варианте. Внутренне он не искахен (ср. его 'монашество' и избегание "(аб"). Внешним соответствием этого 'логоса' являются его "гусли" - именно они изолируют его от земного соблазна и ограхдают от Мачехиных посягательств (они - соответствне громоноснов стихии=божественного Слова и как таковые разрушают ее 'зимнюю' наузу в сцене пляски). Но вклочиться в мировон поток 'логосов' и устремиться к Логосу ему мешает его собственная материальность, отсутсявие божественного плана ('хаос' под видом "бараньих жилочек" и "вевевьица"), лишенность божественноһ "печати". Предрасположенность Царевича включиться в божественның мир и есть та притягательная сила, которая влечет к нему царь-девицу. Любовь царьДевицы не эротична, она носит характер нисходяния божественнои благодати, взративаюме достоиного ее (кремение, орошение слезами"даром души"). Тем не менее воссоединение их 'логосов' в земных пределах невозможно, тут всегда их будет разъединять некая нетохдественность, как внутренняя, так и обоюдная, вытекаюмая из материальности, пусть самои слабои (хотя бы под видом "следа бус").

2.5. Некое родство царь-девишы с Гермесом и определение царевича в "гусляры" заставляет усматривать в поэме, хотя не развитыя, и автотематическин сюжет. Его смвлл мог бы быть прочитан в свете сухдения, высказанных цветаево в эссе Искусство при сөете совести (главки Точка зрения и Небо поэта). Там, в частности, говорится:

"По отношению к миру духовному - искусство есть некия Физическин мир духовного.

По отношению к миру Физическому - искусство есть некия духовны мир Физического" (Проза I, 394).

"Искусство - искус, может быть самњ последния, самы тонкин, самы неодолимы соблазн земли [...]" (Проза I, 395). И еще:

"Так же и душа, которую бытовик полагает верхом духовности, для человека духа - почти плоть. Уподобление с искусством не случанное, ибо стихи - [... ј - все событие стихов - от наития поэта до восприятия читателя - целиком происходит в душе, этом первом, самом низком небе духа" (Проза I, 395).

С этор точки эрения Царевич был бы более материален, чем мы это показали. Но ввиду слабой разработанностилето Downloaded from PubFactory at 01/11/2019 09:56:43AM поэме ее следует репать в расииренном контексте, вне рамокеноэмы. 
1. Поэма датирована: "14 июля - 17 сентября 1920. Москва". Текст поэмы цитируется по изданию: Марина ЦВЕТАЕВА, Нзбранкие произведекия, Москва - Ленинград 1965, 341-435. Отсылки даются только номерами страниц. Другие произведения Цветаевои цитируются по изданиям: Марина ЦВетАЕВА, Стихотөорения и поэми. $B$ пяти тоmax, Russica Publishers, Inc. New York 1980, 1982, 1983, ссылки на которые даны сокращением СиП и римской цифрон тома; Марина ЦВЕТАEBA, Нзбранкая проза. В дөух томах, Russica publishers, Inc. New York 1979, дальше сокраменно: Проза I и Проза II.

2. Дверь и забор играют роль гранишы мехиу внутренним, организованньм пространством и внешним врахдебньм, разрушительньм. См.: В.В.КВАНОВ, В.Н.ТОПОРОВ, Слаөянские язиковие моделируюиие семиотические системи. (Древний период). Москва 1965, 169-170 и др.

3. Подключить сюда "петуха" позволяет его амбивалентность и то, что обычно он 'оглашает' конец света. См.: А.АФАНАСЬЕВ, $1103-$ пические өоззрения сливян на природу. Oпит сравнителокого изучения славянских преданий и өеровакий, в связи с мифическими сказакиями других родстөенних народов, Том I, Москва 1865 , 518-533. В связи С тем, что Цветаевския Царь обнаруживает ряд черт волоса-велеса, небезынтересно отметить факт, что волос-велес выступает также в функцин 'куриного бога'. а это еме сильнее подчеркивает 'самоистребительную' сущность Царя. См.: Б.А.УСПЕнСКй, Филологические разискания в области славянских древностей. (Реликта язичества в восточнославянском жулоте Николая Мирликийского), Москва 1982, 150-158.

4. СМ.: О.М.ФРЕДДЕНБЕРГ, МИф и литература древности, Москва 1978, 30 ห 536 .

5. Соль связана у Цветаевоя с земноя Формоя жизни, которая, правда, расценивается в ее системе как 'косная', но по отношению к подземному царству это все-таки 'жизнь'. Ср. в Переулочках (СиП II, 180): "Ручьи с земли Помин привезли: Ресницами шли, Глазницами шли, Землицею шли, - Солоны! Солоницами - глазницы у ржаноя земли. Что ж вы, гости имениты, Мало по-были? Салонище - землица, Сколько хошь - соли! Что ж вы, плоти румянисты, Мало по-жили?" (см. 10.5. в разборе Переулочков; ср. также стихотворение Кто создан из камкя, кто создан из глина... - 23 мая 1920; СиП II, где сказано: "Меня - видишь кудри беспутные эти? - Земною не сделаешь солью"). В народных же представлениях соль, наравне С кисльм, как правило, соотносится с миром жизни (примечательно, что Царь-девица велит давать царевичу не "квас", а "вино" - 368: "А пить ему вино, не квас, [...] Чтоб выхмелел весь сонны хмель - День за море, Гусляр - в постель", где "квас" явно соотнесен в системе поэмы С 'жизнью' в ее земном, телесном варианте, тогда как царь-девица озабочена 'духом' , 'бесплотием' Царевича) .

6. СМ.: О.М.ФРЕЯДЕНБЕРГ, уж. СО४., 82.

7. СМ.: А.АФАНАСЬЕВ, Поэтические воззремия слаяян ка природу, Tом III, Москва 1869, 282.

8. О символике слона в европенских культурах см. статью "Elephant", in: J.E.CIRLOT, A Dictionary of Symbols, Second Edition. Trans-

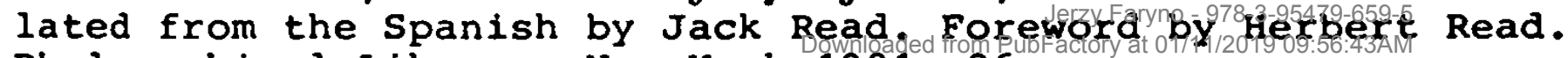
Phylosophical Library, New York 1981, 96. 
9. Тем более, что дракон мохет выступать в народнон мифологической системе в двух вариантах: эловемем и доброжелательном, как хтоническия, и как небесны (иногда различаемые как "Змен" н "Змия"). См. хотя бы: J. i R. TOMICCY, Drzewo zycia. Ludowa wizja swiata i czlowieka, Warszawa 1975.

10. СМ.: MO.M.ФРЕЯДЕНБЕРГ, yx. соч., 41.

11. Ср. 'аморфность' в картине вставания: "Ручкон-нохкон себе путь распростал" (373), где "ручкои-ножкои" подразумевает недиФФеренцированность 'рук' и 'ног' и сообмает им статус 'конечностен'.

12. СМ.: 0.M.ФРЕИДЕНБЕРГ, ук. сс4., 66, 159, 574; 0.М.ФРЕИДЕНБЕРГ, "Мотивы", в: Лоэтика. Труди русских и советских поэтических щкол., Составители Дьюла Кирая и Арпад Ковач, Budapest 1982, 681-682; В.ДАЛЬ, Толковий словаро живого өеликорусского язика. Tом I, Москва 1978, 386-387 (статья "Гость"). Ср. также цитированную в примечании 5 выдержку из Переулочков.

13. СМ.: О.М.ФРЕЯДЕНБЕРГ, Миф и литература древкости, ук. соч., 148; Б.А.УСПЕНСКИЯ, ук. Соч., 60 и след.

14. См.: Б.А.УСПЕНСКИЯ, ук. соч., 60-61, 62. О красном как погребальном у греков и римлян CM.: W.KLINGER, Doroczne sivizta $l_{u-}$ dowe. Tradycje grecko-rzymskie, Kraków 1931, 20.

15. СМ.: О.М.ФРЕЯДЕНБЕРГ, Миф и литература древкости, ук. соч., 149. Ср. такую явную дубликацию у самой Цветаево в в Поэме кокиа (1 февраля - 8 июня 1924; СиП IV, 177-178): "По-следния мост. [...] Вьклағываю монеты. День-га за смерть, Харонова мзда за Лету. Мо-неты тень в руке теневой. Без эвука монеты те. Итак, в теневую руку - Мо-неты тень. Без отсвета и без звяка. Мо-енты - тем. С умериях довольно маков. Мост", и в стихотворения Настанет деко - печалокий, говорят!.. (11 апреля 1916; СиП I, 216 из цикла Стихи о Москве): "- Остухены чухимн пятаками - Мои глаза, подвижные как пламя. И - двояника намупавши двонник - Сквозь легкое лицо проступит лик", где 'смерть' и 'двонник', сохраняя некую общность с мифологическими представлениями, истолковываются в православно-теологическом коде (стихотворение дополнительно помечено еме так: "1-н день Пасхи", см. излохение суиественных для Цветаевои теологических посылок в 2.3. и 2.4.).

16. СМ.: О.М.ФРЕДДЕНБЕРГ, МИФ и литература древности, ук. соч., 68; В.Я.ПрОПП, Нсторические корни волшебной сказки, Ленинград 1946, 268-279, где оговаривается мотив золотор метки, которую получают герои сказок в тридесятом царстве. Тему эту расширяет Б.А. УСПЕНСКИЯ, ук. соч., 78: "В других сказках того же сюжета героя метят в тридесятом царстве иначе, а именно отрезают у него прядь волос [...]; соответствующия ритуал наблюдается в траурных и погребальньх обрядах и, вндимо, знаменует прехде всего символическую смерть (ПроПп, ук. соч, 281), а в более широком смысле - приобщение к царству мертвых как обители волоса-Змея; такую же в общем функцию выполняет и золотая отметина на лбу сказочного героя. Совериенно также появление желтого пятна на руке согласно славянским поверьям предвещает смерть или деньги". В Царо-Девиие противовесом этои 'печати' является "печать" 'царя небесного', приобщаюая К Бохественному миру - она в свою очередь восходит к церковньм таннствам (CM. 1.5.4. и 2.4.). 
17. Связь волос с водоя у цветаевон повсеместна. Ср. хотя бы: Сөияиовий полдеко деревенский... (иють 1918; СиП I, 230): "В ручьях овечьего руна я к небу воздеваю руки"; Волоси \& - или воздух иелуо?.. (9 ноября 1918; СиП I, 247): "Голос и волосы: струны и струи"; в цикле Бессонкицаср. переход от"меха" к "раковине" - "Вздымаются не волосы, а мех! и душны ветер прямо в душу дует" (в Сегодня ночор $я$ одма в ночи... - 1 августа 1916; СиП I, 243), а затем "я только Раковина, где еме не умолк океан" (в Черная, как зрачок, как зрачок, сосучая [...] - 9 авгутса 1916; СиП I, 244). Ср. еме связь "меха" со 'звериньм' и 'колдовским": "Полнолуние и мех медвехия, и бубенциков легкия пляс..." (27 ноября 1915; СиП I, 195). Конечно, ценность этих трансформация зависит у цветаевон от того, какон вид 'смерти' имеется ею в виду: духовноя или же телеснон. В случае подземюого царства подразумевается, естественно, 'смерть духовная' , почсму "волосы" вообще могут быть тут носителями 'гибели', a в других контекстах - носителямн 'духовного начала'.

18. M. ELIADE, Traite d'histoire des religions. Пользуюсь польским изданием: M.ELIADE, Traktat o historii reiigii, Warszawa 1966 , 197.

19. CM.: L.STOMMA, Szorice rodzi sie 13 grudnia, warszawa 1981, 2444; O.M.ФРЕЯДЕНБЕРГ, МИр и литература древности, ук. сои.. 500-502 и 531 .

20. Ср. выдержку из работы успенского в примечании 16.

21. СМ.: О.М.ФРЕПДЕНБЕРГ, МИф и литература оревкости, ук. сои., 41: "'сидение' - метафора преисподнен, и оно имело место в погребальнои обрядности: античные люди в быту не сидели, а полулехали"; 140: "Вставание' дублирует воскресение прибьвамего тотема; в религия это определенны культовы момент, В быту - знак учтивости". Отметим еме, что возврат царя после падения и обморока в свою прехнюю 'сидячую' позицию зиаменует в Цветаевскон системе движения двикение механическое, нетворческое, и на деле есть 'неподвихность'.

22. Упомянутая в этом эпизоде "лучина" - энак 'темноты', в какон пребывает царь, а с другоя стороны - 'датоуказатель': события поэмы происходят до 25 марта, т.е. до Благовещенья. О 'датировке' в мире поэмы поддет речь дальше, в 1.1.8. "Нагнись-ка" более эксплицитно выдает свон смысл в 'сгорбленности' Царевича, - чем нихе.

23. СМ.: О.М.ФРЕИДЕНБЕРГ, МИФ и литература древности, ук. сои., 506-508 и примеч. 72 на 527-528.

24. Ср. соблюдаемы во многих европенских этикетах обьчан пить слева направо, т.е. со стороны соотносимо со 'смертью'. 'npeисподнеЯ' - СМ.: О.М.ФРЕПДЕНБЕРГ, МИф и литература древности, ук. сои., 137. Видимо, этот смысл стоит за фннальнон сказочноЯ формулой 'не-питья' В рассказанном мире: "И я там был, мед-вино пил, по усам текло, да в рот не попало". Небезынтересно отметить, что в русскон литературе 'питье' со 'смертью', с 'преисподнен' связывается сильнее, чем можно было бы судить на первын взгляд - ср. хотя бы первоначальны замысел достоевского назвать "Пьяненькими" Престулление и наказание, а из ново литературы наиболее показательна в этом отношении повесть Ерофеева Москва - Петушки, ее анализ см. В: И.А.ПАПЕРНО, Б.М.

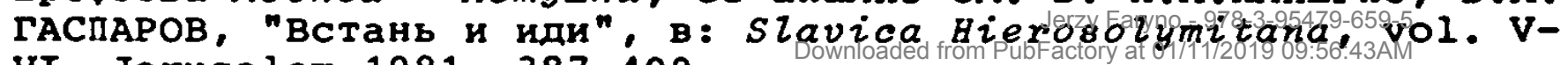
VI, Jerusalem 1981, 387-400. 
25. CM.: M.ELIADE, op. cit., 197.

26. Везмохно, что "вино" здесь играет роль сказочной 'мертвой воды', которая выполняет только 'целющую, сраниваюную' функцию, а для охивления нухна еще 'живая вода', т.е. в данном случае - 'другое вино'. "Бревно" может означать, в свою очередь, полнериую 'обездвихенность', 'бесчувственность', 'бесдуховность', всегда сочетающнеся у цветаевоя с переделом

'оренного, косного'.

27. CM.: A. van GENEPPE, Les rites de passage, Paris 1909. Cp. также анализ концепции van Geneppe в применении к славянскоя обрядности в: L.STOMMA, op. cit., 32-38.

28. См. примечание $12 \mathrm{k}$ разбору Переулочков.

29. За 'кругами' царя мохет еме стоять идея 'повторяемости', которая родственна 'оглядке', 'обратному пути', что связывает 'круг' с представлением о 'смерти'; см примечание 23.

30. Учетверение "пропал-пропал, пропал-пропал" ассоциируется $\mathrm{C}$ учетверением царевича: "Кто сам ¿ косоя да в юбочке - Тому пускай - деа юноши. Кто вокруг юбок веется - Тому пускай - две девици" (365), которые в виду соотнесенности обоих этих персонахея с 'луноя' могут рассматриваться как отсылки к четырем Фазам луны. И Царь и Царевич, как окахется позже, соотнесены также и с годовьм циклом, тогда в этом учетверении позволительно усматривать и отсылку к четырем временам года. Это означало бы, что царю грозит полнедшая гибель.

31. СМ.: О.М.ФРЕПДЕНБЕРГ, Миф и литература древкости, ук. соч., 158-159.

32. В случае цветаевоя такои подход вполне закономерен - многие свои вещи она пишет (если ее датировки в этих случаях не Фиктивны) в период определенных обрядовых и культовьх торхеств и им прнурочивает их 'сюжеты' . Ср. Хотя бы Кра кор кистою... (16 августа 1916; СиП I, 219) из Стихов о москөе, где весь смысл поконтся на совпаденин дня рождения "я" и самой Цветаевон н дня Иоанна Богослова (т.е. 26 сентября Ст. Ст. 1892 года в субботу; это, жонечно, одно из проявления 'теологизирования" "я" и одна из предпосылок Цветаевского моделирования себя как носителя Логоса, о чем нике, или отохдествления С такнми персонахами, как например, в случае эдесь не оговаримаемьх, но нєсомненных, перекличек мехду само म Цветаево и и царь-Девнцеи) ; Закинуе голову и опустие глаза... (март 1918; СиП II, 20) с его темон Благовеменья; цикл Сугроби (с февраля по март 1922; СиП II, 160-173) - и создавшияся в период Масляницы и Маслянице же посвященның; поэму Переулочхи (апрель 1922; СиП II, 174-183), являюнуюся своеобразным продолхением внутритекстовоя обрядности. Сугробов и деиствительноЯ народноя обрядности, приходяшенся на период От Пасхи до Пятидесятнищы.

33. См.: В.ДАЛЬ, Толкоөй словаро хиөого өеликорусского язика, том II, москва 1979, 175-176, статьи "Костерь" и "Кострома". См. также статьи "Кострома" и "Кострубонька" в: Мифи народов мира, том II, Москва 1982, 10-11.

34. Для царя 'метаморфоза' опасна, грозит ему гибелью. Его 'спасение - механическое повторение. Но с Цветаевской точки зрения знаки этих явления принципиально меняются, тут дахе ме-

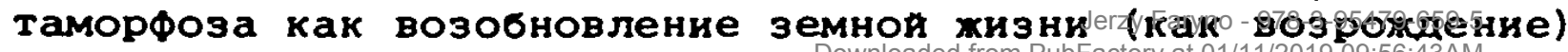
расценивается как вариант косного бытня. • 
35. И астрономическин и культовы характер этого явления детально анализируется в: L.STOMMA, op. cit., 64-72.

36. См.: С.И.СЕЛЕшников, Кстория календаря и хрояология, Москва 1977,96 и след.

37. J.iR.TOMICCY, op. cit., 126; K.MOSZYNSKI, KuZtura Zudowa SZowian, Tom II: "Kultura duchowa", Cześc 1, Wydanie drugie, Warszawa 1967, 28-32 (\$\$ 10-13), где приводятся такхе и кавказско-иранские представления о том, что под конец кахдого месяца луна на два дня прячется в лоно своеи матери и потом ролдается сызнова (с. 32). Может быть, нечто такое стоит за контаминацией Даревичевой "кроваточки" с 'локусом' его умершеम матерн (о чем нихе).

38. СА.: С.И.СЕЛЕшникОВ, ук. соч., 160-164 (там же, 164, говорится: "В течение многих веков началом года считалось 1 марта, но в 1492 г., В соответствии С церковнои традициея, начало года было официально перенесено на 1 сентября и отмечалось так более двухсот лет. Однако через несколько месяцев после того, как 1 сентября 7208 г. москвичи отпраздновали своһ очереднои Новы год, им пришлось празднование повторить. Это произошло потому, что 19 декабря 7208 г. был подписан и обнародован именно указ Петра I о реформе календаря в России, по которому вводилось новое начало года - от 1 января и новая эра - христианское т.е. леточисление (от "рождества Христова"). [...] в указе предписьвалось день после 31 декабря 7208 г. от "сотворения мира" считатв 1 января 1700 г. от "рождества Христова").

39. L.STOMMA, op. cit., 49.

40. См. статью "Девять чинов ангельских" в: Мифа мародов мира, том I, Mосква 1980, 362; CM. также: J.MEYENDORFF, Byzantine Theology. Bistorical Trends and Doctrinal Themes, Fordham University Press, New York 1979, пользуюсь польским изданием: J.MEYENDORFF, Teologia bizantyjska. Bistoria i doktryna, Przełozy Jerzy Prokopiuk, Warszawa 1984, 33-38, 176-177. Смсл же отмечаемон здесь 'сакральности' и ее корректура оговариваются в связи С разбором образа царь-девишы и скоетов поэмы.

41. См.: Б.А.УСПЕнСКй, "Культ Николы на Руси в историко-культурном освещения". (Специфика восприятия и трансформация исходного образа), в: труди по зиаковим системам, т. Х: "Семнотика культуры", Тарту 1978, 86-140; пользуюсь в основном расширенным книжным вариантом этоЯ работы: Б.А.УСПЕнСКй, Филологические разискания..., ук соч.

42. См.: Б.А.УСПЕнСКИЯ, Филологические разискания..., ук. сои., 52 и след., 85 и след., 99 и след.

43. См.: Б.А.УСПЕНСКИЯ, "Культ Николы на Руси...", ук. соч., 110, 123: Б.А.УСПЕНСКИ,, Филологические разискания..., ук. сои., 173-175, там же говорится о связи шапки с магическон, колдовскор силов и с погребальньм обрядом (в этом свете похвала Даря звучит как 'включение' царевича в свое подземное царство).

44. См.: Б.А.УСПЕнСКИЯ, Филологические разискаяия..., ук. сои.. 56 и след. - о связи Волоса-Велеса с загробньм миром и богатством; 70 и след. - о связи Николы С загробным миром и богатством; 94 и след. - О связи Николы с лешим. Как правило, однако, у европенских соответствия Николы красны цвет мотивируется цветом кардинальского церковного oблаченй 
45. СМ.: Б.А.УСПЕнСКИЯ, Филологические разискивакия..., ук. сон., 89 и след., 114 и след., 182 и след.

46. Tan $x e, 90$.

47. Tам $x e, 37$.

48. Там хе, 86 и 95-100; рядом с 'комарьея'темо появляется в поэме и 'пчелиная' тема, тоже связанная с подземньм царством и С Царевичем $(401,410)$; она, естественно, амбивалентна, но небезынтересно отметить, что Никола может выступать как покровитель пчеловодства, и что пчелы связываются в народных представлениях также с водяньм - они "отроились от лошади, заезженноя водяны дедом и брошенноя в болото". Там хе, 84-85.

49. См.: Б.А.УСПЕнСКИЯ, "Культ николы на Руси...", ук. соч., 114.

50. На деле картина более сложна: никола может становится антиподом Св. Михаила в своем зимнем варианте как' запираюяия землю': в остальньх случаях он, как правило, равен св. Михаилу вплоть до их контаминация. Об упопобления одного другому см.: уСІінския, Филологические разискания..., ук. соч., 18-30 и 111-112. В связи с тем, что в поэме царь-Девица именуется "Михаклом Архистратигом" (356), а в финальном видения Царевича в нер просматриваются иконные черты Архангела Миханла, целесообразно отметить, что за таким их слиянием может стоять отмечаемая Успенским частая контаминация Архангела Михаила, св. Николы и Богородицы (maм $x е, 23-24)$. В этом свете более понятным становятся некоторые сходные детали в образе царя и в образе царь-девицы, но с противополохньми знаками, хотя на событинном уровне эти персонахи вовсе друг с другом не сталкиваются.

51. См.: Б.А.УСПЕНСКИЯ, Филологические разискакия..., ук. соч., 114-115.

52. Ср. там $x е, 45-46$, Об именования николы "пивным богом" и о ритуальном пьянстве в Николин день, "отсюда глагол 'николить' в значения 'пить, гулять, пьянствовать'". Сp. еме уподобление небесньх вод 'вину', а водоносных туч - 'бочкам' (А.АФАнАСЬЕВ, Позтические воззрения славяк ка природу..., т. I, ук. сои., 581) и 'боченочное' окружение Царя и Волоса-Велеса как похитителя небесных, животворямих вод. Ср.: В.В.ИВАнОВ, В.Н.ТОПОРОВ, Исследовакия ө области славякских древкостей. Лексические и фразеологические вопроси рекокструкиии текстов, Москва 1974,40 и след.

53. СМ.: Б.А.УСПЕНСКИЯ, 108 ; Б.А.УСПЕНСКИЯ, 64,106 .

54. СМ.: Б.А.УСПЕнСКия, "Культ Николь на Руси...", ук. соч., 105, 114: Б.А.УСПЕНСКИЯ, Филологичксие разискаяия..., ук. соч. 55.

55. См.: Б.А.УСПЕнСКиЯ, Филологические разискакия..., ук. соч., 29-30.

56. См.: Б.А.УСПЕнСКнЯ, Филологические разискаяия..., ук. соч., 44 и след.

57. Там хе, 52 и след. 
58. Там хе, 95, здесь же отмечаются связи пастуха с лешим (леши как зверины пастырь) и с колдовством.

59. См. Примечание 58 и Э.В.ПОМЕРАНЦЕВА, Мифологические персонахи в русском фолоклоре, Москва 1975, 39-40.

60. См.: Б.А.УСПЕНСКй, Филологические разискакия..., ук. сои., 44-49 (О связи СО скотоводством и С коневодством в частности) , 122-125 (о 'письме'-'разрешительнон молитве' к Николаю), $83,95-97$ (о молитве $к$ лешему).

61. Tам $x e, 34,40-41,55$.

62. Tan $x e, 55$.

63. Там $x е, 44$ и след.

64. В.В.ИВАНОВ, В.Н.ТОПОРОВ, Һследования в области славянских древкостей, ук. соч., 47.

65. Там $x е, 44-45$.

66. Ср. В стихотворении "Масляница широка!.. (21 февраля 1922;

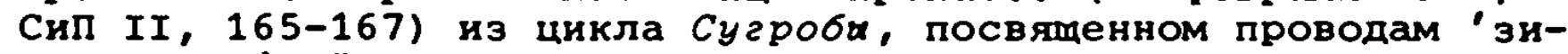
мы-смерти' : "в тыпу девятьсот-от Семнапцатом - счетом Забралась, растрепа, К мужику в окопы. Восставан, михальч! Твое дело - жалость. Восставан, Егорьч, твое дело - горечь. [...] Масляница! Вафељњнца! Румнная висельница! [...] Қути, парень, пакто в жут! Нынче масляницу жгут. Гикалу! Шугалу! Хапалу! Чучелу!", при этом заметим, что оба пронзведения - Царо-Девииа и Сугроби соотнесены с почти одним и тем же периодом в народном обрядном годовом цикле. Само собои разумеется, что новы мировон цикл надо читать в контексте "нового солнца" (427), т.е. восхождения К Абсолюту (См. ниже разбор образа царь-Девицы и сюжетов поэмы).

67. "Дом" в системе цветаевоЯ, как правило, - 'узилиме'. "Вечның дом" - прекрамение супествования. Ср. в цикле Бессокница в тексте Kmo cnum no ночам? Hикто ке cnum!.. (12 дектбря 1916; СиП I, 248): "- Не спи! крепись! говорю добром! Не то - вечның Сон! Не то - вечның дом!", где "дом" эквивалентен "сну" 'смерти' - 'отсутствия бытия'.

68. Анализ этого ритуала см. В: О.Р.АРАНОВСКАЯ, "О Фольклорных истоках понятия 'катарсис'", В: Фолоклор и эткография. Обряди и обрядовий фолоклор, Ленинград 1974, 60-68; предисловие к польскому изданию Семиотики кияо Лотмана: J. ЕотмAN, Semiotyka filmu, Warszawa 1983, 5-7.

69. Ср. именование сына - царевича - 'товаром' : "Смотрит: не шелкянтарь - мусор-товар: На дне - с гуслями в обнимку - гусляр!" (362).

70. См.: Г.А.ЛЕВинтОН, "Некоторые общие вопросы изучения свадебного обряда. Свадебның обряд в сопоставления С другими", В: Тезиса докладов IV Леткей Школа по вторичнам моделируоиим системам. 17-24 августа 1970 2., Тарту 1970, 27-35; А.БАЯБУРин, Г.Лввинтон, "Тезисы к проблеме 'волшебная сказка и свадьба'", B: Quinquagenario. Сборник cmameй молодиx фuлологов $к$ 50-леmuю проф. D.M.Лотмака, Тарту 1972, 67-85. Ср. в этом контексте слова мачехи: "Отчего я не девица, А чукая жена!" (342). 
71. Вопрос 'внуков' возникает и в случае царь-Девицы в ее разговоре с нянькои о замухестве (352-353) и в споре с соблазнителем-Ветром (417) и тут хе ею отклоняется, но на этот раз по иньм сообрахениям - 'хизнь' понимается Царь-девицея не в виде продолхения земного рода, а в виде устремленности к чистои дуХОВности.

72. СМ.: Г.А.ЛЕВинтОН, "Некоторые общие вопросы изучения свадебного обряда", ук. соч. В связи С этим отметим удивительную последовательность цветаевоЯ: сборы Царь-Девицы $к$ 'хениху' сопровохдаются словами: "Перехоху в иную веру, Всю вольность отдаю за гром..." и тут же в моделирующеи лексике появляются "лес" и "реки в половодье" (357; ср. возглас мачехи "помру за грош!" - 381 и см. о 'монете' в 1.1.2.в. и в примеч. 15); эквивалентность "смерти" и "свадьбы" на уровне плана вырахения, т.е. сновидения Царевича, в вопросе царевича о смысле сна: "За перст безвмянны Прикован - леху. АЯ к смерти? А к свадьбе?" (397).

73. Однако в другом месте царь назsвает царевича "птицей в небе": "- Птица в небе - вьлие нас родилась! Над тобою нашl не властен приказ!" (398).

74. С..: О.М.ФРЕДДЕНБЕРГ, Миф и литература древности, ук. сои., 78: "Женшнна 'умирает' - значит, 'рохдает' и 'рохдается'".

75. СМ.: А.АФАНАСЬЕВ, Поэтические өоззрекия славян ма природу, том III, Москва 1869, 209-210 и ср. 197-199.

76. СМ.: А.АФАНАСБЕВ, Поэтические өоззрения славян ка природу, том I, Москва 1865, 99-100, где показана народная эквивалентность 'mоM - черт'.

77. Taм $x e, 101,166,549$.

78. Тут имеют место только перенменования ("эпитеты") или неопознавания.

79. Ср. слова царевича о самом себе: "Снеговые скатерти, мертвец весь сказ!" (350) или похелание одного из обитателея моря на вид царевича: "кивого такого Напеть бы друхка!" (390).

80. В церковном культе особо отмечены двенадцать пятниц: 1) перед Благовещением, 2) первая перед и 3) десятая после Воскресения Христова, 4) перед Троицея, 5) перед Успением Богородишы, 6) перед ињинм днем, 7) перед праздником Усекновения головы иоанна Предтечи, 8) перед Воздвихением, 9) перед Покровом, 10) Введением во храм святоя Богородицы, 11) перед Рождеством Христовьм и 12) перед Кремением. В народе пятницы праздновались наравне с воскресениями - так "Константинопольския патриарх окрухною грамотою 1589 года к литовско-русским епископам запрещал праздновать день пятницы наравне с воскресением" . А.АФАНАСЬЕВ, там $x e, 232$, а дальше 233-235 оговаривается связь Со Св. Пятницеи и Св. Анастасиея (имя котороя и значит 'воскресение') и с языческим посвямением этого дня солнцу по образцу христианского воскресения. Одновременно пятница связана и С демоническими силами - С водоя, С кикимороя, С хтоническими двенадиатью девами-лихорадками. См.: В.В.иВАНОВ, В.Н . топоРОВ, Славянские взиковие моделируюиие семиотические системи, ук.соч. 150-151, 190; Б.А.УСПЕнСКиА, Филологические разискания..., ук. соч., 137. За соотнесенностью Цареви-

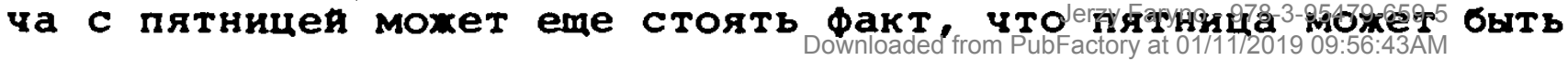


и 'николиньм днем'; См. там $x$, 113 и 136-138 о контаминации николы и Параскевы Пятнишы (136: "в некоторых местах резные изобрахения Николы и Параскевы Пятницы объединяются под обцим названием 'пятниц'") и Николы-Волоса и Пятнищы-Мокоши.

81. СМ.: А.АФАНАСЬЕВ, там $x e, 233-234 ;$ Б.А.УСПЕНСКИЯ, там $x$, $^{-}$ 134-138. Подробнее об этих чертах 'матери' Царевича см. $1 \cdot 3 \cdot 3 \cdot \pi$.

82. См., кроме источников, указанньх в пркмечаниях 80 и 81 , статьи "Мокошь" и "Пятница" в: Мифи кародов мира, том II, москва 1982,169 и 357 .

83. См. 2.2., 8.9., 9.8. и 12.8. в разборе Переулочков.

84. Ср. народные представления о радуге как 'смоке-змее'. См.: А. АФАНАСЬЕВ, Поэтические өоззремия слаеяк ка природу, том I, yк. соч., 357-358.

85. О 'похоронном' аспекте ладьи или корабля и о их странствовании по 'водньм пространствам' = 'поту сторонни мир усопших' См.: А. АФАНАСЬЕВ, Поэтические воззрекия славяк ка природу, том I, ук. соч., 580-581 и др. О николе как водителе дуи в загробном мире и 'перевозчике душ' см.: Б.А.УСпЕнския, Филологические разискания..., ук. соч., 25-27.

86. Б.А.УСПЕНСКИ,, там $x$, 13-14 и 119-122.

87. А.АФАНАСЬЕВ, Поэтические өоззрекия славян ма природу, том I, Ux. COY., 349-363.

88. См. там $x е, 483-487$.

89. $T$ an $x e, 486$.

90. CM.: Apokryfy Nowego Testamentu, pod redakcja Ks. Marka Starowieyskiego, Tom I: "Ewangelie apokryficzne", TN KUL, Lublin $1980,201(X X 1)$.

91. TaM $x e, 239(74)$.

92. TaM $x e, 380$ (XXVIII).

93. См. статью "Кресть" в: В.ДАЛЬ, Толковай словаро хивого великорусского язика, том II, москва 1979, 192. См. еме статью "вода" в: Cловаро библейского богословия, под редакиней Ксавье Леон-Дюфура и др. Изд. "Жизнь С Богом", Брюссель 1974, кол. 143-148.

94. А.АФАНАСЬЕВ, Позтические воззрекия славяя ка природу, том II, Москва 1868, 219-220; статья "Пятница" в: Мифи мародов мира, TOM II, yx. cou., 357 .

95. В поэме эти пряности ассоциируются с 'купеческим' мотивом в образе царя. Но, кроме того, уместно отметить обытая выноса иконы Св. Параскевы убранноя лентами, монистами и душистыми травами - "Эти цветы и травы оставались в церкви, и отвар их давали пить безнадехно больньм, как вернершее средство к исцелению. Кто соблюдает пятницы, к тому, по общему поверью, не пристает лихорадка". А.АФАнАСЬЕВ, Поэтические воззремия слаөян на природу, том I, ук. соч., 240-241. О связи "пятниц" C "лихорадками" см. в примеч. 80. 
96. См. "Кто спит - тот пьян, кто спит - тот сыт. Да, цветик благовонныя!" (424). В связи с упоминанием здесь "цветика" см. примеч. 103.

97. См. примечание 37. Ср. еме немецкое (но не только) убехдение - том, что "на исходе старого месяца хоропо расторгать брачные узы, ломать дом, рубить лес и косить траву: лес и трава нухны сухие [...] ибо скоро усохнут как месяц [...] плоды, растудие над землею, лучпе сеять при возрастающе луне, а которые под землею (морковь, редька) и следовательно не любят света - при лунном умербе". А.АФАнАСБЕВ, там $x,, 192$.

98. Такое разграничение, видимо, не всегда возмохно, но как принцип оно объясняет причины контаминации одних и тех же культовьх персонахе то с представителями неба, то с представителями подземного мира.

99. Если держатья только рамок Цветаевской системы, здесь долиен начаться 'второя' ее сюхет - 'восхохдение, вознесенне' в нетварне. В данном случае мохно вполне согласи'ься с предположением, что свое (правда не буквальное) продолжение получает Царо-девииа в Переулочках. См.: С.ПоляковА, "К вопросу об источниках поэмы Цветаевоя 'Дарь-Девица"", в: Russica '81. Литературкий сборкик, New York 1982, 226.

100. О соотнесенности 'вырия' или 'ирия' С подземным царством, куда уползают на зиму (с Воздвикения) змеи и где остаются до первого весеннего грома (до вешенего орьего дня), См. В: Б. А.УСПЕнСКиЯ, оилологические разискания..., ук. соч. 59-60 и 144-149. С этоя точкя зрения преврамение мачехя в Змея означало бы своеобразное ее 'воскресение', возобновление ее телеснои ипостаси.

101. Примечательно, что подлинная ипостась ('зме́евая') возобновляется при ударе об земтю ("о кремень-кирпич"), и что 'воскресение' передается здесь 'падением'. Первое восходит к Фольклорньм законам оборотничества (см. примечание 38 в разборе Переулочкоо), второе - $к$ Дветаевскому пониманию 'рохдения' 'обретения плоти' как 'падения' в мир веса, меры, праха и т.л. (ср. ухе упоминавшееся стихотворение Сивилла - мласекиу). Освобохдение от "гроба" оказывается тут (по системе Цветаевоя) обманчивьм - 'гроб' получил только инои вид, может быть, еще более 'бездушның', так как "дух" - "вылетел".

102. Это связано с особенноя активностью в данныя период акватических демонов, т.е. душ "залохных покоиников", людея умериих прехдевременно иия неестественнои смертью и не осупествивших своих плодородных потенция, которые они могут осуцествить как раз теперь и поэтому похищают младенцев, прикидываются невестами или тенихами и т.л.; у великоруссов это период Русалия - помннальньх обрядов и поклоненин "залохникам", имеюиях целью предотвратить их нежелательные деиствия. CM.: J. 1 R.TOMICCY, op. cit., 129-130, 192-195.

103. СМ.: О.М.ФРЕЯДЕНБЕРГ, Миф и литература древкости, ук. сои., 142. Ср. в самон поэме - в Кояие: "- От купцов твоих, Кумач, - одна быль! там, где розаны цветут и на святки В том краю теперь разбили палатки!" (434), где 'цветы' однозначно соотнесены С обрядом помнновения и С загробным миром. 
104. СМ.: О.М.ФРЕЯДЕНБЕРГ, "МИФ Об Иосифе Прекрасном", В: Язик и литература, том 8, Ленинград 1932, 147; И.Г.ФРАНК-КАМЕНЕЦКИН, "Вода и огонь в библеиской поэзин", в: Яфетичесхий сборких, том 3, Ленинград $1926,152$.

105. Отчасти он передается царь-девице - под видом 'орошения' и 'взращнвани''. Но надо отметить, что и в этом случае в семантическом плане поэмы 'вегетативная активность мира' еме не есть 'Жизнь', поэтому все 'весенне-дождевые' акты Царь-девишы решены только в плане сновидения царевича и истолкования Дядьки. Их истинның смысл им еме не открывается. Однако так или иначе есть возможность видеть в царь-Девице хотя бы частичного 'двонника' Мачехи с положительным знаком.

106. "- Постеля узка!" (343), "Я, мальчипка узкогрудыя" (354), "зашнурованность", "Как ременным кушаком ската грудь" (415), "- Ен вонска, а тебе - тоска! -" (428) - за всем этим стоит мифологема 'хаотическон узости' См.: В.Н.ТОПОРОВ, "Поэтика Достоевского и архаичные схемы мифологического мпшления. (Преступлен:1е и наказание)" , в: Прсблемх поэюики и истории литератури. (Сборкик статей, Саранск 1973, 101: "Если вспомнить, что все эти слова [тескота, узость, тоска, тошкота, угол и др. у достоевского - E.Ф.] восходят в конечном счете к тому индоевропеискому корню, которыр отразился в вед. athas, обозначакмем остаток хаотическон у структуре макрокосмоса и в душе человека и противопоставлено uru loka - ш и р о к $о$ у м миру, торжеству космического над хаотическнм, - то окакется, что указанные Фрагменты романа в силу своен архетипичности могут трактоваться как отдаленное продолкение мифопоэтическон традиция. Главны ведияскин ритуал (как, впрочем, и в других традициях) состоял в инсценировке того, как главны актер-герон свокми деяниями-жертвон делал возможным этот переход от amhas $k$ uru loka. Типологически то же делает и герон Преступлекия и каказания".

107. Эта 'бездвижность' усложняется возможностью видеть в "весле" соответствие 'крыла' в виду наличия "перины", с однон стороны, а с другоя - собственнон символико "весла" как источника деятельности, творческон мысли и Слова. Иначе говоря, здесь даетсл картина пассивного 'логоса' под видом "Струнного рукомесла". См. статьо "Oar", in: J.E.CIRLOT, A Dictionary of symboli, op. cit., 238-239.

108. См. А.АФАНАСЬЕВ, Поэтические воззрекия славяк ка природу. TOM I, 578-580.

109. Об эквиваленции птиц и молнин См.: Там хе, 294-5, 491-532.

110. О звездах как распахнутых небесных окнах, их которых выглящавают ангелы, см.: Там $x e, 161$. Естественно, в случае цветаевон имеется в виду некое более абстрактное явление, но, несомненно, родственное представлению об 'ангеле'. Тем более, что все предваряется подьемом по "лесенке". В сочетании с "гробиком" (показателен такон же деминутив) эта "лесенка" ассоцияруется $C$ 'приставноя' - подставляемой $k$ гробу или полагаемоя в могилу, дабы душа могла легче подняться на небо. См.: А.АФАНАСЬЕВ, Поэтические өоззрения славяк ка природу, TOM I, yK. COY., 124-125.

111. "Сорок" - библеиско-церковное число, означаюмее символичес-

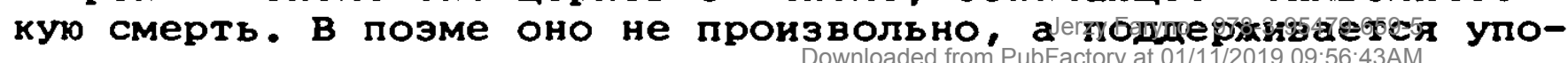


минаниями о Великом Посте (411: "Как от свечки воск дает В церкви́ ночноя - Речь великопостная, Шумок свечнои"), длямемся 46 днеи (с воскресениями) и означающем временную смерть мира перед воскресением в новую жизнь.

112. Об оппозиции 'правы - левы' См.: В.В.ИВАнОВ, В.Н.ТОПОРОВ, Славянские язиковие моделируюиие семиотические системи, ук. соч., 91-98 и др. Противопоставление "гуслен" и "бус" по этому признаку выдает в "гуслях" связь С тнз. 'сильноя водон', C 'небом', с духовньм началом, а в "бусах" - со 'слабо водон" (См. постоянную у Цветаевон связь "бус" с акватической стихиея - СР. хотя бы этот мотив в цикле Бессоняица, в Поэме кокиа, В Поэме воздуха), с хтоническим, с несвободой и телесньм. Возмохное же противопоставление 'мухской - женския' в поэме не активизируется, по причинам, о которых - в разборе $\infty-$ раза царь-девищы и сюжетов поэмы.

113. 'Палец' - эквивалент молния, громоносноЯ стихии, деятельноя, творческон энергин. Ср. в самои поэме: "Гром-барабанщик следом мчит. 'Как две руки мон отбиты, Даң хоть с мизинца ноготок!" (357). где "мизинец" и "ноготок" однозначно соотнесены с 'громом' и 'молниеи'. См. о таких эквиваленднстья в нараднех гредставлениях В: А.АФАНАСБЕ, Поэтические воззрекия слаөяк ка природу, том I, ук. соч., 123, 501, 504, 259, том II, ук. соч., 386-7, 394-5, 701, 735-7, 747 и др.

114. "Память", вероятнее всего, здесь мылится как нечто неотчухдаемое от субъекта, как его сумность, и имеет прямое отношение к 'логосу', которы мохет заглушаться или извраматься 'материальностью'.

115. Однако оформление этого 'духовного начала' в виде "льна" подсказввает, что это далеко не 'чисты дух'. На деле здесь необходима некая более тонкая градация, чем та, которои мы пользуемся. у цветаевоя она наличествует в ее богатод шкале материалов, но почти не поддается эксплицитному выявлению.

116. См. статью "Пятница" в: Мифа мародов мира, том II, ук. соч., 357.

117. См. примечание 38 в разборе Переулочков.

118. СМ.: А.АФАНАСБЕВ, Поэтические воззрекия славян ка природу, TOM II, YK. COY., 591.

119. См.: Там $x e, 299,382$; в томе I - 265, 788-9; в томе III 500. Здесь же объясняется этимологическая мотивация уравнения дождя и смолы, дегтя.

120. Здесь возмохны и апокрифические мотивы; см. примечание 48 в разборе магдалика.

121. Не исключено, что она являет собои, говоря словами из Позми воздуха, "газовыя мешок"='душу'='узилище для духа' (СиП IV, 285). Ср. еме в: Белье ма речке полощу... (мехду 26 мая и 4 июня 1918; СиП II, 224): "Душа и волосы - как шелк". Если "янтарь" читать как вариант 'смолы' со всеми ее коннотациями в поэме, то "шелк-янтарь", денствительно, долкен читаться как 'дуиа' но еме, так сказать, слишком 'отверделая', что и позволяет ее именовать как "мусор-товар". 
122. Ср.: Волоси я - или воздух иелую?.. (9 ноября 1918; Cип II, 247): "Друг! Все проддет на земле, - аллилуяя! Вы и любовь, - и ничто не воскреснет. Но сохранит моя темная песня - Голос и волосы: струны и струи"; Встречалисо ли в поиелуе... (22-27 июня 1917; СиП II, 34 из цикла Ноаки): "Иоанна кудри, как струи Спадают на грудь Христа. [...] Иоанна руки, как крылья, Висят по плечам Христа".

123. См. разбор мотива 'искания' в предании О Егории Храбром В: А.АФАНАСБЕВ, Позтические өоззрения славян на природу, том II, ук. соч., 591-592; о связи расчесывания волос и дождя там $x$, $768-774$.

124. О связи коня С ГрозовоЯ стихиеЯ См.: А.АФАНАСЬЕВ, Позтические воззрекия славян ма природу, том I, ук. соч., 611-636.

125. См.: А.АФАНАСЬЕВ, ук. соч.; тучи как кудель, пряха, ткань TOM II, 517, TOM III, 128-136, 154, 276, 354-5, 467-8, 492-3; тучи как пламенная рубашка - том I, 179 (ср. в поэме "Красен рубахи холст" - 425; "Ох, латы ломает! Рубаха в крови!" 427); молния как роза, пион, цветы вообме - том I, 375, 744, том II, 375-388, 395-400, 422 и др; молния как питца - том I, $372,396,489-502,510-532,540-1,590$, тOM II, 280, 286, 295. Ср. еме - молния как рука и щипшы - том I, 187, том II, 701, том III, 541-544 и ср. в поэме слова мачехи об 'обятиях' Царевича: "Жезлом ты в меня впился, Как огневая полоса Под красньми мипцами след твокх рук - на память!" (382).

126. Н.И. и С.М.ТОЛСТыЕ, "Заметки по славянскому язычеству. 2: Вызывание дождя в Полесье", в: Славянский и балканскай фальжлор. Генезис - Архаика - традииии, Москва 1978, 102-103, и др.

127. Более расширенно о Цветаевском "льнуть" см. 12.8. в разборе Переулочков.

128. Наиболее эксплицитно это вырахено в Поэме воздуха. См. ее разбор в: М.Л.ГАСПАРОВ, " Поэма воздуха " Марины Цветаевон: Опыт интерпретации", в: Tруда по змаховим системам, том XV: "Типология культуры. Взаимное возденствие культур", Тарту $1982,122-140$.

129. Шире по поводу "обуви" См. 12.7. и примечание 115 в разборе Переулочков.

130. См. примечание 96, 97, 103. Здесь уместно отметить, что 'цветы' подбираются в поэме по принципу 'галлюциногенов' ("одуванчик", "конопля", "мак", 'благовонность' как 'пряность'), с одноя стороны, a c дургоя,- по принципу причастности к 'Волосо-Велесовому" началу: "лен" и "конопля" как 'волокнистость' с их соотнесенностью с 'волосами', 'пенькоя' (407: "Пенька баба ловкая!"), которые связаны со 'смертью, соблазном' ; "одуванчик" - как 'пуиистость', 'шерстистость'; "василек" С возможньм его значением 'волос', 'болезнь' и 'Василия' и Связью как С Громовержцем так и с его противником Змеем. По поводу "василька" См.: Б.А.УСПЕнСКнИ, Филологические расискания..., ук.соч. 131 .

131. Ю.М.ЛОТмАН, Cmamоu nо mипологии жулотури, тарту 1970, 15, 0 синтаксическом значении см. 24 и след.

132. J.MEYENDORFF, Teologia bizantyjska, op. cit., 245-8.

133. Там $x e, 36-37$. 
134. Там хе, 33-38, 176-177. См. еме примечание 40.

135. Ср., например, уже упомннавшееся стихотворение "Раковина", сюжет которого построен на эахвате лирическим субъектом - "я", уподобляомемся морскои раковине-жемчухнице, партнера - "Ты" и претворения его в "жемчужину", которое понимается как 'cnaсение От мира сего"="Нз лепрозория лхи и зла" (СиП III, 89). "море" с его "жемчужньм всплеском" означает также 'мировой поток душ', единение logoi.

136. См.: В.В.ББчков, Византийская эстетика. Теоретические проблеми, Москва 1977, 99-107.

137. О соотнесения пчел и их гуда с молниями и шумом гроэы см.: А. АФАНАСЬЕВ, Поэтические воззрекия славян ка природу, том I, ук. соч., 381-385. Там хе, 332-333 см. об эквивалентность 'гром гусли-самогуды' 'Опибка' в восприятии шума ("Нет, не пчелки") на мифологическом уровне мотивируется также и связью пчел с Волосом-Велесом. По этому поводу См.: Б.А.УСПЕНСКИЯ, ФИлологические разискакия..., ук. соч., 84-85. Перенменование "гуда" в "спор" восходит, по всеи вероятности, к общему для всех этих явления знаменателю - 'слову' или Слову: в народных представлениях и 'гул пчел', и 'гром' и 'слюна' и 'гусли' эквивалентны не только в соотнесения С громом, но и в соотнесения со 'звоном' (колокольіњМ), С Бохьим СЛовом. Об этих соотнесениях см.: А.АФАНАСЬЕВ, там $x е, 392-393,285-287,298-301$.

138. СМ.: А.АФАНАСЬEB, maM $x e, 332-333$.

139. См. статьи "Harp", "Harpist", "Lyre", "String (or Cord)", in: J.E.CIRLOT, op. cit., 139, 140,195, 316.

140. CM. cratblo "Swan", in: J.E.CIRLOT, op. cit., 322 .

141. См.: A.АФАНАСЬEB, maM $x e, 368,391-401$.

142. См.: В.В.ИВАНОВ, В.Н.ТОПОРОВ, Исследовакия в области славякских древностей. Лексические и фразеологические вопроси рекокструкиии текстов, Москва 1974, 54, 65-66, где в частности обсухдается гипотеза Якобсона' о связи имени Велеса с древне-ирландским file - 'поэт, жрец, гадатель'.

143. См. 1.4.3. и примечание 126. В контексте 'сгорбленности' "голуби" выдают свою связь с понятием 'духа' и 'Свободы', Осо бенн если учесть, что данның эпизод предваряет 'встречу первую" С Царь-Девицея, у которои "на правом плече - голубь" (352) и которая во время этои встречи производит акт "крещения" царевича (366-367).

144. См. примечание 113.

145. См.: А.АФАНАСЬЕВ, Поэтические воззрекия славяк ка природу, том I, yк. соч., 552-6. C другон точки зрения именование корабля "костром" и отсылка к библерскоя "купине" (344) сообщает ему как 'облаку' смысл Славы Господнеи (см. 1.5.4.).

146. См.: А.АФАНАСЬВ, Поэтические воззрекия славян ма природу, том II, ух. сои., 636-783, т.е. главу Великаки и карлики, где одни и другие одннаково соотносятся с облачной грозовод стихиен (в этом контексте диспропорция масштабов Царевича и ЦарьДевищы как вариантов 'Громовника' оказьвается несудественноя).

147. О возмохных тут апокрифических ассоциациях см. примечание 48 в разборе магдалики. 
148. По иным вариантам жаворонки прилетают 9 марта (ст. ст.), а 25 - на Благовещенье - ласточки. См. А.АФАНАСЬЕВ, там $x е, 138$. у самоя же Цветаевоя "хаворонок" родственен "голубк" и является носителем 'Благои Вести' ('спасения'). Ср. хотя бы $3 a-$ кинуе голову и опустив глаза... (март 1918 СиП II, 20), где "В день Благовеменья [...] голос, голубем покинув грудь, В червонном куполе обводит круг", и Благая весто (2 иоля 1921; СиП II, 119), где 'вестником' является "хаворонок"; "ласточка" же у цветаевон слишком прочно связана с "Психеен" и, по этои, видимо, причине вовсе не появляется в поэме; см. еме примечание 143.

149. CM.: J.MEYENDORFF, op. cit., 246-247.

150. CM.: O.KOLBERG, Dzieła wszystkie, t. 7: "Krakowskie, cześ́ III, Warszawa 1979, 26 (\$37).

151. См. статью "Слава", в: Cловаро библейского богословия, ук. соч., кол. 1036-1037 и след.

152. О костюме КаК Об Овнешненности достоинств См.: Д.С.ЛИХАЧЕВ, Человек в литературе древней Руси, Москва 1970, 32-33: "Кахдая 'добродетель' обрамена к зрителю, надета на нем, как доспех, механически соединена с соседнея. [...] они - как бы его парадная одежда. Это хорошо подметил даниял Заточник:

'Паволока 60 испестрена многими шолки и красно лице являеть тако и ты, княхе, многими людми честен и славен по всем странам'. Eме отчетливее сравнение добродетелеи князя с его одеянием в пространно посмертно характеристике вољынского князя Владимира Васильковича. 'Ты правдою бе 06 ○ $л$ ч е н, -

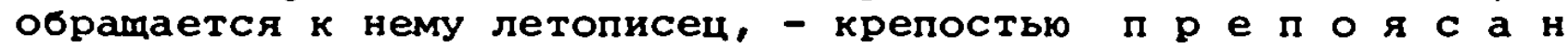
и милостынею яко гривною утварью златою $y k p$ a $c$ y $g$, истинон $О$ б и $T$, смыслом в $е$ н ч а н" "одехда", в: Словаро библейского богословия, ук. соч. , кал. 706-710, где в частности "одежда" толкуется как "отражение божественного порядка в мире", и статью "Steel", in: J.E.CIRLOT, op. cit., 312, где вслед за Эволен "сталь" интерпретируется как трансцендентная 'твердь', как принцип всепобеждаюмего духа.

153. См.: П.ФЛОРЕНСКИИ, "Иконостас", В: Богословские труди, 9, издание Московской Патрнархия, Москва 1970; 1.М.ЛОТмАН, "Риторика", в: Труда по знаковим системам, т. XII: "Структура и семиотика художественного текста", 'арту 1981, 15-16 и 22.

154. См.: Р.Д.ТИмЕнчик, "Храм Премудрости Бога: Стихотворение Анны Ахматово "широко распахнуты ворота..."n, B: Slavica Hierosolymitana, vol. V-VI, Jerusalem $1981,305$.

155. Ср. толкование 'сверхматериальностью' иконного мира в: Л.Ф. ЖЕГин, Язак хивописного произөедения. (Условносто древнего искусства), Москва 1970, 70-75.

156. Б.А.УСПЕнСКиЯ, Филологические разискания..., ук. соч., 25-26 н 122-125.

157. Сp. там xe, 35, приводимы пример причитания:

Расшиби-ко ты, громова стрела, Eme матушку - мать сыру землю. Развались-кось ты, мать сыра земля, На четыре все сторонуики. 
158. Tan $x e, 26-27$.

159. Не исключено, что эдесь имеется в виду мистическия, теологическия смысл "головы" - невидимого в 'мире сем', но возглавляюмего все побуждения 'Головы-Христа'. Ср. наличие этого мотива в Поэме өоздуха: "Дитя - в отца! Час, когда потомственность Ска-зы-ва-ет-ся. Твердь. Голов безтормозных - Трахт! [...] Грунт! Гермес - свиои! Полное и точное Чувство Головы С крыльями" (СиП IV, 285) и его анализ в: М.Л.ГАСПАРОВ, уж. соч., 139 .

160. См.: А.А.САЛтыков, "Семантическая структура "Троншы" Андрея Рублева в свете ареопагитик", в: Материалх өсесоюзкого симпозиума по өториимим моделируюиим системам, I (5), тарту 1974, 148; за 'поясньм' изобрахением здесь Царь-девицы мохет стоять и иконографическая традиция изобракения ангелов "без ног или без нихнеи части тела", означағиего прибввание из невидимого потустороннего мира. См.: В.В.БЫчКОВ, ух. соч., 155-157.

161. Так объясняется, например, неотличимость или дахе 'сраменность' Царь-дениы $c$ ее "конем" (356) и именование его "женихом" и "братом" (358), так объясняется также неразлучность Царевича с "гуслями" (362: "На дне - с гуслями в обнимку гусляр!") и т.д. На этом фоне глубокия смнсл получает как опозиция 'один персонах небесного царства - мнохество (главньх - три) подземного', так и разъединенность персонахер на уровне подземного мира, их даже локусная изолированность друг от друга (Мачеха - на своея "половиночке", Царь - в "шатре", Царевич - в "кроваточке" и "за дверью"), а кроме того их 'монадность', оборачиваюиаяся их упербностью. Видимо с этоя точки зрения объясняется и выбор для симолизации 'Солнца' комбинированного кода: более древнего - 'женского' и более нового 'мужского', т.е. "царь-девицы". О разных традицияХ в связи С изобрахениями солнца См. В: Л.МОНЧЕВА, "К проблеме символьного образа в древнерусскоя литературе" - Disвertationes Slavicae, XVI, Szeged 1984, 37-47.

162. См. статьи "Гордость/Гордын", "Гордость (Дерзновение)" и "Дар" в: Словаро библейского богословия, ук. сои. , кол. 225-231 и 256-258.

163. См.: Народние русские сказки А.Н.AФAНACbEBA, в трех томах, том 2, Москва 1958. А вот их краткое изложение. Царо-Девииа (N 232, прежни - 128a, 227-230): Жил купец. Жена его померла, остался сын. Купец приставнл к сыну дядьку, а сам женился на другоя. Однахды этот сын в море на плотике охотничал. Повстречал 30 кораблер. Тогда его полюбила царь-девица и они обручились. Мачеха надумала расторгнуть эту помолвку, и всякия раз, когда Иван долхен встретиться с возлюбленноя, усыпляет его. После третьея 'не-встречи' осталось у Ивана письмо от Царь-Девицы. Теперь иван отправляется искать ее. избуика. Там он узнает, где спряталась царь-девица. Летит туда на жар-птице. При помоми содеиствуюмея старушки заманивает царь-Девицу с ее свитои в гости к старушке. Угомая гостеи старушка подкладывает Царь-Девице янцо с любовью. Царь-Девица съела его и тут же снова полюбила Ивана. Старуха вывела Ивана из укрытья. Бурная радость. Свадьба. Царо-Деөича ( 233 - прехния 128b, 230-235): Жил-был царь с царицею и был у них Василия-царевич. И $\mathrm{x}$ нему был дя-

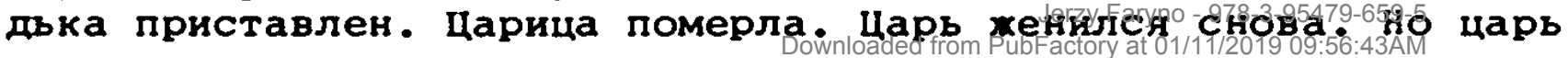


вскоре тохе помер, а царица (вторая хена) связалась с дядькою. Василия гуляет по городскор стене. Освобохдает льва, змея и ворона. Узнает от них о свое невесте, которую ему подыскали еме родители. Советуют гулять по морю, но не засыпать. Но Василия все-таки засыпает. "Не пичужечка то увивалася, а прекрасная царь-девица миловала, целовала, на полотнах качала, холоднов водоя обливала, и никак не могла добудиться". Оставленное письмо. Василия отправляется на поиски Царь-Девишы. Получает меч-кладенец, жеребца. Бой С Иваном русским богатырем. Победив пробирается с гуслями в сад царь-девишы. По гуслям та узнает Василия. Пир.

164. Кстати, эта работа уже довольно детально проделана в статье: С.ПоЛЯковА, "К вопросу Об источниках поэмы цветаевоя ЦароДевииа", ук. соч., 222-228 (здесь же учитыается и Царо-деөица Дерхавина).

165. См.: Б.А.УСПЕнСКнЯ, Филологические разискания..., ук.соч., 25; J.MEYENDORFF, Teologia bizantyjska, op. cit., 170-177. 


\title{
I. ПРЕДВАРИТЕЛЬНЫЕ ЗАМЕЧАНИЯ
}

\begin{abstract}
"Раскроите былины - пишет Цветаева Иваску по поводу поэмы 'Переулочки' - и наддите былину о Маринке, живущен в Игнатьевских переулочках и за пологом колдующе - обрамаюме добрых молодиев в туров - задуряюмен. У мекя - совами, болтовнея, под шумок которон все и делается: ух полог не полог - а парус, а вот и речка, а вот и рыбка и т. Д. И лентмотив один: соблазн, сначала 'яблочками', потом речною радугою, потом - огненноя бездноЯ, потом - седьмыми небесами... Она - морока и играет самым страшным. А конь (голос коня) - его богатырство, зовущее и ржупее, пытаюмееся разрушить чары, и - как всегда - тщетно, ибо одолела - она:

\section{Турии след у ворот -}

т.е. еме один тур и дур". (СиП, ІІ, 380-381). 1

Как известно, простое заглядывание в былины безрезультатно:
\end{abstract} в "Переулочках" от них почти ничего нет, кроме разве мотива колдовства, 2 но этот с равньм успехом мог быть навеян любьм другим проявлением народно культуры, как архаическон, так и встречаемод в современном цветаево быту. ${ }^{3}$ иначе говоря, никакая конкретная былина ни самоя Цветаево ни читателю ее поэмы не нужна. Цветаевская же отсылка к"былине о Маринке" - не столько указание объясняюего источника, сколько предложение прочитать этот источник поцветаевски: не в "Переулочках" наяти-опоэнать былину, а в былине наяти-опознать ее "Переулочки". Деиствительно, не трудно заметить, что в былинно Маринке увидела цветаева в первую очередь свою Марину или шире - свое лирическое Я - и согласно этор Марине-я и вывела ее в "Переулочках", а в былинном мотиве колдовства-завораживания - вариант своего же архисюжета 'завладевание миром' или, несколько Һже, 'завлекание, захватование в себя (в я) внешнего мира, партнера (ТЫ) и т. п.'.4

Emе разительнее отклоняется от былины жанровое решение "Переулочков". И не только потому, что с первого же стиха едва ли не вся речевая инициатива передана здесь внутритекстовому персонажу Сводне-ведунье ${ }^{5}$ и обращена к внутритекстовому же Герою, 6 а потому eще, что те немногие стихи, о которых мохно сказать, что они ис-

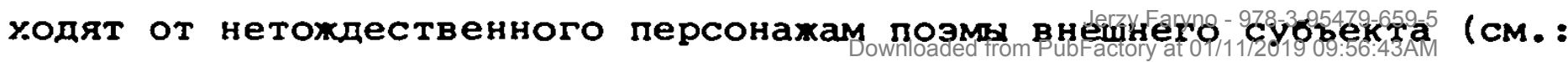


$43-52,57-60,65,93-104,137-146,175-181,247-255,372-373), 7$ почти все лишены привычно нарративно нагрузки, т.е. осведомления о пронсходямем и упорядочивания происходнщего. Сама Цветаева всю речедеятельность своеи Маринки-"мороки" называет колдовством "словами, болтовнеи, под шумок которов все и делается" (СиП, II, 380). Цель такон речи-"болтовни" - не нечто осознать или уяснить себе (артикуляция) и не нечто сообщить адресату (наррация), а создавая безобидны "шумок" отвлечь, умиротворить адресата и вызвать у него желаемое поведение или состояние (увлечь за собоя, завладеть им и т. П., а в других терминах - перестроить его личность). Эта цель достигается рядом специальных приемов, хотя бы таких как:

-сплошно речевон поток, не допускающи к слову адресата-собеседника:

-"речевое сопровождение" или "выручаюиая вербализация", которые состоят в том, что говоряция поочередно именует производимые денствия и этим самым вербализует их не столько для "ты", сколько за н е $\boldsymbol{\Gamma}$, и в уже готовом "акцептированном" виде вводит их в это "ты" (ср.: 71-82, 113-128, 159-160, 215-216);

- управление поведением собеседника при помощи "доброхелательных" советов-подсказок и прямх, вплоть до категорических, повелевания (ср. хотя бы: 17-18, 33-36, 41-42, 53-56, 83-84, 87-88, 91-92, 115-116, 151-152 и т. д.);

-предвосхищение возмохных ответных реакция или возрахения "ты", и например, при помочи выручаюиих ответов за него (ср. вмешательство Ведуньи в 147-148: "А на што нам лен, Зелена башка?" предотвращаюиее нежелательное поведение Героя в ответ на напоминание голубея):

- инклюзивное "мы", которое подключает "ты" (адресата) к "я" (к говорящему субъекту) навязывает этому "ты" требуемую точку зрения, внушает ему обиность мнения, смягчает, если и вовсе не снимает, диалогическое напряжение и в итоге стремится растворить "я" собеседника (адресата), вытеснить (подменить) его своим "я" (ср. такое "мы" в стихах 128, 147, 297, 310, 314):

- перевод собеседника на позицию постороннего (третьего) лица, т.е. отчухдение его от него самого же (ср. 280-281: "Не за раннею обеднея Молодиу - помин..." и 284: "другу - славу поют", где "молодец" и "друг" - тот же "ты", к которому обращается Ведунья, 
но как бы в его прехнеи и чухдоя ему теперь ипостаси).

Для разбираемого тут аспекта поэмы наиболее юллостративна, похалуя, ее вводная часть (стихи 1-72). Соответственно привычному строенио нарративного текста именно эдесь естественно охидать традиционноя экспозиции - ознакомления читателя с местом, временем, участниками события - и завязки события, т.е. возникаюмеи перед героями задачи.

Традицию эту Цветаева отчасти соблодает, но решает ее по приншигу драматургическо: вводит третьего, пока отсутствуюмего и безьмянного персонаха (Ведунью), о котором и повествует Сводня. 8 Речь Сводни преследует одну определенную цель: вызвать у Героя любоптство и тем самым соблазнить его понти к Ведунье. Одно и другое осупествляется при помоми рассказа о непостикимости Ведуньи и пути к нея, а в более конкретнон форме - при помочн загадок и умолчания (1-2: "не вемо-што", "не знамо-што"; 24: "Дальше - язьк не велит!"; 27: "на пустые слова не тратятся"), деминутивов (3, 4, $9-11,19-20,34,36,54:$ "В [...] платьицах В переулочках", "3апястьица!", "Заклятьице!", "Всех окошечек - семь", "С берехочку" и т. П.), льстивых комплиментов Герою (1-2: "млад"; 23: "башковиткрасовит"), "доброжелательных" советов и подскаэок (17-18; 29-30; 33-35; 41, 53: "Пока дома сидишь - подумыван, А шестое проидешь послехивая" и т. П.) и подстрекаюиих придержек (41-42: "Погоди, молодец, успеется! Чая не диво како под пологом!"). Вся эта речь, как видно, носит характер заманивающе-завлекающеи, и, само собоя разумеется, что, будучи агентом или даке двонником Ведуньи, Сводня не заннтересована ни в каком более отчетливом разъяснения.

И тем не менее некия событияны ряд и некая форма экспозиции тут улавливаются: Герон слушает (1-8), он заинтригован и проявляет некую заинтересованность (9-10), продельвает путь в игнатьевские переулочки (13-18), останавливается перед пологом Ведуньи (29-36), пытается проникнуть вовнутрь полога (41-42) и наконец оказьвается внутри (53-58). Но все это только косвенно вытитывается из неугомоннои речи Сводни и спорадичных вопросов Героя (которые могут также восприниматься всего лишь как расспросы - особенно 29-32, - а не как вопросы на месте). Их характера речи Сводни и ее "советов" Герою явствует и еме нечто: Сводня не столько объясняет как попасть в переулочки к Ведунье, сколько неотлучно сопутствует Герою вплоть до входа под полог (37-40, 57-66) Иначе: 


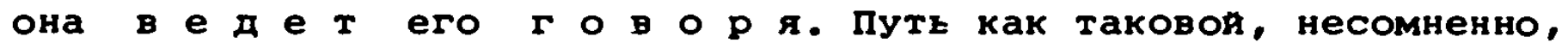
проделан, и мохно липш задаваться вопросом, проделан ли он Физически или ие только ментально. Но пока более сумественно нечто

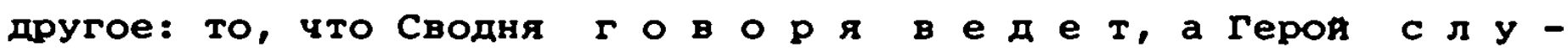
m a $g$ и д е т; то, что речь совпадает с путем и герод оказышает-

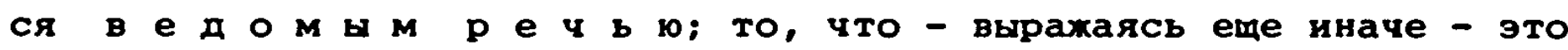

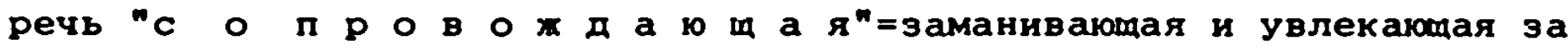
co6or.

Отсутствие внешнего повествователя и передача речи безьмянному внутритекстовому персонаху (Сзодне-ведунье), притом адресованнон к другому безшмннному внутритекстовому персонаху (Герою), сталкивает читателя поэмы лицом к лицу с внутренним ее миром без какод-либо предварительноя подготовки н тем самым ставит его в полохенне не осведомляемого, а разгашываюмего. Иначе говоря, задача читателя - разобраться в предстоямем перед ним мире, разобраться "что это эа герон?" и "что мехду ними пронсходит?"

\section{II.PA3EOP}

1.0. Кпоч к понимания поэмы содержится уже в первых ее строФax :

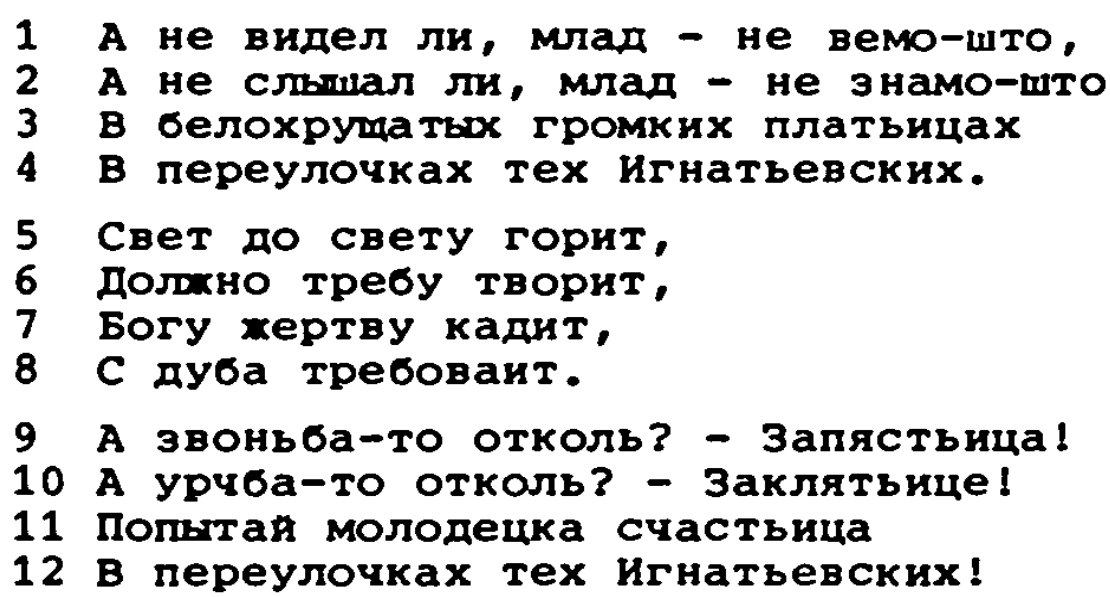

1.1. Снимая нарративны модус с заведомо фольклорного сюжета, Цветаева одновременно минует ряд свонственньх народньм повествованиям предварительных испытания героя и сразу же ставит своего Героя перед нанболее трудноя и наиболее опаснои задачеи: "не вемошто" (1), "не знамо-што" (2), "Попытан молодецка счастьица" (11) недвусмысленно отсылают к известноң сказочнон Формуле "Поди туда, не знаю куда, принеси то, не знаю что". члену "не знаю куда" со всея очевидностью соответствуют "Игнатьевские переулочки". И не

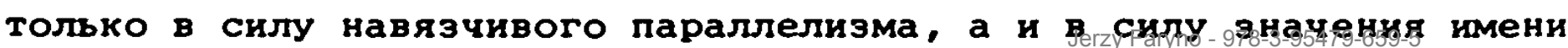


Игнатия, которое расшифровывается как 'не рохденның', 9 однон стороны, а с другон - перекликается с латинским ignis, означающим, в частности, 'огонь'. "Игнатьевские переулочки" оказьваются, таким образом, неким сверхъестественньм огненньм локусом и такую же сверхъестественность сообиают и своен обитательнице "не вемо-што". Безьмянность, а то и неопределимость, этоя обитательницы дополнительно повьшает ее ранг: уклончивое не-именование (кроме своен завлекаюмея интригуюее цели, О чем ухе говорилось) звучит здесь как табуирование имени грозноһ бохественнои судности; субститутнэвфемизмы "не вемо-што" и "не знамо-што" могут читаться и как указание на непостикимость, и как указание на отсутствие каких-либо отличительных признаков ('одушевленның - неодушевленның', 'мухскон - женския' и т. П.), что еме сильнее подчеркивает связь этод сущности с указанным значением 'не рожденның' локуса "игнатьевские переулочки" .

1.2. "Переулочки" вводят представление о запутанности пути к "не вемо-што" (ср. епе в 15: "Без следочку - да в темь", а в 33 упоминание "плет-паутиночки") и упрятанности этого "не вемо-што". Многочисленность "платьиц" (3), а потом "платков" (57-58: "Уж как плотно-на-плотно Те платки запахнуты!"), перекликающаяся С многочисленностью "переулочков" усиливает упрятанность, а самому "не вемо-што" сообщает ореол углубления-умаления до чего-то невидимого, бесплотного (по принципу упрятанности и измельчания Кацеевон смерти-жизни). 10

1.3. Единственные признаки, обнаруживаюмие "не вемо-што", звук и потом свет (3: "В белохруиатых громких платьицах"; 9-10: "звоньба" и "урчба"; 5: "Свет до свету горит"; 16: "всех окошечек - семь").

Формула "Свет до свету горит" (5), сталкивая друг с другом две разновидности света, усугубляет таинственность, необычность мира и поведения обитательнишы Игнатьевских переулочков. Надлехит еще досказать, что это мир ночноя.

1.4. Очередные стихи (6-8) определяют ее как поклонницу или жрицу еще более таннственного культа.

треба - жертва, приношение. требу творить - отправлять таинство или свяменныя обряд, покоящияся на хертвоприношении. Поэтому "требу творит, Богу жертву кадит" - тавтология, усиливающая впечатление неистовости, транса (равно как и Формула "Свет до свету 
горит"). Упоминание "дуба" снимает с этого обряда церковныя христиански характер (ср. 32: "Все Христы-то где ж? - Вышедши".) и ситуирует его в рамках древнего языческого культа и колдовства (cp. 10: "заклятьице!").

Тресовать - настоятельно домогаться чего-нибудь как долхного. и если учесть, что 'требовать' восходит к древнеи 'требе=жертве' (и в данном контексте и вне его), то вся эта ситуация значительно услохняется: исполняя обряд жертвоприношения своему бохеству эта жрица одновременно взыскивает с него взаимную жертву для себя (8: "С дуба требоваит"). Заметкм, кстати, что возникшая картина удивительно согласуется с древнерими отношениями к божествам: первоначально обрамение к бохеству ('молитва') состояло из просьб и требования (проклятин-угроз) одновременно, а в случае невыпонения этих просьб-требования непослушное божество могло подвергаться серьезньм наказаниям. 11

Эквивалентность 'БоГ = дуб' (даке если здесь имеется ввиду 'голько идол, а не живое дерево) в силу оспеизвестного мифологического статуса дуба как свяменного, непосредственно связанного с небесными громами, Перунова дерева позволяет видеть в этом Боге соответствие язнческого Перуна, а шире - Громовника или Громовержца вообме. 12 А это в свою очередь значит, что цветаевская героиня по краянея мере - громопоклонница, если и вовсе не громовладъица или заклинательница громов ( $\mathrm{Cp}$. насыменность посвяменных ен стихов звуком "p" и определение ее платьиц как "громких" в стихе 3).

1.5. "Звоньба", "Запястьица!" и "урчба", "заклятьице!" - признаки колдовского заклинательного сеанса. Не трудно также предполохить, хотя прямхх указанин в тексте нет, что 'звон запястия' вызван особо ритуальноһ жестикуляциеи или пляскон.

Естественно, "Запястьица!" и их "звоньба" - в первую очередь атрибуты женскон красоты и привлекательности, соблазна. Отсюда подстрекательное "Потытан молодецка счастьица" (11), обращенное к Герою. Но звуковая характеристика героини не однородна: если "звоньба" благозвучна, возввшенна и предполагает красоту, юность, непредвзятость, то "урчба", восходя к 'ворчать' или 'урчать', подразумевает безобразное, старое, нечеловечески зловепее ('звериное"). Кроме того "звоньба" соотнесена с "запястьями", т.е. С украшениямя, а в итоге с внешним обликом героини, тогда как "урч6а" - с "заклятьем", т.е. с собственньм голосом героини й этим 
самьм с ее скрытон судностью (ср. отмеченнын в 1.2. мотив упрятанности). Иначе говоря, это - обман, опасның соблазн. Отсюда ласкательные, призванные усыпить бдительность Героя, деминутивные Формы в речи Сводницы: "Запястьица!", "Заклятьнце!", "счастьнца", "В переулочках" и льстивое "молодецка".

1.6. В пределах вводнов части поэмы (стихи 1-72) "запястьица" имеют свои соответствия в "платьицах" (3) и "платках" (57-58: "Уж как плотно-на-плотно Те платки запахнуты!"): если их рассматривать с точки зрения фольклора и народнои обрядности, то все они имеют характер волшебнод наузы и указывают на замкнутость, связанность или закованность героини, т.е. на ее причастность к царству смерти. 13

1.7. "Звоньба" и "урчба" здесь легко опознаются как обрядовын шум, сопровождаюиия магическое жертвоприношение (5-8). Упоминание "дуба", громового Перунова дерева, позволяет видеть в обрядовом шуме заклинательницы именно эквивалент громов, их имитацию, цель которов - вызвать гром небесның; этот в свою очередь подлежал бы заклятию и подчинению ее власти (так, кстати, могут читаться стихи 8 "С дуба требоваит" и потом 9, где "урчба" есть "Заклятьице ! ").

Далее: наличие "дуба" с его языческими коннотациями заствляет видеть в определения "громкие" (3), предпосланном "платьицам" определение аналитическое, самы элементарныя эпитет, т.е. читать его как исконное сводство "платьиц", как их 'громоносность' (тем более, если "платьица" - науза, временная телесная оболочка героини; см. 1.6.). То же самое наблюдается и в определения "белохрущатые" (3), с явньм наличием 'хруста, хрустения', особенно ввиду насыпенности всего образа героини звуковыми характеристиками как на уровне лексическом, так и Фонетическом. Но, заметим, 'хруст' в контексте "платьиц" не только звук, но и признак 'упругости', 'отвердения'. А это значит, что суть "платьиц" - застьвин,, так сказать, полоненны гром. Признак 'белың', вписанның в определение "б е л о хрудатые". ввиду его легкои совместимости с подразумеваемьм 'бело с н $е$ н н $\mathrm{e}$ ', подсказывает связь "платьиц" со снегом или снежными покровами (ср. гораздо позже в 108: "Сне - го - веи" и в 263: "Прохлада моя!").

1.8. В пространственном отношения героння цветаевоя пребывает "В переулочках тех игнатьевских" (4, 12, 28, 56) Как уже го-

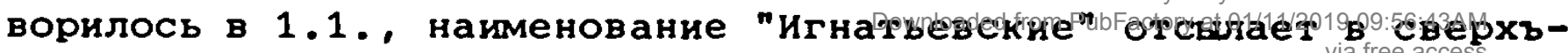


естественное, запредельное, буквально - 'не родившееся', что позволительно читать как 'извечное', 'не тварное', 'не сумее', а его связь с латинским ignis, означаюем не только 'огонь', но и 'молния' и 'огонь плоти' (как в плане эротическом, так и в плане болезненного хара), вписъвет в представление о "переулочках" признак 'жгучести', 'соблазна', 'болезни'. "Переулочки Игнатьевские" являли бы собоя, следственно, некия 'мопне-хгучия' локус, вполне согласуюшиня с 'громоносньм' характером его обитательнишы (см. 1.4. 1.7.$)$.

Что хе касается "переулочков", то теперь они обнарухивают нечто большее, чем только 'упрятанность'. В силу подразумеваемого в них признака 'застроенности', 'лабиринтности' они - вопломение так называемого подземного царства смерти. Но без строгоя локализации, ибо такое царство мохет находиться как под землея, так и з облаках. Сумественно другое, то, что, как правило, в распространенньх народных представлениях оно получает вид гор, пемер, жилим, степ, крепостея, городов и т. П., то, что там обитают демонические силы, похищаюие.и заковываюие носителея хивотворямих стихия природы (небеснут воду, небесные громы и молнии и т. П.), и то, что оно господствует над миром в период приостановки природного вегетативного годового цикла, т.е. осенью-зимон. 14

1.9. На открываюемся мифологическом уровне цветаевская героиня оказывается, таким образом, владычицея преисподнея, царства смерти, а в иньх терминах - зимнего состояния мира. Совратительное же уговаривание Героя Своднея "Попытая молодецка счастьица В переулочках тех Игнатьевских!" (11-12) - что иное как зазывание его в мертвое царство, соблазнение смертью.

Однако супность этого Героя пока никак не раскрывается. На основания его речи-вопросов и на основании даваемых ему Своднея 'инструкция' как себя вести, можно только сказать, что он прямодушен, простоват, бесхитростен, богобоязнен (9-10, 29-32. 53-55, 67-68). Но если учесть мифологическия уровень и фольклорные сюжеты, то этот Героя должен быть того же ранга, что и героиня, и являть собоя противоположное ер начало (часто скрытое под внешнея нерасторопностью, как, например, в случае ивана-дурачка).

Это значит в конце концов, что он, по краянея мере потенциально, - соответствие Громовника, которого она пытается заполонить, и которыр в свою очередь далжен победить ее, разрушить 
царство смерти и высвободить заколдованные ею хивотворямие стихии . Цветаева, конечно, решает этот архисюхет по-своему, но разбирая ее поэму никак нельзя его игнорировать. 15
2.0 .
13 Две колдобины. Пень.
14 Развалёны плетень,
15 Без следочку - да в темъ,
16 всех оконечек - семь.
17 Пока дома сидишь - подумшвая,
18 А шестое проидешь - послехивая:
19 С берехочку рыбачка юная
20 В полглазочку косит: не клюнуло-ль?
21 Дунет - костром загарит,
22 Плонет - рублем подарит,
23 Ох, башковит-красовит,
24 Дальше - язык не велит!
25 Оттого-то и в полглазочку-то
26 Сверх крутого плеча покатится.
27 На пустые слова не тратятся
28 В переулочках тех Игнатьевских!

2.1. Картина вьморочного, необитаемого места, а точнее - пути в потусторонния колдовскоя локус: путь без дороги ("Две колдобины. Пень"; "Без следочку") и в никуда ("в темь"); хилиме - не жилое ("Развалёны плетень"), "окошечко" же - не окочечко, а некая акватория (подразумеваемое равенство 'из седьмого окошка' = " $C$ бeрехочку рыбачка юная В полглазочку косит").

2.2. "Пень" - не дерево, а знак срубленного или сломанного дерева, а в мифологическом плане - знак устраненноя вертикали вверх, сообщения с верхом-небом. 16 то же имеет место в случае "развалёного плетня", с тем, что он лишен не только вертикали, но и орранительноя функани от внеинего опасного, омертоносного мира. На этом Фоне "колдобины" и "темв" в состояния глтуить смысл "провала, стуска, вниз', завершаюегося "берехочком" и подразумеваемым 'акватическим локусом'. Традиционная длительность-далекость пути исчисляется тут "окошками": "Всех окошечек - семь". В контексте "провальноя' лексики "окошка" тоже могут рассматриваться как 'проваш', а их линеяная выстроенность в один ряд (ср. "шестое проддешь - послехивая") приписывает им смысл очередных этапов 'спуска'. 17 "Oкоико" предполагает 'избу', некое помещение, откуда следовало бы, что спуск ведет через (или вдоль) семь локусов, семь сфер ("Всех окошечек - семь").

\section{"Семь" - и мифологическое и чисто цветаевское структурное} число, покоящееся в основе мироздания. В других вемах цветаевон

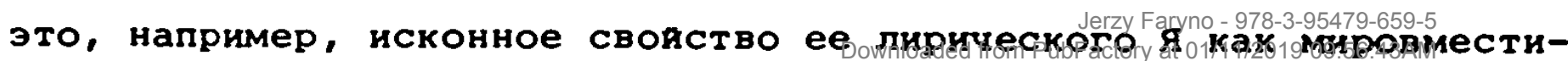
лища и как сплошного потока перевопломения lсD. " "нo 
я пришла домоя..." - 13 мая 1918, СиП II, с. 21 - из цикла "Психея": "я - страсть твоя, воскресны отдых твоЯ, Твоя день седьмоя, твое седьмое небо"; семь змеиных шкур в "Здравствун! не стрела, не камень..." - 25 июня 1922, СиП III, С. 17: "я сегодня в новов шкуре: Вызолоченноя, седьмон!"), семь воздухов как семь сфер бытия и абсопотное свяменное "Семь" (в "поэме воздуха" - весна 1927, Сип IV, с. 284: "Семь- heilige sieben! Семо - в основе лиры. Семо - в основе мира"), семь небес и аналогичньх им есмь покоев подземного царства (Ср. в "царь-девице" - 14 июля- 17 сентября 1920 , Сип IV, С. 39: "Семь небес у Девы Чистон, у царицы - семь покоев") и т.

Таким образом, данные "семь оконечек", предполагаюине представление о 'избах', - несомненно, эквивалент "семи покоев" мертвого подземного локуса Цветаевскои царицы-смерти, тут именуемон "рыбачкоя юноя", и не исклочено, что они также эквивалентны самои этой "рыбачке", т.е. что и она мыслится здесь как л о к у с.

2.3. Наименование "рыбачка" отсылает к акватическим демоническим сумествам типа народньх русалок. Тем более, что 'косямия взгляд' и 'полуоткрытость плаз' ("В полглазочку косит") - не только признак игривости или соблазна, но и определение демонического статуса этого персонаха. С однод стороны, "В полглазочку" и "косит" - пограничное полохение мех реальностью (жизью) и потусторонностью (смертью), а с другон - признаки опасного, присущего демоническим силам (ср. возмохность видеть 'опасение' в обрыве речи Сводни: "Ox, [...] Дальше - язык не велит!") .

Ассоциация с русалкон определяет только пограничның статус героини, но не больше. Наяменование ее "рыбачкои" показывает, что Цветаева руководствуется иными коннотациями и отсылает к народньм представлениям грозовых туч и гроз как рыбноя ловли. 18 иначе говоря, "рыбачка" - вариант громовладыиицы (см. 1.4. и 1.7.), а ее акватория - мертвая вода.

$$
\text { 2.4. "Дунет" и "Плюнет" (21-22) - здесь }
$$

контамннация Фольклорных коммуникативных формул "взглянет..." и "молвит..." и противокоммуникативных колдовских жестов (например, изгоняюиих или заворахиваюиих хворь в заговорах) .

"Костер", несомненно, продолхение предыдудеи неявноя жгучести-громоносности Ведуньи, а "рубль"-'слюна' ("плюнет - рублем подарит") - предидмея акватичности. В контексте громоносности "Плю- 
нет" или 'слюна' вполне закономерно воспринимаются как соответствие дохдя, а "Дунет" и особенно "костром" - как соответствие ветра-молния. Однако данның 'дождь' - не влага, а "рубль" (вероятнее всего - золотоя), т.е. некия отвердевшия, застъшия докдь, что значит, что это не столько дохдь, сколько снег. При таком вэтяде палин "костер" - не что иное как соответствие жгучего мороза. Все это не снимает с Ведуньи ее обольстительнон прелести, а только усиливает ее и приоткрывает истинную супность Ведуньи как влащичицы мертвого заво (мо) рахиваямего царства (см. 1.7.).
3. 0 .
29 А вояти-то как? - Выходом.
30 А речи-то как? - Выкрутом.
31 А на што мне креститися?
32 Все Христы-то где ж? - Вкшедия.
33 на плет-паутиночку
34 Крестись без запиночки!
35 Смекаи, мол, детинуика,
36 Своя здесь святынишка.
37 Занавес-мон - занавес!
38 мурзамецкин мо отрез!
39 पасть-рябь-слепь-резь!
40 Мне лица не занавесь!
41 Погоди, молодец, успеется!
42 Чай не диво како под пологом!
43 На князъке вороные голуби
44 В ползобочка воркуют до-люби:
45 про белье плечи,
46 Которых не смети,
47 Про сладкие смеси -
48 Потом не жалети...
49 Про неги, про лести,
50 зеленые листья,
51 Про яства - не ести,
52 Орешки - не грыэти.
53 А еме, молодец, не тупиться!
54 Али К чаше-идеиь-причастьицу?
55 Прямо в очи глядят, - не застятся
56 В переулочках тех Игнатьевских!

3.1. Картина наоборотного демонического мира и заклинательная формула входа (37-40). На последнея целесообразно остановиться, так как она вводит ряд существенных, развиваемвх позже, смыслов.

3.2. "Отрез", будучи иным наяменованием "занавеса", означает 'кусок ткани'. Но, рифмуясь с "резь", субстантивированнон отглагольной формой от 'реэать', он выдвигает на первое место свою связь с 'отреза́ть' и в результате становится синонимом "занавеса" 
по признаку 'резкого разграничителя', 'порога, границы' мехду двумя принципиально разньми сферами бктия (а осторохнее - пространства.

3.3. "Мурзамецкия" , подобно упоминаемқм позхе "шемаханским парусам" (127-128), - разновидность тонких восточных шелков. Шелк же в цветаевскоя поэтическоя системе занимает место предела истончения плоти, последнея, так сказать науэы, сдерхиваюмеи бытие в неких обособленных очертаниях, предела, за которым сущность разрешается акватическим потоком (слезами, ливнем, ручьями и Т. $\Pi$. вечных внутренних вод), 19 происходит, как в "Поэме воздуха" (Сип IV, 282), "Старая потеря Тела через воду".

3.4. Все эти смысыы содерхит в себе образ "зандвес" Он граница мехду хизнљю и потусторонним бытием. В частности, как в стихотворении "Занавес" (23 июня 1923; Сй III, 83), он - 'водопад', 'пена', 'пламя', 'хвоя', 'рацуга' и 'Сновиденның лес' "Сонных снадобия, трав, зерн...", т.е. сфера забвения, забытья. Более того: занавес - вариант цветаевского "я" и граница, за которои ренается судьба ее "ты", разытрывается самы глубокия цветаевския сюхет: "занавес" - я"; "Я скрываю героя в борьбе с Роком, место деиствия - и - час".

3.5. В этом контексте форма "Занавес-мои" (37) вводит тождество Сводни, Ведуньи и авторского "я" и сообщает им статус локуса, иноЯ, глубинноя Формы существования мира. На Формальном уровне это единство вырахено полноя неопределенностью субъекта речи: до стиха 42 речь исходит как бы только от Сводни, стихи 43-52 мохно читать как исходямне от внешнего повествователя, но тут же (53-56) опять подхваченные Своднея, а стихи 61-64 без всякого делимитатора являют собон 'внутреннюю' речь самоя Ведуньи. 20

3.6. В этом хе контексте заклятье "Мне тица не занавесь!" (40) - предотвращение опасности остаться по стороне оформленноя материальноя хизни, остаться обособленно ипостасью. 21 не исключено такще, что тут имется ввиду и древнеславянския брачның обычан: девушка, на голову которой удавалось парню набросить платок, становилась его хеноя. 22 тогда это заклятие говорило бы о том, что Героя заманивается под полог не с брачноһ целью.

3.7. Имитируюиее магическую заумь "часть-рябь-слепь-резь! " (39) - вовсе не бессмыслица, хотя не все ее компоненты вычитываются из данного контекста. "Часть-", подобно Форме "резь", - от- 
глагольное существительное от 'частить', которое одинаково ассоциируется как с 'дрожью', так и с 'дохдем' Последнее очевидно: это - экспликация акватическои потенции "занавеса" и "мурзамецкого" 'шелкового' "отреза", еме более явственная в форме "-рябъ", означающея волнующуюся водную поверхность. 'Дрожь' же получит свое развитие несколькими стихами поэже в виде "лихоманки" (62, 71-72), "зноби" (70) и эротическоЯ внутреннея напряженности (64: "В теле жилочки гудут!"). 23

"-Рябъ", сохраняя в себе смысл 'дрохи' и 'воды' (ср. пляску царишы в "царь-девице" - СиП IV, 62-63: "Та - рябь рябит, Плечьми дрохит. [...] Та - пруд-река, колеблет бока. [...] Он, рябь! Он, зыбь! Oम, жар! ОЯ, хлад!"), подводит к следующему компоненту "-слепь" своен связью с 'рябить в глазах' или 'частить в глазах', означаюиих 'терять четкость очертания' и 'терять способность четкого видения', 'слепить, резать глаза'.

"Резь!" - 'боль', но и 'резка', а после "-слепь" - 'боль в глазах от ослепительного света'.

В итоге вся эта Формула "Часть-рябь-слепь-резь!" - Формула ознобного обморока, отклочения от мира сего, в одном плане, а в другом - Формула цветаевского 'за-занавесного', потустороннего континуума: от предельно истонченноя плоти-ткани ("часть-" как "отрез" ='шелк'="занавес") через акватическия поток до ослепительного света и не-бытия. 24

3.8. Воркующие "вороные голуби" (43) с их локализациеи "на князъке" как на стыке двух противоположных царств, т.е. царства жизни и царства смерти, - соответствие мифологических молние-громоносных птиц, гнездяпихся по краям туч, которые либо спровахнвают живоя небесның огонь на земпю (в частности, опекая домашния очаг), либо предохраняют человечекое жилище от грознои стихии огня. 25 но Цветаевские "голуби" - "вороные" (т.е. темные) и воркуют "В ползобочка", что можно читать как промежуточное полуактивное неразбуженне оостонне небесно громоносноЯ стихии. А выбор "голубея", вместо более неитратыьх "птиц" либо вещих и так же громоносных "воронов", подключает весь этот образ к представлению о нежнон небеснои любви и О противостояпем ея губительном коварном соблазне Ведуньи (явствуюием из предупрехдения в 45-52).

Факт же, что предупреждения голубен адресованы Герою (ср. ене в 87-88 слова Ведуньи, обраменные к нему же: "Голубеи вверху 
Не слухать"), свидетельствует о его причастности к общему с голубями громоносному небесному началу (см. $1.9 . ;$ ср. еме в $31-32$ его христианскую приверженность) .

Предупрехдения голубен построены по образцу сказочных доброжелательных советов-запретов, несоблодение которых влечет за собод гибель героя: оцепенение, забвение, сон, смерть (попутно отметим, что "зеленые литья" в 50 и "орешки" в 52 выводятся из "занавеса" как 'леса' "Сонных снодобия, трав, зерн...", а "сладкие смеси" в 47 иэ акватических свонств того же "занавеса" - см. 3.4. и 3.7.). 3.9. Обрамение "молодеи" (ср. 1-2, 11, 35 и 41) и весь лексическия и синтаксическия стров стихов 53-56 демонстративно повторяет уговаривание Сводниноя речи (ср. 11-12 и особенно 27-28). В случае Сводни "А еще" продолхает ее подсказки и Фактически должно следорать после стихов 41-42, но синтаксически оно уместно и после голубиного перечня запретов, особенно ввиду формальноя тохдественности отрицанин (ср. "не смети", "не жалети", "не ести", "не грызти" и потом - "не тупиться!", "не застяться [...]!" с убехдаюме-приказательными интонациями помеченными восклицательными знаками). Это значит, что здесь состоялся превратны перехват голубиного предупрехдающего воркованья и его поддельное продолжение Своднея. Совет-требование глядеть "Прямо в очи" (55) покоится в свою очередь на фольклорном запрете смотреть в глаза чудовиму, ибо такое смотренье наиболее опасно и губительно пля героя. 26
4.0 .
57 Уу как плотно-на плотно
58 Те платки эапахнуты!
59 Яблочками, яхонтами
60 Улемает, шахматами.
61 (От моих горячих губ -
62 Лихоманочки идут!
63 От монх горячих губ -
64 В теле жилочки гудут!)
65 шахматами, яхонтами...
66 Уста мои сахарные,
67 Совсем еме матупкиным
68 Молочишком пахнете!
69 (Разумяниста моя
70 Знобь-Тумановна!
71 Лихоманочка моя
72 Лихомановна!)

4.1. Субъект речи размыт до неопределенности, особенно в случае стихов 57-60. Это слова могут принаплехать как внешнему повествователо (тогда с оттенком иэумленно-тревожноя интонации), так 
и Сводне (тогда с оттенком разхигаюмим любопытство Героя). Но самое сумественное, что и в одном и в другом случае они передают также впечатление Героя и определяют его как в $о$ w $е$ д ш e $\Gamma$ 。 и В

Вместо "В белохруматьх громких платьицах" (3) Ведунья видится теперь Герою плотно закутанною в платки. Первы образ - соблазняющее описание Ведунъи Своднеи, этот - Фактически представши перед Героем. Будучи обликами Ведуньи они не противоречат друг другу, а всего лишь указывают на отдельные ее свонства. Первы на громоносность. Второя - на смертоносное начало: закутанностьзапахнутость - признак связанности и, этим самы, смерти (см. 1.6.); кроме того "платки" - признак зрелости-старости (в отличие ст прехних "платғиц" - признака юности; ср. 1.5.) и намек на погребальную пелену (ср. позже в 223-226, где речь идет о поминальных льнах, и 305, где говорится о саване).

4.2. Аналогичная семантика стоит и за набором Ведуньиных "улещения"-соблазнов. Перечисление одним залпом яблок, яхонтов и шахмат, конечно, призвано создать впечатление недоступного разуму магического денства, но тем не менее оно удерхано в рамках строгои логики, а не поверхностная имитация. Все три "улеменья"-соблазна равноценны, одноранговы, с явно снятыми категориабықм различиямя мехду ними, что еще прочнее увяэєпает их с демоническим подземньм миром.

4.3. "яблочки" - символ губительнои страсти и опасного для героя запретного смертоносного плода. В частности, попав в один ряд с "яхонтами"-камнями, они уже не могут читаться как сказочные молодильные яблоки, а как яблоки мертвые; 27 попав же в однородның ряд с "шахматами", они не столько "яблоки" сколько хитроумная игра, коварныя подвох.

4.4. "Яхонты" - опасные обманчивые подземные самоцветные камни. Функционируя как украшения, они могут ассоциироваться тут еме и с охерельем как атрибутом скованности, связанности-смерти. 28 Принадлеха земле, миру подземному, они включают в себя представление о 'глубине' (ср. В 292: "Глыбь-яхонтовна") и могут читаться как противополохның полюс "яблок", ассоциируюцихся с "раем" и через него с 'высью' (ср. 73-78). "яблоки" и "яхонты" образовывали бы в этом случае вертикальную ось мироздания, но внутренне не дифФеренцированную: и 'глыбь' и 'высь', и 'подземныя мир' и 'рай' 
- проявления одного и того ше потустороннего мира, а их мнимое различие имеет свое целью только передать представление о его беспредельности (ср. В 290-293 объединение в недифференцированную "Лазорь" всех мнимых пространственных стратификация: "ВысьЯстребовна, Зыбъ-Рануговна, Глыбь-Яхонтовна: Лазорь!") .

4.5. "шахматы", в свор очередь, - игра, которая и в случае более типичных для фольклора карт, предполагает или игру некоен высшен силы судьбами фигур-людея или же игру с самон этон силоя, т.е. С судьбон, с собственноя жизнью-смертью, с вечностью.

В поэтическои системе цветаево игра и шахматы устончиво соотносятся с представлениям о плутовстве, о деноническом начале, - смерти. Ср. хотя бы следуюшие контексты: "Пятистише" (1919; (иח II, 267) -

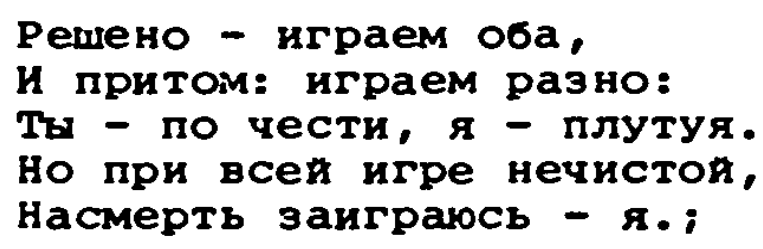

"Поэма горы" (1 января - 1 февраля 1924; СиП IV, 163), где гора

Еще говорила, что это демон

Крутит, что замсла нет в игре.;

"Поэма конца" (1 февраля - 8 июня 1924; СиП IV, 175 и 180) -

- Так первая? Первын ход?

Как в шахматы, значит? Впрочем,

Ведь дахе на эшафот

Нас первьми просят...

[... ]

Так смертники ждут расстрела

В четвертом часу утра

За шахматами... Усмешко

дразня коридорның глаз.

Ведь шахматные же пешки!

и кто-то играет в нас.

Кто? Боги благие? Воры?

Во весь окоем глазка -

Глаз. Красного коридора

Лязг. Вскинутая доска.

[...]

... По сим тротуарам в шашку

Прямая дорога: в ров

и в кровь. Потанное око:

Луны слуховон глазок...

Факт, что в "Переулочках" шахматами "улемает", т.е. инициирует шахматную партио, Ведунья, в приведенном контексте однозна-

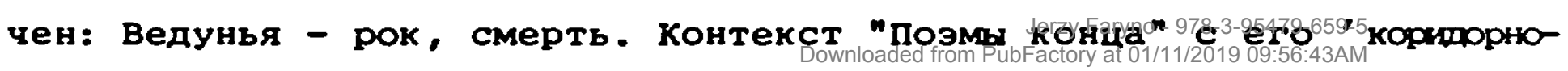


тротуарнон" трактовкон шахмат и шахматноң доски позволяет видеть аналогичнуо подспудную связь мехду "шахматами" и "переулочками" а такхе между "шахматами" и "занавесом" ("Вскинутая доска" в "Поэме конца" - не только конец партии, но и открьваюинся ход в смертв) .

В самоя же поэме "Переулочки" появление соблазнительных "шахмат" мотивируется как исходноя задачея Героя (стихи 1-4 с их намеком на формулу "Поди туда, не знаю куда, принеси то, не знаю что" - см. 1.1.; стих 11: "Попытая молодецка счастьица"), так и глубинным смыслом Цветаевского "занавеса", скрываюего за собо "героя в борьбе с Роком, место денствия - и - час" (см. 3.4.).

В отличие От "Поэмы горы" и "Поэмы конца", где некие высшие силы ("демон"; "Боги благие? Воры?") играют героями-"пешками", здесь игра в шахматы передана самим этим героям (как в "Пятистишия"). А это значит, что эти герои возведены тут в ранг наивысших сущностея, что она происходит в сфере запредельного и что эта игра есть архисюхет, a не его производны вариант более низкого уровня (т.е. не его разыгрывание - ср. постоянные усилия героев "Поэмы горы" и "Поэмы кониа" интерпретировать происходямее с ними в терминах архисюхета и видеть во всем реплики высшего, тогда как "Переулочки" в такои перекодировке уже не нуждаются, что и производит впечатление их невнятности, их "заумного характера") .

Поднимаясь на уровень своего архисюжета, Цветаева, вероятнее всего подсознательно, т.е. как исконның носитель культуры, 29 поднимается одновременно на уровень культурного архискхета и, не повторяя его, во многом С ним совпадает. Так, упоминание "дуба" (8), "яблочков" и рядом с последними "шахмат" - отнюдь не имитация народности и не подделка колдовскон "зауми", а однородның ряд взаимоэквивалентных овнешнения идеи 'мирового древа' или 'древа познания'. "Шахматы" подключаются к "яблочкам" и по признаку 'соблазна' (как игра), и по признаку 'познания' (как интеллектуальная игра), и по признаку 'универсальноя модели мира': во многих архаических представлениях шахматы - соответствие мирового дерева, С одноң стороны, и с другои - соответствие исходного поединка черного и белого, женского и мужского, смерти и жизни. 30

и последнее замечание. Если согласиться, что "яблочки" и "яхонты" образуют вертикальную ось мироздания (см. 4.4.), то В "шахматах" позволительно усматривать ее горизонтальную проекцию, 
плоскость, на которон разыгрывается основнон сюхет. Вряд ли случаяно в стихе 65 цветаева вводит обратную последовательность: "шахматами, яхонтами...".

4.6. Учитывая все излохенные коннотация, естественно закичит, что за такоя последовательностью стоит намек на проигрьл Героя, на то, что он поддался соблазну и заманивается теперь в глубь ("яхонты" как соответствие 'глубины' - см. 4.4.) и увлекается в бесконечность (ср. вместо подразумеваемых под многоточием "яблочек" обрыв и переход $к$ сладострастному губительному поцелую, уводямему в "рап", т.е. ввысь). отсода, по всен вероятности, сюхет остальноя части поэмы построен не по принципу борьбы противостоямих начал, а по принципу увода-пути.

4.7. Стихи 61-72, за исклочением, похалуи, стиха 65, - речь Ведуньи. Стих 65 же мохно читать и как рече-деяствие Ведуньи, завершацееся поцелуем, и как чисто нарративны, и, наконец, как ставяши на точку зрения Героя (но тогда следовало бы ожидать и его противоденствия, но это едва ли оправдывается дальнеңшм ходом поэмы) .

Графическое (пунктуционное) оформление даннон речи разбивает ее на два параллельных (одновременных) уровня. Если стихи 6668 могут расцениваться как произносимое вслух и сльинмое, то взятые в скобки 61-64 и 69-72 - как подразумеваемое под "улемениями", Т.е. как неслишмое, как произносимое или знаемое про себя. Такое удвоение дает полнья, стереоскопны, образ Ведуньи: показьтает ее как с внешнен, обманчивон стороны (57-60, 65-68), так и с внутреннен, истинноп или сущностноһ. За таинственноЯ "закутанностью" (57-58) и эаманчивыми "улемениям" (59-60) стоит буквальная 3 а М а н ч и В О С Т ь: автонаяменоване Ведуньи "Лихоманочка" содержит в себе 'манитьллгать, обманывать, заманивать', с однон стороны, и 'манья'=привидение в виде старод тщедушной женщины 31 (ср. второе наяменование Ведунъи в 70: "Тумановна"), и "лихо-", указываянее на ее злонамеренность, на ее вредоносность. Но это не все. 4.8. "Лихоманочка" (62, 71-72), "знобь" (70), 'жар губ' (61, 63) и 'разрумянистость' (69) - признаки и опасного болезненного состояния (лихорадки), и предельно напряхеннон эротическон страсти (61, 63: "От моих горячих губ" = От их прикосновения-поцелуя; и подразумеваемы поцелуя в 66-68). Серия "Лихоманочки" (62), 
нечно, читаться как набор синонимов, отобрахаюми колдовское бормотанье ("урчбу" в 10), но она отнодь не произвольна, а подсказана цветаевон народньми верованиями.

Согласно последним, существует девять или двенадиать демонических сестер-лихорадок, которые объчно сидят в снехных горах или подземньх адских вертепах и, выходя оттуда к весне, с началом оттепелея, они при помоми всяческих уловок - в часности прикидпаясь целующими девами - завладевают людьми и начинают их трясти, ломать, жечь и т. П. Они имеют свон имена: 1 - трясея, Потрясуха, трясца: 2 - огнея; 3 - ледея, Озноба, Знобея; 4 - Гнетея; 5 Грудея; 6 - Глухея; 7 - Ломея; 8 - Пухлея; 9 - Желтея; 10 - корчея; 11 - Глядея; 12 - огнеястра, Невея (от нава=смерть или навье=мертвец) . По материалам Афанасьева "невея (мертвямая) - всем лихорадкам сестра старепшая, п л я с а в и ц $а$, ради которои отсечена была голова Іоанну предтечи; она всех проклятье и если вселяется в человека - он уже не избегнет смерти". 32

В этом контексте стихи "От моих горячих губ - Лихоманочки идут!" (61-62) могут теперь читаться как указание на то, что данная Ведунья соответствует самои главнои лихорадке - Невее. Ср., в частности, мнохественное чнсло лихоманок исходямих от ее губ, а потом, в стихах 205-206, упоминание двенадцати мук; кроме того не исключено, что в Формуле "не вемо-што" (стих 1), играюмей роль эквивалента табуированного имени, заанаграмировано именно имя невея, еще более явственно проступающее в стихе "А - и - вен!" (74). 33

Еще отчетливее сущность Ведуньи как олицетворения превратнод сладострастно Невеи-Смерти раскрывается при помоми патронимов насылаемых ею лихорадок: "Знобь-тумановна!" (70) связывает Ведунью с туманом, т.е. морб́кон или мб́роком, а этим самьм - со смертью, 34 а "Лихоманочка моя Лихомановна!" (71-72), особенно ввиду тавтологин, - с лихорадкои как таковоя, с ее исконноя 'лихоманноя' сущностью.

4.9. На событинном же уровне "Знобъ-тумановна!" и "Лихоманочка моя Лихомановна!" - уже не столько персонахи или ипостаси Ведуньи, сколько состояние, в которое ввергнут Герон: состояние всеобъемпюего помрачительного озноба-соблазна (63-64: "От моих горячих губ - В теле жилочки гудут!"; 69-70: "Разрумяниста моя Знобь-тумановна!"). Иначе говоря, путь Героя заверпается в этон части поэмы состоянием знобяне смертоноснои страсти. 


\begin{tabular}{|c|c|c|}
\hline \multirow[t]{5}{*}{5.0} & $\begin{array}{l}73 \\
74 \\
75 \\
76\end{array}$ & 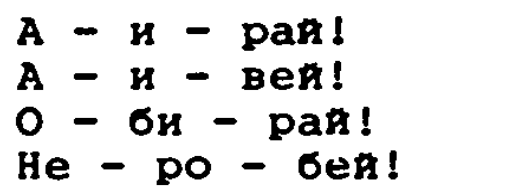 \\
\hline & $\begin{array}{l}77 \\
78 \\
79 \\
80\end{array}$ & $\begin{array}{l}\text { яблок - яхонт, } \\
\text { яблок - злато. } \\
\text { Кто зачахнет - } \\
\text { Про то знато. }\end{array}$ \\
\hline & $\begin{array}{l}81 \\
82 \\
83 \\
84\end{array}$ & $\begin{array}{l}\text { яблок - лесть, } \\
\text { яблок - ласть. } \\
\text { Рук за пазуху } \\
\text { не класть. }\end{array}$ \\
\hline & $\begin{array}{l}85 \\
86 \\
87 \\
88\end{array}$ & $\begin{array}{l}\text { Зорким - слепость } \\
\text { чутким - глухость. } \\
\text { Голубея вверху } \\
\text { Не слухать. }\end{array}$ \\
\hline & $\begin{array}{l}89 \\
90 \\
91 \\
92\end{array}$ & $\begin{array}{l}\text { Робким - плеть, } \\
\text { Дерзким - ласть. } \\
\text { Глазком яблочка } \\
\text { Не красть! }\end{array}$ \\
\hline
\end{tabular}

5.1. Построенны по оразцу колдовского заговора "соблазн [...] 'яблочками'" (СиП II, 380). Стратегия соблазна здесь очевидна: захваливание "яблок" (73: "А - и - рая!"; 77-78: "яблок яхонт, Яблок - злато"; 81-82: "Яблок - лесть, Яблок - ласть"), подталкивание и подбадривание к деяствию, т.е. взятию "яблока" 175-76: "О - би - рая! не - ро - бея!"; 89-90: "Робким - плеть, Дерзким - ласть") и сиюминутные, разжигающие страсть, воздерживающне и подталкиваюине двусмысленные приостанавливания запретами 183-84: "Рук за пазуху Не класть"; 91-92: "Глазком яблочка Не красть!") . Колдовскоя хе, заклинательны характер этого соблазна состоит в заворахивания или отключения чувств, связывающих Героя С реальностью: зрения (85: "Зорким - слепость"), слуха (86: "чутким - глухость") и сообрахения, рассудка, трезвости ума (87-88: "Галубея вверху не слухать", где "слухать" не столько 'слушать', сколько 'внимать', 'поступать согласно их советам' - ср. 45-52: "не смети" прикасаться к бељм плечам, сладким смесям; "не ести" явств, "не грызти" орепков).

$$
\text { 5.2. Скандированные "А - и - рар!" (73), "О - би - рая!" }
$$

и пятикратное упоминание "яблока" $(77,78,81,82,91)$ однозначно вводят смал 'рая', 'раяского сада', раяских яблонь и яблок (рифмованныя слог "pan!" в 73-75; "О - би - paя!" совпадает с глаголом 'обирать' = 'снимать с деревьев плоды') со всеми их библеискими и Фольклорными коннотациями, кстати, отчетливо экспо- 
нирующимися в стихах 77-80, где указывается на связь яблок со смертью и жизнью (с Фольклорными "мертвьми" и "молодильньми" = = 'охивляюмими' яблоками: "Кто зачахнет - Про то знато"), и в стихах 81-82, где в свою очередь доминирует связь с соблазнительноһ, эротическои семантикои яблок ("яблок - лесть, яблок - ласть", где "ласть" восходит $k$ 'ластить' = 'ласкать, улемать'; сюда же мохно отнести и второи смысл в словах "Кто зачахнет" 'любовнои тоски' и вписываеми поэтому в "яблок" смысл приворахивающего средства; $\mathrm{cp}$. еме в "царь-девице" - СиП IV, 64: "Плоть ли бабця аң Просто яблонь-ман? Бабья пазуха - Али Божия рая?"). И тем не менее все это только основа для более "Цветаевских" категория 'рай' и 'яблоко'.

5.3. 'Ран' здесь не только некия локус, но и состояние вменяемое Герою и наводимое на него. Ср. возмохность прочтения инициального "А - и - рая!" как повелительнои глагольно Формы в контексте трех остальных явно глагольных Форм.

"А - и - вен!" - вводит представление о 'ветре-воздухе'. Если это повелительны глагол, то он может читаться двояко: как превращение Героя в пневматическую струю, в лишаемую тела душу (иначе: тут имело бы место отвеивание души от тела, соглашанщееся со смыслом сбора плодов в "О - би - раи!"): 35 как эквивалент глагола "о - би - ран!", т.е. 'вея отряхивая, колоти яблоки' (ср. дополнительно наличие вычлененного слога "бен" со смыслом 'колотить, обивать" в "не - ро - бея!"). Если же это существительное, то оно может читаться как мухскоя вариант 'невеи' или 'навья', т.е. обитателя потустороннего мира, царства умерихх.

Так или иначе, данны "рая" содержит в себе все признаки народного ирия - потустороннего локуса душ усопши. А если Герои здесь и не некто погибши, то во всяком случае принципиально отключаемы от своен физическо телесноя формы бытия и погружаемы в состояние забытья (ср. 85-88).

Если же учесть Цветаевския контекст и многоступенчатость ее мироздания (ср. в "новогоднем" - 7 февраля 1927: СиП IV, 276: "не один ведь рая, над ним другоя ведь Рая? Террасами?"), то данның "ран", особенно при наличии формы "-вея", позволительно читать как соответствие первоп степени отсечения от земного бытия, первоя степени смерти. 36

Как "рая" - иносказательное имя первого состояния смерти, так 
"яблок" - иносказательное чмя нанболее поверхностнон сунности Ведуньи: прельмаюмея Героя "лестью" и "ластью" (81-82, 90). Хотя ухе и здесь просвечивает ее более глубокая вторая сущность: коварның обман-соблазн, подразумеваемы под лестью, и змеиное пагубное начало, кроющееся под "ластью", где из-за необтиности усеченнои формы на первое место выдвигаются ее связи не столько с "ластить" = = 'ласкать', сколько с "ластить" = 'конопатить', т.е. с лодочньм делом, а этим самьм с женским началом и смертью, а с другон стороны - с "ласть" = 'лапа' (чаме всего передняя) водного животного, морского зверя. 37

\begin{tabular}{|c|c|c|}
\hline \multirow[t]{3}{*}{6.0} & $\begin{array}{l}93 \\
94 \\
95 \\
96\end{array}$ & $\begin{array}{l}\text { Как за праву-то рученьку } \\
\text { Хлест да плеск! } \\
\text { Вместо белод-то рученьки } \\
\text { ямєров хвост! }\end{array}$ \\
\hline & $\begin{array}{r}97 \\
98 \\
99 \\
100\end{array}$ & $\begin{array}{l}\text { Как за леву-то рученьку } \\
\text { Схватит - хляст! } \\
\text { опалелон гадюченькоя } \\
\text { В левы глаз! }\end{array}$ \\
\hline & $\begin{array}{l}101 \\
102 \\
103 \\
104\end{array}$ & $\begin{array}{l}\text { Пояском через плечико } \\
\text { Хочет - клек: } \\
\text { Раю-ранскою реченькоя } \\
\text { Шелк потек. }\end{array}$ \\
\hline
\end{tabular}

6.1. Первь поединок Героя С Ведуньен или, по словам Дветаевон, первая попьтка разрушения чар (СиП II, 381). Справиться С Ведунье Герою, естественно, не удается: она видоизменяется, преврамаясь в "реченьку" (103-104), и увлекает за собон Героя епе дальше, на более глубокин уровень бытия (или, точнее, - небытия).

6.2. Преврапение Ведуньи в "ящера" и "гадюченьку" (96, 99) закономерно: это одна из ипостасен властительницы мертвого царства (ирия, "рая") и соблазнительного "яблока" (ср. 82: "яблок ласть" и 5.3.). Так же закономерно, хотя на первын взгляд и менее очевидно, ее преврамение в "реченьку", в акватическин поток.

6.3. На уровне стиховон Фактуры "реченька" подготовлена прехде всего троекратным повторением "рученьки" (93,95, 97) и сопутствуючими звуковыми характеристиками 'вплеска': "Хлёст да плёск!" (94; ср. еме 122: "Ръбка - плеск"), "хляст!" (98), "клек" (102).

На лексическом уровне "реченьке" предшествуют: "С берехочку рыбачка юная" (19), "плонет" (22), "Занавес-мои [...] мурзамецкия" и "часть-рябь-" (37-39; см. 3.3., 3.4., 3.7.), "сладкие смеси" (47). "Али к чаше-идешь-причастьицу?" (54), "Знобь-тумановна!" (70), "яблок - ласть" (82; см. 5.3.), "плеск!" (94), упоминание 
"молочишка" (68) и морфема "-ран" (73, 75, 103; о ее связи с водон См. 8.6.).

На уровне Фольклорньх коннотацин "реченька" может мотивироваться как упоминанием "платьиц" (3), так и "платков" (58), которые обычно трансформируются в скаэочном мире именно в водную стиxหro.

6.4. Но самы существенны здесь, конечно, уровень мифологических коннотацин. Разбор стихов 3-12 показал, что Ведунья являет собои владычицу подземного царства, похищаюую и порабомающую животворящие силы природы, т.е. небесные громы и небесную воду. В этом смысле она равносильна космнческому похитителю громов и.вод известному во всех индоевропеяских мифологиях под видом Змея. Поэтому было бы более странно то, если бы данная Ведунья не обнаружила своеи змеинои и акватическон сущности, нехели ее трансформация в "ящера", "гадюченьку" и "реченьку", которые только последовательно поднимают ее на все более универсальные уровни.

Тот же разбор стихов 3-12 поэволял предположить, что данның Героп долкен быть каким-то образом соотнесен с самим Громоверхием. теперь это почти уже очевидность:Ведуньин шелк-науза проливается водоя в момент удара "пояском", т.е. в момент соответствующи громовому удару 38 - ппояском через плечико Хочет - клек: Раю-ранскою реченькон Шелк потек" (101-104). Удар, правда, еме не состоялся ("Хочет", но - "клек"), Героя только замахнулся, а Ведунья успела обернуться "Раю-раяскою реченькон", т.е. принять ипостась соблазнительных потусторонних вод.

6.5. Тако поворот сохета проливает определенны свет на инт тенцию цветаевоя. Ведунья, в отличие от Змеев в зказочных поединках, ведет себя, так сказать, пассивно, она только иэворачивается и этим самым провоцирует активность ('разжигает') своего противника, вынуждая его выявить свою сущность и увлечь за собон. забегая вперед, скахем, что собственную активность она проявит лишь после второго поединка (со стиха 207).

7.0.
105 А - ю - ран,
106 А - о - рея,
107 об - ми - ран,
108 Сне - го - вен.
109 чеснок - яблочку
110 Неровня.
111 Аю-раюики
112 Раевна.


7.1. Стихи 105-108 построены по принципу переназывания, что ведет к сплошно синонимии лиш с минимально внутреннер смысловоя градациея. Если "рая" предполагает, как уже говорилось, потустронния локус душ усопших, то "А - ко - раң" и "Об - ми - раң" разнятся лиш очевидностью их связи со смертью и еме, быть мохет, степенью заговаривания или погружения Героя Ведуньеи в смертное состояние.

"A - 0 - рея" ввиду эатемненности морфемы "A - 10 -" заставляет домннировать морфему "- реи" и читать ее как повелительнут глагольную форму от 'реять', которое значит: "плавно стремнться, быстро нестись или течь, лететь, падать", 39 а также 'плыть, валиться, погрухаться'. Это значит, что "А - 10 - рей родственно "Об - мн - ран" из-за общности признака 'впадать в (бесчувственное, бессознательное состояние') и родственно форме "Сне - го вен", где сочетаются оба признака двихения: падения (по связи со 'снегом') и парения (по связи С вычлененньм "- вен", напоминаюиим - стихе 74 "А - и - веи" и этим самвт включаюинм ассоциацию $C$ 'веять' и, что уке отмечалось в 5.3., с 'навьем') .

Короче говоря, здесь осушествляется очередное заклинание Героя, погрушаюmее его в обморочное - "Об - мн - рай - и, так сказать, зимне-сонное, 'замороженное' состояние - "Сне - го - веи", где кроме связи со снегом слоговая разбивка предполагает еме и связв слога "Сне -" со сном. 40

7.2. Помня о "белохруматых громких платьицах" Ведуньи (3; см. еме 1.7.) и о возмохности читать "знобь-" (70) не только как 'жар', но и как 'холод', в форме "Сне - го - вен" (108) правомерно видеть заклинание Ведуньеи громоносноя стихии. Кстати, кроме 'снега' имеются здесь и другие отсылки к мифу о Громовнике.

С однон стороны это созвучие "А 106) С именем Грия (Егория, Георгия), получившего в народноң традиции основные признаки прехнего бога-громовнико и олицетворяющего хивотворяпие сиы весенне прирошы. 41 с другон - чеснок (109-110: "Чеснок - яблочку Неровня"). Чеснок - оберег, средство отпугивающее всякую нечистую силу и лишающее деяственности колдовство ведьм. Это толькование чеснока покоится на более древнем: на его связи (также этимологическои) с небесным огнем, жаром, почему он используется часто как средство предотврамаюиее удар молнии, и со змеино травоя, в частности назьваемой Егорьево копье, которая 
предохраняет от укуса змеи. 42

7.3. Цветаевское противопоставление 'чеснок - яблочко' имеет также, несомненно, и эротическия характер и являет собои вариант более Фундаментального противопоставления 'мужское начало женское начало'. В частности, оно оправдывается мифологическими коннотациями яблока как соблазна идущего от женского начала, с однон стороны, и с друго - связи чеснока с мужским началом, с фаллюсом (ср. известның славянский обычай пить пиршественның напиток прежие положив в него чеснок и окунув мужскои детородны орган) 43

\section{4. Сюжетно "Аю-раюшки Раевна" (111-112) вьрахает превос-} ходство (так сказать, победу) "яблочка" над "чесноком" или Ведуньи нап Героем. Семантически - перевес губительного женского начала С доминантои смысла 'смерть'. Рифмовка слога " рай" в "А рая" и "Об - ми - рая" теперь однозначно связывает "рай" с корневым 'мир' в 'обмиран' и этим самым со смертью, вследствие чего "Раевна" включает в себя все предадущие смыслы графемо-морфемы "- рая" : губительного женского соблазна, пагубной страсти, ббаменства и смерти, падения-парения (соответственно перекличке '- ран : - pen').

$$
8.0 \text {. }
$$

113 Речка - зыбь,

114 Речка - рябь,

115 Рукон - рыбоньки

116 не лапь...

117 не то на кривь,

118 Hе то на бок

119 Р аю-радухнын

120 Кораблик.

121 Речка - хлип,

122 Рыбка - плеск.

123 От всеи рыбоньки -

124 Лишь хвост.

125 Уж и странствьице -

126 Любота пля глаз!

127 Шемаханские

128 Паруса у нас!

129 (Что за дурость-така-соплячество

130 Башкоя русою в юбки прятаться?)

131 Ранскои слюночко

132 между прочих рек

133 Сльву, - вьюношам

134 Crame, бают, нет.

135 (Шепоточки-мои-смеюнчики,

136 Сладкослюнчаты, сладкострунчаты!)

137 Как за те шепота -

138 Брыком-ревом душа,

139 Как за те шепота - 
141 на корме вороные голуби

142 в ползобочка воркукот до-люби:

143 про ребра, про десны,

144 Голодную весну,

145 Про лен-тот-нечесан,

146 Поклон-тот-непослан.

147 А на што нам лен,

148 Зелена башка?

149 Твоя земноя поклон -

150 В широки шелка:

151 Кланяяся,

152 Кланяяся!

153 Под расчесочку

154 Подставля ленок,

155 Чтоб и спросыпу

156 Hе сказал сынок:

157 K маменьке,

$158 \mathrm{~K}$ маменьке!

159 Река - радукну

160 ilupoty струит.

161 Видишь - матуика

162 На лулку стоит:

163 Кланяяся,

164 Кланяяся!

165 Eme кланянся

166 На восток-ковыль.

167 волеваньице,

168 дорогая бышь -

169 С памяти!

170 С памяти!

8.1. Семантически тема плавания и тема лодки присутствовала уже в стихе 106: "А - ю- рен" (См. примечание 39), а тема зыбкости и кораблика - в подрахательности колыбельному убаюкиванию стихов 105-106 и 111-112. Но теперь они выведены на событинны уровень - в виде плаванья-паренья на радухном кораблике (119-120) по радухноп реке (159-160). Смысл этого "странствьица" (125) очевиден: Оно не что иное как вариант мифологического перевоза дуии по водам мертвого загробного царства, по реке забвения (169-170). Однако, если присмотреться внимательнее, здесь имеет место нечто более существенное, чем только поверхностная потусторонняя переправа души.

8.2. В первую очередь бросается в глаза новая метаморфоза Ведуньи. Она давно ухе не "яблочко" и не 'змея', а "речка", "рыбонька", "кораблик" и "раяская слюночка", Т.е. акватическая сти- 
Мотив "рыбки" и "слюнки" продољхает семантику разхигаюмего соблазна и сладострастья (запрет в 115-116: "Рукон - рьбонъки Не лапь..."; поддразнивание в 122: "Рыбка - плеск"; увиливание в 123-124: "От всер рыбоньки - Липь хвост"; вожделение плоти в 131: "Ранскоп стоночкон" и намек на брачанье в 133, где "вьюной" означает не только юнону, но и первую брачную весну). 44 Как и прехде, соблазн этот губителен: "плеск" рыбоньки хвостом (122-124) отсылает к народным суеверьям, согласно которьм это знак скород смерти рыбака: 45 "слюночка" же, да еме "Мехду прочих рек" (131132) - суцность подземньх вод, 'мокрота' со всеми ее демоническими коннотациями как в мифология, так и у самои цветаевон. 46

8.3. Во многом родственна указаннор и семантика "кораблика" (120). Прежде всего он - соответствие мифического летучего корабля (ладьи)-гроба, на котором отправляются в потусторонния мир души усопши, с одно стороны, а с другон - носится по мировому океану умерши или временно заколдованны бог-громовник. 47 Последнее прочтение привнесено не извне, а вытекает как из ухе отмеченных признаков громовника в Герое поэмы, так и из новых мотивов тура в 137-140, голубен в 141, весны в 144-146, льна и обрамения "зелена башка" в 145-148.

8.4. Тур и его рог - известные вопломения бога-громовника, причем рог, как правило, золотод, являет собон плодоносную молнию. 48 Сфере молниеноснои стихии принадлежат и голуби (см. 3.8.). Упоминание в этом контексте весны (144) теперь самоочевидно: события поэмы приурочены времени пробуждения оплодотворяющих природных сил. Более того: гур - представитель небесных стад-туч, влияющих на состояние стад земных. Возможность ассоциировать Героя поэмы с Егорием и Громовником еще теснее связывает его с туром: весеннин Егорин - покровитель земледелия вообще и покровитель весенних стад в частности. Стих 148 - "зелена банка?" - кроме укора содержит еце и отсылку к распространенному народному имени весеннего Егория "Зелены". 49 напоминание "голубен" (141) про "Голодную вёсну" (143-144) вообще рисует картину голода-обнищания и является напоминанием О том, что Герою-Егорию пора деиствовать, т.е. расправиться с похитителем (противником Громоверхиа) вегетативных плодотворных сил, освободить их и вернуть земле. но сожет поэмы развивается иначе: Герод как бы все более поддается чарам Ведуньи, все глубже погружается в состояние забытья (ср, 167-170) 
"Волеваньице, Дорогая быль - С памяти! С памяти!") и все дальше уносится от земли кораблем-гробом-тучеи по запредельным губитепьнвм водам. 50

8.5. В соотнесении С Ведунье "кораблик" мохет читаться еще как раковина Naut1lus, которая "распускает род паруса плғучи по ветру". 51 эта возмохность подсказывается его тотальноя акватичностью. Эпитет "радухнын" (119) не только вписываєт а него эаманчивую красочность, но и усугубляет его связь с водон. По внутреннему контексту эта его сущность очевидна хотя бы при сопоставления следуоиих детален: "-радухкий Кораблик" (119-120) и "Река радухку широту струит" (159-160); "Раю-радухкий Кораблик" (119120) и "Рар-райскою речекокой" (103): "ШемаханскиеПаруса у нас!" (127-128) и "Раю-ранскою речекокой йлк потек" (103-104; см. еме оговариваемое присутствие признака 'акватичности' в "шемаханских" "шелках" в 3.3.). По внешнему, но цветаевскому, контексту раковина - одна из наиболее глубоких ипостасе лирического цветаевского я, имежих смысл акватического женского начала захватываюмего и погломаниегв себя начало мухское. 52

8.6. По внешнему - мифологическому - контексту "радуга" - похититель земных вод и мост, перекинуты меж миром земным и миром потусторонним. 53 небеэынтересно ене отметить эволюиию эаговаривания-убаюкивания от Формы " $A$ - 0 - рая, $A$ - 0 - pen" (105-106) череэ "Ао-ракаики Раевна" (111-112) по "Раю-радукның", где наконец появляется более вразумительны слог "Раю-" сопряженнья фонетически и С "раем" и с "радугон". Если учесть, что этнографы толкуют слог 'ра-' в слове 'радуга' как некогдашнее обозначение воды, то станет ясно, что и "ран", и "радужнын" и "Раевна" и даже "коРАблик" - не что иное как проявление все одноя и то же акватическон стихии. 54 но самое интересное, пожалун, то, что Ведуньины "шепоточки" и "шепота" (135; 137-139), кстати, тоже имеющие характер 'мокроты', так как они - "сладкослюнчаты", грозят Герою преврамением в "тура" (139-140): "Как за те шепота - Турьим рогом башка!"), т.е. в животное, связанное в народных представлениях С водон, что в частности сохранилось в названиях озер типа волотур, турово, Тур-озеро и т. П. 55 А это значит, что Герою грозит слиться с водами Ведуньи и раствориться в них (ср. в самон поэме - стихи 273-277 - наименование "Котлов" Ведуньи, ее локуса "Лазори" и ее "Ладони" патронимом "Озеровна": "Котел без дна! Ладонь- 
глубизна! Лазорь, лазорь, Синь-Озеровна: Ла - зорь!" .

8.7. "Лён" в разбираемом Фрагменте уломинается трижшы - в Стихах 145,147 и 154 .

В первом случае он включен в картину 'голоднод весны' (144), назван "нечесаным" (145), и напоминают об этом Герою "голуби" (141-142). Нужны контекст для семантизации "льна" дан здесь, таким обраэом, вполне отчетливо. Это - весенняя народная обрадность. Самы обмия ее смысл - вызвать оплодотворение матери-земли небесным мухским семенем, т.е. вызвать грозы, осеменительның дождь и предотвратить от губительных для нового урожая засух. Для этого, с одноя стороны, долхны быть прекрамены зимние работы, т.е. теперь на них налагается запрет, а с другоя - провоцируются дохди при помочи всяких водооблизания, поливания полея маслом, медом, пивом, при помоми посыпания в определенные водоемы семян мака, гороха, льна, соли, бросанья туда чеснока, лука и часто пими вообmе. 56 на этом уровне "лен" и "чеснок" (109) оказываются эквивалентым - они соотносятся со сворствами дожде-громоносно небесно стихии и этим самым с богом-Громовником. Поэтому напоминание Герою о льне (145) здесь вполне естественно (особенно рядом с предупреждением о голоднои весне - 144). Так же естественно и включение льна в образ самого Героя: в стихах 153-154 его волосы именуются "ленком"; тем более, что раньше, в стихе 109, он именовался эквивалентным льну "чесноком".

"Лен-тот-нечесан" подразумевает в свою очередь обьчая не оставлять к весне необработанны лен и запрет на обработку такого льна весноя - он просто сжигается. 57 Голуби, таким образом, напомннают Герою о его земных хозяяственных обязанностях, намекают на бедствия, к каким может привести его забытчивость.

8.8. Во втором случае имеет место понятное теперь мгновенное вмешательство Ведуньи: "А на што нам лен, Зелена башка?" (147-148). Его смысл - разомкнуть годово цикл, прервать кольцо преврамения (природных умирания и воскресания), отторгнуть Героя от земного мнра. 58 "Льну" противопоставляется здесь "шелка" (150): огненному началу - акватическое (ср. 101-104), мужскому - женское, памяти беспамятство, забытье (см. 169-170 и упоминаняе "ковыля" как травы забвения и "востока" как страны усотитх в 164), плоти - бесплотность (см. упоминание в 143 "ребра" и "десны"), озабоченности беззаботность ("про" в 143 и 145 и "радужность" "реки" в 159), 
узам - освободдение, воля (разрыв родственных связея в 155-158, прочальные поклоны в 161-164 и, с другон стороны, "широта" "шелков" и "реки" в 150, 159-160). Попутно отметим, что принудительность поклонов и настаивание на них (151-152, 163-164, 165) эаставляот видеть в них не только продальные жесты, но также и 'крен-сникание' (в первон его стадия; позже он станет возрастать вплоть до иссекновения плоти в 217-220: "Клонись" - "Креньсь" "Лохись" - "льни"), погрухения в небытье-забытье (в этом смысле "земноя поклон" в 149 - не столько 'глубокия', сколько 'в глубь'; ср. употребленнуг тут конструкцию 'поклон [...] в': "Твоя земнон поклон - В широки шелка").

8.9. В третьем случае (153-158) расчесыванье льна-волос Героя допускает несколько прочтенин:

Как намеренное нарушение запрета чесать лен по весне, а этим самым нарушение или разрушение годового цикла (ср. 8.7. и 8.8.), которое открывает выход в бесконечность и беспредельность.

Как погрухение Героя в беспамятство, отрыв его от наипрочненших связен с миром земньм (155-158: "чтоб и сnросипу Не сказал сынок: К маменьке, К маменькеІ"; 161-164: промальны поклон "матушке", предполохительно такхе 'матери-сырои-земле' из-за ее локализации "на лухку"; 169-170: "С памяти! С памяти!") и приворахивание к себе (ср. колдовскую приворахиваюцую функцию гребеика-расчески у самон Цветаево хотя бы в стихотворении "чтобы помнил не часочек, не годок..." - 20 октября 1918; СиП II, 14: "Чтоб дружочку не спалось без меня - Гребень, гребень моЯ, расческа моя! [...] чтоб друхочку не хилось беэ меня - Семиструнная расческа моя!"). Далее. И в народньх представлениях и у самон цветаевоя волосы связаны не только с представлениями О витальности, душе, но и о воде, о потоках дохдя (ср. в стихотворении "Волосы я - или воздух целую..." - 9 ноября 1918, из цикла "Комедьянт", СиП II, 247: "Голос и волоси: струны и струи"). Расчесывание волос рассматривается поэтому во многих народньх поверьях и обрядах как акт влияющия на погоду, как вызывание дохдя, града, гроэы и т. п. 59 Лен же, как ухе говорилось, связан с представлением о небесном огне, грозе и Громоверхие. Поэтому расчесьвание 'льна-волос' Героя ведет не топко к забытью, беспамятству, но и к выявлению его трозовон' или 'громовниковод' сущности (См. стихи 171-174).

В поэтическон системе цветаевон "расчесочка" ( а чаме "гpeбенв", 
"гребенка", "гребешок") прочно связана с женским эротическим началом, с хенским соблазном, а такхе с семеричнои структурои ее мироздания. Так, в цитированном ухе стихотворения "Чтобы помнил не часочек, не годок..." говориться: "Струны - зубья у расчески моен! Чуть притронешья - поидет трескотня Про меня одну, да всё про меня. [...] Чтоб друхочку не жилось без меня - Семиструнная расческа моя!", а в "царь-Девице" (Сип IV, 39-40) игрон на гребенках атрибутируются "семь покоев" царицы-ведьмы, которые именуются как "С семью смертными грехами цельх семь укладок бабьих", где "чесальщицы Камарин- // скую шпарят на гребенках!" и где "чесальмици" определены одновременно как "семв чертовых арапок, Семь царицынх купальщиц" с очередньм перекменованием "покоев" Царицы на "кухны женского обману" и отсылкон к история Самсона и Далилы. 60

В "Переулочках" все эти смысыы "расчесочки", несомненно, очевидность для Цветаевои и не всегда внятны для читателя. Но зная соответствуюши контекст, не трудно теперь увидеть их даке неискушенному глазу. "Расчесочка" оказывается очередноя, высшең формод соблазна и приворахивания: "яблок" $\rightarrow$ "кораблик" $\rightarrow$ "расчесочка"61 (в случае Героя этои градации соответствует: "чеснок" - "соплячество", "башка русая" $\rightarrow$ "ленок"), 62 с однон стороны, и с другон "шепоточк - [...], Слацкостончаты, слашкострукчаты!" (135-136) - "расчесотка" (так как 'гребень' у цветаевоя 'звучап' и 'мривораживаки'). Иначе говоря воря, Ведунья искуиает теперь Героя всен свое греховно преисподнеи, всеми семью смертными грехами (ср. В 193-196: "Лкеи-то в груди Семь да семижды Семь, да еме - семъ"), а погружение его в беспамятство равносильно 'одержнмости страстью' ('предельнои воспламененности', что в 171-172 передается метафоро 'паляне молния' и переименованием "Не - молния: Конь - ржет!" в 173-174).63

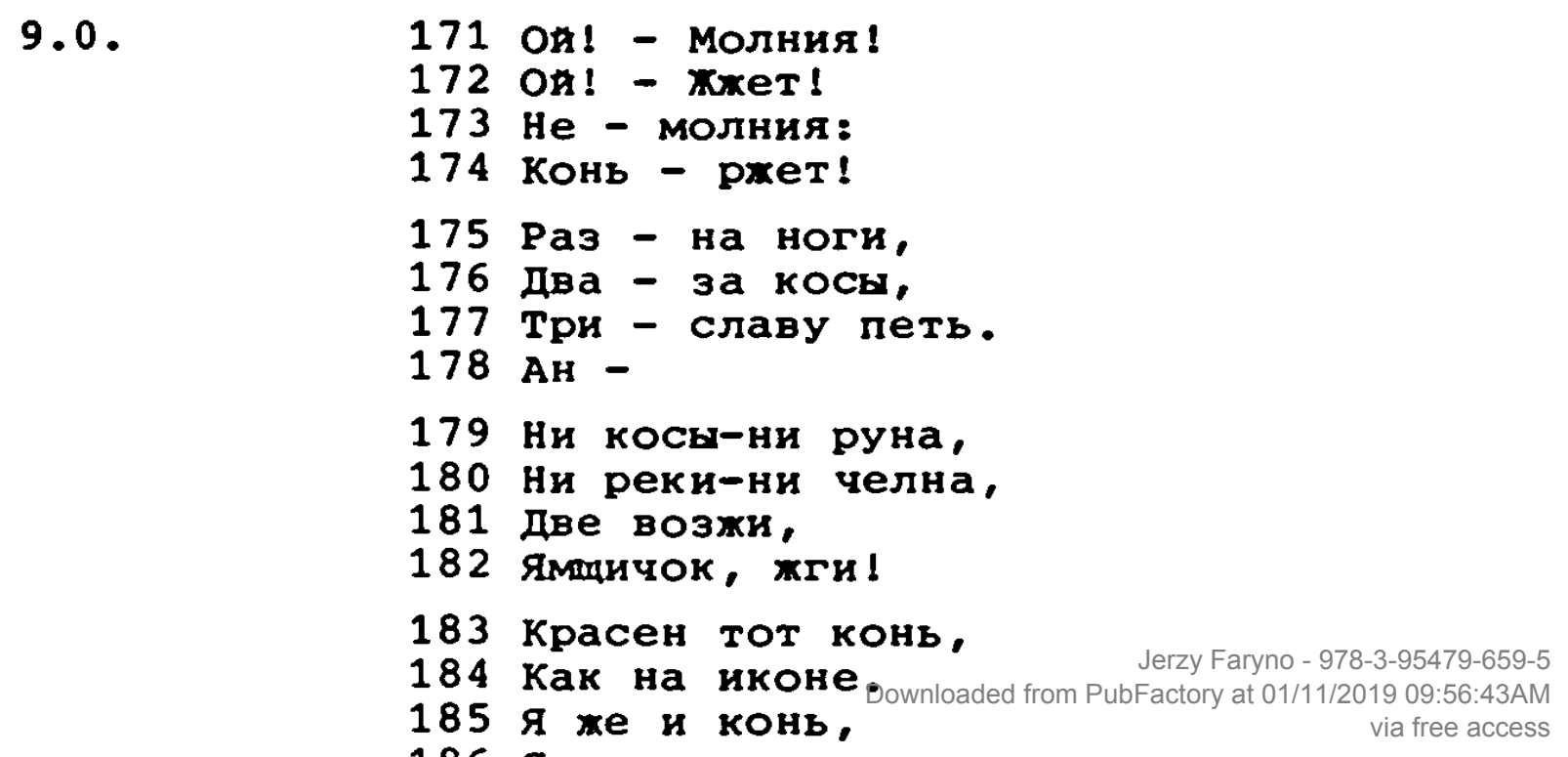

172 On! - жхет!

173 не - молния:

174 Конь - рхет!

175 Раз - на ноги,

176 Два - за косы,

177 три - славу петь.

$178 \mathrm{AH}-$

179 Ни косы-ни руна,

180 Ни реки-ни челна,

181 Две возжи,

182 Яминчок, жги!

183 Красен тот конь,

184 Как на иконе Jerzy Faryno-978-3-95479-659-5

185 я же и конь,

$18 a$ a $-\cdots$ - nano... 


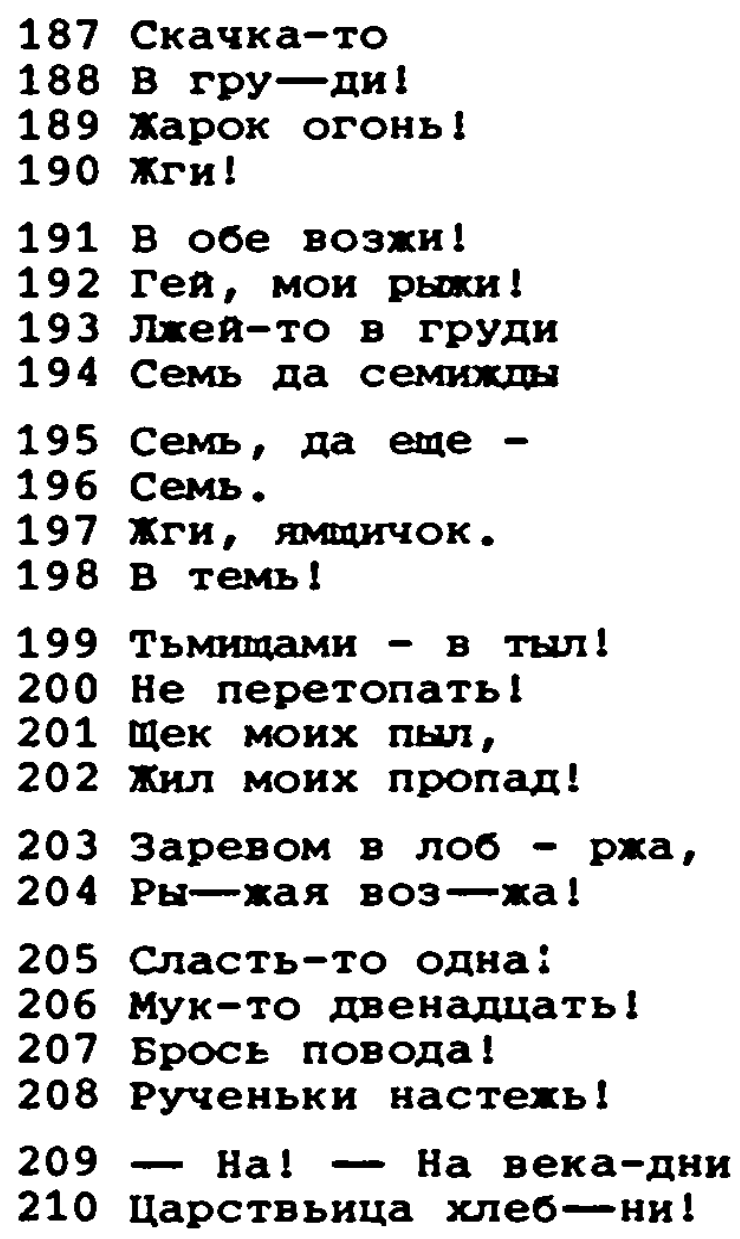

9.1. Второя поединок Героя С Ведуньея. В свете вскрытых уже связе Героя С Громовником данное переоформление его в терминах стремнтельноя грозы-гонки не долкно быть неохнданностью.

"Ямичок" и "возхи", "повода" (181-182, 191, 197, 203-204, 207) покоятся на общеиэвестном народном представлении грозы как грозноя колесница ильи-пророка (ср. у самон Џветаевоя в ее "ЦарьДевице" - Сй IV, 82: "Первья глухо удар Грома далекого. [...] Гонит пророк конея. Гривами хлябь пошла. Пуше взметнулся бич В длани пророковоя. [...] Не оплошая бичом, - Вожоки уж вырваны!"). "Красен тот конь, Как на иконе" (183-184) - на тои же народноя контаминация предхристианского Громовника и христианских Нльи и Егория. То, что этот образ соотнесен с Героем, следует из упоминания "иконы" как продолхения христианского ореола Героя в стихах 31-32 и 54, а такхе из противопоставления "тот конь, [...] Я xe" (183-186).

"Не - молния: Конь - рхет!" (173-174) и "Красен тот конь" (183) - на известных хотя бы по сказкам и загадкам уравнениях рхушего коня с молниея, громом, ветром. 64

В пределах поэмы эволоция Героя по шкале "Чеснок" - "ленок"

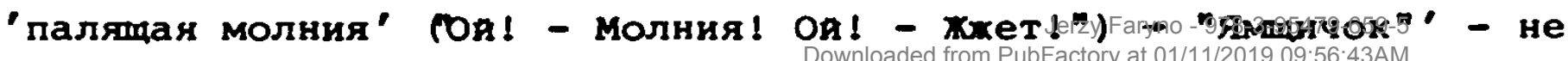


столько результат колдовства Ведуньи, сколько спровоцированного ею самовыявления глубинно суцности Героя, покоившегося в нем "богатырства" (по определению цветаевон, см. СиП II, 381) или 'громовникова' начала. Это значит, что повынаясь в ранге до неземно божественноя сумности, Героя одновременно заманивается Ведунье в подвластные ей (а то и тождественные ең) запредельнье миры. Показательно, что если раныше подчеркивалось неравенство между Героем и Ведуньен (109-110: "Чеснок - яблочку Неровкя"), то теперь они уже почти равносуцностны: он - "ямдичок"-Громовник, она "погоня" (186); он - "молния : Конь" (173-174), она - "конь" (185). "Почти" потому, что некия перевес сохраняется все-таки за Ведуньен, так как она - "и конь, [...] и погоня" (185-186).65 Искомы перевес Ведуньи кроется, вероятнее всего, в подразумеваемом тут свонстве объединять в себе противоположности ('преследуемоя, везупен' - Ямшичок, жги!" и "преследуюмен, увозямен' - "я ж и погоня"; "Геи, мои рьхи!", где "рьки" - демонические огненные кони), в нечленимости на 'наездника' и 'коня', Т.е. В их тождественности (187-188: "Скачка-то В гру-ди!"), и, наконец, во внутреннен, сумностнов динамике в отличие от внешнеи, более механическо Героя (если он - "Ямпичок" - 182, 197, то она - "погоня" - 186 и "Скачка" у нее "В гру-ди!" - 187-188; если его "конь" статичен "Как на иконе" - 184-185, то ее 'конь' - она сама: "я же и конь" - 185 н являет собо вопломение стремительного движения). 66

9.2. Как и первья, этот поединок Героя с Ведунье тоже неудачен: она опять изворачивается, превраяаясь на этот раз в "Две возжи" (181) и "коня" (185: "я же и конь") и, подбадривая Героя (182: "жги!"; 190: "Жги!"; 197: "Жги, ямпичок"), увлекает его за собои (а то и 'на себе') еме дальше. Вся эта гонка в первую очередь ассоцияруется со сказочньм изнурительньм полетом на ведьме. но это, скорее всего, поверхностное и случаиное сходство, так как на деле Цветаевския полет имеет совершенно иную основу.

Превращение Ведуньи в молниеносную ("Две возжи" - 181; "Ры一 жая воз-жа!" - 204; где признак 'рьоия' знаменует демоническия огонь) 'тучу-коня' (опять-такя демонического огненного коня - см. 192 "Гей, мои рьки!" с явньм переосмыслением "ржанья" 'молнии-коня' Героя) вполне закономерно, так как ее молние-громоносная суть уже просвечивала сквозь самын первья ее облик в поэме (см. 3-4; см. также 1.4. и 1.7.). Правда, преврамение в 'коня' здесь менее 
очевидно, но и оно отнюдь не плод Фантазия. Однако, чтобы его понять, необходимо обратиться к другим вемам Цветаевоп.

9.3. "Да, друг невиданнын, несльханны..." (апрель 1920; СиП $I I, 280):$

\begin{tabular}{|c|}
\hline $\begin{array}{l}\text { Да, друг невиданныя, неслыханны } \\
\text { С тобон. - Фонарик потуши! } \\
\text { Я знаю все ходы и выходы } \\
\text { В тюремнои крепости души. }\end{array}$ \\
\hline $\begin{array}{l}\text { Вся страха - розами увенчана: } \\
\text { Слепая, шалая толпа! } \\
\text { Всех ослепила - ибо хенмина, } \\
\text { Все виху - ибо я слепа. }\end{array}$ \\
\hline $\begin{array}{l}\text { Закрон глаза и не оспариван } \\
\text { Руки в руке. - Упал засов. - } \\
\text { Нет - то не туча и не зағево! } \\
\text { То конв мон, ждумия седоков! }\end{array}$ \\
\hline $\begin{array}{l}\text { पужанся: я твон шит и мужество! } \\
\text { - страгть твоя, как в оны дни! } \\
\text { А если голова закрухится, } \\
\text { На небо звездное взгляни! }\end{array}$ \\
\hline
\end{tabular}

"я" этого стихотворения - "представительница потустороннего мира, мертвого царства, о чем свидетельствует ее физическая 'слепота' и внутренняя 'прозорливость' ("Всё виху - ибо я слепа"). 67 Она, кроме того, - 'смерть' ("всех ослепила" = 'умертвила'; "Фонарик потуни", "Закроя глаза" = 'умри'). Далее: она 'освободительница' и 'водитель душ' ("я знаю все ходы и выходы В тюремноя крепости души", "упал засов", "не оспариван руки в руке"). короче: она влашьчнца потустороннего царства душ и в этом смысле - равносильна Ведунье в "Переулочках" (заметим, что это стихотворение написано Цветаево за два года до "Переулочков"). Их совпадение заметно и по другим признакам: по признаку 'лабиринтности' локуса ("ходы и вьходы В тюремнод крепости" аналогичны наяменованию "переулочки" - ср. 1.8. и 4.5.) и по признаку 'непостикимости' (тут я есть "Друг невиданныя, несльханны", а в "Переулочках" Ведунья вводится в текст так: 1-2 - "А ке видел ли, млад - не вемо-ито, А ке слихал ли, млад - ке змамо-ито"); как и в "Переулочках", Я здесь являет собо 'женское начало' и такую же 'соблазнительную страсть' ("- Всех ослепила - ибо хенщина [...] ко 'лишила зрения', но и 'прельстила', что в свою очередь следует как из 'мухского' состава "страхи", так и из "шалости"). 68 Подбадриваюеее "Муханся" и автояменование "Я - страсть твоя, как в оны дни!" тон коварноя страсти противопоставляет спасительную страсть искупительного испытания. 
Средство для "переправы" этой уносительницы и водительницы душ - конь. И, что самое существенное, конь этот уподоблен "туче" и "зареву": "то не туча и не зарево! То конь мои, хдуиин седоков!"

9.4. "Похираюмин огонь - мон конь!.." (14 августа 1918; СиП II, 13):

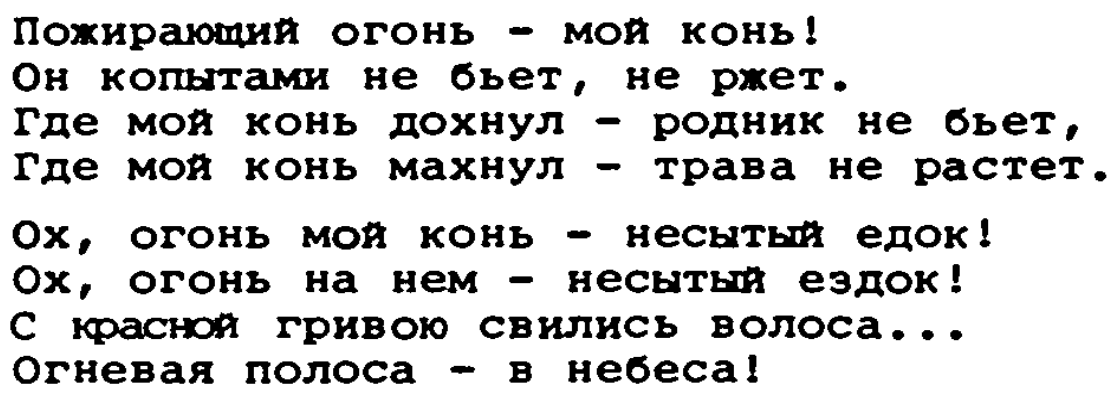

В этод сплошнов тождественности отметим только те признаки, которые соотносимы с "Переулочкамя". "я" этого текста - владслица ('женственность' я угадывается в "свились волоса" в силу подразумеваемой 'длины волос') коня и одновременно наездница ("ездок"). "Конь" же - "огонь", но и "ездок" - тохе "огонь". "я" и "конь", таким образом, равны друг другу по признаку их огненнов суцности. Сущности же "я" и "коня" выражены одинаково: эквивалентными их овнешнениями, Т.е. "гривою" и "волосами", и эквивалентными нравами: "несытың (едок!)" = "несытыя (ездок!)". 'Несытость' восходит в свою очередь к инициальному предикату "Пожираюиня огонь", где 'пожирание' истолковано как 'истребление жизни" ("родник не бьет", "трава не растет"). В итоге тождество 'огонь = конь : ездок (я)' покоится на смертоносном начале. Но есть между ними и разчица: если "конь" - "несытын едок!", то "я" - "несыты ездок!", т.е. если первья - 'неутолимая страсть истребления', то вторая - 'неутолимая страсть двикения'. Дополняя друг друга, они образуют органическое единство ("С краснов гривою свились волоса") и окончательно сливаются в стремнтельнын взвив вверх ("огневая полоса - в небеса!"). 69

Заметим еме, что данның "конь" наделен не небеснод, а демоническоम (хтоническои) природод: "Где мод конь дохнул - родник не бъет", тогда как богатырским небесньм коням своиственно выбивать копьтами колодца, источникн и Т. П. И, более того, он - бесплотен ("копьтами не бъет, не рхет") и сплош 'пневматичен' ("дохнул", "махнул" с подразумеваемым 'хвостом' которья аналогичен "гриве", и поэтому 'духовен' и 'палящ'; С. 'молниехвостость' коня в 
"Георгии" - июнь 1921; СиП II, 115). В связи с этим наблюдением небезынтересно напомнить, что в "Переулочках" Ведунья изобрахена тохе 'огнешьламен' (21: "Дунет - костром загарит"), что ее "конь" лишен всяких свонств (в противовес 'рханию' коня Героя) кроме 'демоническои огненности' (192: "Гея, мои рьки!") и 'страсти двихения', и что "конь" и Ведунья являют собоя одно нерасчленимое единство (185-186: "я хе и конь, Я хи погоня").

9.5. В поэме "на красном коне" (13-17 января 1921; 155-160, СиП IV) аналогичны огнедшащия громовои конь вьведен как двоиник "я". В отличие от рассмотреннвх вариантов в 9.3. и 9.4., этот конь связан еме - наравне с огнем и громом - и со снегом и метелью: "и снегом - конь", "Как будто бы выюгон взшыблен Стоглавын храм", "Но прядет конь - и громом Взгрсмел алтарь!", "Стоните, стоните, стены! Метель, ярись! Померкло от конскои пены Сиянье риз" (СиП IV, 157-158). 70 но самое сумественное отличие в том, что он с первьх же стихов поэмы противопоставлен "Музе" (СиП, 155):

Не Муза, не Муза

Над бедною лютько

мне пела, за ручку водила.

[...]

В большие поля уводила - не Муза.

Не муза, не черные косы, не бусы,

не басни, - всего два крыла светлорусых

- Коротких - над бровью крылатой.

Стан в латах.

Султан.

К устам не клонился

на сон не крестил.

О сломанно кукле

Со мно не грустил.

Всех птиц моих - на свободу

Пускал - и потом - не жалея шпор,

на красном коне - промеж синих гор

Гремямего ледохода!

и еме в финале (СиП, 159-160):

не Муза, не муза - не бренные узы

Родства, - не твои путы,

О Друкба! - Не женскон рукоя, - лютоя

Затянут на мне -

узел.

Cен страшен союз. - В черноте рва

Леху, - а Восход светел.

О кто невесомых моих два

крыла за плечом -

Взвесил? 


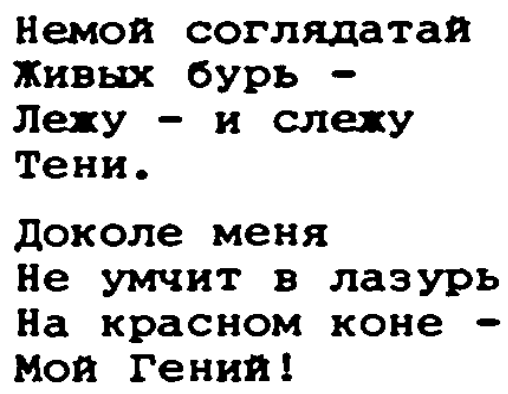

"муза" дана здесь как 'текстослагательница' в самом инроком смысле. Она - и 'песнеслагательница' ("над [...] люлькои мне пела"), и 'жизнеслагательница' (с ее ролью няни: "Над [...] люлькон", "за ручку водила"; с ее креациен 'девичества' Я: "черные косы", "бусы"; с ее 'союзотворчеством': "узы Родства", "Друхба"), и 'блостительница традиция' (ея приписан весь традиционныя воспитательны репертуар 'няни'), и, наконец, 'вдохновительница' (ср. отсылку к античнон одерхимости музами в "В большие поля уводила"). 71 но все это 'тексто творчество' расценивается тут как 'празднословие, небылица' ("басни"), 'мелочность', 'суетность' ("косы", "бусы" с их намеренно заникенным рангом в контексте противопоставляемых им "крыл", "лат", "султана"; "сломанная кукла", "бренные узы"), 'несвобода,скованность" ("за ручку водила", "косы", "бусы", 'кремение ко сну', 72 "узы", "путы"), 'нехивое, предметное" ("люлька", "косы", "бусы", "сломанная кукла" и противостоящие им "крыла", "птицы"), "бездвижное, пассивное' ("лютька", "за ручку водила", "уводила", "клонился", "сон", "сломанная кукла", "грустил", "узы", "путы" в отличие от 'динамичности' и 'внутреннея энергичности': "крыла", "птицы", стремительная скачка "не жалея шиор", 'напор" "Гремящего ледохода", "хивые бури", "умчит").

"Конь", а строже - 'всадник-гения', - 'жизне-тексторазруиитель', он являет собоя некое свободное, лишенное всяких организующих и поэтому сковывающих норм, начало. Его суть - жечь и ломать мир форм-узилим, возврапать ему раскрепоменное состояние и уносить "в лазурь". Позиционально он эквивалентен "Музе", но Функционально противополохен ен (ср. отрицательные конструкции "не муза, не муза", предполагаюмие инокачественность 'сопроводителя' жизни Я, и оппозицию '"над люлькон" $\rightarrow$ "В черноте рва Лежу"', где "люлька", говоря словами цветаевоя, есть "рожденье в жизнь= =смерть", а "чернота рва" - рохденье-воскресение-уход в Жизнь, 73 "Из днесь- В навек" [...] Восстанье в день". "Сивилла - младенцу" , 17 мая 1923; СиП III, 26). Если "муза" первоистоки творчества 
('поэтического') переводит с потустороннего уровня на земноһ,оформляя их в тексты ("песни", "басни" и т. П.), то 'Конь-Гения' высвобохдает из земных форм творческую энергию и приобщает к исконному мировому ('запредельному') потоку ("Гремямин ледоход", "Качая-раскачивая язык", Сполошның колокоя! - Велик Пожар! - Душа горит!" и т. д.), а аналогом 'поэтического текста' становится в этом случае обретаемое в финале состояние 'не-сущности' ("лазурн") 74

Не трудно заметить, что,будучи 'противо-Музоя', Цветаевския 'конг-гени' родственен Пегасу, существу хтоническому, которь возник иэ крови брызнувшея после отсечения головы горгоне-Медузе и которь вознесся на Олимп и стал завешпатв молниями и громами высшего бохества Зевеса. 75 От этого мифа у Цветаево почти ничего не осталось на уровне Фабульных построения, но Фундаментальные свонства ее громоносного коня те же. 76

Подмен "Музы" 'конем-Гением' имеет и другие еще аспекты. Вопервых, гения - персонификация внутренних свояств человека, он рождается вместе с человеком, руководит его жизнью, а после смерти воссоединяется с другими богами, 77 что, естественно, гораздо сильнее роднит его с цветаевскоя поэтическои системо (а точнее: С Цветаевским Я), чем музы. Во-вторых, хотя гении и были бохествами олицетворяющим внутренние силы мужчины, их пол, как правило, скрывался. Так наппись на щите, посвященном Гению рима, гласила: "или муху, или женщине". 78 надо ли говорить, что и эта 'неятрализация' пола гения родственнее цветаевскои системе (и ее я), чем однозначно вырахенная 'хенственность' муз. 79

$$
\text { 9.6. "Хочешь не хочешь - дам гебе знак!.." (март 1920; Сип }
$$

II, 273-274):

Хочешь не хочеш - дам тебе знак!

Cпор наш не кончен - а только начат!

В нынешне жизни выпало так:

мальчик поет, а девочка плачет.

В будупея жизни - любо глядеть! -

Tи будешь плакать, $\&$ буду петь!

Бубен в руке!

Дьявол в крови!

Красная юбка

В черных сердиах!

Красною юбкои - в небо пыпо!

Хизнь малодую - ковром подстелешь!

Как с мотыльками тебя делю -

Так С моряками меня поделишь ! Jerzy Faryno-978-3-95479-659-5 
Красная 10бка? - как бы не так!

Огненны парус! - Красның маяк!

$[\ldots]$

Слушая приметы: бела как мел

и не смеюсь, а губами движу.

А чтобы - как увидал - сгорел! -

Не позабудь, что приду я - рыхея.

Рькеи, как этот кленовь лист,

Рьркея, как тот, что в лесах повис.

$[\ldots]$

Этот текст ценен для нас тем, что он позволяет отчетливее увидеть сичтемность некоторых, казалось бы произвольных, мотивов в разбираемом теперь Фрагменте "Переулочков".

Врахда между мужским и женским началами ("Cnop наш") переносится здесь на 'за-жизненныя' уровень ("В будумея жизни"), где ведуде стороноя становится начало женское, мстямее мужскому за свои 'обиды' на прехнем 'жизненном' уровне. Этот момент, как кажется, значительно проясняет сюжет "Переулочков", т.е. эаманивание Героя под полог Ведуньи (=в запредельнын мир), где и разыгрывантся основные события, передачу всея инициативы Ведунье и ' бескорыстность' ее губительного соблазна.

"Бубен в руке! Дьявол в крови!" - один из многочисленных вариантов колдовского, демонического Цветаевского Я. Такова также и Ведунья в "Переулочках" с ее "звоньбоя" и 'огненњм дхханье' (См. 1.5. и 4.7.). Но наиболее суцественно то, что и тут и там геро спроваживается в потусторонния мир при помоии магических, заклинательных практик, и то, что в обонх случаях он подвергается пыткам (страстям) схигаюиего соблазна ("А чтобы - как увидал - сгорел!").

"Красная юбка? [...] Огненның парус!" (ср. в "Переулочках"

3 и 127-128: "В белохрущатых громких платьицах" - "Шемаханские Паруса у нас!") - та же трансформация волшебнов ('земноя') наузы в 'ладью' смерти-перевозчицы (ср. 8.3.), в средство запредельного странствия.

'Огненность' - не только внешния атрибут этого Я, но и его суцность, О чем свидетельствует переход от "КрасноЯ юбки"="Огненного паруса" к 'рыбеволосости' : "А чтобы - как увидал - сгорел! - Не позабудь, что приду я - рихей". Но это особая 'огненность'. Будучи внутренним свояством Я, она получает смысл демонического мстительного соблазна: демонизм 'рыкести' следует из "дьявол в крови!" и из "тот, что в лесах повис", 'соблазн' - из "Красная

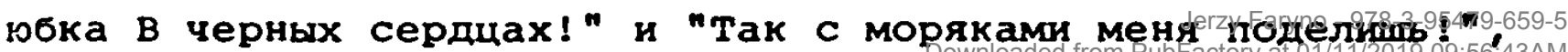


'мстительность' из "Та будешь плакать, $я$ буду петь!" "бела как мел и не смеюсь", где дополнительно вводится в я примета 'смерти' ("бела как мел"). Дьявольския характер 'рькести' явствует еме и из сравнения "приду я - рьхея. [...] Рькея, как тот, что в лесах повис", где "тот" подразумевает и лешего и, ассоциируясь с рыхеволосьм Иудоя, 'коварство, измену', а локализация "в лесах" указывает на запредельныр локус смерти и одновременно вечного страданияскитания (так как "повис" предполагает 'непогребенность' и 'левитацию" в недифференцированноя сфере между землея и небом). 80 Доскахем еме, что вытекахиия из этого стихотворения смыслы 'рыжеволосости' имект свое основание во многих мифологиях, в том числе и в народнои русскон традиции: рыпеволосые интертретируются обычно как носители пагубного эротического соблазна и как одержимые зльми бесовскимн силамн. 81

В этом контексте название ведуньея своея конея 'рыхими' (192: "Ген, мои рьхи!")и "возжи"='молнии' "рыбеи" (203-204: "3аревом в лоб - рха, Ры-жая воз-жа!") знаменуют переход к самому опасному и самому губительному из ее соблазнов. Этот же контекст позволяет увидеть логическую связь упоминаемьх "рьбеи" (192), "льен" (193), "жил" (202), "пьла" (201), "сласти" (205) и "мук" (206). Строго говоря, всё это варианты одноя и тои-же неистовон демоническо мстительноя страсти. Для Героя это означает окончательное подчинение Ведунье (в тексте отрахенное категорическими повелениями, СР. 207, 208, 210, 211-214, 241-242) и окончательную гибель, а для Ведуньи - некия предел ее исступления, исчерпанность ее чувственноя сущности. Предел, за которьм открывается ухе соверпенно иное бытие (данное в поэме как бесконечның взлет ввьсь, в "лазорь").

"Так с моряками меня поделишы!" вводит тему моря и погружения-раствореняя В нем. В "Переулочках" она вьражена еме отчетливее, См. 209-210: "-На! - На века-дни царствьица хлеб-ни!" и потом появленне "котлов смоляных" (211-214). В стихотворении "Хочешь не хочешь - дам тебе знак!.." морская тема не очевидна, она мотивируется прехде всего тохдеством лирического Я и имени "Марина Цветаева": стих "Как с мотылками тебя делю" подразумевает равенство 'я = цветок' ( -"цветаева"), стих же "так с моряками меня поделишы" - равенство 'меня = море' ( "марину"='морскуо'). Вторая мотивация восходит К тохдеству цветаевского "я" с 'води- 
тельницея-перевоэчицея' душ в потустороннем мире (ср. 9.3.). В "Переулочках", как уке неоднократно было показано, акватичность Ведуньи разветвлена гораздо сложнее, но во всех случаях тоже позволяет видеть ведунью как двояника "Марины". и тем не менее более сунественно тут нечто другсе : в соих:сопоставляемх произведениях выразительно прорисовывается поглсмаюиия характер их героинь, их отохдествление с губительноя морскоя стихиеи, а в итоге - 'захват героя в себя', 82 'подмена собоя всего пространства'. Стих "Жизнь молодув - ковром подстелешь!" мокн понимать как знак безусловноя покорности, и как образ 'потери', плоти (ср. В следуямем стихе упоминание "мотыльков" как недолговечных суместв. с однор стороны, так и душ умериих). 83 В "Переулочках" та же закономерность: 'потопление' (209-210: "На века-дни царствьица хлеб-ни!") сопровохдается темор изъятия души (208: "Рученьки настежь!" - типичны Цветаевския жест с усторчивым смыслом высвобождения души из телесноя клетки; ср. в "Другие - с очами и с личиком бледнъм..." - 2 августа 1920; СиП II, 292: "А я - руки настехь! - застыла - столбняк! Чтоб выдул мне душу - россинския сквозняк!") и темоя 'истончения, сникания' плоти: "Льни, Льни" (211-212) и потом переход к теме льна-ткани (223-224).

9.7. Теперь, возврамаясь к вопросу о преврамения Ведуньи в коня (см. 9.2.), можно сказать, что это п р е де л в н о e еe превращение. За ним может уже последовать только качественны скачок в образе Ведуньи. 'Ведунья-конь' - вариант 'коня-Гения' (см. 9.5.). Это значит, что в данном случае внашн обаз доведен до окончательного отождествления с наиболее глубокимн внутренними качествами персонажа, или, иначе, - образ целиком "овнешнён", "гения" является в чистом, не упрятанном под "платьицами", "платками", "шелкамы", "корабликом" и т.п., виде.

Цветаевския демоническия 'конь-Гения' родственен хтоническому Пегасу, противостоямему музе покровитело творческого вдохновения (см. 9.5.). Если учесть, что осново Цветаевского мироздания является "лирика" (ср. в "Поэме воздуха" - CиП IV, 284: "Семо в основе лиры, Семо в основе мира. Раз основа лиры - Семь, основа мира - Лирика"; См. также 2.2.), то преврамение в пегасообразного коня-Гения есть отохдествление с осново мира. В "Поэме" у этого превращения имеются все основания: сначала 'сладко с т р у н ны $е$ " "шепоточки" (135-136), потом "расчесочка" c eе 


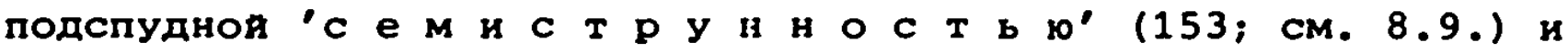
наконец их явленность в виде коня-гения, т.е. персонификация глубочанших свонств человека (тут - Ведуньи), и переименование его в семикратность "локея- соблазнов" (191-196: "В обе возхи! Гея, мои рари! Лея-то в груди Семь да семижы Семь, да еме Семь") и в 'хилы' (201-202: "Мек моих пыл, жил моих пропад!") с их созвучнем со словом "Лхейто" (192) и ассоциациея со 'струнами' 84 Дело, конечно, не в том, что отохдествление "Ведунья конь" могло бы иметь тут нечто обмее с темо лирики или творчества вообще, а в том, что 'конь' таит в себе представление о семеричноя основе бытия. На этом уровне в рассматриваемом Фрагменте Ведунья деяствительно доведена до своего предела и до предела своего 'царства' (ср. в 210: "царствьица хлеб-ни!", а в 224: "царицыны льны!"; См. еме 9.6.), до отохдествления с ним и растворения в нем (упоминание "котлов" в 213-214). Очереднои воэмохнь шаг - качественное перерождение и воспарение в бесконечность, именуемую "лаэорью" или аналогичными преисподнея 'семью небесами'.
10.0 .
211 Льни,
212 Льни,
213 Черны
214 Котлы смоляны!
215 не лги: смоляны,
216 то льны зелены.
217 Клонись,
218 Кренись,
219 Ресницами льни.
220 Лохись под Свист
221 Стрелы калены.
222 Ан, льны!
223 АЯ, льны льняны,
224 царичины льны!
225 Ручьи с земли
226 Поклон привезли:
227 Ресницами шти,
228 Глазницамн шли,
229 Землицею шли, -
230 Солоны!
231 Солоницами - глазницы
232 у ржанон земли.
233 Что х вы, гости имениты,
234 мало по-бьли?
235 Солоницею - землица,
236 Сколько хошь - соли!
237 Что х вы, плоти румянисты,
238 мало по-хили? 
239 Мало ль, много ли -

240 дроги поданы!

241 Проходи со мнон

242 Муку огненну!

10.1. Появление "муки огненноя" (242) подготовлено в поэме с самого начала: "Богу жертву кадит" (7), "Дунет - костром загарит" (21), "От моих горячих губ - Лихоманочки идут! От моих горячих губ - В теле жилочки гудут!" (61-64), "Разумяниста моя Знобь-Тумановна! Лихоманочка моя Лихомановна!" (69-72) и далее вписанның в Ведунью образ демонического огненного коня и молния: "Два - за косы" (176) - "Ни косы-ни руна, Ни реки-ни челна, Две возжи" (179-181) - "хги! В обе возжи!" (190-191) - "заревом в лоб - ржа, Ры-хая воз-жа!" (203-204), где "косы"="возжи"='молнии'; "Геи, мои рыхи!" (192), где "рыки" = 'огненные кони', и "щек моих пыл" (201) с отзвуком 'лихорадочноя', 'знобяен' природы Ведуньи (61-72). Итак, "огненная бездна" (СиП II, 380) или "муки огненные" - не что иное как очередная ипостась самон Ведуньи, как погломение ею Героя в себя. Так сладострастное коварство (209-214: " - На! - На века-дни Царствьица хлеб-ни! Льни, Льни, Черны Котлы смоляны!") оборачивается окончательным взятием Героя Ведуньећ.

Разгадка же "Котлов смоляных" кроется в стихах 215-216: "Не лги: смоляны, То льны зелены", т.е. в явноЯ эквиваленции " "котлы" = "льны"' и '"смоляны" = "зелены"'.

10.2. Разбирая румынскую фольклорную "Повесть конопли", Т. В.Цивьян вскрывает в ее основе мифологему 'испытание' или 'смертьвоскренение' и попутно замечает о существовании ана:огичного операционного текста "Обработка льна" в русскои традиции с возмохностью аналогичноя мифологемы и приводит следуюаую русскую загадку О льне: "Били меня, били, колотили, колотили, клочьями рвали, по полю валяли, на ключ запирали, за стол сажали". 85 иньми словами, в Цветаевских "льнах" позволительно видеть наличие смысла 'смерть-воскрешение'. Это тем более вероятно, что, как уже было показано раньше, "лен" связан с мужским началом, с громовержцем (см. 8.8. и 8.9.), т.е. с периодически умираюмим и воскресахиим космическим персонахем (ср. у Френденберг: "Мы не знаем мифов об умирающих и воскресаюии женщинах, а только о мухчинах. У хенцин 'воскресение' заменено метафорон 'родов' и 'рохденин'. Рождая, женцина рождается. Ее лоно - земля, могила, сосуд, яма. [...] 'Роды' и 'рождение' - более древние метафоры, чем метафора 
'воскресения', хотя означают то хе, что и та").86 Эпитет хе "зелены" - в противовес предыдудему, В 145, "лен-тот-нечесан", т.е. 'старың' - подсказывает смысл 'молодоя', 'обновляющнися', 'проиэрастаюиня'.

"Котлы смоляны" отсылают в свою очередь к сказочньм кипямнм котлам и их Функция 'испытания' и 'преобрахения' ('воскрешения') героя. Как правило, они обновляют и облагорахивают телесную оболочку сказочных героев, возврамают им молодость и витальные силы. Будучи хестоким - огненным - испытанием, они одновременно воскрешают, вьводят в состояние блахенноя вечности (долгоя и счастливоя жизни: на купанье в кипящих котлах все невзгоды и перипетии сказочных героев обычно прекрамаются).

С этоя точки зрения эквивалентность "котлов смоляных" и "льнов зеленьх", думается, очевидна.

10.3. Необходимо еме только учесть, что "черны Котлы смоляны" (213-214) полвляотся в цветаевском тексте не произвольно, не извне, а логически выводятся из предыдуших состояния мира поэмы - они всего лиш вариант одного и того же образа небесноя грозы, весеннего синвлен прирошы. Ср. у Афанасьева: "Этот смоляноя ад известен у славян и литовцев под именем $\pi$ е к $\boldsymbol{л}$ a [...], каковое слово пронсходит от глагола $\pi$ е ч ь, $\Pi$ е к у и равно означает и смолу, которая гонится через сохокене смолистых деревьев, и геенское пламя. [...] На Руси смолу называют в а $\mathbf{p}$ м м, а слово д ё $\Gamma$ о т и имеет в санскрите корень dah (dagh) - гореть. следуя буквальному значению этих слов, предки наши буквально свяэьвали их с представлениямн весенних вод и дождея, рождаюиихся деяствием яркого солнца и молниеносного перуна из растопленных

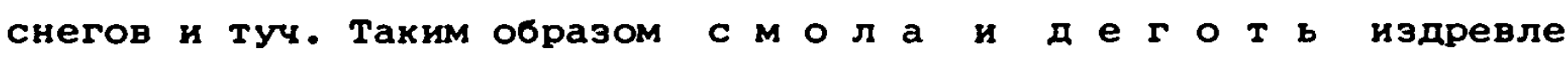
быии метафорами дохдя (I, 788-9), а слово $\Pi$ е к $\pi$ о к обозначению 'ада' перепло от понятия громово тучи, пылающея молниями и преисполненноя кипучею влагоя хивоя вошы. В старинных славянс-

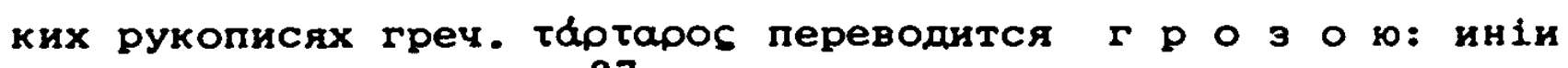
$r$ p 0 t п предаются". 87

О том, что под "смоляными котлами" и "мукоЯ огненноя" скрывается архаяческия народны образ весеннего возрождения природы, явственнее всего свидетельствует Факт, что и "котлы", и "лен" и "муки", т.е. весь "соблазн безднор огненноя", включены вовнутрь грозового эпизода поэмы: 171 - первое упоминание молния; 181-204 
- несомненная картина грозы; 211-219 - речь о "котлах" и "льнах" , но ухе в 220-222 снова О молния ("Ложись под свист Стрешы калены. Аम, льны!"), потом в 242 говорится о "муке огненно" и сразу це за этим (243-246) снова гроза, почти тохдественная первоя (171-174): "ОЯ - молния! Он - гром! Не - молния: Конь - в дом!".

10.4. Тавтология "льны льняны" (223) и определение "царииика льны!" (224) значительно повьшают статус "льна" и, кроме того, удваивают его, разводя на 'лен-растение-материал' ("льняны") и 'лен-ткань-изделие' ("льны"; "царицыны льны!").

'Лен-ткань' предполагает несколько прочтения вполне согласуюмихся с предшествующим семантическим ходом поэмы. Прехде всего по народньм представлениям 'лек-ткань' прочно соотнесен с облачньм небом, т.е. оно рассматривается как покрытое тканями противника Громовержиа 88 (ср. кстати, в само поэме упоминание "белохрудатых громких платьиц", "занавеса" и "платков" ведуньи, превращакинхся в потокн воды - см. 1.7., 3.3., 3.4., 3.7., 6.3., 6.7.). Это прочтение повторяет ухе известные нам смыслы поэмы, но оно подводит к другим, вщдвигаемым на первы план лиш теперь: к смыслу 'савана' и 'плоти'.

'Лен-ткан-саван' ведет к погребальноя народноя обрядности, согласно которой сопровохданине усопшего саван, полотенца, руиники и т. П. атрибуты рассматриваются как своеобразные, грубо вырахаясь, транспортные средства, переправляющие его в потусторонния мир 89 (ср. 240: "Дроги поданы!"; 305: "Синь-Савановна"; 3740: "Занавес - моя - занавес! [...] Мне лица не занавесь!": кроме того ср. в стихотворении "Барабанщик" - 1918; СиП II, 238: "Бедноп матери в оконце Вечно треплется платок" или в стихотворении "Вятие Крьма" - ноябрь 1920; СиП II, 88: "Все окна Флагами кипят. Одно - завешено", где очевидна отсылка к обычаю вывешивать из окон полотенца после кончины кого-нибудь из родных). 90

'Лен-ткань-плоть' - к тем же народным представлениям, согласно которьм плоть рождающегося человека, его земную ризу-наузу, ткут таинственные девы судьбы (рожаницы, парки, норны и т.п.). 91 О связи льнов с тканью-плотью в поэме свидетельствует как переименование "котлов смоляных" во "льны зелены" (215-216: "Не лги: смоляны, То льны зелены"), погрухение в которые (211-212, 217-219: "Льни, Льни [...] Клонись, Кренись, Ресницамя льни") подразумевает мену телесного облика героя, так и прямое упоминание умершея 
плоти: "Что ж вы, гости имениты, Мало по-были? [...] Что ж вы, плоти румянисты, Мало по-хили?" (233-234, 237-238), где "гости" естественно читаются как временно пребывавшие, т.е. 'гостивше' на земле (231: "у ржанон земли") дуин.

10.5. Упомннание 'Царищы' (224: "царицыны льны") имеет дворное основание. В связи со 'льнами-тканью' - она являет собоя влапьчицу нинего мира управляющую человеческоя судьбон: пряденье, тканье, выделыание полотна (в том числе и плоти) - занятия именно мира подземного. 92 В связи с поэтическо системо Цветаевон 'царица' - та же влаштиица подземного мира (ср. ее противопоставление "Деве Чистон" в "царь-Девице" и мотив воэделывания - плетения в ее "семи покоях" 'тканен' сплетен-крухев, союзов, разлук, т.е. 'судеб', а такхе упоминание "чесальщиц"; СиП IV, 39-40; см. 2.2. и 8.9.; ср. еме оппозицию "царица" - "царь-Девица"' с акцентом на женском хтоническом начале перво и мужском небесномгромовниковом второн), иногда отождествляемая со 'страноя-землен' (ср. в "царь-девице", СиП IV, 33: "Мы прондем пока на половиночку к царице. [...] Посмотрим, как мается, Слезон обливается, Как С ночью справляется Страна - без Царя").

В разбираемом Фрагменте "Переулочков" этот исходнын мотив Царишы-земли разработан детальнее и в несколько ином направления. 10.6. Эпитет "ржаная" ("У рханон земли" - 232) в окружения настоячивого упоминания "соли" (230: "Солоны!", 231: "Солоницамн", 235: "Солоницею", 236: "соли!") и "гостен" (233: "гости имениты") отсылают к вырахению 'хлеб-соль' означаюмему 'гостеприкмство' . "Мало по-были?" и "Мало по-жили?" подразумевают 'кратковременность'пребыаняя на земле, в гостях. В итоге земля получает тут статус 'гостинищ', т.е. локуса смерти, 'преисподнен' (ср. возмохность причтения "котлов смоляньх" как тон же 'преисподнен', 'ада'), а "гости" - 'умеритх', 'странников', 'путников'.93 Связь земли со смертью дополнительно явствует из стиха 231 "Солоницами - глазнищы У рханои земли", где кроме ассоциации с 'черепом' ("глазнищ") присутствует смысл 'слепоты' как признак принадлехности к мертвому царству (см. 9.3. и примеч. 67).

из пространственно градация в стихах 227-230, построенноя по принципу 'углубления' : "Ресницами" - "Глазницами" - "Землицею" - 'соль' ( -"Солоны!")', следует, что 'соль' локализована глубке всего и что этим самым она занимает место 'суиности'. T.e. ассо- 
цинрована с понятием 'соль земли' означаюмем самье ценное. Но одновременно с так понимаемо 'соли-сущности' снимается ее имматериальныя духовны аслект, так как она дается тут и как 'вемество', 'мннерал' (235-236: "Солоницено - земтица, Скопко хашь - соли!") уравниваемия с "землицею" и в итоге с понятием' праха'.94 Это значит, что 'сольсуцность' мыслится здесь все еме как бытие умербное, нуждаюмееся в дальнершем отсеве-отборе или очимении от 'материальности' (отсюда очереднои этап: "Проходи со мноя муку огненну!" - 241-242).95

11.0.
243 ОЯ - молния!
244 Он - гром!
245 Не - молняя:
246 Конь - дом!
247 Раз - выступом,
248 Два - выскоком,
249 Три - искры лоб!
250 Ан:
251 Ни огня-ни котла,
252 Ни коня-ни седла,
253 Два крыла,
254 Да и ла -
255 Зорь!

11.1. Третия поединок Героя с Ведуньея, как предыдуиие, завершается порахением Героя и ново метаморфозо обоих персонахен. Последовательность метаморфоз Ведуньи очевидна. Она всякия раз превращается в уносяпее, увлекающее за собод средство передвижения: 'речка-кораблик' (120-121), 'конь-погоня' (185-196: "Я же и конь, Я ж и погоня") и, наконец, "Два крыла" (253). То есть: 'плаванье' - 'поднебесная скачка' - 'полет'.96

'Плаванье' механично и инертно (кораблик уносимы речкон) и предполагает переправу, мену места (ср. 'прощальные поклоны' в 149-164) и, так сказать, совериается на пцинном земном уровне. Но отношению к Герою оно играет роль убаюкивающего, усыплющего, погужаюмего в состояние забытья (требуюиаяся Ведунье настоятая суть раскланивания в 146, 151-152, 163-165).

'Гонка-скачка', в отличие от 'плавания', - активна, но и она пока скорее вынужденное внешнее двикение, чем внутреннее, что видно как в идее "погони" (186: "Я х и погоня"), так и 'колесницы" (182: "Ямпичок, жги!"; "Жги, ямиичок, В темъ!"). По отношению к Герою эта скачка активизирует его, вовлекает его в движение, в страстную самозабвенную гонку. для Ведуньи вся эта гонка осумествляется на поднебесном уровне. для Героя же она оборачивается падением вниз, вглубъ (ср. переход от прехнихаги́поклоновя́-5 - 
"Кланянся!" - в 151-152, 163-165 до 'падения-ньрка': "Клонись, Кренись, Ресницами льни. Лохись" в 217-220 и упомннание о "котлax" в 214; С. 8.8. и 9.6.).

'Полет' , подразумеваемы под 'крыльями'и 'Лазорью' (253255: "Два крыла, Да и в ла-Зорь!"), знаменует уже некое чистое двикение-устремленность ввысь.

Для Ведуньи вся эта эволоция естественна. Ведунья изначально являет собоя сущность запредельную, только радн совращения Героя принявшую кахимость земных Форм (лькивых, обманчивых, соблазнительных; ср. автокменования Ведуньи: 177- "яблочко"; 131133 - "Ранскоя слоночкой Мехпу прочнх рек Сливу; 185-186 - "я хе и конь, Я и погоня"; 193-196 - "Лхея-то в груди Семь да семихды Семь, да еме - Семь"; 262-263 - "Лазорь-лазорь, Прохлада моя!"). И истинны ее локус - уходямая в бесконечность беспредельная высь: в одном варианте "переулочки игнатьевские" (4, 12, $28,56)=$ 'нетварному локусу' (см. $1.1,1.8 ., 4.5 ., 9.3)$, а в другом "дом" (246) = "Лазорь" (254-256 и след.) = "котел без дна!" (273) и т. п.

Для Героя же его эволюция - результат очарованности-соблаэненности. Дабы завладеть соблазнительницеи, он должен проити тот же путь, но поскольку он принадлехит миру земному, этот путь окаэьвается одновременно и совершенно иным. Сначала он должен погибнуть и потом воскреснуть, т.е. сначала лишиться свонх земных форм и связен, всех ограничителен удерхиваюцих его в сфере земного бытия (чувств, памяти, привязанностея, страстея), потом воспарить и бесследно раствориться в беспрелельности. Поэтому в принципе совпадая с путем Ведуньи его путь ведет сначала вниз, в смерть, через "Котлы смоляны", и лишы потом уже - по ту сторону "Котлов" - вверх по восходямеи (ныряя вниз он одновременно воспаряет ввысь, ср. 273-275: "Котел без дна! Ладонь-глубизна! Лазорь, лазорь" и 256: "Лазорь, лазорь, Крутая гора!") .

11.2. Было бы однако неправомерно читать всю эволюцио Героя как результат магических заклинания Ведуньи. Пока Ведунья ни во что его не преврамает. Она лишь усылляет его бдительность и завладевает все более глубокими и все более сумностными аспектами его естества. Эволюция от простецкого любопытства до богатырских качеств Громоверхца (молние-громоносного коня) - это лишь выявление залохенных в нем исконных начал. Примечательно, что в 
третьем поединке он уке лишен всякого земного (человеческого) облика, он уже не "ямпичок" (182, 197) а "конь" (246: "Конь - В дом!"), т.е. только противостоямее и аналогичное ведунье стихинное космическое начало. Примечательно и то, что теперь Ведунья не принимает никаких новых обольщающих форм. Соблазн уже не нужен: Герой очутился за пределами самого себя, за пределами земного, в царстве Ведуньи. А тут возможен уже только бесконечны полет ввысь .

11.3. В отличие от стихов 171-174, где речь только о "молнии" и о признаке "коня" (173-174: "не - молния: Конь - рхет!"), здест есть и "молния" и "грам" и, кроме того, появляется "конь" (246: "Конь - в дом!"). Легкс заметить, что разница идет в сторону самоявленности 'грома' и его эквивалента 'коня'. Это означает, естественно, окончательное выявление или овнешнение нанболее глубокон сущности Героя: его 'громоносности' ("гром") и его "богатырства" ("конь"; ср. аналогичное распределение достоинств в образе Георгия в написанном в июне 1921 года цикле "Георгия" - ChI II, 112-119).

Стих "Конь - в дом!" (246) перекликается с темон "гостен" В стихах 231-238 и с темон очистительного прохождения через "Котлы смоляны!" (214) и "Муку огненну!" (242). 'Гость', как уке говорилось в 10.6., - 'умершия'. Но у 'гостя' есть и другое значение. Это - "сам тотем, 'господь' [...] мало того. Гость со временем получит значение эпифанируюего бога, господа, приходящего в дом, являющегося людям; с 'приходом' этого бога-тотема начнет увязываться мотив гостеприиства". 97 С другон стороны, в архаических системах 'гость' понимается не только как тотем, но и как 'враг' и 'жертва', причем 'жертва' при обмене с богом (ср. лат. hostia). 98 все эти смыслы в поэме налицо:

- "гром" и "конь" - окончательно эпифанируючия и скрыто присутствовавшин в Герое бог-Громовник;

- он же 'жертва' того же Громовника, вытребованная Ведуньеи в обмен за свою жертву (см. 7-8: "Богу жертву кадит, С дуба требовант"; См. 1.4.);

- он же 'враг': "Конь - в дом!" значит также разрушение "дома" (ср. разрушение храма конем в поэме "На красном коне" - СиП IV, 158: "Престол опрокинут! [...] Стоните, стоните, стены! [...] шатается купол. - Рухая, Сонм сил и слав!"). При этом "дом" значит 
тут скорее всего подземны мир Ведуньи (Ср. о ее локусе в 16: "Всех оконечек - семь" и вообме устоячивы у Цветаевон смысл "дома" как локуса смерти), в том числе и ее самое как некое пространство (это мохет быть, в частности, как 'дом-туча', т.е. подземная ипостась Ведуньи, так и 'заоблачнын дом', т.е. Ведуньина "лазорь"; Ср. В "Георгии" - СиП II, 113 и 116: "За красною тучею Белы дом. Там впустят вдвоем С конем"; "Славьте - Георгия! [...] В дом Госпохи свое Коннвм - вступившего!").

11.4. В отличие от стихов 179-180, где и 'коса-руно' и 'река-челн' соотнесены С Ведуньея, стихи 251-252 имеют ввиду и Ведунью ("Ни огня-ни котла") и Героя ("ни коня-ни седла"). А это значит, что тут нмеет место исчезновение их обоих и преврамение в одну органическуо пару 'крыл' ("Два крыла") .

Как и во всех іредыдумих метаморфозах, меняется здесь такхе и пространство, меняется ипостась мира. "Котел", несомненно, соотнесен с низом, с преисподнея, поэтому "седло" долхно знаменовать верх, небо; "огонь" и "конь" - некия средния уровень. их исчезновение означало бы выход за пределы этого 'космоса' в 'космос' второго ранга, на некия инои уровень бытия, еще более универсальны, чем предиушия (кстати, этот смысл видимо и стоит за стихами 258-259: "Лазорь, лазорь, Вторая земля!") .

Если отстанвать соотнесенность 'коня-седла' с Героем, то 'седло' означает тут не только 'высь-небо', но и предел тварного Божественного мироздания. Ср. В "Георгия" (СиП II, 116-117): "C apхангельских высот Седла - копья - содеянного дела" и "С архангельскои высоты седла Евангельские творить дела". Тогда "вторая земля" и "Лазорь" означали бы ухе сферу нетварного.

11.5. В рамках подспудного присутствующего в поэме мифологического сохета борьбы природных стихин последния поединок с его заклочительньм полетом "в ла-3орь!" (254-255) можно чктать как финал грозы, когда исчерпьваются обе противоборствующих стороны: и похитительница-туча-змен и разбивающи ее молние-громоверхец, т.е. когда устанавливается космнческое равновесие (253: "Два крнла") и начинается новын природны цикл (ср. упоминание "жаворонка" В 353 и 'златорогого тура' в 365-371, одинаково знаменующих весну и плодородие).

11.6. В рамках хе Цветаевскон поэтическон системы последнин поединок читается аналогично, но все-таки иначе. Он ведет к новон трансформации, но на этот раз окониатедыны 
Героя и Ведунъи отменяотся; снимается также антогонизм мехду Героем и Ведуньеи - они образуют теперь одно диалектическое единство ("Два крыла" - 253; "мы" в 310) и выходят за предель земного измерения (точнее: тварного мира). И здесь, собственно говоря, завершается сюхет поэм, хотя это всего лиш две третьи ее текcra.

11.7. Остальная треть текста (стихи 256-373) посвящена полету, возношению ввысь, в Лазорь. Такая камозинонная диспропорция длины текста отобрахает, по всен вероятности, идею бесконечности и беспредельности Дазори. Отсутствие хе события и изменения-трансформация героев в это части текста может в свою очередь читаться как отрахение недискретности и беспризнаковости Лазори, ее, говоря словами Гаспарова, "не-сущности", 99 ее непрерьвно и бесконечнов динамики. и тем не менее соблазнительно присмотреться внимательнее к этой Лазори и хотя бы в наиболее обих чертах осознать влагаемы в нее смысл.
12.0 .
256 Лазорь, лазорь,
257 Крутая гора!
258 Лазорь, лазорь,
259 Вторая земля!
260 Зорь-Лазаревна,
261 Синь-Ладановна,
262 Лазорь-лазорь,
263 Прохлада моя!
264 Ла-зорь!
265 Во останнь во разочек
266 Затянись, замри!
267 То последния ветерочек
268 С аржанои земли:
269 Горбы, бороды, да борозды,
270 да зеленя.
271 Дух навозенны, забористы, -
272 Моя земля!
273 Котел без дна!
274 Ладонь-глубнзна!
275 Лазорь, лазорь,
276 Синь-озеровна:
277 Ла-зорь!
278 Во останны во последнин
279 Через всю-от-синь:
280 не за раннею обедне
281 Молодиу - помин...
282 в кузне - славу куют,
283 К устам - чару несут,
284 другу - славу поют
285 в ла-зорь. 


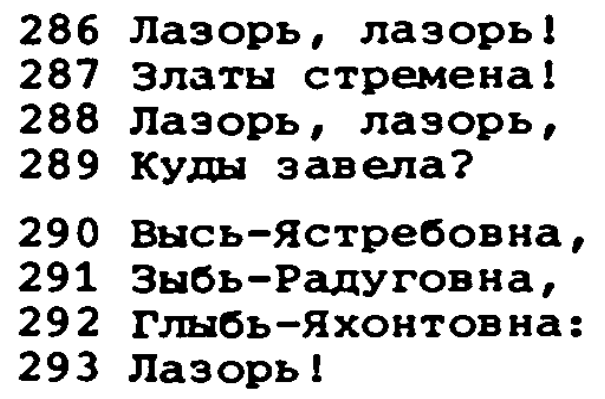

294 Звончея, Звоннишы-бессоннишы,

295 Во весь-От-звон!

296 Здесь головушки не клонятся:

297 и так взоддем!

298 Синея, дњмницы-кадильницы,

299 Во весь-от-дым!

300 На груди моеи - одиннадцать

301 Eме с одним!

302 Аминь,

303 ПОМн,

304 Морская Хвалынь,

305 Синь-Савановна,

306 A -

307 Весь-от-и мир,

308 маревом - дни!

309 Беэ вести - мир,

310 Без вести - мы.

311 Синь-ты-Хвалынь,

312 Сгинь-Берехок!

313 Звездная синь -

314 наш полохок.

315 но через весь

316 Морок - взгляни! -

317 Лестницею -

318 Ризы мои!

319 Глух пуховик:

320 Дна не достанешь,

321 Каменем крик

322 Панет - и канет.

323 Поволевав,

324 Пошалевав:

325 Синь - в canorax,

326 Синь - в головах...

327 пасть - не упасть,

328 Плыть - не доплыть.

329 Дарственными -

330 मушу насыть!

331 миљы, растрать!

332 С клашью не примут!

333 дабы принять -

334 Надо отринуть!

335 Первая цель,

336 Пригород липь!

337 Этих эемель -

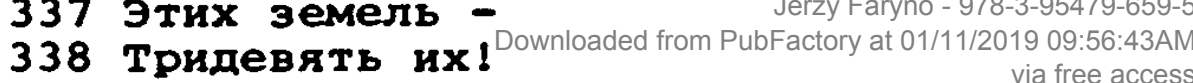




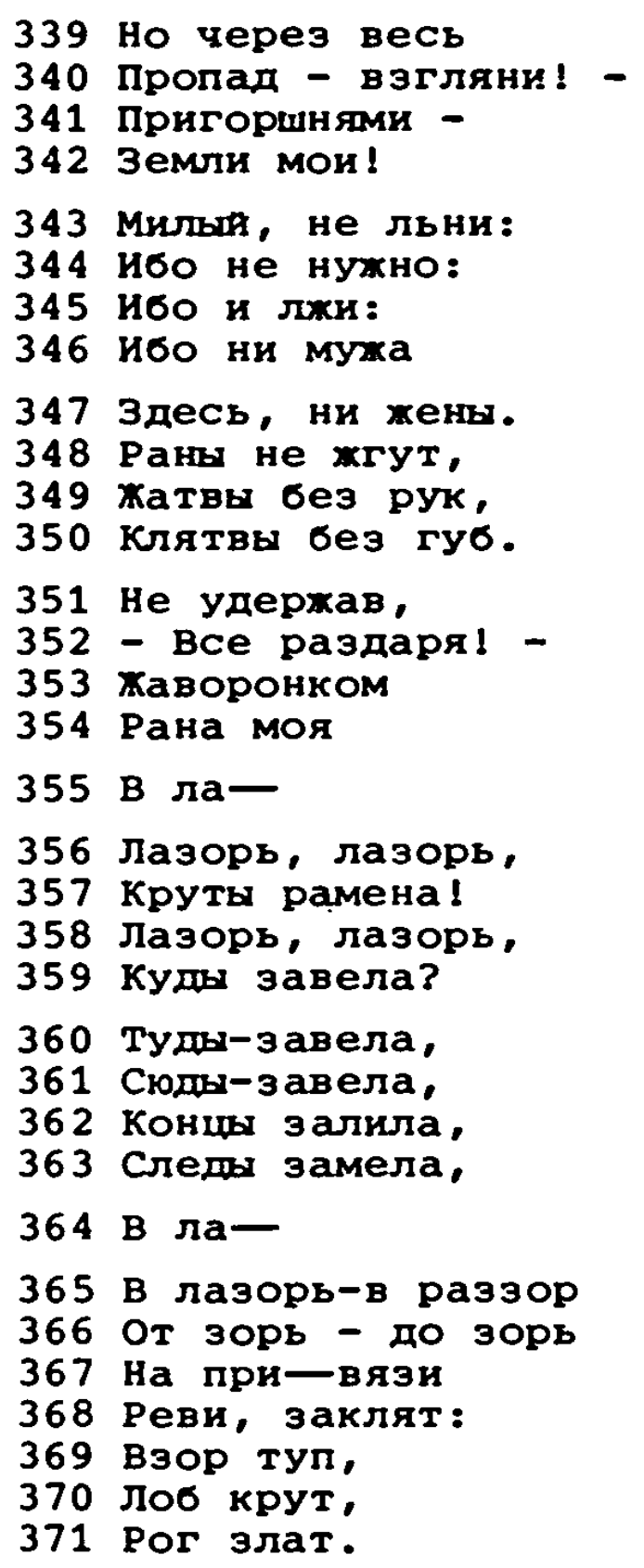

372 тури след у ворот,

373 От ворот - поворот.

12.1. В стихах 256-277 "Лазорь" сопоставляется с "землеи" и одновременно противопоставляется еА. И со- и противопоставление содержится в наяменованиях "Лазори" Ведуньер "Лазорь, лазорь, Вторая земля!" (258-259) и "Дух навозенны, забористын, - Моя земля!" (271-272).

"Вторая земля!" читается в первую очередь как некия инод мир, не тохдественны обычному земному, и как созвучны библеискод земле обетованноя (ср. соблазн 'раем' в 73, 103, 105, 119, 131 и его эволюцию как путь выявления глубиннои сущности этого 'рая'). Но одновременно она может пониматься также и как 'вторая'по счету 
СФера владенин (царства) Ведуньи (ср. В 337-338: "Этих земель Тридевять их!"; см. также 11.4.).

Наяменование "Лазори" "Крутоя гороя" (257), а затем переименование во "Вторую земдо" (259) локализует данную сферу "Лазори" вверху, над обычным земньм уровнем. Это мохет быть как 'небо', так и лобая иная ипостась потустороннего, внеземного мира. Кроме признака 'выси', 'вертикали', "Крутая гора" вписввает в нее по краянея мере еще два иньх признака: 'требовательность, бескомпроми ссность, неуступчивость' 'труднодоступность' (ср. 331-334 с их смалом 'отказа', 'требования жертвы': "Милың, растрать! С кладью не примут! Дабы прияять - Надо отринуть!", и 348-357, где 'хертвенность' еще более очевидна: "раны", "без рук", "без губ", "Рана моя" и "круты рамена", которые позволительно ассоциировать С 'крестно мукоя' В виду наличия христианскои лексики в 31,32 , 34,54 ) и 'центральность, Фундаментальность в мироздании' (если учитывать мифологические коннотации "горы" как 'мирового центра'), а такхе некую 'вериннность, граничность с очередноя сфероя' (особенно если учитывать коннотации "горы" в иных произведениях Цветаевон; ср. хотя бы стихотворение "С этов горы, как с крыши мира, где в небо спуск" - 30 августа 1923, СиП III, 96).100

Противопоставление 'земля - Лазорь, Вторая эемля' несколько уточняется В стихах 269-272. "Горбы" (269), отчетливо перекликающиеся с "горои", знаменуот тякесть, бремя (доли и усилия), согбенность, склоненность-по (при) давленность вниз и внешния, Физическия уродливын облик. 101 "Бороды, да бороэды", наравне с "горбами", - физическую старость, обетшание плоти, уродство. 102 "зеленя" - 'вегетативность', 'прозябание' и 'незрелость, неумность" (ср. 147-148: "А на што нам лен, Зелена башка?"; 129-130: "что за дурость-така-соплячество Башкоя русою в юбки прятаться?"; 'наивность', 'простоватость' Героя, звучамие в его вопросах в 9 , $10,29-32) .103$ "зеленя", кроме того, противостоят здесь "голубизне' и 'синеве' Лазори, где 'голубизна' сочетает в себе и представление о цвете ("Лазорь" как "синь" в 261, 276, 279, 305, 311, $313,325-326)$ и представление 'глубине-умудренности' (273-275: "Котел без дна! Ладонь-глубизна! Лаэорь, лазорь", где двуименность 'котел-ладонь' объединяет в одно и поглашақиую бездонную 'прорву' - ср. "пропад" в 340 , и поддерживаящия принцип: "ладонь", в частности, как 'поверхность вод', 104 ср. тут же в 276 переиме- 
нование в "Синь-Озеровна", т.е. создает диалектическия образ 'мировместилима') .

\section{Стихи "Дух навозеннья, забористыя, - моя земля!" (271-272)} вводит в понятие 'Лазори' и ее переименованид признак 'духовного', 'не-Физического' . Примечательно при этом, что "дух" противостоит здесь одновременно и земному 'воздуху', получившему тут вид "ветерочка" (267: "То последнир ветерочек С арханои земли").

"Забористь" (271) значит, в частности, 'цепкия, острын, опьяняющи, заманчивын' 105 "навозеннын" (271) активизирует как признак интенсивности, так и признак 'гниения, тлена'. В контексте 'хлебопашескон' картины стихов 269-270 ("Гробы, бороды, да борозды, Да зеленя") "навозенның" и "забористын" могут читаться как предпосылки нового вегетативного цикла, 'возрохдения'. Но переход к "котлу без дна!" принципиально этот цикл размқает, хотя идеи 'возрождения' и не снимает (из-за 'поддерхивающея' "Ладони-глубизны") . Возрождение возмохно, но не обратно, а в противополохную сторону от земли, возрождение как качественное перерождение. 106 Этот смысл, кстати, улавливается в серия "Царствьица хлеб-ии!" (210) - "черны Котла смоляка!" (213-214) $\rightarrow$ эквиваленция "смоляны, то лока зелеки" (215-216) - "С архакой земли" (268) $\rightarrow$ "Дух кавозекний, забористий" (271) $\rightarrow$ "Котел без дна!" (273) - "К устам - чару несут" (283) и в серии "Синь-Лат дановка" (261) - "Затякисо" (266) - "Дух навозеннья, забористий" (271) - "Синен, димкици-кадилокици, Во весь-от-дам!" (298-299), которые подразумевают 'перестранващее' денствие гальоциногенньх средств (напитков и воскурения), 107 способствуюиих 'воспаренин' души в трансцендентның мир (Сp. 294 упомннание "бессонницы", в 295 "звона" и самопроизвольного вознесения в 296-297 "Здесь головушки не клонятся: И так взоддем!" рядом с картиноп обморочного состояния в 300-304: "На груди моен - одиннадцать Еме с одним! Аминь, Помнн" С обрывающимся в 306 "А - ", которьм передается 'последния вздох').

"Вторая земля" = "Моя земля" = "Дух" оказывается, таким образом, сфероя последнего воздуха (267: "То последния ветерочек") и последнего вздоха (306: "А - "). Кроме того, в отличие от 'первоя земли', где осуществляется циклическая перестрояка плоти (стихи 269-271), "вторая земля" - сфера перестровки души.

В контексте стихов 227-238 'первая земля' раскрывает свою 
хтоническую сущность: она - временнын локус матернальноя ипостаси бытия, локус отмираюмен плоти, т.е. смерть в ее биологическом решения (таков смысл приписанных ең "глазниц" и таков смысл ее 'гостеприямства', ее 'хлеб-соли': См. 10.6.). По сравнению С нею 'лазорь' - бесплотна, она - "дух", притом 'галпюциногенны', - и безгранична, ср. со- и противопоставление 'Солоницею - землица, Сколько хошь - соли!" (235-236) $\rightarrow$ "котел без дна! Ладоньглубизна!"' (273-274) по признаку 'малое беспредельное' (Сp. дальше, в 341-342: "Пригоршнями - Земли мон(") и по признаку 'медрое ненасытное'.

12.2. Патроним "Лазаревна" (260: "зорь-Лазаревна") совмемает в себе два исходных имени - "Лазорь" и 'Лазарь'. Отсыка к имени 'Лазарь' вводит в контекст и Лазаря Четверодневъого и Лазаря убогого. Историея Чертверодневного объясняются тут, по-видимому, стсылка к ладану в патрониме "дадановна" (261), "Дух навозенныя, забористыр" (271), поминки (278-285) и потом трансформация ладана в "дымницы-кадильницы", "дым" (298-299), "марево" (308). "морок" (316). Контекстом же Лазаря убогого - "Котел без дна! Ладонь-глубизна!" (273-274), потом "Дарственньми - дугу насыть!" (329-330) и "Милья, растрать! С кладью не примут!" (331332).

Патроним "Ладановна" (261) и поздненшие его трансформация объясняются такхе и предидумим контекстом поэмы: "Богу жертву кадит" (7), "сладкие смеси" (47) и "Котлы смоляны" (214-215) с постоянным смыслом 'дурманямего средства' .

При этом чрезвычаяно интересно расчленение назваяия "лазорь" в стихах 260-261 на слог "-зорь" С переведением его в 'Зорю' ("зорь-лазаревна") и на слог "ла-", осмысляемы в свою очередь как 'лазурь', т.е. 'синь' ("Синь-Ладановна"). 'Лазорь=синь' в дальнеңшем тексте последовательно связывается с разными вариантами 'ладана-дьма' и 'воды-савана', т.е. с 'погребально-заупокояньм' ореолом "Лаэори" (276: "Синь-Озеровна" ; 274: "Ладонь-глубизна", где "Ладонь-", кроме созвучяя с "ладаном" и 'дланью', означает еме как водную поверхность, о чем была ухе речь в 12.1., так и 'ладыю' - ср. наличие "кораблика" в 120 и его связи с 'летучим гробом', оговоренные в 8.2., 8.3., 8.5.; 279-281 с откровеннои рифмовкон слов "синь" и "помин"; 298-301, где 'синь' и ее интенсивность - "Синея" - связаны С "дымом" "дъмниц-кадильниц" и С 
захоронением "на груди моен"; 302-306, где "Синь" получает патроним "-Савановна", а корме этого является иным именем "морскон Хвалыни" и как бы экспликащиен слов "Аминь, Помнн", оэначауоих конец, смерть, завершение; 311-312 и 325-326 с семантикоп 'сгинуть, исчезнуть' и погребальнои позоя).

'Лазорь эорь' связывается с непрерывным восхохдением или уводом ввысь: в 286-289 она - "златы стремена!", означаконе вероятнее всего стремительность и энергичность двихения; в 290-293 она - весь макрокосм в одном единстве ("Высь", "Глыбь" и промехуточная, соединяющая оба этих полюса "зыбъ-радуговна": ср. В 39 : "Часть-рябь-слепь-резь!" и 3.7.), а в финале - весь временноп континуум, некая 'беззакатность' (365: "От зорь - до зор").

"зорь-Лазаревна", отсылая к Лазарю Четверодневному, сохраняет, как видно, только смысл ухода в потустороннин мир через смерть и бесконечное восхохдение - по ту сторону - к абсолюту. Евангельское воскресение из мертвых в земную 'хитенскую' Форму здесь демонстративно удерживается в поле зрения читателя, но так же демонстративно устраняется. В Цветаевском решении 'обратного воскресения' нет, как нет и периодического 'вегетативного' возрохдения (см. 9.5. и 12.1.). В ее модели 'воскресение' означает бесповоротны уход 'по ту сторону' и устремленность к 'абсопоту', к 'за-тварному' - Это решение, думается, не противоречит христианскоя модели бытия, оно лишь переводит акцент на состояние мира после 'Второго Пришествия', т.е. 'за-тварного', а этим самым и 'дотварного', 108 что и есть цветаевское 'воскресение' Ср. по поводу Лазаря в "Земных приметах" (1919; Проза I, 111-112):

"'Воскреси его, потому что нам без него скучно!' - то же самое, что: 'Разбуди его, потому что мы без него не спим'... Разве это довод? - О, какое мертвое,плотское, чудовитное чудо! Какое насилие над Лазарем и какое - страшнеңшее - над собод!

Лазарь, возврамаюиияся оттуда: мертвын к живьм, и Орфея, спускающияся туда: живоя - к мертвьм... Разверстая яма и Елисенские поля. - Ах, ясно! - Лазарь отmуда мог принести только тлен: дух, в Жизнь воскресшия, в жизнь не 'воскресает'. Орфен хе из хизни ушел - в Жизнь. Без чухого веления: жахдоя своен.

$[\cdots]$

Как мне жаль Христа! Как мне жаль Христа за его насильственные чудеса! Христос, пришедини горы двигать - словом! 'Докахи, 
тогда поверим!' - 'Верим, но подтверди!' Мехду чудом в Кане (по просьбе Марии) и испьтуочим перстом Фомы - странная перекличка. Если бы Мария была зорче, она бы, вслед за преврамением воды в вино, увидела другое преврамение: вина - в кровь...

убехдена, что Иоанн у христа не проскл чудес".

"Синь-Ладановна" же - обратная сторона этого хе восхохдения, его, так скаэать, условие, т.е. непрерывное умирание и растворение в небытии (тут уместно видеть смысл ассоциации "-Лазаревны" с Лазарем Убогим). Как одно единство эта 'Лазорь' оказывается апофатическим путем к абсолюту, ср.: $331-334$ с их требованием полного отказа и полноя растраты; 343-350 с их отсутствием или снятием каких-либо различия, каких-либо омущения, какоя-либо 'орудияности' и какого-либо плана вырахения; 352-354, где 'боль' ("рана моя") оборачивается 'леснея-хаворонком' танен в беспредельности (обрываюмиеся, 'недосказанные' "В ла-" в 355 и 364).

12.3. Если на последовательность текста смотреть как на отрахение 'проходимого пути' в 'Лазорь', то за 'воздушньм' слоем "Второв земли" (267: "То последния ветерочек" и 271-272: "Дух навозенның, забористы, - Моя земля!") следует 'звуковоя', а за ним еме 'дымны' . Их логическое оформление отсылает к церковному обряду отпевания и к обряду помннок (278-284, 294-295, 298-299). Их же семантика - к идее 'вознесения' и 'увековения'.

"слава" (282, 284) ухе сама по себе 'звучна' и сама по себе 'возвьшает'. Но у цветаевон эти смыслы "славы" эксплицируются еще сильнее: "В кузне [...] куют" и "славу поют" переводят "славу" в сплошнов 'звук'; "уста", композиционно помеменные между "куют" и "поют", тохе 'озвучаются', а 'оэвучаясь' наполняют признаком 'звучания" такхе и "чару"; "чару несут" и "славу поют В ла-зорь" не талько активизируют признак 'возвышения' в "славе", но и актуализируют его - 'звучамая слава' оказывается также и 'возносямен', что тут же и получает свою реализацию под видом 'уносянея Лазори" (287: "златы стремена!"; 289: "Куды завела?"). Поэтому интенсификация эвуковоя зоны в 294-295, ее трансформация в сакральнья "звон" ("звонниц") в отличие от проФаническон "кузни" (282) и в 'высокое' в отличие от 'низкод', а то и вовсе - 'подземнон', "кузни", в первую очередь означает 'убыстрение' воспарения, 'вознесения' к пределам и 'воскресения' (упоминание "бессонниц" и "здесь головушки не клонятся" явно противостоят "пред- 
гибельному" эпизоду в 217-220: "Клокисо, Крекисо, Рескииами локи. Лохисо под свист Стрелы калены").

"Синея, дьмницы-кадильницы, Во весь-от-дьм" (298-299) отсылает к тон же 'прославляюмея' семантике 'воскурения', что и "слава" н "звон". Но последовательность "звон!" (295) - "ды!" (299) меняет эту семантику, "славу" превращает в "дым", так сказать, 'рассеивает' ее, делает ненукноя, а точнее: возносямая "слава" тут же преодолена, герои очутились за ее пределами (ср. пренебрехительное "И так взондем!" в 297, следующее тут же за зоной "звона"; ср. еме мену стилистическую, явно сникамоую ранг 'воскурения" : 261 - "-ладановна", 294 - "звонницы-", но в 298-299 "дымницы-кадильнищ", "дым" и овемествляющее этот "дым" поторапливаюее "Синен", а в 308 и 316 ухе откровенно пеиоративные "марево" и "морок"), где никакого звука уке нет: 319 - "Глух пуховик", 321-322 - "Каменем крик Панет - и канет" и, наконец, 350 "Клятвы без губ". Иначе говоря, это уже 'звуконепроводимая' сфера, это сфера бестелесного смысла, 'самопонимаемая'.

12.4. "Слава", как уже говорилось в 12.3.. подразумевает также и идею 'увековечения', что наглядно видно в стихе 282: "В куэне - славу куют". Ее трансформация в "дым" (ср. возмохность переклички "кузни" с "дымницами-кадильницами" в 298) замыкает предполагаемую ею 'вечность' в узких пространственно-временных пределах и переводит ее в условность. Но это едва ли не самын основноя параметр "Второй земли". Дело в том, что впервые здесь появлпоти в тексте поэм временнбе отношения (если не учитывать стиха 5:

"Свет до свету горит").

Время здесь мыслится как уже законченное, замкнутое, преодоленное. "Вторая земля" - краяняя его граница: "Во останнвя во разочек Затянись, замри!" (265-266), "то последния ветерочек" (267), "Во останны во последния" (278), "помин" (281 и 301). 3а нен время исчезает, "Лазорь" безвременна и беззакатна: "Маревом дни!" (308) и "От зорь - до зорь" (366; ср. еме упоминание "-бессонниц" в 294). То же происходит и со "славои"-"помнном": "Без вести - мир, Без вести - ма" (309-310).

Стих "Маревом - дни!" (308) вводит календарную единицу времяисчисления. Насьпенность "второя земли" 'терминальностью' (265: "останның", 278: "останнья", "последния", 281: "помнн", 302-303: "Аминь, Помин"; 266: "замри"; 279: "через всо-от-гинь", 295: "Во 
весь-от-звон!", 299: "Во весо-от-дым!") такую же 'терминальность" и 'исчерпанность' вписьвает в "На груди моея - одиннадцать Еме с однкм!" (300-301), где "на груди" предполагает 'захороненность" (ср. в 265: "замри!"), а "Eме с одним!" - 'финальность' счета,

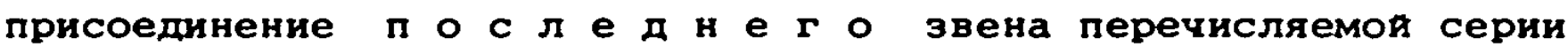
(аналогично союзу "Да" в 270: "Да зеленя"). Доминация временных показательея и потом сведение их в один суммируюмия, в "дни!" (308), позволяет видеть в "одиннадцати Еме с одним!" такие же календарные единишы - 'месяшы', т.е. замкнутость и исчерпанность земного временного кольца-года. Иначе говоря, здесь имеет место выход в 'за-время' , выход в сферу не объятуло временным кольцом. "В кузне - славу куот" (282) предполагает не только смвсл 'увековечения', но и 'венец славы', а этим самвм представление о 'кольце вечности'. Но "куют" вписывает в эту 'вечность' признак 'созданности', а шире - 'тварности', чем и дискредитирует ее, эксплициует ее не-подлинны характер (ср. "марево" в 308), делает ее лип одним из параметров 'конечного' (детерминированного) "мнра" (ср. 307-310: "Весо-от-мир, Маревом - дки, Без вести мир, Без вести - м"). 109 Еме иначе: здесь кончается и преодоле-

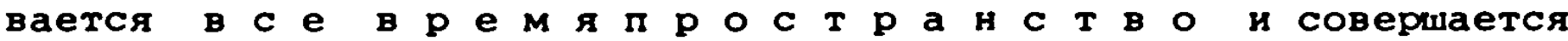
выход 'з а - ми ' $^{\prime}$ ' в $0^{\prime}$ (в 'никуда'; ср. 312: "Сгинь-Берекок!"; 359-366: "Куды завела? Туды-завела, Сюды-завела, Коншы залила, Следы замела В лаВ лазорь-в раззор От зорь - до зорь", где: 'туды-сюд' аннулирует какую-либо локализацио, сохраняя единственно 'двикение', "раззор" вводит представление о 'пустоте', а "От зорь - до зорь" - нелимитированности, и пространственноя и временноя, этоя 'пустоты'; ср. еще ее перекличку с именованием "переулочков" "И $r$ н а т в е в С к и ми", указываюиими на не-суиествование, о чем уже говорилось в 1.1 . и 1.8.$) .110$

12.5. В отличие от "второя земти", ознаменованноя своея 'конечностью' (265: "останны", 278: "останны" и "последния") и 'исчислительностью' (300-301: "одиннадцать Еме с одним!"), очереднбе - 'за-мирные' - зоны 'Лазори' необозримы и неисчислимы (316-318: "взгляни! - Лестницею - Ризы мои!"; 337-338: "Этих земель - Тридевять их!": 340-342: "взгляни! - Пригоршнями - Земли мои!") и являот собов лиш 'начальные' этапы восхождения (335336: "Первая цвель, Пригород лиш!", где "Первая цвель", отсылая 
к популярному изреченио 'Это еме цветочки, а ягодки впереди', намеренно преуменьшает ухе открывшуюся беспредельность, ср. 341-342 "Пригоринями - Земли мон!", где в свою очередь "пригорини" - не только 'необъятная численность', но и 'малость' отдельных 'беспредельностен' -"земель") . Но самое главное, что теперь 'лазорь' - беспризнаковы континуум. "Синь - в сапогах, Синь - в головах..." (325-326) снимает различие мехду 'низом' и 'верхом': "Пасть - не упасть, Плыть - не допљать" (327-328) - мехду 'вертикалью' и 'горизонталью". Кроме того "не упасть" и "не доплыть" снимахт представление о 'цели' и вводят категорию 'непрекратимости' движения самого в себе. Движение же лишается признака 'мены места', оно представлено тут лиив при помоми мотива 'теряемости', 'исчезания': "но через весь Морок - взгляни! - Лестницею - Ризы мои!" (315-318), где "Морок" и есть 'затерянность', с одноя стороны, а с другон 'кахимость', нечто лишенное физическоя Формы сумествования; "взгляни!" предполагает бессилие зрения, невозмохность увидеть, и этим самьм родственно 'слепоте', подразумеваюмея в свою очередь внутреннее 'видениетпонимание' (См. 9.3.); "лестница" же означает 'путь', но опять-таки запредельнын, имматериальнья, на что указывает Факт, что 'лестницею' именуются "ризы" Ведуньи, и что будучи иным наименованием прехних "платьиц" (3), "платков" (58) и "шелка" (104) сакрализованное "ризы" предполагает иноя ранг и инон статус бытия - нематериальны, совпадағия по свое сумности с сущностью мироздания как пути-исчезания. Аналогичное исчезание наблюдается в стихах 319-322 и 339-342: "морок" эволицинирует тут в "пропад" с его очевидноя связью с 'пропадать', которое еме заметнее в контексте 'умаляющих' "пригоршнея". Любопытно, однако, что ни с "морока", ни с "пропада", ни с "пригоршнея" не снимается смысл 'беспредельности', 'бесчисленности'. Этим самым и данные признаки уравниваются или примиряются друг с другом: 'малое' и 'огромное' оказываются равновелики. В результате весь этот континуум 'Лазори' можно определить как 'исчезающе-возрастаюмия', а двихение - не как преодолевание пути и перевопломения, что имело место в 'тварных' проявлениях мира поэмы, а как 'избывание' каких-либо дифФеренцирующих признаков, как 'обретание' беспризнакового и невычленимого из 'окружения' состояния.

12.6. Так, некогдашния "полог" (42) уже не "полог", а "звездная синь" (313); "платьица" (3), "платки" (58) и "шелк" (104) - 
не 'одеянья' и дахе не "ризы" (318), а "лестница" (317). При этом "звездная синь" и "лестница" только разные имена одного и того хе, т.е. нетварного 'локуса-пути'. Ср. в других вещах цветаевон: В "Ищи себе доверчивых подруг..." (18 июня 1922, СиП III, 14): "Всю лестницу бохественную - От: Дыхание мое - до: не дып!"; в "О, его не привякете..." (5 октября 1922, СиП III, 43) из цикла "Бог": "ибо бег он - и движется. ибо звездная книжима Вся: От Аз и до ихишы - След плама его лишь!" или в "Друг! Не кори меня за тот..." (3 мая 1923, СиП III, 72) из "так вслуниваются...": "так в ткань врабатываясь, ткач Ткет свод последния пропад", где все три компонента, хотя и выступают по отдельности, соотнесены по смалу друг с другом именно как 'нетварное', 'динамическое' (а точнее 'ведумее, увлекаюмее движение') и 'растрачивающее' и 'исчезаюмее' (предел "лестницы" - "не дыли", звездное небо "след плама", а "ткань" - "последния пропад"; ср. в самоп поэме параллелизм переназьвания "морок" В 314 и "пропад" в 340). Последовательность "Звездная синь - наш полохок" (313-314), "Лестницею - Ризы мои!" (317-318) и "Глух пуховик: дна не достанеші" (319-320) образует своеобразное новое мироздание со своим 'верхом' ("Звездная синь"), со своим 'низом' (упоминание "дна") и со своим объединяюия их промехуточньм уровнем ("лестница"). Однако, в отличие от тварноя "втород земли" это новое мироздание беспредельно: 'верх' - не "полохок", а "звездная синь", 'низ' недосягаем ("Дна не достанешь" а дальше в 327 "Пасть - не упасть"), промехуточная же растякенность теряется как по вертикали ("лестница" как "морок" и потом в 328 "Плыть - не доплыт"). но самое вахное то, что данның макрокосм отнюдь не нечто внешнее, а ипостась Ведуньи, что и она и этот макрокосм полностью совпадают друг с другом, о чем свидетельствует прехде всего отолдествление "лестниш" с "ризами" Ведуньи. Но это не все. В пределах поэмы соотнесенность "пуховника" $C$ 'низом' (с "дном") заставляет видеть в нем новы вариант "яхонтов" и 'слюны'-"рубля" (ср. в 290-292 аналогичную позицию 'низа' "Глыбъ-Яхонтовны" и в 22 'внутреннюю" поэицио 'драгоценности'-"рубля": "плюнет - рублем подарит"), а такхе соблазнительных "улемения" в 59 "яблочками, яхонтами", где "яхонтам" тохе отведена позиция 'низа', а точнее 'внутреннего', упрятанного в 'глыби' (см. 4.4. и 4.5.). Именование хе этого 'низа' "пуховиком" менее очевидно. С весьма созна- 
тельноя натяккон его появление могло бы объясняться следуюми образом:

- Это продолхение и трансформация эротико-Фунеральных свонств Ведуньи: "пуховик" как 'брачное ложе', что следует как из его позиционального соответствия соблазном "яхонтами"= "рублем"="раискоя слюночкон" (СР. 22 и 131), так и из возмохности прочтения стихов 282-285 не только в коде "помнна", но и в коде 'свадебном': 111 "пуховик" как 'смертны одр', что в свою очередь следует из подземных, 'адских' коннотация его соответствия "яхонтов" (см. 4.4.) и из погребального характера стихов 282-285 (См. 12.3.) и стихов 325-326, подразумеваюмих 'похоронную позу' ("Синь - в сапогах, Синь - в головах...") .

- Это трансформация "белохрущатых громких платьиц" (3), с их подспудноя связью со 'снегом' и 'заморохенньм громом' (См. 1.7.; ср. еме 108: "Сне-го-вея", 263: "прохлада моя!"), на что дополнительно указывает 'звукопогланаемость' "пуховика" (319-322: "Глух пуховик: [...] Каменем крик Панет - и канет"), и трансформация "крыл" (253), особенно в виду весьма очевидного здесь 'парения' на "пуховике" (325-326 с их позои 'покоящегося' и далее 327-328 с их возмохностью прочтения как образа 'реянья-парения' - см. 7.1. и примечание 39).

- Это трансформация "груди" Ведуньи (см. 300-301: "На Груди моен - одиннадцать Еме с однкм!"), где "грудь" мохет читаться как вариант прехнего "кораблика"='гроба'='лона' (см. 8.3. и 8.5.), с тон разницен, что теперь эта "грудь"-"пуховик" из-за ее беспредельноя раздвинутости ("Дна не достанешь) являет собои все 'мировместилиме' и характеризуется только внутренним аспектом, не имея и не предпологая ничего внешнего. Иначе говоря, в этом случае имело бы место погломение Героя Велунье в себя, вовнутрь, в "грудь"-"пуховик" - Эквиваленция "грудь"="пуховик" не снимает с "пуховика" смысла 'брачно-губительного соблазна', а лишь еме раз его подтверждает, если вспомнить, что прехде (стихи 193-196) "грудь" определялась как вместилиме бессметного количества "лхен", что она повторяла там признак семикратного строения мироздания, и что носила характер внутреннен 'страстнон' "скачки"-"погони" (185-189). Кстати, в менее откровеннои, но все-таки явственнои форме, семантика 'соблазна' наличествует и здесь под видом "лестницы"-"риз", где "лестница" восходит, несомненно, к "утешать" (60), 
"лести" (81), "ласти" (82, 90) и к трансформации "шелков" (103104) в "раяскую-реченьку" и "раяскую слюночку" (131).

Выход за пределы поэмы, т.е. в обмую Цветаевскую семантическую систему, позволяет не талько прочнее обосновать появление здесь "пуховика", но и уточнить его смысл.

В стихотворении "В мозгу ухаб пролёхан..." (26 ноября 1924; Cип III, 114) из цикла "Сон" есть следующне строки:

Не доверян перинам:

С сугробами в родстве!

Занехат, - лести хенскон

Пух, рук и ног захват.

Как хенщина младениа

трехдневного заспят.

$[\ldots]$

Заокеанских тропик

Прель, Индостана - ил...

В постель иду как в пропасть:

Перины - $6 е 3$ перил!

Кроме знакомо по поэме связи "перини"-"пуха" со 'снегом', 'хенским соблазном'. 'инкорпорациея', 'пагубньм началом' и 'беспредельностьо', здесь налицо еще связь С 'выходом-путем' в запредельное, в 'ведее', и связь С 'изхиванием' всего оформленного, ограничнваямего, тварного (См. В пропущенных строках: "В постель иду [...] Сновидеть: рая Давидов Зреть и Ахиллов шлем Свяменның, - стен не видеть! [...] В постель иду как в прорубь: Вас, - не себя топить!", где "прорубь" - ход в нетварнын мнр для я, а для 'обывательского' : мира - казнь 'небытием'; ср. в поэме 321-322: "каменем крик Панет - и канет", где "крик" - последнее проявление причастности к тварному). 112

В стихотворения "Как по синея по степи..." (иначе "Колыбельная", 13 февраля 1923; СиП III, 48-49) из цикла "Скифские", соответствие "пуховика" - "подуика" - играет роль пути выбывания из мира сего и раль способа преодолевания 'тварности', но, кроме того, она хе - способ преодолевания смерти и выхода в бессмертие ("спи, Смерть подушками глуша [...] Тони - да не кань. Волыньперезвонь, Хвалынь-целовань", где "волынь", "-переэвонь" и "Хвалынь" - потусторонее восхохдение в 'за-тварны' мир, а "-целовань" предполагает как состояние забытья, так и слиянность 'целостность', 'единство' - с нетварньм бытием).

И, наконец, в стихотворении "Не возьмешь мою душу хиву..."

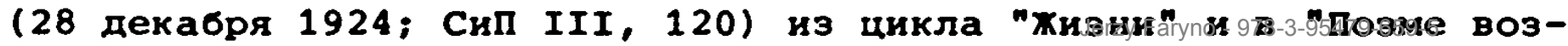


духа" (СиП IV, 284) "пух" однозначно соотнесен с "душоя". В первом это выглядит так:

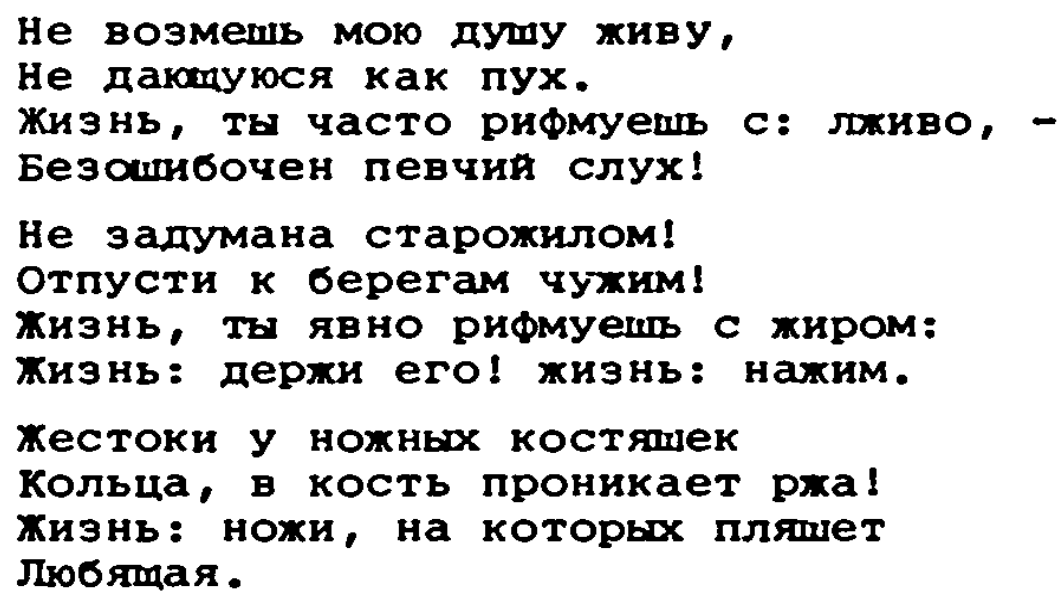

\section{- Заждалась ножа!}

Предпосылки семантическон системы этого стихотворения, собственно, уже нам знакомы: ничему не подвластная вечно живая душа временно детерминирована земными формамн жизни (буквально: 'закована' или 'прикована' - "Жестоки у нохных костяшек Кольца"; "держи его!", "нахим"), которые расценивает как лохное бытие, 'не жизнь" ("Жизнь, ты часто рифмуешь с: лживо"), стремится покинуть его и уити в область подлинноя Хизни ("К берегам чухим"). Выход - "нох", орудие, отсекаюпее от земных Форм жизни и одновременно ликвидирующее эти Формы. Вскрытие одноң жизни есть выход в иную, в Жизнь С прописноя буквы. Это значит, что душа (которая "не задумана старохилом!", т.е. на вечное земное поселение) неуязвима и неуловима. Именно 'неуловимость', 'невесомость', 'парение' (ср. противопоставление "жир", "держи его!", "наким", "ржа", жестокость "колец"-'кандалов' - 'эквилибриум' или "пляска" на "ножах"') и имеются ввиду в сопоставлении "души живон" и "пуха". При этом чрезвычаяно любопытно, что в предшествующем этому стихотворению "не возьмеиь моего румянца..." (25 декабря 1924; СиП III, 119120) "дула живая" сопоставлена с "конем Аравияским", которы уходит от настигаюмен его "погони"-'жизни' "перекусывая жилу". В этом смысле "конь" и "пух" эквивалентны друг другу, но их последовательность "конь" - "пух" подразумевает определенную градацию: ' бег в земное запределье' - 'парение в запределье за-земное' ("конь Аравийский" - "пух", "к берегам чужим", "нохи, на которых пляпет Любямая"). Возврамаясь к "Переулочкам", заметим, что и тут имеет место такая же последовательность: "Я же и конь, Я ж и погоня" (185-186) с поднебеснон скачкоя $\rightarrow$ "два крыла" (253) С вос-

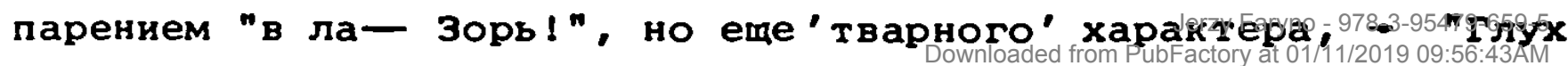


пуховик" (319), тохдественнь с открывшеяся 'нетварноһ' запредельностью, и упоминание о 'разрезе" (354: "Рака моя").

В "Поэме воздуха" (СиП III, 284) "пух" сопоставляется с дуmон по признаку 'невесомости' и 'бестелесности' (т.е. отсутствия плана вьрахения) :

O, еме в котельноя
Тела - "легче пуха!"
Старая потеря
Тела через ухо.
Ухом - чистым духом
Быть. Оставьте буквы -
Веку. чисты слухом
или чнствм звуком
Двкхемся Преднота сн
Сна. Предзноб блахенства.

Этот контекст поэволяет уяснить смысл 'глухости' "пуховика" и его свонства 'изьмать' звук-"крик" (319-322): это переход если и не на "чисты звук" (подобно "Поэме воздуха"), то во всяком случае на 'не-акустическое' (ср. 86: "Чутким - глухость" и 63-64: "От моих горячих губ - В теле хилочки гудут!") и, может быть, на внутренния 'гуд', особенно ввиду очередньх стихов "Поволевав, Пошалевав" (323-324), вслед за которыми идет картина умиротворенного парения: "Синь - в сапогах, Синь - в головах..." (325-326).

12.7. Упомннание "сапог" в этом имматериальном космосе нескотко обескурахивает. Да и в предыдудем контексте поэмы не видно никаких для них предпосылок, кроме разве именования Героя "ямщиком" (182, 197), 'помннального' аспекта стихов 278-285 и 298-306 и Фундаментальноя для всен поэмы темы 'двихения' .

Последняя в первую очередь навязывает ассоциацию "сапогов" со сказочным средством локомоции - с сапогами-само- или скороходами. С данноя точки зрения "сапоги" могли бы перекликаться со "стременами" в 287, где так - как 'самонесущая' - именуется "Лазорь": "Лазорь, лазорь! Злати стремека! Лазорь, лазорь, Куды завела?" (286-289). Такая перекличка тем более вероятна, что в разбираемьх стихах 325-326 "сапоги" однозначно соотнесены с вариантом "Лазори", т.е. с "синью": "Синь - в сапогах". Но ни Фольклорные сапоги-самоходы, ни предполохительная цветаевская параллель " "златы стремена" - "сапоги"' не представляются тут нанболее суместеным, хотя бы по причине демонстративного параллелизма "Синь - в сапогах, Синь - в головах", подразумеваюего некое равенство мехду "сапогами" и "головоя" (аналогично паралдепияну9549"-бмоляны" 
- "зелены"' в стихах 215-216). Принцип уравнения, несомненно, очевиден для Цветаево , но он менее очевиден для читателя и требует дополнительного контекста.

Согласно мифологическому контексту, обувь - атрибут высших потусторонних, часто связанных С загробным миром, суместв. Такова, например, крылатая обувь психопомпа Гермеса, т.е. водителя душ в загробном царстве. Такова на деле и природа фольклорньх сапогов-самоходов, позволяющих не столько быстро покорять расстояния, сколько перешагивать границы иного мира. Более того: обувь призвана предохранять от опасного для мифологических суместв - соприкосновения с миром земньм, что в свою очередь мотивируется особьм статусом ног или стоп: они часто расцениваются как вместилима энергии, духовно силы (совместно с руками иногда изобрахаются в виде солнечных лучеи). 113 Поэтому попрать ногон врага - не только победить его, но и подчинить себе плотское (а шире - хтоническое) начало, а повредить ногу - нанести духовның yruepo.

Не менее показателен в этом отноления и собственны Цветаевския контекст. "На красном коне" (СиП IV, 369):

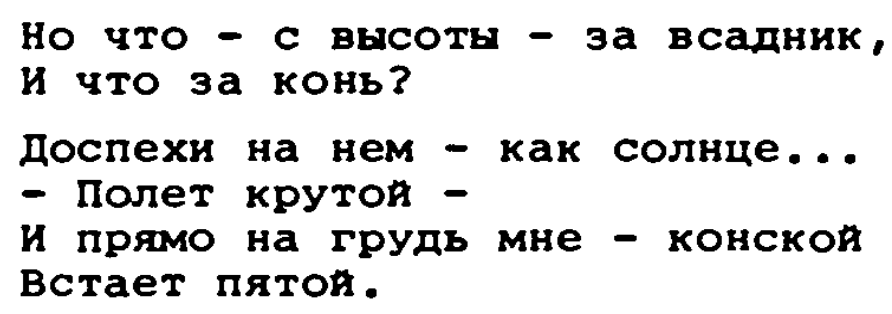

и в более полном варианте этон поэмы (СиП IV, 369):

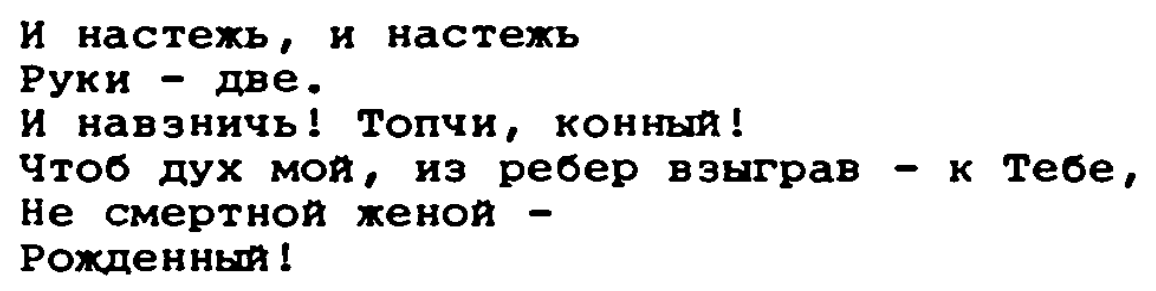

Исключительно интересно в данном случае то, что непосредственная борьба и этим самъм непосредственное столкновение с бренностью или со смертным началом мира сего перепоручается Цветаево д дводнику "всадника" - "коню". Сам же "всадник" сохраняет свою потную невозмутимость и непричастность к делам земньм. Аналогичным образом решается проблема победы над "гремучим гадом" и в "Георгии" (СиП II, 112-123) : 


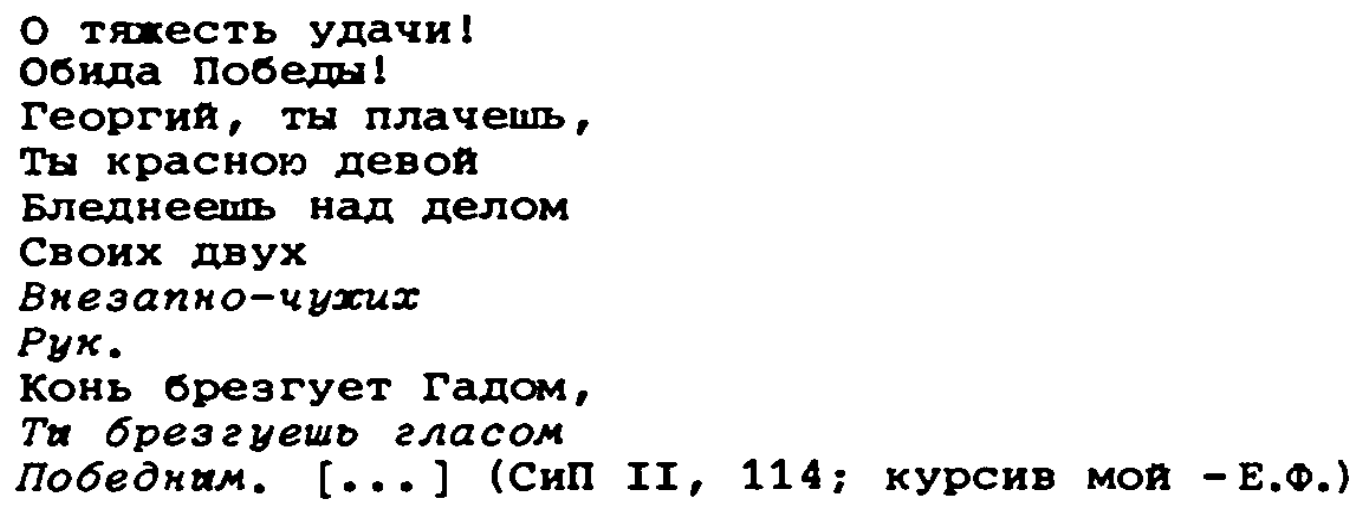

При этом удваивается и само понятие "победт": "победа" коня (а такхе "Внезапно-чухих Рук") - "победа" земного порядка: "Победа" же Георгия - 'победа над "победон"' и принадлехит небесному порядку. "Конь" и "всадник" или Георгин являют собон два нетождественных уровня духовного. "Всадник" запределен и никак не соприкасаем с миром бренного, "конь" же - 'посредник' и ичрает роль 'зациты" "всадника" от такого соприкосновения (Фигурально выражаясь, "конь" несет ту хе Функцию, что и мифическая обувь), соприкосновения, чреватого уязвлением духовного начала, 114 т.е. замешанностью в земные дела и этим самым 'узничеством' (ср. в цитированном в 12.6. "Не возымаш мою душу живу...": "Жестоки у кохких коcmsшек Колоиа, в косто прокикает рха!").

Последнее прекрасно видно в стихотворении "Возврапение вохдя" ( 3 июля 1921; СиП II, 123), где 'хромота' передана "коню", а 'ржавчина' - "мечу", т.е. двоиникам или посредникам "вождя" ("Конь - хром. Меч - рхав. Кто - сен? Вождь толп"), тогда как сам "вохдь" дан 'отрешениьм' от мира сего ("maг - час, Вздох век, Взор - вниз. Все - там. Враг. - Друг. Терн. - Лавр. Всё сок... [...] плам - стар. Стан - прям", где 'Уязвимость бренньм' доведена только до "плама", 'дух' же - "Стан" - непоколебим: "прям").

и еме один пример, из триптиха "Магдалина". В первои его части - "Мех нами - десять заповеден..." (26 августа 1923;

Сип III, 95) - говорится:

$$
\begin{aligned}
& \text { [...] в волоса заматьваю } \\
& \text { ноги твои, как в мех. } \\
& \text { некою тканью под ноги } \\
& \text { Стелюсь... [...], }
\end{aligned}
$$

а в третьен - "О путях твоих пытать не буду..." (31 августа 1923; Сип III, 95-96) - тот же эпизод в истолковании Героя триптиха 


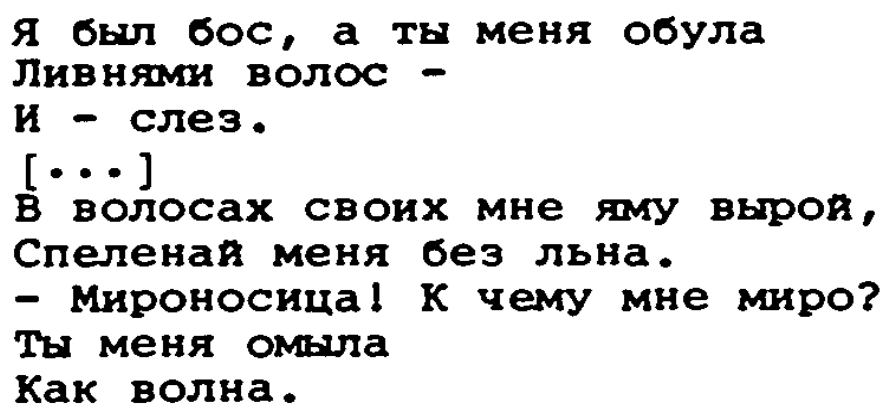

Евангельское омовение ног Христу Магдалино интерпретирует Цветаева в терминах собственнои поэтическои системы: истончения плоти и инкорпорация, захвата в себя. При этом истончения плоти и инкорпорации, захвата в себя. При этом истончение плоти знамезнаменует वңовременно одухотворение (как во втсром отрывке поэмы "на красном коне": "Топчи, коннын! Чтоб дух мон, из ребер взыграв - К Тебе, не смертнод женои - Рожденның"), которое достигнет своего предела во второ части триптиха ("Масти, плоченные втрое..." - 31 августа 1923; СиП III, 95) в внде "спломного Ксструекия". "Ты", опознаваемы Магдалиноя как Христос, представлен в триптихе только "ногамн" и "бос". Легко заметить, что это атрибуты Высшен Сущности, как у само Џветаевоһ, так и во многих мифологических системах. Поэтому обычная мифическая реляция 'Героя - бестия', к том же пиенная 'посредствуюмего 'зашитного' звена типа "коня", "мита", "копья", 'обуви' и т. П., у Цветаевои подверглась инверсии: не Героя 'наступает' на "я"-'блудницу', а "я"-' блудница" "стелется" "некою тканью под ноги". Но и это не все: сопряженное с истончением плоти до "ткани" одухотворение "я" произошло несколько раньше, получив вид предварительного экзорцизма, извержения бесовского начала. Соприкосновение с "ногами" Героя произошло, таким образом, уже после 'очимения' "я" от блуда, от греховного начала, и требуемое условие выполнилось.

В истолковании Героя (Христа) это омовение и укутывание ног называтся 'обуванием'. Из процитированноя выдержки явствует отчетливо, что 'обувь' несет здесь духовнь характер, что она пониматся как 'предохранитель' от 'смертного' или, точнее, как 'сохранитель 'бессмертия', как 'возродитель' (ср. "обула Ливнями волос - и - слез. [...] "омыла Как волна"). В итоге 'обувь' тут одухотворенное вместилище духовности высшего порядка. 115

Даже в свете этого, столь скудного, контекста ясно, что уломинание "сапог" переводит Героя на высияя уровень духовности, возводит его в ранг 'чистого духа', но пока еме замкнутого в некотороя 
менее совершенноя 'оболочке' (ср. отказ от "льна" и "мира" в "Магдалине" или понятие "газового мешка" в "Поэме воздуха" Сип IV, 285, - за которым начинается "трахт" чистого духа-мысли к отцу-Богу).

Этот же контекст вплотную подводит к пониманию на первын взгляд противоречивых требования в стихах 329-334.

12.8. Последовательность "насыть!" - "растрать!" подразумевает ту хе структуру, что и 'победа над победоя' (12.7.): в обоих случаях постулируется отказ от завоеванного, преодоление достигнутого состояния или ранга и переход на инои, по краинея мере, один уровень вьше. Если учесть, что 'победа' вкточается обьчно в состав личных неотъемлемых своиств победителя (иногда оформляясь в виде внепних атрибутов - крыльев, венцов, современных медалея, иногда получая вид второго имени героя типа "Георгия Побадоносец"), то отказ от 'победы' есть одновременно 'победон над собоя' - В фольклоре, особенно сказочном, свояство победителя часто вырахается при помом таких меток как хромота, отрезанная прядь волос, золотая отметина и т. П. Метки эти, энаменуя победителя, одновременно означают символическую смерть героя, приобмение его к царству смерти. 116 цветаевская 'победа над победоя' в этом свете не что иное, как 'победа над смертью' или, точнее, - над подвластны смерти собственньм началом (совершенно не случанно, локализуя некоторых своих героев в области идеального духа - Георгия в "Георгии", Вохиь в "Возвращении воқд", Ты-Христос в "Магдалине" и т. Д., - знак их победы и уязвимости смертью типа 'хромоты', 'рхавчины', 'истрепанности' передает цветаева посредникам-атрибутам этих героев: "коню", "мечу", "пламу" и т. П., а они сами наделяотся 'пассивно-отсутствующим' состоянием). 117 Последовательность "Душу насыть!" [...], растрать!" как раз и призывает к преодолению себя, т.е. свояств, ставиих содерханием 'души' ("душу насыть!"), а в итоге - к отказу от "дуии", к победе'над нен: в стихе 332 "душа" однозначно названа "кладью" грузом, помехоя, чем-то отъединяемым (запасньм) и поэтому не необходимам (к тому стилистически "кладь" - не ценность, не 'клад', а нечто сугубо бытовое, материальное, особенно в окружении такои лексики как "дарственньми", "дабы", "отринуть!" и интимное "Ми$\left.\operatorname{san}{ }^{\prime \prime}\right)$.

Родственная семантика содержится и в слове "Дарственньми" 
(329). Для дара характерны два аспекта: дубликация и взаимность.

"То, что дарится, долхно дублировать того, кому дарится:

мухчине не дают женских подарков, женщине - детских, и здесь выдерхивается - сперва без всякоя каузализации - возраст, пол, Функция лица. [...]

Подарки и приномения умершему - это его как покоиника атрибуты: еда, посуда с едоя, панспермия (каша иэ всевозмохных семян), горики с семенами, с кладом (имеюмим первоначально не имумественное, а хтоническое значение), одехда, утварь, куклы, маски, позднее статуэтки. Есть особые атрибуты и у брачащихся: солнце - 'жених' и луна - 'невеста' вырахались всяким кругом, кольцом, венком, и теперь венки и кольца - вещная принаплежность невесты и жениха: [... $]^{n} 118$

у Цветаевон эта сторона дара выдерхивается с удивительнор строгостью. Так, в диптихе "Вифлеем" (23 ноября 1921; СиП II, 138-139) "Три царя" одаривают Младенца царством его земнғм ("Первын ларь-вся земля С синкми морями. Ларь второй: Весь в нем Ноя, Весь, С ковчегом-с-тварью") и 'Страстями Господними' ("Ну, а в том? что в третём? Что в третём-то, царь мод? царь дает, Свет мон свят! Не понять, что значит! Царь - вперед, Мать - назад, А младенец плачет"; ср. такое же табуирование 'смерти' в "Переулочках" в стихах 1-2: "не вемо-што", "не энамо-што"), а "Я", к тому "первее всех!", что значит наиболее адекватны дар, дарит ммматериальные 'заоблачные высоты' ("Не с серебром пришта, не с янтарем пришла, - [...] Вот воздух гор мокх, Вот остры взор монх Двух глаз - и красның пых Костров и зорь моих"). В "Сугробах" (в стихотворении "не здесь, где связано..." - 12 Февраля 1922; СиП II, 161-162) "Ты" вовсе не одаривается: "Здесь нету дарственной тебе - моеи" [...] Здесь нету вотчины тебе - моеи", но причина тому, сверхсущность "Ты" и полнеяная неадекватность ему земного, $к$ тому еще 'зимнего' мира "здесь". Дело в том, что посвяменные Эренбургу "Сугробы" открываются стихотворением "небо катило сугробы..." (10 Февраля 1922; СиП II, 160) построенном на семантике имени 'Илья', что, совместно с семантизациер фамилии и ее "p", возводит "Ты" в ранг "Грома небесного", в ранг запредельноя высшей суцности. Акт дара может состояться только вне мира сего, "Там, где отпудено", но "там" "даке слов-то нет: - Тебе моеи...", 119 что значит, что "там" акт дарения ухе не имеет смысла. 
Разбираемы аспект дара в "Переулочках" эксплицирован наиболее отчетливо: "Дарственными - душу насыть!" предполагает приятие дара в себя, символическое 'съедание' ("насыть"), и обретение тохдества со своим духовньм двояником-'тотемом' ("душу наСыть") 120

В контексте "Сугробов", возникших всего лишь за месяц-два до "Переулочков", под 'даром' поэволительно здесь соответствие "вотчины" = 'владения-пространств' и 'отчизны'. С одноя стороны, это значит воэвращение-'дарование' Герою его исконнон 'родины' (подобно возврату душ, откуда она временно прибыла на 'земло' в цитированном в 12.6. стихотворения "не возмешъ мою душу живу..."). С другоя - отохдествление с самон Ведуньея, так как эта дарственная необъятность - и ее 'владенья' и она сама (См. 12.6.).121

Второ аспект дара - взакмность - заклочается в следуюмем: "Жертва и дар содерхат обмия смысл: в обоих актах обычно реализуется принцип 'do ut des' ('даю тебе, чтобы ты дал мне', 'дар долкен быть вознаграхден'). Так, в греко-римском мире девизом участников новогодних праздников было: 'дая и возьми' 122 (ср. в принципе идентичнуг формулу стихов 7-8: "Богу жертву кадит, С дуба требовант"; см. 1.4. и примечание 11).

"Миль, растрать!" - логичное требование взаимного дарахертвы, повернутого, однако, в сторону 'победы над собоя', 'отказа от себя-души' и, что особенно вахно, такхе отказа от 'подарившенся'Ведуньи (так как ее 'дар' есть такхе и она сама).

"С кладъю не примут!", кроме ухе отмеченного смысла несовершенства, материальности души, вводит представление о переходе или входе в качественно новое 'пространство', 'пространство' высшего ранга ("С кладью не примут!", как, скажем, не принимают в салон С мешком, "в сапогах" и т. п.). Но на деле это не столько новое пространство, сколько инокачественная зона бытия, требующая очереднон трансформацин. Такон смысл этого подразумеваемого перехода подсказынается все тем же 'даром'. Дело в том, что дар всегда временно приурочен: одариваются те, кто меняет собоя общественнви или бытияны статус (новорохденныя, брачапияся, умершия), и тогда, когда меняет свон статус мир (Рохдество, Новын год и т. П. кризисные в мировом годовом цикле моменты) 123 поэтому "Дарственные" Ведуньи - 'пропускаюме-отпускающия' хест, лишенны какои-либо поссеснвности (ср. в "Сугробах": "там, [...] Где вся расплескана 
Измена днеи. Где дахе слов-то нет: - Тебе - моен..." - СиП II, 161-162).

Эта победа над собои, отрешение от всех уэ, формулируется еме раз в стихах 333-334 в виде предписания или эакона, обязуюмего в новои зоне бытия: "Дабы принять - надо отринуть!" (Ср. аналотичы 'свод правил поведения' даваемьх Герою Сводней сти$\operatorname{xax} 17-18,27-28,35-36,53-56)$. Сумественно в данном случае то, что этот же закон обязует и самое Ведунью - и она вынухдена все "отринуть" или "раздарить" и стать 'сквоэью' ("Не у дерхав, Все раздаря! - Хаворонком Рана моя" - 351-354).

В первую очередь это - отказ Ведуньи от 'захваченного' или 'инкорпорированного' Героя: "Мильи, не льни" (343) в отличие от "Льни, Льни, [...] Клонись, Кренись, Ресницами льни" (211-212, 217-219). Если раныше в "льни" вписывалось сладострастное забытье-смерть (с "льнуть" = 'никнуть', 'сникать'), то теперь вся эротика и все соблазны потеряли всякия смысл, они аннулированы отсутствием какойлибо дифференциации.

Цветаевское "льнуть" родственно ее же "лик" (ср. рифмовку и эксплицируючие двоеточия в 343-345: "Милы, не льни: ибо не нушно: ибо не лхи:") по нескольким приэнакам. В принципе "льнуть" и "лгать" мохно бесконечно, т.е. до предела бытия: оба этих акта перкрамаются в момент достижения состояния 'не-бытия' (ср. В 193196: "Лхеи-то в груди Семь да семихша Семь, да еме - семь", где ' семикратность' является одновременно и Фундаментом Цветаевского мироздания вообще - см. 2.2. и 9.7., а в стихотворении "Рано еме - не быть!..." - 19 июня 1923; СиП III, 81-82: "Как глубоко ни льни - Небо - бездонны чан!" и аналогичную 'бездонность' в 211214 и 273: "Льни, Льни, Черны Котлы смоляны [...] Котел без дна!"): "льнуть" и "лгать" одинаково связаны с губительнод эротическон одержимостью, со страстноЯ, т.е. и чувственнои и причиняющеи бать любовью (ср. 197-198: "Жги, ямпичок, В темь!" - 213214: "Черны Коты смоляны!" и в "Рано еме - не быть!..": "Рано еме - не жечь! [...] Как глубоко ни льни - Небо - бездонны чан! О, для такои любви Рано еме - без ран!"): "льнуть" и "лгать" родственны друг другу по их причастности к чувственному, материальному, обособляюмему (разъединяющему) началу, 124 с тон, однако, разницей, что если 'ложь', являя собоя это материальное начало, создает впечатление истинного слияния сущностея двух субъектов 
(или субъекта со своен собственнон сущностью; ср. В "Наяде" 1 августа 1928; СиП III, 139-141: "-нереида! - Волна! Ничего нам

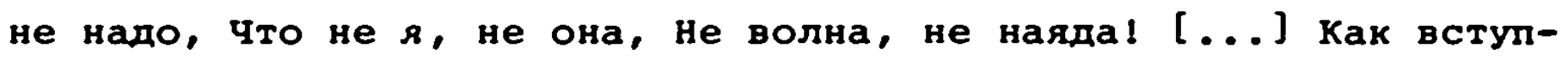
ло в тебя, брак, Раз мех мною - и мною х - что? Да нос на тени, [...] Что? Да всё, если нечто!"), то "льнуть" - 'преодолевать" это начало, ликвидировать его, а самому субъекту 'истончаться' до перехода в состояние 'не-бытия' (такон, в частности, смысл стоит за масохистским на первьн вэгляд "ямпичок, хги! [..] Хги, ямпичок, В темь!" - 182, 197-198, да и за всем провоцирующим поведением Ведунъи, вызывающем казалось бы опасную для нее 'громовикову' сущность Героя).

Предел "лхи" и предел 'истончения' - некая глубочаяшая потусторонность. Но это не 'вэрыв' страстен, а бесстрастное состояние. Иногда оно определяется у Цветаевон словом "немноть"; мемду геролм устанавливается пфинитанысе равенство - родство, братство, и т. п. 125 (ср. в "Рано ене - не быть!..." : "Рано еме - не быть! Рано еме - не хечь! Нехность! Жестоки бич Потусторонних встреч. [...] Рано еще для льдов Потусторонних стран!").

теперь, думается, все эти значения находятся в стихах 343-355. Обрамение "Миши" (331, 343), после предательски-льстивых "млад" (1,2), "башковит-красовит" (23), "детинунка" (35), "молодец" (41, 53), "Уста мои сахарные" (66), грубьх "Что за дуростьтака-соплячество, Башкоя русою в юбки прятаться?" (129-130), "зелена башка?" (148) и ласково-иронического "ямиичок" (182, 197 , где ирония возникает за счет аналогичных деминутивов в 208-210: "Брось повода! Рученьки настежь! - на̀! - На векаั-дни Царствьица хлеб-ни!"), естественно воспринимается как вырахение 'нехности' и является знаком выхода обонх персонахен в окончательную 'потусторонность', лишеннул какои-либо 'чувственности' и причастности к какои-либо тварности (ср. в "О путях твоих пытать не буду..." из "Магдалины" - СиП III, 95: "О путях твоих пытать не буду, Мнлая! - ведь все сбилось", где обращение "Милая!" появляется после 'исчерпанности' земных Форм бытия и играет роль их окончательного делимитатора и акта, предақиего их небытио, забвению - см. 3.0. в моем разборе "Магдалины"; кстати, и здесь "Мильи" в обоих случаях - 331, 343 - предваряет 'отрицание', 'отказ', а шире - 'прекрамение": "Мишт, растрать! [...] Милы, не льни!"). 
211-222) с их перекличкон со "льнами"='плотью-тканью-смертью' в 222-238 'упокоительное' "не льни" с последуомея 'аргументациеи' "ибо не нухно:" (344) кроме уже отмеченных смыслов вносит еме один: выход за пределы подвластного смерти (ср. в "О путях твоих пытать не буду..." из "магдалины" - СиП III, 96: "Спеленан меня без льна" со смыслом достихения чистого имматериального бытия и истинного воскресения - см. 3.4.1. и 3.4.4. В том же разборе этого триптиха) и потерю 'смертоносного' начала самон Ведуньен, т.е. и ее собственную трансформацио ("ибо ни лхи" означает также упразднение "лхен", составлявиих некогда ее суть - 193-196: "Лхеито в груди Семь да семижды Семь, да еме - Семь"), а еме иначе - ее 'победу над собственнон победон'.

Если наглядности ради с последовательности в стихах 343-347 снять отрицания, то смысл этон последовательности проступит гораздо отчетливее: 'льни: (ибо) нухно: (ибо) ложь: (ибо) мух-жена'. Двоеточия играют роль 'выводителя' содержания или сущности упомннаемого явления. Поэтому вся конструкция, построенная на целон серия таких двоеточия-'выводителея', являет собои постепеннуо экспликационную шкалу, поочередно снямающул или сухающую варнантность и устремленную к выявлению конечного инварианта, т.е. сумности лишенно всякого плана вырахения. С этои точки эрения 'мухжена' долико чнтаться как предел, инвариант всеи данноң шкалы. А это означало бы, что под 'мужем-женон' понимается эдесь неустранимость и изначальность сущности 'пол' (иначе: мухского и женского начал). Дводственность 'пола', естественно, противоречит эксплицирующему акту устремленному к обнарукению единого инварианта. Обнаруженные 'инварианты' ('мук-жена') еме, таким образом, не инвариант, они все еме варианты 'пола'. В этом смысле "муж" и "хена" одновременно и самы поверхностның план вырахения, т.е. 'житеяские', 'бытовые' Формы. В результате вся эта шкала мохет свободно читаться и в обратном направленин: 'муж-хена: ложь: нухно: льни', где 'льнуть' - естественное следствие вытекающее из 'быть мужем и женоһ'. Так объясняется наличие на этон шкале элемента "нужно": Он эксплицирует ее детерминированность, зависимость или подчиненность бытия от нередуцируемого двонственного 'муж-жена'. Такую же роль в этон серин играет и причинно-следственныя союз "ибо", выстраивающи ее в жестко детерминированную програмоу 'жизни': 'быть мужем-женон' (или: 'быть носителем пола') 
' льнуть' = 'изанвать себя' со всеми вытекаюмими отсюда следствиямн. 126

Отрицания хе "не" и "ни" упраздняют всю эту детермннированную модель, но самое вахное, что тут упраздняется прежде всего детерминируочия источник - 'пол' (это и есть причина, почему 'мух-хена' заняли на данноң шкале краянюю позицию 'инварианта', хотя на деле требованиям инварианта не отвечают) .

не рискованго сделать и шаг дальше, т.е. читать эту модель как модель мира, предопределенного его естественньмн законами (вьчленимостью 'пола') . Тогда упразднение этоя модели означает вьход за пределы предопределенности, за предешы естественного (материального, тварного, 'физиологического'), равно как и за прелелы собственного естества, в иных терминах - выход на тсансцендентны уровень, за предешы "дуй" (ср. 329-334 и 12.7.), в область чистого духа. 127 такоя же смысл вскрывается в стихах $348-350$.

"жатвы без рук" и "клятвы без зуб" - здесь не только образ

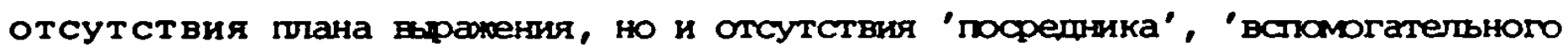
орудня', а то и вовсе 'исполнителя', 'причнны' ("рук", "губ): так "хатвам" и "клятвам" сообмается мистическия характер 'самопронзвольного сбора плодов' и самоутверждаюиеися воли'.

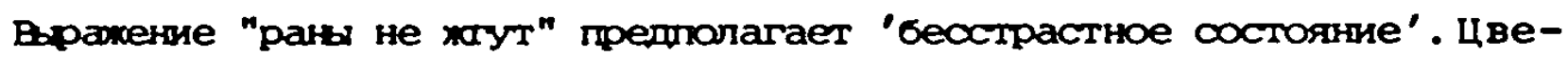
таевские "раны" означают болепричиняюмую страсть, нензбывное стремление преодолеть разъединяюиее 'материальное' начало мира сего, изживание его (ср. хотя бы многократно цитированное в 12.4. "Рано еме - не быть!.."). По ту сторону, на трансцендентном уровне, "раны" претерпевают метаморфозу: они, как здесь, или "не хгут" или хе, как в "Рано еме - не быть!.." преврамаются в "обмин шов" ("К пока общия шов - Льюсь! - не налохинь Сам - Рано еме пля льдов Потусторонних стран!" - СиП III, 82, - где "льды" и есть 'бесстрастье', 'не хгучесть') .

12.9. Серия "борозшы, Да зеленя" (269-270), "Дух навозенньи, забористья, - Моя земля!" (271-272), "Первая цвель, Пригород лишь !" (335-336), "Пригоршнями - Земли мон!", стихн $343-348$ с их упразднением "лия", т.е. не-истинных тварных Форм бытия, и с предидуне семикратностью "ликен" (192-196). "жатвы без рук" (349), "клятвы без губ" (350) и "хаворонком Рана моя" (353-354) дает весьма определенные основания ассоцинровать ее с циклом ' сев - сбор, хатва' (ср. еме присутствие смыслов 'веяния' и 'сбора' 
в 74-75 и см. 5.2.-5.3.), но не с аграрным, а с разомкнутъм, однонаправленньм мистическим, завершающимя "Жатвон без рук", так сказать, "жатвон" 'нерукотворнон', 'божественнон', или еме иначе - 'сбором нерукотворного'. А это значит, что здесь позволительно видеть семантическую перекличку с библеиским праздником Жатвы и с его христианским вариантом - праздником Седмиц или Пятидесятницеи (именуемым в народе такхе зелеными Святками).

идея бохественных 'сева - жатвы' наиболее ясно излагается в Первом Послания к Коринфянам святого Апостола Павла (гл. 15: 42-56): "сеется в тлении, восстает в нетлении; [...] Сеется тело душевное, восстает тело духовное. Есть тело душевное, есть тело и духовное. Так и написано: 'первың человек Адам стал душою живупею'; а последнй Адам есть дух животворямия. Но не духовное прехде, а душевное, потом духовное. Первын человек - из земли, перстны; второп человек - Господь с неба. [...] и как мы носили образ перстного, будем носить и образ небесного. Но то скаху вам, братия, что плоть и кровь не могут наследовать царствия Божия, и тление не наследует нетления. Говорю вам таину: не все мы умрем, но все изменимся. Вдруг, во мгновение ока, при последнеи трубе: ибо вострубит, и мертвые воскреснут нетленными, а мы изменимся; ибо тленному сему надлехит облечься в нетленное и смертное сие облечется в бессмертие, тогда сбудется слово написанное: 'поглощена смерть победоя'. 'Смерть! где твое жало? ад, где твоя победа?' - жало же смерти - грех; а сила греха - закон".

Ветхозаветны иудеиския праздник Жатвы (а точнее: праздник начатков Жатвы см. Нсход, 34: 22 и ср. Нсход, 23: 16; Числа, 28: 26; Левит, 23: 15-16) именуется праздником Седмиц (Исход, 34: 22), так как он празднуется по истечении семи недель после Пасхи (см. Левит, 23: 15-16: "Отсчитаяте себе от первого дня после праздника, от того дня, в которь приносите сноп потрясания, семь полных недель, До первого дня после седьмои недели отсчитаите пятьдесят днея, и тогда принесите новое хлебное приношение Господу"). Со временем он стал и праздником Союза-завета, заключенного днен через пятьдесят (Нсход, 34: 22) после исхода из Египта, празднуемото на пасху (Второзакокие, 16: 1) и ему пюнается такое значенне,как и празднику Пасхи и Кумеи: и в этот день народ "должен являться пред лице Господа, Бога твоего, на место, которое изберет Он: в праздник опресноков, в праздник седмиц и в праздник кумеи; и 
никто не долхен являться пред лице Господа с пустыми рукамн, Но кахшы с даром в руке своен, смотря по благословению Господа, Бога твоего, какое он дал тебе" (Второзакокие, 16: 16-17).

Празднуемая в пятидесяты день после Воскресения Христова христианская Пятидесятница наследует праздник Хатвы или праздник Седми и в принципе сохраняет то же содержание. Это день исполнения Боких обетования, день дарования духа (Деяния, 2: 17-21 и след.), день теофания, проявившеяся,в частности, в харизме речи и пророческого ясновидения, т.е. В обретении Божественного Логоca. 128

Считать, что автор здесь имеет в виду именно Пятидесятницу, было бы, по меныне мере, неосторожно, но видеть здесь только чилто случанное семантическое совпадение, тохе не совсем правшын.

"Жатвы без рук" (349), особенно после преодоления героями их телесного и душевного обликов, естественно чнтаются как обретение облика духовного, животворямего божественного начала, вдунутого в человека Богом и теперь к Богу же возврамаюмегося (ср. выне цитату из Перөого Послания к Корикфянам). Такои же смысл имеет и праздник Седмиц, обязующия человека "явиться пред лице Господа" (Второзакокие, 16: 16). С праздником Седмиц ассоциируются также и "Клятвы без губ", в которых не сложно увидеть отрамение идеи Союза-Завета и исполнения Боини обетования. Еще сильнее $c$ идеея этого праздника связыает выход за предешы 'перстного', т.е. тварного, бренного, тленного (от 'перст' = 'земля, прах"), исчисляемого тут "землями" (342) н "лхами" (345), число которых сплошь 'семикратно' (16, 193-195). Это выход в 'день восьмон" (ср. 366: "От зорь - до зорь" и богословское толкование седмицы: "Согласно богословию священнического кодекса, свяменньм первообразом седмишы, определяюиим ритм человеческо деятельности явилась творческая деятельность Самого Бога [Eитие, 1: 1-2: 3; Нсход, 20: 9 и след., 31: 17]. Закон о семи днях рассматривается таким образом как божественное установление, имеюеее всемирное значение.

В Новом Завете седмица преобретает новую религиозную ценность. Отныне она начннается с воскресения, дня Господня, с ехенедельного празднования Его победы [Откровекие, 1: 10; Деякия, 20: 7; Первое Послание к Коринфякам, 16: 2]. Труд, которы затем в течение недели совершает христианин, исполняется таким образом 
в зависимости От Христа-Искупителя, господствующего над временем. но Седмица продопжает стремиться к восьмому дню, которыя, $3 а$ пределами седмичного кругооборота, введет народ Божия в пределы великого Божьего покоя [Евреям, 4: 1-11];воскресны покоя уже предвенает его наступление). 129

"не удержав, - все раздаря!-" (351-325): кроме чисто цветаевскоя идеи окончательного истончения плоти и кроме связи с идее Лазаря убогого (см. 12.2.) имеет свою основу и в празднике Седмиц или Пятидесятнице (ср. О долге дароприношения во Второзакокии, 16: 16-17: "никто не долхен являться пред лице Госгода с пустыми руками, но кахдын с даром в руке своен, смотря по благословенио Господа Бога твоего, какое он дал тебе"). Оставаясь в рамках богословского контекста, легко заметить, что упоминание 'дарения' (329-330 и 351-352) качественно меняет Ведунью в существо исполненное благодати Бохьея: 'дарение' невозмохно без предварительного полученного от Бога 'дара дарить' "Библия учит, что всякия Дар происходит от Бога. 'Всякое даяние ... нисходит от Отца светов' [греч. Послакие Накова, 1: 17; ср. Товит, 4: 19]. Начало всякого творения есть Бог, всем дающи пиму и жизнь [Псалом 103]; Он же кладет начало спасенио [Второзакокие, 9: 6; Первое Послакие Ноакка, 4: 10]. Поэтому заблуждается человек, думаюми проявить медрость раныше, чем сам получил благодать [ср. Ноакк, 13: 37 и след.]; первая обязанность человека - открыться Дару Божию [Марк, 10: 1ј и след.]. Принимая его, человек становится способньм на подлинную щедрость и призванным в свою очередь к дарению [Первое Послакие Ноакка, 3: 16]" 130

Способность дарить, обладать 'даром дареняя' - проявлять заложенное в себе божественное начало (духа). В этом свете теперь еце очевиднее мена онтологического статуса героев поэмы. Будучи одаренньм, Героп одновременно к выявлению полученного дара (329-331: "Дарственными - Душу насыть! Милы, растрать!") и этим самым его душа обоготворяется, возвыпется в ранг духа. То же происходит и с Ведуньея, с тоя однако разницея, что будучи одаряюще , она получает статус равносильны божеству (ср. 317318: "Лестницею - Ризы мои!"; 341-342: "Пригоршнями - Земли мои!" и далее в 357 "Круты рамена!" С их намеком на распятие Христа и этим самљм - присоединение к Богу, Сына к Отцу; ср. дополнительно упоминание "Крутоя горы" в 257 и "Раны" в 354). 131 Вряд 
ли случаяно поэма начинается с 'языческого' образа Ведуньн, с ее 'идолопоклонства' (7-8: "Богу жертву кадит, С дуба требоваит"), а завериается образом благословенноя праведницы. Вероятнее всего здесь имеет место не столько эволюция, сколько 'всевластие' и 'всеведение' Ведуньи - от преисподнея по 'восьмые' небеса, от смерти по вечную Хизнь. Последнее однозначно явствует из сопоставления полярных (а композиционно - краяних) звуковых характеристик Ведуньи: "громкие платьица" и "урчба" в 3 и 10 и "шаворонок" в 353 .

В контексте народно-мифологического сюжета поединка Громовника с похитительницен небесных громов и вод смертью-зимои появление "хаворонка" знаменует раскрепомение и торхество животворямнх сил природы, наступление весны и господства солнца: в народнон культуре жаворонок как раз являет собон скмвол весны и зооморфна образ солнца. 132

В контексте собственно цветаевского сюжета поэма, т.е. выхода за пределы тварного мира и развопломения до имматериального, лишенного всякого плана вырахения, состояняя, "жаворонок" мохет интерпретироваться как соответствие незримоя, но содерхательнои 'точки', 'значимого зияния' (Ср. упоминаняе "раззора" в 365: эквиваленцио в 353-354: "хаворонком" = "Рана моя"; ср. еме: "Aх, в раззор, в раздор, в разводство Широки - воротцы! Промая, снег, зим сиротскоя даровая роскошы" в "А сугробы подаются..." - 27 Февраля 1922; СиП II, 168 из цикла "Сугробы"; и в стихотворении "дочь Каира" - 3-4 Февраля 1922; СиП II, 156: "В просторах покроя - Потерянность тела, Посмертная сквозь").

Прочтение "хаворонка" как 'песни' или 'трели' тоже закономерно. Тогда завершалась бы последовательность: "урчба" и "звонь6а" (9-10) - "Шепоточки-мои- [...], сладкострунчаты" (135-136) - "расчесочка" 'семнструнная' (153; см. еме 8.9. и 9.5.. где показана связь "коня" С Пегасом) - "жаворонок"' и, означая все ту хе глубинную звуковую сущность Ведуньи, менял бы только ее ореол С губительноя, смертоносноя ("урчба" как грозное, звернное; "звоньба" как звук "запястьи", Т.е. скованности, смерти; "шепоточки" и "расчесочка" как наводямие сон-забытье-смерть) до жизнеутверхдаюмея, хивотворянея. Кроме того небезынтересно отметить, что "жаворонок" в данном случае не имеет инструментального характера и что у него нет плана вырахения в отличие от остальных звуковьх 
проявления Ведуньи. Он - чистая неакустическая 'трель', дахе без "жаворонка": "Жаворонком Рана моя", где "жаворонок" занимает только позицию сравнения, а не объекта. В этом случае выбор "хаворонка" диктуется, вероятнее всего, именно признаком 'дрожи' как в песне жаворонка, так и в его парения, признаком, которым в начале поэмы характеризовалась сама Ведунья именуя себя "Лихоманочкон" и "знобью" (см. 61-72). Ради большен наглядности еме один пример, объединяюшия и 'трель' и 'эротическин озноб': "Я любовь узнаю по срыву Самых верных струн Горловых, - горловых уделин Ржав, живая соль. Я любовь узнаю по мели, нет! - по трели Всего тела вдоль!" ("Приметы" - 29 ноября 1924; СиП III, 115).133

В контексте праздника Седмиц переход от 'зверинон' "урчбы" (9) и колдовского 'бормотанья' -"шепотов" (135, 137) к 'трели' "жаворонка" (353) может рассматриваться как соотеетствие харизмы речи и пророческого ясновидения, т.е. выявление в себе Бохественного Логоса іпонимание его и владение им). Такое толкование отнюдь не произвольно, оно органически вхондт в основы Цветаевскои поэтическон системы, хотя и вырахается иногда прямо противоположньми вариантами.

Героиня "Переулочков" дана в ракурсе 'колдуньи-соблазнительничы'. И одно - 'колдовство', и другое - 'соблазн' - варианты 'посвященности', владения некими танньми знаниями, способности 'видеть' недоступное и 'ведать' этим недоступным. Такая установка - далеко не механическое заямствование из Фольклора. Она встречается во всех поэмах и выражает как ее героев, так и ее лирическое "я", как 'порицателея', так и 'поэта'.134 Более того: цветаевское "Я", но также и 'персонажи' часто идентифицируются с Богом, но опять таки не по принципу поэтического вымысла или произвола, но по принципу вездесущности Бога, в том числе и в "я" и в его окружения. 135 в этих случаях цветаевския сюжет (судьба ее "Я" или персонажеи) строится как путь к Богу в себе, как выявление божественного начала, а в итоге - самоидентификация, означаюцая идентификацию с Богом. 'Колдовство' и 'пророчество' противостоят друг другу только в том смысле, что являют собой разные ступени однои и тоя же "лестнишы" в область божественного. 'Соблазн' же, как в "Переулочках", играет роль психопомпа - губит, несет смерть 'телу' (истончение плоти) и 'душе' (лишает ее последнеи разъединяюмеи материальности), и возносит 
чисты дух, изначально исшедия от Бога, Т.е. возврамает его на исконны его уровень (ср. хотя бы уже цитированные "Дочь Иаира" или "Не возьмешь мою душу хиву..."). Короче: Цветаевския 'соблазн" - соблазн воскресаюмей смертью, и такова разгадка цветаевского парадоксального единства 'колдовство-соблазн-пророчестBo'.

По ЦветаевоЯ, одна из нанболее Фундаментальных форм пребывания духа (Бога) в человеке - голос. Ср.: "Закинув голову у опустив глаза..." (март 1918; СиП II, 20):

В день Благовеменья, у Царских врат,

Перед лицом тяоим - глядиц - стою.

А голос, голубем покинув грудє,

В червонном куполе обводит круг.

"Сивилла: вылокена, сивилла: ствол..." и "Каменнор глыбоя серон..." из цикла "Сивилла" (соответственно 5 и 6 августа 1922; CиI III, 24 и 25):

(1) Потом, под веками - в разбег, врасплох, Сухими рекамн взметнулся бог.

и вдруг, отчаявшись искать извне:

Сердием и голосом упав: во мне!

Сивилла: вемая! Сивилла: свод!

так Благовещенье свериилось в тот

Час не стареющин, так в седость трав

Бренная девственность, пемероя став

Дивному голосу...

Сивилла: выбывшая из хивых.

(2) Каменно глыбоя cepon, С веком порвав родство.

тело твое - пемера

roroca твoero.

"В сокровищницу..." из цикла "Благая весть" (2 июля 1921; СиП II, 119):

В заоблачную
Песнопенную высь -
Двумолнием
Осмеливаюсь - и вот
Мне хаворонок
Обронил С высоты -
Что за морем ты,
Не за облаком ты!

и еме ср. "вдохновенны - Всем пророкочет голос мон крылаты -

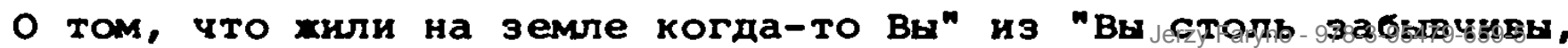


сколь незабвеннд..." (25 ноября 1918; СиП II, 243 - из цикла "Комедьянт") .

Во всех этих случаях "голос" эквивалентен божественному Логосу, Благон Вести, 136 нисходяме свыше $к$ "я" или же воспаряомен, исходяме из "я" обратно к Богу (как в "Закинув голову и опустив глаза..."). Важно при этом, что Цветаевския "голос"-Логос" "крылат" и получает вид то канонического "голубя", то народного вестника - "жаворонка" (ср. диалектные наэвания хаворонка: "вемевременец", "вемевременник"). 137

Выбор "жаворонка", а не "голубя", мотивируется, таким образом, в "Переулочках" легкой объединяемостью в нем как смысла теологического (харизмы речи, духа-Логоса), так и смасла мифологического (наступление весны). В свою очередь выбор "жаворонка", а не популярнои у цветаевон и еме балее популярно народнои вестницы весны "ласточки", диктуется виднмо сильнон связанностью ее "ласточки" с психеен-душоя, гораздо менее совериеннон чем чисты дух-Логос, с однон стороны, а с другон - календарными соображениями: ласточка как вестница весны неизбежно смемала бы события поэмы в мартовскую обрядность, тогда как жаворонок такон строго локализации не предполагает, 138 и, кроме этого, хаворонок обладает таким преимудеством как 'быть незримым' и 'быть средоточием неба" (ср. выдерхку выле из "Благои вести"), т.е. "песнопенноя высью", голосом как таковьм, без источника (не "жаворонок" как таковон, а "рана" в 353-354 и обрывающееся "В ла-" в 355 и 364 , которое позволительно читать как иконическия знак 'растаивания', 'исчезновени' и 'непроизносимости', т.е. не акустического характера этого Логоса-"песнопения") .

"Рана" же в 354, в отличие от "ран" в 349 , должна читаться не как знак экстатического преодолевания материальнон разъединенности (не как болепричиняюмее изхивание плоти, т.е. не как производное от "льнуть"; См. 12.8.), а как знак полнон 'раздаренности' (351), в том числе и отказа от захваченного Героя (343: "Милыя, не льни"), и 'растворенности' до 'зияния' (ср. "раззор" B 365). 139

13.0. Стихи 365-371 возобновляют тему жертвоприношения В стихах 5-8 и 351-352 и тему колдовского преврадения Героя в турин "рев" и "рог" в 137-140 (там, правда, всего лишв предполагавшегося). Прослеженныя семантическия ход поэмы (при условии, что он 
был опознан более или менее правильно) сам по себе к такому Финалу не подводит. Следовательно, разгадку этого финала надо искать во внешнем контексте прекде всего.

13.1. Помня об эволоции Героя "молодец" $(41,53) \rightarrow$ "яминчок" (182, 197) - "Конь" с переяменованиями "молния" и "гром" $(171-174,243-246)^{\prime}$, В рассматриваемон трансформации из-за наличия таких указания как "на при-вязи", "Реви" и "Рог злат" (367-368, 371) естественно видеть его преврамение в мифического и мистического Единорога, т.е. коня с вырастакщим на его лбу единичнвм рогом.

В традиционньх, но относительно поздних, толкованиях Единорог соотносится с непорочностью, с Бохественным Словом, откуда и с Христом (христианская традиция); с Меркурием-Гермесом, откуда его Функиия покровителя поэтического творчества, с одноң стороны, а с дургон - представителя загробного мира: психопомпа (античносредневековая традиция); и рассматривается как гермафродит (особенно в алхимическон традиция). 140 В иньх толкованиях крик Единорога уподобляется колокольному звону, а он сам трансформируется нногда в белого голубя. 141

Все эти возмохности потенциально присутствуют и В "Переулочках". "Рёв" (368) явно соотнесен с "дуиои" (138: "Брыком-ревом душа"), "молниея" - 'рханьем' -"громом" (173-174, 243-246) и провоцируется 'словом' (137-138: "Как за те шепота - Брыком-ревом душа"). Те же соотнесения наблодаются и в случае "рога". Со "словом" в 139-140: "Как за те шепота - турьим рогом банка!" и тут же упоминание вемих "голубея" в 141-142: "на корме вороные голуби В полэобочка воркуют до-люби" С 'громом' и 'молниея' - через противопоказанны Герою контакт с "голубями" ='громами-молниями' (см. 3.8.) и через народную символику 'рога' как грозы и молния. 142 'Слепота' (369: "Взор туп" и ср. раньше в 85, 91-92 "зорким - слепость, [...] Глазком яблочка Не красть!") подразумевает внутреннюю проницательность вместо внешнея 'зоркости', т.е. дар 'провидческия', 'пророческия' (см. 9.3. и примечание 67). В итоге мохно сказать, что Герой здесь преврацается в равносильное "жаворонку" Бохественное Слово, в Логос как таковод (см. 12.9.).

Трансформация Героя В Единорога-Логоса закономерна и по другим признакам. По признаку его 'громовниково-Егориевоя' сущности, 
позволяюще соотносить его с наивысши божеством (см. 1.9., 7.2., 8.4.. 9.1.) и этим самым возвести в ранг Логоса. По признаку его 'конскоя' сущности, которая, как ухе отмечалось в 9.4.-9.5., соотностися у Цветаевон со словесньм творчеством. Эти закономерноСти подводят К более существенному: $K$ эквналентноти'Ведунья : Героя', хотя формальная разница мехду нимя в финале не снята, что требует еме дополнительных замечания.

13.2. Представление о 'Едннороге' вытекает из упомннания "рога" в стихе 371 и из факта, что прехде в связи с Героем упоминался "конь" (171-174, 243-246). Но последовательность "конь" - "рог"' верна только отчасти, в тои мере, в какон не расстранвает ее промехуточны текст поэмы. На другом уровне "рог" и "рёв" восходят не к "коню", а к "туру", т.е. к стихам 137-140. Правда, с символическон точки зрения 'единорог' и 'тур' могут рассматриваться как равносильные варианты 'однорогости' вообще (и в стихе 140 и в стихе 371 "рог" дается в единственном чнсле) и этим самым интерпретация Героя как 'Единорога' правомерна, однако разница между 'единорогом' и 'туром' не только терминологическая. Дело в том, что если "конь" - самопроизвольное выявление более глубокой сущности Героя, то "тур" является продуктом магических заклятия Ведуньи (137-140 с их явным угрожакцим характером: "Как за те шепота" и 368 с финализируюиим приговором: "Реви, заклят") .

Превращение Героя, обладаюмего сущностью "коня" и 'грома', в "тура" имеет свою основу в народноя контаминации коня С туром и eme co змеем:

Зрявкает бурко по туриному, Он шип пустил по змеиному, 143

или :

Не сльхал ты шипу змеинова,

А тово ли крику зверинова,

А зверинова крику турннова, ${ }^{144}$

гле все три зверя являют собои зооморфное представление грозовон тучи или самого грома. В этом контексте "На при-вязи Реви, заклят" (367-368) читается как пленение и подчинение себе 'грома' (= животворяиих сил природы) 'громовлашыицен'-ведуньея (см. 1.4., 1.7.), так как 'привязь' означает если и не 'умермвление', то по краянея мере сильную 'детерминированность' (см. 1.6. и 4.1.), 145 а угроза "Как за те шепота - Турьим рогом башка!" (139-140) - 
как угроза перевода Героя на 'бестелесныя' уровень, низверхение его до подвластного еи имяатериального состояния ("Рог злат" в 371 как символ 'бесплотного' бытия) или хе ен подвластного 'хтонического' оостояния ("тур" читаемы как разновидность 'зверного'). В том же народном контексте преврамение Героя в "тура" и особенно в 'турью голову' (упоминание "банки" в 140 и 148, а такхе редуцированность до компонентов 'головы' в стихах 369-371: "Вэор туп, Лоб крут, РОГ злат") мохет читаться как традиционное хертвоприноиение (и дахе 'дар' - ср. стихи 351-352 и 5-8) некоему собственному 'громоносному' бохеству (см. упоминание "дуба" в 8 и 1.4., 1.7.) его хе 'громоносного' подобия (о семантике 'даpa' cM. 12.8.$)$.

Само собон разумеется, что все эти значения веры только в тон мере, в какоя данная поэма реализует, хотя бы подспудно, мифологически архисюхет поединка противника Громовержаха с самым Громоверхием, завершающися победои первого. При таком толкования воэникают, однако, и некие сомнения. Не совсем ясно, например, почему в таком случае Герои преврамен не просто в "тура", а в 'златорогого', т.е. в некое бохество, или почему он представлен здесь не полньм 'корпусом' а всего лиш 'головон' ("бамка" в 140 и детали только верхнең части головы в 369-371) с настопчивьм акцентом на "роге" (140: "Турьим рогом башка!" и финальнын, а этим самвм особо значимы, стих 371: "Рог злат"). Eще менее ясно появление "при-вязи" (367), придаиея смысл 'детерминированности', тогда как до сих пор весь смсловоя и событиннья аспект поэмы строился как раз на упразднении любых уэ, любых детерминантов, и лобых различительных признаков (особенно в стихах 331-355).

13.3. Впервье 'голова' Героя ("башка") упомннается в стихах 129130, где этор голове принсыветс 'незрелость', 'ребячество', 'золотистость', за котороп стоит его причастность К солярной суиности, и 'улрятанность', которую позволительно читать как 'инкорпорированность в материнское лоно' или, по инои терминология, причастность к земному, хтоническому началу: "что за дурость-такасоплячество Башкон русою в юбки прятаться?" (129-130). Признак 'незрелости' и связи с 'земньм-материнским' началом возобновлен через несколько строф еме явственнее: "А на што нам лен, Зелена башка? Твоя земноя поклон - В широки шелка: Кланянся, Кланяяся! [...] Чтоб и спросыпу Не сказал сынок: К маменьке, К маменьке! 
[...] Видишь - матушка На лужку стоит: Кланянся, Кланяяся!" (147-164). В промехуточном же тексте 'голова' упоминается в угрозе Ведуньи: "Как за те шепота - Брыком-ревом душа, Как за те шепота - Турьим рогом башка!" (137-140). Угроза хе заключается в 'изъятии-умерщвлении' "дуия" ("Брыком-ревом душа", где "Брыком-" происходит от 'брыкнуться'='испустить дух, умереть') и 'обезглавлении', так как превращение головы в "рог" эквивалентно усекновению головы. Последовательность '"душа" - "башка"' свидетельствует о иерархически высшен позиции (или ценности) "башки" и о высшея опасности 'обезглавления', чем 'умершвления' душ, хотя казалось бы, что обе операции ведут к одному и тому же результату. Тем временем разница мехду "дуюои" и "башкон" выявляется в разнице их превращения: первая становится "рёвом", вторая - "рогом". О том, что "рог" ценнее "рёва", ярче всего говорит последовательность в описании финальноя ипостаси 'Головы' Героя.

Описание совершается по совходящеи линии: "Взор" "Лоб" - "Рог"', где "рог" занимает наивысшее место. наивысшее место ему приписывается и стилистикои предикатов: пеноративное "туп" - полохительное "крут" - возвьпенное "злат" (славянизм) . но заметим и обратное: стилистически высокое "Взор" сменяется неитральньм "Лоб" и завершается бытовым "рог". И еме: высокое "Взор" предицировано низким "туп", бытовое "Рог" - возвьпенньм "злат", "Лоб" же получает соответствующия ему неятральны прешкат. "Взор" - не 'зрение', а высшее, внутреннее зрение. Поэтому если его 'тупость' может и читаться как 'слепота' (см. 13.1.), то это вероятнее всего 'слепота' висшего порядка, 'слепота дуия'. Характерологически 'крутизна лба' соотносится обычно с 'интеллектуальностью', с незаурядным умом, с остроя мыслью. на Фоне предыдущего пеноративного "башка" $(140,148)$ и предпосылаемо ен 'незрелости' (129: "дурость-така-соплячество", 148: "зелена башка?") переименование в "Лоб крут" (370) решительно повьшает интеллектуальныя статус 'головы' Героя и иерархически ставит его вьше "души" или - над "душон". Но "Лоб крут" в этом построения всего лиш промехуточное, так сказать неятральное звено: над ним возвъшается еще "Рог злат". О том, что так именно следует читать эту позицию "Лба" говорит и Факт, что если от "Взора" ко "Лбу" нет никакого перехода, скорее контраст их разъединяюиия (ибо после "Взор т у $\boldsymbol{\Pi}^{\prime}$ естественно ожидать аналогичнод характеристики 
"Лба", но это охидание демонстративно не выполняется), то от "лба" к "Рогу" такоя переход очень отчетлив: "крут" - "рог" с объединяоме их восходямея линиея, и Факт, что 'крутизноя' характеризуется в поэме восхохдение вверх, в "Лазорь" (256: "Лазорь, лазорь, Крутая гора!"; 356-357: "Лазорь, лазорь, Круты рамена!"). Иначе говоря, "Рог" - устремленное ввысь продолкение 'интеллектуального лба', его более ценная ипостась.

Если "Взор" и "Лоб" могут соотносится С 'человеческим', то "Por" - с 'нечеловеческим'. И если 'угроза' Ведуньи предполагала преврамение Героя в 'нечеловеческое звериное' (138: "Бржком-ревом душа"; 140: "Турьим рогом башка!"), да и сам Герон так ею потрактован (ср. 'животның' характер "брыка-рёва" и "банки"), то финально заклятие преврамает его в 'нечеловеческое возвьненное' или просто 'сверхчеловеческое' либо дахе 'бохественное' ("Рог злат" заведомо фантастичнее "Турьего рога"). Учитывая изложеные в 13.1. ассоциации С Единорогом, легко заключить, что и на этом уровне Ведунъя преврамает своего партнера в некое подобие Joroca.

13.4. 'Угроза" Ведуньи изъять "душу" Героя и превратить его 'голову' в "турия рог" (137-140) не имеет характера 'наказания' за некия проступок Героя, так как "шепота" исходят от нее, а не от него: "山епоточки-мои-смеюнчики" (135) и "Как за те шепота" (137, 139). Конструкция "за те шепота" долхна поэтому читаться в категориях хотя и принудительного,но все-таки 'обмена' (аналогичного 'дару' в 329-334: "Дарственньмн - Душу насыть! Милы, растрать! С кладью не примут! Дабы принять - Надо отринуть!"). Как в основе жертвы и дара, так и в основе обмена покоится один и тот хе механизм мены сумностея. 146 в данном случае, ввиду обязательности 'обмена', событие получает смысл изъятия сумности Героя, т.е. его "души" (138: "Брыком-ревом душа") и 'интеллекта" (140: "Турьим рогом башка") и замену его души - иноя, Ведуньиноя сумностью, названнои тут "ревом" (138) и "Турьим рогом" (140). При этом примечательно, что все это угрохажиее Герою преврамение носит характер симпатическон магии (а 9же - гомеопатическон), которая предполагает родственность (подобие) результата причине. 147 дело в том, что и "рёв" и "рог" вызываются тут "шепотами", т.е. неким 'речевьм потоком', и что "рев" и "рог" подразумевавт не только некую 'звучность', но и некую, пусть и 
нечленораздельную, 'речь дуй', 148 мохет быть дахе последнее, самое глубокое ее 'слово' или ее 'зов'. "Шепота" - речь неполнозвучная и, если учесть, что они исходят от Ведуньи-'колдуньи' , такхе и с редуцированно артикуляциен. То есть: эта речь безразлична к плану вырахения (мохет быть дахе непонятнов и невнятноя), но денственна семантически (способна вызывать нухның эФФект) . Иначе говоря, есть определенные основания считать ее более глубоким, 'под-речевьм' семантическим потоком, а в иньх терминах - инвариантом речи. При таком подходе естественно окидать, что аналогичным долхен быть и ее эффект. Тогда явственнее становится удвоенны характер 'взыскания'-'обмена' : его структура иерархична с поэтапным сниманием плана вырахения с 'заполучаемои' речи Героя. "Рёв" уже не речь, но все еме 'звучащ', "Туры рог" же и не речь и не 'звучам', он - всегс лишь потенция 'звука', 'семантика' без какого-либо плана вырахения, а иначе - таков же 'инвариант речи' как и "шепота" Ведуньи. Заметим теперь, что Ведуньины "шепота" - "смеюнчики" и "Сладкослюнчаты, Сладкострунчаты!" (135-136).

Причастность к 'струнам' ставит "шепота" на уровень Фундаментального начала и Ведуньиного и Цветаевского мироздания (см. $2.2 \ldots, 8.9 \ldots 9.5 \ldots, 9.7 \ldots$ прнмечание 84 и ср. немедленную замену "шепотов" на "расчесочку" в 153, одно из задания котород - изъять "память" Героя в 169-170). В случае Героя взамен за "шепота"'струн' предполагается получить "Турия рог", где "рог" в окружении звукогенно лексики выдает свою связь с 'музыкальным инструментом' и может рассматриваться как вариант Цветаевскои "лиры" (см. примечание 148 и упоминание "лиро-черепахи" в "Поэме воздуха" - СиП IV, 284: "Соловьиных глоток Гром - отсюда родом! Рыдью, медью, гудью, Вьюго-Богослова Гудью - точно грудью Певчея - несвобода нёбом или лоном Лиро-черепахи?"), а определение "турин", благодаря тому же окружению, напоминает о том, что зодиакальның знак тура (таurus) управляет горлом и голосом. 149

Причастность к 'слюне' ("сладкослюнчаты" - 136) в контексте змееобразности Ведуньи (93-100) сообщает "шепотам" статус 'запредельных знания, запредельноһ, сверхчеловеческо мудрости'. Поэтому воздеяствие на "башку" Героя "шепотов" долкно приобщать его именно к этим 'запредельньм знаниям', а результат - "Турия рог" - должен быть их эквивалентом (ср. локализацию "рога" над 
'интеллектуальнт' "крутьм лбом" в 370-371 и возведение его в ранг "золотого", т.е. в соответствие хранимои под видом драгоценностеи змеинов мудрости) 150

Причастность к 'смеху' (135: "Шепоточки-мои-смеюнчики") ассоциирует "wепота" с представлением о 'плутовстве' и 'игре', а этим самьм с "улепениям" (ср. 49-52, 59-60, настоячивое упоминание 'сладости' в 131-136: "Райской слоночкой [...] Сльу, вьюношам Слаще, бают, нет. Мепоточки-мои-смеюнчики, Сладкослюнчаты, Сладкострунчаты!/" и 'словеснов молвы' в виде "Стыв", "бают") и "яблочками" как плодом познания, "яхонтами" как глубинно зменнов мудростью, "шахматами" как интеллектуальной игрои и универсальнов модельь мира (см. 4.5.).

таким образом, "за те шепота" Герою предстоит стать 'инва риантом' звука и слова или 'звуко-смыслопорохдаюмен потенциен' ("Турьим рогом" - "Рог злат"; ср. в заметке "Скобка о роде слуха" из "Искусства при свете совести" - 1932; Проза I, 402: "Физическия слух либо спит, либо не доносит, замеменнын слухом иньм. слиту ке слова, а какойто беззөучкай капев өкутри голова, какуюто слуховую ликио - от намека до приказа, но об этом сенчас долго - это целы отдельны мир, и сказать об этом - целын отдельныр долг" - курсив моя - Е.Ф.), а Ведунье - выявить и извлечь ее из Героя. Промежуточные звенья события поэмы этому как раз и подчинены: Героя, как уке было показано, постепенно выявляет себя и теряет поочередно все более сущностные свои ипостаси (182, 197: "ямиичок" - 243-246: "гром", "молния", "конь" - 323-334 с их смьслом 'растворяюменся души' $\rightarrow$ 371: "Рог злат").

13.5. Один из источников повьшенноя сосредоточенности Ведуньи на 'голове' Героя (23: "Ох, башковит-красовит": 129-130: "что за дурость-така-соплячество Башкоя русою в юбки прятаться?"; 130-140: "Как за те wenoта - Турьим рогом башка!"; 147-148: "A на што нам лен, Зелена башка?"; 325-326: "Синь - в сапогах, Синь - в головах..." и трехчленное описание 'головы' в 369-371: "Взор туп, Лоб крут, Рог злат") - мифологическия и фольклорнья поединок С противником, как правило, хтонического характера, и, как правило, завершаюмияя обезглавлением его. Непосредственного обезглавления в поэме нет, но его соответствие вряд ли вызывает сомнения. Кроме трансформации в 'турью голову' имеются в тексте еме и другие показатели. Один из них - постепенное исчезание 
'головы' : переименование "башки" во Фразеологизм "в головах" (326), где 'голова' ухе не столь 'часть тела', сколь абстрактная 'позиция', 'значимая пространственная точка', и иерархическия набор детален в 369-371, хотя и подразумеваюин 'голову', но прямо вовсе ее не упоминаюмин. Второи - графико-композиционное решение стихов 369-373 с промехуточньм знаком мехду стихами 371 и 372. Данны знак явно рассекает финальны 'турын' образ Героя надвое, на верхнюю и нихнюю части, на подразумеваемую 'голову' и так хе подразумеваемое 'туловище':

369 вэор туп,
370 Лоб крут,
371 рог злат.

372 Турия след у ворот, 373 От ворот - поворот.

При этом показательно, что верхняя часть, 'голова', не идентифицируется, а композиционно - устремлена вверх (см. 13.3.), тогда как никняя названа конкретно ("турин"), дана как физически наличная ("след" в отличие от в 363 "Слешы замела"), крарняя никня (тот же "след") и устремленная в 'обратную сторону" ("поворот" = 'назад') с признаком 'вдаль' и 'назад'='вниз'='в смерть' (если пространство 'за воротами' читать как 'внешнее'). 151 такое рассечение и противопоставление разъятых частен тела удивительно родственно архаическон символике декапитация, означающен независимость духовного начала, локализованного в голове, от начала витального, представляемого телом вообще. 152 нетрудно замәтить, что под всем этим кроется Фундаментальная Цветаевская оппозиция 'Жизнь жизнь', т.е. 'духовное - материальное', 'возвьшенное $\rightarrow$ низменное', 'вечноењ тленное' и Т. П.

Второи источник интереса Ведуньи к'голове' Героя - собственно поэтическая система Цветаевоя. В связи С этим нанболее показательны стихотворение "Так плыли: голова и лира..." (18 ноября 1921; СиП II, 137) и Финальная часть "Поэмы воздуха" (весна 1927; СиП IV, 285-286). В первом случае "голова" и "лира" почти синонимичны и едва ли различимы ("крово-серебряныя, серебро-Кровавыи след двоинои лия, Вдоль обмираюмего Гебря - Брат нежны моһ, сестра моя!"; "не лира ль истекает кровью? не волосы ли - серебром?"), кроме одного признака: "лира" несколько опережает "голову" и устремлена вперед, в сторону запредельного, тогда 
как "голова" 'отстает'и обнарухивает тенденцию к 'оглядке', к тоске о покинутом бытие ("и лира уверяла: мира! А губы повторяли: жаль! [...] Пороя, в тоске неутолимоя Ход замедлялся головы. Но лира уверяла: ммо! А губы ея вослед увы!").

В "Поэме воздуха" после преодоления всех семг "воздухов" и вьхода за "Твердь" небеснут, "Я" оказьвается в пространстве "Голов безтормозных" и в состоянии определенном как 'Полная оторванность Темени от плеч Сброшенных", т.е. в сфере Гермеса ("Беспочвенных - Грунт! Гермес - свои!"). На этом, однгко, вознесение не завериается: 'оторванная голова' обретает "крылья" ("Полное и точное Чувство головы С крыльями"), а эатем редуцируется до "лба" или еще точнее - устремляется в 'гарство "лба"' ("Из лука-выстрелом - Ввысь! не в царство душ - В полное влашычество Лба"), которое опять-таки не есть "Предел": "лоб" отстает от очередноя ипостаси - "смбла", уносямегося еме далее. 'оторванная голова', таким образом, всего лишь первыя этап возкесения по ту сторону тверди небесноя и еи предстоит 'отсзать' от отрывакмегося от нее 'смысла'. При этом показательно, что на данном уровне 'голова' возведена уже в ранг 'инварианта': она - "С крыльями" и родственна как Гермесу-психопомпу, так и Гермесу-покровителю поэтического творчества.

В этом контексте "Рог злат" (371) в "Переулочках" - не что нное как вариант 'крыльев' (ср., в частности, сказочные преврамения оленя, будущего варнантом тура, в птичку-золотуло головку) 153 а "Лоб крут" - вместилиме 'смысла'. Если и далее проводить параллель с "Поэмон воздуха", то в стихах 365-368 заметнее становится конструкция "В лазорь-в раззор [...] Ревн" со смыслом 'устремленности ввнсь', но и со смыслом 'отставания'. Отличне же от финала "Поэмы воздуха" состоит в том, что дальнеңшая трансформация Героя здесь ухе не предполагается (на что особенно однозначно указывает совершенны вид причастия "заклят" и упомннание "при-вязи") .

Решение этого парадокса подсказывается синтаксисом стихов 351-368, снимаюинм разницу между Ведуньнным "я" и "ты" Героя: обстоятельство места-цели ("В лазорь") одинаковым образом предпослано им обокм: "Жаворонком Рана моя В ла- Лазорь, лазорь, [...] Слеш замела В ла- В лазорь-в раззор [...] Реви, заклят". это значит, что Геро тут тохдественен ведунье и что она, дабы 
продолхать свое вознесение освобохдается не столько от него, сколько от себя же. Сюхетное же различие мехду ними состоит в неодинаковон 'быстроте' трансформация: как раньше, так и здесь Ведунья оперехает своего Героя по краннеи мере на один уровень (ср. 9.1.), т.е. она уже ничем не детермянированная "рана"-"раззор", растаивахиая ввысь "хаворонком", тогда как он только что оформляется в идеальное инобытие, в "Рог злат", и этим самым все еще детерминирован ( $c p$. упоминавшуюся ухе серию преврамения оленя, эавериаюиюся птиккои-золотои головкои), почему ему как 'туру' и предстоит "От ворот - поворот" (373), где "ворота", несомненно, - вариант "раны"-"раззора" $(354,365)$ и очередньх уровнен "Лазори".

13.6. И Ведунья и Герон обретают в финале статус Логоса (см. 12.9., 13.1. и след.), но на неодинаковьх этапах его развития (см. 13.5.). Но возмохно, что есть мехду ними и другие различия. исходя из того, что 'златорогин тур' хотя и эквивалентен 'Единорогу' (см. 13.1.), однако не тохдественен ему, позволительно предположить, что явленнь в Герое 'Логос' умербнее 'Логоса'-Bедуньи: если первы определен 'рёвом' (386: "Реви, заклят"), то второя - 'песнопенны" (определен "хаворонком" в 353), если первы получает вид языческого бохества, то второи явственно подразумевает связь с сакральнон Благон Вестью (см. 12.9. и оппозиино 'тур $\rightarrow$ жаворонок'), и, наконец, если первын 'оформлен' ("при-вязь", "заклят", "Рог"), то второи полностью 'раскрепомен" и 'не-суи' ("Жаворонком Рана моя", "раззор").

Если теперь учесть все 'витальные' и 'оплодотворяющне' коннотации Героя как 'Громовника' и финального 'тура' ("рога"), 154 то станет ясно, что 'златон рог' есть кранняя, первая или последняя, точка эволюции Героя, точка, где либо начинается либо завершается слово - или смыслорождение, процесс 'формирования' - В свете этого ясно также, что, соответственно с цветаевско системон, отсюда начинается либо 'спуск' на земпю, в 'бренные' формы бытия, либо 'подъем' в вечную 'Хизнь', ничем не ограниченную. Но в последнем случае необходимо устранить 'Формообразовательную' потенцию. В "Переулочках" этот акт дан под видом мифического 'привяэывания-умерщвления', с одно口 стороны, и с другоя - 'самовскрытия" ("на привязи Реви заклят" "Рана моя"), выхода в 'не-сушее', в предел "ворот" (ср. в цитированном ухе "А сугробы 
подаются...": "АХ, В разэор, в раздор, в разводство широки - вороты! Промая, снег, зимы сиротскои даровая роскопш!", где "снег" и "зима" носят характер детерминируомих, 'Формообразующих' начал, и ср. возмохное прочтение "переулочков тех игнатьевских" как локуса 'не родившегося' - см. $1.1 ., 1.8$.$) .$

В итоге позволительно здесь видеть ту семантическую структуру, которую более эксплицитно разъясняет Цветаева в "Искусстве при свете совести" ("точка зрения" и "небо поэта" - Проза I, 394396):

"По Отношенио к миру духовному - искусство есть некин Физичесан мир духовного.

По отношеию к миру Физическому - искусство есть некиम духовны мир Физического.

Ведя от земли - первын миллиметр над нея воздуха (-неба, ибс небо начинается сразу от земли, либо его нет совсем. Проверить по далям, явления усеняюмим).

Ведя сверху неба - этот хе первы над землея миллиметр, но последния - сверху, то есть уже почти земля, с самого верху совсем земля.

Omкуда cмотрето.

[... ]

Искусство - искус, мохет быть самы последния, самь тонкия, самы неодолими соблаэн земли, та последняя тучка на последнем небе, на которую умирая глядел - ни на что уже тогда не глядевшия и окраску которы словами пытался

-все слова тогда ухе забывшин брат-брата - Жюль Гонкур.

третье царство со свонми законами, из которого мы так редко спасаемся в высшее (и как часто - в низшеe!). Третье царство, первое от земли небо, вторая земля. Между небом духа и адом рода искусство чистилите, из которого никто не хочет в рай.

Сказать, что в "Переулочках" речь идет об искусстве, было бы слишком грубор натяхкои, хотя сама по себе тема 'словесного', как мы видели, пронизывает явно и подспудно всю поэму: от завлекаюме и уводяме речи Сводни (1-56; см. Предварительные замечания) через "сладкострунчатые ... шепота" (131-140) с их разветвленньми ассоциациями с лирон ("расчесочка" в 153, 'ревущие' "душа" и "рог" в 140 и 371) по "песнопенныя' образ Ведуньи-"раны" как "хаворонка" (351-355) и интеллектуалистическия "Лоб" и "му-

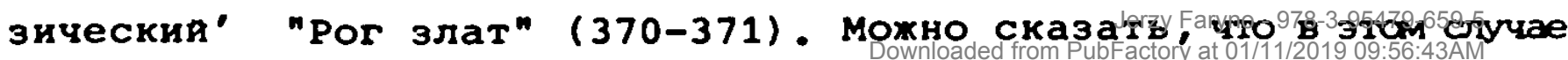


имеется в виду не столько искусство, сколько "искус", "самын неодолима соблазн земли" (Проза $I, 395)$ и его преодоление героинеи поэмы (Ведуньея), "соблазн", преодоление которого возносит на "небо духа" "Вопломением же "соблазна" является, несомненно, Героя. Цветаевское 'соблазнять' двувалентно: оно означает такхе и 'соблазняться' - ср. в записях "Из дневника" 1919 года (Проза $I, 79-80)$ аналогичную иновалентность Цветаевского "љьстив":

"- Кахшы поэт - придворнын: своего короля. Поэты всегда падки на величие.

- Как короли - на лесть.

- Которут я обохаю, ибо веду ее не от лицемерия, а от прелести - того, кому льстишь. Льстить - прельматься. Льстить льнуть. ИноЯ лести не знаю. А вы?". 156

В этом контексте сюхет поэмы, т.е. безраздельное ибладение Героем, есть одновременно преодоление героинен собственнон ' соблазняемостя', завершаюмееся отказом как от соблазняемого, так и от самого себя: он - "эаклят" и 'умерщвлен' (367: "на привя-зи"), а она - выходит за предељы 'искуса', в 'не-сущее' (353355: "не удерхав,-Все раздаря! - Жаворонком Рана моя В ла-", где оборванное "ла-" - и энак 'эияния' и знак растворенности самон Ведуньи; $\mathrm{cp}$. В 360-363 объяснение этого знака как изъятия какихлибо признаков бытия: "Коншы залила, следы эамела В ла-").

\section{III. ЗАКТDЧEHИE}

По своему образному и речевому строю "Переулочки" - поэма глубоко нараное, с однон стороны, а с другон - полностью оригинальное, авторское (Цветаевское) проиэведение. Если о "Магдалине" мохно было скаэать без особого риска, что это очередноя своеобразны "апокриф" (См. 4.0. в статье "Магдалина"), то помимо всен народности о "Переулочках" никак нельзя сказать, что это очередная "былина" или "сказка". И дело вовсе не в том, что у Цветаевов былинның сюхет переосмыслен или что он выражен иным языком.

Апокриф - играющее роль предания сообщение на естественном языке или текст, притом текст претендующия на позицию Текста, имеюего статус культурного текста-кода. 157 у былины ше и сказки иная тенденция. Они создаются не в терминах яэыка, а в терминах определенного инвариантного текста или, точнее, выработанного культуроя текста-кода, т.е. такого текста, которы для волшебнод сказки реконструировал Пропп, или того, которы 
мифологическон поэтике определяется понятием "основного мифа" (см. хотя бы работы иванова, Топорова или Мелетинского) . Владея таким текстом-кодом, таким специализированкым языком, вполне не трудно создать и прибавить к уже известным епе один текст-вариант, с тем, однако, что это не будет принципиально новое сообщение, так как его основная семантика (информация) - всегда один и тот же исходны текст-код. Тенденция былины или сказки, таким образом, - превратить текст-код в конкретны текст, а не - как в случае апокрифа - создать кодирующия текст, исходную текстообразуюиую инстанцио. Цветаева в "Переулочках" (но само собон разумеется, что не только здесь) этим бшлинным (а шире - народньм орядовм) текстом-кодом владеет в совершенстве (и вправе сказать - себе "Я сама народ" - СиП II, 380), но подходит к нему иначе: пользуется им как языком, как кодом, но решнтепьно отклоняет его текстопорождающую судность, что и позволяет еи строить и подлинно народное и одновременно сугубо индивидуальное произведение. Иначе говоря, цветаева двихется не от мифа к варианту, а от варианта к мифу, но не останавливается на уровне мнфа, а поднимается еме вьле - на уровень мифотворчества (в иньх терминах: миФопоэтического мпшения). Точно такая же картина наблодается и в случае ее 'теологии'. Вьход за пределы текста-кода в область кодообразуюших начал, на уровень кодотворчества, позволяет ен не противореча основньм теологическим положениям строить свою семантику, а одновременно вскрьвать их первооснову. 158 По этоя именно причине ее магдалина гораздо блике к утерянному евангелистами праобразу святоя блуднищы, чем упомннаемая мария из Магдалы. И по этоя те причине Џветаевская версия воскресения ност характер более глубокия, чем в популярньх церковных толкованиях. Истинное, по цветаевоя, воскресение есть возврат духа, которы Бог вдохнул в дуиу человека, к Бога от человека, а не восттановление плотского обика или подобного земному образа бытия. Воскресение у нее - воэврат не сода, а туда. На уровне сюжета это означает у цветаевоя погружение в смерть, преодоление всех земных искушения, и очищенное духовное воспарение. Популярның круг бытия у цветаевоя размыкается и получает вид бесконечного пути-восхождения. Но это в отдельных произведениях. Если же брать творчество во всея Фовопности, нетрудто онарумит здесь инои - более универсальнын - қруг: его исходная топка - не земне быне, а орера Бога, откуда человек и прибывает 
на землю, чтобы потом вознестись туда обратно (ср. хотя бы стихотворение "Сивилла - младенцу" - 17 мая 1923; СиП III, 25, где говорится: "Рождение - паденье в дни. С заоблачных нигдешних скал, младенец мон, Как низко пал! Ты духом был, ты прахом стал. [...] Рождение - паденье в кровь, и в прах, и в час... [...] Но встанешь! То, что в мире смертью названо - паденье в твердь. Но узришь То, что в мире - век Смеженье - рохденье в свет. Из днесь - В навек. Смерть, маленькия, не спать, а встать, не спать, а вспять. Вплавь, маленькин! Уже ступень Оставлена... - Восстаньте в день").

Самое интересное однако то, что по законам этон модели перестраивается у цветаевон и,казалось бы, перестронке не подағоми ся сюжет основного мифа, а в частном варианте - сюжет былины, т.е. лежания в основе годового обрядного цикла и поэтому наиболее универсальның по своему значению поединок Громоверма (змееборца) с его противником (Змеем). Если текст-код предполагает исход,восстанавливаюия нарушенное первичное равновесие космических сил и этим самым замыкает космнческия природныя цикл и подводит к очередному строго тохдественному циклу, то цветаева этот цикл размыкает и выпряляет: вместо возобновления исходного полохения у нее имеет место бесконечная качественная эволюция вплоть до обретения статуса абсолютного космического начала. Само собо разумеется, что в конкретных решениях эта идеальная точка никогда не достигается - Цветаевские сюжеты обрываютя гораздо раньше, но как правило всегда там, где все мылимые (имеюия земноя характер) препятствия если и вовсе не преодолены, то по краянея мере низведены почти к нулевому состоянию, а "герои" эвоташониукия до статуса чистого духа или чисто мысли. На этом фоне, думается, уже совершенно естественно читается и перестановка местами Ведуньи и Героя в их поединке, и победа Ведуньи, и их эволюция. Носительница интеллектуального начала, обладательница таяных и глубиных значения (см. интеллектуальность "уленвания" Ведуньи в 59-60: "яблочками, яхонтами, улемает, шахматами" ; сам статус героини как колдуньи, владеющен магическим 'потусторонним' словом - "wепота" в 131-140; способность к преврамениям, т.е. власть над своим и чужим физическим обликом или планом вырахения и Т. П.) не мохет не победить носителя хотя и божественноя но физическоһ силы Героя-'молодца'-'Громовержца' и не может не эвопанонировать до 
состояния чистого духа-мысли ("жаворонок" в 353 с подспудными Цветаевскими коннотациями "песнопеннон" - 'Логосовон' - зыси). как не мохет не довести до предела выявления самод краянен суиности своего партнера или противника: С него должны быть сняты все промехуточные облики и долхна выявиться скрытая под зими сущкость, сущность Бога-Громоверхиа, а в каком-то смысле тоже логоса (тур как предельная ипостась Героя и - в народнои традиции - как ипостась верховного бохества, Громовержиа). Но цветаевски Бог бесконечен и бесконечно динамичен, как в стихотворения "новогоднее" (7-го Февраля 1927; СиП I, 266 или СиП IV, 276277): "не один ведь ран, над ним другоя ведь рая? [...] ヨе один ведь Бог? над нкм другон ведь Бог?", - поэтому цветаевская Ведунья с жесткоя необходимостью долкна вынти за пределы эгого 'первого' Бога и устремиться к тем, что "над ним".

Прочтение Героя "Переулочков" в термннах мнфа о Громоверхце позволяет уточнить место Громовержа в џветаевской системе: он занимает в ее мироздании позицию тоя космическон энергии, того Бога, слова и т. П. сущностеи (ср. в "Поэме воздуха" локализацию "гуди вьюго-Богослова", т.е. сына громов иоанна Воанергеса - см. Марк, 3: 17 - в сфере "пятого воздуха" и на стые слова поэтического со словом божественньм: "В песне, в большеротон Памяти народноя. Соловьиных глоток Гром - отсюда родом! Рыдыю, медъю, гудъю, Вьюго-Богослова Гудью - точно гудъю Певчея - несвобода нёбом или лоном Лиро-черепахи? Гудок, гудче Дона В битву, гудче плахи в жатву... [...] Семо в основе лиры, Семо в основе мира" - СиП IV, 284), которьм свояственно деградировать, т.е. вопломаться в земные формы бытия (отсюда Героя мохет ассоцинроваются как с оплодотворяющим, так и с поэтическим началом - "турия рог" как символ осеменения, с одноң стороны, а с другор как властитель горла и голоса; см. 13.4.: приуроченность поэмы весеннему возрохденио природы и связаннон с этим народнон обрядности; и т.п.) тогда как Ведунье (и большинству вопломения авторского я) свопственно стремиться как раз в противоположном направленин - К Абсолюту. В результате поединок Громовержца со Змеем, сохраняя все сходство С основньм народньм мифом, на самом деле есть поединок двух противоустремленных тенденция или иначе - поединок Духа и Материи. И это и есть цветаевскин архисюжет, которын лежит в основе не только "Переулочков", но и больиннства других ее вещеи, всякия раз, 
конечно, решаемых в соответствии со степенью материальности-духовности противоборствующих сторон, которые то получают вид двух самостоятельны персонажея, то являют собоя внутреннюю антиномию одноЯ и тоЯ же личности.

\section{П Р Р Н}

1. Здесь и дальше произведения ЦветаевоЯ цитируются по изданио: М. ЦВETAEBA, Стихотворения и позми в пяти томах, том первын: Стихотворения 1908-1916, Russica Publishers, INC., New York 1980, далее сокрапенн: СиП I; том второв: Стихотворения 19171922, Russica Publishers, INC., New York 1982, далеe cokpaщено: СиП II; том третия: Стихотворения. Переводы 1922-1941, Russica Publishers, INC., New York 1983, далее сокраменно: СиП III; том четвертыр: Поэмы, Russica Publishers, INC., New York 1983, далее сокращенно:СиП IV. М. цВЕTAEBA, Избранмая nроза ө дөух томах, Russica Publishers, INC., New York 1979, далее сокрацєнно:Проза I Проза II.

2. См., в частности, комментарин составителей в СиП II, 381 , а также показывающую аналогичные расхождения между поэмов "царь-Девица" и ее отправньми сказками статью: С.ПоЛЯКОВА, "К вопросу об источниках поэмы цветаевскон "царь-Девица'", в: Russica '81, Литературны сборник, New York 1982, 222-228.

3. Ср., например, комментарий к циклу "Гаданье" (М.ЦВеТАЕВА, Избранкие произведения, Москва-Ленинград 1965, 737): "В трехпрудном пер., рядом с нашим домом, гадали на заборе, - 19 мая 1917 г., - вспоминает Цветаева в 1939 г.. перебеливая стих. - Лимии мало - точнее слово шыганки, которого бы никогда в щганском гадании не употребила... "но Аллах - мудрее " и далее: "В тетради 1939 г. (АрЦ) к 3-му стихотворению помета: "Переписываю в Париже... 22 года спустя. И - одобряю. Эти стихи, кстати, горячо одобрил на каком-то вечере, в чехия, в 1923 г....древни и ученьд старичок с зеленьми глазамн змея, оказавиндся мировьм ученым - археологом Кондаковьм. Одобрил - за настояmесть шыганской речи. - Где же вы так изучили шыган? - о, они мне только гадали..." .

4. Не исключено, что почти не соприкасаюцаяся с цветаевскоЯ сюжетикоя былина привлекла внимание Цветаевон именно благодаря совпадению имени былинной колдуньи Маринки с собственным именем Цветаевоя, ставшем ко времени написания "Переулочков" (апрель 1922) одно из наиболее фундаментальных категория ее моделирующе системы (прежде всего в переводе на лунарно-акватическую символику; См. хотя бы "Дуиа и имя" из сборника "волшебның фонарь", выпуиенного в 1912 году - СиП I, 122 , "Кто создан из камня, кто создан из глины..." - 23 мая 1923; СиП II, 286, стихотворения вошедшие в цикл "Бессонница", а написанные в 1916 году, особенно "Черная как эрачок, как зрачок сосуиая..." - Сип I, 244), и кроме того совпадению еще и с 'колдовским' характером Цветаевского лирического Я (Ср. хотя бы стихотворение "Колдунья" из сборника "Вечерния альбом" 1910 года - СиП I, 57: "Я - Эва, и страсти мои велики: Вся жизнь моя страстная дрожь! [...] Я призрачнвы 
А если забросишь колдунью в тюрьму, То гибель в неволе быстра!" или стихотворение "Канун Благовещенья..." - 24-25 марта 1916; Сй I, 211: "Дан здоровья ен, [...] От словеснон храни - пьшности, Чтоб не вышла как я - химницея, Чернокнижницея"):. Более того, опознаниє в былине ухе прочно оформившегося своего и позволило Цветаевон на свободное с ней обрамение, а не пассивное следование за ее схемон.

5. Героиня поэмы безьмянна. Ради удобства здесь условно она названа Ведуньея, что, с одноя стороны, не противоречит деиствительноя семантике этого персонажа поэмы, а с другои - позволяет отличить ее от аналогичных персонажей (например, Колдуньи) иньх произведенин Цветаевоя. Именем же Сводня обозначается нами так хе безымянная носительница речи первон части поэмы (стихов 1-56), что в свою очередь вытекает из ее функцин-задачи 'завлечь Героя под полог Ведунья'. В дальнеишем окакется, что это один и тот же персонах, поэтому иногда здесь употребляется удвоенное имя: Сводня-Ведунья.

6. Как и героиня, героя поэмы тоже безымянен. Логичнее всего было бы назвать его молодием, но это ввело бы путаницу в Связи с поэмоя "Молодец". Поэтому здесь употребляется наименование героя С прописноп буквы (в частности в отличне от "героя" как описательного литературоведческого термина).

7. Текст поэм "Переулочки" цитируется в настояшея работе по СиП II, 174-183. Все стихи поэмы пронумерованы нами сплошнов нумерациея; цифры привлекаются вместо дополнительного цитирования.

8. В отличие от нарративноя речи, которая то более то менее откровенно адресуется к слушателю-читателю, речь Сводни направлена вовнутрь мира поэмы и этим самым преврамает читателя в постороннего, третьего, стоямего вне коммуникационного процесса. В этих условиях какая-либо адресованность к читателю (попытка включить его в протекающия процесс общения) долхна привести к раздвоению говорящего или превратить читателя в участника события, т.е. навязать ему статус еме одного персонаха. Но ни одно, ни другое в поэме не имеет места. Факт хе, что со стиха 73, т.е. с момента перехода на колдовскон сеан, Герон липен статуса субъекта речи и его прнсутствие угашыается только по речи Ведуньи, и Факт, что иногда появляются стихи нсходящие как бы от внешнего субъекта, соблазнительно толковать не как нарративность, а как разыгрывание, свонственное исполнению обрядных текстов с его зыбкостью границ мехду носителем текста н его исполнителем. Так, в частности, могла бы здесь объяснятся контаминация Цветаевского Я с Я Ведуньи, а в более глубокоя семантическоя структуре - Марины (т.е. самон ЦветаевоЯ) и Маринки, т.е. былинноя колдуньи. Еме иначе: не Цветаева моделирует Маринку, а Маринка Цветаеву, не автор создает текст, а текст становнтся автором автора. Cp. по поводу этон проблемы в моен статье: "Из заметок по поэтике цветаeво" ". In: Marina Cvetaeva. Studien und Materialien, Wiener Slawistischer Almanach, Sonderband 3, Wien 1981, 42, См. та-

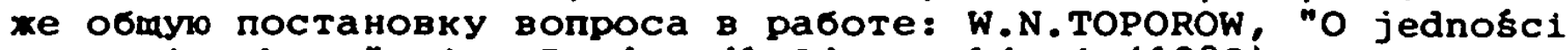
poety 1 tekstu", in: Pamietnik Literacki, 4 (1980). 
9. Н.А.ПЕТровСкия, Словаро русских личких имен, Москва 1966, 118. Построение текста на семантике имени собственного (как своего - Марина, - так и чухих), причем часто без упоминания этого имени, - явление для Цветаевоя типичное. Кроме прямеров в примечании 4 см. еме "небо катило сугробы..." (10 февраля 1922; СиП II, 160), целиком построенное на семантических и формальных свонствах имени Ильи Эренбурга, или "Имя твое - птица В руке..." (15 апреля 1916; СиП I, 227), которое расшифровьвается только при знании не упомянутого имени Блокъ (анализ этого стихотворения см. в моен статье: "Некоторые вопросы теории поэтического языка. Яэык как моделируюмая система - Поэтический язык Цветаевон", в: Semiotyka i struktura tekstu, Warszawa 1973). Попутно целесообразно обратить внимание на устоячивость в Цветаевскоя поэтической системе категория 'нигде' как идеального локуса и идеальнои формы бытия. Ср. хотя бы в "Бессонница! Друг мон!..." (ман 1921; Сип II, 105), где "мир без вести пропал. - В нигде Затопленные берега. - Пея, ласточка моя! [...] Ты море пьеш, ты зори пьешь" означает для Я выход в запредельное, нетварное, идеальное состояние, или в "Сивилла - младенцу" (17 мая 1923; СиП III, 25), где 'нигде' та же дотварная сфера духа: "Рождение - паденье в дни. С заоблачных нигдешних скал, Младенец моя, Как низко пал! Ты духом был, ты прахом стал". Этот контекст, думается, лишния раз управомочивает нас этимологизировать название "Игнатьевские" и видеть в нем отсылку на 'нетварны' ('не родившияся') уровень Цветаевского мироздания .

10. Ср. у Неклюдова: "Отделение души от тела есть смерть. Но: отделение души от тела и изолированное хранение ее есть бессмертие. Таков, например, Комен Бессмертны русскон сказки, 'омерт' которого, т.е. на самом деле 'жизнь', или точнее, 'внешняя душа' надежно спрятана от посторонних глаз в недоступном месте. $[\ldots]$

О том же свидетельствует скрывание 'внешнен дупи' в центре предметов, концентрически вложенных один в другоя [...]; ср. 'смерть Кощея' в русскон сказке - в игле, игла в янце, яицо в утке, утка в заице и т. П. [...] ступенчатое сукивание угла зрения и постепенное уменьшение кахдого последуюмего предмета долхно в пределе дать не 'увеличение четкости', $a$, напротив, полное 'размывание' объемности, переход от 'видимого' к 'невидимому', т.е. в конечном счете эФФект 'дематериализация'" . С.ю.НЕКЛюдОВ, "Душа убиваемая и мстящая", в: Труди по зиаковим системам, т. VII, Тарту 1975, 66-67.

11. По словам Френденберг, "'моляиннся' угрохает бохеству, потому что угроза выполняет в религиознон молитве адоративную Функцию. Самая 'мольба' очень своеобразна в древности. Человек называя и восхваляя божество, всегда 'просит' его, 'умоляет' : дая, пошли, исполни. Он неизменно напоминает ему, что сам он давал, исполнял, посылал" - О.М.ФРЕЯДЕНБЕРГ, Миф и литература древкости, Москва 1978, 60 и ср. комментарин на 546 , а также развитие тема на 119-120, 128. О явления наказывания икон в русскор народноя культуре См.: Б.А.УСПЕнСКиЯ, Филологические разискания ө области славянских древкостей (Реликти язичества ө восточкославянском хулоте Николая Мирликийского), Москва 1982, 90 , 114-117 и 182-186. 
12. "Первоначально слово д у 6 заключало в себе обмее понятие дерева, что до сих пор слинтся в производных д у б и на, д у бинка, д у б е ц - палка; точно также греч. броқ - quercus соответствует санскр. dra - arbor, слав. д p t $\mathrm{B}$, , krmp. deru, армор. dérô. Впоследствия эти названия (д у б, боО̆) слились $c$ понятием самого крепкого и долговечного дерева, которое и было посвямено богу-громовнику. У сербов дуб называется $\Gamma \mathrm{p} M, \Gamma \mathrm{p}$, $\mathrm{B}$ (дубовы лес - $\Gamma \mathrm{p}$ м к ), что без сомнения указыает на блихаршее отноление его к Перуну и небесным $\Gamma$ р $о$ м а м. Старинные грамоты, определяя по этому священному дереву гранишы родовьх владения, называли его $\Pi$ е $р$ у н О в м М. Согласно с демоническим представлением туч, С которым постоянно срахается праведны Перун, сербы дают дубу эпитет в $\mathrm{p}$ a $\mathrm{x}$ e $\Gamma$ o (в p a $r$ - чорт, CM. I, 740): "да је сваки

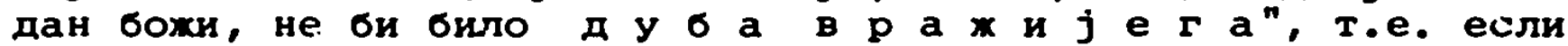
бы всякия день - "бохичь" (Рохдество), не было бы дуба вракьего; все бы дубы на бадняки были посечены". А.АФАНАСЬЕВ, Позтические воззрекия слявян на природу. Опат сравкителокого изучекия славянских предакий и веровакий, в связи с мифическими сказакиями других родственких мародов. том второн, Москва 1868, 298-299. В дальнеңшем ссылки на труд Афанасьева даются сокраменно: на Том первыр (Москва 1865) как Афанасьев I, на Том второи как АФанасьев II, на Том третин (Москва 1869) как Афанасьев III. Связь этон героини, являющея собоя, как окахется, демоническое начало, С дубом оправдывается народньми поверьями, по которьм демоны-противники Бога Грозы во избежание гибели прячутся во время грозы именно под дубом как наиболее безопасньм, с одно стороны, и с друго - статусом дуба как мирового дерева, в корнях которого локализовано подземное царство. См., в частности, детальны анализ этих мотивов в: В.В.ИВАноВ, В.Н. топоРОВ, Нсследования в области славянских древкостей, Москва $1974,7,12,22,78,88$.

13. О связанности как признаке смерти См.: ФРЕЯДЕнБЕРГ, ук. сои., 500. Роль завязывания, а при родах - развязывания, на ряде примеров, в том числе и гусскон обрядности, детально проаналиэирована в: L.STOMMA, Szohce rodzi sie 13 grudnia, Warszawa 1981, 24-44. У Щветаевоя этот акт встречается повсеместно. Ср. один из наиболее очевидных примеров - цикл "Бессонница", куда вошли стихотворения 1916 года. В первом ("обвела мне глаза кольцом..." - СиП I, 224-225) говорится:

Обвела мне глаза кольцом

Теневьм - бессонница.

Оплела мне глаза бессонница

теневым венцом-

[...]

Пару моих колец

носи, бледноликая.

Kликала - и накликала

Теневои венец.

[... ]

Ляхешь, легка лицом.

Люди поклонятся,

Буди тебе чтецом

Я, бессонница.

спи, успокоена, 
$[\ldots]$

Чтобы спалось - легче

Буду тебе - певчим:

[...]

Вот и выпущены из рук -

Твои рученьки.

Вот ты и отмучилась,

милая мученица.

СОН - Свят.

BCe - спят.

Венец - снят.

Но земная смерть, по системе Цветаевоя, вовсе не смерть, а раскрепомение и выход в Хизнь, в вечное бытие, на что и укаэывает финальное "Венец - снят" и что получает свое развитие в очередных текстах цикла. Во втором ("Руки любло..." - СиП I, 231) - намечается выход вовне: из 'дома', но и из собственного 'телесно-личностного узилища' -

Руки люблю

целовать и люблю

имена раздавать

и еме - раскрывать

Двери

- Настехь! - в темную ночь!

Выход этот осумествляется в третьем тексте "В огромном городе моем - ночь..." - (СиП I, 238) и ослохняется освобохдением от всех возмохных земньх "уз":

В огромном городе моем - ночь.

из дома сонного иду - прочь.

[...]

Ах, нынче ветру до зари - дуть

Сквозь стенки тонкие груди - в грудъ.

•

И шаг вот этот - никому вслед,

и тень вот эта, а меня - нет.

Огни, как нити золотых бус,

Ночного листика во рту - вкус.

Освободите от дневных уз,

Друзья, понмите, что я вам - снюсь.

И в пятом тексте ("Нынче я гость небесның..." - СиП I,239) наконец выход во внеземное пространство ("нынче я гость небесны В стране твоеи. Я видела бессонницу леса и сон полея."), откуда начинается Цветаевское восхождение-спуск к подлинному космическому бытию. (Ср. более подробныя, но с иноя точки зрения, разбор этого цикла в моеи статье:" 'Бессонница' Марины Цветаевой. Опыт анализа цикла", в: Зборкик за Славистику, т. 15, Нови Сад, 1978).

Фольклорная волшебная науза имеет вид ремнен, поясов, колец, обручея, одежд и т. n. атрибутов, которые при одевании преврамают героя в неопознаваемые сушества (в волков, гусея, ле-

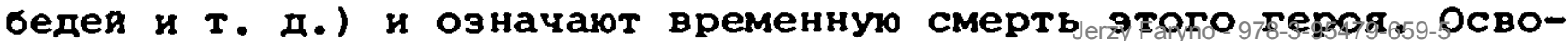


бодить-воскресить героя мохно только сорвав с него его наузу. См. об этом в: Афанасоев III, 551-556. Учет этон семантики и традиции позволяет понять смысл далеко не редкого у Цветаевон атрибутирования своих героев запястьямн кольцами, поясаки, шнуровками, ожерельями, рыцарскими доспехами (как в случае царь-Девицы), бусами, одеждами (в противоположность ризам и пламам). Все эти атрибуты укаэывают у цветаево н на 'обреченность' героя, на его неполноценность, на причастность к сковываюиим и потому смертельным и унербньм Формам земного бытия. Их же срывание, хотя и знаменует земную, так сказать - биологическую, смерть, ведет к воскрешению подлиннои сущности и знаменует приобщение к вечнор Кизни (см. В частности "Не здесь, где связано..." - СиП II, 161-162). Эта же традиция позволяет понять смысл Цветаевского пристрастия к 'оборотничеству' как отдельных персонажея (хотя бы Ведуньи в разбираемых "Переулочках"), так и Цветаевского Я, особенно если взять во внимание весь корпус ее лирических текстов сразу. Некоторые наблюдения по этому поводу См. в моен статье: "Из заметок по поэтике Цветаевоя", ук. соч., 43-45 (где речь о мене лирическим я цветаевоя имен и телесньх обликов).

14. Ср. почти буквальное наличие этод образности в написаннам за несколько недель до "Переулочков" цикле "Сугробы", особенно в открывахоем его (Сип II, 160):

Небо катило сугробы

Валом в полночную муть.

Как из едино утробы -

небо - и глыбы - и грудь.

Над пустотоя переулка,

По сталактитам пемер

Как раскатилося гулко

Вашего имени Эр!

[... ]

Грому небесному тесно!

- Эр! - леопардова пасть.

Появление 'города' ("переулка") и раскатов 'грома' объясняется семантизациен имени илья Эренбург, которому этот цикл посвямен. Но 'снежная' тема ("сугробв") мотивируется иначе - годовьм обрядным циклом: "Сугробы" пишутся в феврале, в котором празднуются проводы эимы-смерти, называемые Масляницен (кстати, центральным текстом цикла - шестьм по счету, а всего их в цикле 11 - и есть стихотворение "Масляница широка! Масляницу за бока! Масляница! Увальница! Провожаяте масляницу!" , СиП II, 164-167). Самое любопьтное, однако, то, что эти обе семантики совпадают друг с другом. Ср. у Афанасьева (Афакасоев III, 696-697): "В великорусских губерниях торхество Кивы и гибель Мораны чествуется возжением праздничных огнең на масляницу. Так как неделя эта сходится с началом весны и так как следующи за нея пост должен был вызывать особенно строгие церковные запрещения, направленные против языческого культа, то неудивительно, что по всей Европе масляница (карнавал) получила эначение самого разгульного празднества, посвященного проводам Зимы и встречи Лета (Изиды, Фреи, Гольды=Лады), рассыпание по земле медрые дары плодородия (СМ. I, 554-6), у нас воэили

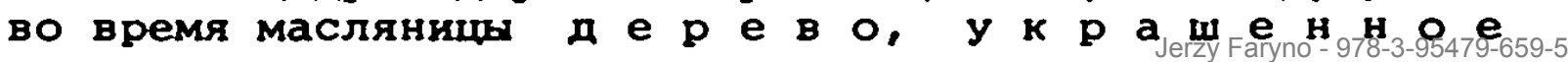




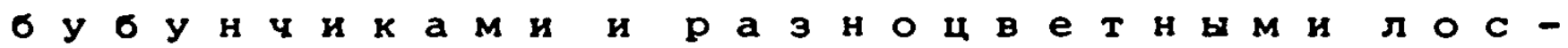

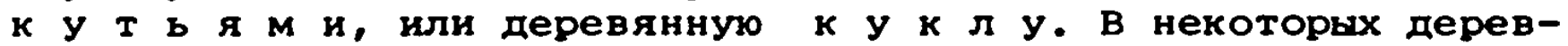
нях н доныне возят $п$ в я н

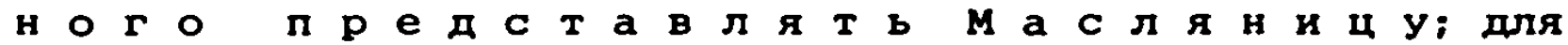
этого запрягают в сани или повозку лошаден десять и более

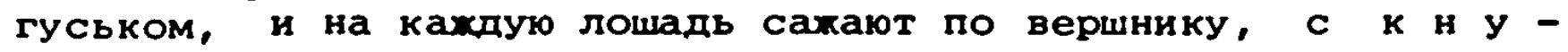
т $о$ м или м е т л о 10 в руках: везде, где только мохно, привешивант маленькие к м у ш к н; сани нли повозку убирают в е н и ка м и, мужику-

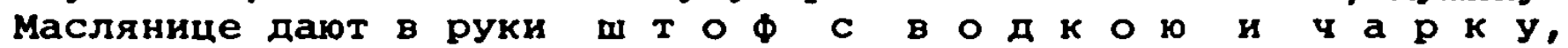
и сверх того ставят подле него 6 о ч е н о к

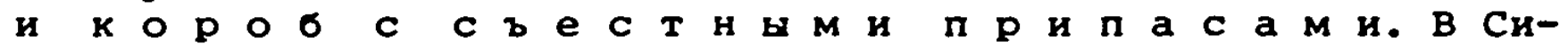
бири устраивают на нескольких санях $k$ o $p$ a 6 л в, на котором

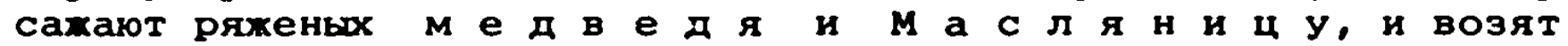
по улицам, в сопроводдения песенников. Дерево, корабль и медведв - все это эмблемы весеннеи природы и ее творческих, плодоносньх сил; звуки колокольчиков и бубенчиков - знамения грозовод музики, метла, веник и кнут - вихреи н молнин, пиво х внно - всеохнвляюиего дождя. В таком обрядовом поезде празднуется прншествне (возврат) благодатноя Весны. Наряду с зтим совершаются и другие обряшы, указываюшие на борьбу Весны с Зимою и порахение последнен. В разных губернях в субботу сырноя недели строят на реках, прудах и в полях с н $е x$ н $а$

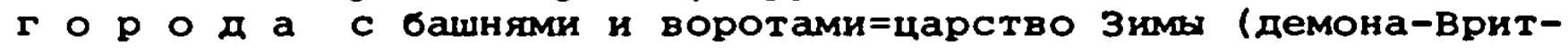
ры), долхенствуюшее пасть под ударамн Перуна: участвующне в

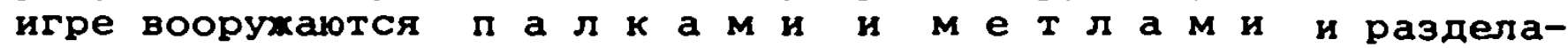
ются на две стороны: одна занимает город, а другая нападает на него, и после упорнои, более или менее продолинтельнов схватки, врылется в ворота и разрушает укрепления; воеводу взятого с боя и разрушенного города в старнну $к$ у $\Pi$ a $\pi$ н в $\Omega$ p 0 р у 6 и. Вечером в воскресенье (последнй день мас-

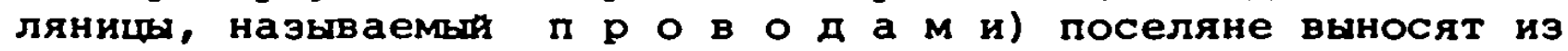
своих дворов по снопу соломы, и слохивин ее на окраине деревни, сокигают при радостных кликах и песнях собравшегося народа, - каковоя обряд называется с л я н и ц н. Иногда пуки соломы навязывают на шесты, расставляот по дороге и палят после солнечного заката, а нногда заменяют их дегтярньми бочками. Сумествует еме обынар с о $и$ и -

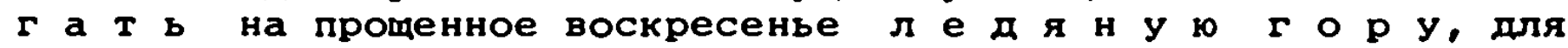
чего собиракт по дворам хворост, щепки, худые кадки, складывают все это на ледяно горе, и затем разводят костер, служамия символическим знамениемвесеннего солнца, яркие лучи которого растапливают снехные гокровы зимы".

15. 'Равноранговость', 'равносуцность' Цветаевских героев или ее Я и Ты - исключительно устоичивое требование ее поэтической снстемы, выполняемое часто даже вопреки бытовому правдоподобир. так, например, в поэме "царь-девица" по этому закону (или, может быть, даже с целью подчеркнуть его непреложность) она пренебрегает возрастноя диспропорциеи мехду 'невестои' , лоп Царь-девицеи, и 'женихом', младенцем-царевичем (CиП IV, 30: "над ухом аукает: 'жених мон! - Aу!' На грудке баюкает Добьуу свою. 'Спи, копна моя льняная, Одуванчнк на стебле! Будет грудь моя стальная Колыбелочкон тебе. Сна тебя я не лиwaw, Алма3, яхонт мон! Оттого что я большая, А ты - махонькон! [...]'"). Cр. eme 'программные' в этом отношении стихотворения "Есть рифма в мире сём..." (30-го нюня 1924; CиП III, 107) и "В мире, где всяк..." ( 3 нюаля 1924: 
цикла "Двое". В таком контексте естественно ожидать, что сюжет противоборства мохет тут получить вид борьбы за 'равносунность" партнера.

16. Ср. интерпретацию "столба" из "Поэмы конца" у Ревзиноя: "В первоя части 'Поэмы конца', до появления моста двахшы появляется столб - в самых первых строчках, где подчеркивается его символическое значение для дальнеңшего хода событин ("В небе, ржавее жести, Перст столба. Встал на назначенном месте, Как судьба") и после разговора в кафе, на наберехнон, где со столбом также связана тема разрыва ("Столб. Отчего бы лбом не стукнуться В кровь? В дребезги бы, а не в кровь!"). Мост, таким образом, может, по-видимому, естественно рассматриваться как поваленны столб (ср. загадку, приводимую В.В.Ивановьм и В.Н.Топоровьм: Когда свет зародился, тогда дуб повалился, и теперь лехит)", где "столб" понимается автором как соответствие "дерева", которое в свою очередь читается в терминах мирового дерева и дороги, соединяюмеи небо, земтю и подземное царство. О.Г.РЕВзКнА, "Из наблюдения над семантическон структурон 'Поэмы конца' М.Цветаевоп", в: Труди по змаковим системам, T.IX, Тарту 1977, 76. Небезынтересно отметить, что "Брюс" в стихотворении "Небо катило сугробы..." (см. примеч. 14) предполагает также и прочтение 'брус', т.е. бревно, дерево. тогда - в свете вьлеизлохенноя символики - не неохиданно упомннание "наклонного пути" и "двух женщин", которже означали бы два противополохных, соединяемых путем-деревом, локуса мироздания: небо и преисподнюю. Ср. очередных две строфы из этого стихотворения:

\author{
Под эановескою сонноя \\ Не истолкует Вам Брюс: \\ Женшины - две - и наклонны \\ Путь в сновиденную Русь. \\ Грому небесному тесно! \\ - Эр! - леопардова пасть. \\ (Женщины - две - и отвесньд \\ Путь в сновиденную страсть...)
}

\begin{abstract}
"Брюс"-'брус' мохет тут толковаться также и как промехуточная, земная, бытовая, косная форма жизни в отличие от потусторонних Форм Кизни и Смерти ("двух хенщин").
\end{abstract}

17. "Окошка" могут тут означать 'просветы' мировод лестницы. Кроме того в народно культуре окно являет собо проем в потусторонния мир и обнарухивает связь С водон и С противником Бога Грозы. См.: В.В.иВАнОВ, В.н.ТОПОРОВ, Нсследования в области славянских древностей, Москва 1974, 115, 125-126, 130, 171, 209; там хе, на 170-172 разбираются и некоторые мотивы былин - маринке, т.е. "Илья ездил с Добрынею" и "Три года Добрынюшка стольничал", особенно связь Марины с мифологическим образом змея, а богатырен - с образом Громоверхиа-Змееборца.

18. О грозе как рыбнон ловле см.: Афакасоев II, 154-155. Не исключено также, что тут имеется ввиду выдергивание ("не клюнололь?" предполагает удочку) наверх рыбы-души из ее 'среды', которую расценивает Цветаева как ограничиваюиее, косное начало. Cр. такоя именно поворот 'рыбноя' темы несколько лет спустя в "Поэме воздуха" (весна 1927; СиП IV, 282, 285). 
19. Ср. аналогичное превращение в воду царицы-Мачехи в "царь-Девице" ( 1 иоля - 4 сентября 1920 по Ст. Ст.: СиП IV, 63, 64):

$$
\begin{aligned}
& \text { Та - рябь рябит, } \\
& \text { Плечьми дрожит. } \\
& \text { [...] } \\
& \text { Та - пруд-река, } \\
& \text { колеблет бока. } \\
& \text { [...] }
\end{aligned}
$$

Не змеины шип - шелков рваных скрип,

то не плетка-хлыст - шелков рваных свист,

то на всем плясу - шелка̀ ручьями вниз!

Из нефольклорных произведенин См. триптих "Магдалина" (26 и 31 августа 1923; СиП III, 94-96), где Я-Магдалина постепенно преврамается в сплоннон акватическия поток. Эти преврамения в воду несомненно состносятся непосредственно с автомоделированием ЦветаевоЯ по значению собственного имени (см. гримеч. 4) и поэтому получают статус более сунностно формы бытия. Одновременно необходимо помнить, что по цветаевов "Твердое тело есть мертвое тело" (как говориться в "Поэме воздуха" - СиП IV, 281) и что 'вода' (и предваряюине ее 'ткани', 'волосы' или 'плоть') - элемент гораздо более 'живоя', что прекрасно согласуется и с мифлогическим статусом вошы как жизнепорохдающего начала. Добавим еме, что Цветаевские 'воды' всегда носят запредельнын характер, отчего для поверхностных, земных Форм бытия они губительны.

20. Так сливаются тут воедино все три субъекта речи, о чем ухе говорилось в примеч. 8.

21. Ср. стихотворение "наяда" (1 августа 1928; СиП III, 139-141). где речь о нетреадотыс обособленности и этим самm нетождественности самому себе, т.е. нетварнои своеи сумности.

22. См.: Aфанасоев I, 237-238.

23. Ср. цитированное в примеч. 4 стихотворение "Колдунья" 1910 года: "я- Эва, и страсти мои велики: Вся жизнь моя страстная дрохь!" Попутно заметим, что в мифологических представлениях дрожь, трясенье, трепет соотносятся с потусторонним миром, $C$ провидческим даром (также соотнесенным с царством смерти) и, кроме того, с громом и грозон. См.: В.Н.топоров, "Mочбаl 'MУЗЫ': соображения об имени и предыстория образа (К оценке Фракияского вклада), в: Славякское и балканское язикозкание. Ант тичкая балкаяистика и сравкителокая грамматика, Москва 1977, $51-52,70$ и др.

24. Ср. в "Бессоннице" в стихотворения четвертом (19 июля 1916; СиП I. 239):

После бессонно ночи слабеет тело, Мильм становится и не свонм, - ничьим, В медленных жилах еще занывают стрелы, и улыбаешься людям, как серафим.

[...]

Нежно светлеют губы, и тень золоче

Возле запавших глаз. Это ночь замгла

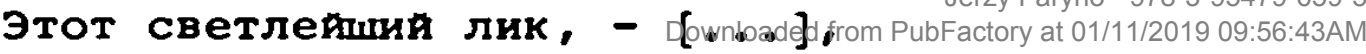


после чего следует ухе упоминавшееся стихотворение (в примеч. 13; "нынче я гость небесны...", а завершается цикл приобмением Я к морю и зорям, т.е. Бессоннице=вечности=небытию: "Ты море пьешь, Ты зори пьешь. [...] А если спросят (научу!) Что, дескать, щечия не свежи, - С Бессонницеи кучу - скахи С Бессонницей кучу..." ("Бессонница! Друг мод!..." - май 1921; СиП II, 104). Или в стихотворении "не краскоя, не кистью!... (8-9 октября 1922; СиП III, 32-33) из цикла "Деревья: "Свет, смерти блахеннее И - обрывается связь. [...] ...Уже и не светом: Каким-то свеченьем светясь... Не в этом, не в этом ли - и обрывается связь". По признаку 'света' предел эволюции и идеальное состояние мира и Я - стать (отождествиться со) свеченьем.

25. О молние- и громоносном характере птиц (голубя, ворона, сокола, орла, дятла, аяста и др.), о их связи с Перуном и, соответственно, С грозовьми тучами См.: Афанасоев I, 488-513. Cp. в седьмом стихотворенин "Сугробов" (25 февраля 1922; СиП II, 167): "Наворковала, Наворокила. [...] Руды-пожары, Бури-ворохбы - Поверх державна Воркота Бохья", где "Воркот Бсжия", несомненно, - весенния гром (о чем свидетельствует как его соотнесенность с "громом небесным" в первом стихотворении, см. примеч. 14, так и блиханти контекст пения весенних птиц - кукушки и соловья) перекликается С голубиньм 'воркованьем' в "Наворковала". Другоя семантическия пласт еще сильнее связывает "Воркот" =громовон Логос с Богом=духом-Голубем, на что в свою очередь позволяет открывающая цикл ассоциация имени илья с громовержцем ильен-пророком.

26. "Наличие глаза еще не обозначает наличие эрения (слепой глаз или вообще особий глаз) а его отсутствие - отсутствие зрения (ср. внутреннее зрение или вообме особое зрение). К этому присоединяется относительность слепоты: она может быть временной (здесь сумественен не столько мотив лишения глаз и их возврамения, сколько мотив видения В отмеченны момент, см. Вия и аналогичные примеры): она может зависеть от особых условия, в частности от субъекта и объекта вйдения. Видимое для одного может быть кевидимим пля другого, - в этом проявляется непривативность оппозиции. Слепота принаплехит миру мертвых, более того мертвые и хивые не видят друг друга, и одним из условин обоюдного видения является с м о $\mathrm{T}$ e н и $е$ д $\mathrm{p}$ у $r$ д $\mathrm{p}$ $\Gamma$ у в $\Gamma$ л а 3 a (причина гибели Хомы Брута, посмотревшего на Вия; ср. на бытовом уровне избегание взгляда, чтобы остаться незамеченным и обратны способ, - чтобы привлечь внимание)". Т.В.Цивъян, "Категория видимого/невидимого: балканские маргинали", в: ваZсапіса, Лингвистические исследовакия, москва 1979, 201-2.

27. Ср.: "С цветом и веткою Перуна соединялась идея не только возрохдения природы, но и всеобщего ее омертвения . Молния - орудне смертоносное; [...] Смерть же на древне-поэтическом языке есть непробудны С О н; два эти понятия: и смерть и сон в миФических сказаниях индоевропенских народов слукили для обозначения зи мы и н о ч и. Весною, разбивая облачные горы, бог-громовник творил земное плодородие; но осень, предшественница бесплодноя, всеоцепеняющея зимы, также сопровохдается дождямя и грозами, и как в апреле и мае Перун представлялся отпирающи светлое небо и даруюиим миру медрые благодеяния, так тем же золотьм ключом (молниеи) он, в качестве предвядителя 
демонических сил (о Перуне-царе адских подземелия см. гл. XXII), запирал небо на продолхительное время зимы. отскда также молния, которая весною воскрешает природу к жизни, позднею осенью погрухает ее в смертны сон. Чехи различают два громовых удара: один - огневон, возжигаюини пламя (=хизнь), другон - ледянон, погломаюиия пламя. Если взять во внимание, что В сказаниях О битвах Индры С Вритрою они представляются срахаюшимися $М \circ л$ н и но, что леденяшие природу удары грома суть удары, наноснмы демоном [не отсюда ли возникли сказания, что богатырь долхен побивать великанов, бабу-ягу и нечистую силу О д н и м У д а -

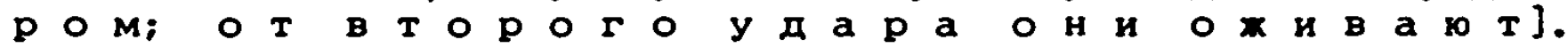
Вот основания, руководясь которьми - Фантазия приписала Перунову цвету или пруту могучее свонство погрухать все, на что только направлены его удары, в долговременны непробудны сон. Подобное своЯство приписьвалось и гуслям-самогудам (=грозовоя песне, см. I, 332-3), и $M$ e $P$ т $O$ в $о$ д $е$ осенних ливнен. Дохдь, как мы знаем, постоянно уподоблялся опьяняющим напиткам, которые с одноң стороны возбукдают человека к дикому разгулу, к неумеренному заявлению своих сил, а с другои отнимают у него сознание и погрухают в усыление. Такому усыплению подвергается и вся природа - вслед за теми шумньми оргиями, какие заводят облачные духи и жены во время бурнои, дождливон осени. ... В русских сказках, вместе с "моложавьми яблоками", дающими молодость, здравие и самую жизнь (= то же, что $\approx$ и в а я в $о$ д $а$, см. 309-317), упоминаются и яблоки волшебные: кто съест такое яблочко, то впадет в непробуднын сон". Афанасоев II, 419-420.

28. Ср. примеч. 13. На одном уровне "яхонты" соотносятся, несомненно с Фольклорньми подземньми кладами, которые символизируют похименые противником Громовержца живые, творческие силы природы - солнечны свет и молнин; См.: Aфанасоев II, 361. На ином уровне особенно в контексте обнаруживающеися несколько позже (в стихах 93-100) змеиноя природы Ведуньи ("ящеров хвост", "гадюченькон"), предваряющен 'слюны'-"рубля" (22: "Плюнет рублем подарит") и промежуточноя позиции меж "яблочками" и "шахматами", т.е. меж носителямы запретных и слохных знания, "яхонты" могут чнтаться как символ 'змеиноя мудрости', которая и в фольклоре и в эмблематике (на фольклоре основаннои) получает вид хранямеяся в пасти змеи драгоцнности-камня. О связи слюны с дождем, живои водон, вемим словом и змеями см.: Афакасоев I, 397-399 и след.: "чтобы пастух [одной из разбираемых сказок - E.Ф.] мог сльшать=понимать говор животных, всезнающия царь-змеи плюет ему в рот, т.е. передает этот говор из уст в уста. Слюна (=дождь) здесь символ самого слова (=говора мифических животных, вецаюмих в грозе). Поэтому в наших сказках слюнам придан дар слова: собираясь в бегство, сказочные герои и героини плюют в углах покидаемо ими комнаты, и эти слоны отвечают, вместо беглецов, на предлагаемые вопросы и тем замедляют погоню" (399).

29. В этом контексте Цветаевския ответ Иваску на вопрос о народности ее фольклорных поэм, в том числе и "Переулочков", отнюдь не звучит заносчиво: "Русская стихия во мне обескровлена? обездушена?... 'Народныя элемент'? Я сама народ, и никакого народа кроме себя - не знала, дахе русскоя няни у меня не было... - и в русскон деревке я не жила јёу никөзда, 
природе - да. [...] Эту вещь ["Переулочки" - Е.Ф.] из өсех моих (Молодца тогда еме не было) больше всего любили в Россия, ее понимали, т.е. от нее обмирали - все, кахпы полуграмотны курсант" (СиП II, 380-381).

30. См.: В.н.ТОПОРОВ, "Семантика мифологических представления о грибах", в: Balcanica, op. cit.: "[...] тахматы представляли собо более позднюю и слохную ступень развития, на которои

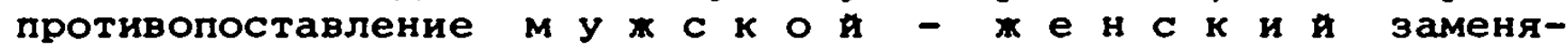
ется более абстрактным $\sigma$ е л

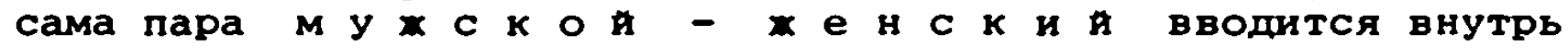
элемента белы и внутрь элемента черны. Следует при этом помнить, что некогда отношение мехду всемн этими элементами выглядело иначе (напр., м у ж С к $\circ$ и 6 е лы ки и ч $е$ р н ы . ... Подобная указанная интерпретация фигур обеих сторон заставляет предполагать, что и вся первоначальная схема игр типа шашек или шахмат (др.-инд. caturahga, собств. "четыре угла", ср. ниже о роли числа ч е т ы ре,

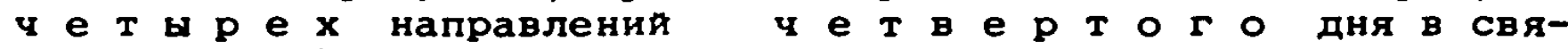
зи с грибами) могла представлять собоя что-то вроде универсальной композиции типа мирового дерева с акцентом на социальньх отночениях. Характерная терминология игры ('бить', 'поражать', 'есть', 'брать') опосредствованно воспроизводит названия основных предикатов в мифе о происхохдении грибов или шире - культурнх растени, см. нике. Наконец, следует отметить, что 'бить', 'порахать', 'ударять', 'брать', 'есть', (как и 'палка', 'кия' и т. П.) - все это слова, употребляюмиеся в отчетливо эротическом смысле. [...] учитывая все это, приходится видеть в играх типа шашек (по кранне мере, для определенного периода) если не сам ритуал, то его имитацию в миниатюре, сопоставимую с другими архаичными ритуалами, в которых идет игра на амбивалентности понятин жизни и смерти, на неитрализация этого противопоставления" (с. 247-248). Согласно этоя интерпретации Цветаевские "шахматы" содержали бы в себе и 'эротическия соблазн', аналогичның эротическому соблазну "яблочек": и подразумевали бы нентрализацию оппозиции 'хизньсмерть', тем более естественную, что по цветаево с смерть есть вьход в истинную Жизнь, а привычные формы жизни если и не являот собон смерть, то понимаются как неистинная жизнь.

31. Афанасьев III, 81.

32. Афанасоев III, 88. Аналогичны перечень лихорадок рассматривает и В.н.топоров в ухе цит. работе "мочбац 'Музы' .. (см. примеч. 23) и показывает их связь с музами и с мифологическими представлениями, предшествусмими музам, в частности - с мышами как детьми Бога-Громовержиа и Матери-земли и т. П. (см. 44-47, 50-53, 69-75 и след.). В связи С этим автонменование Цветаевскоя Ведуньи "Лихоманочкон" и "Знобъ-Тумановноя" открывает возможность видеть в нея также и определенное родство с музоя, а осторохнее - с поэтическои темоя (ср. насьменность поэмы, о чем позхе, мотивамн слова и музыки - самы яркия пример: стихи 135-136 "џепоточки-мон-смеюнчики, Сладкослюнчаты, сладкострунчаты!", особенно выразительные, если учесть, что Цветаевское лирическое Я неоднократно именует себя "строительницея струн"; как, например, в написанном 30 июня 1923 года - СиП III, 84 - стихотворении "Строительница струн - приструню и эту...", где одновременно упоминается и "гром", и

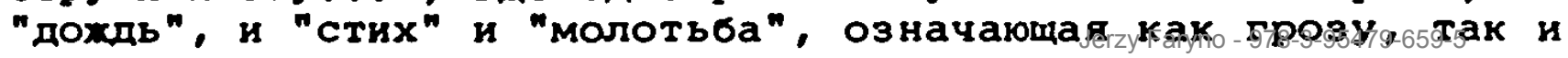


библенскую хатву=сбор душ). Если в "Лихоманочке" акцентировать смғсл 'дрохи', то ее связь с поэтическим началом почти гольм галэом видно в "Посвямении" "Поэмы горы" (1 января 1 Февраля 1924; Сип IV, 161):

\author{
Вздрогнешь - и горы с плеч, \\ и душа - ropè. \\ Дая мне о го̆pe спеть: \\ O moet rope! \\ Чернор ни днесь, ни впредь \\ не заткну дыры. \\ дар мне о горе спеть \\ Ha верху горы.
}

Тут 'дрохь' однозначно соотнесена с 'воспарением души', C вьходом на запредельны уровень ("горы с плеч" $\rightarrow$ "горе́" ="вверх" $\rightarrow$ "На верху горы"), и с 'песнопенным даром'. Более широко, но с другон точки эрения, тема 'поэтического' в "Поэме горы" прослеживается в статье: A.M.KROTH, "Toward a New Perspective on Marina Tsvetaeva's Poetic World". in: Marina Cvetaeva. Studien und Materialien, in: Wiener Slawistischer Almanach, Sonderband 3, Wien 1981, 9-11. Попутно любопнтно отметить, что автор статьи почти вплотную подводит нас к проблеме 'текст как автор автора' у цветаевод (См. примеч. 8).

33. Современные исследователи выводят имя невея, навь, навье (польск. Nya, Nyja, Nija) из корня ny- встреча火щегося в nyd (='ныть'), которое означает 'никнуть', 'поникать', 'сникать', т.e. 'исчезать', 'умирать'. A.GIEYSzTó, Mitologia Szowian. Warszawa 1982, 149-150. Позже такоя именно смысл будет активизирован в неотьемлемом от Ведуньи 'образе поведения" "льнуть", подразумеваюмем динамику истончения плоти или усклие преодоления разъединяюме плоти до полного ее исчезновения (о чем нихе) .

34. "Мороку" или "морок" в патрониме "тумановна" естественно вит деть потому, что в стихах 315-318 именно так описьвает себя Ведунья: "но через весь морок - взгляни! - Лестницею - Ризы мои!" В метереологическом смысле это, конечно, синонимы:

"M ò $0 k$ (

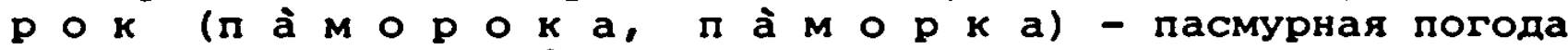
с мелким дождем, м $о р \circ$ ч

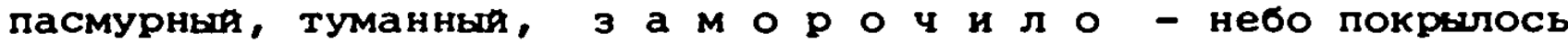
туманами или тучамн [...]. Слово м e $p$ e м и т в с $я$ значит: и темнеть, и плохо, слабо видеть: 'тебе видно так померешилось!" (Афанасьев $I, 166)$. В мифо-поетнческом отнашения "морок" вводит связь со смертью и зльми духами: "M $p$ a $k$

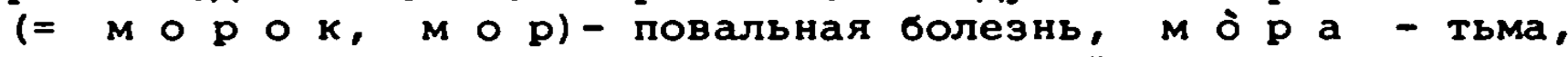
м а $\mathrm{p}$ a $\mathrm{T}$, $\mathrm{M}$ a $\mathrm{p}$ - носилки для поконников, $\mathrm{M}$ а $\mathrm{p}$ призрак, нечисты дух, $м$ ѐ $p k$ или $M$ ѐ $p e T$ - чорт,

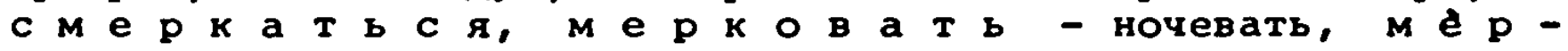

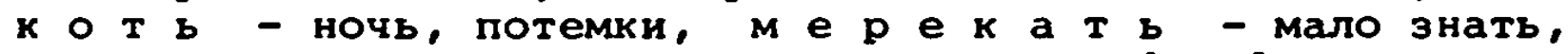
собственно: не распознавать за темнотою; [...] п о м о p и и н а - большая смертность [...]. Здесь кроется между прочим основание тоя тесио связи, в какую поставила народная Фантазия болезни, особенно повальные, С нечистою силою, почему она олицетворяет их в безобразных, уродливых формах, и почему простолюдины до сих пор почитают недуги испорченности

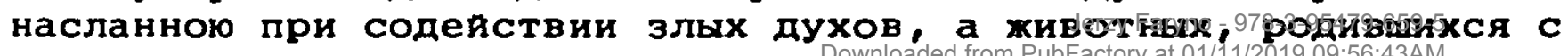


каким-нибудь Физическим недостатком - порохдением тои хе демоническои скты. Мепду народнвми клятвами известны: 'побея тебе м $о \mathrm{p} \circ \mathrm{K}$ a!" (Афанасьев I, 101).

35. Ср. анализ образа "веют дуйу от тела" в: Б.ГАСПАРов, Позтика "Cлова o noлxy Hzopese", B: Wiener Slawistischer Almanach, Sonderband 12, Wien 1984, 56-57. Такое прочтение "А - и - вен!" оправдывается еще наличием отсылки в поэме к библеиской жатве: "Жатвы без рук" (стих 349).

36. Или дахе как соответствие "первого воздуха" в "Поэме воздуха". Анализ этои поэмы См. в: М.Л.ГАСПАРОВ, "Поэма воздуха' Марины Цветаевои: Опьт интерпретации", в: Труди по змаковим системам, т. XV, тарту 1982.

37. СМ. Статьи "ЛАСА", "ЛАСТИТЬ", "ЛАСТЬ" В: В.ДАЛЬ, ТОЛКОвиЙ словаро тиваго великорусскаго язика, Т. II, Москва 1979, 238239; очередные ссылки на этот словарь даются сокраменно: Дало и римская цифра указывакмая том.

38. См. примеч. 13 и 27. Анализируя Феномен наузы, АФанасьев говорит: "Народные сказки свидетельствуют епе, что колдуны и ведымы преврамают люден в различных зверея и птиц, у д а -

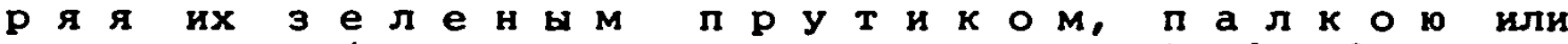

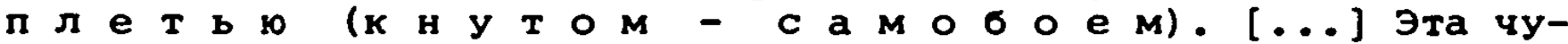
десная трость (Wunschruthe) или плеть - эмблема молнии и указывает на тесную связь оборотничества с грозовьми тучами; C этон эмблемою (как объяснено вьие - II, 423) сочетались противоположные представления: с одно стороны удар волшебного прута повергает сказочных героев в окаменение и непробудны сон (=энмнее оцепенение), а с другои - призывает их к жизни (= к весеннему творчеству). То те двоякое значение придается удару волшебного прута и в преданиях о волкулаках и оборотнях: им преврамаются люди в звериные образы и наоборот им те разрушается сила заклятия и преврапенные возврамаются в среду людея. На Укранне думают, что если у д $а$ р и т ь вовкулака в и $\Omega$ а $M$ и или ц $е$ n $O M$, то он тотчас же делается человеком, т.е. бог-громовник, ударяя своеи палицей, срывает с него волчью плаку (=разноскт тучу) . Оборотни, т.е. стихинные духи и тени усотших, облаченные в облачные шкуры, появляются и исчезают вместе с бурными грозами. [...] с ках-

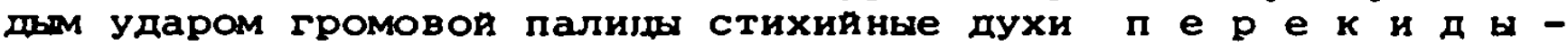

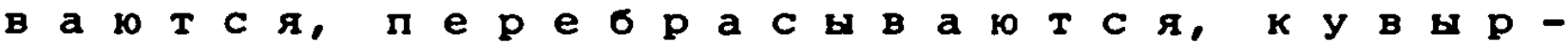

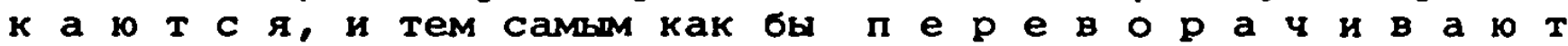
или $\pi$ e $p$ e $M$ н $я$ н 1 свои облачные одежды из одного видимого (телесного) образа в другон". (Афанасоев III, 555-556). О том, что здесь имеет место именно этот тип мотива, свидетельствует не только преврапение Ведуньи, но - в первую очередь - переход с символического "пояска" на "молнию" и "гром" в очередных поединках героев (стихи 171-174 и 243-246).

39. См. статью "Реять" в: Дало IV, 95 и приводиме там примеры: "Ветры веют", "Вешние ручьи реют с гор", "Реет лодка по волнам", "Птица реет по выси", "Кони их начаша реятись в воды, в болота и в лесы", и т.

40. Ср. непосредственнуо связь "снега" и "сна" в "Имя твое - птица в руке..." (Сип I, 227): 
имя твое - поцелун в снег.

Ключевои, ледяноя, голубои глоток...

С именем твоим - сон глубок.

41. Aфанасоев I, 699: "Кроме Св. Василия, крестьяне наши признают покровителем стад великомученика $\Gamma$ e $о$ p $\Gamma$ и я или ю $p$ и я. Так как память его празднуется весною - 23 апреля, и так как предание, сложившееся еме в Палестине и Сирии, приписьшает ему победу над драконом; то в народных верованиях он заступает место бога-громовника, творца весеннего плодородия, победителя демонического змея и пастыря небесных стад. С таким характером является он в эпических сказаниях и преданиях почти у всех христианских народов. Георгио принадлежат те же чудесные знамения, какие дают сказки свокм мифическим героям, олицетворяюмим собою могучие силы весеннеи природы".

42. Афанасоев II, 569-571: "народные поверья приписывают змеям знание целебных зелий, и некоторьм травам присваиваются на Руси названия: $з \mathrm{M}$ и н т в а 6 ○

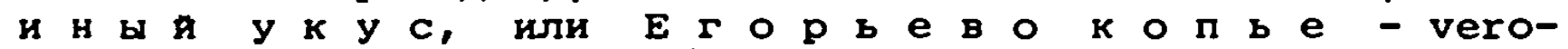
nica latifolia. Воспоминание о мифической змеиноя траве по

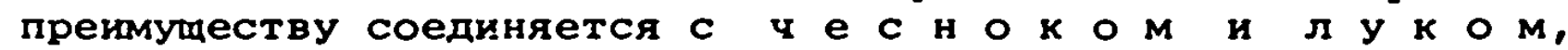
так как растения эти, ради их острого, жгучего сока, получили свои названия от корнен, означаюмих $x$ a $p, r$ o $p$ н и $е$ от ush - urere, санскр. ushpa, перс. sqch, лат. unio (вместо usnio) - луковица: рус. ч е С н о к, илл. ćesan, лит. сzе́sznakas роднятся c перс. Ćashn - жар. По мнению чехов, дикин чеснок на кровле дома предохраняет здание от у д a $p$ a м О $л$ н и . В Сербии суиествует поверье: если $\pi$ e $p$ e д Б л а $Г$ г в е $е$ е н д и т в и у ч е с н $о к а$, потом привязать этот чеснок к шапке, а шапку надеть на голову, то все ведъмы сбегутся и станут отымать его - конечно потому, что в нем заключается великая сила; [...] В некоторых деревнях южноя России, когда невеста отправляется в церковь, ен завязввают в косу головку чеснока, для отвращения порчи. По сербскоя поговорке, чеснок защицает от всякого зла; а на Руси говорят: 'лук от семи недуг', и во время морового поветрия крестьяне считают за необходимое носить гри себе лук и чеснок, и как можно чаме - употреблять их В питу"

43. Афанасоев II, 570-571: "По указанию памятников, В старину пили в честь языческих богов, вкладывая в чани чеснок; в слове христолюбца (рукопись XIV в.) сказано: 'и огневе (Сварохнчу) молятся, и ч е С н о итокp $я$ T - егда оу кого будет пир, тогда же кладут в ведра и $в$ чаши, и пьют о идолех своих, веселяияс не хухьши суть еретиков'. В слове, приписанном Григорию Богослову (рукопись XIV в.): 'словене же на свадьбах, вкладываяе срамоту и у е с н О в и т О К в ведра, пьют" ".

44. См. Статью "Вьять" в: Дало I, 328-329.

45. См.: Афанасоев II, 161. 
46. См. разбор оппозици "огонь - влага", "сухоһ - мокрын" и "земля - вода" В: В.В.ивАнов, В.Н.ТОПОРОВ, Слаөякские язикоөие моделирующие семиотические системи. (Дреөний период), москва 1965, см. соответственно, 140-147, 147-155, 155-156. Некоторые наблодения по поводу оппозиции "сухое - мокрое" у Цветаево см. в: О.Г.РЕВЗИНА, "Из наблодения над семантическоя структуроя 'Поэмы конца' М.Щветаевоя", в: ук. соч., 71 и др. Ср. наиболее обобменную Цветаевскую формулу "влахен Ил, бессмертье - сухо" ("Поэма воэдуха", СиП IV, 283), где 'влага' и 'ил' соотнесены с материальным аспектом бытия и этим самым с 'умербностью', 'несовершенством', 'узничеством- смерты', a 'бессмертье' и 'сухость' с нетварным Божественным духом, т.е. абсолютным, духовным аспектом бытия. Промехуточные же звенья этои оппозиция часто меняют у Цветаевои свод знак по дополнительному признаку 'более тверды - менее твершы' (ср. в тон же "Поэме воздуха" - СиП IV, 281 - Формулу "Твердое тело есть мертвое тело" и примеч. 19), тогда 'вода' , будучи губительноя для земных Форм хизни и растворяя их, на деле окаэывается более 'духовноң', чем и объясняется, в частности, парадокс проявления духовного, просветленного начала в виде акватического потока в "Магдалине" (см. моя разбор этсго триптиха) или в самих "Переулочках" соотнесенность "слоночки" с 'вещим словом', 'поэтическим началом' и где-то в пределе с Бохественным Логосом (см. примеч 24 , где в одном из примеров очевидна эквиваленция "моря" и "зорь", 25, 28 и 32 ). Не исключено, что 'вода' у цветаево - одна из предельных гранея "мира сего", за которои открывается сфера 'духа' (вряд ли случаяно в "Поэме воздуха" - СиП IV, 283 - "цедкость" приписьвается "воздуху", "ситу творческому", "глазу Гётевскому" и "слуху Рильковскому", т.е. явлениям безотносительным к категория 'влахности'), хотя, с другой стороны, этот признак 'способности процехивать' и этим самым некоен причастности к 'влахному' линает их статуса Абсолютного Духа - этот долхен пребьпать на еще более высокие ступени бытия.

47. Ср. у само цветаевои в "Во имя расправы..." из цикла "Благая весть" (7 иоля 1921; СиП II, 123):

не с моря, а с неба

Ударит возмездье.

Глядите: небесним

Свинцом налитая,

Грозна, тякела

Корабельная стая.

См. еме Aфакасьев I, 574: "воздушны океан, по которому плавают корабли=облака и тучи, отлеляет мир живых людеи (землю) от царства умериих, блахенных предков (От светлого небесного свода) - Души усопших, издревле представляемые легкими стихияньми сумествами, подобньми веющим ветрам и пламенеюинм молниям (См. гл. XXIV), долхны были переправлятвся в страну вєчного покоя через шумные волны этого океана, и перепљыали их на облачных ладьях и кораблях. Потому Фантазия первобытного народа уподобила корабль-облако плаваюмему в воздушных про-

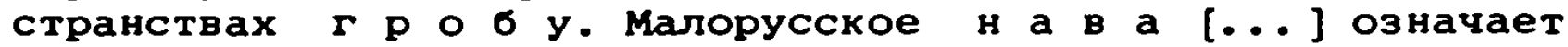
вместе и водояодное судно и гроб; [...] в старинных русских летопнсях н а в в е - мертвец, н а в b - ад, областн. н а в и д д е н ь - мертвецкин праздник". и дальше - 579:

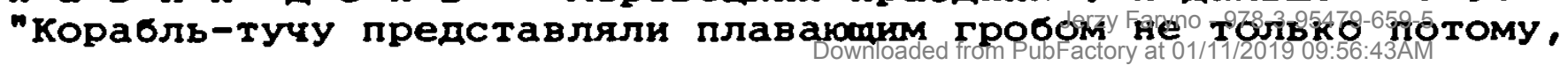


что С ним связывается верование о переезде душ в царство блахенных, но и потому, что он слухит печальньм одром для молниеносного Перуна. Могучин и деятельны в летние месяцы года, Перун у м и р а е т на зиму: [...] В таком поэтическом образе изображает народная загадка весеннюю тучу, несущую бога-громовника, пробужденного от зимнего сна: " $r$ p 06

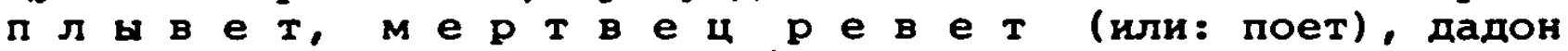

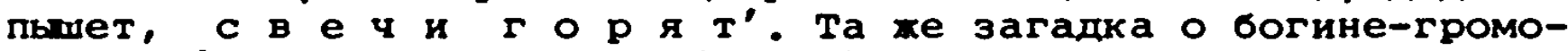
внице: 'на поле царинском (=небе) в дубу $\Gamma$ p $о$ н н и ц $a$, в гробе девица - 0 г о в в захигает"".

48. См.: Аранасьев I, 661 и след., 679-680; В.В.иВАнОВ, В.Н.ТОПОРОВ, "Исследования в области славянских древностеи", В: עк. COu., 169.

49. См.: Калемдарние обичаи и обряди ө страмах зарубехной Еөропи. Кокеи XIX - мачало XX века. Весенкие праздники, Москва 1977, 265 и след. (здесь же вскользь отмечается и связь Егория сс льном). У Цветаевон Егорин как небесны громовержец упоминается в "царь-Девице" (СиП IV, 17) : "В небесах Егория не разжег вонны", что означает, также и по другим признакам, что речь здесь идет о предвесеннем периоде и что под "воннои" подразумевается тут весенняя гроза, первьи гром, открываюиия земло или разбиваюин подземное царство.

50. Здесь уместно обратить внимание на одну поразительную особенность Цветаевон - строгую и всегда последовательно выдержанную приуроченность ее Фольклорных вемен определенньм периодам годовон народноя обрядности. Так, "царь-девица" со всен ее образностью цепиком удерживается в рамках народных представленин связанных с периодом Средпостья или так называемон Смертельнои Недели; "Сугробы", соответственно, - в рамках обрядности в период маслянишы; "Переулочки", написанные тут же после "Сугробов", однозначно соотносятся с весеннен обрядностью, начиная с орьева дня (т.е. 23 апреля). Более того: некоторые веми даже пишутся ею в соответствия с этим народным календарем - даты под стихотворениями цикла "Сугробы" совпадают с периодом Масляницы, "Переулочки" подписаны "апрелем", а большинство стихотворенй с темой Благовеменья - либо "мартом" либо точноп датон (ср. "В день Благовеменья..." - 23 марта 1916; СиП I, 209; "Канун Благовеменья..." - 24-25 марта 1916; СиП I, 210-211; "закинув голову и опустив глаза..." - март 1918; СиП II, 20). С этон стороны 'народность' - не отчушденная от нее тематика, а как бы внутреннее ее свонство, Цветаева не пишет о обрядах, а самым своим писанием их соблодает-исполняет (и поэтому тем более право она имела сказать о себе "Я сама народ" - см. примеч. 29).

51. См. Статьо "КОРАБль" в: Дало II, 161.

52. Ср. в "черная как зрачок, как зрачок сосудая..." (9 августа 1916; СиП I, 244) из цикла "Бессонница": "Клича тебя, славословя тебя - я только Раковина, где еме не умолк океан" или в "Раковине" (31 июля 1923; СиП III, 89-90): "Из лепрозория лхи и зла Я тебя вызвала и взяла В зори! Из мертвого сна надгробнын - В руки, вот в эти ладони, в обе, Раковинные - расти, будь тих: Жемчугом станешь в ладонях сих! [...] Спи! Застилая моря и земли Раковиною тебя объемлю". Кинемограмма захваты- 
ваюмея и преврапаюен в "хемчуг" (= душа, духовное начало и т. п.) раковины повсеместна у Цветаевоя, но мохет вырахаться по-разному: чрево, Груды, пепера, ладонь, Фступание горы, обтекающие остров реки, изгородь, обвивакминся плом и т. Д. В этом смысле она присутствует и в "Переулочках" (см. дальше мотивы "котлов", "ладони", "раны", "раззора") и в этом смысле исход заворахивания-преврамения Героя очевиден уже теперь.

53. Афанасьев I, 354-358 и 361-363.

54. См. Афанасьев I, 352-353: "Первая часть слова - р а, по напему мненио, стоит в родстве с санскр. f (настоящ. arâmi ire, procedere), эаклочајомм в себе понятия быстрого двикения, равно прилагаемого и к свету, и к текучея воде, к бегу коня и полету птицы; отсюда ara - быстрын, ar - вестник, arvan конь и эпитет солнца, чешск. оr - конь, литовск. arelis орел, наше $р$ е т в - летать и р и н у т - смертельно бросить; санскр. гі и зендск. rudh - течь, санскр. rud плакать, р д д $а$ т $\dot{b}$, немецк. rinnen. Отсюда понятно, что $P$, древненпее имя Волги, означает собственно: текучую воду, реку (rivus): сравни: сибирск. p a - $\Gamma$ o p о к - холм, курган на роднике, арханг. p à д a - мокрое место в лесу. таким образом $p$ a д у $r$ a первым своим словом соответствует немецкому regen и означает водоносную, дождевуло дугу" . И еще ср. "Метафорическия язьк народньх загадок назьвает 'раем' водные источники: 'два братца (=ведра) пошти в рая (вариант: в воду) купаться', что указвает на древнейую связь рая с небесньми дохдевьми колодцами" (Афакасоев II, 134).

55. Афанасьев I, 662-663.

56. См. В частности, статьо: Н.И. и С.М.ТОЛСтыЕ, "Заметки по славянскому язычеству. 2: Вызывание дождя в Полесье", в: Славянский и балкакский фолоклор. Гекезис - Архаика - Традииии, москва 1978, 102-103 и след.

57. См. man $x e, 118$.

58. Ср. по поводу льна и тканья в: Т.В.цивьян, "Повесть конопли": К мифологическон интерпретации одного операционного текста", в: Славянское и балканское язикознание. Карпато-востоикославянские параллели. Структура балканского текста. Москва 1977, 310: "Прядение, ткачество само по себе имеет глубокие мифологические и космогонические связи, например, представления о творении мира с помощью прядения нити человеческоя хизни (старухи-Парки). В связи С этим переориентировка мифологемы о возрохдении уничтоженного растения и превращения его с помощью комплекса культурньх деиствия не в наркотическия н а $\Pi$ и -

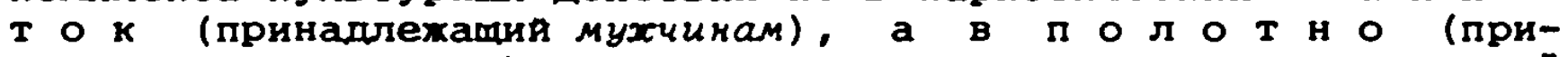
надлехамее хекиикам), представляется достаточно оправданноя" : и 317 (в примечания 18): 'Операционның текст 'Обработка льна' вошел в русскую традицио в виде хороводноя песни 'Ух я сеяла, сеяла ленок', сопровохдаемо пантомимон, изобрахаюмея все стадия обработки льна, перечисляеме в песне. см. еме эагадку о льне, в основе котороя такхе лехит операционның текст, которы одновременно мохет быть интерпретирован в рамках расставаемоя мифологемы как испитание или смерто/өосхресекие:

'Били меня, били, колотили, колотили, на клоч запирали, за стол сахтали" ".

Оппозиция "лен - шелка" имела бы здесь вид оппозиции 'зам- 
кнуты цикл, т.е. воскресение=репродукция $\rightarrow$ открытын континуум, т.е. умирание-воскресание=перевопломение в качественно инут ипостась'.

59. См.: Aфанасьев II, 772-773; G.JOBES, Dictionary of Mythology, Folkzore and Symbols, New York 1961, The Scarearow Press Inc., "Hair: Combed out hair" (710).

60. См. комментария в СиП IV, 368: "Филистимлянка Далила покорила сердие Самсона и, пока он спал, обрезала ему волосы, в которых заключалась его сила (Кн. Судей, 16: 4 и далее)".

61. О тесном сходстве символизма гребня и ладьи см. статью "Сомв", in: J.E.CIRLOT, A Dictionary of Symbols, Second Edition, Translated from the Spanish by Jack Sage, New York 1981, Philosophical Library, 61.

62. Вероятнее всего здесь имеет место возрастание духовного начала и выявление Ведуньея сущности Героя. "Ленок" здесь 'волосы', которые в системе Цветаевод являют собод 'духовның аспект' (подробнее об этои связи см. в моем разборе 'Магдалины"). А С другод стороны, воэрастание 'подвластности' Ведунье: хотя все три члена одинаково соотносятся с представлением о 'громоносности', 'волосы" ("башка р у с а я" и затем " $л$ e н $\left.\circ \mathrm{k}^{\prime \prime}\right)$ блихе к представлению о дождевьх тучах и этим самым 'родственнее' сумности Ведунын.

63. О представления грозы в эротическом плане - как бракосочетания бога плодородия Громовника с землеи или как брачного союза молниеносньх духов С облачньмн менами см.: Афанасьев $I$, 283 и след., 328-330 и след.

64. Ср.: "С т у К О т и Т В, Г У

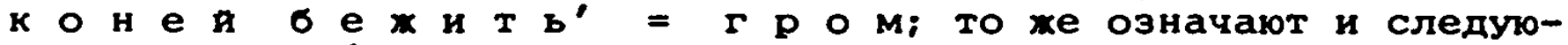

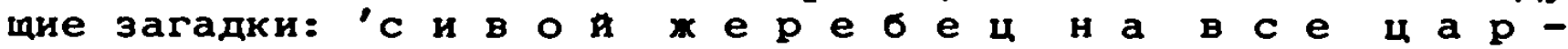

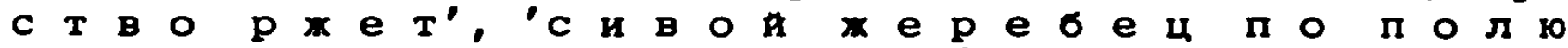

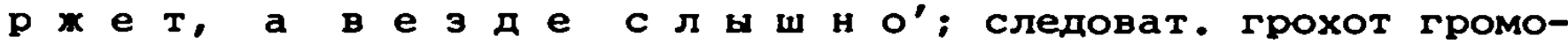
воя тучи уподобляется ржанию и топоту бегуиих конея. Особенно

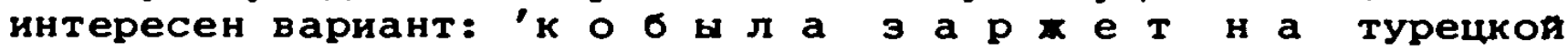

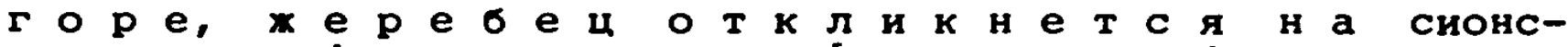

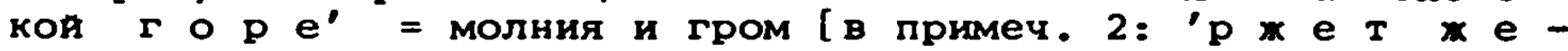

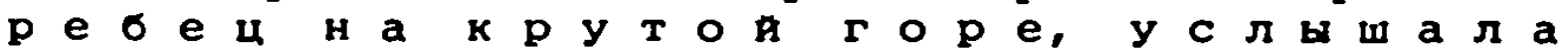
к $о$ б $л$ а в $а$ с мовод конь ржет на горах, потому что гора есть древнеңная метафора облака. [...] В старинном византияском романе, встречающемся в наших рукописях под названием 'Девгениева хития' упоминаются три волшебные коня, 'рекомые: $\mathrm{B}$ е $\mathbf{T}$ р е н и -

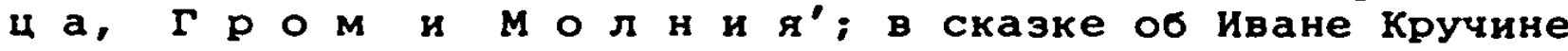

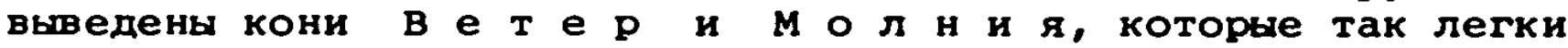
на ногу, что никто не в состоянии обогнать их; армянские сказки знают коня-вихря и коня-облако, а новогреческие коня-молнию" . Афакасоев I, 612-613. У самон Цветаевон См. хотя бы в стихотворении "Синие версты..." (28 ионя 1921; СиП II, 115) из цикла "Георгин":

Громокипямего

Славьте - Георгия!

[... ] 
65. На фольклорном уровне перенменование Ведуньи "конем", равно как и переименование Героя "тур" (140) $\rightarrow$ "конь" (174 и потом 246) восходит к одному и тому же фонду народных зооморфных представления громовоя стихии быком (туром), конем и огненньм змеем. Ср. в былине:

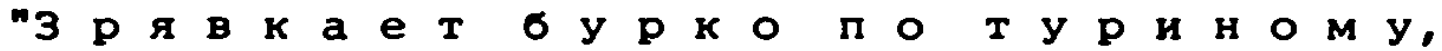

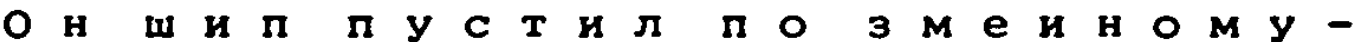

$$
\begin{aligned}
& \text { [... ] }
\end{aligned}
$$

'Бурко [конь - Е.Ф.] зрявкает по туриному, а шип пускает по зменному' - вырахение, указываюмее на сродство чудесного коня С зооморфическими представлениямн громовоя тучи биком (турам) и "змеем" (Афанасоев I, 616-617). На уровне собственно Цветаевскоя системы уравнение 'Ведунья - конь' дополнительно указьвает на уравнение Ведуньи и Цветаевского Я (см. пркмеч. 4, 8 и параграфы 9.4. и 9.5.).

66. Интериоризация "Скачки" ("В гру-ди!" C, видимо, не случанньм графическим 'размканием' "груди"), а тем самқм и "погони", формулу "я хе и конь, Я " и погоня" позволяет читать как искснно Цветаевскую формулу 'ухода от себя же и гонки за собоя хе', где 'уход' означает отбрасывание мало-мальских материальных форм бытия и устремленность к ничем не вырахенному Абсолюту (отсюда Цветаевские раздвоекия), а 'Гонка' - стремление слиться с собственнод сущностью, которая мохет быть достигнута только на уровне Абсолюта (отсюда Цветаевские метаморфозы, построенные по принципу постепенного истончения плоти) - Ср- в связи с этон проблемон финал "Поэмы воздуха" (СиП IV, 285-286: "Предел? - Осиль: В час, когда готическин Храм нагонит шпиль Собственныр - и вычислив Всё, - когорты числ! В час, когда готическия шпиль нагонит смысл Собственның..." ) и ее анализ в: М.Л.ГАСПАРОВ, "Поэма воздуха' Марины Цветаевон: Опыт интерпретацин", в: ук. сои., 138-139.

67. Ср. В: Т.В.цивьян, "Категория видимого/невидимого: Балканс-

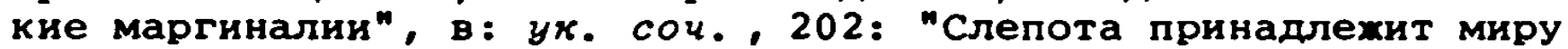
мертвых" и в примечания 5 (там $x e$ ) о возмохности "описывать др.-гр. Аид - нихния мир, царство мертвых, бог нихнего мира двумя различительньми признаками: ке видяиий, т.е. слепоя, и неөидимий, имеюий в свою очередь два смысла, 1) недоступнын виденио представителеи иного, верхнего мира и 2) не имеюаи вида, формы, 'безвидны', соответствуюмия хаосу (ср. библ. 'и земля была безвидна')". и далее, 206-207: "Однако более судественен принципиально инои вид зрения - то, что мохно назвать вкутренним зрекием, связанньм прехде всего с особьм знанием (прорицаниями) [примеч. 13: В русском прорицатело, предсказатело отрахен слособ с 0 ○ 6 虫 $е$ н н я информацин, в то время как өпровидеи - слособ ее $\Pi$ о $л$ у ч е н и я] и С творчеством. Такого рода внутреннее зрение предполагает внешню слепоту. [...]

Мотив внутреннее эрение=знание (значенне совмещенное в д. $-г p .0[\delta$ ) приводит $\mathrm{K}$ теме пренмудества внутреннего зрения перед внешним и отсода - к преимуцеству слепоты. К мотиву 'Слепота как наказание за проступок, компенсируемое обретением знания' см. на уровне сказочных скхетов AT 613 II: The blinded by his companion man overhears a meeting of spirits of (b) animals and learns valuable secrets [nprmey. 16: Cp. другоя сюхет, где закрывание глаз ('намеренная,степята'́) 
водит к 'отказу от знания', [...] Bad Luck Cannot be Arrested: Rich man leaves money for poor, but latter $c 10$ s $s$ e $y$ e $s$ and fails to see it]. Cледуоми war - внешнее зрение как помеха внутреннему зрениюззнанию, и здесь наиболее яркин пример - "царь Эдип", где отношение слепота $\rightarrow$ внутреннее зрекие/знакие впервые доведенодо экспиицитного вырахения: пока Эдип обладает внешним зрением, он слеп внутренне, т.е. не обладает знанием (которое есть у слепого Тиресия). обретя знание, он ослепляет себя, осознав слепоту условием истинного знания и, в частности, самопознания".

68. Не исклочено, что слова "розами увенчана" подразумевают античные поминальные обряды розалии (предполохительно давшие названия славянским русалиям) . О связи цветочноЯ обрядности С погребальноН СМ.: О.М.ФРЕИДЕНБЕРГ, МИФ и литература дреөности, Москва 1978, 142.

69. Оно возмохно потому, что Цветаевское'движение' и есть 'изхи- вание' ('истребление') материальных Форм бытия (ом. примеч. 66).

70. На событияном уровне это мотивируется событиями зимои, в Феврале, и разъединяюще Я и Коня метелью. На семантическом господством зимнего царства смерти ("Как рокот Сорокоуста Метель взмелась" - курсив мон, Е.Ф.), подчиняюмего себе и громоносную стихию; cp. дальше о "гремямем ледоходе" как образе освобожданиегося грома.

71. "Поле"-и в мифологических представлениях и у цвеатево являет собой локус смерти, равно как "бусы", 'держание за ручку' и т. П. знаменуют 'скованность-смерть'. Поэтому все эти акты совершаются "Не Музон" (предполагающен "бренные узы Родства" = 'гармония'), а ее противополохностью, которая в системе цветаево гораздо ценнее, ибо ведет в смерть=истинное бытие. Добавим, что эта 'не-муза' архаичнее традиционньх образов муз. См. yж. соч. Tопорова "MOYӨAI-'MУзы'" .

72. 'Крестить' в этом контексте явно означает 'налагать узы, связывать' и этим самым приобмать к смерти, конечно, в Џветаевском отрицательном понимании смерти=оформленного бытия; ср. примеч. 13.

73. Ср. рассуждения на тему воскресения в "Земньх приметах" (1919; Проза $I$, 111-112): "'Воскреси его, потому что нам без него скучно!' - то же самое, что: 'Разбуди его, потому что мы без него не спим'... Разве это довод? - 0, какое мертвое, плотское, чудовипное чудо! какое насилие над Лазарем и какое страшнейее - над собон!

Лазарь, возвращаюцияся оттуда: мертвын к живьм, и Орфен, спускаюцияся туда: живон - к мертвьм... Разверстая яма и Елисенские поля. - Ах, ясно! - Лазарь оттуда мог принести только тлен: дух, в жизнь воскресши,, в жизнь не 'воскресает'. Орфей же из жизни ушел - В Жизнь. Без чукого веления: жахдон своен". Ср. еще эту же тему во втором стихотворении "Сугробов" (12 февраля 1922; СиП II, 161): "Не здесь, где связано, А там, где велено. Не здесь, где Лазари Бредут с постелею, ....] здесь нету рученьки тебе - моен. [...] не здесь, где взыскано, Там, где отпущено, Где вся расплескана Измена днеи. Где даже слов-то нет: - Тебе - моеи...". 
74. Ср. стихотворение "Прокрасться..." (14 мая 1923; СиП III, 76), темо которого является преодоление-отказ от поэтического іи всякого) творчества как 'сковываюмего' и поэтому все еме разъединяюмего С истиннои сушностью Я и С абсолютом:

\section{А мохет - лупшая потеха Перстом Севастиана Баха органного не тронуть эха? \\ Распасться, не оставив праха}

На урну...

и еме заметку "Точка эрения" в "Искусстве при свете совести" (1932; Лроза I, 394): "По отношению к миру духовному - искусство есть некия физическия мир духовного.

По Отнопенио к миру Физическому - искусство есть некия духовнй мир физического".

75. См. статью "ПЕГАС" в: Мифа мародов мира, т. 2, Москва 1982, 296.

76. Если исходить из "Поэмы воздуха", где цветаевская концепция строения мироздания и концепция бытия эыражена наиболее отчетливо, то мохно сказать, что в мифе о Пегасе ее привлекает в первую очередь его возникновение из отсеченнои головы, что уподобляет его само-бытноң мысли, и блиэость к верховному божеству (Зевесу). См. анализ поэмы в: М.Л.ГАСПАРОВ, "Поэма воздуха' Марины Цветаевон: Опыт интерпретации", в: ук. соч., особенно 138-139.

77. См. статью "Гения" в: Мифи народов мира, т. 1, москва 1980, 272. В связи С Финальньм стихом "Моя Гения!" бросается в глаза навязчивын мотив "кукл" в начале "на красном коне" ("О сломанноя кукле Со мноя не грустил"; "Бешеның всплеск маленьких рук В небо - и крик: - Кукла!"; "Крик. - Громовои удар. Вздьмая куклу, как доспех, Встает, как сам Похар" ; "Я спас ее тебе, - разбея! Освободи Любовь!"; "что это вдруг - рухнуло? - Нет, Это не мир - рухнул! То две руки - конному - вслед Девочка - без - куклы" - СиП IV, 155-156). "Кукла" тут, несомненно, двояник, дубликат Девочки-я, и как всякия дворник принадлехит к миру мертвых. В этом смысле в данной кукле соблазнительно было бы видеть античную, римскую, ларву, душу умершего. Не отсюда ли в финале обраэ "В черноте рва Леху" семантика 'взвива' "в лазурь", т.е. воскресения, после избавления от "куклы"? О соотношения 'ларвы - куклы' в римскоя культуре СМ.: О.М.ФРЕДДЕНБЕРГ, Миф и литература древкости, Москва 1978, 40-42, 64, 132.

78. Мифа народов мира, т. 1, Москва 1980, 272 (статья "Гения").

79. "Пол" в системе цветаевон - одна из существеннериих преград на пути Џветаевского Я $к$ слиянио с абсолотнон сушностью. Ср. стихотворение "Наяда" (1 августа 1928; СиП III, 139-141) и в этом контексте финал "Переулочков" (стихи 343-350). Заметим еме, что идеальные герои Цветаевои 'бесполы', что либо выражается при помоши их 'двуполости' (царь-девица, царевич, о котором говорится: "- Гляху, гляку, и невдомек: Девица - где и где друхок? [...] А ну как зорче поглядим - И вовсе всё обман один, И вовсе над туманом - дым, Над херувимом - сераФим?" - СиП IV, 29-30), либо нентрализируется 'родством' (всякие братства, сестры, брат и сестра) или специальнор наузон 
- "пламом". Некоторье наблюдения по поводу такои именно Функции плама у Дветаевоя См. в: С.И.ЕЛЬницкАЯ, "О некоторых чертах поэтического мира M. цветаевон (IV)". B: Wiener slawistischer Almanach, Band 11, wien 1983, 302.

80. См. статью "HANGED MAN", in: J.E.CIRLOT, A Dictionary of Symbols, op. cit., 138-139.

81. См. О.Г.ФРЕИДЕНБЕРГ, МИФ и литература древности, ук. соч.. 499; статья "HAIR" in: G.JOBES, Dictionary of Mythology, Folklore and Symbols, op. cit.. 71 ("Red hair"): cratbr "HAIRS" in: J.E.CIRLOT, A Dictionary of Symbols, op. cit., 135; Афанасоев $I$, 196. Во всех этих толкованиях показана также связь "рьбкего цвета" с солнцем и молниями. Поэтому Цветаева вправе громоносных конеи Ведуньи и ее "возхи"-'молнии" называть "рькими", но выбор именно этого названия позволяет ен активизировать и смысл 'соблазна' и 'коварста' (что явствует из употребления Цветаевон в других произведениях как слова "рыкия", так и отличных по смысловым оттенкам "золотоя" или "русын") .

82. "Царствьица хлеб-ни!" (210) - опять же чисты цветаевскин акт питья, означаюмего приобщение к всерастворяющему мировому акватическому потоку, переход в блаженное растворенное состояние мирового потока (ср. в "Бессонница! Друг мои!" - ман 1921; СиП II, 105: "Мир без вести пропал. - В нигде Затопленные берега. - Пен, ласточка моя! - На дне Растопленные жемчуга...", где "ласточка" и "жемчуга" одинаково означают "душу" но с разньм статусом у цветаевон - если "ласточка" есть 'психея', то "кемчуг" родственен ее категория 'духа', как в уже цитированном стихотворении "Раковина" в примеч. 52). А В контексте мифологических и фольклорных отсылок поэмы позволительно здесь сльлать отголосок весеннего обряда топления конеи и сказочного купанья в кипяних котлах (ср.: Афанасьев $I, 623-624$ ).

83. См.: Афанасоев III, 215-218 и, в частности, на 217: "[...] сло-

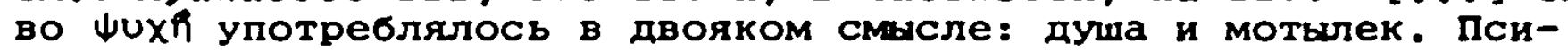
хею они изображали бабочкою и даже в человеческом олицетворении надеяли ее легкими и прозрачньми крыльями этого насекомого. Смерть греки представляли с погасшим факелом и венком, на котором сидела бабочка: факел означал угасшую жизнь, а бабочка - душу, покинувшую тело. В древние времена на гробницах изображалась бабочка, как эмблема воскресения в новую жизнь. По рассказам новых греков, души усотиих в течении сорока днеи после Воскресения Христова носятся над цветучими полямн в

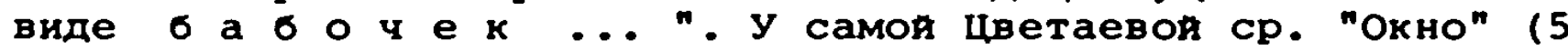
мая 1923; СиП III, 74):

\author{
Атлантским н сладостньм \\ Дьханьем весны - \\ Огромною бабочкон \\ Mon занавес - н - \\ Вдвою индусскою \\ В жерло златоустое, \\ Наядою сонною \\ В моря заоконные...
}

По свидетельству комментаторов, в рукописи это стихотворение озаглавлено "Занавес" с подзаголовком "Bдох 
453). "весна", "окно", "занавес", "костер" = "херло златоустое", "моря заоконные" и "бабочка" - все это знаки Цветаевского

'воскресения души', ее выхода в запредельное, вечное.

84. Ср. хотя бы в "Короткне крылья волос я помню..." (Декабрь 1920; СиП II, 44) из цикла "Плащ": "-Стон! Хнлы не могут! Коготь Рехет кивую плоть! Господь, ко мне!... То на одноя сруне Этод Паганини": в "Сон" (24 ноября 1924; СиП III, 114): "Тело, что все свои двери заперло - тщетно! - уж ядра поют вдоль хил"; "Приметы" (29 ноября 1924; СиП III, 115): "я любовь узнаб по жиле, Всего тела вдоль Стонумей. [...] я любовь узнаю по срыву Самых верных струн Горловых".

85. См. примеч. 58 .

86. О.М.ФРЕЯДЕНБЕРГ, МИФ и литература древкости, ук. соч., 78.

87. Афанасьев I, 19-20. Ср. в "Царь-Девице", где соотнесенная с Солнцем и громоносньми небесами царь-девица, уподобленная к тому Перунову дубу, плачет именно смолои, тут же переназваннов в "Дар души еe" (СиП IV, 54-55):

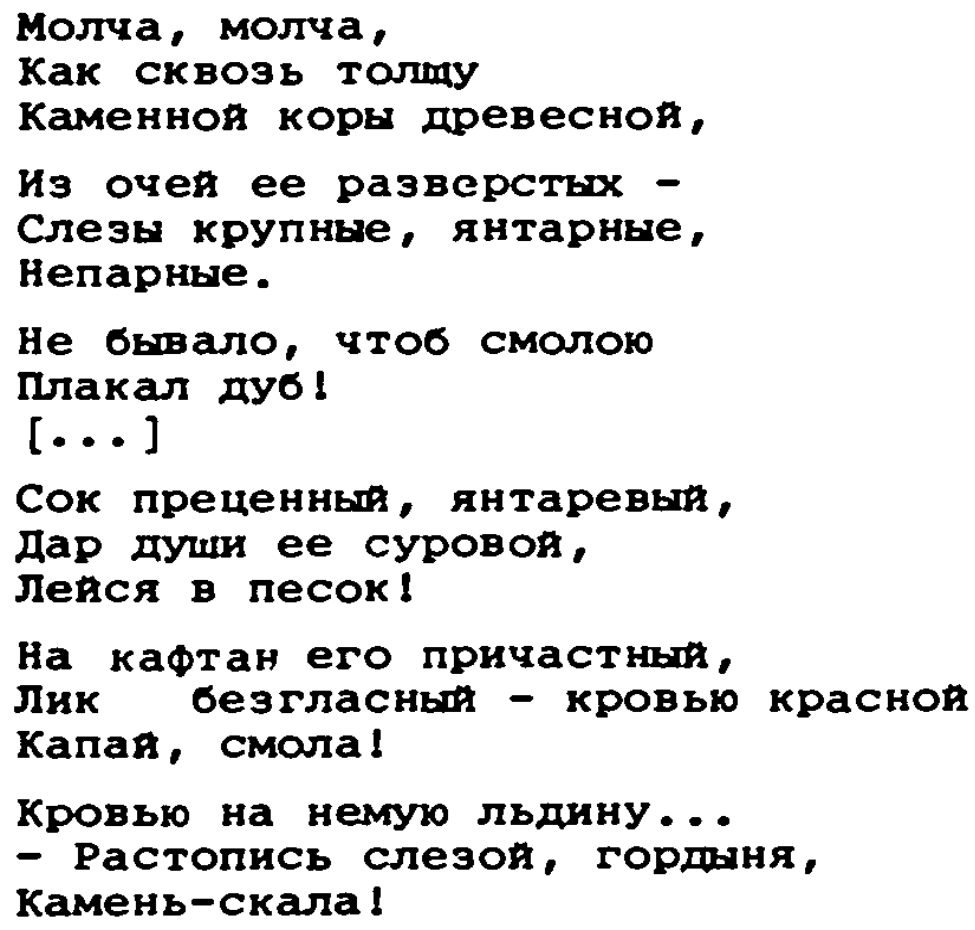

88. Sм.: Афанасьев I, 542-546 и Aфанасьев III, 128-130. Ср. у Цветаевон "Да будет день!- и тускы день туманны Как саван пал над мертвою водов" (1917; СиП II, 200) из цикла "Князь тьмы" .

89. См.: Афамасоев I, 40 и Aфанасоев III, 275-277; попутно папомним высокую частотность "ткани". "полотна" у Цветаево как определения пространства, пути, как правило наделяемых тогда смыслом наскльного разъединения-смерти.

90. Афанасьев III, 277.

91. См.: Афанасьев III, 359 и след.

92. См.: Т.В.Цивьян, "'Повесть конопли': К мифологическоя интерпретации одного операционного текста", в: ук. сои.. 307-311 и след. 
93. СМ.: О.М.ФРЕИДЕНБЕРГ, "МОтивы" [ГЛава из книги Позтика сихета и ханра, Ленинграя 1927, 247-255], В: Поэтика. Труда русских и советских поэтических школ. Составители Дьюла Кирай и Apпад Ковач, Budapest 1982, 682: "Образ 'внезапно Гибели' и 'внезапного охивания' передается в обычнои формуле исчезновения и появления; то, что солярная ветвь транскрибирует метафороя 'поединка' и 'преследования' врага, то здесь понимается как 'поиски'. Эта черта очень любопытна; и там и тут Фаза смерти изобрахается, - я уле говорила об этом, - в виде дословного хождения, прохохдения: нухно 'проити' страну смерти,'пространствовать' сквозь нее, 'исколесить': 'мертвын' это путник, странник: смерть - 'гостиница', широко принимающая гостей-пришельцев; она 'гостеприямна' и 'имрокодверна' ". СМ. eme по этому поводу в: О.М.ФРЕДДЕНБЕРГ, МИф и литература дреөности, ук. соч., 65-66, 159, 547. Ср у цветаевоя в уже цитированном стихотворении из цикла "Бессонница": "Нынче $\Rightarrow$ гость небеснья В стране твоея. Я видела бессонницу леса и сон полен", где Я - покинувшая свое тело, а "лес" и "поле" - миФологические пространства смерти.

54. Такое понимание "соли" имеется и В "Кто создан из камня, кто создан из глины..." (23 мая 1920; СиП II, 286): "Меня - видишь кудри беспутные эти? - Земною не сделаешь солью. Дробясь - гранитные ваши колена, Я С каждоя волнои - воскресаю!", где наличие 'дробления' (напоминаюмего о 'сыпучести' "соли") и 'воскресания' вписывает в "соль" представление как об окончательном 'продукте' ("сделаешь"), не предполагающем уже никаких изменения, т.е. обезжизненном.

95. Ср. главу "ФиЛЬтр" в: М.Л.ГАСПАРОВ, "Поэма воздуха' Марины Цветаевон: Отыт интерпретации", в: ук. соч., 135.

96. Ср. аналогичную траекторию пути я в "Быть голубкон его орлинон!..." (28 апреля 1921; СиП II, 102) из цикла "Марина":

Сальных карт захватив колоду,

Ногу в стремя! - сквозь огнь и воду!

Где верхом - где ползком - где вплавь!

Тростником - ивняком - болотом,

А где конь не берет, - там лётом,

Все ветра полонивши в плам!

[... ]

Гул кремлевских гостея незваных.

Если имя твое - Басманов,

Отстранись. - Уступи любви!

Распахнула платок нагруднья.

- Руки настехь! - Чтоб в день свон судны

Не в басмановскон встал крови.

В своих собственньх пределах такои путь соотносится с моделью макрокосма (подобно фольклорноя модели вырахаемоя, например, водои /рыбон, волком, конем и птицамн, под которьми подразумевается 'низ' или 'подземное царство', земноя промехуточның уровень и 'верх' или 'небесное царство'), и часто цветаевския сюжет на этом останавливается. Но эта картина - лиш часть истинного Цветаевского макрокосма, она соотносится только со срединньм уровнем ее мира. Метаморфозы на этом уровне знаменуют только 'экстаз' Я, т.е. прибликение яل 
Формы, за которым открывается возмохность настоямего 'возрохдения' или 'воскресения' - Поэтому, воспаряя вверх, Цветаевское я прибликается к 'спуску'-'смерти' (ср. "С этоя горы, как с крыти Мира, где в небо спуск" - 30 августа 1923; СиП III, 96), после которого начинается восхохдение 'ввысь', т.е. к Абсолоту. Нанболее лаковично эта модель вырахена у цветаевон 'заглавиями' отдельных частея "Эпитафии" (из соорника 1910 года "Вечернин альбом" - СиП I, 49): "на земле" $\rightarrow$ "В земле"

"над землен" (которую следовало бы еме дополнить предваряющен стадиен типа 'Пред землея' или 'До земли', учитывая, например, уже отмечавшееся стихотворение "Сивилла - младенцу" и ему подобные).

Цветаевскин сюжет может, конечно, остановиться в конце любоя из этих стадия (в денствительности ке он чаmе всего обрылается на второи - у исхода фазы "на земле"), но он заведомо

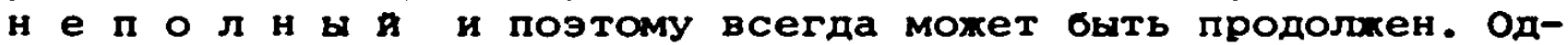
нако в читательском восприятии охидание продолкения не возникает, отсюда впечатление 'нескольких' Финалов во многих произведениях Цветаевон (самв яркия пример, кроме "Переулочков", - "Поэма воздуха", где кахшын очереднон этап "восхохдения' замыкается лексемон означаюме 'пресекновение' : "Землеотпутение", "Землеотлучение", "Землеотсечение", "Кончен", "Предел?" - СиП IV, 282, 283, 285) и как бы нескольких начал (типа "Смерть, где всё с азов, Заново..." в "Поэме воздуха" Сип IV, 281). На глубинном уровне это явление объясняется резкои качественнои менои как ипостасея Я, так и проходимых сфер мироздания.

97. М.О.ФРЕЯДЕНБЕРГ, Миф и литература древкости, ук. сои., 66.

98. Там $x е, 547$.

99. М.Л.ГАСПАРОВ, " Поэма воздуха Марины ЦветаевоЯ: Опьт интерпретащии", в: $y к$. сои., 138: "[...] бог цветаевскон теологии противополохен христианскому (Цветаева сказала бы: церковному) богу: последнин - абсолотное бытие, где нет времени, движения, изменения; шветаевскин - абсолютное становление, движение, изменение, ускользание. (Так же изобрахалась Артемида в "Федре" - "в оперехаюпем тело беге"). Если церковни бог - Суши, то цветаевския - не-сунин: первын - бесконечная статıка, второя - бесконечная динамнка".

100. Определяя нанболее интенсивную форму бытия на срединном уровне Цветаевской модели мира, гора знаменует одновременно предел 'этон' хизни, ее 'смерть' почему она часто определяется как 'спуск' (см. примеч. 96), с однои стороны, а с другор - возникает на очередном этапе сызнова, как требование качественного перерождения, как испытание 'духа' .

101. Ср. еме стихотворение "Бесупречен и горд..." (13 августа 1918; СиП II, 232):

Бесупречен и горд

В небо подняты лоб.

Непонятен мне греб,

И не страшен мне гроб.

мехь вельмох и рабов.

Мех горбов и гербов,

Землио роюинх лбов -

я - из рода дубов. 
Тут "гроб" вклочен в более богатьи ряд оппозици и эквиваленция. В одном отномения он приравнивается "гробу" как пределу мнимон 'эволоции' косноң материальности (см. примеч. 94), в другом - "рабам" как признак отсутствия 'духа, своеволия", в третьем - "лбам" (данньм тут во мнохественном числе) как 'тупости, безмыслия'. Оппоэиция ему - "лоб" как символ интеллекта, мысли и 'гордость' как признак 'духа' . Поэтому и в "переулочках" нельзя исключить наличия в "горбах" 'духовноя' и 'интеллектуальноһ' уродливости (ср. неоднократное упоминание в поэме "башки", "головы" и потом "лба" по отношению к Герою и "лба" по отношению к Ведунье, о чем нике).

102. Сама по себе 'старость' в поэме не упоминается. И, думается, по следующе причине. На мифологическом уровне старость прямым образом соотнесена с царством мертвых и с присумен этому царству 'мудростью' . у самои Цветаевоя мотив старости именно так и ретается; ср. О Сивилле "выбытая из живых" ("Сивилла: вьокена, сивилла: ствол..." - 5 августа 1922; СиП III, 24) и хотя бы "Скоро уж из ласточек - в колдуньи! Молодость! Простимся накануне..." (7 ноября 1921; СиП II, 136). Иначе говоря, старость у Џветаевор интеллектуалистична и 'потусторонняг', что противоречило бы семантике ее "горбов" (См. примеч. 101).

103. Ср.: "От бесконечноһ динамики - вторая черта цветаевского бога - его интеллектуалистичность. Чувства неспособны охватить бесконечность, мысль способна; чувства неспособны меняться бесконечно, мсль те есть именно бесконечное двикение. Поэтому в стихотворении "Бог" сказано: "в чувств оседлоя распутице он - седои ледоход", а в поэме "не в день, а исподволь Бог [Сквозит?] сквозь дичь и глуль чувств". Начнналась поэма оголением души от "прослояки чувств", а "дерхавоя" бога оказывались "мыслители"; кончается поэма оголением мисли от душ, "царство дут" остается по сю сторону тверия, а по ту - "полное владтество лба", голова с гермесовыми крыльями, несумими в бесконечность. Голова сбрасывает плечи, как шпиль сбрасывает храм ("Бог из церквен воскрес!...") "дням", "веку", а сам стрелою из лука (готического?) летит в вечность". М.Л.ГАСПАРОВ, "Поэма воздуха' Марины Цветаевон: Опыт интерпретации", в: ук. соч., 138-139. Упорное упоминание "бапки" Героя в "Переулочках" указывает в этом контексте на его потенциальную, но еме умербную ("зелена башка"), неудовлетворительную интеллектуальность, и не исключено, что дальше сюжет ('колдовство' Ведуньи) разовьется как извлечение (выявление) именно этого аспекта Героя (имея черты Громовника он совершенно естественно мохет являть в себе и 'гром-Логос') .

104. См.: Дало II, 233, статья "ЛАДОНЬ" и приводнмы там пример: "По ладони озера рябь пробехала" - Приписываемая "ладони" "глубина" мохет мотивироваться у цветаевон постоянным ее мотивом захватыващеи раковины (ср. в цитированном стихотворенин "Раковина": "В руки, вот в эти ладони, в обе Раковинные - расти, будь тих: Жемчугом станешь в ладонях сих!" в примеч. 52).

105. См. статьо "ЗАБИРАть" в: Дало I, 552. 
106. Ср. стихотворение "я - страница твоему перу..." (10 июля 1918; СиП II, 226) :

$$
\begin{aligned}
& \text { Я - страница твоему перу. } \\
& \text { Всё приму. Я белая страница. } \\
& \text { Я - хранитель твоему добру: } \\
& \text { Возраму и возвраму сторицеи. } \\
& \text { Я- деревня, черная земля. } \\
& \text { Ты мне - луч и дохдевая влага. } \\
& \text { Ты - Господь и Господнн, а я - } \\
& \text { Чернозем - и белая бумага! }
\end{aligned}
$$

Эквиваленция "земля, чернозем - бумага" сообмает 'возрохденно' творческия, одухотворяюми характер (вместо пассивноя репродукия и умнохения, если бы речь шла только о "земле-черноземе"), качественно меняюиия 'засеянное' ('семена' или 'Слово Господне') в 'поэтическое'. Частичны разбор этого текста см. В: Е.Г.Эткинд, "Опыт о местоимения в системе поэтическон речи", в: Поэтика и стилистика русской литератури, Ленинград 1971, 406-407.

107. Ср. "Сок лотоса" (23 июля 1923; СиП III, 132) или его вариант "Из папоротников, гвомеА..." (Июль 1923; СиП III, 219), где галлоциногенны напиток очень близок более частым у Цветаево напиткам 'из моря и зорь' и подобен ее "Lарствьицу" (стих 210) и где его деиствие двояко: ведет к "забвенио вемен". "наводит сон" и приобщает к мировому потоку ("Бохественно и детски-гол Лоб - сквозь тропическуо темень").

108. Хотя 'до-тварное' может у нее расцениваться как 'не одухотворенное' и поэтому требуюмее творческон 'обработки' и 'испитания' на промехуточном - земном - уровне мироздания. Ср. уже отмечавшуюся оппозицию в Формуле "влахен ил, бессмертье - сухо" ("Поэма воэдуха", СиП IV, 283) в пркмеч 46.

109. О связи кузнеца, кузнечного дела с 'мудростью', но и 'колДовством', 'Коварством' и этим Самым С 'обманом'. 'мнимоСтью' См. В: В.В.ИВАНОВ, В.Н.ТОПОРОВ, Исследовакия в области славянских древностей. Лексические и фразеологические вопроса рехокструкиии текстов, Москва 1974, 158-160. (Ср. у Цветаевон в "царь-девице" (Сип IV, 40): "Так из кухоньки - да в кузню: Кто-то молот взявия в руки, Из стекла кует союзы, Из свинца кует разлуки").

110. В определенном смыле это была бы сфера, подобная библеяскои, где "ничего ухе не будет", а только "престол Бога и Агниа" (Oткровение, 22: 3-5).

111. О вьковьвании кузнецом "языка, речи" (славы) и о свадебном величания СМ. В: В.В.ИВАНОВ, В.Н.ТОПОРОВ, Исследовакия в области славянских древкостей, ук. соч., 161-162.

112. Ср. в "Емче органа и звонче бубна..." (23 декабря 1924; СиП III, 118-119): "Ох, когда трудно, и ах, когда чудно, А не дается - эx! [...] Ax: разрываюmееся сердие, Слог, на котором мрут. Aх, это занавес - вдруг - разверсты. Oх: ломово хомут [...] Неодолиме возгласы плоти: Ox! в: "Вот опять окно..." (23 декабря 1916; СиП I, 248) : "Крик разлук и встреч ты, окно в ночи! Мохет сотни свеч, Мохет, три свечи...", где сочетание "окна" как 'проема' в потусто- 
ронния мир, с "криком" как "возгласом плоти" и неопределенность происходящего (то ли 'пир' - "сотни свеч", то ли 'помннки - три свечи) строит картину обесцененного мира. Добавим еще, что антитеэисом "крика" является у Дветаевон "голос", как носитель 'слова' и "Слова', т.е. Логоса (ср. в "Закинув голову и опустив глаза..." - март 1918; СиП II, 20: "А голос, голубем покинув грудь, В червонном куполе обводит круг").

113. См. статьи "FOOT", "SHOES", "WINGS", In: J.E.CIRLOT, A Dictionary of symbols, op. cit., 111, 295-296, 374-375.

114. Ср. в "Прокрасться..." (14 мая 1923; СиП III, 76): "А мохет, лучшая победа Над временем и тяготеньем - Проити, чтоб не оставить следа, Пройти, чтоб не оставить тени на стенах...".

115. В связи с этим небеэннтересно отметить, что некоторые персонахи цветаевон (те, с заведомо идеальным потенциалом) так или иначе 'оторваны' от земли - им полагаются либо заместители, либо хе они локализованы на играющих роль 'изоляторов' сооружениях (в роде кроваточки, лесенок и лодки в случае царевнча из "царь-девишы"); и наоборот, персонахи хтонического ряда подчеркнуто связаны. с землен и полом (так о царе в "царь-девице" сказано: "Сидит царь в нутре земном" - СиП IV, 35: Мачеха-царица в сцене брачной пляски показана 'разувающеяся': "- Скидыван босовики! Босая пляши! Эн, топ, босовичок! ЭЯ, скок, босовичок! Наших босых ног - Не белен снехок!" и "Ах пол подметает - космами!" - СиП IV, 63 и 67). По всен вероятности такая же 'замитная' функция содерхится и в захватываюме цветаевско "раковине" со всеми ее вариантами (см. примеч. 52).

116. См.: Б.А.УСПЕнСКЙ, Филологические разискания в области славянских древностей, ук. соч., 37, 78; В.я.ПРОПП, Нсторические корни өолиебмой сказки, Ленинград 1946, 268-279. Ср. наличие этого мотива в "царь-девице": "Бель стан с шнуровочкоЯ, Да красның кушак. - Что за круг мех бровочек, Кумашны пятак?" (СиП IV, 47), где прнчастность к мертвому царству повторена еще и в "шнуровокке" (см. примеч. 13) и в "пятаке". О монете как потустороннем двоЯнике см.: О.М.ФРЕЯДЕнБЕРГ, миф и литература древности, ук. соч., 66-67, 133, а у Цветаево см. в четвертом стихотворении цикла "Стихов о Москве": "- Остужены чужими пятаками - Мои глаза, подвижные как пламя. И - двонника напупавшия двоиник - Сквозь легкое лицо проступит лик" (11 апреля 1916, 1-ы день Пасхи; СиП I, 216).

117. См. примеч. 115. Ср. также стихотворение "Прокрасться..." (СиП III, 76), где "победа Над временем и тяготеньем" осумествляется также и при помоми отчукдаетмости от речи-языка в последовательности: "победа" $\rightarrow$ "потеха" $\rightarrow$ "обман", т.е. при помощи расторжения связи между планом выражения и планом содерхания. Моя более подробнь анализ этого стихотворения в печати (SLavica Hierosolymitana).

118. О.М.ФРЕДДЕНБЕРГ, МИФ и литература древкости, ук. соч., 133. Такое понимание дара позволяет полнее понять второе стихо творение триптиха "Магдалина" и слова Христа "- Магдалина! Магдалина! Не издариваяся так!": теперь она уже не только "сестра", но и некин 'дубликат' христа. Тогда понятнее ста- 
новится перевод взгляда-"зрака" Христа "В красную сухую глину" как указание магдалине ее настоямен миссии (СиП III, 95: См, такхе мон разбор этого триптиха).

119. 'Дару' противостокт у цветаевоя 'торговля' как мена - размен=потеря сумности 'продакмего'. Подробнее об этом См. В моем разборе "магдалин". Кроме того ср. 'купеческия' мотив в "Царь-Девице" или мотив базара в "Поэме горы".

120. Акт ешы равносилен жертвоприношению и дару. Даруицему он дает право на одариваемое и приниманщее дар бохество. См.: 0 . М.ФРЕИДЕНБЕРГ, МИф и литература древности, 138-140; Э.А.РККМАН, "Место даров и жертв в календарно обрядности", в: Календарние обичаи и обряди в странах зарубехной Европи. Нсторические корни и разөитие обичаев, москва 1983, 174. В этом свете понятнее опасность "улещени" " Ведуньи и предупрехдения "голубен" "Про яства - не ести, Орешки - не грызти". в стихах 49-52 и 61-65, а также последовательность стихов "Богу жертву кадит, С дуба требоваит" (7-8), так как после возложения жертвы и ее приятия божеством осумествляется приаво владения этим бохеством. То же имеет место и здесь: "Дарственными - Душту насыть!" (329-330) и в очередном (331) "Милын, растрать!".

121. Но здесь со всен очевидностью речь идет не о завладении 'душон' Героя а его 'духом'. Ср. различение у само цветаевоя в главке "точка зрения" из "Искусства при свете совести" (Проза I, 395): "Так же и дупа, которул бытовик полагает верхом духовности, для человека духа - почти плоть. Уподобление С искусством не случанное, ибо стихи - то, с чего глаз не свожу, говоря искусство - все событие стихов - от наития поэта до восприятия читателя - целиком происходит в душе, этом первом, самом низком небе духа". O традиции различения "души" и "духа" в русскор литературе см.: М.Ф.мурьянов, "Золото в лазури", в: Проблема структурной лингвистиа 1981, Москва 1983, 273 и след. С этоя точки зрения весьма понятен вторичнья материальның аспект, появляюминся здесь в грубом "пуховике" (319) и в "canorax" (325), а также наличие "последнего возгласа плоти" в "крике" (уподобленном "камню", 321-322). Ср. еmе градацию в "Поэме воздуха" от "каменного мешка" плоти до "газового мешка" души и высвобохдение из них духа, а потом мысли. См.: М.Л.ГАСПАРОВ, "Поэма воздуха' Марины Цветаевон: Опьт интерпретации", в: ук. соч., 139.

122. Э.А.РИКМАН, "Место даров и жертв в календарноЯ обрядности", в: ук. соч.. 173 (и там же ссылки на тэнлора, Леви-Брюля, мосса, Веселовского).

123. "Самы обмен подарками в бвту имеет свое строгое приурочение: он совершается в день рохдения, в день брака, в день смерти, в день нового года и т. Д. - В те дни, которые соответствуют семантике самого 'обмена' и самого 'подарка'". О.М.ФРЕЯДЕНБЕРГ, МИФ и литература древности, ук. соч.. 133; см. также наблюдения над календарноя приуроченностью дарени в статье: Э.А.РККМА, "Место даров и жертв в календарно Обрядности", в: ук. Соч., 176 и др.

124. Здесь уместно обратить внимание на факт, что Цветаевская 'лохь' (или 'Фальшь') не имеют характера коммуникативного акта со сдвинутон референцие и разрывом мехпу планом выра- 
хения и планом содерхания. Такая 'лохь' называется у цветавон 'обманом' и встречается кранне редко (один из немногих примеров - стихотворение "Прокрасться...", но там "обман" несет эащитную Функцио, является способом преодоления детермннантов земного бытия) . Цветаевские 'лощь' и 'фальшь' - исконные свовства плана вырахения и означают нетохдество с чистьм планом содерхания. Поэтому и возмохны у нее такие оксюмороны, как в следуюмем стихотворения (12 декабря 1923; Cиח III, 133-134):

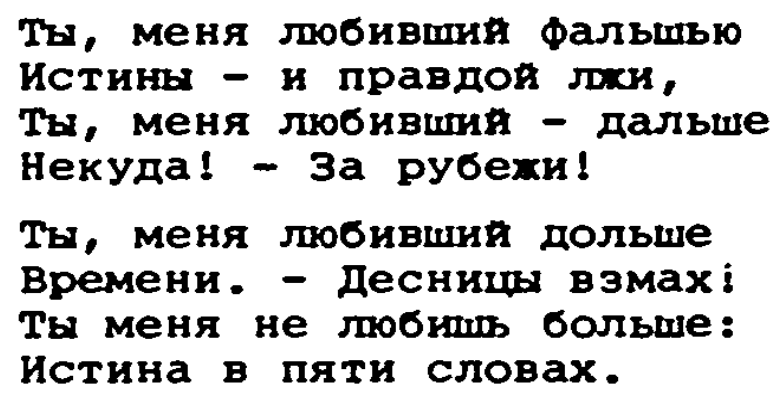

Любовь, дахе наиболее истинная и интенсивная ("дальше Некуда!"), - все-таки 'лкива', ибо предполагает обособленность любянего. Снятие ще обособленности энаменует конец любви. Поэтому у Цветаево пюбовь никогда не осудествляется, она в этом смысле трагична, но, С другоя стороны, - она является одним из способов (путен) самоотождествления.

125. Равенство, а не тохдество, под видом, например, братства или родства выбирается Щветаевои, по всеи вероятности, как неитрализатор разиитељьх признаков, а не как их устранитель: судественно не столько отсутствие различительных признаков, сколько лишение их их детерминируюеего характера (что при ином выборе могло бы быть менее очутимо).

126. Эта шкала покоится в основе многих лирических сюхетов цветаевоя, особенно любовных, которые кульминируют не в точке 'брак', а в точке 'смерть' (типа "Предсмертного лоха свадебного" - см. "что, Муза моя? Жива ли еме?..." 15 января 1925: СиП III, 124). Брак, образуюция социальные роли "мука" и "жены", - в системе цветаевон принципиально отвергается.

127. По сути дела это бы был возврат в первоначальное состояние, как в стихотворении "Сивилла - младенцу" (17 мая 1923; СиП III, 25-26) из цикла "Сивилла": "Ты духом был, ты прахом стал. [...] Смерть, маленьки, не спать, а встать, Не спать, а вспять. [...] Восстанье в день".

128. См. Статьи "СЕЯТЬ", "ЖАТВА", "ПЯТИДЕСЯТНИЦА", "СЕДМИЦА", "ХАРИЗМЫ", "ДУХ", "ДУUіА" В: Cловаро библейского богословия, под редакцие Ксавье Леон-дюфура и др., Брюссель 1974, Издательство Жизнь с Богом, колонки 1028-1031, 338-340, 958$962,1023-1024,1199-1203,300-312,313-317$.

129. Там $x e$, кол. 1024 (Статья "СЕДМИША /НЕДЕЛЯ/").

130. Там хе, кол. 256 (статья "ДАР"; ср. еме статьи "БЛАГОДАТЬ, МИЛОСТЬ", КОЛ. 53-58 и "БЛАГОДАРЕНИЕ", КОЛ. 50-53). ЭТОТ смысл дара легко читается в триптихе "Магдалина" (СиП III, 94-95), в последовательности 'расточительность - распродажа $\rightarrow$ опознание в безьмянном Ты ЕГО-Христа $\rightarrow$ одаривание мастями - издаривание-исструение' (детальнее об этом См. в моем разборе "Магдалины"). 
131. См.: М.Л.ГАСПАРОВ, "Поэма воздуха' Марины Цветаевон: Опыт интерпретации", в: ук. сои., 139 (\$ 33: "Христос. Амфион. Op(en").

132. См.: В.В.ИВАНОВ, В.Н.ТОПОРОВ, "Славянские языковые моделиругине семиотические системы", В: ук. соч., 129, 135. В частности, авторы говорят также о представлении весны птицен вообще, О связи птишы-весны с понятием и $\mathrm{p}$ ь я или рая и отмечают эквивалентность птичьих и звериных (коровы, быка, свиньи) образов как образов весны и солнца. В этом контексте соотнесенность Ведуньи в начале поэмы с раем, a в финале с жаворонком оказывается абсолотно последовательной. та же народная система выдерживается и в случае упомннания в финале поэмы тура-'быка'. O жаворонке как символе весны см. также в: Aфанасоев $I, 663-664$.

133. Ср. еще стихотворение "не любовь, а лихорапка!..." (20 ноября 1918;СиП II, 241) из цикла "Комедьянт", где "лихорадка" постепенно подменяется "лицемерием" и "лицедеиством" , все более 'удаляясь" от "любви" ("Не любовь, а лицемерие, Лицедеиство - не любовь!"), и в финале подлехит переведению в "стихи" (ср. примеч. 32).

134. Ср. хотя бы ухе не раз здесь упоминавинеся "не чернокникница! В белои книге...", "Скоро уж из ласточек - в колдуньи!..." и др. Само собон разумеется, однако, что тогда я или персонах ставится в особое положение, отключающее его от мира сего.

135. Ср., например, "имя твое - птица в руке...", где заанаграммнровано и имя 'Блоки' и имя 'Бог'; "Магдалина", где имеет место отохдествление я с обоготвореннои Магдалиноп; "Я страница твоему перу...", где Я - "хранитель" и 'взрамиватель' посевов Господних (в том числе и слова).

136. В связи с этим интересно отметить стихотворение "необьчаяная она! Сверх сил!..." (5 декабря 1921; СиП II, 141), где Благая Весть не поддается воспроизведению (даже Ангелом), а понимание смысла Вести дано как "звон Такойликующин..." и затем "тишв такая...". В этом контексте "голос" становится всего лишь неким промехуточным состоянием логоса (уже не артикулируемвм, но еме звучамим) .

137. См. статьи "В४山ать" и "ЖАВОРОНОК" в: Дало $I, 336$ и 524. Возмохно, что Цветаевская связь жаворонка с Благой Вестью (как в стихотворении "В сокровищницу...") навеяна народньми представлениями О развязывании птичьих языков в день Благовещенья. Ср. Статью: М.Я.САЛМАНОВИЧ, "Румыны", в: Калекдаркие обичаи и обряди ө странах зарубехкой Еөропи. Конеи XIX качало ХX в. Весеккие праздкики, Москва 1977, 302.

138. Ср. Связь ласточки-психеи С понятием страсти и любви в "Не самозванка - я пришла домон..." (апрель 1918; СиП II, 21): "Я - страсть твоя, воскресның отдых твои, Твои день седьмои, твое седьмое небо. [...] - Возлюбленнын! - Ужель не узнаеиь? я ласточка твоя - Психея!" и противопоставление (или точнее: эволочио) 'ласточка как молодость-беззаботность - колдунья как зрелое умудренное состояние' в "Скоро ул из ласточек в колдуньи!..." (7 ноября 1921; СиП II, 136). Если учесть датировку "Переулочков" - "Апрель 1922 Г." - и соотнесенность 
многих Цветаевских вемен с народноң календарноң обрядностью (о чем уже упомнналось в примеч. 50), то небезынтересно отметить, что апрель 1922 года был особо насылен народньми празднествамн: 3-го апреля - Пасха, 23-го - Орьев день и 22-го мая - Пятидесятница (по старому стилю; по новому же два основных весенних праздника приходились на одну и ту же неделю: Пасха 16-го апреля, а ррьев день в следуюмее воскресенье, т.е. 23-го апреля, но с сильно отодвинутои Пятидесятницея - на 4-е нюня).

139. Ср. в стихотворении "Над синеморскою лоханью..." (12 декабря 1921; СиП II, 142): "Объятие, когла руки и ноги и тело - не при чем. Ресни-ца-ми сбропенны вызов: Вырвалась! Догоняя! Из рук любовниковых - ризы Высвобохденны края. и пропастью в груди (что нужны В сем: косное грудь в грудь?) Архангельскон двуострои дружбы Обморочная круть". Этот контекст позволяет усматривать в заклятия Героя Ведуньея освобождение от него и от бохественного обольменья ( СM. O6 этоM B 13. 6.).

140. CM. статы "UNICORN" in: J.E.CIRLOT, A Dictionary of symbols, op. cit., 357-358.

141. C.G.JUNG, "Psychology and Alchemy", in: Collected Works 12 , London 1953.

142. О представлении грома и молни небесноһ трубон и рогом см. в: Афакасоев I, 679-680, 762; Афакасоев II, 347; Афакасьев III, 757 .

143. Цит. по: Афакасоев I, 616. Об эквиваленция коня и тура см. eme maм $x e, 616-617,653-666$.

144. Цит. По: В.В.ИВАнОВ, В.Н.ТОПОРОВ, Исследовакия ө области славякских древкостей, ук. соч., 169. См. еме: В.В.ивАнов, В.Н.ТОПОРОВ, "Славянские язнковые моделируюине семиотические системи", в: $y x$. соч., 132, где обсуждается представление турицы "С $К$ О н С $К$ ○ головоя и ногами, похожимн на П т и ч $и$ и .

145. Если настаивать на связи финала с периодом Пятидесятниш, то тогда здесь мохно было бы усматривать летния переломны момент в восхождения солнца, С которого оно начинает 'умирать', а перевес одерживают силы противника Громовержца. В пределах же чисто Цветаевскон поэтическо системы здесь имело бы место преодоление самого последнего "соблазна земли" (См. в 13.6.), являюмего собон 'притяхение к земле', способность 'воскресать-облекаться' в земные формы, на что указывало бы упоминание "рева" (368: "Реви, заклят") и 'вемевременника' - "хаворонка" . Ср.: "некогда голос был связан с жертвоприношением: он умирал и ожнвал в актах разрывания и еды. Впоследствии всякая 'весть', всякое 'провозглашение', 'глас', 'голос', речевое звучание связываются с 'жизнью' тотема. Вестники 'провозглашают' смерть и оживание растерзанного зверя, словесно дублируя этот акт. В храмовоя обрядности функция вестника - у жреца, провозглашающего в религиях умираюиего и воскресающего бога о гибели и об ожиВания божества" О.М.ФРЕДДЕнБЕРГ, Миф и литература древкости, ук. соч., 138. Слова "Взор туп" (369) в контексте "Прямо в очи глядят, - не застятся В переулочках тех игнатьевс-

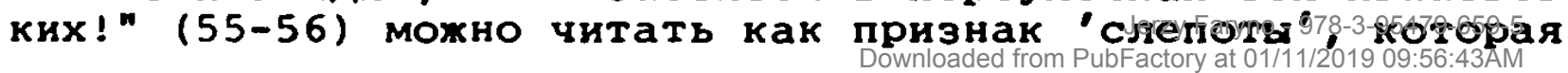


в сочетании C 'ревом' осмыслялась бы как признак 'творческого, поэтического', тоже являюмегося в системе цветаевскон препятствием, ограничением на пути в бесконечность и поэтому подлежамего радикальному преодолению.

146. СМ.: О.М.ФРЕЯДЕнБЕРГ, Миф и литература древкости, ук. соч. 69-70. С. рассухдения самон цветаевон в "Земньх приметах" (1919; Проза I, 115-116):

"я хочу в тебе уничтохиться, то есть я хочу быть тобо . но тебя уке в тебе нет, ты ухе целиком во мне. Пропадак в собственно груди (тебе). Я не могу пропасть в твоен груди, потому что там тебя нет. Но, может быть, я там есть? (Взаимная любовь. Души поменялись домами). Нет, и меня там нет. там ничего нет. Меня же нигде нет. Есть моя грудь - и ты. Я тебя люблио тобод.

Захват? Да. Но лучше, чем товарообмен.

Ну, а взанмная любовь? (Товарообмен). Единовременния и перекрестны захват (отдача). Два пропада: дуин X в собственнои груди, где $Z$, и дути $Z$ - в собственнои груди, где $X$.

Но раз я в тебе живу, я не пропала! Но раз ты во мне живешь, ты не пропал! Это бытие в любимом, это "я в тебе и ты во мне" "это все-таки $\&$ и $m и$, это не двое стали одним. Двое стали одним - небытие. Я говорила О небытии в люобнмом.

\section{... Когда ухе ничего не мое - все мое! Это прямоя доро-} гон подводнт нас к смерти: Физическор смерти любимого. только не смениванте с ревностью! "Не будь" ревности - от ниметы и страха. ("Раз в гробу, то уже нет соперников!") Для захвата ни соперников, ни гроба: "не будь" захвата - это последния отказ, даюми последнюю власть".

147..J.G.FRAZER, The Golden Bough, London 1911-1915 (Chapter "The Sympathetic Magic").

148. Ср. эквивалентность "эова", "пожара в груди" и "Рога" в стиХотворения "Роландов рог" (март 1921; СиП II, 298):

Стою и шию, закаменев от взлету,

Сен громкз зов в небесные пустоты.

и сен похар в груди тому залог,

Что некин Карл тебя усльинт, Рог!

149. CM. статью "TAURUS" in: J.E.CIRLOT, A Dictionary of symbols, op. cit., 331-332.

150. См. примеч. 28 и в бълине:

А и третьеи-то мудрости учился Волх

обертываться гнешым туром - золотые рога.

Цит. По: В.В.иВАнОВ, В.Н.ТОПОРОВ, "Славянские моделируюине семиотические системи", В: уж. соч.131.

151. См. там хе, 168-175. кроме того имеет смысл учитыать здесь и распространенное мнфологическое представление "скот = души умериих поден" и мотивы из запирания или освобохдения. См.: В.В.ИВАНОВ, В.Н.ТОПОРОВ, "Исследования в области славянских древностея", в: ук. соч., 70-71. Тогда 'рассечение' "тура" и "От ворот - поворот" читались бы как разъятие на смертную телесную оболочку и остаюмуюся в пределах ворот 'дyury'. 
152. См. главу "HEAD" in: J.E.CIRLOT, A Dictionary of Symbolo, op. cit.. 141; H.KUHN, L'ascension de l'humanite, Paris 1958.

153. СМ.: В.В.КВАНОВ, В.Н.ТОПОРОВ, Славянкие язаковие моделируоиие семиотические системи, в: ук. сои., 131.

154. Cм. статьи "BULL", "TAURUS", "OX", "hORNS" in: J.E.CIRLOT, A Dictionary of Symbols, op. cit., 33-35. 331-332, 247-248, 151-152; Афанасьев I, 196, 653-664; В.В.ИВАнОВ, В.Н.ТОПОРОВ, "исследования в области славянских древностеи", в: ук. сои., 168-172 и др.

155. Другое дело, что по Цветаевои искусство тохе есть "искус", воздерживающи по эту сторону бытия. Ср. стихотворение "Прокрастьdя...", темоя которого является как раз преодоление (отказ от) предначертанности быть худохником. См. такхе некоторые наблодения над взаимностью у Цветаевоя категория 'любовь' и 'поэзия' а шире - 'Страсть' и 'искусство' в стаTbe: A.M.KROTH, "Toward a New Perspective on Marina Tsvetaeva's Poetic World", in: op. cit.

156. С этон точки зрения адресованные к Герою слова "башковиткрасновит" (23), "Уста мои сахарные" (66) и др. - не только льстивые комплименты, но и признак 'соблазненности' или 'обольиеннссту' самои Сводни-Ведуньи. На этом механизме строится, В частности, постепенная идентификация $Я$ с вообрахаемои Магдалиноя в первом стихотворении триптиха "Магдалина" (см. 1.4.-1.5.4. в моем разборе этого произведения).

157. "Характерноң чертоя культуры с мифологическоя ориентацие является возникновение мехду языком и текстами промехуточного звена - текста-кода. Этот текст может быть осознан и выявлен в качестве идеального образца (ср.., например, роль "Энеиды" Вергилия для литературы Воэрождения и классицизма) или оставаться в области субъективно-неосознанных механизмов, которые не получают непосредственного вырахения [примеч. 7: До тех пор, пока они не сделались объектом научноя реконструкции.], а реализуются в виде вариантов в текстах более низкого уровня в иерархии культуры. Это не меняет основного: текст-код является именно текстом. Это не абстрактның набор правил для построения текста, а синтагматически построенное целое, организованная структура знаков. Следует подчеркнуть, что в ходе культурного Функционирования: в процессе текстообразования или при исследовательском метаописании - кахды знак текста-кода может представать гред нами в виде парадигмы. Однако "для себя", с позиции своего собственного уровня, он выступает как нечто наделенное не только единством выражения, но и единством содержания. ДифФузны, амби- и поливалентның, распадаюиияся на парадигму эквивалентных, но разных значения, то на систему антонимических оппозиция для внешнего наблодения, "для себя" он монолитен, компактен, однозначен. Входя в структурные связи С элементами своего уровня, он образует текст, наделенны всеми признаками текстово реальности даже если он нигде не выявлен, а лиш неосознано судествует в голове сказителя, народного импровизатора, организуя его память и подсказьвая ему пределы возможного варьирования текста. Именно такая

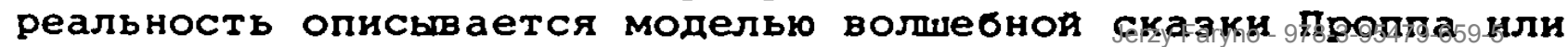


моделью детективного романа Ревзина. Супественно подчеркнуть, что эти исследовательские модели описывают не структуру объекта (она лишь косвенно выводится из этих описания), а стояпи эа этои структурод реальны, хотя и невыявленны текстовы объект [примеч. 8: Мы называем этот объект текстом-кодом и отличаем от описы⿴аңмего его метатекста Проппа и др.]". D.м.ЛОТмАН, "Текст в тексте", в: Труда по зиаковим системам, т. XIV: Текст в тексте, тарту 1981, 6-7.

158. Это явление у Цветаевоя повсеместно и охватывает все уровни ее произведенин. Его сумность не столько риторична (направленная на построение текста), сколько герменевтична или экэегетична (направленная на выявление смысла), что независимо от результатов с необходимостью роднит Цветаевскук систему с теологиея. Готового, "чужого" слова у Цветаевон нет (отсода минимальная роль ханра сообщения, нарративности, цнтация или реминисценция), а если и есть, то оно либо отвергается либо отодвигается в 'пред-обиходные' сферы. Ср. в "Поэме конца" (1 Февраля - 8 кюня 1924; СиП IV, 173): "- Любовь - это значит: жнзнь. - Нет иначе называлось у древних...". Слово подлежит реартикуляция и переосмыслению вплоть до лишения его всякого плана вырахения и отчуждаемости от говорямего (От Я) отсюда бесконечные переназывания или семантические парадигм (ср. роль двоеточия, тире, отчерков, обрывов или непривыгных синтаксических конструкция; это превосхопно апнсано в: О.Г.РЕВЗИНА, "Знаки препинания в поэтическом языке: Двоеточие в поэзия М.цветаевон", в: Marina Cvetaeva. Studien und Materialien, Wiener Slawistischer Almanach, Sonderband 3, Wien 1981; О.Г.РЕВЗИНА, "Из лингвистическоя поэтики (деепричастия в поэтическом языке М. Цветаевоя)", в: Проблеми структуркой ликгвистики 1981, Москва 1983). Наравне со словом и язьком переосмысляются и реартикулируются предметы, люди (с самим Я включительно), события и сюжеты - они тохе выстранваются в парадигматические серин, в пределе которых маячнт чисты бестелесны смысл. Ср. внутреннюю и взаимную парадигму вемен в "Поэме лестниш" (июль 1926; Сй IV, 265): "Сткло, с полок берехных: - Пе-сок есмь! Вдребезги ж! [...] Тю-Фяк: солома есмь! Мат-рас: есмь водоросль! Всё, вся: природа есмь! Час пахнет бомбою. Ве-ревка: льном была! Огнь, в куче угольноя: - Был бог и буду им!" телесную видоизменяемость Я, колдовские метаморфозы Ведуньи, Героя, прерьвность - от этапа к этапу - сюжета (как в "Переулочках" или "Поэме воздуха"), погрухения Я вовнутрь и "перерывание" сознания (как в стихотворении "Сон" - 24 ноября 1924; СиП III, 113-114) и т. П. То же самое имеет место и в случае восприятия внешнего по отношенио к Я мира, предел которого - ндентификация субъекта с объектом на самом глубоком, так сказать 'инвариантном' уровне. Ср. в "Так вслушиваются..." ( 3 мая 1923; Сип III, 72-73): "Так внюхиваются в цветок: Вглубь - до потери чувства! [...] так влюбливаются в любовь: Впацьваюся в пропасть" или в "Имя твое - птица в руке..." (15 апреля 1916; СиП I, 227), где выговариваемое имя заглатывается Я вовнутрь и становится органическим состоянием Я (но не только оно теряет какую-либо произносимость - Я тохе впадает в гулбокое оненрическое состояние, в забытье). Выявление сущности и требование непосредственного контакта на уровне сумностея и создают основу как Цветаевскоя мифо- 
логия, так и Цветаевско теологин. Доскахем еме, что и чужие сюжеты (как в "Магдалине" или в фольклорных вещах) Џветаевоя не заимствуются, а подлехат осмысленио, сущностному восприятио (в Цветаевском понимания), чем и объясняется отохдествляемость Я (а в краннем случае - неотличимость) С персонахами этих сюхетов (как с Магдалинон или Ведуньея). 
a

$\therefore$ -

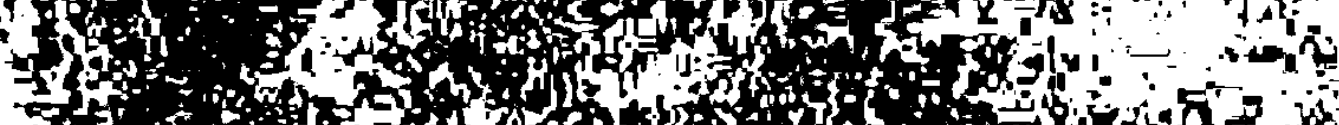

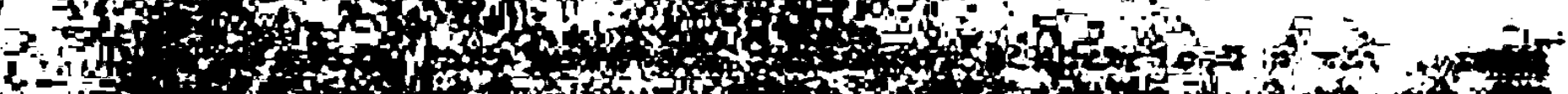

2ta

of

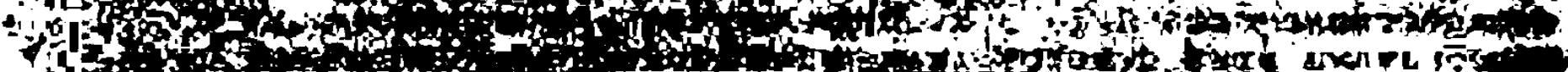

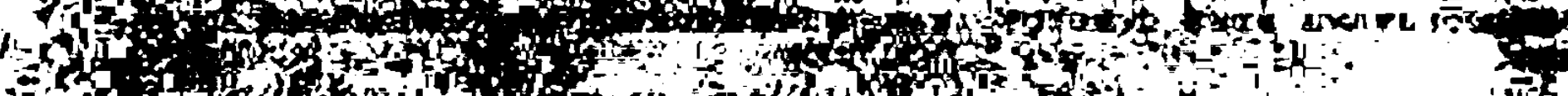

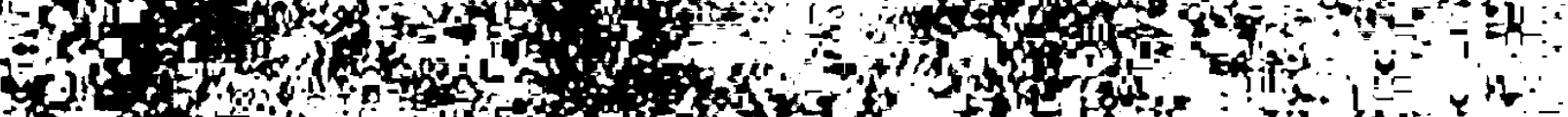

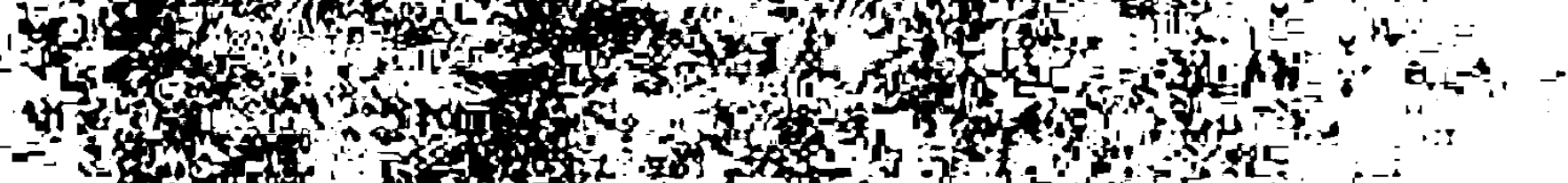

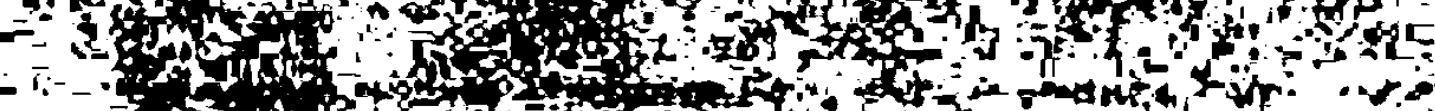

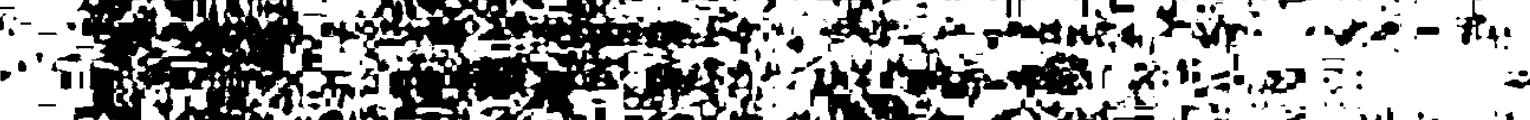

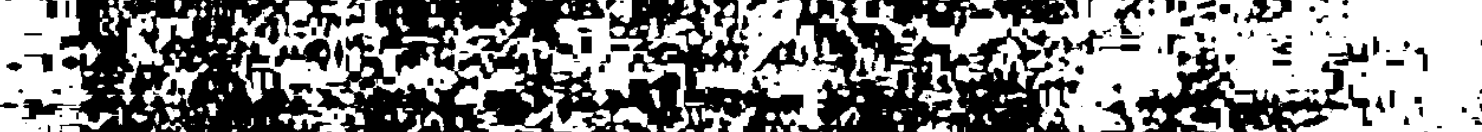

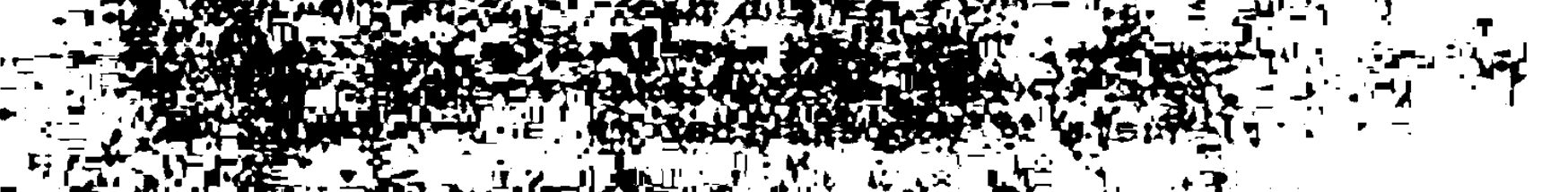

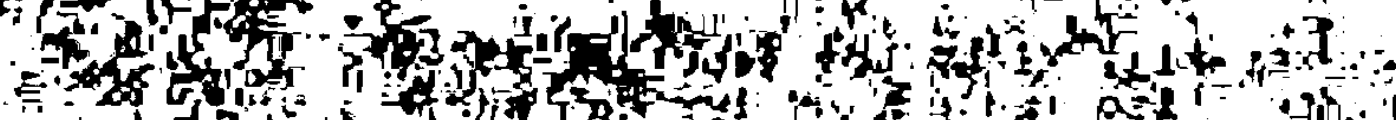

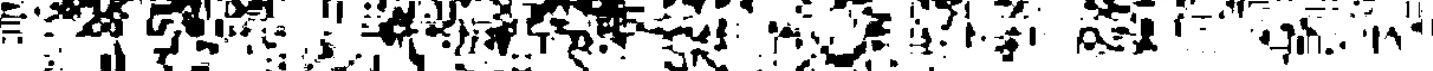

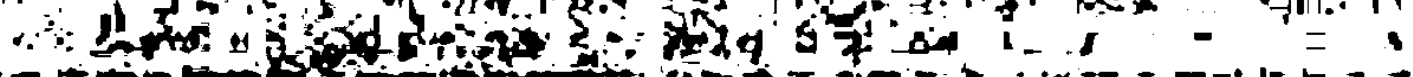

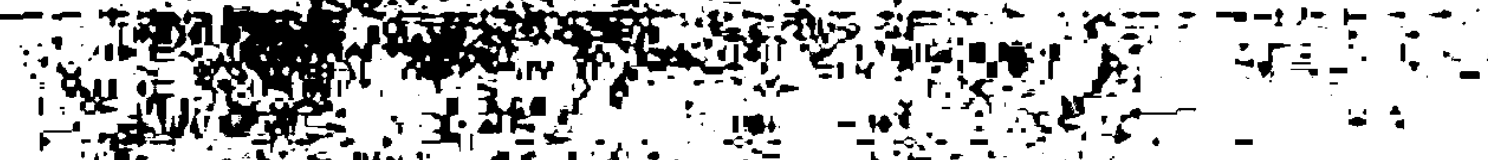

4.

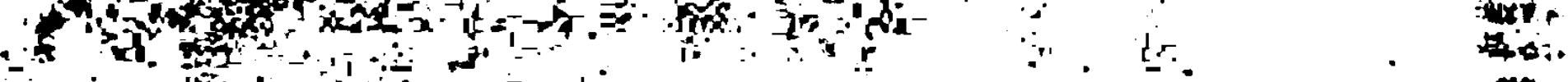

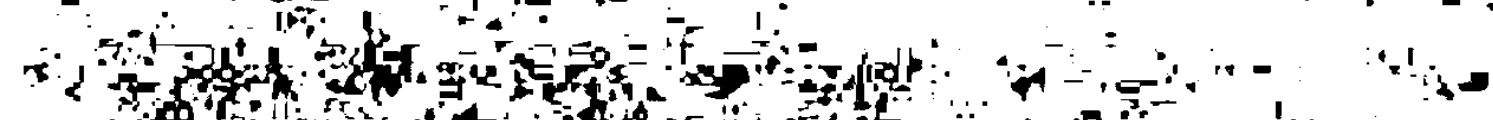

- i lof

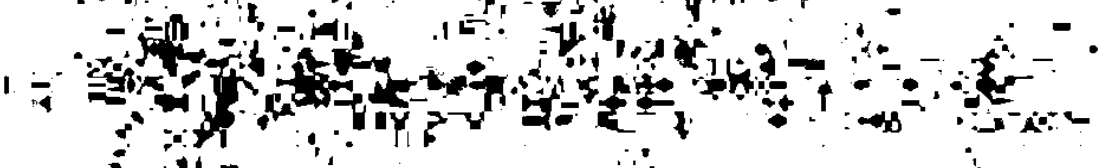

पif

$\therefore$

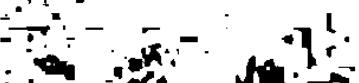

$\frac{1}{28}$

‥

$\geq p^{0}+m^{-1}=$

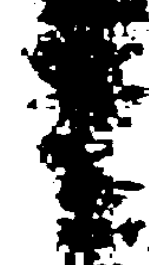

at:

.

$8 x$

4

$\rightarrow$

जitio

40

os

ans:

- neter

-

?

,

15

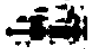

:

1.65

$\therefore$ -

An Ali

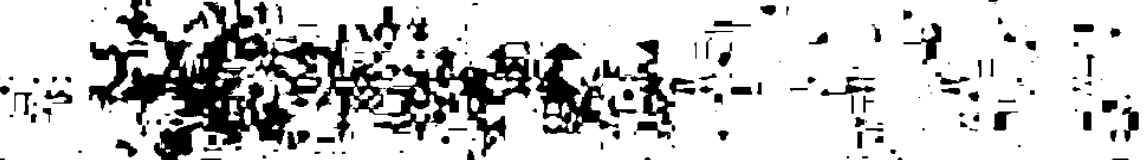

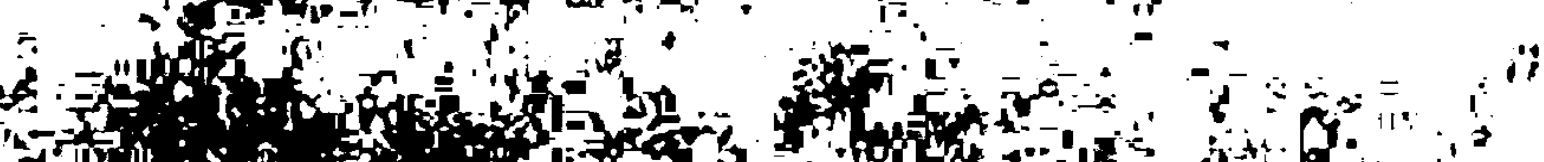

11 Mind 0 ,

11.

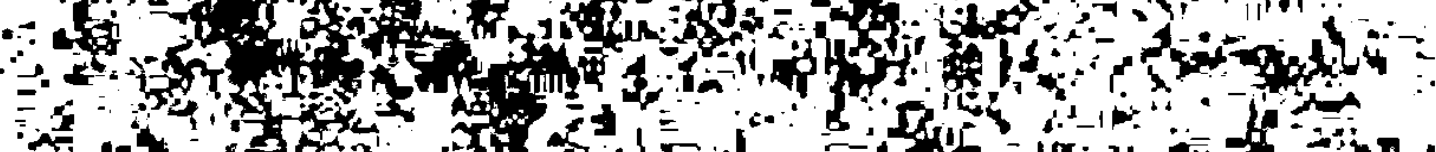

mate

ind

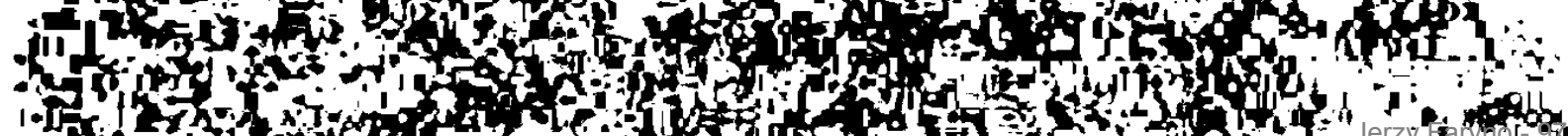
1.If

.

12

tris

Ty

is

i 


\section{SOME ASPECTS OF CVETAEVA'S POETICS}

(Instead of a Résumé)

I.MARINA. In previous poetical formations it is hard to find at least one poem in which a lyrical subject "I" would call itself by name, although there are numerous ones where a proper name has an inner poetical addressee "YOU". Avant-garde trends, particularly Acmeism and Futurism, have changed even this situation. Majakovskij's "I" has a name, "Vladimir", and sometimes even "Vladimir Majakovskij", Xlebnikov's "Velimir", Axmatova's "Anna", which appears however more often in a latent form, as in translation from old Hebrew "Hanna" meaning "grace, charm, pleasure" and "favour, blessing" and so on (see 39). Similar but also different is the situation with Cvetaeva. Her "I" uses the name "Marina" and its derivatives, but the addressee, "You", is nameless on the whole, even in the works of the epic character as for instance in the poem $P e-$ reulodki (sidestreets) where it happens that the hero remains anonymous.

Similarly to Majakovskij, Xlebnikov (see 58: 186-196), Mandel'stam or Axmatova Cvetaeva also leaves her lyrical subject without any name, using its meanings instead and placing on them the whole material load of the composition or the whole innertextual systematics. She translates her baptismal name as "marine" and surrounds it with a set of relative aquatic equivalents: "water", "foam (marine)", "wave", "sea"; dispersing, vanishing and reviving again similarly to waves braking against a cliff; comp. Dusa $i$ imja (Soul and Name), Kto sozdan iz kamnja, kto sozdan iz gliny... (Some are made of stone, some are made of clay...; for the analysis of this poem ss 17), a set of five poems entitled Pesenki (Songs) or a poem Xocer' ne chode $z^{\circ}$ - dam tebe znak... (No matter whether you want it or not - I' $l 2$ give you a sign...) where the words "Kak s motylkami tebja delju - Tak s morjakami menja podelis'l" ("As I share you with butterflies - You will share me with marines") are based on the equivalent "I = flower" (Russian "cvet") and "I = sea" and also "fate" (so: "I = Marina", but not only in the meaning of Russian "more = sea" Cvetaeva sometimes understands as the Latin "mori" from the saying "memento mori" = "remember of the death", which is clearly visible in the words "Už ne memento, - a prosto - more" "No more memento - but simply - sea!" from the Poema gory - Poem of the Hill; see 14).

Regarding "Anna" Axmatova, read literally, places her "I" directly in metaphysical spheres, so to say on the level of theological notions, "Marina" requires one more step, and Cvetaeva always remembers 1t: she "consecrates" or "mythicises" her water - she elevates it to the level of a cosmogonic element, 1.e. provides it with features and meanings such as are assigned to water both in slavic and ancient (Greec) mythology as well as in Christian theology (oomp. Dusa $i$ imja - Soul and Name). In this way she gives herself or her lyrical "I" the character of a world-creating power, at times independent, equal to the creator (clearly visible are the traces of a folk tale about the creation of the world by God and the Devil, who emerged from the foam; and so Cvetaeva's "I" often describes itself as foam taking over its demonic character - see 17) and sometimes to the chtonic element but always having the satus of a fundamental principle of existence, of being (water of "I" can take the shape of the saliva of an adder signifying a secret magical 
wisdom ruling over all that has been or has not been created, see "saliva = whispers" in the Pereulodki).

Cvetaevan motives with her last name - "Cvetaeva" - have less visible links. But even here one can trace such origin in the transformation of her "I" into osiers, a honeysuckle, ivy, a blooming paradisiacal apple tree (and even chess as it is the equivalent of a tree of life). The difference is that while her set of equivalents from "Marina" shapes the spiritual sphere, the equivalerts of "Cvetaeva" form a bodily (material) and sensual sphere.

Axmatova's "I" and Cvetaeva's "I" have their historical predecessors - Annas and Marinas - and often they identify with them or find in themselves some of their characteristic features. While Axmatova refers to the Grand Dutchess St Anna from Kashin (Axmatova was born on the eve of this St Anna's day celebrated by the orthodox on June 12 (25); see 39: 51-53), Cvetaeva - aside from Saint John the Divine (comp. Krasnoju kist'ju rjabina zazglas'... - The rowan tree set on fire with red berries...) in which her theological tendencies are seen - particularly fancies Maryna Mniszchówna, both historically (being of Polish descent) and literarily, mainly from Pushkin's Boris Godunov (it is worth noticing that Cvetaeva's "I" also derives its origin as "marine" and "Marina" from Pushkin's marine themes) and also from folklore - a nameless witch of the $P e-$ reulodki has its archetype in Marinka from an ancient Russian epic song - bylina - of the Dobrynia Nikitic cycle (and it probably derives from the historical Maryna Mniszech - see $31: 18$ and 225.226). She has even succeeded in imposing on Mandel' completely different structure, the role of Dimitrij while offering him Moscow during his first visit to Moscow in 1916 (6, I: 364$)$. Returning the gift, Mandel'stan writes Na rozval'njax, ulozennyx solomoj... - On sleigh inlaid with straw.... In which he recognizes himself not so much as one of the Pretenders or False Dimitrij (Maryna Mniszchowna's husbands) but more as "Tsarevich", eight year old Dinitrij, the son of Ivan the Grim, the victim of a conspiracy, and Aleksej killed by the father tsar Peter I (see 22).

In the same way Cvetaeva treats her heroes and addressees as "You". As I alread ${ }_{y}$ mentioned they are, on the whole, anonymous. But the works are not anagramatic. The reader's task is not to decipher the name but, together with the speaking subject, reach its own being hidden behind this name and possess it totally or unite with it. It has the form of articulating the name, its semantic analysis, removing the features or meanings which can be removed, $1 . e$. those which are not essential. And thus in the poem Imja tvoe - ptica $v$ ruke... (Your name - a bird in hand...) from the stixi $k$ Bloku (Verses to $B Z O k$ ) "I" comes to unpronounceable 'God' and the process of coming has the character of the holy communion, of receiving God's Word (see 15). In the poem Nebo katilo sugroby... (The sky rolied the snow drifts...) opening the cycle Sugroby (Snow Drifts) dedicated to II'ja Erenburg, the dominating motives are "thunder" which is the semantics of St II'ja (St Elijah'), the Thundering on the ane hand and a "whoman" and "town" on the other - the semantics of the name "Ehrenburg". But this is not the end. The deciphering of the addressee's name will reveal its proper meaning when we realize that sugroby appears during time of the carnival, Russian Maslanica, when there is a visible turn in the life of cosmos, when the first thunder wakes up and the demonic winter forces gradually start to retreat. "Town" only partly originates from "burg" as it primarily comes from the folk images (ideas) of the winter sky (clouds) as caves, fortresses, and castles where temporaty thunders and heavenly waters have been kept (see 11, Ifiri:43:696-697). 
And only in this context does the final location of the "resounding thunder" "mezdu nebom $i$ nëbom" become clear ("between the sky and the palate": as the speaking subject "I" absorbs the articulated "name" and, as the being, it identifies itself with the universe, with the world creating and world-carrying power; see analyses of Magdalina and Pereulodki).

II. SOMA. In the previous poetical tradition, symbolists included, "I" is entirely mental and although it becomes particularly sensual and emotional especially at the end of the XIX century it still remains abstract, stipulated and more importantly - bodiless (asomatic). Even Pushkin's Prorok (Prophet) is no exception, as the autopsy of his "I" is of a mystical character (see 15, III: 106 and fol.). At the instance of acmeists and futurists the structure of the lyrical subject has totally changed even in this respect. "I" is no longer a mere soul but also a body.

Majakovskij's "I" makes public presentation of its body, performs its autopsy, turns it inside out like a shirt, treats it like a musical instrument and so on. In one of his earlier poems Mandel'Stam says: "Dano mne telo - Cto mne delat' s nim, Takim jedinym 1 takim moim?" ("I have a body - so what to do with it As it is so exclusively mine?"). Axmatova's "I" has a lot of features of her physical appearance. Cvetaeva's "I" is slightly different: it has very little in common with her looks but it always exists physically as a material person of flesh and blood.

One of the tendencies which stands behind this phenomenon (best seen in the case of Majakoskij) can be called the democratization of a man, a restoration of the balance between a public and private man, between an ideological (in a broader sense) and a biological one - similar to an ancient democratic man where the difference between the public and private sphere was unknown (see 21: 238-246, 253-259). It is the same tendency that we know from modern architecture: the outer glass walls enable one to see the interiour, the inner walls imitate the old ones protecting against the penetration of undesireable eyes, but altogether ot makes the impression of staying in a street, on such a square, or among other people.

Another tendency of no lesser importance but at that time very little recognized was the one considering a man as a cybernetic machine: as a collector, convector and transmitter of the information received from the outside, mainly on the levels beyond the scope of the "standard" mental or verbal division. Edward Balcerzan calls this man a "Kontakter" - "Contactor" (see 3: 119-136). It is not difficult to find the features of such a man in Mandel''stam's or Axmatova's "I". Mandel'stam's "I" mediates between the history and the present day and the future. It interacts with the history of comprising one within the other, that is, the history within "I", but without identification with the baggage of the heritage. Axmatova's "I" is a specific store of memory but also not identical with "I" itself. But Pasternak's or Cvetaeva's "I" can be trated as the indivisible contactor totally united with the outer world (with the assumption that in Cvetaeva's works this phenomenon is based more or less clearly on the theological conception of the uniting of $l o g \circ i$ in pursuit of Divine Logos - God; comp. 41 : 167-178).

The fact that the lyrical its consequences in the case of the Muse and the the Muse or Inspiration less often descends from above, 1.e. from a body also has heaven, but comes out from the nether world, foron nhel-1954xmatova, 
Mandel'stam, Pasternak), from within "I", from its own body (Mandel'Stam's "guby" - "lips". Axmatova's "ilxoradka" - "fever", Pasternak's "vysokaja bolezn" - "high decease", Cvetaeva's "Iixananka". "znob"n - "fever". "shivers"). The text itself, instead of having an author, becomes the author's author (Mandel'stam's "Cuzaja pesnja" - "somebody else's song. Axmatova's compulsory writing to somebody's dictation, the "deserts" writing instead of Pasternak's "I") and wants to be Identical with the author (see Toporov's remark in 56). In this respect the proper name (or more precisely the author of self-model) is also the author's author. It provides the author with the categories for self-articulation and self-modelifing on the one hand and it essentially reduces if not liquidates the distance between the real person of the poet and the stipulated "I" of the text in the other, introducing this real person into the text. It is self-evident that this general culture tendency appears in different ways in various artists, it shapes different things and serves different purposes.

The body of Cvetaeva's lyrical subject has two essential functions: it absorbs the information (world) and consequently emits 1t, already transformed, in another shape.

The first function is expressed by the aggressive, invasive, conquering and captivating body. In this case it usualiy has the shape of a cave, grotto, closing shell, shutting palms, embracing arms and encircling and closing within mountains, and a forking river, and the incorporated world takes on the shape of a rolling in a wave, a cultivated pearl, caressed island and so on. This picture is automatically associated with a feminine element, with a lunar and aquatic system (see chapter IV and V in 10; see also 15: 162-165): still this is merely one of its aspects but not its most important.

The second function os expressed by almost literal transformation and emission of information. And so, for example, in the poem Ja - stranica tvoemu peru... ( $I$ am the page for your pen...) "I" identified with the earth gives back the Creator his inseminating rain in the form of poetry (vomp.12: 406-407); in the poem $V 8 k r y l a$ zily: neostanovimo.... (I opened my vains: unrestreinedly...) instead of blood, the iife and poem sluice out of "I" (Russian: "Nevosstanovima xlescet żizn' ... Nevosstanovimo xlescet stix" - "Unreturnable effuses life ... Unreturnable effuses the poem"); in the Rakovina (Seashe 2 ) the lover conquered and burled in the chest of "I" turns into a pearl which signifies the ennoblement of the spirit in Cvetaeva's systematics. In the Pereulodki the hero engulfed by "I-witch". is turned into the "last earthly temptation" ("poslednij iskus zemli" - 6, I: 395) that is, into the equivalent of the poetic word, "gold horned bull" (zodiacal Taurus governs the throat and voice). And only here, as we can see, do more essential perspectives of Cvetaeva's erotics (partly seen in 34) open up.

III. MULTINAME AND MULTISHAPE SUBJECT. What I have al ready said is only true with regard to each poem separately: then Cvetaeva's "I" really has a name and body. But if we consider all her poetry or at least several of her works together the picture is totaliy different.

Both in classical and in the majority of XX century lyrical works the lyrical subject is invariable: although it can express or experience different emotions it still remains the same. Thus, very often even a sort of blography composed by the poem can be created (such 18 "I" of Blok, Mandel'stam, Pasternak to name a few

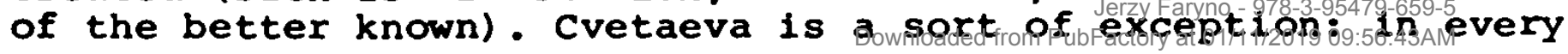


poem her lyrical subject can change not only its name but also its physical shape. In one poem it is Marina and a continuously reviving sea wave, in another Eve, Sybil, Hagar, Magdalene or somewhere else a witch, sorceress, harridan, viper, butterfly, earth or someting else. In this respect, having a name it has none and having a body it is bodiless as it takes on a different shape on any occasion. It would not be so fascinating were it not for the fact that "I" takes such names not on the basis of the conventional metaphor but on the basis of the metaphor realized - it becomes the thing it calls itself - totally identifying with a given character. And this is what I have in mind when I talk about the variability or inconstancy of Cvetaeva's lyrical subject.

Cvetaeva's "I" often changes its addressees or partners "You", but there is a certain stable element in this variability. As a matter of fact, "YOU" is alsways one and only the same one (or more precisely invariably similar). And that is probably why it neither has a name (expressed explicitly) nor a more distinctive material shape. It is a person or personality with definite stable features. The requirements regarding the addressee are also generally the same. If it is not perfect it at least has to equal "I". If it is perfect it ends up with passing by "I" and "serene tenderness of meetings in the other world" ("Neznost"!.... Potustoronnix vstrec" as in the poem Rano eże - ne byt'l... - Still too early - not to be...) as this unity appears on the level of logoi. If it is "equal" to "I" there is a risk that it will be totally annihilated, totally absorbed or engulfed by "I" and taken to the other world where "there is neither husband, nor wife" nor where "there are such-words - For You - mine..." (Pereulodki: "ni muža zdes', ni ženy: Sugroby: "daze slov-to net: - Tebe - mojej.."). This "You" is usually the object of the lyrical subject's love but never becomes its sexual partner not even mentioning husband.

IV. GETTING RID OF THE BODY. The cantinuous variability of names and shapes of Cvetaeva's lyrical subject or heroes indicates more than merely her inventiveness or folklore examples (particularly the transformation of persons and objects in a magic fairytale). This variability can easily be noticed within particular works or their series arranged by the poetess in certain cycles, and in certain order: it takes a pattern "from to" based on the gradual riddance of the body by "I", by riddance of the material shape and any possible links with the surrounding world.

In the cycle Bessonnica (Insomnia; for its analysis see 16, and the poem $V$ ogromnom gorode moem - nod... - In my huge city it is night... in 24) in the case of personified sleeplessness: "I" falls asleep, a special state meaning sleep-watch in opposition to the physiological sleep treated as a passice state and characterized by death. In this watchful sleep "I" starts on a journey, a trip to the other world. But first it gets rid of all names (distributes them), next of all family and friendly ties: "ljudi dumajut: Zena, dot'. A ja zapomnila odno: not'.... menja net... Osvobodite ot dnevnyx uz, Druz'ja, pojmite, Cto ja vam - snjus'" ("people think: a wife, a daughter. But I remember one thing only: the night. ... I do not exist. ... Friends, free me from daily ties, Understand that you dream me only."). At the same time the chest partition becomes so thin, that the wind penetrates through ("skvoz" stenki tonkie grudi - v grud'"), the angel-like body becomes weightless and "I" turns into a visitor in a certain "heavenly country". Next "I" compares itself to a "Cernica" - "nun" pointing ${ }^{n}$ gut in 
this way the riddance of any sensual element and reaching the state of immaterial soul. But it is still too little: the soul is not a spirit yet (see 26: 139), it is still too animistic: "Vzdymajutsja ne volosy, a mex! I dusnyj veter prjamo $v$ dusu duet" - "Not hair but fur rises up And choking wind blows into the soul". So next it descends to a lower level - it changes into a seashell "in which the hum of the ocean has not died out yet" ("gde esce ne umolk okean"; here an association with Lamarck of Mandel'stam in Ivanov's interpretation comes to mind - see 28: 56-60) and finally it melts into the pre-ocean of "sea" and "dawn" while drinking it ("Ty more p'ës'. Ty zori p'ës"."): "the world disappears with no news in the shores sunk nowhere" ("Mir bez vesti propal. - V nigde zatoplennye berega") and "I" reaches the state of non-existence or ideal existence united with the being of the cosmic ocean itself and at the same time with 1 ts own being remaining in the assumptive "I - Marina".

We have to remember that most of the poems from the Bessonnica cycle were written in 1916 , i.e. In the period of the formation of Cvetaevan poetic code. Later it will become more developed in, so to say, a "theological" and "self-thematic" direction (the poem Pereulocki - 1922, Magdalina - 1923, Poema vozducha The poem of the Air - 1927), the spacial and hierarchical structure of her world will become clearer. But the apophatic principle consisting in getting rid of any outer manifestations accessible to the senses, coming to oneself (to one's own logos or nous) and to the being of the world (Logos, Absolute) will remain in the unchanged form.

V. THEOLOGY. In the triptych Magdalina "I" gradually identifies itself with the evangelic harlot: while adoring and tempting "YOU" it experiences violent exorcisms and a mystical revelation. In "YOU" it recognizes Christ unnamed in the text, and in itself a woman from Magdala, 1.e. Mary Magdalene (regarded in the Orthodox as equal to the Apostols).

The following two poems of the triptych can be read as the epectasis, which means "impetus, extreme tension and [...] synthetizes two aspects of one act: ecstasis - exit, and entasis - entrance. The soul tears out from itself towards Somebody Else, and this Somebody Else makes his dwelling in the soul becoming more integral in relation to the soul than the man himself. This explails a paradoxical saying: 'to find God means a continuous search for Him'. 'a man advances by the fact that he has stopped', he is 'the source of the water of Iife'" (13: 134, footnote 346).

The ecstasis of "I" has the shape of its transformation into a pneumatic-aquatic stream of aromatic extracts and in the emission of tear-waters which are the waters of the eternal life, the epiphanic waters. The entasis in turn has been represented by the incorporation of "YOU" by "I" = "water-wave=cave".

But in the introduction to the final poem (which corresponds to entasis) the motifs of the "wall" (justified by the etymology of the name "Magdalene" - Hebrew migdă and Aram. magdala meaning "tower") and the "pit, hole" (Rus. "jama") clearly prove that Cvetaeva's Magdalene is much more archaic and closer to the pagan Mother-Earth and that on this level it constitutes the preunity of IIfe and death: to give life she has to cause death first and the god, in order to be able to resuscitate, has to fulfil the sacrifice of the earth (still it is not the matter of renewal or revival of the cycle of life but the transition to a Jhighergosigual level) 
Often though in Cvetaeva's works these "plots" appear separately and do not seem to be connected with each other. But her burnings at the stakes, her trees in flames (see 47 and 48) or houses on fire (as in Poema lestnicy - The Poem of the Staircase) represent only another side of the sacrifice of earth, namely the sacrifice of fire, that is, purification of all material elements and liberation of the divine being dwelling in man, trees and other objects. This leads to an ideal fraternal community, to total equality, where all differentiating features with the division into male and female elements - which according to Cvetaeva is the hardest to remove - will be eliminated or at least invalidated. The transformation into water or dispersion in an aquatic cosmic stream leads to the identification of "I" with the world-birthgiving and world-carrying principle. And when Cvetaeva's burnings are characterized by highly dynamic impetus upwards and the intellectual reflection then the aquatic changes are characterized by a slow descent and the achievement of the lethargic state, the state of "forgetting oneself", which the poetess often describes as something spacial, as it is a "watchful" sleep or death (for another interpretation of these states see 42). We have to add that Russian "zabyt'sja" - "forget ineself" and "zabyt"ë" - "oblivion, forgetfulness" also mean "recall", not something outside however, but something which is inseparable from one's own being, in other words: to regain one's own identity (see 17: 46-47, footnote 18) or - in theological terms - to regain one's own logos (nous).

The greatest obstacle in regaining one's own identity, one's own deepest being ( 20908$)$ is the body or any physical personifications (comp. 41: 171-175). To dwell in a material shape is only a temporary and fatal adventure of an object or man.

In the poem Sivilia - miadencu (Sybil to Infant) birth is treated as the fall of a spirit from the depths of cosmos, from "nowhere" ("S zaoblacnyx nigdesnix skal"), onto the earth into its transistory state and marked with nothingness, personification with physical decay: into time, age,weight, body, blood, sex and so on, i.e. into everything that differentiates, divides, limits, binds the spirit ( 20908 ) with "mesurements" and "ties" (thus the Cvetaevan equivalents "body = prison, coffin", thus oppositions of the type "Only, exclusive, undivided - numerous, common, divisible", "dynamic changing movement - mechanic movement, passive replacement without any transformation". "stake and burning - grave and decay" and so on). Being born into the earthly forms of life is in fact the fall into death. The death though, not as existence but separation from temporality, means being born backwards into eternity, into immortality, into Life (thus often indistinguishable in poems but marked in her prose with the use of small and capital letters in writing "Iife" and "Life", "death" and "Death" and so on. The stay on the earth in the material shape means a prison on the one hand but also a mission, a task for "I" and man on the other. The task is to liberate the spirit but in an improved condition. Those who accept passive existence and do not stimulate their spirit to activity condemn themselves to eternal death, to turning into dust of which they were born (see for example Kamennoj glyboj seroj... - Like a grey bouzder...; Kto sozdan iz kamnja, kto sozdan iz gliny...; the world of burghers and holiday-makers in Poema gory and so on). They are those who are most violently condemned by the Cvetaevan "I". It even "drowns" and curses them (see the poems Citateli gazet - Newspaper Readers or 0 s lëzy na glazax...

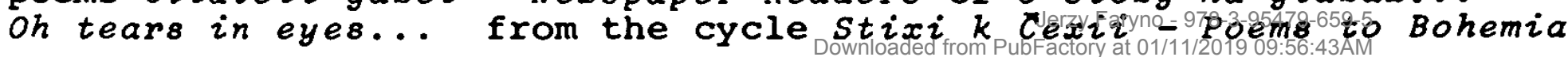


and comp. the analysis of the latter in 35: 210-219). Here we will also find the Orthodox Church both as an institution and as the architectural construction confining God, but it has to be stressed that it is not an iconoclastic attribute but rather a particular defence of God against "imprisonment" and "becoming shallow". Here there will be also a place for Cvetaeva's cult of "defeat" - already doomed in the advance struggle against something stronger, an element and fate (see 22: 125-126).

Depending in which stage a particular poem concentrates on the way to perfection there will be different variants or degrees of the personification of " $I$ " and the world. But one has to bear in mind that these are only parts of a larger whole "of fiction", since in a separate poem (not only in Cvetaeva's) it is very difficult to realize it. Cvetaeva was fully aware of this fact when she arranged her poems in definite cycles. Sometimes she supplemented them with new poems and sometimes she added a continuation to already existing ones (this is how the cycles Bessonnica or Magdalena were written) or she employed the form of a poem which looks as if it was continuously supplied with new additions because any transformation can be regarded as final (particularly to a reader less familiar with Cvetaeva's works) as in Pereulodki or Poema voz$d u x a)$.

The starting point for Pereulodki is the story of Marinka - a witch who lured and cast a spell over brave young men in a bylina about Dobrynia. But this is merely a starting point, as both the development of the plot and the manner of narration have very little in common with that bylina. The changes progress in a very Cvetaeva-like way: the poem has the character of a narration by "I" = witch-fever-shiver (Rus."lixomanka", "znob" ; and here let me point out the connection of "lixoradka=fever=shiver" with Muses from mythology and with a poetry creating element in Cvetaeva's works), who is tempting, tantalizing and enchanting. From the outside it looks as if her main aim is to inflame the brave young man but the real purpose is to get inside him and conquer his being. The consecutive change of the hero leads to the loss of his human physical shape. Even his passage through the infernal cauldrons similar to a hot water or milk bath does not restore his proper beautiful shape (as it happens in the fairytale) but merely changes him into a soul deprived of any lust. As much as a body is merely a prison for a soul so much the soul is also a confining pouch, integument for more a subtle and perfect spirit (a differentiation between "dusa" = "soul" and "dux" = "spirit" is not the Cvetaevan intention - it comes from the theological tradition on one side and the poetical one, mainly Lermontov's, in the other). The next step then is to draw the spirit out of his soul. At the end which is only partly surprising the hero as a spirit already is enchanted into a gold-horned head of "tur" = "bull", "taurus" and stays imprisoned in space. Thus the witch - "Lixomanka" = "Shiver" - has evoked its thundering divine being (20g08) which was initially unnoticeable (for the reader; see the place of Taurus in slavic country beliefs - comp. 1, 29, 30). But at the same time this one-horned taurus has appeared in the poem from a previous character of the hero as a "horse" and assumptive thundering Egorij (that is st George) - the horse and bull (taurus) are also the parallel names of the Thunders in Russian folklore, mainly in the riddles (see 30: 169 and others). Therefore it is related to a Unicorn - the symbol of both the poetic word and Divine Logos. "I" = "the witch" also does not remain unchangeable 
hero she takes on the shape of a serpent first, then water, a boat, a rainbow, and later the horse-persuit to appear next as the ruler of the universe to finally become an immense "wound" "gap" (Rus. "rana", "razzor", "skvoz"n) and disappear into infinity. Having lured the hero into the other world and having enchanted him into a formulated "word" - she gets rid of him thereby escaping to even higher perfection. The poetic word or God's word (Logos) constitutes the border in Cvetaeva's poetry which separates the created sphere (of creatures) from the non-created one (the God Himself). From the earthly point of view as Cvetaeva writes in her essay Iskusstvo pri svete sovesti (Art in the Light of Conscience), this border is the most spiritualized matter but from the superior point of view, it is already the material state if the spiritual element. The direction down, towards the earth, thus means stronger and stronger materialization - corporality and what follows certain imperfection, defects and bonds. In order to be totally free one has to step over this border, one has to get rid of the "word-spirit" (com. 6, I: 394-396). Beside it and above it there is a sphere of God Himself, God Unattainable, God continuosly flying away, dynamic and losing any palpable personification. Later in Poema vozduxa Cvetaeva calls this state a "mysl." = "thought" or "smysl" = "sense". And it is this sense towards which the whole world moves leaving all the material forms behind: the shrine is pushed away by the spire following its sense into the air but the sense in turn rejects the spire and flies away even higher. In the case of "I" - a man - this stage is presented by Cvetaeva through a transformation into an unexplicable, pure thought which pushes away an already unnecessary winged head which has previously pushed away the burdensome body. The final goal - skopos - is the unification with God, Absolute or in other terms: non-existance. Therefore for Cvetaeva's "I" the highest achievement and victory is sometimes such a state in which it would be possible to be Sebastian Bach "Organnogo ne tronut' exa" - "Not to touch the organ echo" (in the poem Prokrastsja... - To steal by.. - see the analysis of the poem in 20).

VI. KINESICS. In Cvetaeva's works overcoming matter is not characterized by automatic changes or mechanical movement. Her transformations are the result of a strenuous effort, an utmost mobilization of inner dynamics.

Cvetaeva's movements presented in a graphic shape show: a straight line usually directed upwards; a crooked line or more precisely a broken straight line; and a curve or sinuous line.

The first group of kinemograms is always connected with the movement (rush) of God and towards God. It has a double justification: in the theological iconic tradition the straight, perpendicular movement has always been reserved for God; as the straight line is artificial and needs to overcome the natural motive power of the hand, it therefore has always been connected with the conception of something supernatural (comp. in 2: 183: "To produce a reasonably straight line is difficult, especially for a child. If straight lines nevertheless occur frequently in early art, this proves how highly they are valued. The straight line is an invention of the human sense of sight under the mandate of the principle of simplicity. It is characteristic of man-made shapes but occurs rarely in nature, because nature is so complex a configuration of forces that straightness, the product of a single, undisturbed force, seldom has a chance to come about. [...] Being the simplest the straight line stands for all elongatedoshapes abefore 
of this feature takes place.").

The second group of movements and shapes is connected with the degenerative, lazy and mechanical world. One possibility is that traditionally the crooked movement has been connected with imperfect creatures, the other one is that Cvetaeva sees the "distortion" of the idea of God in it (see similar remarks on the subject in 47 ).

The third group is connected with the creative attitude, with inner bodily and spiritual dynamics, with transformations and will. This type of movement is reserved for the poets, witches and all alternations of the Cvetaevan "I". One of the manifestations of such dynamics is Cvetaeva's "adhere" which means an effort of will causing flattening, spreading to the thinnest fabric, to disappearance. There is only one step from this "spreading as a fabric" to transformation into water (as for example in Magdalene or in Zanaves The curtain, where the curtain is directly defined as the waterfall and later renamed as "I".

Another variant is the climbing, ascension and rising, all requiring a distinct physical effort visible also in the difficulty of articulation of frequent words starting with "vzm-", "vzl-", "vzd-", "vst-", "vsp-", "vzb-", "vsx-" and so on (see 47: 60-61 and footnote 24). At the base of still another variant is the kinemogram of the highly tense and swiftly unwinding spiral, a rapid jump of a viper or a tense bowstring (this movement is characteristic for the "witches" but also always proceeds their transformations), a hitting wave, embraces and enclosures (also of a creative character as it announces both the transformation of the embracing character of "I" - grasping "hands" become a "shell" and the "shell" becomes the "dephts of the sea" - and also the change of the character of "YOU" that has to undergo a nobilitating spiritual transformation: in Rekovina - The Shell - becoming a "pearl")

Cvetaeva's "I" does not only absorb the world but also wants to unite with is as much as it wants unification with God or its own being $(20 g 08)$. Thus listening to the divine Logos, called "gud" = "roar". by Cvetaeva, is treated as the "staraja poterja Tela Cerez uxo" - "Old loss of the body Through the ear" (in: Poema vozduxa) , which signifies the emergence of the spirit following God out of the ear (it is the reversal of the iconographic Annunciation stressing the idea of an ear accepting God's Word; we also find a similar reversal in the case of volce, see the poem zakinuv golovu $i$ opustiv glasa... - Raising head and casting down eyes...: "A golos, golubem pokinuv grud', $\mathrm{V}$ Cervonnom kupole obvodit krug." "And the volce like a dove having left the chest circles round in the pure golden dome").

In the same way Cvetaeva expresses the communication with the common surrounding world as well as with the world of ideas (with the cosmic stream of $20 \mathrm{goi}$ ); the most important thing is to reach the idea ( $\log 08$ ) of an object or phenomenon. For an object such attainment means a transformation into a pure "idea" (Cvetaevan "smysi" = "sense") for the subject - getting lost in the "idea", entailing a superhuman inner effort based on the kinemogram of "penetration" and "adherence" or in other words: causing one's own disappearence and "getting across, so to say, beyond oneself", to "the other side" of the being. It is best seen in the poem Tak vslusivajutsja... (So much they listen into...): "Tak vnjuxivajutsja v cvetok: vglub' - do poteri Cuvstva! [...] ...Tak vljublivajutsja v Ijubov': vpadyvajutsja v propast'.[...] Tak vglatyvajutsja v 
glotok: Vglub' - do poteri Cuvstval Tak v tkan' vrabatyvajas', tkac tkët svoj poslednij propad. Tak deti, vplakivajas' v plac, vłeptyvajutsja $v$ sëpot." ("so much they smell into the flower: Into depth - till the loss of senses! ....... And so much they fall in love with love: They fall into depths. ... Drinking they sip into a sip: Into depth - till the total loss of senses! And spinning into the fabric The weaver weaves the last thread. And so the children crying into a cry. They whisper into a whisper."). And as it seems, it is easier to understand why the meetings with the world have to end "with the crossing onto the other side" (and in common words "tragically" as it is with "death" " "dispersion" and "nothingness").

VII. FALLING IN LOVE WITH LOVE. The character of Cvetaeva's love has probably been best expressed by the notion of "falling in love with love". As we already know the total unification of "In" and "You" stipulated by this notion is impossible. Some sort of obstacle (even the slightest) always appears, even "nos na teni" "the nose of the shadow", even "smert", Kak tebja ni zovi: V syne rost, $v$ slive - Cerv': vecnyj tretij v ljubvi." - "the death, No matter what it is called: Growing - in the son, a worm - in the plum: The eternal third one in loven (from the poem Najada - Naiad). But if such a state is eventually achieved then love loses its previous meaning becoming erotic "neznost" " "tenderness" or in other terms agape (as for example in Magdalene). Thus love is never completed before this fatal point, never reaches its required fulfilment, leaves the impression of lack and even more it is understood as "untrue" or even "false" in spite of its enormous intensity (see

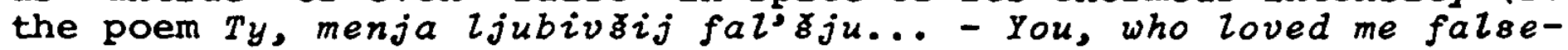
$\left.i_{y} . ..\right)$. Being not love but coming to love, "falling in love with love" it has to be more mad, exhausting, hurting and painful. Reaching fulfilment it takes on more clearly the character of a "wound" (Rus. "rana") from where it is only one step into "nothingness", the depths of the other world (such is the character of "wounds" and "seams" or "scars" - Rus. "Svy" and "కramy, rubcy" - in the Poema gory or Poema konca - The Poem of the End; for their other meanings see 45). Of course, "seams" sometimes mean the unity of "I" and "YOU", and "wounds", their separation or the riddance of an already burdensome, too iittle spiritual "YOU" by "I" as in Pereulodki; see also Ras-stojanie: versty, mili... - Distance: versts, miles...

It is self-evident that Cvetaeva's "I" with its maximalistic program has to reject any other solution as for instance an earthly unit of two people and does so more decisively the closer it comes to a form of marriage, family, "roof with a stork's nest" ("Kry $\$$ s aistovym gnezdom!" in Poema gory). The last one is partiaularly unacceptable since apart from the bodily differences, it anticipates an involvement on family and social ties and in every day troubles, $1 . e$. In everything that dies not free but binds the spirit. Thus in Poema konca the lovers being madly in love with each other decide to separate and it is (particularly for her) the best solution. If any earthly form of love could be accepted by Cvetaeva's "I" it would by Gypsy (bohemian) love or adultery (comp. in Poema gory: "Budet devkami vasi doceri I poetami - synov'jal Do¿', rebënka rasti vnebrađnogo! Syn, cygankam sebja stravi!" "Your daughters will be harlots And your sons - the poets! Daughter, bring up your illegitime child! Son, frivol yourself away with the Gypsy girls!" 
The other reason for unfilfilled love comes from the requirement of equality of lovers, from their destiny of being one for the other, being "the rhyme" for themselves. Sometimes Cvetaeva describes this requirement as the fundamental rule (base) of the world (see the poem Dvoe - Two of Them). When it is not realized, when the destiny is not recognized, then it causes the collapse of the world. But in that case more often the lovers do not so much fall to reoognize each other but they are too ideal to unite with each other in earthiy erotic love yet not too ideal to be united on the level of their logoi. They are too ideal in the sense that they are perfect like gods, and although they are somehow different, the differences are not essential enough from the earthly point of view. But they are essential enough (even in the form of a trace of differentiating corporality) that although loving, searching for and wanting each other, they are doomed for passing each other by for ever. The poem falry-tale Car'-Devica (Tsar-Maiden) is the clearest example of this.

Although in narration their "non-meetings" are explained by a trick putting Tsarevich to sleep by his loving and jealous stepmother-witch, still this is not the main cause. The point is that both Tsarevich and Tsar-Maiden are perfect characters. Their perfection even reaches the biological level. She is a "man-woman", the empress of heaven, and he is a "girl-boy" and "woman-man" staying in the underworld. But they are separated by the trace of the "beads" ("sled bus") on her armour; thus she is not a spirit free from matter (she is merely Archangel Michael); meanwhile Tsarevich hardly reaches the lowest heaven of the spirit (he is merely "guslar" = "Psaltery-player"). And in order to meet each other, according to the logic of Cvetaeva's poetics and the poetic of the myth they would elther have to degrade themselves to an imperfect human shape, to offer themselves to earth or to annihilate themselves. The first variant is unacceptable to Cvetaeva so she choses the other one: Tsar-Maiden stabs her steel breast with a sword, tears out her heart, throws it to the sea and disappears into infinity, and Tsarevich jumps into the water in search of her heart which means melting into non-existence. And here there is a transition to a theological conception of the world (clearly seen in the poem Car'-Devica, and it would be even better if the Tsar-Maiden and Sidestreets - Pereulodki - were read as a whole).

VIII. "I AM THE PEOPLE MYSELF". It is difficult to find a poet more connected with the folk culture than Cvetaeva. From Nekrasov (even Pushkin) to Esenin she is probably the only one who has the right to say: "I an the people myself" ("Ja sama narod" - in the letter to Ivask explaining his doubts concerning "the folklore element" of the poem Pereulodki; 5, II: 380). I am not concerned with these easily recognizable signs of folklore such as melodies, xhythm, stylistic figures, plots or connections with various sorts of charms sorcery. witchcraft and fables, although even they are not mere imitations but true folklore expressions and also very individual expressions of Cvetaeva. I want to point out a much deeper connection with the folk culture in general and not with the products of this culture - verbal folklore.

I would call these connections the participation of Cvetaeva in the annual folk ritual cycle or even submersion in these rites, naturally without personal particlpation but through writing. For instance the cycle Sugroby (Snow Drifts) will be unclear until we

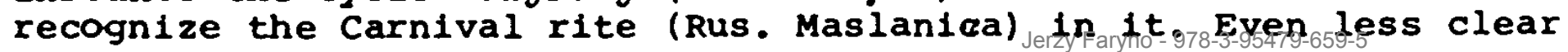


is the poem Pereulocki written soon after the sugroby until we realize its connection with the spring rites taking place in the pariod from St George's Day to Pentecost (Whit Sunday) and it is important that Cietaeva writes both these poems in this folk calender period from February to April. In order to understand the world structure of the poem-fable Car'-Devica and what really happens there, it is necessary to reconstruct the calender of these happenings and it is clear that only the folk calender has to be taken into consideration - the calender regarding the cosmic IIfe (see for example 52, 55). Only this helps explain the composition of the poem, its division not into chapters or books but into "nights" ("Noð" pervaja". "Noð" vtoraja". "Noð" tret'ja" "First night", "second night", "Third night") and "meetings" ("VstreCa pervaja". "Vstreca vtoraja". "Vstreca tret"ja 1 poslednjaja" "First meeting". "Second meeting", "third and last meeting") and their particular "demonism" and "fatalism". From various remarks and behaviours of the heroes it is evident that it is the period of Mid-Lent known also as Mortal Week occuring in the last days before the first spring neomenia (first new moon). Particularly noteworthy in this period are the last three nights, so called "empty nights". when the old moon disappears and the new one has not yet been born. In olden days this was the period of the New Year (March New Year which survived in Russia till 1412 and next September. New Year which survived till 1700). It is clear that in the life of the cosmos it is the most dramatic and dangerous moment: it can happen that before the birth of the new moon, New Year, before the first spring Thunder (also taken into consideration in the poem), the Devil will succeed in biting through the last link of the chain which keeps him in the underground caves (this subject does not appear directly in the poem but there are evident hints). Such is the explanation if the division into "nights". The division into "meetings" can be explained by the fact that neomenia is accompanied by the phenomenon known as sinodos or "approach" referring to the closest encounter of the sun and the Moon at this time. The solar character of Tsar-Maiden and the lunar one of Tsarevich appear practically everywhere in the poem, although it is not the basis for the semantics of the poem or characters.

Tsarevich will appear as the result of Cvetaeva's unbounded fantasy until we realize that he was born on Friday at midnight, on the eve of the Epiphany (in the orthodox religion - Vodosvjatie, Iordan' or Krescen'e). And similarly, the old Tsar, stepmother and the deceased Tsarevich's mother will lose their meaning unless we realize their connection with Volos-Veles and winter st Nikola (St Nicolas), Mokoł-Pjatnica and Paraskeva-Pjatnica-Holy Mother. Only these details and connections help explain the overwhelming attraction of Stepmother-witch and Tsar-Maiden (the latter is also a variant of Archangel Michael) to Tsarevich as well as the marriage of $T$ sarevich to his Stepmother extorted by Tsar, who also ordered them to produce a grand-son Nicolaus being his "duplicate".

Also some other symbolic things of the folk culture remain symbolic in Cvetaeva's works. For example the choice of certain attributes for the heroes and "I" and clothes such as rings, necklaces, jingling bracelets, belts, laced up caftans, swords, armour, "thundering" ("gromkie") dresses, shoes and taking them off, apples, chess, psaltery, combs; particular features - stamps on the foreheads, limping, hair etc.; vehicles - a boat, ship, horse: poses and gestures - the sitting position in case of Tsar and the

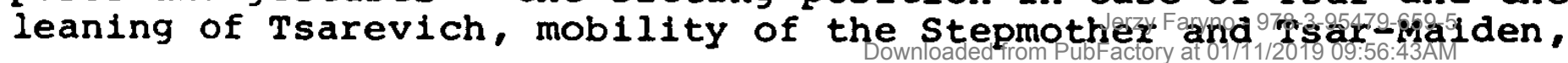


and the kicking off of the sandals by the stepmother during her licentious dance; activity - getting drunk, combing hair or flax, playing psaltery; spatial location - among concentrically placed glasses, bottles, barrels and mountains, in bed, on the stairs or in the boat, in chambers or in the tower. It seems unbelievable that Cvetaeva was unaware of that symbolism. If she were, one should think that she was its natural user, its "native speaker". To prove it there are numerous oppositions consistently based on these elemets (of the type "Cesnok - Jablocku Nerovnja" - "Garlic Not equal To an apple"), renanings ("garlic flax". "glasses maids"). syntactic constructions of the assembling character on the level of the world and not purely linguistic ("drinking away" the kingdom" or "drinking away the cows", where the "kingdom" and "the cows" mean the same: closed in the underworld and swallowed up by the opponent of the King of Thunders, life-giving waters which would enable one to say "drinking off the cows"; comp. 30: 40-45), and mainly gradations and transitions, which appear to be a pure fantasy or even 1 llogical to a reader less acquainted with the folk culture (from temting with "an apple" to tempting with "chess"; from "a horse" to "a thunder" and "goldhorned buli") and which are simply based on the equivalence and exchangeability of these phenomena in the system of folk conception of the world. Still Cvetaeva is not the creator of folk bylinas, fables or charms. She is a most original and contemporary poetess. Folk bylinas and fables are not created in the terms of the language but in the terms of a definite invariable text or, more precisely, in a text-code produced by a given culture, i.e. such a text which has been reconstructed for a fairy tale by propp or one which in contemporary mythological poetics has been defined as a "basic myth" ("osnovnoj mif"; see for example 29, 30, 40, and regarding the notion of a "text-code" see 37: 6-9). Using such a text-code, such a specialized "language", it is easy to construct (or copy at least) and add to an already known one another varianttext, one more bylina or a fable with the understanding that the new text will not contain any essentially new message, since its basic contents (semantics) is always one and the same initial textcode (and perhaps therefore it is possible to reconstruct a lost "basic myth" or any of its links lost by any culture). The task of a story-teller is to transform this text-code into a definite message.

In her folklore poems such as Car'-Devica, Pereuzodki, Sugroby, Molodec (The Swain), Krysolov (The Pied Piper) and others Cvetaeva uses this elementary text-code ifairy-tale or ritual) as a native speaker but in a different way: she uses it as a language, as a code, but decidedly throws away its text-creating rules and this helps her construct both folklore and individual poems. In other words Cvetaeva does not move from a myth to its variants but from a variant to a myth; still she does not stop at the level of a myth (an initial text-code) but moves further onto a myth-creating level (in other terms - onto the level of mythical and poetical thinking; Rus. "mifopoeti(eskoe myšlenie"). A similar thing also happens in the case of her "theology".

Moving beyond the boundaries of a text-code into a code-creating sphere helps her build her own semantics without opposing her basic theological assumptions. It also helps her reach their basis. This is the reason why her Magdalene is closer to a pre-model of a holy herlot lost by Evangelists than Mary Magdalene known from a Gospel or apocryphs. This is the reason whye Qvetwasas 
and resurrections have a deeper character then in common interpretation. Her resuscitation is a return to God Himself of a spirit breathed into man by God and not the recovery of a material shape and resumption of earthly activity. It is the return not to this but to the "other world". On the occurrence level it means sinking into death, the victory over all earthly temptations. The common circle of existence opens up and takes the shape of an infinite ascent, a perpetual fight against matter, against the form-creating element even if it was God Himself (Logos), even if it required even the least personification, Creativeness (see Prokrastsja... To steal by.... where one has to avold a certain feature "a shadow", "trace". first, then a feature of a feature - "echo", then at the end not even to touch "waters" - that is one's own non-transferable being, as "waters" are the equivalent of the being or logos of "I= Marina"; comp. 20).

The most interesting thing is that based on this pattern Cvetaeva also rebuilds an unrebulidable model of the basic myth which is the foundation of the annual ritual cycle and therefore the most universal duel of the Gromoveržec or zmeeborec (King of Thunders) with his opponent Zmej (Dragon, Serpent). While the text-code assumes the restoration of the initially disturbed balance of the cusmic forces which has to close the natural cosmic cycle and lead to the repetition of the same consecutive cycle, Cvetaeva opens up the cycle: instead of reproduction (on different levels), instead of renewal of the initial state there is an infinite evolution towards perfection, the tendency to unite with God (with the Absolute). It is understandeable by itself that in particular solutions this point is never achieved - Cvetaeva's "plots" or "stories" break up much earlier but normally at the point where all created personifications are reduced to a practically zero state if not totally overcome and " $I$ " and the heroes start to evolve from the state of pure spirit to pure thought. As a result, Cvetaeva turns the mythological duel of Life and Death into the duel of Spirit with Matter. And it is just her initial "text-code" or maybe her code-creating energy.

IX. REARTICULATION. Coming to oneself, coming to the being of the objects ( $20 \mathrm{goi})$ or to the background of the myth also has its equivalent in Cvetaevan attitude to the word and expression. The matter of the attitude has no rhetorical character; it does not intend to build a text but is rather hermeneutical or exegetic directed toward revealing the meaning (sense). Cvetaeva does not know "somebody else's". "ready" word - thus a minimal role of the narrative form of presentation, quotations, or reminiscences and if such "somebody else's" word occurs, it is either immediatly rejected or transfered to the mythologized sphere and deprived of common meanings (it appears as something original, primary). For instance the dialogue parts in Poema konca are constructed in this way (comp. "- Ljubov", eto znacit: zizn". - Net, inace nazyvalos' U drevnix..." - "Love, it means: life. - No, the ancients Called it differently...").

The word undergoes another deep rethinking and rearticulation until it is totally deprived of any plan of expression and is separated from talking "I". Thus infinite renamings and continuous choice of new equivalents with a remark that the process is not prepatory for an expression to follow: there will be no expression - the reader and Cvetaeva's "I" merely analyse a word or notion and have to reach its point. At this stage thezprocess95of 65 articu- 
lation and a particular text come to an end. For Cvetaeva there is nothing left - merely pure awareness (see the poem Vas neżnj rot - splosnoe celovan'e... - Your lips - it is nothing but kissing... from the cycle Komediant - The comedian; see its analysis in 19, II: 224-227). Evidently it is a precisely balanced poetical technique: giving an impression of picking up the variants at random, it is a structly orderly choice and it forms a paradigm directed "from to" where the pole "to" is always the same; an unexplicable sphere of pure sense (presumably "God" and "deep sleep" for example in the poem Imja tvoe - ptica v ruke... - Your name - a bird in hand...., see 15: 144-147; 19, I: 68-69). Cvetaeva's special syntax, punctuation and graphics serve this purpose. Although her texts have all the features of a spontaneous spoken language they still have to be read (seen), since few of her colons, dashes, hyphened and unhyphened spellings, "cutting off" with lines, italicized words and brackets can be expressed merely by intonation and voice (on certain features of Cvetaeva's language see: $9,15,23$, $46,49,50,54)$. As in the case of a text-code where Cvetaeva moves beyond its boundaries into the code-creating spheres, she also tries in the case of the language to move beyond and above its frames to the pre-linguistic (pre-articulative) spheres on the one hand and to extralinguistic ones, requiring no language, on the other.

Just as the word and language objects, people, "I" included, happenings and "plots" also undergo re-articulation. They are also arranged in paradigmatic series, which tend towards the pole of a pure, immaterial sense (20goi, God). Compare internal and reciprocal paradigmatics of objects in Poéma lestnicy: "Stklo, s polok berežnyx: - Pe-sok esm'! Vdrebezgi ż ... Tju-fiak: soloma esm'! Mat-ras: esm' vodorosl'! Vsë, vsja: priroda esm'! Cas paxnet bomboju. Ve-rëvka: lnom byla! Ogn', v kuče ugolnoj: - Byl bog $i$ budu im!" - "Glass, from the niggled shelves: - I am the sand, So into dust! ... Palliasse: I am a straw! Mattress: I am seaweeds! All, everything: I am naturel The hour smells of a bomb. Rope: I was flax! Fire, in a coal heap: - I was god and will be!", where all retreat to their initial state and together form a gradation from "glass on the shelves" to "coal in the fireplace" on the substantial plan and in the plan of contents from "sand" through "seaweeds" and "flax" (commonly associated with a shroud and as a "rope" - with a link between earth and heaven) to "God"; we can also see here their self-rearticulation and their inner tension in a graphical recording with the use of dashes.

The regalning of an initial being and initial direct contact on this deepest level is the basis of both Cvetaeva's mythology and theology. Let me add that also somebody else's "plots" (as in Magdalene or in fairy tales) are not Cvetaeva's borrowings. They also undergo reinterpretation and rearticulation, that is, Cvetaeva's understanding - coming to their point. And this explains the mechanism of identification of "I" (and in the worst case - undistinguishing) with the characters of these stories (as with Magdalene, with a witch in the Pereulocki, or even with Tsar-Maiden in Car'-Devica; comp. 43).

Warsaw, November 1984

Translated from the Polish

by Andriej Jacek Cygariski 
1. AFANAS'EV: А.АФАНАСЬЕВ, Поэтические воззрения славян на природу. Oпит сравкителокого изучекия славянских предакий и верований ө сөязи с мифическими сказаяиями других родстөенких народов. Том I - Москва 1865; Том II - Москва 1868; TOM III - Mосква 1869.

2. R. ARNHEIM, Art and Visual Perception. A Psychology of the Creative Eye. The New Version. University of California Press, Berkeley and Los Angeles 1974.

3. E. BALCERZAN, sty $z$ i poetyka tworczosci dwujezycznej Brunona Jasiehskiego. 2 zagadnieh teorii przekZadu. Wrocław-Warszawa-Krakov 1968 .

4. Z. BIENKOWSKI, "Diabeł Cwietajewej".-Tworczost 5 (1972).

5. CVETAEVA: M. ЦBETAEBA, Стихотворекия и поэми в пяти томах. Russica Publishers, Inc. New York 1980-1983.

6. CVETAEVA: M. ЦBETAEBA, Нзбракмая nроза e deyx mомax, Russica Publishers, Inc. New York 1979.

7. Marina Cvetaeva - "Krysolov". Der Rattenfanger. Herausgegeben, ubersetzt und kommentiert von Marie-Luise BOTT, mit einem Glossar von Gunther WYTRZENS. - Wiener Slawistischer Almanach, Sonberband 7, wien 1982.

8. Marina Cvetaeva. Studien und Materialien. - Wiener Slawistischer Almanach, Sonderband 3, Wien 1981.

9. CERKASOVA: Л.П.ЧЕРКАСОВА, "Наблюдения наД экспресснвноЯ функцие морФемн в поэтическом языке (На материале поэзии М. цветаевои) - Развитие современного русского язика. 1972 , Mосква 1972, с. 141-150.

10. M. ELIADE, Traktat o historii religii. Warszawa 1966 (transl. from: Traite d'histoire des religions).

11. S.I. EL'NICKAJA: С.И.ЕЛЬНИЦКАЯ, "О некоторых чертах поэтического мира M. Цветаево"". Wiener Slawistischer Almanach, 3,4 (1979), 7 (1981), 11 (1983).

12. E.ETKIND: E.Г. ЭTКинд, "Опыт о местоимения в системе поэтическои речи". - Поэтика и стилистика русской литератури, Ленинграп 1971.

13. P. EVDOKIMOV, Prawoszawie. Przełozyz ks. Jerzy Klinger, Warszawa 1964 (Transl. from P. EVDOKIMOV, L'Orthodoxie, Neuchâtel 1959).

14. J. FARYNO, "К BOпросу О соОтношении ритма и семантики в поэтических текстах (Пушкин - Евтушенко - цветаева)". - Studia Rossica Posnaniensia 2 (1971).

15. J. FARYNO, "некоторые вопросы теория поэтического языка (Язык как моделируюмая система - Поэтическия язык Цветаевоя) - - Semiotyka i struktura tekstu. Wrocław-WarszawaKrakbw-Gdafisk 1973.

16. Ј. FARYNO, "БЕССОНницА" Марины цветаевоЯ. Отыт аналза цикла".3борких за Cлаөистику 15 (Novi Sad, 1978) 
17. Ј. FARYNO, "Из заметок по поэтике цветаевон" (in: 8).

18. J. FARYNO, "Zarys poetyki Cwietajewej".-Poezja $3(1985)=$ an older version of the present "Some Aspects.."

19. J. FARYNO, Веедение ө лиmepamypoведение. Yасть I - Katowice 1978, c. $62-63,68,78-80$; Часть II - 1978, C. 10-11, 50-53, 224-226; Часть III - 1980, с. 23-24, 62-63,70, 72-73, 113$117,123-124,242$.

20. J. FARYNO, "Стихотворение Цветаево "Прокрасться..." . slavica Bierosolymitana (forthcoming).

21. J. FARYNO, "Семнотические аспекты поэзии Маяковского" Umjetnost Rijedi: Knjizevnost - Avangarda - Revoljucija. Ruska književna avangarda XX stoljeća. Izvanredni svezak, Zagreb 1981 .

22. J. FARYNO, "Блаженное наследство Манделыштама: "на розвальнях, уложенных соломоя...". - Knjizevna Smotra 1985.

23. L.FILIMONOVA: Л. ФилимоновA, "Образная перспектива слова в раннея лирике Цветаевоя". - Сборник научних студенческих paбom. Выпуск II, Воронеж 1970, с. 123-126.

24. JU. FREJDIN: D.Л. ФРЕЯДИН, "Анализ стихотворения Марины Цветаевон "В огромном городе моем - ночь..". - International Journal of Slavic Linguistic and Poetics, XI. Mouton, The Hague 1968.

25. A. GOVE, "Parallelism in the Poetry of Marina Cvetaeva". Slavic Poetics. Essays in Honor of Kiriz Taranovsky. Mouton, The Hague-Paris 1973.

26. М.GASPAROV: М.Л. ГАСПАРОВ, "Поэма воздуха" Марины Цветаево : Опыт нитерпретацин". - Труда по зиаковим системам, XV: Tипология кулотури. Взаимное өоздейстөие кулотур, тарту 1982 .

27. V. IVANOV: ВС. ИВАнОВ, "Поэзия Марины Цветаевон" - Тарусские страниии, Калуга 1961.

28. V.V.IVANOV: В.В. ИВАнОВ, Очерки по истории семиотики ө CCCP, Москва 1976.

29. V.V.IVANOV, V.N.TOPOTOV: В.В.ИВАНОВ, В.Н. ТОПОРОВ, СЛавямСжие язиковие моделируриие семиотические системи. Древний период, москва 1965.

30. V.V.IVANOV, V.N. TOPOROV: B.B. ИВAHOB, B.H. TOПOPOB, HCСлеdOвания в области славянских древностей. Лексические и фразеологические өопроси реконструкиии текстов, Москва 1974.

31. S. KARLINSKY, Marina Cvetaeva. Her Life and Art. University of California Press, Berkeley and Los Angeles 1966.

32. L. KLEBERG, "В ожндания письма. О стихотворения Марины Цветаевоя "Письмо" . - Scando-Slavica 27 (1981).

33. A.N.KOLMOGOROV: A.H. КОЛМОГОРОВ, "Пример изучения метра и его ритмических вариантов". - Теория стиха, Ленинград 1968 (author analyses here the cycle "Stol" - "The Table" and "Poema konca" - "The Poem of the Ende").

34. A.M. KROTH, "Toward a New Perspective on Marina Tsvetaeva's Poetic world" (in: 8). 
35. Ju. LOTMAN: D.M. ЛОТМАH, Структура худохественного текста, Москва 1970, с. 104-111, 209-219.

36. Ju.LOTMAN : D.M. ЛОтмAн, Анализ позтического текста. Структура стиха, Ленинград 1972, с. 235-247.

37. Ju.LOTMAN: D.M. ЛОТМAH, "Текст в тексте". - Труди по зиаковам стстемам, XVI: Tексm в mexсmе, Tарту 1981.

38. 2. MACIEJEWSKI, Proza Maryny Cwietajewej jako program $i$ jako portret artysty. Warszawa 1982 .

39. M. MEJLAX: M.Б. MERJAX, "Об именах Aхматово . I : Анна" Russian Literature 10/11 (Special issue devoted to Acmeism, II. 1975).

40. Е. MELETINSKIJ: E.M. МЕЛЕТинСКНЯ, Позтика мифа, Москва 1976.

41. J. MEYENDORFF, Teologia bizantyjska. Historia i doktryna. Przełozył Jerzy Prokopiuk, Warszawa 1984 (trans from: John MEYENDORFF, Byzantine Theology. Historical Trends and Doctrinal Themes, Fordham University Press, New York 1979).

42. K. ORLOW-LASKOWSKA, "NOC, sen $i$ smier'c $w$ poezji Mariny Cwietajewej". - Studia Rosicica Posnaniensia 12 (1980).

43. S. POLJAKOVA: C. ПОЛЯКОВA, "К вопросу Об источниках поэмы цветаевои "царь-Девица" - Rив8ica'81. New York 1982.

44. S. POLLAK, "Portret poetki". - Poezja 3 (1968).

45. O. REVZINA: О.Г. РЕВ3ИнA, "Из наблюдениम над семантическоम структурой "Поэм конца" М. цветаевон". - Труда по знаковим системам, IX, тарту 1977.

46. O. REVZINA: О.Г. РЕВЗИНA, "Знаки препинания в поэтическом языке: Двоеточие в поэзии М. Цветаевон". (In: 8).

47. O. REVZINA: O.Г. РЕВ3инA, "Структура поэтического текста как доминируюин Фактор в раскрытии его семантики". (In: 8).

48. O. REVZINA: О.Г. РЕВ3инA, "Тема деревьев в поэзии М. Цветаевон". - Труда по знаковим системам, XV: Tипология кулотури. взаимкое воздейстөие кулотур, тарту 1982.

49. O. REVZINA: О.Г. РЕВЗИнA, "Из лингвистическоЯ поэтики. (Деепричастия в поэтическом языке М. Цветаевоя). - Проблеми структурной лингвистики. 1981, Москва 1983.

50. G. SEDYX: Г.И. СЕДБХ, "Звук и смал. О Функции Фонем в поэтическом тексте.(На примере анализа стихотворения М. Цветаевоя "Психея"). - Филологические Науки 1 (1973).

51. G.S. SMITH, "Versification and Composition in Marina Cvetaeva's "Pereulotki". - International Journal of slavic Linguistics and Poetics XX (1975).

52. L. STOMMA, Szoñce rodzi sie 13 grudina, Warszawa 1981.

53. N.K.SAJAXMETOVA: Н.K. ШАЯХMETOBA, "О семантических неологизмах в контексте М. Цветаевоһ". - Вопроси русской филологии, Алма-Aта 1978 , с. 178-188.

54. N.K.SAJAXMETOVA: H.K. ШАЯXMETOBA, "O твОрческом контексте М. Цветаевоя" - Bопроса русской филологии, Алма-Aта 1978 , C. 189-198. 
55. J. 1 R.TOMICCY, Drzewo zycia. Ludowa wisja siwiata i czlowieka, Warszawa 1975 .

56. V.N.TOPOROV: W.N.TOPOROW, "O jednosci poety i tekstu". Pametnik Literacki 4 (1980) (transl. from Russ.)

57. В.A.USPENSKIJ : Б.А.УСПЕнСКИП, Филологические разискакия $\theta$ области славякских древностей. (Реликти язичества в востоинославякском кулоте Нихолая Мирликийского), Москва 1982.

58. W.G. WESTSTEIJN, Velimir Chlebnikov and the Development of Poetical Language in Russian Symbolism and Futurism. Amsterdam 1983.

59. G. WYTRzENS, "Zum Wortschatz des 'Krysolov' der Marina Cvetaeva". - Wiener Slawistischer Almanach, 1, 2 (1978).

60. G. WYTRZENS, "Парихские поэмы Марины цветаевон". - Umjetnost Rijęi: Književnost - Avangarda - Revolucija. Ruska knjizevna avangarda XX stoljeća. Izvanredni svezak. Zagreb 1981.

61. Л.В.зУБовА, "Семантика художественного образа и звука в стихотворения М. Цветаевой из цикла "Стихи к Блоку"п - Вестиих ЛГУ, 2 (1980).

62. Л.Б.зУБОВА, "О семантическоЯ функцин грамматических арханзмов в поэзин М. Цветаевон." - Ворроси стилистики. Фукжииокалокие стили русского язика и методи их изучекия. мехвузовский научниц сборник, Саратов 1982. 


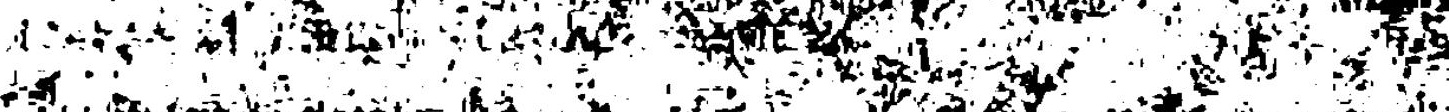

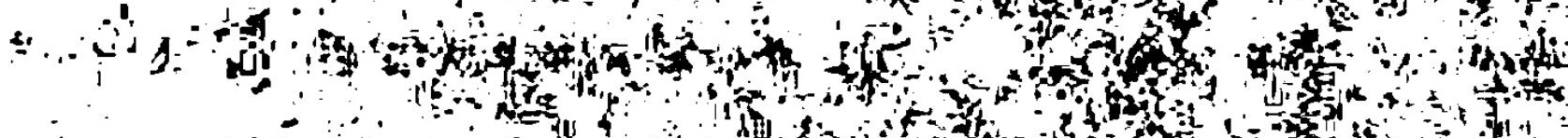
it $\Rightarrow$ a a

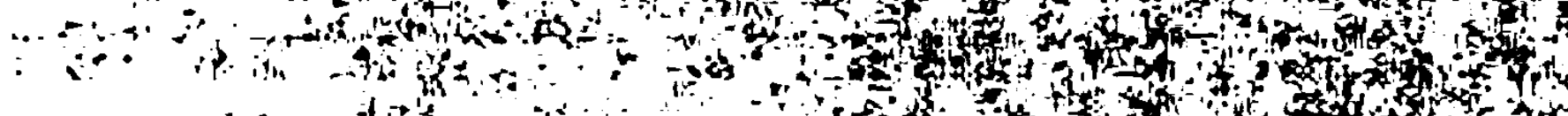

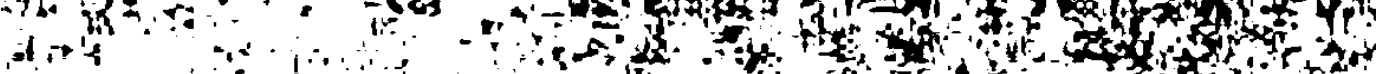

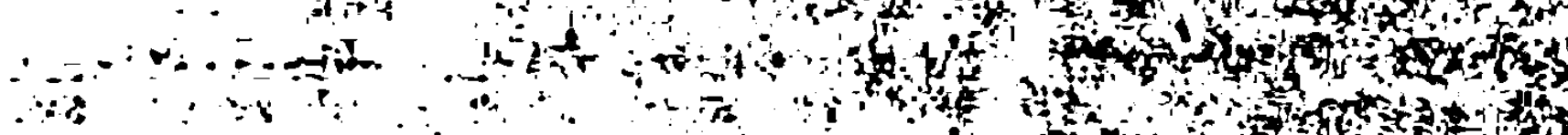

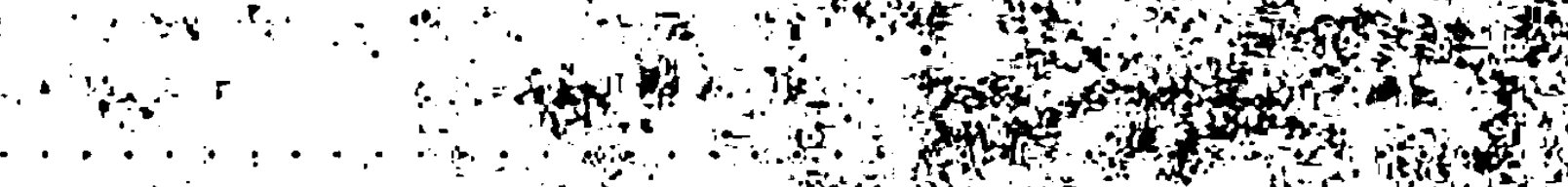
$\because \ldots$

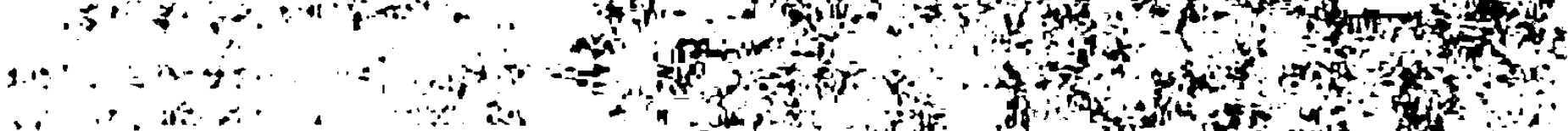

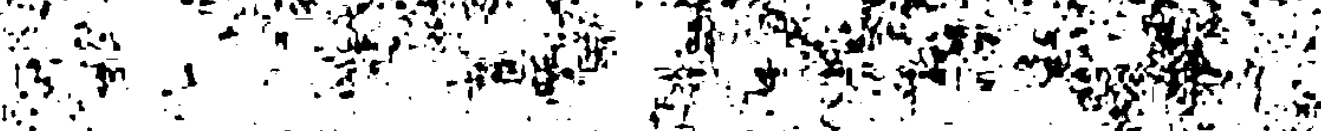

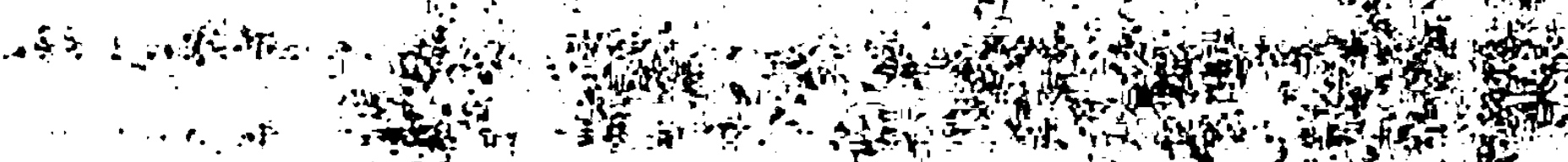

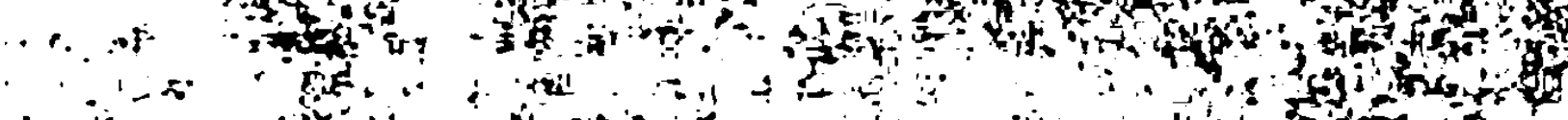

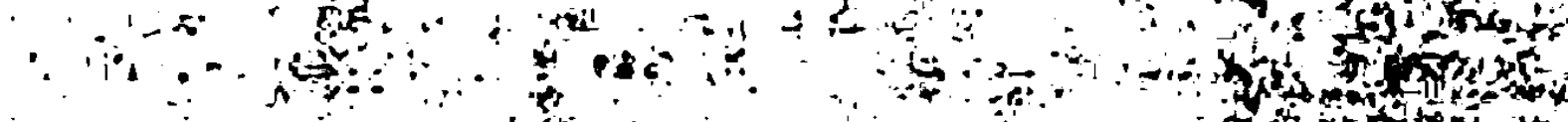

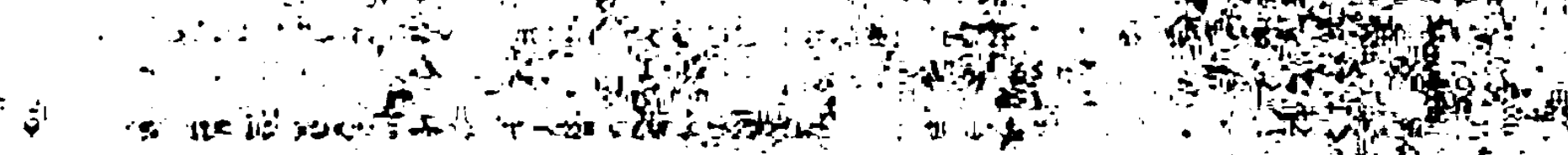

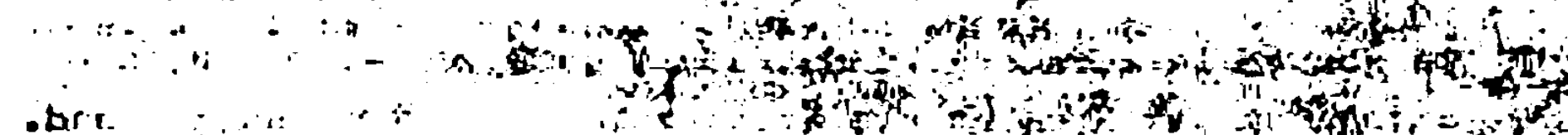

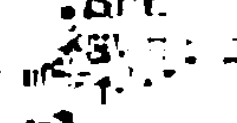
3

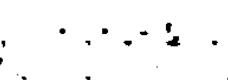

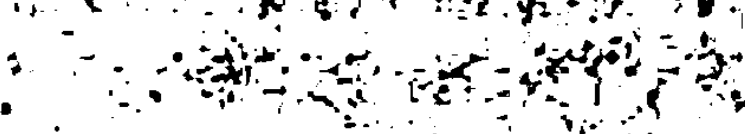

$$
\bar{T}_{Y}
$$

T.

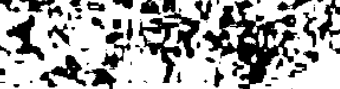
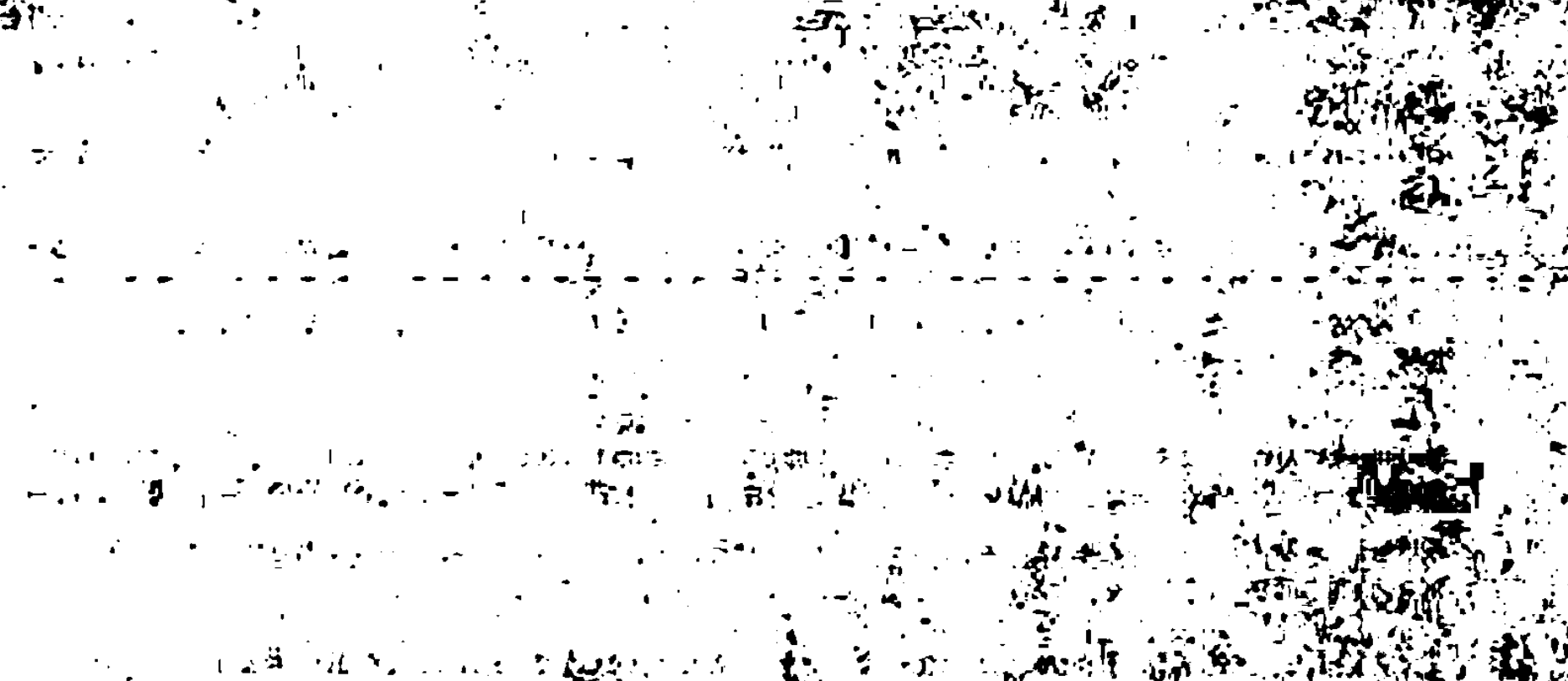

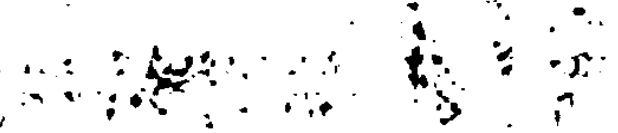

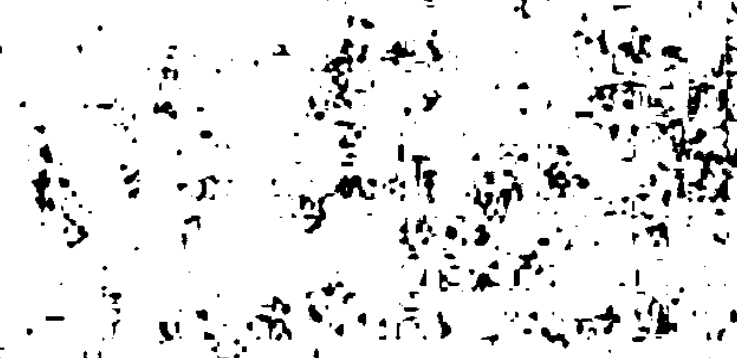

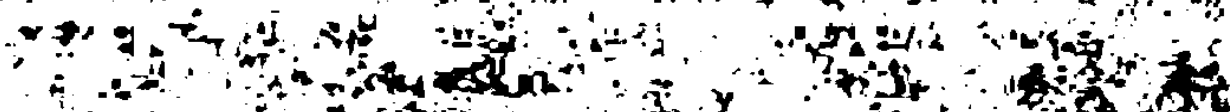

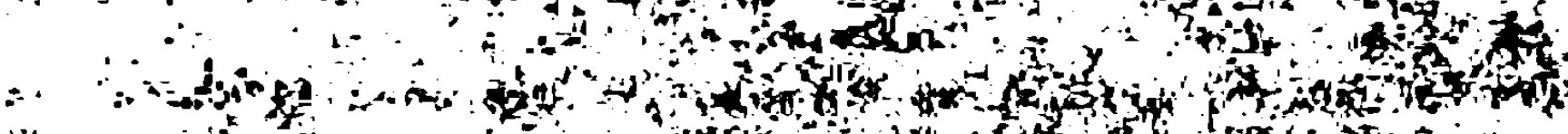
要: 
1. Ju.D.APRESJAN, Tipy informacii dlja poverchnostno-semantiCeskogo komponenta modeli "smysl $\rightarrow$ tekst", 1980, $125 \mathrm{~S}$. OS 120.-, DM 17.-, \$9.-

2. A.K.ZOLKOVSKIJ / Ju.K.SCEGLOV, Poétika vyrazitel'nosti. Sbornik statej, 1980, 256 S., OS 200.-, DM 28,50, \$15.-

3. Marina Cvetaeva. Studien und Materialien, 1981, $310 \mathrm{~S}$. OS 250.-, DM 35.-, \$16.-

4. I.P.SMIRNOV, Diachroničeskie transformacii literaturnych Zanrov 1 motivov, 1981, 262 S., OS 200.-, DM 29.-, \$12.-

5. A.STONE NAKHIMOVSKY, Laughter in the Void. An Introduction to the Writings of Daniil Kharms and Alexander Vvedenskij. 1982, 191 S., OS 180.-, DM, 25,70.-, \$11.-

6. E.MNACAKANOVA, Sagi i vzdochi. Cetyre knigi stichov, 1982, 216 S., OS 150.-, DM 21,40.-,\$9.-

7. Marina Cvetaeva, "Krysolov". Der Rattenfänger. Herausgegeben, übersetzt und kommentiert von M.-L.BOTT, mit einem Glossar von G.WYTRZENS, 1982, 326 S., OS 200.-, DM 28,50.-

8. S.SENDEROVIC, Aleteja. Elegija PuSkina "Vospominanie" 1 problemy ego poétiki, 1982, $280 \mathrm{~S}$., రS 250.-, DM 35.-

9. Th.LAHUSEN, Autour de I'"homme nouveau". Allocution et société en Russie au XIXe siècle (Essai de sémiologie de la source littéraire), 1982, $338 \mathrm{~S}$., OS 200.-, DM 28,50.-

10. Erzählgut der Kroaten aus Stinatz im südlichen Burgenland. Kroatisch und deutsch. Herausgegeben von K.GAAL und G.NEWERLOWSKY, 1983, LXX+339 S., OS 200.-, DM 28,50.-

11. Dialog der Texte. Hamburger Kolloquium zur Intertextualitat, Herausgegeben von W.SCHMID und W.-D.STEMPEL, 1983, 404 S., OS 200.-, DM 28,50.-

12. Bor1s GASPAROV, Poétika "Slova o polku Igoreve", 1984, $406 \mathrm{~S}$. OS 300.-, DM 42.-

13. Protestantismus bei den Slowenen / Protestantizem pri slovencih. Beitrăge zur 3. Slawistentagung der Universitäten Klagenfurt und Ljubljana 1983, 1984, $280 \mathrm{~S} .$, os 200.-, DM 28,50.-

14. I.A.MEL'CUK, A.K.zHOLKOVSKY, Tolkovo-kombinatornyj slovar' russkogo jazyka / Explanatory Combinatorial Dictionary of Modern Russian, 1984, 1000 S., OS 630.-, DM 90.-, \$35.-

15. Gumilevskie ttenija: vypusk vtoroj. Herausgegeben von V.F. MARTYNOV, 1984, 214 S.. OS 200.-, DM 28,50.-

16. I.A.MEL'CUK, Poverchnostnyj sintaksis russkich Cislovych vyrazenij, 1985, 510 S., ó 350.-, DM 50.-

17. I.P.SMIRNOV, Porozdenie interteksta (Elementy intertekstual'nogo analiza s primerami iz tvortestva B.L.Pasternaka), 1985, 205 S., \&S 200.-, DM 28,50.-

18. J.FARYNo, Mifologizm I teologizm Cvetaevoj ("Magdalina - "Car'Devica" - "Pereulocki"), 1985, 412 S. , OS 280.-, DM 40.- 